
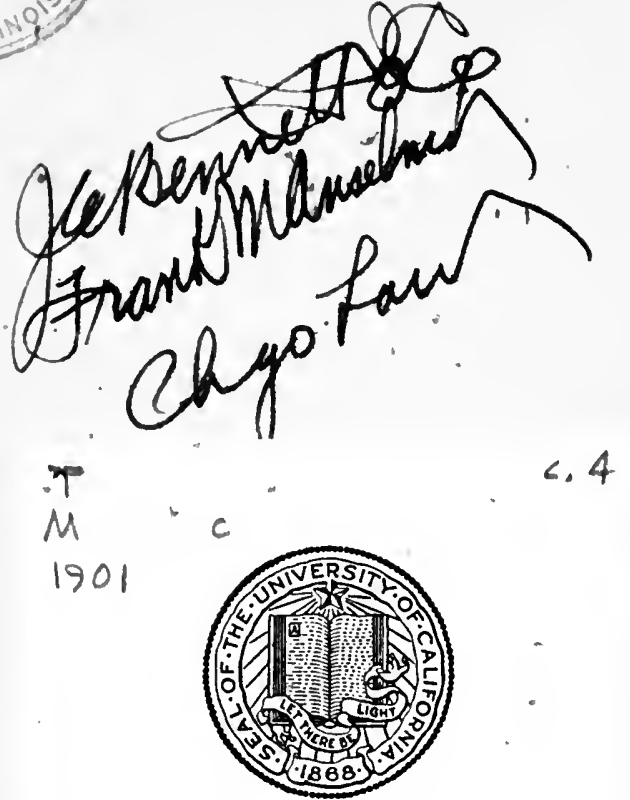

THE LIBRARY

OF

THE UNIVERSITY

OF CALIFORNIA .

LOS ANGELES

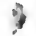

SCHOOL OF LAW 

Digitized by the Internet Archive in 2007 with funding from Microsoft Corporation 


\section{CONFLICT OF LAWS;}

OR,

\section{PRIVATE INTERNATIONAL LAW。}


Lenptit det 


\section{CONFLICT OF LAWS;}

OR,

\section{PRIVATE IN'TERNATIONAL LAW.}

BY

RALEIGH C. MINOR, M.A., B.L.,

PROFESSOR OF LAW IN THE UNIVERSITY OF VIRGINIA.

B OST ON

LITTLE, BROWN, AND COMPANY

1901 
Copyright, 1901,

By Raleigh C. Minor.

All rights reserved.

$T$

$M$ C

1901 
To

Uthe fftemary

oF

\section{Y F A T H R,}

WHOSE PURITY AND SIMPLICITY OF HEART, PROFOUND KNOWLEDGE OF MANKIND, AND ENTHUSIASM IN THE SEARCh FOR TRUTH WILL EVER BE MY INSPIRATION,

THIS BOOK IS REVERENTLY DEDICATED. 



\section{P R E F A C E.}

THe arrangement, as well as the theory, of this book departs materially from that of its predecessors, the offspring of the great intellects and profound learning of Story, Dicey, and Wharton. I should feel that some explanation of this is necessary, save for my belief that the reader will find the arrangement its own best defender.

If from the tangled skein of decisions upon this subject it can be said that a single certain conclusion may be drawn, after a careful and laborious analysis of the cases I should select as that conclusion the fact that the great foundation and basic principle of private international law is Situs. Find the situs of the particular act, circumstance, or subject under inquiry and you will know the law which should properly regulate its validity and effect. This proposition, it is true, is subject to exceptions, but the exceptions are quite clearly defined, and may in general be applied without great difficulty. They will be found discnssed in the second chapter.

It is logical therefore to treat the subject under the heads which follow, each head constituting a separate division or part of the work: Part I., Introductory. Part II., Situs of the Person. Part III., Situs of Status. Part IV., Situs of Personal Property. Part V., Situs of Contracts. Part VI., Situs of Torts and Crimes. PART VII., Situs of Remedies. PArt VIII. Pleading and Proof of Foreign Laws. 
All the principles of private international law (it might more properly be called The Law of Situs) will be found to group themselves under one or the other of these heads.

The branch of the law herein discussed, though of daily growing importance, is at present in a most chaotic condition. Comparatively few points may be regarded as settled. The courts too frequently fail to rest their decisions upon sound foundations of reason and principle; they are too often inclined to indulge in vague generalities and dicta, without analyzing the transaction before them into its elements, and applying the law of the situs of each element to determine its effect.

It has been my constant aim to reduce every proposition to its ultimate principles, for only by this means can order be brought out of the confusion that now exists. In some instances $I$ have been forced to cite decisions which, while supporting the conclusions to which they are cited, have reached those conclusions by fallacious courses of reasoning.

If the principles enunciated in this work shall aid in illuminating even a few of the many dark places to be found along the path, I shall be more than gratified.

R. C. M.

\section{University of Virginia,}

January, 1901. 


\title{
TABLE OF CON'TENTS.
}

\author{
PART I. \\ INTRODUCTORY.
}

CHAPTER I.

InTRoduction Paas

$\S 1$. Origin of Private International Law . . . . . . . 1

2. Public and Private International Law distinguished . . 2

3. Foreign Element essential to Operation of Private International Law . . . . . . . . . . . . 4

4. Basis of Private International Law . . . . . . 5

\section{CHAPTER II.}

Exceptions to the Application of a Foreign Law . 8

§ 5. General Grounds upon which the Exceptions are based . 8

6. First Exception - Policy or Interests of Forum contravened by Enforcement of Proper Law . . . . . . 10

7. Second Exception - Injustice or Detriment to People of the Forum . . . . . . . . . . . . . . . 12

8. Extent of Second Exception . . . . . . . . . . 14

9. Third Exception - Proper Foreign Law Contra Bonos Mores . . . . . . . . . . . . . . . 17

10. Fourth Exception - Proper Foreign Law Penal in its Nature . . . . . . . . . . . . . . 21

11. Fifth Exception - Transactions relating to Immovable Property . . . . . . . . . . . . . . . . 28

12. Same - Application of Lex Situs to Transfers of Land, and Liens thereon . . . . . . . . . . . . . 32

13. Meaning of "Immovable Property" in Private International Law . . . . . . . . . . . . . 38 
\$14. Application of Lex Situs to Transactions relating to Movable Property . . . . . . . . . . . .

15. Effect of Transactions completed and perfected under Proper Law not generally altered by Subsequent

Change of Situs . . . . . . . . . . . . . 43

16. Value of Precedents in Private International Law . . 48

\section{PART II.}

\section{SITUS OF THE PERSON.}

CHAPTER III.

Actual Situs of the Person . . . . . . . . . . . 51

$\S 17$. Importance of Situs in Private International Law . . . 51

18. Actual Situs of the Person . . . . . . . . . . 54

\section{CHAPTER IV.}

Legal Situs of the Pergon, or the Domicil. . . - 58

$\S 19$. Domicil, National, Quasi-National, or Municipal . . . 58

20. Domicil distinguished from Mere Residence . . . . 59

21. Domicil distinguished from Nationality or Citizenship . 60

22. The Legal Situs or Domicil of the Person . . . . . 61

23. Definition of Domicil of Natural Persons . . . . . C2

24. Area of Domicil . . . . . . . . . . . 63

25. Domicil, the Actual Permanent Home . . . . . . 64

26. Domicil, the Constructive Permanent Home . . . . 65

27. Certain General Principles touching Domicil-I. No

Person without a Domicil . . . . . . . 67

28. II. Only One Domicil at a Time . . . . . . . 68

29. III. Domicil retained until another is acquired . . . 70

30. IV. Persons Sui Juris may change Domicil at Pleasure 72

31. Several Kinds of Domicil - I. Domicil of Origin . . 73

32. Original Domicil of Child born Legitimate . . . . . 74

33. Original Domicil of a Bastard - Of Legitimated Child 75

34. Original Domicil of a Foundling - Of an Adopted Child . . . . . . . . . . . . . 77 
\$ 35. II. Constructive Domicil arising by Operation of Law

PAGR

36. Constructive Domicil of Infant - Legitimate Child . 79

37. Domicil of Legitimate Child - Father Alive . . . . 80

38. Same - Father Dead, Mother Surviving . . . . 82

39. Effect of Remarriage of the Mother . . . . . . 84

40. Constructive Domicil of Orphan . . . . . . . 85

41. Power of Guardian to alter Ward's Domicil . . - 87

42. Constructive Domicil of an Illegitimate Child . . . 91

43. Constructive Domicil of Child subsequently Legitimated 92

44. Constructive Domicil of an Adopted Child . . . . 92

45. Domicil of a Married Infant . . . . . . . . . 93

46. Constructive Domicil of Married Woman . . . . . 94

47. Domicil of a Deserted Wife . . . . . . . . . 96

48. Domicil of Wife who Deserts her Husband . . . 98

49. Domicil of Wife whose Husband is Insane or otherwise incapacitated . . . . . . . . . . . . . 100

50. Domicil of Wife contemplating Divorce. . . . . 101

51. Domicil of Wife whose Husband applies for Divorce . 102

52. Domicil of Divorced Wife . . . . . . . . . 103

53. Domicil of Wife, where the Marriage is Voidable or

Void . . . . . . . . . . . . 105

54. Constructive Domicil of Idiots . . . . . . . 105

55. Constructive Domicil of Lunatics . . . . . . . . 106

56. III. Domicil of Choice - Three Essential Elements . 109

57. Party must be free to choose Domicil . . . . . 110

58. Same - Invalids compelled to Reside Abroad . . . 112

59. Further Elements of Domicil of Choice - Actual Presence and Animus Manendi . . . . . . . . 114

60. Actual Presence . . . . . . . . . . . . 115

61. The Animus Manendi . . . . . . . . . . 117

62. Commencement of the Intention . . . . . . 118

63. Duration of the Intention . . . . . . . . 120

64. Evidence of Animus Manendi . . . . . . . . . 121

65. Effect of Abandonment of Domicil - Conflicting Views 124

66. Same - A Solution suggested . . . . . . . . 126

67. Situs (or Domicil) of Corporation . . . . . . 129 


\section{PART III.}

\section{SITUS OF STATUS.}

$\$$ 68. Preliminary - Situs of Status follows Situs of the

Person . . . . . . . . . . . . 131

\section{CHAPTER V.}

Status of Personal Capacity . . . . . . . . . 134

$\$$ 69. Capacity in General - Sereral Sorts of Capacity . . 134

70. Testamentary Capacity . . . . . . . . . . 136

71. Business Capacity in General . . . . . . . . . 141

72. Voluntary Transactions - Capacity to Contract . . . 144

73. Same - Capacity to Marry . . . . . . . . . . 149

74. Particular Incapacities to Marry - Guilty Party to

Divorce prohibited to Marry again . . . . . 155

75. Same - Polygamous and Incestuous Marriages . . 160

\section{CHAPTER VI.}

Dtatus of Marriage . • . . . • • • • . • . 163

$\S 76$. Dual Nature of Marriage . . . . . . . . . 163

77. The Contract of Marriage - Formal Validity . . . 165

78. Substantial Validity of Marriage Contract . . . . . 169

79. The Marriage Status or Matrimonial Union - Its Commencement and Continuance . . . . . . . 172

80. Incidents of the Marriage Status - Marital Rights in Consort's Property - Lands . . . . . . . . 173

81. Marital Rights in Personalty of Consort-In Absence of Express Contract . . . . . . . . . . . 175

82. Same - Express Contract touching Marital Rights . . 179

83. Rights and Duties of Parents towards Children . . 180

\section{CHAPTER VII.}

Dissolution of Marriage Status by Divorce . . . 182 $\S 84$. Causes for Divorce . . . . . . . . . . . . 182

85. Proceedings in Personam and in Rem distinguished . 184 
PAGH

§ 86. Exterritorial Effect of Foreign Judgments and Decrees 186

87. Divorce Causes, Proceedings Quasi in Rem . . . 190

88. The Res in Divorce Causes . . . . . . . . . 191

89. Exterritorial Effect of Divorce - Both Parties Domiciled

in State of Divorce . . . . . . . . . . 195

90. Neither Party Domiciled in State of Divorce . . . 197

91. Only one of the Parties Domiciled in State of Divorce . 200

92. First Theory - Jurisdiction over one Party confers Jurisdiction over the other also . . . . . . 203

93. Second Theory - Divorce, a Proceeding in Personam . 204

94. Third Theory - Divorce neither in Rem nor in Personam, but Quasi in Rem - Requires Best Notification practicable to Non-resident Defendant . . . . 205

95. Exterritorial Effect of Divorce, as respects Costs and Alimony . . . . . . . . . . . 207

96. Exterritorial Effect of Decree for Custody of Minor

Children . . . . . . . . . 208

\section{CHAPTER VIII.}

Status of Legitimacy and Adoption . . . . . . . 211

§ 97. Legitimacy and Adoption Instances of Double Status . 211

98. Legitimacy - Child Born in Wedlock . . . . . . 213

99. Subsequent Legitimation - Intermarriage of Parents of Infant Bastard . . . . . . . . . . . 215

100. Bastard an Adult when Parents Marry - No Intermarriage of Parents . . . . . . . . . . 218

101. Legal Status of Adoption . . . . . . . . 221

\section{CHAPTER IX.}

Status of Fiductaries . . . . . . . . . . . . 224

$\S$ 102. Dual Nature of Fiduciary Status . . . . . . 224

103. Illustrations - Various Classes of Fiduciaries . . . 225

104. Executors and Administrators - Outline of Discussion 228

105. Appointment and Qualification of Administrators and Executors . . . . . . . . . . . . . 229

106. Incidents of Status of Personal Representatives Their Rights and Liabilities in General . . . 232

107. Suits by and against Personal Representatives . . . 235 
§ 108. Right of Foreign Representative to Sue for Decedent's Death by Wrongful Act . . . . . . . . . . 238

109. Voluntary Payment of Debts to Foreign Representative . . . . . . . . . . . . . . . . 242

110. Order of Payment of Decedent's Debts - Marshalling of Assets . . . . . . . . . . . . . . . 243

111. Right of Creditor to Subject Decedent's Land in Hands of the Heir . . . . . . . . . . . . . . 245

112. Exoneration of Realty out of Personalty, and vice versa - Contribution between Heirs or Devisees - 247

113. Termination of Status of Executors or Administrators - Auxiliary or Ancillary Administrations . . . 253

114. Status of Guardians . . . . . . . . . . . 257

115. Status of Guardian with respect to Ward's Person . . 258

116. Status of Guardian with respect to Ward's Property . 261

117. Status of Receivers - In General . . . . . . 263

118. Suits by and against Receivers . . . . . . . 266

\section{PART IV.}

SITUS OF PERSONAL PROPERTY.

§ 119. Preliminary - Outline of Discussion . . . . . 268

\section{CHAPTER X.}

Situs of Chattels and of Debts . . . . . . . . . 270

$\S 120$. Legal and Actual Situs of Tangible Chattels. . . . 270

121. Legal and Actual Situs of Debts . . . . . . . . 274

122. Situs of Debt for Purposes of Voluntary Transfer . . 278

123. Situs of Debt for Purpose of Taxation . . . . . . 281

124. Situs of Debt for Purpose of Administration . . . . 283

125. Situs of Debt for Purpose of Attachment and Garnishment . . . . . . . . . . . . . . 285

126. Same - Exemptions. . . . . . . . . 290 


\section{CHAPTER XI.}

Voluntary Trangfers of Personalty Inter Vivos . . 292

$\S$ 127. Preliminary - Various Kinds of Transfer . . . . 292

128. Absolute Conveyances and Executed Sales of Personalty 293

129. Same - As to Third Persons . . . . . . . . . 297

130. Sale of Personalty, with Reservation of Title in Vendor 300

131. Donations Mortis Causa . . . . . . . . 303

132. Chattel Mortgages - Liens upon Personalty . . . . 304

133. Voluntary Assignments for Benefit of Creditors -

General Principles . . . . . . . . . . 309

134. What Creditors may Attack a Voluntary Assignment. 312

135. Policy of the Forum . . . . . . . . . 316

\section{CHAPTER XII.}

Involuntary Trangfers of Personalty Inter Vivos • 319

$\S 136$. Transfers by Marriage . . . . . . . . . . . 319

137. Involuntary Assignments in Bankruptcy or Insolvency 320

138. Creditors for whose Benefit Assignment disregarded . 324

CHAPTER XIII.

Transfer by Succession . . . . . . . . . . . 327

$\S 139$. Titles of Administrator and Distributee distinguished 327

140. Persons to Take as Distributees - Capacity of Distributees to Take . . . . . . . . . . 328

141. Shares of Distributees . . . . . . . . 331

\section{CHAPTER XIV.}

Transfers of Personalty by Will . . . . . . 332

$\S$ 142. Transfer by Will, Involuntary . . . . . . . . 332

143. Formal Validity of Wills of Personalty . . . . . 333

144. Substantial Validity of the Provisions of the Will . . 335

145. Interpretation of the Will . . . . . . . . . . 338

146. Same - Beneficiaries - Property Disposed of . . . 341

147. Same - Lapse - Electiou . . . . . . . . . . 343

148. Same - Change of Domicil after Execution of Will - 347

149. Revocation of Wills . . . . . . . . . . . 349

150. Wills in the Exercise of a Power of Appointment . . 351 


\section{PART V.}

\section{SITUS OF CON'TRACTS.}

8 151. Contractual Liabilities Transitory - Proper Law to determine Existence of Contract . . . . . . 355

152. Applications of General Exceptions to Foreign Law somewhat restricted in Case of Executory Contracts

\section{CHAPTER XV.}

Locus Conrractus . . . . . . . . . . . . 360

\$153. Conflicting Views as to Situs of Contract . . . . . 360

154. True View - Locus Contractus not necessarily a Single Place, but may consist of One Place for One Purpose, and Another Place for Another Purpose . . 363

155. Three Leading Elements in every Contract - Each may have a Separate Situs . . . . . . . . 367

156. The Various Incidents or Qualities of Contracts . 369

\section{CHAPTER XVI.}

Locus Celebrationis; Locus Solutionis; and Locus CoNSIDERATIONIS . . . . . . . . . 371

$\S 157$. Locus Celebrationis - Place where Contract becomes finally Binding . . . . . . . . . . . 371

158. Same - Contracts of Agents . . . . . . . . 374

159. Locus Solutionis - Optional with the Parties - No Place of Performance named . . . . . . 377

160. Same - Several Places of Performance . . . . 380

161. Locus Considerationis . . . . . . . . . . 382

162. Same - Considerations Executed and Executory . . 385

163. Situs of Particular Contracts - Contracts to Pay

Money . . . . . . . . . . . . . 388

164. Negotiable Instruments - Contract of Maker or Acceptor . . . . . . . . . . . . . . . 391

165. Indorser's or Drawer's Contract . . . . . . . 392

166. Situs of Insurance Contracts . . . . . . . 398 


\section{CHAPTER XVII.}

$\S 167$. Preliminary . . . . . . . . . . . . . . 401

168. Contracts Prohibited to be entered into - In General

- Lex Loci Celebrationis . . . . . . . . . 402

169. Same - Exemptions in Bills of Lading . . . . . 405

170. Same - Insurance Contracts . . . . . . . . . 407

171. Capacity to Contract - Lex Loci Celebrationis . . . 409

172. Formal Validity of Contracts - Lex Celebrationis -

Marriages - Stamps . . . . . . . . . . . 410

173. Same - Contracts in Writing - Statute of Frauds - 413

174. Same - Contracts for the Sale of Land . . . . . 415

175. Performance of Contract Probibited - Lex Loci Solutionis . . . . . . . . . . . . . . . . 418

176. Validity of Consideration - Lex Loci Considerationis

- Executory Consideration . . . . . . . . . 421

177. Executed Considerations - Sufficiency of Consideration . . . . . . . . . . . . . . . . 424

178. Same - Legality of Consideration . . . . . . 427

179. Usurious Considerations . . . . . . . . . . 429

\section{CHAPTER XVIII.}

Obligation and Interpretation of Contracts . . . 438

$\S 180$. Obligation of a Contract . . . . . . . . . . 438

181. Obligation of Contract dependent upon Intention of

Parties . . . . . . . . . . . . . 440

182. Negotiable Instruments - Maker's or Acceptor's Contract . . . . . . . . . . . . . . . . 446

183. Same - Obligation of Drawer's or Indorser's Contract 450

184. Obligation to Pay Interest. . . . . . . . . . 454

185. Covenants and Contracts touching Land . . . . 457

186. Interpretation of Contracts . . . . . . . 459

CHAPTER XIX.

Discharge of Contracts . . . . . . . . . . 464

$\S 187$. Various Sorts of Discharge . . . . . . . . . 464

188. Discharge by Actual Performance or Tender. . . . 464 
\$ 189. Discharge by Substituted Agreement . . . . 467

190. Discharge by Operation of Law - In General . . . 469

191. Same - Discharge in Bankruptcy . . . . . . 470

\section{PART VI.}

\section{SITUS OF TORTS AND CRIMES.}

\section{CHAPTER XX.}

Situs of Torts . . . . . . . . . . . . . . . 475

§ 192. Local and Transitory Actions. . . . . . . . 475

193. Torts, Common Law and Statutory . • • • . 477

194. Exceptions to Operation of Lex Loci Delicti . . . 479

195. Situs of Tort or Locus Delicti . . . . . . . 481

196. Law governing Torts in General . . . . . . . 484

197. Defenses to Actions for Tort . . . . . . . . 485

198. Damages - Compensatory, Punitive, and Penal . . 488

199. Statutory Torts - Death by Wrongful Act . . . . 490

200. Death by Wrongful Act - Increasing Liberality of the

Courts . . . . . . . . . . . . 491

201. Same - Proper Plaintiff . . . . . . . . 493

202. Same - Other Conditions of Suit . • . . . . 495

\section{CHAPTER XXI.}

Situs of Crimes. . . . . . . . . . . . . 497

§ 203. Crimes generally Local, not Transitory . . . . 497

204. Situs of Crimes . . . . . . . . . . 498

\section{PART VII.}

\section{SITUS OF REMEDIES.}

\section{CHAPTER XXII.}

Bitus of Remedies. . . . . . . . . . . . 505

$\S 205$. Nature of the Remedy - Form of the Action . . . 505

206. Modes of Procedure - Parties to the Suit . . . 509 
PAar

$\S 207$. Process, Pleadings, and Rules of Practice . . . . 510

208. Admissibility of Evidence - Presumptions of Law -

Incidents of the Trial . . . . . . . 513

209. Exemptions . . . . . . . . . . . 516

210. Certain Defenses, Matters of Remedy - Statute of

Limitations - Statute of Frauds. . . . . . 521

211. Set-offs aud Counter-claims . . . . . . . 525

\section{PART VIII.}

\section{PLEADING AND PROOF OF FOREIGN LAWS.}

\section{CHAPTER XXIII.}

Pleading and Proof of Foreign laws . . . . . . . 527

$\S 212$. Foreign Laws must be Specially Pleaded . . . . 527

213. Proof of Foreign Laws . . . . . . . . . 528

214. Presumptions as to Foreign Laws . . . . . 530

INDEX . . . . . . . . . , , 535 



\title{
T A B L E O F CA S E.
}

\author{
[REFERENCES ARE TO PAGES.]
}

Abberger $v$. Marrin (Mabs.) . . . . . . . . • 295, 428 Abington $v$. N. Bridgewater (Mass.) . . . . . . 62, 64, 67, 69, 70 Abshire $v$. Corey (Ind.) . . . . . . . . . . . . 467 Abt $v$. Bank (Ill.) . . . . . . . . . . . . 397, 443, 445 Adams $v$. Adaus (Mass.) . . . . . . . 133, 197, 212, 213, 340 v. Palmer (Me.) . . . . . . . . . . . . 160, 173 v. People (N. Y.) . . . . . . . . . . . . . . . . 499 v. R. R. Co. (Vt.) . . . . . . . . . . . 24, 480,489 Aikman v. Aikman (Eng.) . . . . . . . . . . 216, 217 Akers $v$. Demond (Mass.) - . . 18, 368, 372, 379, 388, 428, 433, 434, 436 Alabama, etc. R. R. Co. v. Carroll (Ala.) . . . . . . 407, 482, 487 Albee $v$. Albee (Ill.) . . . . . . . . . . . . . . . . . 499 Alezander $v$. R. R. Co. (Ohio) : . . . . . . . . 407, 487, 530

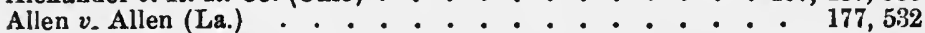
v. R. R. Co. (Ia.) . . . . . . . . . . . . . 267 v. Thomason (Tenn.) . . . . . . . . . $85,84,128$ Alley v. Caspari (Me.) . . . . . . . . . . . 186, 265 Allgood $v$. Williams (Ala.) - . $59,65,67,69,70,72,79,80,81,82,93,109$, $115,117,125$

Allshouse $v$. Ramsay (Penn.) . . . . . . . . . . . . . 467 Ambler v. Whipple (Ill.) . . . . . . . . . . . . . . . 522 American Coal Co. v. Allegheny Co. (Md.) . . . . . . . . 282 American Insurance Co. $v$. Hettler (Neb.) . . . . . . 277, 290 American Mortgage Co. v. Jefferson (Miss.) . . . . . 18, $379,380,431$ v. Sewell (Ala.) . . . . . . . . . . . . 363, 431, 434 American Oak Leather Co. v. Bank (Utah) . . . . . . . . 532 Ames $v$. McCamber (Mass.) . . . . . . . . . . . . . . . 530 Ames Iron Works $v$. Warren (Ind.) . . . - . 44, 271, 272, 304, 307 Anderson $v$. Anderson (Vt.) . . . . . . . . . . . . . . . 109 v. Laneuville (Eng.) . . . . . . . . . . . . . . . 114 v. R. R. Co. (Wis.) . . . . . . . . . . . . . 492 Andrews $v$. Avory (Va.) . . . . . . . . . . . . 232, 233 v. Herriot (N. Y.) . . . . . . . . . . . . 506,507 v. Pond (U. S.) . . . . . . . . . . . . . . 433

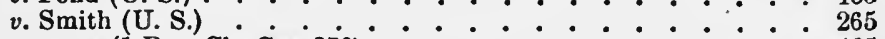
Anonymous (1 Bro. Ch. Cas. 376) . . . . . . . . . . . . . 465 (9 Mod. 66) . . . . . . . . . . . 249, 250 Anstruther $v$. Chalmer (Eng.) . . . . . . . $339,340,344,349$ Antelope, The (U. S.) . . . . . . . . . . . . . . 21 Anthony $v$. Rice (Mo.) Applegate v. Smith (Mo.) . . . . . . . . . . . . . . 341 Arayo v. Currell (La.) . . . . . . . . . . . . . 374, 377 Arbuckle $v$. Reaume (Mich.) ........... 18, 403, 104 
Armistead $v$. Blytlie (Miss.)

Armstrong v. Best (N. C.) . . . 10, 13, 49, 133, 144, 146, 147, 148, 372

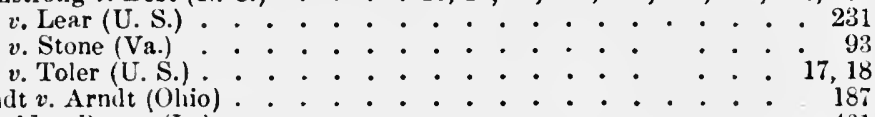

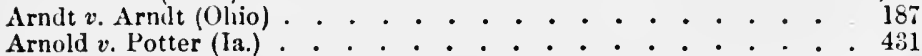

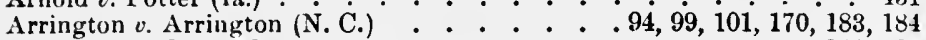

Asl v. R. R. Co. (IId.) . . . . . . . . . . . . . . 241, 492

Askew $v$. Bank (Mo.) . . . . . . . . . . . . . . . 279, 312, 316

Atchison ". Lindsey (Ky.) . . . . . . . . . . . . . 227, 236, 328

Atchison, etc. R. R. Co. v. Betts (Colo.) . . . . . . . . . 479,532

v. Nlaggard (Colo.) . . . . . . . . . . 287, 516

Athertun Co. $v$. Ives (U. S.) ${ }^{\circ} \dot{8}, 13,15,16,49,254,310,314,315,316,317$

Atlantic Phosphate Co. $v$. Ely (Ga.) . . . . . . . 373, 429

Attorney General v. Bouwens (Eng.) . . . . . . . . . . . 280

v. Dimond (Eng.) . . . . . . . . . . . . . . . . 280

v. Hope (Eng.) . . . . . . . . . . . . . . 280

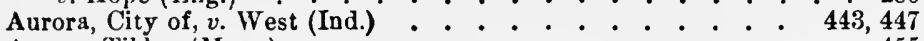

Ayer $v$. Tilden (Mass.) . . . . . . . . . . . . . . . 450

v. Weeks (N. H.) . . . . . .

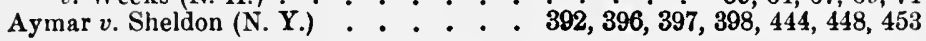

Backhouse v. Selden (Va.) . . . . . . . . . . . . . 434

Bacon $v$. Horne (Penn.) . . . . . . . . . . . . . 16, 314

Baetjer v. La Compagnie (U. S.) . . . . . . . . . 381,406

Bagby v. R. R. Co. (Penn.) . . . . . . . . . . . . . . 16

Bailey $v$. Maguire (U. S.) . . . . . . . . . . . . . 529

Baldwin v. Gray (La.) . . . . . . . . . . . 13, 375,446

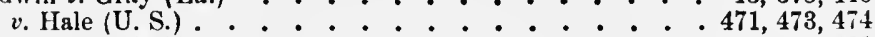

Balfour $v$. Davis (Or.) . . . . . . . . . . . . . . . . 430 v. Scott (Eng.) . . . . . . . . . . . . . 346

Balme $v$. Wombough (N. Y.) - . . . . . . . . . . . . . 434

Baltimore $v$. Hussey (Md.) . . . . . . . . . . . . . . . . 281

Baltimore \& Ohio R. R. Co. v. Glenn (Md.) . . . . . . 130,318 v. Konontz (U.S.) . . . . . . . . . . . . . . . . 130

Bank v. Balcom (Conn.) . . . . . . . . . . . . . . 71, 128

v. Bleecker (Minn.) . . . . . . . . . . . . . . . 288

v. Davidson (Or.) . . . . . . . . . . . . . . . . . 362

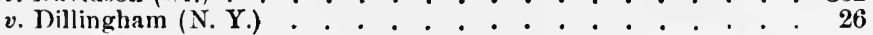

v. Domually (U. S.) . . . . . . . . . . . 505, 506, 513, 522

v. Farle (U.S.) . . . . . . . . . . . . . . . 130,510

v. Ellis (Mass.) . . . . . . . . . . : . . . . . 26

v. Griswold (N. Y.)

v. Hall (Penn.) . . . . . . . . . . . . . . . . 419,445

v. Hartwell (Ala.). . . . . . . . . . . . . $39,145,272,298$

v. IIjll (Tenn.) . . . . . . . . . . . . . .44,45, 304, 307

v. Ifowell (N. C.) . . . . . . . . . . . . . . . . 145, 147

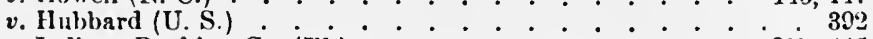

v. Indiana Banking Co. (Ill.) . . . . . . . . . . . . 397, 445

v. Lacombe (N. Y.) . 15, 16, 17, 254, 315, 322, 325, 326, 368, 396, 397,

v. Lee (U. S.) . . . . . . . . . . . . . . 43, 44, 299, 307

v. Low (N. Y.) . . . . . . . . . 371, 373, 389, 434, 436

v. Motherwell Co. (Tenn.) . . . . . . . . . . . 326

๖. National Bank (U. S.) . . . . . . . . . . 280,297 
[References are to Pages.]

Bank v. Nav. Co. (Eng.) . . . . . . . . . . . . . . . . . 368

v. Norwalk (Conn.) . . . . . . . . . . . . . 467

v. Porter (Conn.) . . . . . . . . . . 466, 467, 513, 526

v. Price (Md.) . . . . . . . . . . . . . . . . 22

v. R. R. Co. (Wis.) . . . . . . . . . . . . 516

v. Richmond (Va.) . . . . . . . . . . . . . 281, 283

v. Rindge (Mass.) . . . . . . . . . . . . . 27

v. Rindge (U. S.) . . . . . . . . . . . . . . 27

$v$. Robinson (Conn.) . . . . . . . . . . . . 475, 476

v. Shaw (N. Y.) . . . . . . . . . . . . 462

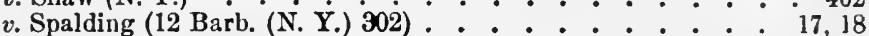

v. Spalding (9 N. Y. 53) . . . . . . . . . . . . 294, 419

v. State (Tenn.) . . . . . . . . . . . . . . 282

v. Stellings (S. C.)

$v$. Sutton (U. S.) . . . . . . . . . . . . . . 391

v. Talbot (Mass.) . . . . . . . . 414, 451, 506, 514, 525

$v$. Trimble (Ky.) . . . . . . . . . . . . 526

v. Walker (Conn.) . . . . . . . . $16,279,314,316$

v. Wells (Mass.) . . . . . . . . . . . . . . 392

v. Williams (Miss.) . . . . . . . . . . . . 17, 38, 247

v. Wood (Mass.) . . . . . . . . . . . . 371

Barber $v$. Barber (U. S.) - . . . . . 94, 95, 96, 97, 98, 99, 104, 207

v. Root (Mass.). . . . . . . . . . . 38, 195, 198

Barker $v$. Brown (Ky.) v. Stacy (Miss.) . . . . . . . . . 43, 44, 304, 307

Barnett $v$. Kinney (U. S.) : : . $10,13,16,49,271,310,313,314,317$

Barney $v$. Pattersou (Md.) . . . . . . . . . . . . . 188

Barnum v. Barnum (Md.) . . . . . . . . . . . . . . . 135

Barrera $v$. Alpuente (La.) . . . . . . . . . . 141, 143

Barrett v. Dodge (R. I.) • . . . . . . . 371, 378, 389, 444, 447

Barter $v$. Wheeler (N. H.) . . . . . . . . . . . . . 381

Barth v. Backus (N. Y.) - : $16,272,310,311,314,315,320,322,324,325$

v. Furnace Co. (Ill.) . . . . . . . . . . . . . . 510

Barton $v$. Barbour (U. S.) . . . . . . . . . . . . . . . 267

Bartsch v. Atwater (Conn.) . . . . . . . . . . . . . . . . 469

Bascom $v$. Zediker (Neb.)

Bath Gaslight Co. $v$. Claffy (N. Y.) :

Baum v. Birchall (Penn.) . . . . . 146, 147, 372, 373, 374, 388, 443

Bauserman v. Charlott (Kan.) . . . . . . . . . . . 190,522

Baxter $v$. Willey (Vt.) . . . . . . . . . . . . . . 36, 37

Baxter, etc. Bank $v$. Talbot (Mass.) . . . . 4 414, 451, 506, 514, 525

Beach v. R. R. Co. (N. Y.) . . . . . . . . . . . . . . . 491

Beal $v$. State (Ind.) . . . . . . . . . . . . . . . . 503

Bearce v. Barstow (Mass.) . . . . . . . . . . . . . . . . 430

Behrensmeyer $v$. Kreitz (Ill.) . . . . . . . . . . . . . . . 120

Belknap Sav. Bank $v$. Robinson (Conn.) - . . . . . : 475,476

Bell $v$. Kennedy (Eng.) . . . . . . . . . . . . . . . 119, 124

v. Morrison (U. S.) . . . . . . . . . . . . . . 522

v. Packard (Me.) . . 144, 146, 147, 363, 371, 372, 373, 378, 380, 388

Belt v. R. R. Co. (Tex.) . . . . . . . . . . . 487,492

Bempde $v$. Johnstone (Eng.) . . . . . . . . . . . . 73, 109, 124

Benbow $v$. Moore (N. C.) . . . . . . . . . . . . . . . . 531

Bennett $v$. B. \& L. Association (Penn.) : 433

Bentley $v$. Whittemore (N. J.). . . . $13,14,15,311,312,313,316,317$

Berrien $v$. Wright (N. Y.) •. . . . . . . . . . . 434, 436

Berry $v$. Davis (Tex.) . . . . . . . . . . . . . 277. 288 
[References aro to Pages.]

Besse v. Pellochoux (Ill.)

175,177

Bethell v. Bethell (Ind.)

$\dot{32}, 33,37,377,457$

Bettys $v$. R. R. Co. (Wis.)

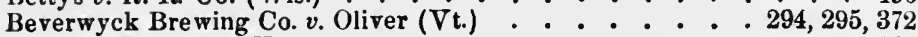

Bevier v. Covell (N. Y.) . . . . . . . . . . . . . . . 430

Bible Society $v$. Pendleton (W. Va.) . . . . . . . . 40, 335, 337

Bigelow $v$. Burnham (Ia.) . . . . . . . . . . . . 432

Bingham's Appeal (Penn.) . . . . . . . . . . . . 235, 352, 354

Birdseye $v$. Underhill (Ga.) . . . . . . . . . . . . 279, 318

Birtwhistle $v$. Vardill (Eng.) . . . . . . . . 33, 34, 35, 133, 216

Black $v$. Zacharie (U. S.) . . . . . . . 272, 278, 280, 293, 312

Blackinton $v$. Blackinton (Mass.) . . . 8, 97, 98, 101, 173, 180, 191, 207

Blackwell $v$. Webster (U. S.) . . . . . . . . . 404, 420, 422

Blake $v$. Williams (Mass.) . . . . . . . . . . . 280, 322, 325

Bloomer $v$. Bloomer (N. Y.) . . . • . • . . . • . . . 349

Blythe $v$. Ayres (Cal.). . . . . . 75, 76, 84, 85, 91, 92, 133, 216, 220

Boehme $v$. Rall (N. J.) . . . . . . . . . . 32, 130, 300, 304

Booth v. Clark (U. S.) . . . . - . - 263, 264, 266, 267, 321, 322

Bootliby $v$. Plaisted (N. H.) . . . . . . . . . . 294, 295, 284, 428

Borden $v$. Fitch (N. Y.) . . . . . . . . . . . . 103, 104

Borland $v$. Boston (Mass.). . . . . . . . . . . 67, 70, 71, 118, 281

Boston Investment Co. $v$. Boston (Mass.) . . . . . . . . 130

Botany Worsted Mills v. Knott (U. S.). . . . . . . 365, 406

Boulware $v$. Davis (Ala.) . • . . . . . . . . 264, 266, 267

Bowditch $v$. Saltyk (Mass.) . . . . . . . . . . . . . 340

Bowen v. Newell (N. Y.) . . . . . . . . . . . . . . . 448

Bowersox v. Gill (Penn.) . . . . . : : : : 190

Bowles $v$. Field (U. S.) - . . . . i0, 11, 3i, 49, 147, 411, 428, 514

Bowman v. Miller (Va.) . . . . . . . . . . . 433, 434, 436

Boyce $v$. R. R. Co. (Ia.) . . . . . . . . . . . 22

Boyd $v$. Selma (Ala.) . . . . . . . . . . . . . . 283

Boykin v. Edwards (Ala.) . . . . . . . . . . . . . 516

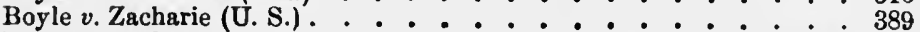

Brabston $v$. Gibson (U. S.) . . . . . . . . . . $893,443,447$

Bradlaugh $v$. De Rin (Eng.) . . . . . . . . . . . . . 393, 394

Bradley $v$. Bander (Ohio). •. . . . . . . . . . . 281, 282

Bragg v. Gaynor (Wis.) . . . . . . . . . . 288, 289

Brantford City, The (U. S.). : : : $356,362,365,406,428,484$

Braver v. Compagnia (U. S.) . . . . . . . . . . 363

Breitung, In re (Wis.). . . . . . . . . . : . : 4399400

Bridger v. R. R. Co. (S. C.) . . . . : . : : : . 486

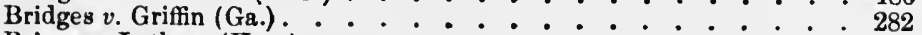

Briggs $v$. Lathan (Kan.) : . . . . . . : $378,394,397,442,452$

Brockway $v$. Express Co. (Mass.) . . . . . . . . . . . 406

Brodie v. Barry (Eng.) . . . . . . . . . . 248, 257, 346

Bronson v. Lumber Co. (Minn.) : . : : . : $: 29,33,515$

Brook $v$. Brook (Eng.). . . . . . . . . . . . 149, 152, 154, 163 v. Van Nest (N.J.) : . . : . : : : : . : 393,394

Brooke $v$. R. R. Co. (Penn.) . . . . . : . . . . . 375

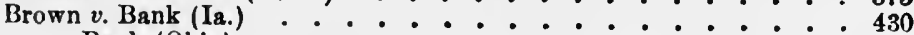

v. Bank (Ohio) . . . . . . . . . . . . . . . 36,37

v. Brown (Eng.)

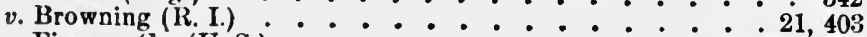

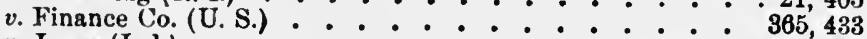

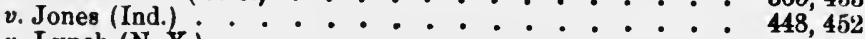

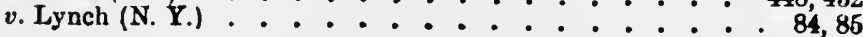


[References are to Rages.]

Brown v. R. R. Co. (Penn.) . . . . . . . . . . . . . . 381 v. Richardson (La.) . . . . . . . . . . . . 247

v. Wright (Ark.) . . . . . . . . . . . . . . 531, 532

Bruce v. Bruce (Eng.) . . . . . . . . 68, 73, 119, 120, 124, 328, 331 v. 1. R. Co. (Ky.) . . . . . . . . . . . 25, 241

Brunel v. Brunel (Eng.) . . . . . . . . . . . . . . . 118

Bryan v. Brisbin (Mo.) . . . . . . . . . . . . . . 316

Bryant $v$. Edson (Vt.) . . . . . . . . . . $373,378,389,448$

Buchanan v. Bank (U. S.) . . . . . . . . . . . . 372, 433, 436

v. Hubbard (Ind.) . . . . . . . . . . . . 531, 532

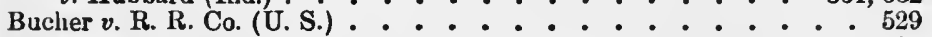

Buck v. Miller (Ind.) . . . . . . . . . . . . . . . 281

Bucy v. R. R. Co. (Miss.) . . . . . . . . . . . . 287

Building \& L. Ass'n v. Logan (U. S.) . . . . . . . . . . . 431

Bull $v$. Conroe (Wis.) . . . . . . . . . . . . 517

Bullock v. Bullock (N. J.) : : : : : : : : 207,512

Burbank v. Payne (La.) . : . : . : : : : : 225, 233

Burchard v. Dunbar (Ill.) . . . . . . . . . 505, 506, 507

Burgett v. Williford (Ark.) . . . . . . . . . . . 522

Burlen $v$. Shannon (Mass.) : . . . . . - 99, 103, 195, 206

Burlington, etc. R. R. Co. v. Thompson (Kan.) • • • . . 290, 516, 519

Burlington University $v$. Barrett (Ia.) . . . . . . . . . 334

Burnett $v$. R. R. Co. (Penn.) - . . . . . . . . 381, 406,411

Burns v. R. R. Co. (Ind.). . . . . . . . . . . 25, 241, 492

Burtis v. Burtis (Mass.) . . . . . . . . . 94, 95, 97, 101

Butler v. Washington (La.) - . - . . . 190, 201

ข. Wendell (Mich.)

Byers v. McAuley (U.S.) •. . . . . . . . 228, 265, 274

CaGill v. Woodridge (Tenn.) . . . . . . . . 44, 45, 264, 265, 268

Caledonia Insurance Co. v. Wenar (Tex.) . . . . . . . . 287

Calloway v. Bryan (N. C.) . . . . . . . . . 156

Cameron v. Watson (Mirs.) . . . . . . $40,137,139,334$

Campbell v. Coon (N. Y.) • . . • . . • . • • . . . 459 v. Crampton (U. S.) 146, 148, 149, 150, 160, 163, 166, 169, 410, 411, 412

v. Tousey (N. Y.). . . . . . . . 229, 231, 232, 243

Canadian Pac. R. R. Co. v. Johnson (U.S.) . . . . . . . . 524

Capper's Will, In re (Ia.) • . . . . . . . . . . . 528

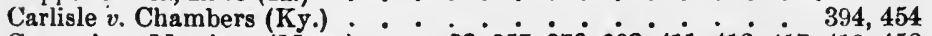

Carnegie $v$. Morrison (Mass.) : . $32,357,376,392,411,412,417,419,458$

Carnegie Steel Co. v. Construction Co. (Tenn.). - 372, 388, 394, 396, 452

Carpenter v. Bell (Tenn.). . . . . . . . . . 29, 32, 136, 333 v. R. R. Co. (Me.). . . . . . . . . . . . . . 532

v. Strange (U. S.) . . . . . . . . . . . . . . . . 188

Carr, Ex parte (Kan.) . . . . . . . . . . . . . . . . 501

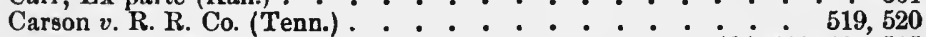
v. Smith (Mo.) . . . . . . . . . . . 484, 488, 489, 515

Carter v. Goode (Ark.) . . . . . . . . . . . . . . 479,480

Case v. Dodge (R. I.) . . . . . . . . . . . 10, 11, 147

Cassidy, Succession of (La.) . . . . . . 30, 33, 37, 457, 458

Castro v. Illies (Tex.) . . . . . . . . 175, 177, 178, 179, 180

Catlin $v$. Silver Plate Co. (Ind.) : : $13,16,46,263,264,266,267,268$

Caulfield $v$. Sullivan (N. Y.) . . . . . . . . . . 340, 341

Cavanaugh $v$. Nav. Co. (N. Y.) . . . . . . . . 4 481, 495, 524

Central Trust Co. v. Burton (Wis.) . : . . . . . . 390, 431, 434 v. R. R. Co. (U. S.) • : : : : : : . . 287 
Chafee v. Bank (Me.; . . . . 13, 15, 31, 130, 311, 312, 314, 315, 317, 325 Chamberlain $v$. Chamberlain (N. Y.) $40,130,137,139,140,334,335,337,338$ v. Napier (Eng.)

Chambers v. Church (R. I.) . . . . . . . . . . . 419,420

Champon v. Champon (La.) . . . . . . . . . . 94, 98, 177, 201

Chapman v. Chapman (Ill.) . . . . . . . . 96, 98, 99, 100, 101, 184 v. Chapman (Kan.) •. . . . . . . . . . . . . 198 v. Robertson (N. Y.) - : $\quad 31,39,362,363,378,389,390,431,432$

Charlestown $v$. Boston (Mass.) . . . . . . . . . . . 87, 93 Chartered Bank of India $v$. Nav. Co. (Eng.) . . . . . . . . . . 363

Chase v. Chase (Mass.) • • . . . . . . . . . . 170, 198 v. Henry (Mass.) . . . . . . . . . . . . . 472

Cheely $v$. Clayton (U. S.) . . . . . . . . . • 94, 99, 195

Cheever v. Wilson (U. S.) . . . . . . . . 95, 96, 99, 101, 190, 196

Chenery 2 . Waltham (Mass.) . . . . . . . . . . . . 123

Chicago, etc. R. R. Co. v. Ferry Co. (U. S.) . . . . . . . . . 528

v. Moore (Neb.) . . . . . . . . . . . 520

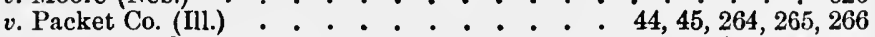

v. Sturm (U. S.) . . • • . . . . . . . . $289,290,521$

China Mutual Ins. Co. $v$. Force (N. Y.). . . . . . . . . . 187

Chipman $v$. Peabody (Mass.) . . . . . . . . . . . 29, 30, 321

Chitty v. Chitty (N. C.) •. . . . . . . . . . 59, 72, 111, 112

Cincinnati, H. \& D. R. R. Co. v. McMulien (Ind.) . . . .482, 485, 492

City of Aurorn $v$. West (Ind.) . . . . . . . . . . . 443, 447

City of Carlisle, The (U. S.) . . . . . . . . . . . . 514

City of Hartford $v$. Champion (Conn.) - : : $:$ 115, 117, 121, 125

Claflin v. Meyer (La.) . . . . . . . 294, 295, 296, 372, 377

Clark v. Child (Mass.) . . . . . . . . . . . . . 456

v. Clark (N. J.). . . . . . . . . . . . . 167, 168

v. Clark (Mass.) : . . . . . . . . . . . . 172, 195

v. Graham (U. S.) . . . . . . . . . . . . . 28, 33

v. Peat Co. (Conn.) . . . . . . . . . . . . . 279

v. Searight (Penn.) . . . . . . . . . . . 378

Clarke $v$. Bank (Ark.) . . . . . . . . . . . . . . . 529

Coad $v$. Home Cattle Co. (Neb.) . . . . . . . . . . 437

Cochran $v$. Benton (Ind.) . . . . . . . . . . . $22,38,247$ v. Ward (Ind.) . . . . . . . . . $416,418,457,525$

Cockle $v$. Flack (U. S.) . . . . . . . . . . . . . . . . 431

Codman $v$. Krell (Mass.) . . . . . . . . . . . . . 296, 339, 340

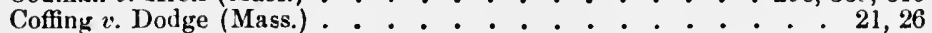

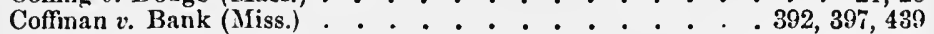

Coghlan $v$. R. R. Co. (U. S.). . . . . . . . . . 363, 390, 455, 456

Colburn v. Colburn (Mich.) . . . . . . . . . . . . . 111, 183, 184 v. Holland (S. C.) . . . . . . . . . . . 73, 95, 96, 120

Cole $v$. Cunningham (U. S.) . . . . 13, 16, 49, 267, 311, 314, 324, 325, 326

Collins $v$. Collins (N. Y.) . . . . . . . . . . 160, 204

Columbian Government $v$. Rothschild (Eng.) . . . . . . . . . 510

Commercial Bank $v$. Davidson (Or.) . . . . . . . . . . . . 362 v. Motherwell Co. (Tenn.) . . . . . . . . . . . . 326

v. R. R. Co. (Wis.) . . . . . . . . . . 516

Commonwenltli $v$. Andrews (Mass.) . . . . . . . . . . 502

v. Aves (Mass.) . . . . . . . . . . . . . . 21

v. Bassford (N. Y.) . . . . . . . . . 47, 423, 424, 428

v. Blanding (Mass.) . . . . . . . . . . . . 502

v. Chiovaro (Mass.) . . . . . . . . . . . . . 501

v. Gaines (Ky.) . . . . . . . . . . . . . . 281 
[References are to Pages.]

Commonwealth $v$. Graham (Mass.) . . . . . . . 87, 93, 167, 531

v. Green (Mass.) . . . . . . . . . . . . $21,22,24$

v. Kunzmann (Penn.) . . . . . . . . . . . . . . 497, 498

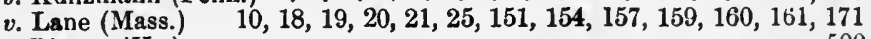

v. Linton (Va.) . . . . . . . . . . . . 500

v. Macloon (Mass.) . . . . . . . . 499, 500, 502, 503

v. Pettes (Mass.) . . . . . . . . . . . . . . . 501

v. Putnam (Mass.)

r. R. R. Co.(Va.). . . . . . . . . . . . 281,282

v. Uprichard (Mass.) . . . . . . . . . . 502,503

v. Van Tuyl (Ky.) . . . . . . . . . . . . . 502

v. White (Mass.) . . . . . . . . . . . . . 502

Compton v. Bearcroft (Eng.) . . . . . . . . . . . . 167

Concord $v$. Rumney (N. H.). . . . . . . . . 105, 106, 107, 108

Connor v. Donnell (Tex.) • . . . . . . . . . . . . . . . 432

Consequa v. Fanning (N. Y.) - . . . . . . . . . . . . 455

Cook v. Cook (Wis.) . . . . 8, 95, 96, 101, 102, 163, 164, 165, 172, 201

v. Litchfield (N. Y.) . . . . . . . . . . . . 372,394

v. Moffat (U.S.) . . . . . . . . . . . 471,473, 474

v. Van Horn (Wis.) . . . . . . . . . . . . 45, 316, 318

Cooper $v$. Beers (Ill.) . . . . . . . . . . . . 64, 71, 120, 121, 328

v. Earl of Waldegrave (Eng.) . . . . . . . . . . 455

v. Reynolds (U. S.) . . . . . . . . . . . . . 207

v. Sandford (Tenn.! . . . . . . . . . . . . . 455

Corbett $v$. Littlefield (Mich.)

Cotting v. De Sartiges (R. I.) . . . . . . . . . . 352, 353, 354

Cottrell v. Cottrell (Eng.) . . . . . . . . . . . . . . 350

$\operatorname{Cox} v \cdot \operatorname{Cox}($ Ohio)

v. United States (U.S.) . . . . . . . . . . . . 390,443

Craig $v$. Gunn $\left(\mathrm{Vt}_{\mathrm{t}}\right)$ • . . . . . . . . . . . . . . . 289

v. Williams (Va.) $:-140$

Crapo $v$. Kelly (U. S.) . $14,15,44,45,271,27 \dot{3}, 274,310,311,322,324,325$

Crawford $v$. Bank (Ala.) . . . . . . . . . . . 397, 455

v. State (Miss.) . . . . . . . . . . . . 157, 158, 159

v. Wilson (N. Y.) . . . . . . . . . . 59, $64,67,69,74$

Cromwell v. County of Sac (U. S.) . . . . . . . . . 431, 456

Cronan v. Fox (N. J.) • . . . . . . . . 44, 271, 272, 274, 304, 307

Cross v. Brown (R. I.) . . . . . . . . . . . . . . . 277, 289

v. Cross (N. Y.)

v. Trust Co. (N. Y.) - 11, 12, 137, 140, 253, 272, 333, 335, 337, 338, 347

Crouch v. Dabney (Va.) . . . . . . . . . . . . 285

Crowley v. R. R. Co. (N. Y.) . . . . . . . . . . . . . 491

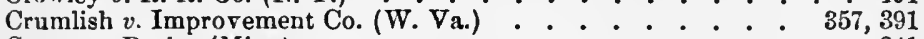

Crusoe $v$. Butler (Miss.) . . . . . . . . . . . . . . . . 341

Culver's Appeal (Conn.) . . . . . . . . . . . . . . . 106, 109

Cummington $v$. Belchertown (Mass.) - 44, 47, 98, 150, 151, 154, 162, 171 ,

196,197

Curran v. Craig (U. S.) . . . . . . . . . . . . . . 265

Curtis そ. Hutton (Eng.) . . . . . . . . . . . . . . . . 40, 140

v. Leavitt (N. Y.) . . . . . . . . . . . $378,390,434$

v. R. R. Co. (N. Y.) . * . . . . . . $362,380,381$

Cutter v. Darenport (Mass.) . . . . . . . . . . 232, 235

Cutts $v$. Haskins (Mass.) . . . . . . . . . . . . . 93

Da Conha, In re (Eng.) . . . . . . . . . . . . . . 141

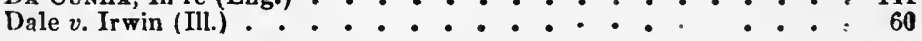


Dale v. R. R. Co. (Kan.)

$22,24,480,489$

1)alhousie $v$. M'Douall (Eng.) . . . . . . . . . 85, 216, 217

Dalpay, In re (Minn.) . . . . . . . . 16, 273, 294, 310, 312,314

Dalrymple $v$. Dalrymple (Eng.) . . . . . . . . . . . 6, 167

Dammert v. Osborn (N. Y.) . . . . . . . . 11, 140, 335, 337, 340

Daniel v. Hill (Ala.) . . . . . . . . . . . . . 88, 89

Darby $v$. Mayer (U. S.) . . . . . . . . . . . . . 28, 333

D'Arcy v. Ketchum (U. S.) . . . . . . . . . . . 189,190

Darden $v$. Wyatt (Ga.) . . . . . . . . . . . . . 86,88

Davidow $v$. R. R. Co. (U.S.) : : : : : : : : : . . 494

Davis v. Estey (Mass.)

v. Gray (U. S.) . . . . . . . . . . . . . . 267

v. Morton (Ky.) . . . . . . . . . . . . . 525

v. R. R. Co. (Wis.) . . . . . . . . . . 406

v. Williams (Miss.) . . . . . . . . . . . . . 299

Davison $v$. Gibson (U. S.) . . . . . . . . . . . . . 531, 532

Dawes v. Boylston (Mass.) . . . . . . . . . . 255, 285 v. Head (Mass.) . . . . : . $\quad 225,227,231,243,253,254,256$

Dawson $v$. Jay (Eng.) . . . . . . . . . . . . . . . 259

Dealy v. United States (U. S.) . . . . . . . . . . . . . . 501

Deberoise $v$. R. R. Co. (N. Y.) . . . . . . . . . . . . 490, 491

De Bonneval $v$. De Bonneral (Eng.) . . . . . . . . . . . . 111

De Brimont $v$. Penniman (U. S.) . . . . . . . . . . 180, 188

Decouche $v$. Savetier (N. Y.) . . . . . . . . . . 180, 331

Dedham $v$. Natick (Mass.) . . . . . . . . . . . . . 83,95

De Haber $v$. Queen of Portugal (Eng.) . . . . . . . . . . . 510

De Ham $v$. R. R. Co. (Tex.) . . . . . . . . . . . . 482, 482

l)ehon $v$. Foster (Mass.) . . . . . . . . . . . . . . 326

De Jarnett $v$. Harper (Mo.) . . . . - . . . . . 81, 82, 83, 93

De La Montanya $v$. De La Montanya (Cal.): $67,6 \dot{\theta}^{\circ}, 70,131,191,207,209$

De La Vega $v$. Vianna (Eng.) . . . . . . . . . . . . . 512

De Meli $v$. De Meli (N. Y.). . . . . . . . . . . 115, 124, 190, 191

Dennick $v$. R. R. Co. (U. S.) . . . . . . 25, 240, 475, 480, 492, 494

Denny $v$. Bennett (U. S.) . . . . . . . . . . . . 471, 472

v. Williams (Mass.) . . . . . . . . . . . . . . 465

Depas v. Mayo (Mo.) . . . . . . . . . . . . . . 37, 174

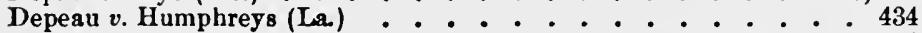

Derringer $v$. Derringer (Del.) . . . . . . . . . . . . . . 243

Desesbats $v$. Berquier (Penn.) . . . . . . . . . . . . . . . 334

Desmare $v$. United States (U. S.) . . : . - $62,67,70,72,109,125$

De Sobry $v$. De Laistre (Md.) . . . . . . . . . . 226, 243, 254

Despard v. Churchill (N. Y.) . . . . . . 10, 39, 253, 254, 255, 328, 338

De Witt $v$. Buchanan (N. Y.) . . . . . . . . . . . 475, 476

De Wolf $v$. Johnson (U. S.). . . . 389, 390, 431, 433, 436

Dial v. Gary (S. C.) - - 13, 225, 227, 229, 231, 232, 233, 234, 242, 271, 275,

Dickinson $v$. Edwards (N. Y.) . . . . . . . 362, 363, 380, 419, 432, 436 v. Hoomes (Va.) . . . . . . . . . . . . . 37, 245, 246

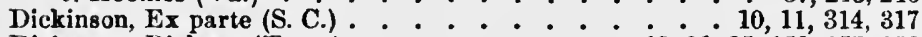

Dickson $v$. Dickson (Tenn.). . . . . . . . . 19, 21, 25, 150, 157, 158

Dike $\imath$. R. R. Co. (N. Y.) • . . . . . . . . . . 380,489

Ditson $v$. Ditson (R. I.) . . . . . . . . . . . . . 201, 203

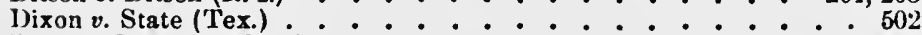

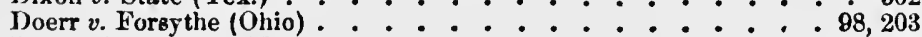

Doglioni $v$. Crispin (Eng.) . . . . . . . . . . . 333

Dolan v. Green (Mass.) 
[References are to Pages.]

Dolphin v. Robins (Eng.)

$96,97,99,104,199$

Don v. Lippmann (Eng.) . . . . . . . . . . . . . 512, 523

Don's Estate (Eng.)

- 216

Donald $v$. Hewitt (Ala.)

17,21

Donovan $v$. Pitcher (Ala.)

Doolittle $v$. Iewis (N. Y.) . . . . . . . . . . . . . . 242, 277

Dord $v$. Bonaffee (La.) . . . . . . . . . . . . . . . 372, 377

Dorsey v. Dorsey (Penn.) . . . . . . . . . . . . . . 199

v. Maury (Miss.) . . . . . . . . . . . . . . . 188

Doty $v$. Hendrix (N. Y.) • • . . . . . . . . . . . . . . 337

Dougherty $v$. Snyder (Penn.) . . . . . . . . 61, 94, 96, 146

Doughty v. Doughty (N. J.) . • . . . . . . . 191, 201, 204, 206

Douglas v. Bank (Tenn.) . - . - . . 16, 317, 818, 394, 396, 453 v. Douglas (Eng.) . . . . . . . . . 79, 89, 90, 127, 129 v. Insurance Co. (N. Y.) - . . . . . . . . . . . . 130, 287

Dow v. Blake (Ill.) . • . • . . • . . . . . . . . . . 207 v. Sudbury (Mass.) . . . . . . . . . 281

1)owner $v$. Chesebrough (Conn.) - - * $414,415,451,50 \dot{5}_{1}, 506,514,525$

Drake v. R. R. Co. (Mich.) • . . . . . . . . . . . . . 518 v. Rice (Mass.) . . . . . . . . . . . . . . 507

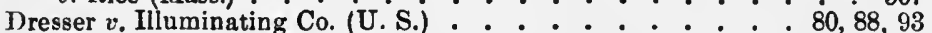

Drummond $v$. Drummond (Eng.) - . . . . . . . . . . . 248, 251

Jugan $v$. Lewis (Tex.) . . . . . . . • . . . . . . . 431

Duke of Brunswick $v$. King of Hanover (Eng.) . . . . . . . . . 510

Dumaresly v. Fishly (Ky.) . . . . . . . . . . . . . 167, 168

Duncan v. United States (U. S.) - . - . . . . . . . . 390

Dunham v. Dunham (Ill.) . . . - . . 101, 164, 191, 199, 203, 205

Dunn v. Adams (Ala.) . . . . . . . . . . . . . . 531

Dunscomb v. Bunker (Mass.) . . . . . . . . . . . . . . . 394

Dupont v. Quebec S. S. Co. (Canada) • . • . . . . . . . . . 481

Dupuy v. Wurtz (N. Y.) - . $65,67,69,70,71,72,109,114,115,117,121$,

$122,124,334$

Dutcher v. Dutcher (Wis.) • . • . • . • . . . . . . 95, 98

Dwight $v$. Boston (Mass.) - . • . . . . . . . . . . . . . 282

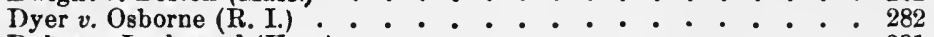

Dykes $v$. Lockwood (Kan.) • •

EAkL $v$. Dresser (Ind.) . . . . . . . . . . . . 258, 261

Earl of Winchelsea $v$. Garetty (Eng.) - . . . . . . . . 248, 249, 250

East Tenn. R. R. Co. v. Kennedy (Ala.) • . • . • . . 277, 519,520 v. Lewis (Tenn.) . . . . . • • . • . . . . . 486

Edgerly v. Bush (N. Y.) - - - i0, 14, 15, 48, 44, 272, 300, 304, 307, 484

Edwards $v$. Jones (N. C.) • . • . . . • . • . • . . . . . 188 v. Kearzey (U. S.) - . . . . . . . . . . . 439,517

Egbert v. Baker (Conn.) - . - . 13, 279, 310, 312, 313, 317, 320, 324

Elbers v. Insurance Co. (N. $\dot{\mathbf{Y}}$.) . . . . . . . . . . . . 122, 124

EIder v. Reel (Penn.) •. . . . . . . . . . . . . . . . . 204

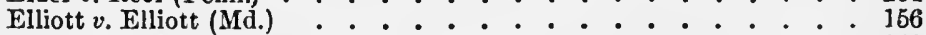
$v$. Lord Minto (Eng.)

Ellis v. Ellis (Minn.) . . . . . . . . . . . . 8, 164, 196, 198 v. White (Ia.) . . . . . . . . . . . . . . . 198

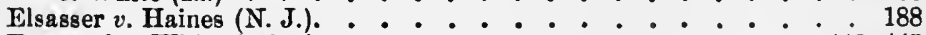

Emanuel v. White (Miss.) - . - . . . . . . . . . . 443, 447

Embry v. Millar (Ky.) •. . . . . . . . . . . . . . 233, 236

Emery $v$. Berry (N. H.) . . . . . . . . . . . . . . . . 529 v. Clough (N. H.) . . . . . . . . . . . . 271, 304 
[References are to Pages.]

Energia, The (U. S.)

379,406 Eunis $v$. Smith (U. S.)

$72,79,111,122,124,328,329,331$

Enolin $v$. Wylie (Eng.) . . . . . . . . . . . . . . 339, 340, 342

Equitable, etc. Society v. Clements (U. S.) . . . . . . . . . . 399 v. Nixon (U. S.) . . . . . . . . . . . . . . . . 398, 408 $v$. Trimble (U. S.)

398,409

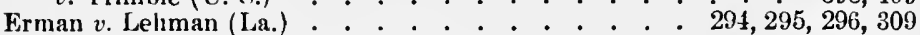

Eureka Springs Co. $v$. Timmons (Ark.) . . . . . . . . . . 580

Evans v. Cleary (Penu) . . . . . . . . . . . . . . . 508, 510

v. Tatem (Penn.) . . . . . . . . . . . . . . . . . 233, 236

Everett $v$. Vendryes (N. Y.) $\quad . \quad . \quad . \quad . \quad . \quad 392,394,396,397,398,449$

Evey $v$. R. R. Co. (U.S.) . . . . . . 475, 477, 480, 485, 488, 490, 515

lix parte Carr (Kan.) . . . . . . . . . . . . . 501

Dickinson (S. C.) . . . . . . . . . . . 10, 11, 314, 317

Kinney (U.S.). . . . . . . . . . 11, 152, 153, 497, 498

MeNeely (W. Va.) . . . . . . . . . . . 500

Picquet (Mass.) . . . . . . . . . . . . 231, 235

Rogers (Tex.) . . . . . . . . . . . . . . 501

Smitlı (U. S.) . . . . . . . . . . . . . . . . 504

Excliange Bank $v$. Hubbard (U. S.) . . . . . . . . . . . . . 352

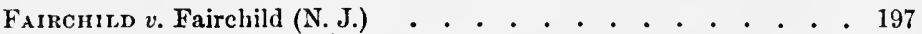

Falls . Sav. \& I. Co. (Ala.) . . . . . . . . . . . . . . . 434

Fanning $v$. Consequa (N. Y.) . . . . . . . . . . . . . . . 455

Fant $v$. Miller (Va.) . . • • • . • . . . . . 388, 394, 412,434

Farmers' Loan \& T. Co. v. Tel. Co. (N. Y.) . . . . . . . 264, 266, 267

Farmers' Nat. Bank $v$. Sutton (U. S.) . . . . . . . . . . . . 391

Faulkner $v$. Hyman (Mass.) ․ . 15, 16, 46, 61, 130, 313, 314, 315, 318

Fauton $v$. Middlebrook (Coun.) . . . . . . . . . . . 522

Faxton $v$. McCosh (Ia.) . . . . . . . . . . . . . . . . . 282

Fay $v$. Haven (Mass.) . . . . . 225, 227, 231, 233, 236, 243, 253, 255

Felch v. Bugbee (Me.) . . . . . . . . . . . . . . . . . 392

Fellows $v$. Miner (Mass.). . . . . . . . . . . . 11, 139, 336, 337

Felt v. Felt (N. J.) . . . . . . . . . . . . . . 170, 191, 206

Ferguson $v$. Craw ford (N. Y.) . . . . . . . . . . . . . . . 197

Ferris $v$. Kimble (Tex.) . . . . . . . . . . . . . . . . . 281

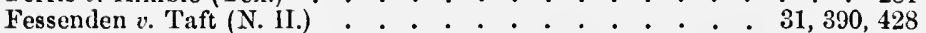

Finch $v$. York Co. (Neb.) . . . . . . . . . . . . . . . . 282

Findley $v$. Hall (Olio) . . . . . . . . . . . . . . $374,377,434$

First Nat. Bank $v$. Balcom (Conn.) . . . . . . . . . . . . . 71, 128

v. Dillingham (N. Y.) . . . . . . . . . . . . . . . . 26

v. Hall (Penn.). . . . . . . . . . . . . . . . . 419, 415

o. Price (Md.) . . . . . . . . . . . . . . . . . 22

v. Shaw (N. Y.) . . . . . . . . . . . . . . . 462

v. Walker (Conn.) . . . . . . . . . $16,279,314,316$

Firth $v$. Firth (N. J.) . . . . . . . . . . 61, 70, 74, 109, 117, 118, 139

Fisher $v$. Parry (Ind.) . . . . . . . . . . . . . . . . . 457

Fithian v. R. R. Co. (Penn.) . . . . . . . . . . . . . . 290

Flagg $v$. Baldwin (N. J.) . . . . . . . . . . $384,424,428,530$

Flannery's Will (Penn.) . . . . . . . . . . . . 231, 232, 334

Fletcher $v$. Insurance Co. (U. S.). . . . . . . . . . . 379, 398, 409

Flood $v$. Growney (Mo.) . . . . . . . . . . . . . . . . . 124

Florance's Will (N. Y.) . . . . . . . . . . . . . . . 96,98

Flower v. Flower (N. J.) . . . . . . . . . . . . . . . . 99, 206

Flukes, In re (Mo.) . . . . . . . . . . . . . . . . . . . . . . . . 521

Foley's Estate (Penn.) . . . . . . . . . . . . . 82, 93 


\section{[References are to Pages.]}

Fonseca v. Cunard S. S. Co. (Mass.) .

Furd $v$. Ford (Micli.)

v. Ford (La.)

$40,339,341$

v. Ford (Wis.)

Fosdick v. Fosdick (R. I.)

Foss $v$. Nutting (Mass.) . . . . . . . . . . . . . 510

Foster $v$. Waterman (Mass.) . . . . . . . . 92, 189, 192, 221, 223

Foute $v$. State (Tenn.) . . . . . . . . . . . . . . 501

Fowler, Appeal of (Penn.) . . . . . . . . . . . . 271, 279, 293

Fowler $v$. Bell (Tex.) . . . . . . . . . . . . . . . . . . 304

Fox v. Adams (Me.) . . . . . . . . . . . . . . . . 315

Frank $v$. Bobbitt (Mass.) . . . 10, $13,14,15,271,310,313,317,318,324$

Frazier $v$. Boggs (Fla.) . . . . . . . . . . . . 30, 32, 33, 136, 333

Fred Miller Brewing Co. $v$. De France (Ia.) . . . . . . 294, 428

Freeman, Appeal of (Conn.) - 10, 11, 17, 131, 141, 145, 146, 147, 372, 374

Freeman $v$. Alderson (U. S.) . . . . . . . . . . . . . . 185

Freese $v$. Brownell (N. J.) . . . . . . . . . . . . . 392, 397, 432

Freetown $v$. Taunton (Mass.) . . . . . . . . . . . . . . 83,84

Frost $v$. Brisbin (N. Y.) . . . . . . . . . . . . . . . . . . . . 59

Fry's Case (Penn.) . . . . . . . . . . . . . . . . . 60

Fulham $v$. Howe $\left(V_{t}\right.$.) . . . . . . . . . . . . . . . . . . 122

Fuller $v$. Fuller (Ala.). . . . . . . . . . . . . . . . . . 158 v. Steiglitz (Ohio) . . . . . . 13, 16, 279, 310, 311, 316, 525, 526

Furgeson $v$. Jones (Or.) . . . . . . . . . . . 221, 222, 223

Fuss $v$. Fuss (Wis.). . . . . . . . . . . 175, 177, 178, 179, 180

Gaines, In re (La.) . • . • • . • . . • . . . . . . . . 189

Ganer $v$. Lanesborough (Eng.) . . . . . . . . . . . . . . 529

Garden City Sand Co. $v$. Miller (Ill.) . . . . . . . . . . . . 458

Gardner $v$. Lewis (Md.) . . . . . . . . . 11, 18, 318, 529, 530

Garner v. Garner (Md.) . . . . . . . . . . . . . . . 157 v. Wright (Ark.) . . . . . . . . . . . . . . . . 531

Garr v. Stokes (N. J.) . . . . . . . . . . . . . . . 512

Garrettson v. Bank (U.S.) . . . . . . . . . . . $373,392,411$

Gay v. Rainey (Ill.) • . . . . . . . . . . . . . 394, 452

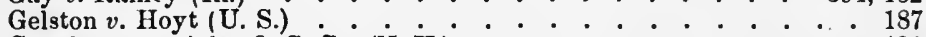

Geoghegan v. Atlas S. S. Co. (N. Y.)

Gettys v. Gettys (Tenn.) . . . . . . . . . . . . . 198, 199

Gibbs $v$. Fremont (Eng.) . . . . . . . . . . . . . . . 455

Gibson $v$. Insurance Co. (U. S.) . . . . . . . . . $398,399,417,443$ v. Sublett (Ky.)

Gilchrist v. Oil Co. (W. Va.) - . . . .

Gilman n. Gilman (Me.) . . . . . 62, 65, 67, 69, 70, 79, 117, 123, 340 v. Ketchum (Wis.) . . . . . . . . 13, 16, 264, 265, 266, 267

v. Lockwood (U. S.) . . . . . . . . . . . . . . 471

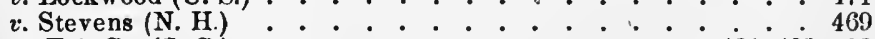

Gist $v$. Tel. Co. (S. C.) . . . . . . . . . . . . 424, 428,532

Glaser v. Priest (Mo.) .

Glenmavis, The (U. S.) . . . . . . . . . . . . 363,406

Glenn $v$. Smitl (Md.) . . . . . . . . . . . . 232, 233, 243

v. Thistle (Miss.) . . . . . . . . . . . . . . . . $30,32,426$

Glenny Glass Co. v. Taylor (Ky.) . . . . . . . . . . . . . 374

Glidden $v$. Chamberlain (Mass.) . . . . . . . . . . . . . 434

Goddard $v$. Foster (U. S.) . . . . . . . . . . . . . . . 515 
[References are to Pages.]

Golson $v$. Ebert (Mo.)

Goodall $v$. Marshall (N. H.)

Goodman, Trusts of (Eng.)

35,216

Goodman v. Goodman (Eng.)

Goodrich $v$. Houghton (N. Y.) . . . . . . . . . . . . . 405

Goods of Reid (Eng.) . . . . . . . . . . . . . . . . . . 351

Goorlwin $v$. Jones (Mass.) . . . . . . . . . . . . . . . 235

Graham $v$. Bank (N. Y.). . . . . . . . . . . 177, 272, 465

Grand Lodge $v$. New Orleans (U. S.) - . . . . . . . . . . . . . 517

Grant v. Healy (U. S.) . . . . . . . . . . . . 391

Graveley $v$. Graveley (S. C.) - - . $227,229,230,232,253,254,255,256$

Graves v. Johnson (Mass.) . . . . . . . . . . . . . . 294

v. Roy (La.) . . . . . . . . . . . . . . . . . . . 318

Gravillon v. Richards (La.) . . . . . . . . . . . . . . 328

Gray v. Holmes (Kan.) . . . . . . . . . . . 33, 34, 36, 133, 222

Great Western T'el. Co. v. Purdy (U. S.) . . . . . . . . . . 522

Green $v$. Iron Works (N. J.) . . . . . . . . . . . . . . . 313, 316 v. Van Buskirk (5 Wall. 307$)^{\circ} .8,11,13,46,49,272,304,305,315,521$

v. Van Buskirk (7 Wall. 139) . . . . . . . . . 8, 10, 187

Greene $v$. Greene (Mass.) . . . . . . . . . . . 69, 96, 102, 129

Greenhow v. James (Va.) •. . . . . . . . . . . . 149, 213

Greenwald $\imath$. Freese (Cal.) . . . . . . . . . . . . . . 443, 457, 462

Greenwood $v$. Curtis (Mass.) - . . . . . 17, 20, 21, 47, 419, 424, 429

Gregory $v$. Gregory (Me.) . . . . . . . . 133, 164, 196, 197, 198

Grimmett $v$. Witherington (Ark.). . . . . . . . . . 258, 259, 261

Griswold v. Golding (Ky.) . . . . . . . . . . . . . . . . 444

v. Waddington (N. Y.) . . . . . . . . . . . . . . 18

Gross v. Jordan (Me.) . . . . . . . . . . . . . . . . 356,444

Grove, In re (Eng.) . . . . . . . . . . . . . . . . . . 216

Grorer \& B. M. Co. $v$. Radcliffe (U. S.)

Guarantee Co. v. Bank (Va.) . . . . . . . . . . . . . . . . 111

Guerney $v$. Moore (Mo.) . . . . . . . . . . . . . . 21, 26, 27

Guier $v$. O'Daniel (Penn.) . . . . . 62, 65, 73, 74, 79, 116, 120, 124, 328

Guildhall, The (U. S.) . . . . . . . . . . . . 406

Guillander $v$. Howell (N. Y.) $\quad \cdot \quad \cdot \quad 29,39,42,46,271,272,273,300,311$

Gulick $v$. Gulick (N. Y.) . . . . . . . . . . . . . 233, 236

Gunn v. Barry (U. S.) . . . . • . . . . . • . . . . . . . 517

Guthrie v. Lowry (Penn.) . . . . . . . . . . . . . . . . 188

IfaGgin $v$. Haggin (Neb.) . . . . . . . . . . . . 532

IIairston v. Hairston (Miss.) - * - * $62,65,115,117,17 \overline{7}_{1}, 178,272,331$

Hale v. Nav. Co. (Conn.) . . . . . . . . . . . . 381, 382, 407

Hall $v$. Cordell (U. S.) . . . . . . . . . . . . . . $363,391,392,414,525$

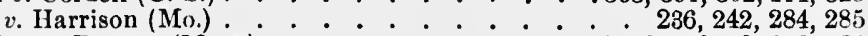

Hallett $v$. Bassett (Mass.) . . . . . . . . 65, 69, 70, 79, 118, 124

Halley $\imath$. Ball (1ll.) . . . . . . . . . . . . . . . . . . . 510

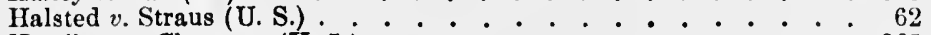

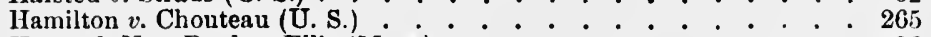

Hancock Nat. Bank v. Ellis (Mass.) . . . . . . . . . . . . . 26

Handley $v$. Harris (Kan.) . . . . . . . . . . . . 44, 304, 307

Ilanks $v$. State (Tex.) . . . . . . . . . . . . . . . 497, 501

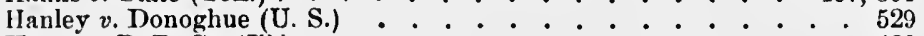

Hanna v. R. R. Co. (Ill.) . . . . . . . . . . . . . . . . . 489

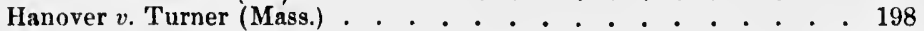

Hanover Nat. Bank $v$. Howell (N.C.) - . . . . . . . 145, 147

IIarding $v$. Alden (Me.) - 38, 94, 95, 96, 97, 98, 183, 184, 196, 201, 203, 208 
[References are to Pages.]

Hardware M'f'g Co. v. Lang (Mo.)

277,290

Harford $v$. Morris (Eng.) . . . . . . . . . . . . . 16!

Harper $v$. Butler (U. S.) - . . . . . 232, $28 t$

Harral v. Harral (N. J.) - 60, 72, 94, 107, 108, 109, 117, 118, 150, 169, 177

Harris $v$. Hardeman (U. S.) . . . . . . . . . . . . . 190 v. Harris (N. C.) . . . . . . . . . . . . . 204

Harrisburg, The (U.S.) . . . . . . . . . . . . . . . 495

Harrison $v$. Edwards (Vt.) . . . . . . . . . . 447, 513, 526 v. Harrison (Ala.) . . . . . . . . . 94, 95, 96, 173, 195, 198

v. Nixon (U. S.) . . . . . . . . . . $339,340,342,347,348$

v. Sterry (U. S.) . . . . . . . $243,280,309,322,324,325,515$

Hart v. Bostwick (Fla.) . . . . . . . . . . . . . 522

v. Lindsey (N. H.) . . . . . . . . . 60, 62, 70, 115, 116, 118

v. Wills (Ia.) . . . . . . . . . . . . $371,388,389,434$

Harteau v. Harteau (Mass.) . . . . . .95, 96, 97, 101, 103, 170, 183, 184

Hartford $v$. Champion (Conn.) . . . . . . . . . 115, 117, 121, 125

Hartman $v$. Aveline (Ind.) . . . . . . . . . . . . . . 504

v. R. R. Co. (Mo.) . . . . . . . . . . . . . . 356

Harvard College $v$. Gore (Mass.) . . . . . . . . 79, 119, 122, 124, 125

Harvey $v$. Merrill (Mass.) . . . . • • . • . . . 531 $v$. Richards (U. S.) - . . . $227,230,244,253,254,255,284,285$

Harwell $v$. Sharp (Ga.) . . . . . . . . . . . 277, 516, 521

Hatch $v$. Hansom (Mo.) . . . . . . . . . . . . . . . 405

Hausman $v$. Nye (Ind.) . . . . . . . . . . . . . . . 377

Haviland $v$. Halstead (N. Y.) . . . . . . . . . . . . . . . 166

Hawkins $v$. Ragsdale (Ky.) . . . . . . . . . . . . . . 203

Hawley $v$. Bibb (Ala.). . . . . . . . . . . . . . . 423

v. James (N. Y.)

Haymond $v$. Haymond (Tex.) . . . . . . . . . . . . . . . 60

Hazel v. R. R. Co. (Ia.) . . . . . . . . . . . . . 406

Healy $v$. Reed (Mass.) . . . . . . . . . . 138, 139, 140, 337

Heath $v$. Heath (La.) . . . . . . . . . . . . . 99, 100

Hedenberg $v$. Hedenberg (Conn.) . . . . . . . . . . . . 233, 236

Heebner $v$. Insurance Co. (Mass.) . . . . 399, 444, 464

Hegeman $v$. Fox (N. Y.) - . . 72, 111, 113, 114, 118, 177, 199, 328, 331

Heine $v$. Insurance Co. (La.) . . . . . . . . . . . 29, 175

Helleman's Will (Eng.) . . . . . . . . . . . . . . . . 141

Helton v. R. R. Co. (Ala.) . . . . . . . . . . .445,486, 487

Hemmaker $v$. State (Mo.) . . . . . . . . . . . . . . 502

Henry $v$. Sansom (Tex.) . . . . . . . . . . . . . . . . . 430

$v$. Sargeant (N. H.) . . . . . . . . . . . . . . . 499

Hernandez, Succession of (La.) - . . - 21, 25, 150, 157, 158, 177

Herrick $v$. R. R. Co. (Minn.) . . . . . . . 475, 480, 485, 487, 490, 493

Herron $v$. Keran (Ind.) . . . . . . . . . . . . . . . . 281

Hervey $v$. Edens (Tex.) . . . $\quad .31,310,311,314,317,320,321,322,324$ $v$. Locomotive Works (U. S.) . . . . . . 8, 302, 307, 309

Hewit, In re (Eng.)

Hiatt v. Griswold (U. S.) - . . . . . . . . . 433

Hibernia Nat. Bank $v$. Lacombe (N. Y.) 15,16 , 17, 254, 315, 322, 325, 326,

Hickox $v$. Elliott (U. S.) . . . . . . . . $389,390,404,419,420$

llicks $\imath$. Brown (N. Y.) . . . . . . . . . . . . . . . 396, 397 v. Insurance Co. (U. S.). . . . . . . . . 372, 377, 399, 408 v. Pope (La.) . . . . . . . . . . . . 178

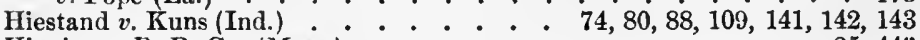

Higgins $v$. R. R. Co. (Mass.) . . . . . . . . . . . . . 25, 448 
Hilbish $v$. Hattel (Ind.) . . . . . . . . . . . . . . 38, 203

Hill v. Bank (N. H.) . . . . . . . . . . . . . . . . 144

v. Chase (Mass.) . . . . . . . . . . . . . . 371

v. Hill (Ill.) . . . . . . . . . 94, 101, 115, 117, 195, 197, 199

v. Spear (N. H.) . . . . . . . . . . . . . 47, 294

v. Tucker (U. S.) . . . . . . . . . . . . . . 230, $2 \% 1,237$

Hilton $v$. Guyot (U. S.) • • . . . . . . . . . . . . 6, 17, 188

Hinds $v$. Brazealle (Miss.) . . . . . . . . . . . . 18

Hoadley $v$. Transportation Co. (Mass.) $. . .+. .356,505,506,514$

Hobson $v$. Hale (N. Y.) . . . . . . . . . . . . . . . . . 40

Hoffman $v$. Carow (N. Y.) . . . . . . . . . . . . 484

v. Hoffman (N. Y.) . . . . . . . . . . . 197, 198, 204

Hohner $v$. Gratz (U. S.) . . . . . . . . . . . . . . . . 188

Hollis $v$. Seminary (N. Y.) . . . . . . . . . . . . . 12, 140

Holmes $v$. Green (Mass.) . . . . . . . . . . . . . . . . . 118

v. Holnes (Eng.) . . . . . . . . . . . . . . . . . 348

v. Manning (Mass.) . . . . . . . . . . . . . . . 434

v. Remsen (20 Johns. 229) . . . . . . . . . . . . 243,318

v. Remsen (4 Johns. Ch. 460) . . . . . . . . . . 280, 321,322

Holyoke $v$. Haskins (Mass.) . . . . . . . . . . . 85, 88, 90, 106

Homestead Cases, The (Va.) . . . . . . . . . . . . 517

Hood's Estate (Penn.). . . . . . . . . . . 71, 72, 117, 125

Hood v. Barrington (Eng.) • . . . . . . . . . . . . . . . 235

$v$. Hood (11 Allen, 196) . . . . . 96, 97, 99, 103, 184, 190, 195, 196

v. Hood (110 Mass. 463) . . . . . . . . . . . . 198

v. State (Ind.) . . . . . . . . . . . . . $3,164,198$

Hooker v. Olmstead (Mass.) . . . . . . . . . . . . . 228, 236

Hope $v$. Brewer (N. Y.) . . . . . . . . . . . . 40, 139, 334,337

Horne $v$. Rouquette (Eng.) . . . . . . . . . 392, 393, 394, 396, 452

Hornthall $v$. Burwell (N. C.) $13,14,43,44,187,271,272,300,304,307,308$,

Hosford $v$. Nichols (N. Y.) . . . . . . . . . . . . . 432

Hoskins $v$. Matthews (Eng.) . . . . . . . . . . . . 113, 114, 118

Houghtaling $v$. Ball (Mo.) . . . . . . . . . . . . . 413, 531, 532

Howland v. R. R. Co. (Mo.) . . . . . . . . . . . . . . 277,290

Hoyt $v$. Sprague (U. S.) • . . . . . . . . . . . . . . 259, 261

v. Thompson (N. Y.) . . . . . . . . . . . $277,279,299,306$

Hubbard v. Bank (U. S.) . . . . . . . . . . . . . . 392, 413

Hubbell $v$. Land \& Imp. Co. (Tenn.). . . . . . . . 372, 434, 437, 513

Hugo, The (U. S.) . . . . . . . . . . . . . 365,406

Hull v. Blake (Mass.) . . . . . . . . . . . . . . . . . . 447

Hullett $v$. King of Spain (Eng.) . . . . . . . . . . . . . 509

Humphreys $v$. Hopkins (Cal.) . . . . . . . • . . . . 264, 265

Hunt $v$. Hunt (N. Y.) $94,95,96,97,99,10 \dot{1}^{\circ} 103,104,170,183,184,195$, 196,529

v. Jones (R. I.) . . . . . . . . . . . . . 370, 413,431

v. Perry (Mass.) . . . . . . . . . . . . . . . 281

v. Standart (Ind.) $. . . \quad . \quad . \quad 392,396,397,443,453,454$

Huntington $v$. Attrill (U. S.) $21,2 \dot{2}, 24,25,26,151,157,189,476,478,480$,

Huntley $v$. Merrill (N. Y.) $\quad 485,490,492$

Hurst v. Mut. L. Ass'n (Md.) . . . . . . . . . . . . . . . 409

Huse $v$. Hamblin (Ia.) . . . . . . . . . . . . . . . . . 462

Hutchings $v$. Kimmell (Mich.) . . . . . . . . 160, 161, 167, 168

Hyde $v$. Goodnow (N. Y.) . . . . . . . . . . . 372, 398, 408 
[References are to Pages.]

Illinors Central R. R. Co. v. Ihlenberg (U. S.) 480,487 v. Smith (Miss.)

In re Breitung (Wis.)

Da Cunha (Eng.). $\cdot{ }_{141}$

Dalpay (Minn.) . . . . . . . 16, 273, 294, 310, 312, 314

Flukes (Mo.) . . . . . . . . . . . . . . 521

Gaines (La.) • . . . . . . . . . . . . . . 189

Grove (Eng.) . . . . . . . . . . . . . . . 216

Helleman's Will (Eng.) . . . . . . . . . . . . . . 141

Hewit (Eng.) . . . . . . . . . . . . . . . . 24!

Johnson (Ia.) • . . . . . . . . . . . . . . . 82,93

Kimball (N. Y.) • . . . . . . . . . . . . . . . 204

Molır (Ala.) . . . . . . . . . . . . . . . 504

Olson's Will (Ia.) . . . . . . . . . . . . . . $69,71,125$

Rice (Mich.) . . . . . . . . . . . . 124, 128, 259

Robert's Will (N. Y.) . . . . . . . . . . . . . 137, 乡34

Steer (Eng.) . . . . . . . . . . . . . . . . . 74

Ingraham v. Geyer (Mass.) - . . . . . . . . . . . 312, 315

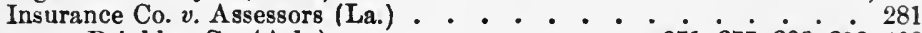

v. Brinkley Co. (Ark.) . . . . . - $371,377,398,399,408$

v. Chambers (N. J.) . . . . . . . . . . . . 277, 288

v. Clements (U. S.) • • • • . • . . . . . . . . . . $39 !$

v. Companhia de Moagens (U. S.) . . . . . . . . . . 461

v. Corbett (Ill.). . . . . . . . . . . . . . . . 288

v. Force (N. Y.). . . . . . . . . . . . . . . 187

v. Hardware Co. (Tex.) . . . . . . . . . . . 188

v. Ilettler (Neb.) . . . . . . . . . . . 277, 290

v. Nixon (U. S.) . . . . . . . . . . . . . 398, 408

v. Portsmouth (Mass.) . . . . . . . . . . . . . 277

$v$. Robison (U. S.) . . . . . . . . . . . . 371, 375, 399

v. Russell (U. S.) . . . . . . . . . . . . . . . 375

v. Sawyer (Mass.) . . . . . . . . . . . . . . 408

v. Trimble (U. S.). . . . . . . . . . . . . . 398, 409

v. Trust Co. (U. S.) . . . . . . . . . . . . . . . 409,443

v. Wenar (Tex.) . . . . . . . . . . . . . . 287

Iowa, The (U. S.) . . . . . . . . . . . . . . 406

Irvine $v$. Barrett (Penn.) . . . . . . . . . . . . . . . . . . 389

Isham $v$. Gibbons (N. Y.) . . . . . . . . . . . . . . . 114

Ives $v$. McNicoll (Ohio) . . . . . . . . . . . . . . 76, 221

Ivey $v$. Lolland (Miss.) . . . . . . . . . . . . 18, 362

JACKs $v$. Nichols (N. Y.) . . . . . . . . . . . . . 436

Jackson v. Com. (Ky.) • . . . . . . . . . . . . . . . . 500

v. Green (Ind.) . . . . . . . . . . . . . . 457

v. Jackson (80 Md. 176) . . . . . . . . 167, 168

v. Jackson (82 Md. 17) … : : 10,152, 153, 160, 161, 167

v. Jackson (1 Johns. 424) •. . . . . . . . . . . 198

v. Johnson (Ga.) . . . . . . . . . . . . . 233,236

v. Mortgage Co. (Ga.) . . . . . . . . . . . . 377,431

Jacobs $v$. Credit Lyonnais (Eng.)

Jacquette $v$. Huguiron (U. S.) . . . . . . . . . . . . . . 190

James' Estate (Cal.) . . . . . . . . . . . . . . . 197

James $v$. James (Tex.) . . . . . . . . . . . . . . . . 532

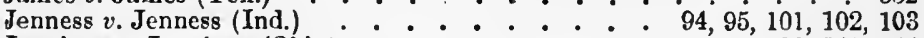

Jennings $v$. Jennings (Ohio) . . . . . . . . . . . 36, 341, 344 
[References are to Pages.]

Jennison $v$. Hapgood (Mass.)

$117,121,124,231,253$

Jessup v. Carnegie (N. Y.)

Johns $v$. State (Ind.)

498,501

Johnson, In re (Ia.).

82,93

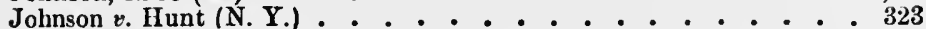

v. Jackson (Ga.)

v. Powers (U. S.)

233,236

v. R. R. Co. (U. S.)

$38,147,247$

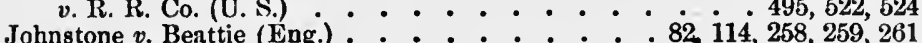

Jones $v$. Jones (Miss.) . • . . . . . • • . . . 133, 183, 196

v. Jones (N. Y.) . . . . . . . . . . 163, 191, 204, 512

v. Leonard (Ia.) •. . . . . . . . . . . . . 504

v. Rice (Ga.) . . . . . . . . . . . . . . . 531

Jopp v. Wood (Eng.) • • . • . . . . . . . . . 62, 68, 122

Jordon $v$. Thornton (Ark.) - . - . - . . . . . . 393,510

Joslyn $v$. Miller (Neb.) • . • . . . . • . . . . . . . 434

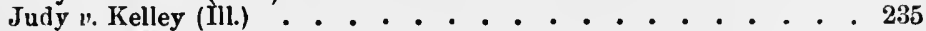

Juillard v. May (Ill.) • • • • • • • • • • • . 31, 311, 313

Kahr v. R. R. Co. (Ala.) • . . . . . . . . . . 478, 487

Kanaga $v$. Taylor (Ohio) •. . . . . . • . . 4 48, 44, 304, 307

Kansas City R. R. Co. v. Cunningham (Kan.) . . . . . . . 518

Kansas Pac. R. R. Co. v. Cutter (Kan.) . . . . . . . . . . 241

Kavanaugh $v$. Day (R. I.) . . . . . . . . . . . . . . . 455

Keegan $v$. Geraghty (Ill.) . . . . . . . . . . . . 35, 36, 222

Keith v. Keith (Mo.) . . . . . . . . . . . . . . 29

Keiwert $v$. Meyer (Ind.) . . . . . . . 371, 377, 384, 413, 428

Kelley $v$. Kelley (Mass.) . . . . . . . . . . 528, 530, 531, 532

Kellogg $v$. Miller (U. S.) . . . . . . . . $373,380,390,431,432$

Kelly $v$. Garrett (Ala.) . . . . . . . . . . . . 60

Kelsey $v$. Green (Conn.) . : . . . . . . 80, 81, 100, 259, 260

Kennebrew $v$. Machine Co. (Ala.) . . . . . . . . 444, 532

Kennedy $v$. Knight (Wis.) . . . . . . . . . . . . . 434

v. R. R. Co. (U.S.) . . . . . . . . . . . . . 267

Kennett $v$. Chambers (U. S.) •. . . . . . . . . . 18

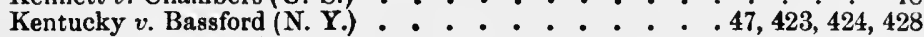

Kern $v$. Field (Minn.) . . • • . . . • . . . . . . . 199

Kerr v. Dougherty (N. Y.) • . . . . . . . . 10, 137, 139, 334

v. Kerr (N. Y.) . . . . . . . . . . . . . . 198

v. Moon (U. S.) - . . . . . . . . . . 28, 33, 235, 333

v. Urie (Md.) . . . . . . . . . . . . . 145, 293

Kershaw $v$. Kershaw (Cal.) . . . . . . . . . . . . . . 200

Kidd $v$. State (Ala.) . . . . . . . . . . . . . . . 502

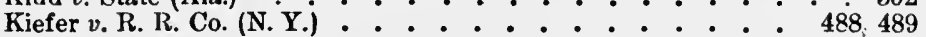

Kilcrease $v$. Johnson (Ga.) . . . . . . . . . . . 4 433, 434, 436

Kilgore $v$. Dempsey (Ohio) . . . . . . . . . . . . 431, 434

Kimball, In re (N. Y.) . . . . . . . . . . . . . . . . . 204

King $v$. Cross (U. S.) . . . . . . . . . . . . . . 289 v. Sarria (N. Y.) . . . . . . . . . . . . . . 375

Kinney, Ex parte (U. S.) • • • -

Kinney $v$. Com. (Va.) . . . . 18, 20, 133, 149, 152, 153, 163, 167, 411 v. Crocker (Wis.) . . . . . . . . . . . . . 267

Kinnier $v$. Kinnier (N. Y.) . . . . . . . . . . . . . 184, 198

Kirkland $v$. Lowe (Miss.) . . . . . . . . . . . . . 322, 324 v. Whately (Mass.) . . . . . . . . . 88,90.91 
[References are to Pages.]

Klinck $v$. Price (W. Va.) . . . . . . . . . . . . . . . 31, 434 Kline $v$. Kline (Ia.)

Kling $v$. Fries (Mich.) . . . . . . . . . . . . . . . 377 v. Sejour (La.) . . . . . . . . . . . . . . . . 457

Knapp $v$. Knapp (Mich.) . . . . . . . . . . . . . . . 531

Kneeland $v$. Ensley (Tenn.) . . . . . . . . . . $38,39,169,174,177$

Knight v. R. R. Co. (Penn.) . . . . . . . . . . . . 480

Knights Templar Ass'n v. Greene (U. S.) : : . 340, 398, 443, 460

Knights Templar Indemnity Co. v. Berry (U. S.) . . . . 372, 399, 408

Knowlton $v$. Doherty (Me.) . . . . . . . . . . . . . . 294

v. Knowlton (Ill.) . . . . . . . . . . . . . . . . . 199

v. R. R. Co. (Ohio) . . . . . . . . . . . 406

Knox v. Jones (N. Y.) . . . . . . . . . . . . . . . . 29, 333

Kohn's Estate (Penn.) . . . . . . . . . . . . . . . . 141

Koshkonong $v$. Burton (U. S.) . . . . . . . . . . . . . 522

Kraft $v$. Wickey (Md.) . . . . . . . . . . . 259, 261, 262

Kritzer $v$. Woodson (Mo.). . . . . . . . . . . . . 26

Kuenzi v. Elvers (La.)

Kulın $v$. Morrison (U. S.) . . . . . . . . . . . . . 433

Kyle $v$ Montgomery (Ga.) . . . . . . . . . . . . 516

LACY v. Palmer (Va.) . . . . . . . . . . . . . . 501

Lamar $v$. Micou (112 U. S. 452) 79, 80, 82, 83, 84, 85, 88, 89, 90, 133, 141,

$225,254,257,258,261,262,628$

v. Micou (114 U. S. 214) . . . . . . 80, 82, 86, 88, 90, 93, 528

v. Scott (S. C.) . . . • . • • . . . . $29,38,39,174$

Lancashire Insurance Co. v. Corbett (Hi.) . . . . . . . . . . . . 288

Lane $v$. Watson (N. J.) . . . . . . . . . . . . . . . . 434

Lanesborough $v$. Berkshire Co. (Mass.) . . . . . . . . . . 283

Langdon $v$. Doud (Mass.) . . . . . . . . . . . . . . 59

v. R. K. Co. (N. Y.) . . . . . . . . . . . . . . 490

Langworthy $v$. Little (Mass.)

Lanusse $v$. Barker (U. S.) • . . . . . . . . . . 389, 391, 455

Larendon, Succession of (La.)

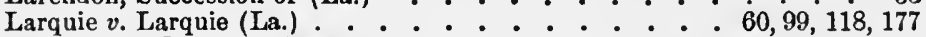

La Selle $v$. Woolery (Wash.) . . . . . . . . . . 38, 247, 518

Law $v$. Mills (Penn.) . . . . . . . . . . . . . $310,316,317$

v.R. R. Co. (U.S.) . . . . . . . . . . . $480,485,493$

Lawrence $v$. Bassett (Mass.). . . . . . . . . . . 372, 388, 488

v. Kitteridge (Conn.) - . . . . . . . . . . . 331

v. Smith (N. H.) . . . . . . . . . . 289,290

Leach v. Buckner (W. Va.) . . . . . . . . . . 238, 255

v. Greene (Mass.) . . . . . . . . . . . . 510

Lebel $v$. Tucker (Eng.)

Le Breton $v$. Miles (N. Y.) . . . . . . . . . . . . . . 109, 180 v. Nouchet (La.) . . . . . . . . . . . . . 177, 179

Lee $v$. Selleck (N. Y.) . . . . . . . . . . . . . . . . . 394 v. State (Ga.) . . . . . . . . . . . 503

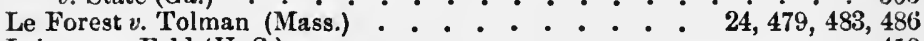

Lehman $v$. Feld (U. S.) . . . . . . . . . . . . . . . . . 419

Le Messurier $v$. Le Messurier (Eng.) • . . . . . . . . . . 178

Lennig $v$. Ralston (Penn.) . . . . . . . . . . . . . . . 391

Leonard $v$. Nav. Co. (N. Y.) . $^{\circ}$. . . $.25,241,485,490,492,532$ v. New Berlford (Mass.) . . . . . . . . . . . 281

Lerkin v. Wilson (Mass.) . . . . . . . . . . . . . 289

Leroux $v$. Brown (Eng.) . . . . . . . . . . 414, 415, 525 
[References are to Pages.]

Le Roy $v$. Beard (U. S.)

Levy $v$. Levy (Penn.)

393,510

Lewis, Succession of (La.)

$83,84,85$

Lewis $v$. Adams (Cal.)

$v$. Headley (Ill.)

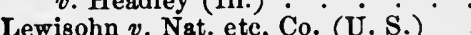

Limekiller $v$. R. R. Co. (Kan.) . . . . . . . . 241,494

Lincoln $v$. Perry (Mass.) . . . . . . . 339, 340, 341, 342, 347, 349

Lindsay $v$. Hill (Me.) . . . . . . . . . . . . . . . . 362

Lindsey $v$. State (Ohio) . . . . . . . . . . . . . . 499, 501

Lingen $v$. Lingen (Ala.) . . . . . . . . . . . . . . 230

Litowich $v$. Litowich (Kan.) . . . . . . . . . . . . . 198

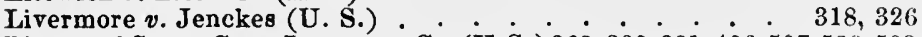

Liverpool Steam Co. $v$.Insurance Co. (U.S.) $363,380,381,406,527,528,529$

Lloyd $v$. Guibert (Eng.) . . . . . . . . . . . . . . . 363

v. Scott (U. S.) . . . . . . . . . . . . . . . . 430

Lockwood $v$. Mitchell (Ohio) . . . . . . . . . . . . . 434

Loker $v$. Gerald (Mass.) - . . . . 96, 99, 103, 195, 201, 203, 206

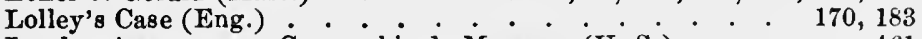

London Assurance $v$. Companhia de Moagens (U. S.) . . . . . 461

Long $v$. Girdwood (Penn.) . . . . 13, 31, 62, 271, 279, 310, 325, 326

v. Ryan (Va.)

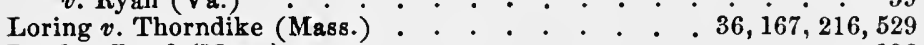

Loud $v$. Loud (Mass.)

Louisville \& N. R. R. Co. v. Williams (Ala.) . . . 478, 482, 483

Lovejoy $v$. Albee (Me.) . . . . . . . . . . . . . . . 287

Loving $v$. Pairo (Ia.) . . . . . . . . . . . . . . 311,317

Lower $v$. Segal (N. J.) . . . . . . . . . . . . . . . 494

Lowry $v$. Bradley (S. C.) . . . . 64, 67, 70, 115, 116, 117, 125, 337

Ludlow $v$. Van Rensselaer (N. Y.) . . . . . . . . . . . 412

Lndwig $v$. Steward (Mich.) . . , . . . . . . . . . . . 522

Lyman v. Campbell (Mo.) . . . . . . . . . . . . . . 523

v. R. R. Co. (U.S.) . . . . . . . . . . . 480,489

Lynch $v$. Postlethwaite (La.) . . . . . . . . . . . . 513

Lyon $v$. Callopy (Ia.) . . . . . . . . . . . . . . . 516,519

v. Lyon (Mass.) . . . . . . . . . . . . . 99, 183,184

Lyons v. R. R. Co. (Tex.) . . . . . . . . . . . . . . 513

Macdonald $v$. Macdonald (Se.) . . . . . . . . . . . . 180

Machado $v$. Fontes (Eng.) . . . . . 475, 479, 481, 486, 493, 582

Mack v. People (N. Y.). . . . . . . . . . . . . . 502

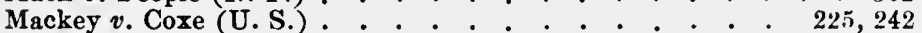

v. Pettijohn (Kan.) . . . . . . . . . . . . 10, 2i1, 304

Maddox $v$. State (Ind.) . . . . . . . . . . . . . . 82

Madrazo $v$. Willes (Eng.) . . . . . . . . . . . . . . 17

Magowan $v$. Magowan (N. J.) . . . . $195,196,197,198,199,206$

Maguire $v$. Maguire (Ky.) . . . . . . . 94, 96, 157, 173, 195, 198

Maillard $v$. Nihoul (La.) $\quad . \quad$. . . . . . . . . . . . . 296

Majestic, The (U.S.) . . . . . . . . . . . . . 406, 407

Male $v$. Roberts (Eng.) . . . . . . . . . . . . . . . 148

Malpica $v$. McKeown (La.) . . . . . . . . . . . . . . 378

Manley $v$. People (N. Y.) . . . . . . . . . . . . . 497,498

Manufacturing Co. $v$. Lang (Mo.) . . . . . . . . . 277, 290

Marden $v$. Insurance Co. (Ia.) . . . . . . . . . . . . . . 399

Marheineke $v$. Grothaus (Mo.) . . . . . . . . . . . 886

Marina, The (U. S.) . . . . . . . . . . . 302, 303 
Marshall $v$. Marshall (N. Y.)

Marvin Safe Co. v. Norton (N. J.) . . • . . . . . 271, 293, 301, 302

Mashassuck Felt Mills $v$. Blanding (R. I.) . . . . . . . . 277

Mason v. Beebee (U. S.) . . . . . . . . 43, 387, 518, 519, 521 v. Dousay (IIl.) . . . . . . . . . . . . . 443 v. Homer (Mass.)

Masonic Ass'n $v$. Jones (Penn.) : . . . . . . . . . . . . . . 461

Massey $v$. Womble (Miss.) . . . . . . . . . . . . . . . 517

Matthews $v$. Lloyd (Ky.). . . . . . . . . . . . . 11, 13, 15, 299 v. Murchison (U. S.) . . . . . . . . . . . . . . 146,411 v. Paine (Ark.). . . . . . . . . . . . . . . . . . . 43:3

May v. Bank (IIl.) . . . 10, 13, 14, 15, 31, 310, 311, 313, 317, 324, 325, 326 v. Breed (Mass.) . . . . . . . . . . . . . . $46 \check{3}$ v. Smith (N. B.) . . . . . . . . . . . . . . . . 485, 486 v. Wannemacher (Mass.) $16,45,272,279,310,312,314,318,320,324,326$

Maynard $v$. Hall (Wis.) . . . . . . . . . . . . . . . 434

Mayo $v$. Equitable, etc. Society (Miss.) - $114,115,118,225,285,328,329$

Maxwell v. Hyslop (Eng.) . . . . . . . . . . 252, 341, 346 v. Maxwell (Eng.) . . . . . . . . . . . . 340, 341, 346

McAllister $v$. Smith (Ill.) . . . . . . . . . . . 24, 513, 514

McBee $v$. Bank (Ind. Ter.) . . . . . . . . . . . . . . . 290

McCallum v. Smitlı (Tenn.). . . . . . . . . . . . . . 39

McCarthy $v$. De Caix (Eng.) . . . . . . . . . . . 170 v. R. R. Co. (Kan.) . . . . . . . . . . 482, 483,492

McCartney v. Osburn (Ill.) . . . . . . . . . . 36, 37, 341

McClees $v$. Burt (Mass, . . . . . . . . . . . . 506, 507

McClure $v$. Campbell (Wis.) . . . . . . . . . . . . . 322

McCormick $v$. Sullivant (U. S.) . . . . . . . . . . . . . 28

McCune $v$. House (Ohio) . . . . . . . . . . . . . . . 334

McDonald $v$. Mallory (N. Y.) . . . . . . . . . . . . . . 481

McElfatrick $v$. Hicks (Penn.) . . . . . . . . . . . 430

McElmoyle $v$. Cohen (U. S.) . . . . . . . . 188, 189, 190, 243

McGill $v$. Deming (Ohio) . . . . . . . . . . . . . 38, 191, 195

McGoon $v$. Scales (U. S.) . . . . . . . . . . . . . . 33

McIlvaine $r$. Legare (La.) • . . . . . . . . . . . . . . . 296

McIntyre $v$. Parks (Mass.) . . . . . . . . . . 47, 294, 384, 428

McKee $v$. Jones (Miss.) . . . . . . . . . . . . . . . . 21,403

IICKeen $v$. Northampton Co. (Penn.) . . . . . . . . . . . . 282

IIcKenzie $v$. State (Tex.) • . . . . . . . . . . . . . 502

McLean $v$. Hardin (N. C.) . . . . . . . . . . v. Meek (U. S.) . . . . . . . . 225, 230, 237, 254

McMaster $v$. Insurance Co. (Ia.) . . . . . . . . . . 375

IIcNamara v. Dwyer (N. Y.) - . . . . . $233,235,236,238,255$

McNeely, Ex parte (W. Va.) . . . . . . . . . . . . . 500

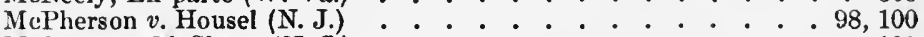

McShane $v$. MIcShane (N. J.) •. . . . . . . . . . . . . .

Mears $v$. Sinclair (W. Va.) . . . . . . . $75,79,80,83,84,88,89$

Medway $v$. Needham (Mass.) . . . . . . . 19, 20, 151, 153, 161

Melan v. Fitz-James (Eng.) . . . . . . . . . . . . 511, 512

Melendy $v$ Barbour (Va.) : . . . . . . . . . . . 267

Melvin v. Martin (R. I.) . . . . . . . . . . . . . $36,133,222$

Memphis, etc. R. R. Co. v. Alabama (U. S.) . . ... . . . 130

Merchants' Bank v. Griswold (N. Y.) • . . . . 377, 391, 392, 434 


\section{[References are to Pages.]}

Merchants' Bank $v$. Spalding (12 Barb. 302) . . . . . . . 17, 18 v. Spalding (9 N. Y. 53) . . . . . . . . . . . . . 294, 419

Meroney v. B. \& L. Ass'n (N. C.) . . . . . . . . . . 434

Merrill $v$. Insurance Co. (Mass.) . 229, 230, 232, 233, 235, 237, 253. 255, 285 v. Preston (Mass.) . . . . . . . . . 339, 340, 342, 348

Meuer v. R. R. Co. (S. D.) . . . . . . . . . . . . . . 406

Mexican Nat. R. R. Co. v. Jackson ('Tex.) . . . . . . .480,488, 489

Meyer $v$. Richards (U.S.) . . . . . . . . . . . . . 296, 444

Middleborough $v$, Rochester (Mass.) . . . . . . . . . . . . 105

Midland Co. v. Broat (Minn.) . . . . . . . . . . 21, 525, 526

Miles $v$. Oden (La.) . . . . . . . . . . . . . . . . 304, 305

Miller, Estate of (Penn.) . . . . . . . . . . . . . . 243

Miller v. Campbell (N. Y.) . . . . . . . . . . . . 133, 145, 400

v. $\operatorname{Miller}(\mathrm{N}$. Y.) . . . . . . . . . $33,35,43,46,133,212,216$

v. Tiffany (U. S.) . . . . . . . . . . . . . 430

v. Wilson (Ill.). . . . . . . . . $413,417,418,525$

Milliken v. Pratt (Mass.) . . . . . 11, 146, 147, 148, 362, 371, 373, 376

Mills $v$. Hopkinsville (Ky.) . . . . . . . . . . . 64, 88, 90,91 v. Thornton (Ill.) . . . . . . . . . . . . . . . . 281

Milne $v$. Moreton (Penn.) : . . 11, 16, 272, 279, 280, 310, 321, 322, 325

Mineral Point R. R. Co. v. Barron (Ill.) . . . . . . . . . 516

Minor v. Cardwell (Mo.) . . . . . . . . . . . . . . . . 39

Missouri Pac. R. R. Co. v. Lewis (Neb.) . . . . . . 241 v. Sharritt (Kan.) . . . . . . . 287, 290, 518, 521, 532

Mitchell $v$. Harmony (U. S.) . . . . . . . . v. United States (U. S.) - . . $62,70,72,109,115,121,122,125$

Mohr, In re (Ala.) . . . . . . . . . . . . . . 504

Mohr v. Miesen (Minn.) . . . . . . . . . . . . . . 531

Monroe $v$. Douglas (N. Y.) . . . . . . . . . . . . . . . 532

Montalvan v. Clover (N. Y.) . . . . . . . . . . . . . 238

Montgomery $v$. Millikin (Miss.) . . . . . . . . . 137, 138, 337

Mooney v. Buford (U. S.) . . . . . . . . . . . . . . . 288

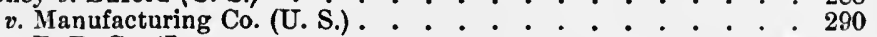

v. R. R. Co. (Ia.) - * . . . . : : 290,519

Moore $v$. Church (Ia.) . . . . . . . . . 16, $31,311,315,317$

v. Hegeman (N. Y.) . . . . . . . . . . . . $151,157,159$

v. Jordan (Kan.) . . . . . . . . . . . . . . . 236

v. Mayor (N. Y.) . . . . . . . . . . . . . . . 174

v. Title \& Trust Co. (Md.)

v. Willett (N. Y.) . . . . . . . . . . . . 273,310,312

Moorehouse $v$. Lord (Eng.) . . . . . . . . . . . . . . 72, 114

Morawetz $v$. Sun Insurance Office (Wis.) . . . . . . . . . . . . 288

Morey v. Morey (Minn.) . . . . . . . . . . . . . . 197, 203

Morgan v. Morgan (Tex.) - . . . . . . . . . . . . . . . 196 v. Neville (Penn.) . . . . . . . . . . $290,516,519,520$

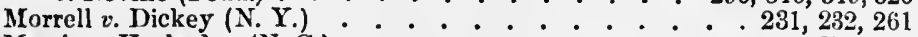

Morris $v$. Hockaday (N. C.) . . . . . . . . . . . . . v. R. R. Co. (Ia.) . . . . . . . . . . $25,241,485,492$

v. Wibaux (Ill.) . . . . . . . . . . . . . . . . . 455

Mortgage Co. v. Jefferson (Miss.). . . . . . . 18, $379,380,431$ v. McLaughlin (Ga.) . . . . . . . . : 363, 390, 432, 434

v. Sewell (Ala.) . . . . . . . . . . . . . 363, 390, 431, 434

v. Vaden (U.S.) . . . . . . . . . . . . . . 389,431

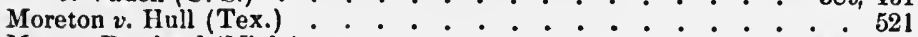

Mott $v$. Rowland (Mich.) . . . . . . . . . : 4431,437

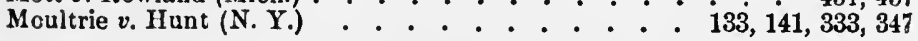


[References are to Pages.]

Mowry v. Latham (R. I.)

$73,107,108,109,122,124$

Mullen $v$. Morris (Penn.) $v$. Reed (Conn.)

$37,340,461$

Mumford $v$. Canty (Ill.) . . . . . . . . . . . . . 307, 508

Munn v. Illinois (U. S.) . . . . . . . . . . . . . . . . . 522

Munos v. R. R. Co. (U. S.) . . . . . . . . . . . 495, 524

Munro v. Munro (Eng.) . . . . . . . . . . . . 73, 76, 216, 217

v. Saunders (Eng.) . . . . . . . . . . . . 216

Munroe $v$. Douglas (Eng.) . . . . . . . . . . . . . . . . 119

Murplyy v. Collins (Mass.) . . . . . . . . . . 403, 404, 532

v. Murphy (La.) . . . . . . . . . . . . . 178

Musson $v$. Lake (U.S.) . . . . . . . . . . . . . . . 396,453

Mutual Ben. Ins. Co. v. Robison (U. S.) $\quad$ - . . . . . . 371, 375, 399

Nashville $v$. Thomas (Tenn.) . • . . . . • . • . . . 282

Nat v. Coons (Mo.) . . . . . . . . . . . . . . . . . 334

National, etc. Ass'n $v$. Ashworth (Va.) . . . . . . . . . . . 432

National Bank $v$. Indiana Banking Co. (IIl.) . . . . . . 397,445

National Insurance Co. $v$. Chambers (N. J.) . . . . . 277, 288, 290

National Union $v$. Marlow (U. S.) . . . . . . . . . . . . 408

Needlam $v$. R. R. Co. (Vt.) . . . . . . . . . . . . 482, 483

Neff $v$. Beauchamp (Ia.) . . . . . . . . . . . . . . . 198, 199

Neil v. Bank (Ohio) . . . . . . . . . . . . . . . . . 456

Nelson $v$. R. R. Co. (Va.) . . . . . . . . 25, 241, 475, 485, 493

Neufelder $v$. Insurance Co. (Wash.) . . . . . . . . . 277, 290

New comer $v$. Orem (Md.) . . . . . . . . . . . 39,40, 174, 177

Newell $v$. Haden (Ia.) . . . . . • . • . . . . . 516

New England Mortgage Co. v. McLaughlin (Ga.) . . . 363, 390, 432, 434 v. Vaden (U. S.) . . . . . . . . . . . . 389,431

Newland $v$. Reilly (Mich.) . . . . . . . . . . . . 289

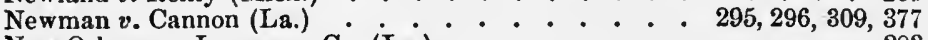

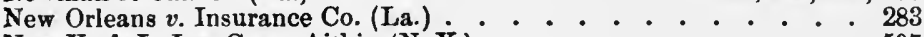

New York L. Ins. Co. v. Aitkin (N. Y.). . . . . . . . . . . 507 v. Russell (U. S.) . . . . . . . . . . . . . . 375

Niblett $v$. Scott (La.) . . . . . . . . . . . . . . . . . . 188

Niboyet $v$. Niboyet (Eng.) . . . . . . . . . . . . . . . . 131

Nichols $v$. Bank (W. Va.) . . . . . . . . . . . . . . . 392 v. Mase (N. Y.) . . . . . . . . . . . . . . . 304,307 $v$. Porter (W. Va.) . . . . . . . . . . . . . 4445, 454

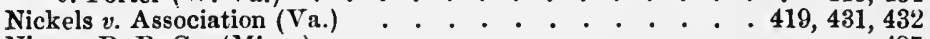

Njus $v$. R. R. Co. (Minn.) . . . . . . . . . . . . . . . . 487

Noble v. Oil Co. (Penn.) . • . . . . . . . . . . . . . . . 187

Nonce $v$. R. R. Co. (U.S.) . . . . . . . . . . . . . . . . 495

Norman $v$. Norman (Cal.) . . . . . . . . . . . . . . . 168

Norris $v$. Atkinson (N. H.) . . . . . . . . . . . . . . . 472 v. Norris (N. H.) . . . . . . . . . 170, 183, 184, 196

North Pacific Lumber Co. v. Lang (Or.) . . . . . . . . . 480

Northern Pac. R. R. Co. $v$. Babcock (U. S.) . . . . . . . . . . 487

North western Association $v$. Jones (Penn.) . . . . . . . . . . 460

Noyes $v$. Wyckoff (N. Y.) . . . . . . . . . . . . . . . 467

Nugent $v$. Vetzera (Eng.) . . . . . . . . . . . . . 259

OAKLeT v. Bennett (U. S.) . . . . . . . . . . . . . . . 321

Obear $v$. Bank (Ga.) - . . . . . . . . . . . . 522

Ochiltree $v$. Contracting Co. (Mo.) - . . . . . . . . . 26

Jckerman $v$. Cross (N. Y.) . . . . . . . . . . 311, 316, 317 
[References are to Pages.]

O'Dea $v$. O'Dea (N. Y.)

$95,99,164,191,204$

O'Dell $v$. Gray (Mo.)

443,447

Odom v. Mortgage Co. (Ga.) . . . . . . . . . . 390, 431,432

Ogden v. Saunders (U. S.) . . . . . . . . . . . . . . . 471

Oliver $v$. Washington (Mass.) • • . . . • . . . . . . . 282

Olivier $v$. Townes (La.) . .

Olmstead v. Mortgage Co. (Neb.) . . . . . . . . . . . . 434

Olson's Will (Ia.) . . . . . . • • . . . . . . 69, 71, 125

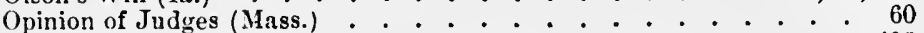

Oranmore, The (L. S.) . . . . . . . . . . . . . . . 406

O'Regan v. Cunard S. S. Co. (Mass.) . . . . . . . . . 406

O'Reilly $v$. R. R. Co. (R. I.). . . * * . - 480, 485, 489, 491, 492

Orr $v$. Armory (Mass.) . . . . . . . . . . . . . . . . . 510

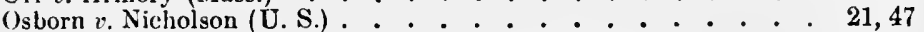

Oscanyon $v$. Arms Co. (U. S.) •

Osgood $i$ Maguire (N. Y.) . . . . . . . . . . . . . . 265, 277

O'Shields v. R. R. Co. (Ga.) • • . • • • • . • . 524

Otis v. Boston (Mass.) . . . . - . . $64,65,67,69,79,118,119,129$

v. Gregory (Ind.) . . . . . . . . . . . . 29,32, 33

Overseers of Alexandria $v$. Bethlehem (N. J.) • • • . . • . . 106

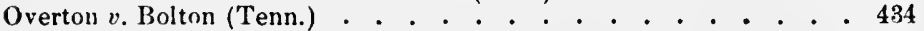

Owen $v$. Miller (Ohio) . . . . . . . . . . . . . . . . . . 277

Packer v. Thompson (Neb.) • . . . . . . . . . . . 190

Packwood, Succession of (La.) - . . . . . . . . 178, 232, 349, 351

Paine v. Lester (Conn.) . . . . . 16, 272, 279, 320, 321, 322, 324, 325

Park $v$. Kelley Axe Co. (U. S.) . . . . . . . . . . . . . 376

v. Manufacturing Co. (U. S.) . . . . . . . . . . . . . 411

v. Rose Bank (Ind.) . . . . . . . . . . . . . . . 396

Parsons $v$ Iyman (N. Y.) . . . . 230, 243, 253, 254, 255, 256, 328, 340 v. Trask (Mass.) . . . . . . . . . . . . 378

Patterson $v$. Gaines (U. S.)

Pattison $v$. Mills (Eng.) . . . . . . . . . . . . . . . . . 376

Pawling v. Bird (N. Y.) • . . . . . . . . . . . . 198, 209

leale $v$. Phipps (U. S.) • . . . . . . . . . . . . . . . . . . . 267

Pearce $v$. State (Tenn.) . • . . . . . . . . . . . . . . 62

Pearl $v$. Hansbrough ('Tem.) . . . . . . . . . . . . . . . 146

l'earsall $v$. Dwight (Mass.) . . . . . . . . . . . . . . . 510

Peck v. Mayo (Vt.). . . . . . . . . . 396, 443, 455, 457, 515

Pedan $v$. Robb (Olio) . . . . . . . . . . . . . . . . . . 91

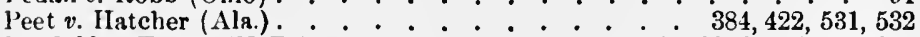

l'enfield $v$. Tower (N. D.) . . . . . . . . . . . $30,33,37,40,333,335$

I'eninsula, etc. Co. $v$. Shand (Eng.) . . . . . . . . . . . 363

Peun Mut. L. Ins. Co. v. Trust Co. (U. S.) . . . . . . . . . 409, 44:3

Pennegar $v$. State ('Tenn.) $10,11,12,18,20,25,152,153,154,159,160,167$

Pemoyer $v$. Neff (U. S.) - . 8, 13, 184, 187, 188, 196, 197, 201, 207, 208, 286

People $v$. Adains (N. Y.). . . . . . . . . . . . 499

v. Baker (N. Y.) . . . . . . . . . . . . 191, 204, 259

v. Burke (N. Y.) . . . . . . . . . . . . . . . 502

v. Commissioners (N. Y.) - . . . . . . . . . . . . 281

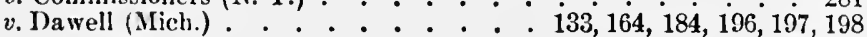

v. IIovey (N. Y.) . . . . . . . . . . . . . . . . . 159

v. Staples (Cal.) . . . . . . . . . . . . . . . . 502

People's Bank $v$. Norwalk (Conn.) - . • . . . . . . . . . . 467

Perkins v. Guy (Miss.) . • • . . . . • . . . . . . . . . 523

Perry v. Insurance Co. (N. H.) . . . . . . . . . . . . 399, 409 
[References are to Pagos.]

Perry v. Iron Co. (R. I.) . . . . . . . . . . . . . . . 373, 413

v. R. R. Co. (Kan.) . . . . . . . . . . . . . 241

Petersen v. Chemical Bank (N. Y.) $3,8,22 \dot{7}, 231^{\circ}, 232,23 \dot{3}, 234^{\circ}, 236,26 \dot{6}^{\circ}, 272$,

Petit, Succession of (La.)

$284,285,328$

Pliillips $v$. Eyre (Eng.)

328,331

$v$. Gregg (Penn.)

$43,167,168,5 \dot{2} 9, \quad 580$

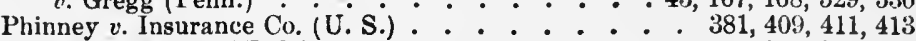

Phipps v. Harding (U. S.) . . . . . . . . . . 372, 388, 448

Picquet, Ex parte (Mass.) . . . . . . . . . . . . 231, 235

Pierce $v$. Indseth (U. S.) . . . . . . . . . . . $396,443,448,452$

Pioneer Sav. \& L. Co. v. Cannon (Tenn.) . . . . . . . . . 432

Plestoro $v$. Abraham (N. Y.) . . . . . . . . . . . . . 324,326

Plummer v. Hatton (Minn.) . . . . . . . . . . . . . . 195

Polson $v$. Stewart (Mass.) . . . . . 29, 32, 144, 175, 352, 416, 417, 459

Pomeroy $v$. Ainsworth (N. Y.) . . . . . . . . . . . . . . . 434

v. Rand (Ill.) . . . . . . . . . . . . . . . . . . . 277

Pond $v$. Cooke (Conn.) . . . . . . . . . . . . . . . 44, 45, 264, 265, 266

Pope $v$. Nickerson (U. S.) . . . . . . . $362,374,380,381,401,411,419$

Poppleton v. Yamhill Co. (Or.) . . . . . . . . . . . . 283

Porter $v$. Price (U. S.) . . . . . . . . . . . . . . 382,391

Post v. Bank (Ill.) . . . . . . . . . . . . . . . . 30 v. R. R. Co. (Mass.) . . . . . . . . . 26,27

Potinger $v$. Wightman (Eng.) . . . . . . . . . . . . . 82,83

Powell v. State (Wis.) . . . . . . . . . . . . . . 502 v. Stratton (Va.) . . . . . . . . . . . . . 255

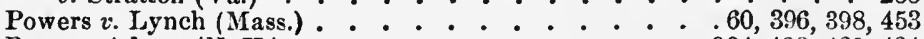

Pratt v. Adams (N. Y.) . . . . . . . . . . 294, 428, 433, 434

Preston v. Melville (Eng.) . . . . . . . . . . . . . . . 242

Price v. Campbell (Va.) . . . . . . . . . . . . . . . . 4330 v. Dewhurst (Eng.) - . - .

v. Price (Penn.) 62, 65, 69, 70, 72, 73, 74, 79, 109, 115, 117, 121, 124, 125

Pritchard $v$. Norton (U.S.) $378,380,383,389,390,411,414,425,426.466$,

Proctor v. Clark (Mass.) 505, 506, 513, 514, 515, 522, 526

Prosser $v$. Warner (Vt.) : . - . 133, 164, 170, 173, 183, 184, 191, 207

Pryse $v$. Association (Ky.) • . . . . . . . . . . . . . . . 434

Public Parks Amusement Co. v. Carriage Co. (Árk.) . . . 301, 302, 303

Pugl v. Cameron (W. Va.) . . . . . . . . . . . 374, 377, 433

Pullen $v$. Hillman (Me.) . . . . . . . . . . . . . 471,472

Pullman Car Co. v. Lawrence (Miss.) . . . . . . . . . 476, 488, 499

Putnam $v$. Johnson (Mass.) . . . . . . . . . . . . . 65 v. Putnam (Mass.) . . . . . . . . . 19, 25, 151, 159

Railroad Co. v. Alabama (U.S.) . . . . . . . . . 130

v. Babcock (U. S.) . . . . . . . . . . . . 487

v. Baker (Kan.) . . . . . . . . . . . . . . . . 277

v. Barnhill (Tenn.) . . . . . . . . . . . 130

v. Barron (Ill.). . . . . . . . . . . . . . . 516

v. Betts (Colo.) . . . . . . . . . . . . 479, 532

v. Brown (Ark.) . . . . . . . . . . . . . . 476

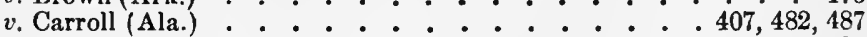

v. Chumley (Ala.). . . . . . . . . . . . . 287

v. Collector (U. S.) . . . . . . . . . . . . . 282

v. Cotton Mills (Ga.). . . . . . . . . . . . . 406, 407

v. $\operatorname{Cox}($ U. S.) . . . . . . . . . . . . 25,492 
[References are to Pages.]

Railroad Co. v. Crane (Ill.) . . . . . . . . . . . . . . 290

v. Cunningham (Kan.) . . . . . . . . . . . 518

v. Cutler (Kan.) . . . . . . . . . . . . . . . 241

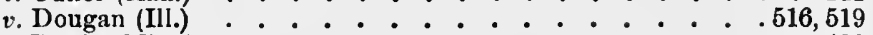

v. Doyle (Miss.) . . . . . . . . . . . . . . 4482

v. Ferry Co. (U. S.) . . . . . . . . . . . . . . 527

v. Glenn (Md.) . . . . . . . . . . . . . 130, s18

v. Ihlenberg (U.S.) . . . . . . . . . . . . 480,487

v. Jackson (Tex.) . . . . . . . . . . . . 480, 488, 489

v. Johnson (U. S.) . . . . . . . . . . . . . . . 524

v. Kennedy (Ala.) . . . . . . . . . . . 277, 519, 520

v. Koontz (U. S.) . . . . . . . . . . . . . . 130

v. Lew is (Neb.). . . . . . . . . . . . . . . . . 241

v. Lewis (Tenn.) . . . . . . . . . . . . . . . 400, 486

v. Maggard (Colo.) . . . . . . . . . . . . 287, 516

v. McCormick ('Tex.). . . . . . . . . . . 480, 485, 492, 493

v. McMullen (Ind.) . . . . . . . . . . . .482, 485, 492

v. Moore (Neb.) . . . . . . . . . . . . . . . 520

v. Nash (Ala.) . . . . . . . . . . • . 287, 288

v. Packet Co. (Ill.) . . . . . . . . . . 44, 45, 264, 265, 266

v. Sharritt (Kan.). . . . . . . . . . 287, 290, 518, 521, 532

v. Smith (Kan.) . . . . . . . . . . . . . . 267

v. Smitll (Miss.) . . . . . . . . . . 277, 281, 518, 521

v. Sturm (U. S.) . . . . . . . . . . . . . . $289,290,521$

$v$. Thompson (Kan.) .. . . . . . . . . . . 290, 516

ข. Whitlow (Ky.) . . . . . . . . . . . . . . 486

v. Williams (Ala)

Ramsay $v$. Stevenson (La.) . . . . . . . . . . . . 314, 315, 318

Rand $v$. Hubbard (Mass.) . . . . . . . . . . . . . . 232

Rankin $v$. Goddard (Me.) . . . . . . . . . . . . . . . . 188

Rathbone v. Coe (Dak.) . . . . . . . . . . . . . . . 524

Reddick $v$. Jones (N. C.) . . . . . . . . . . . . . . . . . 394

Redmond $v$. Rutherford (N. C.) . . . . . . . . . . . 283

Reed $v$. Reed (Mich.) . . . . . . . . . . 111, 112, 146, 197, 198

v. Tel. Co. (Mo.) . . . . . . . . . . . . . . . . . 407

Reid, Goods of (Eng.) . . • . . . . . . . . . . . . . 351

Reimer v. Manufacturing Co. (U. S.) . . . . . . . . 277, 288

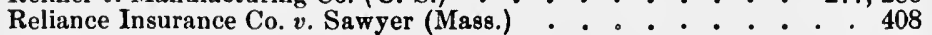

Renaud v. Abbott (U. S.); . . . . . . . . . . . . . . . . 529

Renier $v$. Hurlbut (Wis.). . . . . . . . . . . . . . . . 288

Reynolds $v$. Adden (U. S.) . . . . . . . . . . 267,325 v. Stockton (U.S.) . . . - . . 190, 228, 229, 236, 263, 266, 274

Rhawn v. Peters (Ill.). . . . . . . . . . . . . . . . . 326

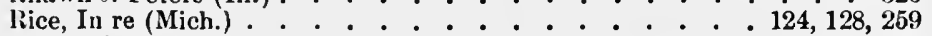

Rice $v$. Courtis (Vt.) . . . . . . . . . . . . . . . . . . 318 v. Harbeson (N. Y.) - : . : . : . . $29,244,249,250,346$ v. Moore (Kan.) . . . . . . . . . . . . . 522

Richards v. Dutch (Mass.) . • . . . . . . . . 231, 236, 255

Richardson $v$. De Giverville (Mo.) . . . . . . 29, 36, 38, 175, 341 v. Leavitt (La.) . . . . . . . . . . . . . 314

v. R. R. Co. (Mass.) . . . : : . : . . 25, 241,492

七. Rowland (Conn.) . . . . . . . . . . . . . 420, 422

v. Shelby (Okl.) . . . . . . . . . . . . . 44, 304,307

Riclımond v. R. R. Co. (Va.) . . : : . : . . . 508

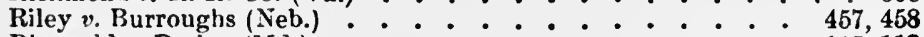

Ringgold v. Barley (Md.) . . . . . . . . . . . . 115, 118 
[References are to Pages.]

Rio Grande, The (U. S.) . . . . . . . . . . . . . 187

Ritchie $v$. McMullen (U. S.) • • • . . . . . . . . . . 188

Roberts, Will of (N. Y.) . . . . . . . . . . 137,334

Roberts $v$. Appleton (Vt.) . . . . . . . . . . . . . . . . 72

v. McNeely (N. C.) . . . . . . . . . . . . . . 433

Robinfon $v$. Bland (Eng.) . . . . . . . . . . . . . 363, 384, 428

v. Nav. Co. (U. S.) . . . . . • . • • • . . . 481

v. Queen (Tenn.) . . . . 5, 15, 14, 49, 145, 146, 147, 443, 509, 510

Rockwell $v$. Bradshaw (Conn.) . . . . . . 228, 229, 256, 274, 340, 344

Rodgers $v$. Rodgers (Kan.) . . . . 29, 30, 107, 108, 109, 203, 207, 209

Rogers, Ex parte (Tex.) . . . . . . . . . . . . 501

Rogers v. McLean (N. Y.) . . . . . . . . . . . . . 259, 261, 262

v. State (Tex.) . . . . . . . . . . . . . . $50 \mathrm{l}$

Rose $v$. Bank (Ind.) . . . . . . . . . . . . 394, 443, 447, 454

Rosenhein $v$. Morrow (Fla.) • . . . . . . . . . . . 471

Ross $v$. Ross (103 Mass. 576) •. . . . . . . . . . . . . 118 v. Ross (129 Mass. 243) 28, 29, 33, 34, 35, 36, 38, 46, 57, 82, 92, 131, 133,

Roth v. Roth (Ill.) . . . . . . . . . . . 8, 60, 150, 170, 191

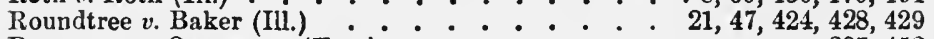

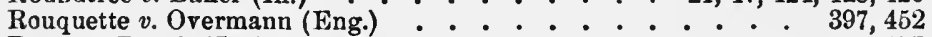

Routh $v$. Routh (La.) . . . . . . . . . . . . . 177

Rudiger $v$. R. R. Co. (Wis.) . . . . . . : . . 482, 483

Ruding v. Smith (Eng.) . . . . . . . . . . . . . . . 169

Ruggles $v$. Kisler (N. Y.) • . . . . . . . . . . . . . 526

Ruhe $v$. Buck (Mo.) . . . . . . $505,506,507,508,510$

Ruse $v$. Insurance Co. (N. Y.) . . . . . . . . . . . 409

Russell $v$. Hooker (Conn.) . . . . . . . . 137, 233, 254, 272 v. R. R. Co. (Cal.) •. . . . . . . . . 26, 27

$\mathrm{S}_{\mathrm{AFE}}$ Co. v. Norton (N. J.) • . . . . . . . 271, 293, 301, 302

Sanders $v$. Gatchell (Me.) . . . . . . . . . . . 60

Sandidge $v$. Hunt (La.) . . . . . . . . . . . . 531, 532

Sands $v$. Smith (Neb.) . . . . . . . . . . . . . . . . 433

Sapplire, The (U. S.) . . . • • . . . . . . . . 509

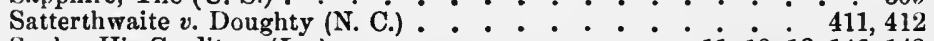

Saul v. His Creditors (La.) . • . . . . . . 11, 12, 13, 146, 148

Sarings Bank $v$. National Bank (U. S.) . . . . . . . . 280, 297

Schefferling $v$. Huffman (Ohio) . . . . . . . . . . . . 180

Schluter $v$. Bank (N. Y.) . . . . . . . . . . . . . . 47, 141,142

Schneller $v$. Vance (La.) . . . . . . . . . . . . 262

School Directors v. James (Penn.) ${ }^{\circ} \quad 6_{4}^{\circ}, 74^{\circ}, 80,83,84,8 \dot{0}^{\circ}, 88^{\circ}, 89,90,91$

Schuler $v$. Israel (U. S.) . . . . . . . . . . . . . 310, 314

Scofield $v$. Day (N. Y.)

Scotland, The (U. S.) . . . . . . . . . . . . . . 481

Scotland Co. $v$. Hill (U. S.) . . . . . . . . . . . . . 455, 456

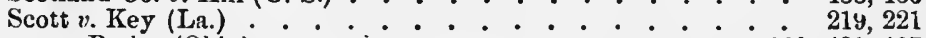

$v$. Perlee (Ohio) . . . . . . . . . $380,431,437$

Scoville $v$. Canfield (N. Y.) . . . . . . . . . 24, 280, 297, 306

Scrimshire $v$. Scrimshire (Eng.) 167

Scudder $v$. Bank (U. S.) $362,368,377,391,392,411,413,414,419,448,454$,

465,514

Sea Grove, etc. Ass'n v. Stockton (Penn.) . . . . . . . . . . . 524

Seamans v. Knapp Co. (Wis.) . . . . . . . . . . . . 368, 398, 408

Searight $v$. Calbraith (U. S) . . . . . . . . . . . . 466

Seiter $v$. Straub (N. Y.) . . . . . . . . . . . . . . 90 
[References are to Pages.]

Selectmen of Boston $v$. Boylston (Mass.) . . . . . . . . . . 230

Senac's Will (La.) . . . . . . . . . . . . . . . . . . . 349

Sevier $v$. Douglass (La.) . . . . . . . . . . . . . . . . . 334

Sewall $v$. Sewall (Mass.) . . . . . . . . . . . . . 197, 198

v. Wilmer (Mass.). . . . . . . . . . . 340, 352, 353, 354

Seward v. Rising Sun (Ind.) . . . . . . . . . . . . . 282

Shannon $v$. Shannon (Mass.) . . . . . . . . . . . . . . . 198

v. White (Mass.) •. . . . . . . . . . . 230, 328

Sharpe $v$. Crispin (Eng.) . . . . . 73, 74, 80, 82, 83, 106, 129, 328, 330

Shattuck $v$. Chandler (Kan.). . . . . . . . . . . . . 532

Slsaw v. Gould (Eng.) . . . . . . . . . . . . . 149, 170, 216 $v$. Shaw (Mass.) . . 67, 70, 71, 96, 99, 115, 118, 119, 121, 124, 125, 195

Sheddon $v$. Patrick (Eng.) . . . . . . . . . . . . . 216

Sheldon $v$. Haxtun (N. Y.) . . . . . . 372, 373, 389, 433, 434, 436, 437 v. Rice (Mich.) . . . . . . . . . . . . . 231, 232, 235 $v$. Wheeler (U. S.) . . . . . . . . . . . . . . 46, 314

Shelton $v$. Tiffin (U. S.) . . . . . . . . . . . . . . . . 62, 122

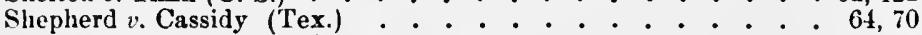

Shields $v$. Colemau (U. S.) . . . . . . . . . . . . . . . 265

Shoe \& Leather Bank $v$. Wood (Mass.) . . . . . . . . . 371,443

Short v. Galway (Ky.) . . . . . . . . . . . . . . . . 246

Shreck $v$. Shreck (Tex.) . . . . . . . . . .94, 99, 169, 183, 184, 196

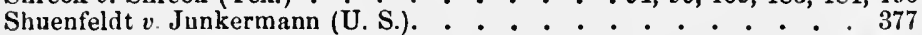

Shultz v. Pulver (3 Pai. Ch. 182) . . . . . . . . . . . 229,328 $v$. Pulver (11 Wend. 361) . . . . . . . . . . . . 234, 328

Sickles $v$. New Orleans (U. S.) . . . . . . . 137, 139, 272, 328, 334, 340

Sill $v$. Worswick (Eng.) . . . . . . . . . . . . . . 270

Silverman v. Lessor (Me.) . . . . . . . . . . . . . . . 472

Simmons $v$. Commonwealth (Penn.) . . . . . . . . . . . . 503

Simonin $v$. Mallac (Eng.) . . . . . . . . . . . . . . . 167

Simpson $v$. State (Ga.) . . . . . . . . . . 482, 500, 501,502 v. State (Tenn.) . . . . . . . . . . . . . 503

Sims v. Sims (N. Y.) . . . . . . . . . . . . . . . . . 21, 24

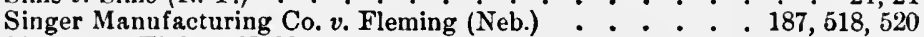

Skinner $r$. 'Tinker (N. Y.) • . . . . . . . . . . . . . . . 412

Skottowe $v$. Young (Eng.) . . . . . . . . . . . . . . . 35, 133

Slack $v$. Perrine (U. S.) . . . . . . . . . . . . . . . . 188

Slaughter $v$ Garland (Miss.)

Slocum v. Pomery (U. S.) . . . . . . . . . . . . . . . . 453

Smith, Ex parte (U. S.) . . . . . . . . . . . . . . 504

Smith $v$. Derr (Penn.). . . . . . . . . . . . . . . $33,35,216$

v. Eton (Me.) • . . . . . . . . . . . . . 287, 324

v. Kelly (Miss.) . . . . . . . . . 35, 212, 213, 216, 217

v. McAtee (Md.) . . . . . . . . . . . . . . 179

v. Mead (Conn.) •. . . . . . . . . . . . . . . 389

v. Parsons (Minn.) . . . . . . . . . . . . . . . 418, 431

v. People (111.) . . . . . . . . . . . . . . 118

v. Smith (Neb.) • . . . . . . . . . 94, 95, 96, 198

v. Smith (La.) . . . : : $96,98,99,101,177,201,203,206$

v. Smith (Mass.) . . . . . . . . . . 134, 198

v. Smith (Va.) . . . . . . . . . . . . . . . . 305

v. 'Taber (Tex.)

$v$ Union Bank (U.S.) $: 0^{\circ} \cdot 10,49,225,227,230,235,243,257,272$

Smytlie $v$. Allen (Miss.) . . . . . . . . . . . . 504

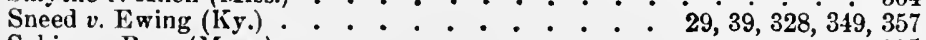

Sohier $r$. Burr (Mass.) . . . . . . . . . . . . . . 337 
Somerville $v$. Somerville (Eng.) . . . . . . 69, 70, 71, 72, 74, 79, 328 Sondheim $v$. Gilbert (Ind.) • . . . . . . . . . . 384,428 Sorrey $v$. Bright (N. C.) . . . . . . . . . . . . . . . 337 Sottomayor $v$. DeBarros (Eng.) . . . . . . . . . . 149, 150, 154 South African Breweries v. líng (Eng.) . . . . . . . . . . 421 Southern B. etc. Ass'n v. Harris (Ky.). . . . . . . . . . . . 434 Southern Ins. Co. v. Hardware Co. (Tex.) . . . . . . . . . 188 Southern Pacific Co. v. Graham (Tex.) . . . . . . . 475, 484 Spearman $v$. Ward (Penu.) . . . . . . . . . . 38, 247, 508 Speed $v$. May (Penn.) - • . . 225, 272, 278, 280, 310, 311, 312, 318, 325 Stacy $v$. Thrasher (U. S.) . . . . . Staigg $v$. Atkinson (Mass.) . . . . 29, 36, 37, 38, 251, 252, 341, 344, 348 Stanford $v$. Pruet (Ga.) . . . . . . . . . . . . . . 394 Staples $v$. Nott (N. Y.). . . . . . . . . . . . $389,434,436$ Starbuck $v$. Murray (N. Y.). . . . . . . . . . . . . 197

Stale $v$. Barrow ('Tex.) . . . . . . . . . . . . . 177, 178 v. Bowen (Kan.) . . . . . . . . . . . . . . 500 v. Brown (N. C.) . . . . . . . . . . . . . 503 v. Carl (Ark.) . . . . . . . . . . . . 296, 373 v. Carter (N. J.) . . . . . . . . . . . . 500 v. Chapin (Ark.) . . . . . . . . . . . . 499, 501 v. Foster (La.) . . . . . . . . . . . . . . . 500 v. Gessert (Minn.) . . . . . . . . . . . . 500 v. Grady (Conn.) . . . . . . . . . . . . . 501 v. Hall (N. C.) . . . . . . . . . . 447, 498, 500, 504 v. Kelly (Me.) • • . • • . . . . . . . . . . 500 v. Kennedy (N. C.) - . 11, 18, 20, 133, 149, 152, 153, 160, 163, 167 v. Mitchell (N. C.) . . . . . . . . 4 497, 498 v. Moore (N. H.) . . . . . . . . . . . . . 501 v. Newman (Neb.) . . . . . . . . . . . . 503 v. O'Neil (Vt.) . . . . . . . . . . 271, 295, 296, 373 v. Palmer (N. H.) . . . . . . . . . . . . . . 117 v. Ross (N. C.). v. Schaeffer (Mo.) . . . . . . . . . . 502 v. Tutty (U. S.) . . . . . . . . 152, 153, 163, 167, 173 v. Weatherby (Me.) . . . . . . . . . . . 157, 159 v. Wyckoff (N. J.) • • • . . . . . . . . . . . 501 State Bank $v$. Richmond (Va.) - . - . . . . . . . 281, 283 State Mut. Ins. Co. $v$. Brinkley Co. (Ark.) - : $371,377,398,399,408$ State Tax on Foreign Held Bond (U. S.) . . . . . . . 281, 282, 283 Stearns v. Burnham (Me.) . . . . . . . . . . . . . 284 Stebbins $v$. Leowolf (Mass.) . . . . . . . . . . . . . 404, 448

Steele v. Braddell (Irish) . . . . . . . . . . . . . . . 167

Steer, In re (Eng.) . . . . . . . . . . . . . . . 74

Steer, Succession of (La.) $: \quad: 62,65,72,73,79,109,115,118,128,176$

Stephens v. James (Eng.) • . . . . . . . . . . . . 262

Stepp $v$. Association (S. C.) . . . . . . . . . . . . . . 455

Stevens $v$. Brown (W. Va.). . . . . . . . . . 516,519 v. Gaylord (Mass.) v. Gregg (ky.) . . . . . . . . . . . . 443, 447, 526 Stevenson $r$. Gray (Ky.) . . . . . . . . . . 19, 20, 151, 152, 154 Stewart $v$. Jessup (Ind.) • . . . . . . . . . . . . . 502 v. R. R. Co. (U. S.) $25,26,27,239,240,241,242,475,477,478,479$, $480,492,493,494$ v. Stewart (W. Va.) . . . . . . . . . . . 207

Stickney ". Jordan (Me.). . . . . . . . . . . . . 455 
[References are to Pages.]

Still $v$. Woodville (Miss.) . . . . . . . . . . . . . . . . . 114

Stirk v. Hamilton (Me.) . . . . . . . . . . . . . . . . . 441

St. Joseph, etc. R. R. Co. v. Smitl (Kan.) . . . . . . . . . . 267

St. Louis, etc. R. R. Co. v. Brown (Ark.) . . . . . . . . . 476 v. McCormick (Tex.) •......... $480,485,492,493$

St. Sure $v$. Lindsfelt (Wis.) . . . . . . . . . . . . . . . . 21, 24, 199

Stoddard v. Harrington (Mass.) . . . . . . . . . . . . 472

Stoneman v. R. R. Co. (N. Y.). . . . . . . . . . . . . . . 508

Stout $v$. State (Md.) . . . . . . . . . . . . . . . . . . 500

Strathmore Peerage (Eng.) . . . . . . . . . . . . . . . 216

Strawbridge $v$. Robinson (Ill.) . . . . . . . . . . . . 379, 397, 441

Street $v$. Insurance Co. (S. C.) . . . . . . . . . . . . . . . 187

Strouther $v$. Commonwealth (Va.) . . . . . . . . . . . 502, 503

Stubbs v. Colt (U. S.) . . . . . . . . . . . . . . 392, 394, 452

Sturdivant $v$. Bank (U.S.) . . . . . . . . . . . . 433, 448

Sturges $v$. Crowninshield (U. S.) • . . . . . . . . . . . 471

Sturtevant $v$. Armsby Co. (N. H.) - . . . 13, 15, 46, 254, 322, 325, 326 v. Robinson (Mass.) . . . . . . . . . . . . . 277

Succession of Cassidy (La.)

Succession of Hernandez (La.) . . . . . . 21, 25, 150, 157, 158, 177

Succession of Larendon (La.) . . . . . . . . . . . . 33

Succession of Lewis (La.)

Succession of Packwood (La.) . . . . . . . . . . . $178,232,349,354$

Succession of Petit (La.) . . . . . . . . . . . . . 328, 331

Succession of Steer (La.) $:{ }^{-} 62,65,72,73,79,109,115,118,128,176$

Succession of Wilder (La.) . . . . . . . . . . . 146, 148, 179

Suit $v$. Woodhall (Mass.)

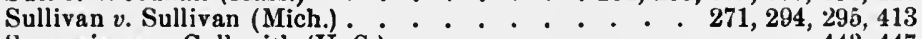

Supervisors $v$. Galbraith (U. S.) . . . . . . . . . . . . 443, 447

Suter $v$. Suter (Miss.) . . . . . . . . . . . . . . . . . . . . 94, 99

sutro Tunnel Co. $v$. Mining Co. (Nev.) . . . . . . . . . . 455

Sutton $v$. Warren (Mass.) . . . . . . . . . . 20, 150, 154, 161, 171

Swank $v$. Hufnagle (Ind.) . . . . . . . . . . . . . . 29, 38

Swann v. Swann (U. S.) . . . . . . . . . . . . 21, 49, 403

Swedish-American Bank v. Bleecker (Minn.) . . . . . . . . . 288

Talbot v. Chamberlain (Mass.) ; . . . . . . 68, 72, 88, 107, 108, 109

Talbott $v$. Transportation Co. (Ta.) . . . . . . . . . . 381, 406, 407

Talmage $v$. Chapel (Mass.) . . . . . . . . . . . . . . 230, 236, 238

Tappan v. Bank (U.S.) . . . . . . . . . . . . . . . . 282

Tarbox $v$. Childs (Mass.) . • . . . . . . . . . . . . 294, 469

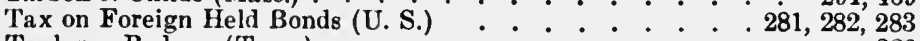

Taylor $v$. Badoux (Tenn.) . . . . . . . . . . . . . . 326 v. Pennsylvania Co. (Ky.) - . . . . - . $v$. Sharp (N. C.) . . . . . . . . 47, 124, 145, 146, 362, 411

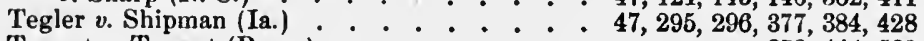

Tenant ". Tenant (Penn.) . . . . . . . . . 378, 444, 529

Texas, etc. R. R. Co. v. Cox (U. S.) . . . . . . . . . 25, 492

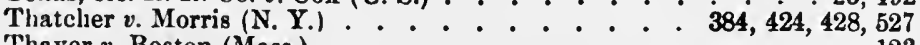

Thayer $v$. Boston (Mass.). . . . . . . . . . . . . . . . . 123

The Antelope (U. S.) • • . . . . . . . . . . . . 21

The Brantford City (U. S.) . * . . . . - 356, 362, 365, 406, 428, 481

The City of Carlisle (U.S.) . . . . . . . . . . . . 514

The Energia (U. S.) . . . . . . . . . . . . . . 379, 406

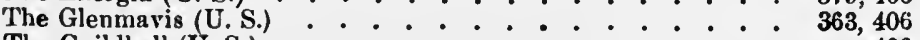

The Guildhall (U. S.) . . . . . . . . . . . . . . . 406 
The Harrsburg (U. S.) . . . . . . . . . . . . . . 496

The Homestead Cases (Va.). . . . . . . . . . . . 517

The Hugo (U. S.) . . . . . . . . . . . . : 365,406

The Iowa (U. S.) . . . . . . . . . . . . . . . 406

The Majestic (U. S.) . . . . . . . . . . . . . . 406, 407

The Marina (U. S.) . . . . . . . . . . . . . 302, 303

The Oranmore (U. S.) . . . . . . . . . . . . . 406

The Rio Grande (U. S.) . . . . . . . . . . . . . . . 187

The Sapphire (U.S.) . . . . . . . . . . . . . 509

The Scotland (U. S.) . . . . . . . . . . . . . . . 481

The Venus (U. S.) . . . . . . . . . . . . . . . . 125

Theroux $v$. R. R. Co. (U. S.) . . . . . . . . . . . . 524

Thomas $v$. Morrissett (Ga.) . . . . . . . . . . . . 189

Thompson $v$. Ketcham (N. Y.) . . . . . . . . . . . 148, 378, 532

v. Thompson (Ala.) . . . . . . . . . . . . . 203

v. Whitman (U. S.)

Thomson-Houston Electric Co. v. Palmer (Minn.) : : 362, 411, 469, 505,

Thorn $v$. Weatherly (Ark.) . . . . . . . . . . . 530

Thorndike $v$. Boston (Mass.) . . . . . . . . . . . . . . 281

Thornton $v$. Curling (Eng.) . . . . . . . . . . . . . . . . 344

v. Dean (S. C.) . . . . . . . . . . . . . 363, 434

Thorp $v$. Thorp (N. Y.) . . . . . . . . . . 19, 101, 159, 160

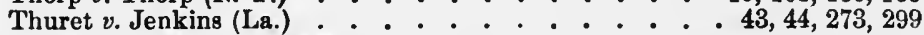

Thurston $v$. Percival (Mass.) . . . . . . . . . . . . . 478

v. Rosenfield (Mo.) • . . . . . . . . . 31, 311, 314, 317

$v$. Thurston (Minn.) . . . . . . 191, 195, 196, 199, 203, 207, 208

Tilden $v$. Blair (U. S.) . . . . . . . . . . $372,391,433,436$

Tillotson $v$. Prichard ( $\left.\mathrm{V}_{\mathrm{t} .}\right)$. . . . . . . . . . . . . . 457, 476

Tingley $v$. Bateman (Mass.) . . . . . . . . . . . . . . . . 289

Tipton $v$. Tipton (Ky.) . . . . . . . . . . . . . 59,67

Tooey $v$. Lindsay (U. S.) . . . . . . . . . . . . . . . 170

Toof $v$. Miller (Ia.) . . . . . . . . . . . . . . . . . . . 272

Toronto, etc. Trust Co. v. R. R. Co. (N. Y.) . . . . . . . 266

Touro v. Cassin (S. C.) . . . . . . . . . . . . . . . 428, 429

Townes $v$. Durbin (Ky.) . . . . . . . . . . . . . . . . . 177

Townsend $v$. Coxe (Ill.) . . . . . . . . . . . . . . . . . 31

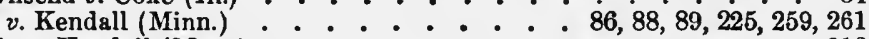

Train $v$. Kendall (Mass.) . . . . . . . . . . . . . 316

Trasher $v$. Everhart (Md.) . . . . . . . . . . . . . 507

Trevor $v$. Wood (N. Y.) . . . . . . . . . . . . . 372

Trimbey $v$. Vignier (Eng.)

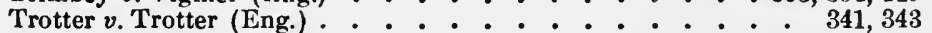

True $v$. Ranney (N. H.) . . . . . . . . . . . . 10, 152, 160

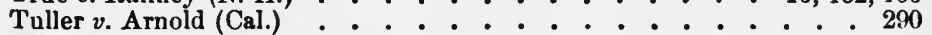

Tunstall $v$. Pollard (Va.). . . . . . . . . . . . . . . 233

Tyler $v$. People (Mich.) . . . . . . . . . . . . . . . . 500 v. Strang (N. Y.) . . . : . . . . . . . . . . . . . 279

UDNY $v$. Udny (Eng.) . . . . . . 72, 75, 114, 120, 125, 126, 128, 149, 216 Ufford $v$. Spaulding (Mass.) . . . . . . . . . . . 528, 529, 520

Underwood $v$. Mortgage Co. (Ga.) . . . . . . . . . . . 484

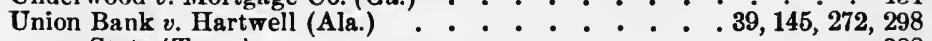
v. State (Tenn.) . . . . . . . . . . . . . 282

Union Pacific R. R. Co. v. Baker (Kan.) . . . . . . . . . 277

United States $v$. Britton (U. S.) . . . . . . . . . ., . . . 501 
[References are to Pages.]

United States v. Crosby (U. S.) . . . . . . . . . . . . . 28

v. Guiteau (U.S.) . . . . . . . . . . . . . . . 500

v. Howell (U.S.) . . . . . . . . . . . . . . . . . 501

v. Plimpton (U.S.) . . . . . . . . . . . . . . 502

v. R. R. Co. (U. S.) . . . . . . . . . . . . . . . 282

v. Wagner (Eng.) . . . . . . . . . . . . . . . . . 509

United States Investment Co. v. Windmill Co. (Kan.). .

United States Sav, and L. Ass'n v. Scott (Ky.) . . . . . . . 379,434

Upton $v$. Nortlıbridge (Mass.) . . . . . . . . . . . . . . 73, 106

Usher $v$. R. R. Co. (Penn.) . . . . . . . . . . 25, 239, 242, 493

VALK $v$. Valk (R. I.) . . . . . . . . . . . . . . . . 199, 200

Van Buskirk v. Warren (N. Y.) . . . . . . . . . . . . . . 305

Van Cleef $v$. 'Therasson (Mass.) . . . . . . . . . . . . . 469

Van Fossen $v$. State (Olio) . . . . . . . . . 101, 133, 170, 184, 196, 198

Van Matre $v$. Sankey (11l.) $36,37,74,75,79,80,82,83,85,93,131,189,192$,

Van Orsdal $v$. Van Orsdal (Ia.)

$221,222,5 * 2$

Van Raden $v$. R. R. Co. (N.Y.) . . . . . . . . . . . . . . . . . . 487

Vall Steenwyk $v$. Washburn (Wis.) . . . . . . . . . 341, 344, 345

Van Storch $v$. Griffin (Penn.) . . . . . . . . . . . . . . . . . 157

Van Vleet $v$. Sledge (U. S.) . . . . . . . . . . . 433

Van Voorhis $v$. Brintnall (N. Y.) · 10,11, 19, 21, 25, 151, 152, 154, 157, 159,

Van Wyck $v$. Read (U. S.) . . . . . . . . . . . . 160, 161, 166

Vauder Donk $v$. Thelusson (Eng.) . . . . . . . . . . . . . 530

Vanderpoel $v$. O'Hanlon (Ia.) . . . . . . . . . . . . . . . 56

Vansant v. Roberts (Md.) . . . . . . . . . . . . . . . . 139

Varnum v. Camp (N.J.) . . . . . . . . . . . $312,313,315,316,317$

Vassar v. Camp (N.Y.) . . . . . . . . . . . . . . . 372,373

Vaughn v. Barret ( $\mathrm{Vt}$.) . . . . . . . . . . . . . . 233

v. Northup (U.S.). . . . . . . . 225, 231, 232, $235,236,254,255$

Vawter v. R. R. Co. (Mo.) . . . . . . . . . . . . 241, 480, 492

Venus, The (U. S.) . . . . . . . . . . . . . . . . . 125

Vermilya $v$. Beatty (N. Y.) . . . . . . . . . . . . . . 232, 236

Vermont Bank $v$. Porter (Conn.) . . . . . . . . 466, 467, 513, 526

Vidal $v$. Thompson (La.) . . . . . . . . . . . . 4 411, 412

Vischer $v$. Vischer (N. Y.) $\quad$. . . . 103, 104, 115, 117, 125, 167, 169, 196

Voorheis $v$. Society (Mioh.) . . . . . . . . . . . . . 371, 398, 409

Vroom $v$. Van Horne (N. Y.) $\quad$. . $227,229,231,232,235,277,284,328$

Wa Bash R. R. Co. v. Dougan (Ill.) . . . . . . . . . . 516, 519

Waldo $v$. Waldo (Mich.) . . . . . . . . . . . . . . . . 197

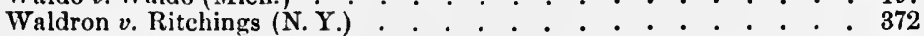

Walker $v$. Marseilles (Miss.) : . . . . . . . . . . . . . . 299

Wall $v$. Equitable, etc. Society (U.S.) . . . . . . . . . 379,409

Walsh $v$. Mayer (U.S.)

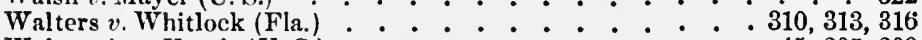

Walworth $v$. Ilarris (U. S.) . . . . . . . . . . . 45, 307, 309

Warder $v$. Arell (Va.) . . . . . . . . . . . . . . 466, 467

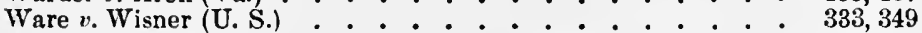

Warner $v$. Jaffray (N.Y.)

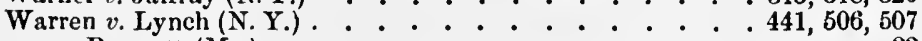

v. Prescott (Me.) . . . . . . . . . . . . . . . 33

Warrender $v$. Warrender (Eng.) $:{ }_{0} \cdot 5,9 \dot{4}, 95,96,104,105,167,169,199$

Washburn $v$. Van Steenwyk (Minn.) . . . . . 29, 341, 344, 345, 346 
[References are to Pages.]

Washburn $v$. White (Mass.) . . . . . . . . . . 82, 92

Washington $v$. Beaver (Penn.) . . . . . . . . 77, 87, 93, 106

Watkins $v$. Holman (U.S.) . . . . . . . . . . . . . 29, 235 v. Watkins (Mass.) - 94, 99, 100, 103, 133, 170, 183, 184, 198, 199, 200 $v$. Watkins (Ind.). . . . . . . . . . 196, 198

Watson $v$. Brewster (Penn.) . . . . . . . . . . . . 507 v. Campbell (N. Y.) • . . . . . • . . . . . . . 306, 318 v. Lane (N. J.) . . . . . . . . . . . . . . . 372,433

Wayne County Bank $v$. Low $(\dot{\mathrm{N}} \dot{\mathrm{Y}}$.) $\quad$ - : : $371,37 \dot{3}, 389,434,436$

Webb's Estate (N. Y.) . . . . . . . . . . . . 158

Webber $v$. Howe (Mich.) . . . . . . . . . . 294, 373, 377, 384, 428

Webster $v$. Howe Machine Co. (Conn.) . . . . . . . . . . 447 v. Munger (Mass.) . . . . . . . . . . . . • 294

Weil $v$. Golden (Mass.)

Weinstein v. Freyer (Ala.) . . . . . . . . . . . 271, 293, 302

Welch v. Adams (Mass.) . . . . . . . • . . 231, 340

Welles' Estate (Penn.) . . . . . . . 227, 253, 254, 255, 328, 329, 331

Wells, Fargo, \& Co. v. Davis (N. Y.) . . . . . . . . . . . . . 456

Wesner v. O'Brien (Kan.) . . . . . . . . . . . . . . . 208

West Cambridge $v$. Lexington (Mass.) . . 11, 18, 25, 150, 154, 157, 158, 159

Western $v$. Insurance Co. (N. Y.) . . . . . . . . . . . . 408

Western, etc., R. R. Co. v. Cotton Mills (Ga.) . . . . . . 406, 407

Western Transfer Co. v. Kilderhouse (N. Y.) . . . . . . . . 371

Western Union Tel. Co. v. Phillips (Tex.) . . . . . • . . . . 355 v. Way (Ala.) . . . . . . . . . . . . 404,419

Wheeler $v$. Hollis (Tex.) . . . . . . . . . . 83, 86, 88, 89, 91 v. Jackson (U.S.) . . . . . . . . . . . . . . 522

Whicker $v$. Hume (Eng.) . . . . . . . . . . . . . . . . 72

Whipple $v$. Thayer (Mass.) . . . . . . . . . . . . . 314

Whiston $v$. Stodder (La.) . . . . . . . . . . . . . . 372

White $v$. Brown (U.S.) . . . . . . . . . . . . . . 111

v. Howard (Conn.) . . . . . . . . . . . . . 32

v. Howard (52 Barb. 294$)$

v. Howard (46 N. Y. 144) . . . . . . . . . 141, 334

v. Tennant (W. Va.) $62,65,67,69,70,109,115,117,118,119,120,176$,

Whitford $v$. R. R. Co. (N.Y.) _ . . 478, 491, 532

Whitney $v$. Sherborn (Mass.) . . . . . . . . . 64,65, 118

Wick $v$. Dawson (W. Va.) . . . . . . . . . . . 29, 38, 247, 505

Wightman $v$ Wightman (N.Y.) . . . . . . . . . . 20, 161

Wilcox $v$. Ellis (Kan.) . . . . . . . . . . . . 281, 283

Wilder, Succession of (La.) . . . . . . . . . 146, 148, 179, 411

Wilkins $v$. Ellett (9 Wall. 740) . . . . . . . 225, 227, 230, 242, 253, 328 v. Ellett (108 U. S. 256) . . . . . . . . . . . 234, 242

Willetts $v$. Waite (N. Y.) - * : * : 264, 265, 322, 323, 324, 325, 326

Williams v. Armroyd (U. S.) •. . . . . . . . . . 187 v. Dry Goods Co. (Okl.) 10, 13, 31, 62, 271, 310, 311, 313, 314, 316, 317 ,

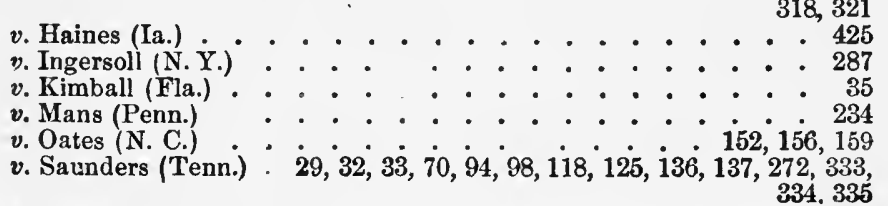

v. Storrs (N. Y.) . . . . . . . . . . . . 242 
Williams $v$. Wade (Mass.)

396,454

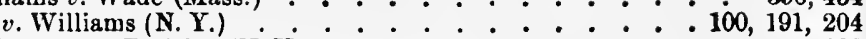

Williamson $v$. Parisien (N. Y.) . . . . . . . . . . . . . . . 198 v. Smart (N. C.) . . . . . . . . . . . . . . . 381

Wilson v. Cox (Miss.) . . . . . . . . . . . . . . . . . . 341

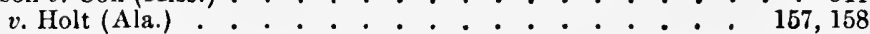
v. Lazier (Va.) . . . . . . . . . . . . . 389, 444, 526 v. Mills Co. (N. Y.) . . . . . . . . . . . . . . . . 413 $v$. Tootle (U. S.) . . . . . . . . . . . . . . . 494 v. Wilson (Eng.) . . . . . . . . . . . . . . 170

Winchelsea $v$. Garetty (Eng.) . . . . . . . . . . 248, 249, 250

Winswall $v$. Sampson (U.S.) • . . . . . . . . . . . . . . 267

Wolf, Appeal of (Penn.) . . . . . . . . . . . . . . 216

Wolf $v$. Burke (Colo.) . . . . . 370, 413, 414, 415, 417, 418, 525, 531

Wood $v$. Insurance Co. (Wash.) . . . . . . . . 371, 398, 399, 408 v. Malin (N. J.) .... . . . . . . . . . . . . . 512 v. Roeder (Neb.) . . . . . . . . . . . . . . 59 v. Watkinson (Conn.). . . . . . . . . . . . . . . 189 v. Wheeler (N. C.) . . . . . : . : . $30,44,144,146$ v. Wood (N. Y.) . . . . . . . . . . 40, $88,89,90,259,337$ v. Wood (Ark.) . . . . . . . . . . . . . . . . 102, 200

Woodard v. R. R. Co. (Ohio) . . . . . . . . . . . . . . . 492

Wooden v. R. R. Co. (N. Y.) . . . . . . . $25,239,242,489,492,494$

Woodruff $v$. Hill (Mass.). . . . . . . . . . . . . . . . . 447

Woodsen $v$. Owens (Miss.) . . . . . . . . . . . . . . . . 447

Woodward $v$. Brooks (III.) . . . . . 10, 16, 266, 279, 312, 313, 314, 315, 318 $v$. Woodward (Tenn.) 33, 35, 80, 81, 82, 83, 84, 85, 88, 92, 93, 133, 141,

$143,216,222$

Woodworth $v$. Spring (Mass.) . . . . . . . 17, 88, 180, 258, 259, 260

Wooley $v$. Lyon (Ill.) . . . . . . . . . . . . . . 396, 397, 452

Worcester Bank $v$. Wells (Mass.) . . . . . . . . . . . . . 392

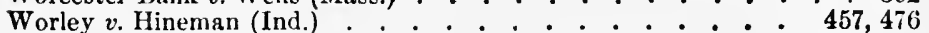

Worth $v$. Ashe County (N. C.) . . . . . . . . . . . . . 282

Wright's Trusts (Eng.) ................ . . . 35, 75, 216

Wrigley, In re (N. Y.) • • . . . . . . . . . . . . . . 59

Wunstan v. Higgins (N. Y.). . . . . . . . . . $: 4188$

Wyman $v$. Halstead (U. S.) . . . . . . . . . . . . 272, 283

Wynne $v$. Wynne (Miss.) . . . . . . $333,341,347,348,349$

YATES $v$. Thompson (Eng.) . . . . . . . . . . . 334, 339, 341

Yelverton v. Yelverton (Fng.) . . . . . . . . . . . . . . 97, 99

Young $v$. Harris (Ky.) . . . . . . . . . . . . . . . 378, 394, 454 v. Pollak (Ala.) . . . . . . . . . . . $72,111,112,117$

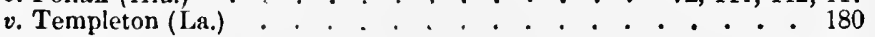

Zipcex v. Thompson (Mlass.) . . . . . . . . . . . . 813, 316 


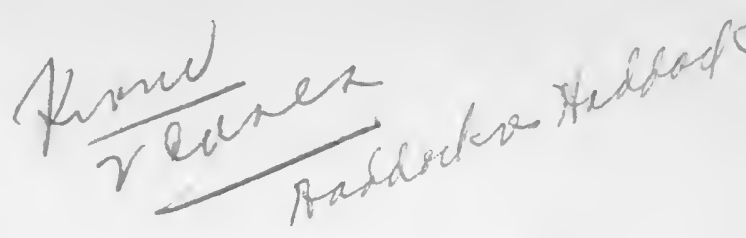

CONFLICT OF LAWS.

\author{
PART I. \\ INTRODUCTORY.
}

\title{
CHAPTER I.
}

\section{INTRODUCTION.}

§ 1. Orgin of Private International Law. - Of the exist. ence among the ancients of the branch of municipal law known as Private International Law, or The Conflict of Laws, we have no authentic record. If there were any such cases, they have left no impress behind them, and were probably decided as they arose, upon no definite principles.

Nor during the Middle Ages was there any material advance. The nations of mediæval Europe had little intercourse with one another, save for warlike purposes. Commerce was as yet but scantily developed, traveling much impeded. With but small occasion for such codes of rules, little attempt was made to establish them.

But with the revival of commerce, the surer guaranties offered for the safety of travelers by reason of the more orderly condition of the European States, the more frequent intercourse between nations, and the advancement of conceptions of justice and order, the need of such rules began to be experienced, just as, at an earlier period, the necessity for the regulations of public international law had been felt.

Only within the past century however has any regular form been imparted to the subject. In recent years it has been much discussed both by English and American writers and judges, as well as by continental jurists, until it has finally assumed the 
proportions of a distinct branch of legal science, though many of its leading principles still remain remarkably obscure and unsettled. ${ }^{1}$

§ 2. Public and Private International Law distinguished. - Private international law may be distinguished frorn the public in three important particulars.

I. As to the persons on whom it operates.

Private citizens are the subjects of this branch of the law, while public international law deals for the most part with nations as such.

It is true that occasionally, under the latter law, individuals are interested in the questions raised, and are sometimes even the cause of international complications, perhaps of war ; but it is not as individuals that public international law interferes in their behalf or condemns them. It is becanse individuals necessarily form a constituent part of every State, parts of which the nation as a whole is made up; and as no injury can be in flicted on one part of the body or by one member without the participation of the whole, so no member of the body politic can be injured without damage to the material interests, the dignity, and the honor of the whole. It is because of this blow to or by the State that public international law interferes in such matters.

Private international law, on the other hand, is a part of the municipal law of each State. It deals with individuals as individuals, as persons asking for justice at the hands of judges who are striving to give it, regardless of nationality or locality.

II. As to the transactions to which it relates.

The law of nations recognizes in general only transactions in which sovereign States are interested. Not so with private international law. The transactions over which it assumes control are strictly private in their nature, in which the State as such has generally no interest. The private contract of the citizen of one State with the citizen of another, or a conveyance or will made by the citizen of one State transferring property in an. other, are subjects of private international law, with which pub. lic international law has no concern.

1 For the contents of this section. cf. Story, Confl. L., ch. i. 
III. As to the remedies applied.

In cases to which private international law is applicable, recourse is had to judicial tribunals acting under the authority and in accordance with the rules of procedure of the country in which they sit. 'They are asked to hear the evidence and ad. minister justice as though the case were one of purely domestic concern. But in a contest between sovereign States arising under the law of nations, no such recourse is ordinarily practicable. No State would consent to have its disputes decided by the courts of another power, nor to appear before them, a suppliant for the justice it demands as a right.

Yet this general principle is not altogether free from exceptions or apparent exceptions, the most pronounced of which, perhaps, arises from the peculiar form of government existing in the United States.

The States of this Union are sovereign States, save in so far as they have by solemn compact yielded their sovereignty to the federal government. They have surrendered their sovereignty only with respect to their public relations with other nations, and with respect to the few other matters named in the federal constitution. In all other respects they are sovereign, having exclusive control over persons and things within their territories. ${ }^{1}$ Hence, though the federal government is the only sovereign in the United States subject to public international law, every State and Territory in the Union may be the subject of private international law.

But sovereign as the States are, in most matters of local concern, it is provided by the federal constitution ${ }^{2}$ that the Supreme Court shall have jurisdiction to decide all disputes arising between the States. Thus is presented with us the extraordinary spectacle of two or more sovereign or quasi-sovereign States submitting their differences to a learned and illustrious tribunal for an orderly and peaceful solution, anticipating the dream of a universal Court of Appeal for all nations.

Meanwhile, in the absence of such an exalted tribunal, to

${ }^{1}$ Hood $v$. State, 56 Ind. 263, 26 Am. Rep. 21, 22 ; Petersen v. Chemicaj Bank, 32 N. Y. 21, 40-41, 88 Am. Dec. 298.

2 U. S. Const., Art. 3, $\& 2$. 
which all nations may resort, the only remedies for the infringement of a nation's rights are a recourse to diplomatic channels; should that fail, to retorsion, reprisal, and other means short of war; and finally to the arbitrament of arms, - that last dreadful resort of an insulted or injured people.

§3. Foreign Element essential to Operation of Private International Law. - Private international law embraces those universal principles of right and justice which govern the courts of one State having before them cases involving the operation and effect of the laws of another State or country. Such cases arise whenever a foreign element is introduced into a transaction.

If the transaction in question arises wholly within a single State, all the parties interested having been, and continuing to be, domiciled and actually present there, the question being raised there also, no foreign element exists to cause any interference with the usual and regular enforcement of the domestic municipal law by the domestic tribunals. There is no room in such case for the application of the rules of private international law.

But if we suppose one or more of the parties to live in another State, or the transaction or some part thereof to have arisen elsewhere, a foreign element is at once imported into the case, and it may be asked whether the court is to be governed in its decision by the domestic law, by the law of the place where the parties, or some of them, live (or, in technical phrase, are domiciled), by the law of the place where the transaction or part thereof arises, or by the law of the place where property affected thereby may be situated?

Thus, if A, a citizen of New York, should there mortgage to $B$, a citizen of Maryland, personal property situated in Virginia, which property $A$ afterwards removes to Illinois and sells to $C$, where B brings suit to recover it, a prominent question before the Illinois court might be: Shall we decide upon the validity of B's title according to the law of New York, where the owner lived and the transfer was made; or according to the law of Maryland, where the vendee lives; or according to the law of Virginia, where the property happened to be at the time of the 
transfer; or shall we discard all these foreign elements entirely, and let the domestic law - the law of Illinois - control ?

It is the aim of the branch of law with which we are now en. gaged to determine, in cases of this character, which law should be followed.

§ 4. Basis of Private International Law. - Effect is given to a foreign law, not through any convention or agreement of nations, but merely because justice and policy often demand that, in the enforcement and interpretation of contracts and other transactions possessing a foreign element, the court should be governed by some other than the domestic law.

When one voluntarily does an act in a particular country, it is, as a general rule, just and proper that the effect of the act should be measured by the law under which it is done. The party need not do the act there unless he chooses, and if he elects to do it there, the just measure of its operation is the law to which he has thus voluntarily submitted himself. In other words, the situs or locality of the act in question furnishes the law which will govern it. And the same general principle, as we shall hereafter see, applies to transactions and circumstances which are not the result of voluntary action. The law of the situs of the particular matter will control.

It is often said that a court, in enforcing a foreign law, acts ex comitate, and if care is observed to note the meaning of the term "comity," the expression is not erroneous. The basis of private international law may be said to be comity, but it is as much a comity shown to the litigants in referring to the law of the situs, as above explained, as a comity to the State whose law is thus enforced. In truth, it is something more even than comity to the litigants. It is in answer to the demands of justice and an enlightened policy. ${ }^{1}$

It is to be observed that the rules of private international law do not derive force from a power superior to the sovereign States which recognize and enforce them. On the contrary, the very essence of a sovereign State is that it has no superior. It is one of the fundamental principles of this branch of the law

1 Robinson $v$. Queen, 87 Tenn. 445, $11 \mathrm{~S}$. W. 38, 39; Warrender $v$. War render, 2 Cl. \& F. 488, 530. See Whart. Confl. L. $\$ \S 1 a, 2,3$. 
that each sovereign State is supreme within its own limits. It is therefore within the power of such a State at any time to exclude any or all foreign laws from operation within its borders. To the extent that it cannot do this, it is not sovereign. Hence, when effect is given to a foreign law in any territory, it is only because the municipal law of that State temporarily abdicates its supreme authority in favor of the foreign law, which, for the time being, with reference to that particular matter, becomes itself, by the will of that State, its municipal law. ${ }^{2}$

There are however some cases in which the courts will not permit a foreign law to supplant the domestic law. These exceptional cases will be considered more at large hereafter. ${ }^{8}$

These principles have been recognized by the United States Supreme Court, as entering into the definition of the "comity" which governs the courts in enforcing foreign laws. In Hilton $v$. Guyot" it is said: "Comity is neither matter of absolute obligation nor of mere courtesy and good will. It is the recognition which one nation allows within its territory to the legislative, executive, or judicial acts of another nation, having due regard both to international duty and convenience, and to the rights of its own citizens or of other persons who are under the protection of the laws."

It is of the utmost importance to observe at the outset that every point that may come up before a court for its decision must have a situs somewhere, and each point that arises will in general be governed by the law of the State where that situs is ascertained to be. Whether the interest before the court be one arising from the voluntary action of the individual, or whether it be created, without voluntary action, merely by the law itself, is immaterial. It must have its situs, assigned by the individual or by the law. Numerous instances of this principle will appear later. A tort, a contract, a conveyance of property, the devise or descent of land or personalty, marriages, all have their situs, whose law will generally govern with respect to.

2 See Whart. Confl. L. $\S \S 1,2,3$; Dalrymple v. Dalrymple, 2 Hagg. Cons. 58.

3 Post, Chapter II.

159 U. S. 118. 
them. To ascertain the situs in such cases and others is in large measure the purpose of this work.

In the future discussion therefore we will examine (1) The situs of the person; (2) The situs of status; (3) The situs of personal property; (4) The situs of contracts; (5) The situs of torts; (6) The situs of crimes; and (7) The situs of remedies. But before entering into the discussion of these heads, a chapter will be devoted to the consideration of certain exceptional cases wherein it is held that neither the claims of situs nor the demands of comity are strong enough to induce the substitution of $\mathbf{a}$ foreign for the domestic law. 


\section{CHAPTER II.}

\section{EXCEPTIONS TO THE APPLICATION OF A FOREIGN LAW.}

§5. General Grounds upon which the Exceptions are based. - In the preceding section it has been shown that the basis of private international law is "international comity," which in reality is nothing more than an enlightened sentiment of justice and policy.

But it must never be forgotten that erory absolute control over the persons and property within its borders, and may regulate them as its awn notions of propriety and policy dictate. ${ }^{1}$ The question in all ouces is, shall it exercise the right to control these matters by its own law, or shall it yield to the law of another State? If it chooses the latter course, it does so not because the foreign legislation or institutions have an exterritorial force within its limits, but simply because policy and justice demand it. ${ }^{2}$

It may be that the legislature of the State in which the question arises has foreseen and provided for the contingency, and has expressly laid down the rule that shall govern its courts should a foreign element creep into a particular case. In such event the legislature may enact that the foreign law is to control, or that, notwithstanding the foreign element, the domestic law shall still govern. This is a matter of policy wholly in the discretion of the legislature, into which the courts cannot in.

I See Blackinton $v$. Blackinton, 141 Mass. 432, 436; Ellis v. Ellis, 55 Minn. 401, 56 N. W. 1056, 1058; Roth v. Roth, 104 Ill. 35, 44 Am. Rep. $81,82,83$; Cook v. Cook, 56 Wis. 195, 43 Am. Rep. 706, 14 N. W. 33, 35 ; Green $v$. Vau Buskirk, 5 Wall. 307 ; s. c. 7 Wall. 139 ; Hervey v. Locomotive Works, 93 U. S. 664 ; Pennoyer $v$. Neff, 95 U. S. 714, 722; Atherton Co. v. Ives, 20 Fed. 894, 896; Moore $v$. Title \& Trust Co., $82 \mathrm{Md}$. 288, 33 Atl $641,642$.

- Petersen v. Chemical Bank, 32 N. Y. 21, 44, 88 Am. Dec. 298. 
quire. In the latter case, there would be no room for the operation of the rules of private international law. It is merely a question of the courts' obedience to the mandates of the State's municipal law.

But it rarely happens that the legislature, in enacting $\$$ statute, expressly deals with cases involving a foreign element. Primarily the legislature enacts laws for its own citizens, touching property and transactions within the State, and does not usually notice expressly those cases in which the person, the property, or the transaction affected may be without the State, in whole or in part. Under these circumstances therefore the duty devolves upon the courts to determine whether the municipal law, by its silence, means to include or to exclude these cases. Here it is that the rules of private international law come into play, and guide the courts in the solution of problems that are often intricate.

There may be said to be five instances wherein it is generally eonsidered that the municipal law of the State where the question is raised (lex fori) forbids the enforcement of a foreign law. (1) Where the enforcement of the foreign law would contravene some established and important policy of the State of the formm; (2) where the enforcement of such foreign law would involve injustice and injury to the people of the forum; (3) where such enforcement would contravene the canons of morality established by civilized society; (4) where the foreign law is penal in its nature; and (5) where the question relates to real property.

These exceptions are of supreme importance in the study of this subject, and must be constantly borne in mind, for they constitute standing exceptions to almost every proposition that can be laid down. Yet they are often lost sight of by the courts, or are confounded with the principles themselves. The unnoticed existence and enforcement of them in many of the cases is one main cause of the confusion that envelops the sub. ject. The reader must therefore pardon a constant recurrence to them in the course of the discussion which is to follow.

In view of these frequently recurring exceptions, and to avoid a lengthy periphrasis, we will in future designate as "Тнв Proper Law" that law which, upon general principles, is the 
proper law to govern the case. If it is one of the exceptional cases above mentioned, the law governing it will be designated The Domestic Law or Lex Fori.

§ 6. First Exception-Policy or Interests of Forum contravened by Enforcement of Proper Law. - Few general principles of private international law are so well settled as the rule that no foreign law (even though, under ordinary circumstances, it be the "proper law") will be enforced in a sovereign State, if to enforce it will contravene the express statute law or an established policy of the forum, or is injurious to its interests. ${ }^{1}$

If the policy of the forum has been expressed in a statute which in terms covers even transactions having a foreign element, no difficulty will be apt to arise. There can be no ques. tion then as to what is the pronounced policy of the forum, a nolicy deemed so important as to be expressly extended by the legislature to foreign transactions. If the forum retains a vestige of sovereignty, the lex fori will prevail. ${ }^{2}$

It is in cases where the domestic law is not statutory but unwritten, or, if statutory, where the statute does not in terms apply to matters involving a foreign element, that the difficulty arises. It is not in every case of this kind that the domestic law is applicable. If this were so, there could never be any

1 May v. Bank, 122 Ill. 551, 13 N. E. 806, 808; Frank v. Babhitt, 155 Mass. 112, 115 ; Mackey v. Pettijohn, 6 Kan. App. 57, 49 Pac. 636, 637; Bowles $v$. Field, 78 Fed. 742, 743; Case $v$. Dodge, 18 R. I. 661, 29 Atl. 785, 786 ; Despard v. Churchill, 53 N. Y. 192, 200 ; Van Voorhis $v$. Brintnall, 86 N. Y. 18, 26, 40 Am. Rep. 505; Freeman's Appeal, 68 Conn. 533, 37 Atl. 420 ; Armstrong $v$. Best, 112 N. C. 59, 17 S. E. 14, 15 ; Com. v. Lane, 113 Mass. 458, 463, 18 Am. Rep. 509 ; Trne v. Ranney, 21 N. H. 52, 53 Am. Dec. 164 ; Jackson $v$. Jackson, 82 Md. 17, 33 Atl. 317, 319 ; Pcnnegar $v$. State, 87 Tenn. 244, 2 L. R. A. 703, 704-5; State v. Ross, 76 N. C. 242, 22 Am. Rep. 678; Edgerly v. Bush, 81 N. Y. 199 ; Woodward v. Brooks, 128 Ill. 222, 20 N. E. 685,686 ; Ex parte Dickinson, 29 S. C. 453, 7 S. E. 593, 594-5; Green $v$. Van Buskirk, 7 Wall. 139 ; Smith $v$. Union Bank, 5 Pet. 518, 527.

2 See Williams $v$. Dry Goods Co., 4 Okl. 145, 43 Pac. 1148 ; May $v$. Bank, 122 Ill. 551, 13 N. E. 806, 808 ; Frank $v$. Babbitt, 155 Mass. 112 ; Corn. $v$. Lane, 113 Mass. 458, 463, 18 Am. Rep. 509 ; Barnett $v$. Kinney, 147 U. S. 476 ; Butler $v$. Wendell, 57 Mich. 62, 23 N. W. 460, 462 ; Pennegar $v$. State, 87 Tenn. 844, 2 L. R. A. 703, 704-5 ; Kerr v. Dougherty, 79 N. Y. 327, 341; Case v. Dodge, 18 R. I. 661, 29 Atl. 785, 786. 
practical question of a conflict of laws. The law which will be applied depends upon the importance attached to the policy advocated by the lex fori. The legislature is primarily the judge of questions of policy, and if it has spoken plainly either for or against the enforcement of a foreign law in a given case, the courts must obey. ${ }^{8}$ If the legislature has not indicated expressly its will that a particular domestic policy should control in all cases, it then devolves upon the courts to determine in what cases it shall control.4

In deciding cases of this kind therefore each court has to pass upon the importance of the domestic policy maintained by its laws. They are generally loath to deny the enforcement of a proper foreign law, and will not, if they consider the domestic policy of minor importance. But where it is a fundamental and important policy of the State, established after careful consideration of the supposed needs and wants of its people, no foreign law will be permitted to supersede it.

If however there is an irreconcilable conflict between the two systems of law, the courts will usually lean towards the lex fori. ${ }^{5}$ Ultimately this question must be decided in each case as it arises, and as the solution of it must depend upon the judg. ment of each court, great conflicts of decision may be expected, and indeed have scmetimes resulted. A particular policy, regarded in one State as of the gravest importance, will be

${ }^{8}$ Green v. Van Buskirk, 5 Wall. 307, 312; Matthews v. Lloyd, $89 \mathrm{Ky}$. 625, 13 S. W. 106, 107 ; Bowles v. Field, 78 Fed. 742, 743; Cross v. U. S. Trust Co., 131 N. Y. 330; Van Voorhis v. Brintnall, 86 N. Y. 18, 40 Am. Rep. 505 ; Pennegar $v$. State, 87 Tenn. 244, A L. R. A. 703, 705; Ex parte Dickinson, 29 S. C. 453,7 S. E. $593,594-5$; State $v$. Kennedy, 76 N. C. 251 , 22 Am. Rep. 683, 684 ; Milne v. Moreton, 6 Binn. (Penn.) 353, 6 Am. Dec. 466 ; West Cambridge v. Lexington, 1 Pick. (Mass.) 506, 512, 11 Am. Dec. 231 ; Ex parte Kinney, 3 Hughes, C. C. 1, 20.

4 Legislation subsequent to the transaction in dispute may be looked to in order to determine what importance the legislature attaches to the policy of the State at the time of the transaction. See Milliken $v$. Pratt, 125 Mass. 374, 28 Am. Rep. 241 ; Case v. Dodge, 18 R. I. 661, 29 Atl. 785, 786; Fellows v. Miner, 119 Mass. 541 ; Freeman's Appeal, 68 Conn. 533, 37 Atl. 420 ; Dammert $v$. Osborn, 140 N. Y. 30, 44.

6 Gardner $v$. Lewis, 7 Gill (Md.), 378, 396 ; Saul $v$. His Creditors, 5 Mart. N. s. (La.) 569, 16 Am. Dec. 213 ; Story, Conf. L. $\$ 28$. 
relegated to the background in another, where the needs of the people are different. Moreover, in the same State, the opinious of men will often differ as to the relative importance of certain lines of policy, or perhaps even the opinion of the same man at different times. Hence, while recognizing and applying the same general principles, the courts of different States may readily reach different conclusions in the same class of cases, and neither violate the rules of private international law. ${ }^{6}$ As has been well said by a learned judge, ${ }^{7}$ speaking of the conflicting authorities upon a point in the conflict of laws: "They lave attempted to go too far; to define and fix that which in the nature of things cannot be defined and fixed. They seem to have forgotten that they wrote on a question which touched the comity of nations, and that that comity is, and ever must be, uncertain. That it must necessarily depend -upon a variety of circumstances, which cannot be reduced within any certain rule. That no nation will suffer the laws of auother to interfere with her own to the injury of her citizens; that whether they do or not must depend upon the condition of the country in which the foreign law is sought to be enforced; the particular nature of her legislation, her policy, and the character of her institutions. That in the conflict of laws it must be often a matter of doubt which should prevail; and that whenever that doubt does exist, the court which decides will prefer the law of its own country to that of the stranger."

\$ 7. Second Exception - Injustice or Detriment to People of the Forum. - This exception, like most of the others, is but a branch of the first, but, by reason of its frequency and importance, is treated separately.

It is natural, and not at all to be reprobated, that the courts of the forum should refuse to enforce a foreign law, if to do so would result in injustice to their own people. The object of the enforcement of a foreign law in any case is to mete out, as far as possible, exact justice to all concerned, as well as to give due effect to the

- Pennegar $v$. State, 87 Tenn. 244, 2 L. R. A. 703, 706 ; Cross v. U. S. Trust Co., 131 N. Y. 330, 343 ; Hollis v. Seminary, 95 N. Y. 166.

7 Porter, J., in Saul * His Creditors, 5 Mart. N. S. (La.) 569, 16 Am Dec. 212, 225. 
laws of other States. But the first and most important of these objects fails altogether when the enforcement of the proper law would result in injustice and loss to innocent citizens of the forum. As between the latter and strangers, it is not remarkable that the courts should elect in a close case to decide the matter in accordance with the lex fori, thus giving their fellow citizens the advantages conferred upon them by the law under which they live and ordinarily transact their business. The observance of comity towards other States cannot reasonably be expected at the expense of injustice to residents of the forum, for whose benefit the courts and the law are primarily instituted. The existence of this exception to the enforcement of the "proper law" is beyond dispute, though its limits are not yet precisely defined. ${ }^{x}$

A dictum in a leading Lonisiana case ${ }^{2}$ will serve to illustrate the operation of this exception. In that case the court, arguendo, supposes a person domiciled in Spain to enter into a contract with a citizen of Louisiana, the Spanish citizen being twenty-three years old. By the law of Spain (lex domicilii) he does not become of age until he is twenty-five. By the law of Louisiana he is of age at twenty-one, and can make a binding contract. Suit is brought on the contract in Louisiana by the

1 Green $v$. Van Buskirk, 5 Wall. 307, 312 ; Pennoyer $v$. Neff, 95 U. S. 714, 723; Cole $v$. Cunningham, 133 U. S. 107, 126 ; Barnett $v$. Kinney, 147 U. S. 476 ; Williams v. Dry Goods Co., 4 Okl. 145, 43 Pac. 1148; Robinson v. Queen, 87 Tenn. 445, 3 L. R. A. 214 ; Bentley v. Whittemore, 19 N. J. Eq. 462, 97 Am. Dec. 671 ; May v. Bank, 122 Ill. 551, 13 N. E. 806 ; Matthews v. Lloyd, $89 \mathrm{Ky} .625,13 \mathrm{~S}$. W. 106, 107 ; Marshall $v$. Sherman, $148 \mathrm{~N} . \mathrm{Y}$. 9, 10, 29, 42 N. E. 419 ; Armstrong v. Best, 112 N. C. 59, 17 S. E. 14, 15 ; Hornthall v. Burwell, 109 N. C. 10, 13 S. E. 721, 722; Frank v. Bobbitt, 155 Mass. 112, 29 N. E. 209 ; Dial v. Gary, 14 S. C. 573, 37 Am. Rep. 377, 738; Catlin $v$. Plate Co., 123 Ind. 477, 24 N. E. 250, 8 L. R. A. 62, 63; Gilman $v$. Ketcham, 84 Wis. 60, 54 N. W. 395 ; Egbert $v$. Baker, 58 Conn. 319, 20 Atl. 466, 467; Sturtevant $v$. Armsby Co., 66 N. H. 557, 23 Atl. 368 ; Chafee v. Bank, 71 Me. 514, 36 Am. Rep. 345, 347-8; Fuller $v$. Steiglitz, 27 Ohio St. 355, 22 Am. Rep. 312, 318; Long v. Girdwood, 150 Penn. St. 413, 24 Atl. 711, 712, 23 L. R. A. 33, note. But see Atherton Co. v. Ives, 20 Fed. $894,897$.

2 Saul v. His Creditors, 17 Mart. 569, 16 Am. Dec. 212, 226. See also Baldwin v. Gray, 4 Mart. N. s. (La.) 192, 16 Am. Dec. 169, 170. 
Louisiana citizen. The defendant urges the law of his domicil as fixing his age of majority (which is a status) and his consequent capacity to make a binding contract. ${ }^{3}$ The court, while alleging (erroneously) the general operation of the lex domicilii in such cases, insists that the foreign law must yield in this instance to the lex fori, as its enforcement would work an injustice to the Louisiana citizen who could not be supposed to be acquainted with the laws of Spain.

But in order for this exception to operate, the enforcement of the proper law must result in injustice to the citizen of the forum. The mere faet suelr enforcement would subject him to a just liability, which he-might escape were the lex fori to operate,-will not suffice.

Again, it is a generally accepted principle that a transfer of personalty situated abroad is governed as to its validity and effect by the law of the place where the transfer is made (lex loci contractus).4 But this rule will not usually be permitted to operate in the State where the personalty is situated in cases where an injustice will thereby be done the people of the latter State; for example, attaching creditors of the assignor. The lex fori will be substituted. ${ }^{5}$

So, in a Tennessee case, ${ }^{6}$ a married woman, domiciled in Kentucky, made there a note as surety for her husband, which note was also payable there. Suit was brought against her on the note in Tennessee. By the law of Kentucky a married woman could bind herself by such a contract; by the law of Tennessee she could not. The court refused to apply the Tennessee law, saying: "If this were a suit against a married woman, a citizen of this State, on a contract made out of the State, there would be much force in the insistence of the defendant."

§ 8. Extent of Second Exception. - The limits of this ex. ception are not as yet very definitely settled. If there be only

s See post, $\S 71,72$.

4 Post, $\S 128$ et seq.

5 Post, $\$ 129$; May v. Bank, 122 Ill. 551, 13 N. E. 806 ; Bentley $v$. Whittemore, 19 N. J. Eq. 462, 97 Am. Dec. 671 ; Frank v. Bobbitt, 155 Mass. 112, 29 N. E. 209 ; Edgerly v. Bush, 81 N. Y. 199 ; Hornthall v. Burwell, 109 N. C. 10,13 S. E. 721,722 ; Crapo $v$. Kelly, 16 Wall. 610, 622.

- Robinson v. Queen, 87 Tenn. 445, 11 S. W. 38, 3 L. R. A. 214. 
one party who complains of the injustice done him by the enforcement of a proper foreign law, and he is a citizen of the forum, the lex fori will generally be substituted in the place of the foreign law. ${ }^{1}$ And the same is true where there are several who thus complain, all being citizens of the forum. ${ }^{2}$

And it has been held, where the complaining parties were partners, some of whom were citizens of the forum and some citizens of another State, that the privileges of the lex fori accruing to the citizens of the forum will enure also to the benefit of those partners who were citizens of other States, because they were jointly interested and their interests could not be separated. ${ }^{3}$

It has been suggested that, as between the States of this Union, to so discriminate against the citizens of other States and in favor of the citizens of the forum contravenes the provision of the federal constitution which declares that the citizens of each State shall be entitled to all privileges and immunities of citizens of the several States. ${ }^{4}$ But the opposite is too well established to be disputed. This constitutional provision applies to fundamental and universal rights, not to special privileges.

There seems to be a tendency in some of the decisions to extend the principle of comity, as between the several States of the Union, beyond the limits marked out by strict international law. These decisions make the distinction already adverted to between citizens of the forum and citizens of foreign countries, but place the citizens of other States of the Union upon the same footing as residents of the forum, giving them also the benefit of the domestic law. But the weight of opinion and

1 May v. Bank, 122 Ill. 551, 13 N. E. 806 ; Matthews $v$. Lloyd, $89 \mathrm{Ky}$. 625,13 S. W. 106 ; Frank $v$. Bobbitt, 155 Mass. 112 ; Edgerly $v$. Bush, 81 N. Y. 199 ; Chafee v. Bank, 71 Me. 514, 36 Am. Rep. 345, 349 ; Crapo $v$. Kelly, 16 Wall. 610, 622.

2 Faulkner v. Hyman, 142 Mass. 53, 55.

${ }^{3}$ Faulkner $v$. Hyman, 142 Mass. 53, 55-56. See Bentley v. Whittemore, 19 N. J. Eq. 462, 97 Am. Dec. 671, 672, 674.

4 Chafee v. Bank, 71 Me. 514, 36 Am. Rep. 345, 349. This case itself - Aerely makes the suggestion to refute it. See also Atherton Co. $v$. Ives, 20 Fed. 894, 897 ; Sturtevant v. Armsby Co., 66 N. H. 557, 23 Atl. 368.

5 Sturtevant v. Armsby Co., 66 N. H. 557, 23 Atl. 368; Hibernia Bank 
reason seems to be in favor of confining the privilege of the lex fori to citizens of the forum, so far as the operation of this exception is concerned. ${ }^{6}$

However it may be as to putting citizens of the forum and of third States (within the Union) on an equal footing, opinion has been divided as to whether it is proper to exclude citizens of the State whose law is properly applicable; it being said that in their favor their own law should not be set aside and substituted by the lex fori, ${ }^{7}$ unless the settled policy of the forum (independently of citizenship) requires its substitution. ${ }^{8}$

Another question arises which involves the scope of this exception. Does it apply only to citizens of the forum, or should it be extended to those, not citizens, who are domiciled there, or even to those who are casually present there? As between the States of this Union, if the party upon whom the foreign law operates injuriously is a citizen of the United States, he must be held a citizen of the forum if he is domiciled there. ${ }^{9}$ But if he be not domiciled there, or if he be an alien, or if the

v. Lacombe, 84 N. Y. 367 ; Catlin v. Silver Plate Co., 123 Ind. 477, 24 N. E. 250, 8 L. R. A. 62, 65 ; First Nat. Bank $v$. Walker, 61 Conn. 154, 23 Atl. 696 ; Gilman v. Ketchum, 84 Wis. 60,54 N. W. 395 ; Fuller $v$. Steiglitz, 27 Ohio St. 355, 22 Am. Rep. 312, 318, 319; Milne v. Moreton, 6 Binn. (Penn.) 353, $6 \mathrm{Am}$. Dec. 466. See Atherton Co. v. Ives, 20 Fed. 894, 897, in which the court seems inclined to place even citizens of foreign countries upon the same footing with citizens of the forum.

6 The first exception operates, regardless of citizenship. See Douglas $v$. Bank, 97 Tenn. 133, 36 S. W. 874, 876 ; Moore v. Church, 70 Ia. 208, 59 Am. Rep. 439, 441 ; Barth v. Backus, 140 N. Y. 230 ; Paine v. Lester, 44 Conn. 196, $26 \mathrm{Am}$. Rep. 442. The last two are cases of involuntary assignments under insolvency laws. Such assiguments have no exterritorial effect. See post, $§ 137$.

7 Barnett $v$. Kinney, 147 U. S. 476, 481; Cole v. Cunningham, 133 U. S. 107,129 ; Baghy v. R. R. Co., 86 Penn. St. 291 ; Bacon v. Horne, 123 Penu. St. 452, 453, 16 Atl. 794; Gilman v. Ketchum, 84 Wis. 60, 54 N. W. 395 ; Faulkner $v$. Hyman, 142 Mass. 53, 55; May v. Wannemacher, 111 Mass. 202, 209 ; Woodward $v$. Brooks, 128 Ill. 222, 20 N. E. 685 ; In re Dalpay, 41 Minn. 532, 43 N. W. 564, 566. But see Barth v. Backus, 140 N. Y. 230, 29 N. E. 209 ; Hibernia Nat. Bank $v$. Lacombe, 84 N. Y. 367.

8 See Moore v. Church, 70 Ia. 208, 59 Am. Rep. 439, 411. See post, $\$ 8134,138$, where this question is more fully discussod.

U. S. Const. Amendment XIV. 
suit be instituted in a foreign country, the point becomes important.

It is believed that the exception comprises within its scope all those for whose protection and benefit the lex fori is enacted. including not only citizens, but aliens domiciled there, and sometimes persons resident there for a temporary purpose. ${ }^{10}$

§ 9. Third Exception - Proper Foreign Law Contra Bonos Mores. - This exception also is merely a particular application of the first. There are certain things which are inherently vicious, demoralizing, and antagonistic to the general principles of morality which form the basis of civilized societies. It is a most important part of the policy of every civilized State that the law should prohibit or discourage such things as far as practicable. They are generally condemned by every system of municipal law.

When we come to examine this principle, as it applies in private international law, we find that there are certain transactions which, though valid in some barbarous or semi-civilized States, and perhaps even in one or two that are civilized, are reprobated by the municipal law of most countries, as immoral in fact or in tendency. Such, for example, are polygamous marriages; marriages between parent and child, grandparent and grandchild, or brother and sister; contracts to reward crime; contracts for the price of illicit intercourse; contracts to corrupt or evade the due administration of justice, to defraud or corrupt public agents; and in general all transactions which in their nature are founded in moral turpitude, and are inconsistent with the good order and substantial interests of the forum. Such transactions will always be discountenanced by the lex fori, regardless of the character stamped upon them by the law which should properly govern them. ${ }^{3}$

10 Woodworth $v$. Spring, 4 Allen (Mass.), 321; Bank $v$. Williams, 46 Miss. 618; Hibernia Nat. Bank $v$. Lacombe, 84 N. Y. 367 ; Freeman's Appeal, 68 Conn. 533, 37 Atl. 420. See Donovan v. Pitcher, 53 Ala. 411, 25 Am. Rep. 634 ; Hilton $v$. Guyot, 159 U. S. 113.

1 Story, Confl. L. § 258; Oscanyon v. Arms Co., 103 U. S. 261 ; Green. wood v. Curtis, 6 Mass. 358, 4 Am. Dec. 145, 147-9 ; Armstrong $v$. Toler, 11 Wheat. 258 ; Merchants' Bank v. Spalding, 12 Barb. (N. Y.) 302 ; Madrazzo $v$. Willes, 3 Barn. \& Ald. 353. 
The same principle will also apply where a contract is made for the purpose of giving aid to the enemies of a country with which the forum is in amity; ${ }^{2}$ or to a contract tending to the bribery and corruption of the officers of a foreign government. ${ }^{3}$

Under this head may likewise be placed those transactions which are so detrimental to the interests of the forum itself, and disclose such a disregard for the public weal as to amount to immorality. Of this character are contracts with alien enemies, contracts to smuggle goods into the forum, or to evade or violate its revenue laws. ${ }^{4}$ Yet, strange to say, the rule has been laid down otherwise in cases where the transaction is a fraud upon the revenue laws of another State, upon the paltry and shortsighted theory that one State has no concern with the revenue laws of another, and that the latter must enforce its own laws. "Sound morals would seem to point to a very different conclusion." 5

So also, if an attempt be made to evade the "proper law," a fraud upon that law is committed, which the courts of that State at least will not in general tolerate. They will substitute the law which should have governed had there been no such fraud. The validity of a transaction cannot be secured by apparently subjecting it to a law by which it is not properly governed. ${ }^{6}$

Thus, in Mortg. Co. $v$. Jefferson, ${ }^{7}$ the plaintiffs, who resided

2 Kennett $v$. Chambers, 14 How. 38 (a contract to furnish aid to Texans against Mexicans).

8 Oscanyon v. Arms Co., 103 U. S. 261.

4 Armstrong $v$. Toler, 11 Wheat. 258; Griswold $v$. Waddington, 16 Johns. (N. Y.) 438; Ivey v. Lolland, 42 Miss. 444, 2 Am. Rep. 606.

5 Story, Confl. I. $\S 245$ et seq. ; Ivey v. Lolland, 42 Miss. 444, 448, 2 Am. Rep. 606 ; Merchants' Bank v. Spalding, 9 N. Y. 53, 63.

- See Story, Confl. L. $\S 106$; Mortg. Co. v. Jefferson, 69 Miss. 770, 12 So. 464, 465; Hinds v. Brazealle, 2 How. (Miss.) 837, 32 Am. Dec. 307 ; Gardner v. Lewis, 7 Gill (Md.), 378, 392 ; Arbuckle v. Reaume, 96 Mich. 243, 55 N. W. 808 ; Pennegar v. State, 87 Tenn. 244, 2 L. R. A. 703, 704 ; Corn. v. Lane, 113 Mass. 458, 471, 18 Am. Rep. 509; West Cambridge $v$. Lexing. ton, 1 Pick. (Mass.) 506, 11 Am. Dec. 231 ; Akers v. Demond, 103 Mass. 318, 324; Kinney v. Com., 30 Gratt. (Va.) 858; State v. Kennedy, 76 N. C. 251, 22 Am. Rep. 683.

769 Miss. 770, 12 So. 464, 465. 
in Tennessee, borrowed money of the defendant, a New York corporation, securing the loan by a deed of trust upon land in Mississippi. The notes were made in Tennessee and payable in New York, and were usurious by the laws of both States, but not by the law of Mississippi. The deed of trust recited (contrary to the fact) that it and the notes were made in Mississippi, where they were not usurious, and that they were to be construed according to the laws of that State. But the Mississippi court disregarded this recital altogether, holding that the laws of a State and access to its courts are not the subject of contract.

'There is an exception, however, to this last principle in the case of marriage. It is of the utmost importance to the very existence of society that its well-spring, the marriage relation, should be kept pure and unpolluted. The courts strain every nerve to uphold a marriage, not in itself immoral. Hence, if citizens of a State leave it to contract elsewhere a marriage, forbidden by the law of their domicil but valid where contracted, and afterwards return to their domicil, though this is an evasion of the domiciliary law, the marriage will be upheld in all States other than their domicil. ${ }^{8}$

Upon the question whether the courts of the domicil will uphold such a marriage, the authorities are much divided. Many influential courts stand in favor of upholding the marriage at all hazards, even though it be contracted in fraud and evasion of the home law, deeming this general policy superior to all special policies of the domicil and forum. ${ }^{9}$ Others, as influential, make the question turn upon the relative importance of the policies involved. While not lightly setting aside a marriage valid where contracted, neither will they lightly set aside important domestic policies closely relating to the moral life of the people. Under this line of cases the relative importance of the policies 444.

8 See post, § 73 ; Dickson v. Dickson, 1 Yerg. (Tenn.) 110, 24 Am. Dec.

9 Medway $v$. Needham, 16 Mass. 157, 6 Am. Dec. 131; Com. v. Putnam, 1 Pick. (Mass.) 136; Com. v. Lane, 113 Mass. 458, 18 Am. Rep. 509 ; Put. nam v. Putnam, 8 Pick. (Mass.) 433; Van Voorhis v. Brintnall, 86 N. Y. 18 , 40 Am. Rep. 505: Stevenson v. Gray, 17 B. Mon. (Ky.) 193; Thorp v. Thorp, 90 N. Y. 602. 
involved is the criterion, and the result in a particular case will depend upon the weight attached by the particular court, in a sound judicial discretion, to the policy indicated by the domiciliary legislation. And this, it is believed, is the better view. ${ }^{10}$

There are some transactions which, though deemed immoral in some States, cannot be said to be immoral by the laws of nature, this being evidenced by the fact that some fully civilized nations do not so consider them. To this head belong marriages between persons related to each other by ties of consanguinity or affinity.

All civilized States reprobate marriages between persons in the direct lineal line of consanguinity, and those contracted between brother and sister. ${ }^{11}$ Such marriages therefore, though celebrated in a barbarous country where they are valid, will generally be adjudged void in all civilized States, as being contra bonos mores. ${ }^{12}$ But when we proceed further than this, to marriages between uncle or aunt and niece or nephew, between brother-in-law and sister-in-law, between first cousins, etc., we find there is no common opinion in Christendom upon the morality of such marriages. Some States prohibit them while others permit them. It cannot then be said in such case that the marriage is universally or even generally deemed immoral throughout the civilized world. The fact is otherwise. Hence in these latter cases the courts will not feel at liberty to depart from the "proper law," even though by the lex fori such a marriage would be disapproved and declared void. If valid by its proper law, it will be valid everywhere. ${ }^{18}$

10 Pennegar $v$. State, 87 Tenn. 244, 10 S. W. 305, 2 L. R. A. 704, 705; Kinney v. Com., 30 Gratt. (Va.) 858 ; State $v$. Kennedy, 76 N. C. 251, 22 Am. Rep. 683. See post, $\S 73$, where this whole topic is examined at large.

11 Story, Confl. L. \$ 114 ; Wightman v. Wightman, 4 Johns. Ch. (N. Y.) 343,349 ; Sutton $v$. Warren, 10 Met. (Mass.) 451, 452.

12 Story, Confl. L. $\$ 114$.

13 Story, Confl. L. $\$ 114$; Greenwood v. Curtis, 6 Mass. 358, 379, 4 Am Lec. 145; Medway $v$. Needham, 16 Mass. 157, 6 Am. Dec. 131; Com. v. Lane, 113 Mass. 458, 463, 18 Am. Rep. 509; Wightman v. Wightman, 4 Johns. Ch. (N. Y.) 343, 349 ; Kinney $v$. Com., 30 Gratt. (Va.) 858 ; State v. Kennedy, 76 N. C. 251,22 Am. Rep. 683 ; Stevenson v. Gray, 17 B. Mon. 
Another illustration of the principle that private international law will not condemn as immoral transactions which are not so considered by all, or at least the great majority, of the civilized States of the world, is to be found in transactions based upon the institution of slavery. Thus a note given in payment for slaves or for slave hire, payable in States where slavery is lawful, will be enforced even in States which condemn or do not recognize the institution. ${ }^{14}$

Neither are Sunday laws treated as rules of positive morality, certainly not by all civilized nations. Hence contracts entered into, or to be performed, on Sunday, and valid by their proper law, will be enforced even in States whose laws prohibit and invalidate Sunday contracts. ${ }^{15}$

§ 10. Fourth Exception - Proper Foreign Law Penal in its Nature. - It is a well-settled principle of private international law that the penal laws of one State will have no exterritorial effect in other States. Each State must look after the punishment of its own people for offences against its laws. Other States cannot and will not undertake to aid it in these matters further than to surrender a fugitive from justice under extradition treaties or laws. This general principle is universally admitted. ${ }^{1}$

(Ky.) 193. The proper law governing the validity of marriages will be discussed hereafter. Post, $\S \$ 75,76$ et seq.

14 Greenwood $v$. Curtis, 6 Mass. 358, 4 Am. Dec. 145 ; Roundtree v. Baker, 52 III. 241, 4 Am. Rep. 597 ; Osborn $v$. Nicholson, 13 Wall. 654. It is otherwise as to the status of the slave himself. See Com. v. Aves, 18 Pick. (Mass.) 193; Donovan v. Pitcher, 53 Ala. 411, 25 Am. Rep. 634.

15 McKee v. Jones, 67 Miss. 405, 7 so. 348; Brown v. Browning, 15 R. I. 422, 7 Atl. 403 ; Swann v. Swann, 21 Fed. 299. For the proper law governing the validity of Sunday contracts, see post, $\$ 1168,175$.

1 The Antelope, 10 Wheat. 66, 123 ; Huntington $v$. Attrill, 146 U. S. 657, 666 ; Com. v. Green, 17 Mass. 515, 539-540 ; Com. v. Lane, 113 Mass. 458, 470, 18 Am. Rep. 509 ; Coffing v. Dodge, 167 Mass. 231, 232, 45 N. E. 928 ; Van Voorhis v. Brintnall, 86 N. Y. 18, 28, 36, 40 Am. Rep. 505; Sims v. Sims, 75 N. Y. 466 ; Succession of Hernandez, 46 La. Ann. 962, 15 So. 461, 24 L. R. A. 831, 842; Marshall v. Sherman, 148 N. Y. 9, 20, 42 N. E. 419, Guerney v. Moore, 131 Mo. 650, 32 S. W. 1132, 1138 ; Dickson v. Dickson, 1 Yerg. (Tenn.) 110, 24 Am. Dec. 444 ; St. Sure $v$. Lindsfelt, 82 Wis. 346 , 19 L. R. A. 515, 519; Midland Co. v. Broat, 50 Minn. 562, 52 N. W. 972 
But the authorities by no means agree as to the meaning to be attached to the term "penal," in the international sense of the word. In Huntington $v$. Attrill, ${ }^{2}$ the Supreme Court of the United States has laid down the following criterion: "The question whether a statute of one State, which in some aspects may be called penal, is a penal law in the international sense, so that it cannot be enforced in the courts of another State, depends upon the question whether its purpose is to punish an offence against the public justice of the State, or to afford a private remedy to a person injured by the wrongful act,"' the court holding that, in the first case, the law has no extraterritorial effect, being penal, while in the second case, being remedial, it may be given exterritorial operation. ${ }^{3}$

First Nat. Bank v. Price, 33 Md. 487, 3 Am. Rep. 204 ; Dale v. R. R. Co., 57 Kan. 601, 47 Pac. 521. Sufficient reasons for the principle may be found in the divergent notions of right and justice current in different countries, the differences existing in the forms of administering justice, and the inherent right of a sovereign State to control all persons within its limits and to judge them by its own laws. See Com. $v$. Green, 17 Mass. 515, 539.

2146 U. S. 657, 6b6, 673. See also Boyce v. Railway Co., 63 Ia. 70, 18 N. W. 673 .

8 The ruling in this case is of such importance that it is deemed wise to bestow more than a passing glance upon it. The decision, in so far as it discusses the general nature of penal laws and their exterritorial effect, is a dictum. The only question before the court was whether a judgment rendered in one State upon a statute of that State giving a private punitive remedy, could be enforced in another State, it being denied enforcement on the ground that the statute under which the judgment was recovered was penal, and not remedial. There is a great difference between the enforcement in one State of a judgment obtained in another, though under a penal statute, and the enforcement in one State of an outstanding claim (not reduced to a judgment) arising under the penal statute of another State. The reduction of the claim to a judgment deprives it in large measure of its penal character. The general effect of a foreign penal statute therefore was not before the court.

The facts of the case were as follows: A New York statute marle the offcers of a corporation, who signed and recorded false certificates of the amount of its capital stock, liable for all its debts. The statute was violated by an officer of a certain New York corporation, and a judgment was recovered in New York against him thereunder. Action being brought upon the judgment in Maryland, its courts held that the New York statute was a penal statute, and refused to enforce the judgment. On appeal to the Supreme Court of the 
A better test, however, would seem to be that indicated by the ordinary meaning attached to the phrase "penal" or "penalty." A person who unlawfully injures another is justly bound to reimburse him to the extent of the damage inflicted; and in a case not provided for by the common law, it may be provided for by statute. If the law places any additional burden upon the wrongdoer by reason of his wrongful act, to this extent

United States, under the "fnll faith and credit" clause of the federal constitation, that conrt held that it had jurisdiction to determine whether full faith and credit had been given in Maryland to the New York judgment, and, in order to determine that question, that it had the right to decide whether the statute in dispute was of a penal character. As we have seen, it was not necessary to decide this question. As a matter of fact. the court was clearly correct in deciding that the particular statute in question was not penal, but remedial, as will be shown presently. But the criterion proposed for the determination of the question whether a statute is penal, with all respect, seems to be the result of fallacious reasoning.

The court's argament is based opon the fact that municipal law distinguishes between a crime and a civil wrong (even where the law gives punitive damages to the party injured by the prohibited act). It is submitted that to thus reason from the rnles of mnnicipal law to those of private international law is apt to lead to erroneous conclusions. The two systems are based on different principles. The former is founded in positive regulation; the latter, in international comity. In enforcing the rules of municipal law, the courts seek to carry out the intention of the legislature; in enforcing the rules of private international law, the courts seek merely to proceed upon broad lines of justice. It is natural and proper that the former should distinguish between crimes, offences against its own majesty, and civil wrongs inflicted upon a private citizen. But in private international law, the ground of the enforcement of a foreign law is international comity, which is nothing more than the enlightened sentiment that exact justice may best be meted out by requiring that a man's acts should be governed by the law under which he acts, provided the enforcement of that law will not conduce to injustice nor affect the interests of the forum. But if to hold a wrongdoer liable in double or treble damages to the party injured is not punishment to the former, it is certainly more than justice to the latter. Justice to him is satisfied by compensatory damages. Hence the forum, in endeavoring to mete out exact justice to the parties by enforcing a foreign law rather than its own, will find itself, undel. this view, rendering to the injured party more than justice requires, and at the expense of the other litigant. He has a right to demand this under the municipal law, not because justice, but because the positive law, requires or permits it. But where he seeks to enforce his claim in another State, what right has he to ask this of the forum whose policy may be entirely different? 
the purpose is to inflict punishment upon him, not merely to save the injured party harmless. The purpose of the law is, by means of the penalty, to deter the wrongdoer from perpetrating the wrong, and this is the object of all punishment. So far as private international law is concerned, it matters not whether that punishment is inflicted through the instrumentality of an ordinary prosecution by the state's officers for a fine, or through the medium of a civil action by the party injured for penal damages. In substance it is an act of punishment; it is punitive in either case. On the other hand, the right given the injured party to recover single damages of the wrongdoer is not by way of punishment to the latter, but merely by way of reimbursement or compensation to the former. It is strictly remedial.4

Under either view, all laws punishing crime in the strict sense of the word, or imposing disabilities as the consequence thereof, are penal, and will be given no exterritorial effect. Hence disqualifications to testify by reason of conviction of felony will not follow the convict into another State. ${ }^{6}$

So it is, according to the weight of authority, with regard to the disability, imposed by the law of many States upon the

4 McAllister $v$. Smith, 17 Ill. 328, 65 Am. Dec. 651; Le Forest $v$. Tolman, 117 Mass. 109 ; Scoville v. Caufield, 14 Johns. (N. Y.) 338; Dale v. R. R. Co., 57 Kan. 601, 47 Pac. 521, 523; Adams v. R. R. Co., 67 Vt. 76, 30 Atl. 687- In Dale v. R. R. Co., suit was brought in Kausas for death occurring in New Mexico by wrongful act. The statute of New Mexico, under which the action was brought, provided that in case of death resulting from the negligence of the servants of a railroad company, the corporation should "forfeit and pay for every person so dying the sum of $\$ 5,000$," to be recovered by the husband, wife, or child. This statnte, though remedial from the standpoint of the municipal law of Now Mexico, was held by the Kansas court to be penal from the standpoint of private international law, because the amount of darnages recoverable was absolute. So, in Adams $v$. R. R. Co., where death was caused in Massachusetts, whose statute provided for a recovery not exceeding $\$ 5,000$ nor less than $\$ 500$, to be assessed with reference to the degree of culpability of the company, it was held that the statute was penal, and not enforceable in Vermont. Both of these cases were decided after Huntington v. Attrill.

5 Huntington v. Attrill, 146 U. S. 657, 673; Com. v. Green, 17 Mass. 515, 539 ; Sims $v$. Sims, 75 N. Y. 466 ; St. Sure v. Lindsfelt, 82 Wis. 346,18 L. R. A. 515, 519. With respect to the situs of crimes, see post, $\S 204$. 
guilty party to a divorce suit, to marry again during the life of the consort. Such a disability is generally regarded as penal in its nature, and will not invalidate a marriage celebrated elsewhere, even where the marriage takes place in evasion of the law of the prohibiting State, and the parties immediately return thither. ${ }^{\circ}$

At one time it was thought that statutes giving the right to recover for the death of a person by wrongful act were penal, and not enforceable in other States; ${ }^{7}$ but this view has long since been rightly overruled, and it is now universally held that such states are remedial, conferring a special remedy and therefore enforceable abroad. ${ }^{8}$

So, also, difficulty has been found in the past in determining the nature of statutes existing in some jurisdictions, which impose liabilities upon stockholders, officers, and directors of corporations, unknown to the common law, with respect to the creditors of the corporation. Such are statutes making the stockholders liable to creditors of the corporation for an amount equal to the amount of their stock; statutes providing that, upon the return of an execution against a corporation unsatisfied, execution may at once issue against any stockholder, or that the stockholders may be charged by action with the amount of the judgment; statutes authorizing suits to be brought against stockholders of corporations dissolved; statutes making

- Huntington $v$. Attrill, 146 U. S. 651, 673; Dickson v. Dickson, 1 Yerg. (Tenn.) 110, 24 Am. Dec. 444; Com. v. Lane, 113 Mass. 458, 470, 18 Am. Rep. 509 ; Putnam v. Putnam, 8 Pick. (Mass.) 433 ; West Cambridge v. Lexington, 1 Pick. (Mass.) 506, 510, 11 Am. Dec. 231 ; Van Voorhis v. Brintnall, 86 N. Y. 18, 28, 36, 40 Am. Rep. 505 ; Succession of Hernandez, $46 \mathrm{La}$ Ann. 962, 24 L. R. A. 831, 842, note. But see Pennegar v. State, 87 Tenn 244,10 S. W. 305,2 L. R. A. 703. See post, § 74.

7 Richardson $v$. R. R. Co., 98 Mass. 85, 89 ; Burns v. R. R. Co., 113 Ind. 169,15 N. E. $230,231$.

8 Stewart v. R. R. Co., 168 U. S. 445 ; Texas, etc. R. R. Co. v. Cox, 145 U. S. 593 ; Dennick v. R. R. Co., 103 U. S. 11 ; Higgins v. R. R. Co., 155 Mass. 176, 29 N. E. 534 ; Wooden v. R. K. Co., 126 N. Y. 10 ; Leonard v. Nav. Co., 84 N. Y. 48, 38 Am. Rep. 491 ; Usher v. R. R. Co., 126 Penn St. 207, 17 Atl. 597 ; Bruce v. R. R. Co., $83 \mathrm{Ky} .174$; Morris v. R. R. Co., 65 la. 727, 54 Am. Rep. 39 ; Nelson v. R. R. Co., 88 Va. 971, 14 S. F. 838. See post, $\$ 200$ et seq. 
the officers of a corporation who sign and record false certificates of the amount of its capital stock liable for all its debts, etc.

Here too it was at one time thought that such statutes were penal and for this reason not enforceable in other States. ${ }^{\circ}$ But it is now settled that such statutes are not penal. Their purpose is not to punish, but to give creditors additional security for their debts. ${ }^{10}$ Such liabilities are quasi-contractual, the situs of which is the situs of the corporation, not of the corporators, and if precise and definite in character, and no special remedy to enforce them is provided by the law creating them, they may be enforced in other States. The general rule has been thus accurately laid down by the California court: "Where a statute creates a right and prescribes a remedy for its enforcement, that remedy is exclusive. Where a liability is created which is not penal, and no remedy is prescribed, tho liability may be enforced wherever the person is found. The procedure however will be entirely governed by the taw of the forum. It the law creating the liability provides for a particular mode of enforcing it, the mode limits the liability. If it be a contract, the parties contracted with the understanding that they can be held liable in no other way. And such liability cannot be enforced in another State. Here a special remedy is provided, and not only so, but plainly it was intended that it should be the only remedy."

The main question in these cases is not whether there existy a liability in other States than the one enacting the statute, for it seems to be universally conceded that the liability does exist even in States which refuse to enforce it, ${ }^{12}$ but whether there is

9 Kritzer v. Woodson, 19 Mo. 329 ; Ochiltree $r$. Contracting Co., $54 \mathrm{Ma}$ 113.

10 Huntington v. Attrill, 146 U. S. $657,666,676$; Stewart v. R. R. Co., 168 U. S. 445 ; Russell v. R. R. Co., 113 Cal. 258, 45 Pac. 323 ; Guerney v. Moore, 131 Mo. 650, 32 S. W. 1132 ; Marshall v. Sherman, 148 N. Y. 9, 10, 29, 42 N. E. 419 ; First Nat. Bank $v$. Dillingham, 147 N. Y. 603 ; Hancock Nat. Bank v. Ellis, 166 Mass. 414 ; Post v. R. R. Co., 144 Mass. 341, 345. But see Coffing $v$. Dodge, 167 Mass. 231, 45 N. E. 928.

11 Russell v. Pac. R. R. Co., 113 Cal. 258, 45 Pac. 323, 324. See alst Marshall $v$. Sherman, 148 N. Y. 9, 29.

12 Post v. R. R. Co., 144 Mass. 341, 344, 345. 
in the State of the forum the machinery proper and necessary to enforce the peculiar liability, so that care may be taken to see that no injustice be done. ${ }^{18}$

It is obvious that if a special and peculiar remedy is given by the law of the State creating the liability, no other State will in general possess the machinery adequate to enforce it, and its courts would have no authority to enforce it by other means. ${ }^{14}$ If the statute creating the liability leares the remedy to be determined by the application of general principles of jurisprudence, then its enforcement in a foreign State must depend upon whether such State, through its courts, possesses adequate machinery to enforce it, without danger of injustice. Hence a liability arising upon the same statute may be enforced in one State when it will not be enforced in another. ${ }^{15}$ Even in the same State the machinery may be adequate for the enforcement of certain rights in connection with the liability, while not adequate for other purposes. In that event, since the existence of the liability is recognized everywhere, such redress as the courts of the forum may properly grant will be afforded. Hence in Massachusetts, whose courts refuse to directly enforce a quasi-contractual liability of this kind, it was nevertheless held that if the relief sought was merely a discovery in equity, by the officers of the corporation, of the stockholders and the number of shares held by each, the relief should be granted, although the purpose of the discovery was to enforce by suit in another State a personal liability imposed upon the stockbolders by the laws of another State. ${ }^{16}$

13 Post $v$. R. R. Co., 144 Mass. 341; Bank v. Rindge, 154 Mass. 203. See Bank $v$. Rindge, 57 Fed. 279 ; Guerney $v$. Moore, 131 Mo.650, 32 S. W. 1132.

14 See Russell v. Pac. R. R. Co., 113 Cal. 258, 45 Pac. 323 : Marshall $v$. Sherman, 148 N. Y. 9, 42 N. E. 419 ; Bank v. Rindge, 154 Mass. 203; Stewart $v$. R. R. Co., 168 U. S. 445.

15 See Bank $v$. Rindge, 154 Mass. 203 ; Bank $v$. Rindge, 57 Fed. 279 [U. S. Court for California]; Guerney v. Moore, 131 Mo. 650, 32 S. W. 1132 . These cases all arose under the same Kansas statute, making stockholders liable to ereditors of the company for an amount equal to the amount of their stock. In the Massachusetts case, it was held that the judicial machinery of that State was inadequate to ensure full justice. In the other two cases the lim bility was enforced.

16 Post v. R. R. Co., 144 Mass. 341. 


\section{§ 11. Fifth Exception - Transactions relating to Immov-} able Property. - It is generally admitted that transactions relating to lands or immovable property of any kind are to be governed by the law of the place where the property is situated (lex loci rei sitæ or lex situs). ${ }^{1}$

Although this principle is generally recognized, the reason for the doctrine has not always been kept clearly in view. In truth it simply constitutes one branch of the first exception, already discussed, and what is known as the lex situs is, in the last analysis, nothing more than the lex fori. Since immovable property is fixed forever in the State where it lies, and since no other State can have any jurisdiction over it, it follows necessarily that no right, title, or interest can be finally acquired therein, unless assented to by the courts of that State, in accordance with its laws. The courts of no other State can finally pass upon such questions, so as to give or take away from any litigant a claim to the property. On the other hand, the courts of the situs of the land will be peculiarly rigid in their requirement that the law of the situs be complied with in regard to the transfer of the title to that class of property. The policies of each State in connection with the transfer of land within its limits are justly ranked amongst the most important of all its policies, no outside interference with which will be tolerated. Every effort is made by each State to have its laws touching the devolution, transfer, and charge of lands within its borders as definite and certain as possible. Particular formalities are required which are not required in other matters. And it is of the utmost importance that the legal records of such transactions, constituting chains of title to land, should be kept free from blemish, irregularity, or confusion with the requirements of other States.

Hence it becomes peculiarly a part of the policy of every State that no transactions relating to the transfer of any interest in or title to immovable property situated there shall be upheld,

1 United States v. Crosby, 7 Cr. 115 ; Clark v. Graham, 6 Wheat. 577 ; Kerr v. Moon, 9 Wheat. 565; McCormick $v$ Sullivant, 10 Wheat. 192; Darby $v$. Mayer, 10 Wheat. 465 ; Ross v. Ross, 129 Mass. 243, 245, $37 \mathrm{Am}$ Rep. 321; and other cases cited in note 5 , infra. 
if violative of its own law, whether valid by the laws of foreign States or not. These considerations are amply sufficient to induce the courts of the situs of land (when the situs is the forum) to prefer their own laws upon this subject to those of any other State. ${ }^{2}$

Nor will the courts of other States attempt to enforce their own laws with respect to land situated elsewhere, not only because of the spirit of comity and their unwillingness to engage in conduct towards other States, which they would not tolerate in other States towards themselves, but also, and perhaps chiefly, because of their utter inability to render any judgment or decree that would be final and effectual to transfer any interest in the land..$^{8}$ Instead, therefore, of rendering idle judgments in accordance with their own law, the courts, in dealing with the title to foreign real estate, will seek to determine the rules laid down by the lex situs of the land, and will decide in accordance with that law, for to it the parties must finally appeal in any event."

Thus it comes to be a well settled principle of private international law, fortified by a great mass of authority, that all questions relating to the transfer of title to immovable property, wherever arising, will be governed by the lex situs, the law of the ultimate forum in which all such questions must finally be decided. ${ }^{5}$

2 See Williams $v$. Saunders, 5 Coldw. (Tenn.) 60, 76 ; Sneed v. Ewing, 5 J. J. Marsh. (Ky.) 460, 22 Am. Dec. 41, 56.

3 See Dicey, Confl. L. 38-40 ; Rodgers v. Rodgers, 56 Kan. 483, 43 Pac. 779, 781. See Guillander $v$. Howell, 35 N. Y. 657,660 .

4 See Hawley $v$. James, 7 Pai. Ch. (N. Y.) 213, 32 Am. Dec. 623.

5 Watkins $v$. Holman, 16 Pet. 26; Ross $v$. Ross, 129 Mass. 243, 245, 37 Am. Rep. 321; Williams $v$. Saunders, 5 Coldw. (Tenn.) 60,70 ; Wick v. Dawson, 42 W. Va. 43, 24 S. E. 587; Swank $v$. Hufnagle, 111 Ind. 453, 12 N. E. 303 ; Otis $v$. Gregory, 111 Ind. 504, 13 N. E. 39 ; Carpenter $v$. Bell, 96 Tenn. 294, 34 S. W. 209 ; Knox v. Jones, 47 N. Y. 389, 395 ; Rice $v$. Harbeson, 63 N. Y. 493, 502; Staigg $v$. Atkinson, 144 Mass. 564, 569 ; Chipman v. Peabody, 159 Mass. 420,34 N. E. 563 ; Polson $v$. Stewart, 167 Mass. 211, 45 N. E. 737; Richardson $v$. De Giverville, 107 Mo. 422, 17 S. W. 974, 977; Keith $v$. Keith, 97 ML. 224, 10 S. W. 597; Lamar v. Scott, 3 Strob. L. (S. C.) 562 ; Washburn v. Van Steenwyk, 32 Minn. 336, 20 N. W. 324 ; Heine $v$. Ins. Co., 45 La. Ann. 770, 13 So. 1; Bronson v. Lumber Co., 44 Minn. 348, 46 N. W. 
Not only does the lex situs control transfers of land to the extent of invalidating such transfers of title as are not in accordance with the lex situs, though valid where entered into, but the converse is also true. If valid by the lex situs, the transaction may be upheld, though invalid where entered into. ${ }^{6}$

A qualification of the rule however must be observed, where the question relates not to the transfer itself, but to sume collateral incident of the transfer. Thus, while in case of a mortgage of land or an assignment thereof for the benefit of creditors the lex situs will still govern to the extent that such transfer constitutes a muniment of title as between the parties, it does not follow that an instrument sufficient for this purpose under the lex situs, but which transfers a title voidable by creditors, will in the latter respect also be governed by the lex situs. Such matters do not constitute any part of the muniment of title, and are merely matters of local policy. Such, for instance, are laws of the situs avoiding, at the instance of creditors thereby defrauded, assignments which prefer creditors, or to which is not appended an inventory of the property assigned, or to which bonds by the trustees for the due performance of their duties are not attached. These requirements, and others of the same kind, are for the benefit of creditors. As between the parties, the assignment, if in conformity to the lex situs, is valid, and if no creditors complain, will be sustained. It is manifest that requirements like those above mentioned do not constitute part of the title, but are intended for the collateral purpose of securing creditors. They are mere matters of policy, and may or may not be intended by the legislature to protect foreign as well as domestic creditors, their effect depending upon the interpretation placed upon the policy by the courts of the situs and forum.

570 ; Ford v. Ford, 70 Wis. 19, 33 N. W. 188, 194 ; Frazier v. Boggs, 37 Fla. 307,20 So. 245 ; Rodgers $v$. Rodgers, 56 Kan. 483, 43 Pac. 779, 781; Glenn v. Thistle, 23 Miss. 42, 49; Penfield $v$. Tower, 1 N. D. 216, 46 N. W. 413 ; Post v. Bank, 138 Ill. 559, 28 N. E. 978 ; Wood $v$. Wheeler, 111 N. C. 231, 16 S. E. 418.

- Succession of Cassidy, 40 La. Ann. 827, 5 So. 292 ; Post $v$. Bank, 138 IIl. 559, 28 N. E. 978 ; Chipman v. Peabody, 159 Mass. 420, 34 N. E. 563. 
In suits by domestic creditors the law of the situs will undoubtedly prevail, not because it is the lex situs however, but because it is the lex fori, being an instance of the second exception. ${ }^{7}$ But if the creditors who institute the suit are not citizens, unless the requirements of the lex situs are intended to secure all creditors, the law of the place where the assignment is made (lex loci contractus) will control in these particulars, even though the subject be real estate located elsewhere. ${ }^{8}$

So also with respect to mortgages of land, though the mortgage itself must be such as will constitute a transfer of title under the lex situs, the question as to whether the debt secured thereby (if contracted in another State) is a valid consideration to support the mortgage (for instance, whether it is usurious) is to be determined by the law which properly governs the validity of the debt.9

The same may also be said of contracts to convey land situ. ated elsewhere. So far as they constitute links in the chain of title (passing the equitable title thereto), they are to be governed by the lex situs of the land. But if the vendee waives his right to a conveyance, or has none, and looks upon it in the

7 Ante, § 8 ; May $v$. Bank, 122 Ill. 551, 13 N. E. 806 ; Williams v. Dry Goods Co., 4 Okl. 145, 43 Pac. 1148, 1149; Long v. Girdwood, 150 Penn. St. 413, 23 L. R. A. 33, note.

8 May $v$. Bank, 122 Ill. 551, 13 N. E. 806 ; Juillard $v$. May, 130 Ill. 87, 22 N. E. 477; Williams v. Dry Goods Co., 4 Okl. 145, 43 Pac. 1148; Long v. Girdwood, 150 Penn. St. 413, 23 L. R. A. 33, note, 24 Atl. 711 ; Thurston $v$. Rosenfield, 42 Mo. 474 ; Chafee $v$. Bank, 71 Me. 514, 36 Am. Rep. 345. But see Moore v. Church, 70 Ia. 208, $59 \mathrm{Am}$. Rep. 439. It is otherwise if the policy of the State is violated by the assignment. Bank $v$. Stellings, $31 \mathrm{~S}$. C. $360,9 \mathrm{~S}$. E. 1028. In respect to this point, there is no difference in principle between assignments of land and of personalty. See post, §§ 133-135. In case of involuntary assignments of land under foreign insolvent or bankrupt laws, such assignments being given no exterritorial force in the United States, the lex fori (or lex situs) will govern, at least as to creditors domiciled in other States than that where such assignment ocenrs. See Townsend $v$. Coxe, 151 Ill. 62, 37 N. E. 689 ; Moore v. Land, etc. Co., 82 Md. 288, 33 Atl. 641 ; Hervey v. Edens, 66 Tex. 420, 6 S. W. 306 ; post, $\S 138$.

${ }^{2}$ Fessenden $v$. Taft, 65 N. H. 39, 17 Atl. 713, 714 ; Klinck $v$. Price, 4 W. Va. 4, 6 Am. Rep. 268. See Bowles $v$. Field, 78 Fed. 742. But see Chap. man v. Robertson, 6 Pai. Ch. (N. Y.) 627, 31 Am. Dec. 264. 
light of a mere personal contract, suing for damages for the breach thereof, it will be governed by the law properly applicable to an ordinary executory contract. ${ }^{10}$ Whether the latter principle will apply in case of a suit by the vendee for the specific erecution of a deed to the land, instead of a suit for aamages, may be doubtful. It is believed however that it will, at least in cases whoie a proper deed can be made, in conformity to the lex situs of the land. ${ }^{11}$ The courts of the situs would recognize and enforce a contract of this character, even though not in conformity to the lex situs, if it conforms to the proper law. If they did not, there would be nothing to prevent the courts of other States from compelling the vendor to make a suitable deed, in accordance with the lex situs, which the courts of the situs would be bound to recognize. ${ }^{12}$

§ 12. Same-Application of Lex Situs to Transfers of Land, and Liens thereon. - Subject to the qualifications mentioned in the preceding section, the lex situs regulates all transfers of land, in every point which constitutes part of the conveyance.

Thus, the capacity to devise lands, or to be a devisee thereof, or to transfer them inter vivos by conveyance or mortgage, will be controlled by the lex situs of the realty." So also the forms

10 See Glenn $v$. Thistle, 23 Miss. 42.

11 The kind of conveyance which is to be made in pursuance of the contract of sale is to be determined by the lex situs of the land, that being the place of performance of the contract. See Carnegie $v$. Morrison, 2 Met. (Mass.) $381,398$.

12 This is the conclusion of a majority of the court in Polson $v$. Stewart, 167 Mass. 211,45 N. E. 737 . That case however was a suit for the specific performance of a covenant by a husband made in North Carolina to release and extinguish his marital rights in the wife's land in Massachnsetts. The covenant did not purport to pass any title. But the principle would seem to be the same.

1 Carpenter $v$. Bell, 96 Tenn. 294, 34 S. W. 209 ; Williams $v$. Saunders, 5 Coldw. (Tenn.) 60, 72 ; Frazier v. Boggs, 37 Fla. 307, 20 So. 245 ; Ford v. Ford, 70 Wis. 19,33 N. W. 188 ; Cochran v. Benton, 126 Ind. 5S, 25 N. F. 870 ; Otis v. Gregory, 111 Ind. 504, 13 N. E. 39; Bethell v. Bethell, 54 Ind. 428, 23 Am. Rep. 650, 652 ; Polson v. Stewart, 167 Mass. 211, 218, 45 N. E. 737; Boehme v. Rall, 51 N. J. Eq. 574, 26 Atl. 832; White v. Howard, 38 Conn. 342. 
and solemnities required by the lex situs for valid conteyances or devises of land, or for powers of attorney to convey the same, must be followed. Compliance with the law of the party's domicil or of the place where the instrument is executed will not suffice. ${ }^{2}$

The same principle applies in the determination of the validity and effect of the substantial provisions of the conveyance, mortgage, or devise. The lex situs of the land governs. ${ }^{8}$

So it is also in respect to the devolution of land by descent. No one is heir to a deceased owner of land, unless he belongs to the class designated as such by the lex situs of the land. ${ }^{4}$ And the same law will control the shares each heir shall inherit, as whether they shall take per capita or per stirpes. ${ }^{6}$ If the rules of primogeniture or of representation prevail in the State where the land is situated, they will furnish the guide, whatever may be the law of descent in the domicil of the deceased owner. As was said in a leading case: ${ }^{6}$ "If a man domiciled in England has two legitimate sons there and dies intestate, owning land in Massachusetts, both sons have the status of

2 Kerr $v$. Moon, 9 Wheat. 565 ; Clark $v$. Graham, 6 Wheat. 577; Williams v. Saunders, 5 Coldw. (Tenn.) 60, 72 ; Otis $v$. Gregory, 111 Ind. 504, 13 N. F. 39 ; Bethell $v$. Bethell, 54 Ind. 428, 23 An. Rep. 650, 652 ; Ross v. Ross, 129 Mass. 243, 245, 37 Am. Rep. 321 ; Ford $v$. Ford, 70 Wis. 19, 33 N. W. 188, 194 ; Succession of Larendon, 39 La. An. 952, 3 So. 219, 220.

8 McGoon $v$. Scales, 9 Wall. 23 ; Ross $v$. Ross, 129 Mass. 243, 245, 37 Am. Rep. 321 ; Williams $v$. Saunders, 5 Coldw. (Tenu.) 60, 72, 75; Hawley $v$. James, 7 Pai. Ch. (N. Y.) 213, 32 Am. Dec. 623 ; Frazier v. Boggs, 37 Fla. 307, 20 So. 245 ; Bethell v. Bethell, 54 Ind. 428, 23 Am. Rep. 650, 652 ; Bronson v. Lumber Co., 44 Mirn. 348, 46 N. W. 570, 571; Penfield v. Tower, 1 N. D. 216, 46 N. W. 413; Succession of Cassidy, 40 La. Ann. 827, 5 So. $292,295$.

4 Woodward $v$. Woodward, 87 Tenn. $644,11 \mathrm{~S} . \mathrm{W} .892,895$; Williams $v$. Saunders, 5 Coldw. (Tenn.) 60, 75 ; McGoon $v$. Scales, 9 Wall. 23 ; Miller $v$. Miller, 91 N. Y. 315 ; Gray $v$. Holmes, 57 Kan. 217, 45 Pac. 596, 33 L. R. A. 207; Warren v. Prescott, 84 Me. 483, 17 L. R. A. 435, note; Ross v. Ross, 129 Mass. 243, 37 Am. Rep. 321 ; Smith v. Derr, 34 Penn. St. 126, 75 Am. Dec. 641 ; Birtwhistle $v$. Vardill, 5 B. \& C. 438,7 Cl. \& F. 895.

5 Story, Confl. L. $\$ 481 a$.

- Ross v. Ross, 129 Mass. 243, 247, 37 Am. Rep. 321. See also Story, Confl. L. $\S 481$ a. 
legitimate children here, but by virtue of our statute of descents the land descends to them equally, and not to the eldest son alone, as by the law of England."

But though it is well settled that the lex situs shall determine who shall inberit lands, it has not always been found easy to interpret that law. For example, should that law provide that an intestate's land shall go to his "children," a question may be, and has been, raised whether that term will include bastard children, subsequently legitimated by a proper foreign law. ${ }^{7}$

In such case, if the lex situs of the land also admits of subsequent legitimation, though by a different method, there can be little doubt that such a child will be included in the class designated by the lex situs as "children." 8 It is in cases where the policy of the situs altogether prohibits such legislation that most difficulty arises. The famous English case of Birtwhistle $v$. Vardill ${ }^{9}$ was of this character. The question there was whether a bastard son of Scotch parents, afterwards legitimated by the marriage of the parents (which by the law of Scotland had that effect), could inherit lands in England as heir. The Court of King's Bench held that he could not, though admitting that he must be considered in England as legitimate. This decision, after elaborate argument, was affirmed in the House of Lords. The decision was based upon the strict letter of the English statute of Merton, and the history of its passage. ${ }^{10}$ That statute was construed to mean that, in order to inherit, the claimant must not only be a legitimate child (which was admitted to be the fact in this case), but must also have been born in wedlock.

7 The "proper law" governing the status of a bastard subsequently legitimated will be examined hereafter. Post, $\S 97$ et seq.

8 Ross $v$. Ross, 129 Mass. 243, 37 Am. Rep. 321 ; Gray v. Holmes, $57 \mathrm{Kan}$. 217, 45 Pac. 596, 33 L. R. A. 207.

95 B. \& C. 438 . Afterwards affirmed in the House of Lords, 7 Cl. \& F. 895.

10 The statute of Merton was passed by the English nobility in Parliament in response to a demand of the clergy that the Roman law of legitimation per subsequens matrimonium be adopted in England. The assembled barons curtly and emphatically declined through the statute of Merton. See Ross $v$. Ross, 129 Mass. 243, 252, 37 Am. Rep. 321. 
But the basis of the English decision is purely technical, being founded on the statute of Merton alone, and the modern tendency in the United States - at least in States where that statute is held not to be in force - seems to be in faror of permitting the subsequently legitimated bastard to inherit, provided his status of legitimacy has been fixed by the proper law. ${ }^{11}$ Thus in a New York case, ${ }^{12}$ an action of ejectment was brought there by the plaintiff, who was born a bastard. The parents subsequently intermarried in the State of their domicil, the effect of which, by the domiciliary law, was to legitimate the infant. The law of New York did not permit such an effect to a subsequent marriage. The plaintiff claimed the New York land as heir to his father, under a statute of that State providing that the land should pass to "the lineal descendants" of the decedent. It was also provided by the laws of New York that "children and relatives who are illegitimate shall not be entitled to inherit." It was held that the plaintiff, being legitimate by "the proper law," must be so considered in New York, and accordingly he recovered the land.

The same doctrine is applicable, in America at least, to children legally adopted in accordance with the proper law, where that law gives them the same status and puts them on the same footing as the real children of the adopting parent. They will in general be entitled to inherit land from the adopting parent

11 Miller v. Miller, 91 N. Y. 315 ; Scott v. Key, 11 La. Ann. 232 ; Woodward $v$. Woodward, 87 Tenn. $644,11 \mathrm{~S}$. W. 892, 895 ; Ross $v$. Ross, 129 Mass. 243, 256, 37 Am. Rep. 321. Smith v. Kelly, 23 Miss. 167, 55 Am. Dec. 87, was a case in which the child was not legitimated by the "proper law." See post, $\$ \S 97$ et seq. Even in England the rale is believed to be otherwise with respect to the succession of personal property, the statute of Merton not being applicable. See Wright's Trusts, 2 K. \& J. 595, 25 L. J. (Ch.) 621 ; Goodman v. Goodman, 3 Giff. 643; Goodman's Trusts, 17 Ch. Div. 266; Skottowe v. Young, L. R. 11 Eq. 474 ; Ross $v$. Ross, 129 Mass. 243, 256, 37 Am. Rep. 321. Some of the American courts however have followed, with respect to lands, the decision in Birtwhistle $v$. Vardill, holding that the statute of Merton is in force in their States. Smith $v$. Derr, 34 Penn. St. 126, 75 Am. Dec. 641 ; Williams v. Kimball, 35 Fla. 49, 16 So. 783 . See Barnum v. Barnum, 42 Md. 252 ; Keegan v. Geraghty, 101 Ill. 26; Smith v. Kelly: 23 Miss. 167, 55 Am. Dec. 87.

12 Miller $v$. Miller, 91 N. Y. 315. 
in other States, as if they were in reality lineal descendants of the adopter. ${ }^{18}$

The provisions of a deed of conveyance of land will be in general governed by the lex situs of the land, not only with respect to their validity and effect, as has been already shown, but also with respect to the interpretation to be given ambiguous legal phrases used therein, such as "heirs;" "children" (as whether including illegitimate or legitimate children); "brothers" (as whether or not including those of the half-blood); whether or not a provision for a wife is to be deemed intended in lieu of her dower; whether a limitation to one for life, with remainder to his heirs, vests an inheritance in the ancestor, etc. Where the legal effect of such provisions in a deed varies in different States the lex situs of the land (not the lex loci contractus), it is believed, will control; for in the construction of a deed to land, legal terms are given their strict legal interpretation, in the absence of plain evidence of a contrary intent. They constitute, as it were, rules of property, muniments of title. ${ }^{14}$ It may be doubted, however, whether the same rule will necessarily control the interpretation of ambiguous phrases in a deed, when the phrases in question have no particular legal signification in connection with transfers of land. In regard to such matters the actual, not the legal, meaning of the grantor's words will be sought, in accordance with the prin-

13 Ross v. Ross, 129 Mass. 243, 37 Am. Rep. 321 ; Melvin v. Martin, 18 R. I. 650, 30 Atl. 467 ; Gray v. Holmes, 57 Kan.217, 45 Pac. 596, 33 L. R. A. 207; Keegan v. Geraghty, 101 Ill. 26 ; Van Matre v. Sankey, 148 Ill. 356, $36 \mathrm{~N}$. E. 628 . It would seem to be otherwise where the recognition of the foreign status might result in injustice to third persons, citizens of the forum, as where the adopted child claims to inherit, because of the adoption, from collateral kindred of the adopting parent, unless the statutes of the situs provide for such a case. Keegan v. Geraghty, 101 Ill. 26 ; Van Matre $v$. Sankey, 148 Ill. 356, 36 N. E. 628 . See Loring $v$. Thorndike, 5 Allen (Mass.), 257.

14 Van Matre $v$. Sankey, 148 Jll. 356, 36 N. E. 628; McCartney $v$. Osburn, 118 Ill. 403, 9 N. E. 210 ; Brown v. Bank, 44 Ohio St. 269, 6 N. E. 648 ; Staigg $v$. Atkinson, 144 Mass. 564, 12 N. E. 354 ; Jennings $v$. Jennings, 21 Ohio St. 56 ; Richardson v. De Giverville, 107 Mo. 422 ; 17 S. W. 974, 977 ; Baxter v. Willey, 9 Vt. 276, 31 Am. Dec. 623. 
ciples whereby is determined the law governing the interpretation of ordinary contracts, hereafter to be noted. ${ }^{15}$

But in the case of a devise, the courts are more prone to abide by the actual (as opposed to the legal or constructive) intent of the testator, in matters depending merely upon his will. The law which he most probably had in mind when he used the words (generally the lex domicilii of the testator), it is believed, will determine the testator's meaning. ${ }^{16}$

Whether a valid trust in lands is created by the provisions of a deed or will, whether or not a trust results by implication of law, whether or not a conveyance absolute on its face shall be deemed a mortgage, and other questions of this character, are to be governed by the lex situs. ${ }^{17}$

Another point that should be observed in this connection arises in regard to the effect to be given to covenants contained in a deed conveying lands, where the deed is executed and the grantor resides in one State, and the land is situated in another. In the solution of this question, it must first be observed that although a covenant is contained in a deed of conveyance it is itself in general anly an executory entract, and for most purposes it is to be gorern by the law ontrolling executory contracts. But if it be a covenant running with the land, especially if it be a covenant of title, it is the better opinion that the effect of it must be determined by the lex situs in all cases where its breach imposes a liability or confers a right upon the party holding the title to the land. A covenant of title follows the title and should therefore be governed by the same law, though the liability be sought to be imposed elsewhere. ${ }^{18}$

16 Post, $\$ 186$. See Mullen $v$. Reed, 64 Conn. 240, 29 Atl. 478.

16 Post, $\S 145$; Story, Confl. L. $\S \S 479 h, 479 \mathrm{~m}$. There is authority however in favor of the lex situs of the land in snch cases. See Van Matre v. Sankey, 148 Ill. 356, 36 N. E. 628 ; McCartney v. Osburn, 118 Ill. 403, 9 N. E. 210. But see Staigg $v$. Atkinson, 144 Mass. 564, 12 N. E. 354.

17 Hawley v. James, 7 Pai. Ch. (N. Y.) 213, 32 Am. Dec. 623 ; Penfield v. Tower, 1 N. D. 216, 46 N. W. 413 ; Baxter v. Willey, 9 Vt. 276, 31 Am. Dec. 623 ; Depas v. Mayo, 11 Mo. 314, 49 Am. Dec. 88.

18 Post, § 185; Dickinson v. Hoomes, 8 Gratt. (Va.) 353, 410 ; Succession of Cassidy, 40 La. Ann. 827, 5 So. 292 ; Bethell $v$. Bethell, 54 Ind. 428, 23 Am. Rep. 650. But see Brown v. Bank, 44 Ohio St. 269, 6 N. E. 648, which appears not to have been very carefully considered. 
So, according to the better opinion, the right of a creditor to charge in equity a married woman's equitable separate estate in lands (apart from charging her personally) is to be determined by the lex situs of the land, regardless of the locality of the debt. Such a claim on the part of the creditor is practically the assertion of a lien, created as to the wife in invitam; and the effect of a lien upon land, as well as the capacity to create such a lien, since it affects the title to the land, is to be gov. erned by the lex situs. ${ }^{10}$

So also the marital rights of the husband or wife in the lands of the consort, such as dower or curtesy under the common law system, community rights under the civil law, or other rights of a similar nature created by the statutes of particular states, will be regulated by the lex situs of the land in question, and not by the law of the parties' domicil, nor by that of the place where the marriage was contracted. ${ }^{20}$ And the effect of a divorce of the parties upon their marital rights in the lands of the consort will be governed by the same law, regardless of the law of the place of divorce, ${ }^{21}$ although the validity of the divorce itself will be determined upon entirely different principles. ${ }^{22}$

$\S 13$. Meaning of "Immovable Property" in Private International Law. - In the previous sections the term "immovable property" has been used as synonymous with "real property," and for the most part they may be used interchangeably. In-

19 Bank $v$. Williams, 46 Miss. 618, 12 Am. Rep. 319; Wicks v. Dawson, 42 W. Va. 43, 24 S. E. 587; La Selle v. Woolery, 14 Wash. 70, 44 Pac. 115, 32 L. R. A. 75 ; Johnston v. Gawtry, 11 Mo. App. 322 ; Cochran v. Benton, 126 Ind. 58, 25 N. E. 870; Swank v. Hufnagle, 111 Ind. 453, 12 N. E. 303. But see Story, Confl. L. $\$ \S 266,267,268$; Spearman $v$. Ward, 114 Penn. St. 634,8 Atl. 430. These authorities regard the charge upon the land as a part of the married woman's obligation, and governed by the lex solutionis of her contract.

20 Lamar v. Scott, 3 Strob. L. (S. C.) 562 ; Staigg v. Atkinson, 144 Mass. 564, 12 N. E. 354 ; Kneeland v. Ensley, Meigs (Tenn.), 620, 33 Am. Dec. 168; Richardson $v$. DeGiverville, 107 Mo. 422, 17 S. W. 974, 977.

21 Barber $v$. Root, 10 Mass. 260 ; Ross $v$. Ross, 129 Mass. 243, 248, 37 Am. Rep. 321; Harding v. Alden, 9 Greenl. (Me.) 140, 23 Am. Dec. 549; McGill v. Deming, 44 Ohio St. 645, 11 N. E. 118, 123 ; Hilbisb v. Hattel, 145 Ind. 59, 33 L. R. A. 783, 787.

22 See post, $\$ \$ 89$ et seq. 
deed it may be postulated that all such property as at common law was real estate is to be classed as immovable property. ${ }^{2}$ But the reverse of this is not always true. It is the quality of immovability which international law looks to. Thus, terms for years or leasehold estates constitute immovable property, and yet at common law they are to be deemed personalty. From the standpoint of international law, these interests, according to the better opinion, are to be classed as immovables, to be regulated by the lex situs of the land. ${ }^{2}$ On the other hand, property may be movable (following the owner), though considered in the State where it is situated as real property for some purposes.

In any event, it is universally admitted that each State may impress upon all property within its limits whatsoever character it sees fit, and that character will attach to it everywhere, as long as the property remains within that jurisdiction. The lex situs will determine what is or is not to be considered real or immovable property so as to possess a locality of its own. ${ }^{4}$ But if personalty has impressed upon it by the law of its actual situs the character of real estate, as was sometimes the case in Southern States, prior to the war, with respect to slaves, and such property is afterwards removed to another State by whose law it is to be regarded as personalty, the latter character is deemed to have been imposed upon it from the time of the removal. ${ }^{6}$

1 Story, Confl. L. § 447.

2 Dicey, Confl. L. 72 ; Whart. Confl. L. §§ 286, 287; Sneed v. Ewing, 5 J. J. Marsh. (Ky.) 460, 22 Am. Dec. 41, 58, 59, 60. But see Despard v. Churchill, 53 N. Y. 192.

3 Sneed v. Ewing, 5 J. J. Marsh. (Ky.) 460, 22 Am. Dec. 41, 56, 61; McCollum v. Smith, Meigs (Tenn.), 342, 33 Am. Dec. 147, 148. In the first case, a testator domiciled in Indiana owned slaves and other property in Kentucky. The Kentucky law declared slaves descendible to the heirs like land, but the court held the will to be governed by Indiana law (lex domicilii).

4 Chapman v. Robertson, 6 Pai. Ch. (N. Y.) 627, 630, 31 An. Dec. 264 ; Newcomer $v$. Orem, 2 Md. 297, 56 Am. Dec. 717, 718; Lamar v. Scott, 3 Strob. L. (S. C.) 562 ; Guillander v. Howell, 35 N. Y. 657, 663; McCollum v. Smith, Meigs (T'enn.), 342, 33 Am. Dec. 147, 148; Kneeland v. Ensley, Meigs (Tenn.), 620, 33 Am. Dec. 168, 169. See Union Bank v. Hartwell, 84 Ala. 379, 4 So. 156, 157; Story, Confl. L. § 447.

6 Minor v. Cardwell, 37 Mo. 350, 90 Am. Dec. 390. The rents and profits 
If the owner of land directs his lands to be sold and converted into personalty, the question whether the principle of equitable conversion will apply so as to convert it instanter into personalty, or whether it shall remain land, will depend upon the lex situs of the land. ${ }^{6}$ On the other hand, should a testator, domiciled in one State, by his will direct personalty to be invested in land, so that an equitable conversion into land takes place, the essential validity of the trusts or provisions of the will should be controlled, not by the law of the testator's domicil (as if it were a will of personalty ${ }^{7}$ ), but by the lex situs of the land actually purchased under the directions of the will. ${ }^{8}$ But in the latter case, the question whether in the first instance there is an equitable conversion of the money into land must be decided in accordance with the law of the testator's domicil, for that is the law by which his will is to be interpreted. Hence also the question whether or not the testator had the legal capar city to make the will is to be determined by the law of his

of lands (already accrued) are personal property, and, like other personalty, are legally sitnate with the owner. Cameron $v$. Watson, 40 Miss. 191, 208; Wood v. Wood, 5 Pai. Ch. (N. Y.) 596, 605, 28 Am. Dec. 451.

- Curtis v. Hutton, 14 Ves. 537; Hawley v. James, 7 Pai. Ch. (N. Y.) 213, 32 Am. Dec. 623, 625; Newcomer v. Orem, 2 Md. 297, 56 Am. Dec. 717, 718-19 ; Chamberlain v. Chamberlain, 43 N. Y. 424, 432, Hope $v$. Brewer, 136 N. Y. 126 ; Hobson v. Hale, 95 N. Y. 588 ; Bible Society v. Pendleton, 7 W. Va. 79 ; Ford $v$. Ford, 80 Mich. 42, 44 N.W. 1057; Penfield $v$. Tower,

1 N. D. 216,46 N. W. 413.

7 Post, 144.

8 Ford v. Ford, 80 Mich. 42, 44 N. W. 1057; Penfield v. Tower, 1 N. D. 216, 46 N. W. 413. But see Wood v. Wood, 5 Pai. Ch. (N. Y.) 596, 28 Am. Dec. 451 , in which it was held that a will made by a citizen of New York, directing his personalty to be invested in Ohio lands upon trusts violating the New York law against perpetuities, must be governed by New York law. It unight well be asked, Why? If the provisions of the will had been carried out, the money would have gone to the person in Ohio from whom the land there was purchased, and the land would have been in Ohio. Of what interest could it be to New York whether or not Ohio property was held in perpetuity? This case seems to have been tacitly overruled by the later New York cases. Thus, it is said in Chamberlain $v$. Chamberlain, 43 N. Y. 424, 434: "It is no part of the policy of $\mathrm{New}$ York to interdict perpetuities or gifts in mortmain in Pennsylvania."

- See post, $\$ \$ 145$ et seq. 
domicil, not the lex situs of the land into which he directs his money to be converted. For unless the will is a valid will of the personalty, the conversion into land cannot take place. ${ }^{10}$

§ 14. Application of Lex Situs to Transactions relating to Movable Property. - It is a general principle of private international law that movable property, such as chattels and choses in action, are to be considered in contemplation of law as situ. ated with the owner, regardless of their actual locality. The maxim "mobilia personam sequnntur" applies very generally; so that no matter where the chattels may be actually situated, their legal situs follows the situs of the owner himself. ${ }^{1}$

But if the movables are situated in one State and the owner has his situs in another, transfers may be made by him, the enforcement of which may contravene the interests or policy of the State where the property is situated, or may work a wrong upon its people, or may be contrary to its views of morality. These are the very cases which constitute exceptions to the operation of a proper law. ${ }^{2}$ Hence if, under such circumstances, it is attempted to enforce the transfer in the State where the property is actually situated (and such questions will in general arise there) that State becomes the forum, and the lex fori will be substituted for the proper foreign law (the law of the situs of the owner), in accordance with the principles already noticed in discussing these exceptions. It therefore frequently comes about, where there is a litigation over the transfer of movables situated in the State where the suit is brought, that the lex fori, not the law of the owner's situs, will control. Furthermore, in such cases the litigation is almost always based upon one or the other grounds of exception above mentioned, and if the existence of the exceptional circumstances is

10 Post, $\$ 70$.

1 The term "lex situs" when applied to movables does not generally mean the law of the legal, but of the actual, situs of the property. For a full discussion of the situs of personalty, and the law governing transactions connected therewith, see post, $\S 120$ et seq. The distinction between the actual and the legal situs of the owner will be noted hereafter. Post, $\$ \S 18$ et seq, 120 et seq.

2 Ante, $\$ \$ 6,7,8,9$. 
established, the law of the actual situs of the personalty will usually prevail over the law of the owner's situs (the proper law)..$^{3}$

But it cannot be too carefully observed that this result is not due to any inherent force of the lex situs of the personalty, as such, but because it is in general also the lex fori. There is, in the last analysis, in respect to personalty, no such thing as the "lex situs," apart from the lex situs of the owner. It is only where the actual situs of personalty is the forum, that it assumes any importance in private international law." In those cases (so numerous as almost to obscure the general rule) where the law of the actual situs of personalty does control, it is because of the effect given to it as the lex fori. Hence, if the litigation takes place in the domicil of the owner, or in any state other than that of the actual situs of the property, the situs and the forum are no longer identical, and the grounds for the enforcement of the lex situs disappear.

These principles have sometimes escaped the attention of the courts and text writers, so that the proposition is frequently stated that "the lex situs controls the transfer of movables."

8 All this will be explained more fully hereafter. Post, $\S \S 120,129,132$, $134,135$.

4 For purposes of jurisdiction movables must always be considered as situated within the territory where they actually are. To hold otherwise would be to impeach the sovereignty of that State over everything within its borders. The point maintained in the text is not that movables may not possess an actual situs apart from the owner, but that there is no such thing as a substantive "lex situs" in such cases, as there is in the case of real property.

5 See Guillander $v$. Howell, 35 N. Y. 657. Mr. Wharton takes this position unreservedly. Whart. Confl. L. $\$ \$ 298$ et seq. In defence of this view he says (\$299): "If it is the domicil of the owner which is to decide, it becomes a difficult and sometimes insoluble question to determine who this owner is. An action is brought to decide as to the ownership of a chattel. The litigants have different domicils ; and if the article in dispute is to be subjected to the owner's domicil, the question as to who is the owner not being yet decided, the suit has to be stopped at the outset from inability to determine how it shall be tried." It is manifest that the case put by Mr. Wharton is not one of substantive law, but of jurisdiction. It is not denied that for such a purpose a chattel has a situs of its own. In no case could a 
It will do so where the situs is also the forum, provided grounds exist (as they frequently will) for the operation of any of the exceptions already discussed, but not necessarily, nor generally, in other cases.

§ 15. Effect of Transactions completed and perfected under Proper Law not generally altered by Subsequent Change of situs. - Before concluding the discussion of these general exceptions to the operation of a proper law, it will be well (even though we must anticipate some general principles) to call attention to a point which will often necessitate some modification of the propositions laid down in the preceding sections.

Courts will be reluctant (though they will not always refuse) to apply these exceptions to a transaction which has been validly entered into der its proper law, and has, under that law, been once valid as against the entire world, merely because, by some subsequent change of situs, the transaction has oome under the dominion of the law of some other State, which renders it void or voidable. In such a case the courts of the forum will not so readily substitute the lex fori for the proper law, and will usually refuse to do so altogether, except in those cases where the lex fori is expressly prohibitory of the enforcement of such transactions, even when entered into abroad, or unless the policy of the forum or the possible injury to its people is of the most pronounced character. ${ }^{1}$

judgment for a specific chattel be given in any other State than that wherein it is actually situated, for the judgment is in rem, and the court must have jurisdiction over the res. But it is one thing to say that the courts of the actual situs alone can have jurisdiction to determine the title to a chattel, and quite a different thing to say that, having jurisdiction, they must determine that question in accordance with their own substantive law, or to say that the courts of another State in which the validity of such title comes collaterally into question must be governed by the law of the actual situs. See Mason v. Beebee, 46 Fed. 556.

1 See Kanaga $v$. Taylor, 7 Ohio St. 134, 70 Am. Dec. 62 ; Hornthall $v$. Burwell, 109 N. C. 10, 13 S. E. 721 ; Thuret v. Jackson, 7 Mart. (La.) 318 ; Langworthy $v$. Little, 12 Cush. (Mass.) 109 ; Bank v. Lee, 13 Pet. 107 ; Edgerly $v$. Bush, 81 N. Y. 199 ; Miller v. Miller, 91 N. Y. 315 ; Phillips $v$. Gregg, 10 Watts (Penn.), 158, 36 Am. Dec. 168 ; Barker v. Stacy, 25 Miss. 477; 
One of the most prominent instances of the application of this principle occurs in the case of qualified transfers of movable property, for example, a chattel mortgage, where the chattels mortgaged are situated at the time in the place of transfer, but are subsequently removed to another State, by whose laws the mortgage is invalid as against creditors of the mortgagor, though valid as against the world by the law of the State where the mortgage was executed and the chattels were at the time situated. In such case, the transaction has been completed under the law of the first State, all the requirements of its law (the "proper law" at the time) have been complied with, and the parties have been vested with a perfect title, not only as between themselves, but as to third parties. This title should not be divested merely by reason of the fact that the chattels thus transferred are subsequently brought under a new jurisdiction, at least if this be done without the consent of the mortgagee. ${ }^{2}$

Thus, in Kanaga $v$. Taylor, ${ }^{8}$ the plaintiff sold a piano in New York to $G$, who there executed a chattel mortgage upon it to secure the unpaid purchase money. The mortgage was recorded in New York as that law directed, and was there valid

Wood v. Wheeler, 111 N.C. 231,16 S. E. 418 ; Cummington v. Belchertown, 149 Mass. 223, 227, 21 N. E. 435 ; Crapo v. Kelly, 16 Wall. 610, 622 ; Pond v. Cooke, 45 Conn. 126, 29 Am. Rep. 668 ; Chicago, etc. R. R. Co. v. Packet Co., 108 Ill. 317, 48 Am. Rep. 557 ; Cagill v. Wooldridge, 8 Baxt. (Tenn.) 580, 35 Am. Rep. 716 ; Richardson v. Shelby, 3 Okl. 68, 41 Pac. 378; Craig v. Williams, 90 Va. 500, 505 ; Bank v. Hill, 99 Tenn. 42, 41 S. W. 349 ; Handley v. Harris, 48 Kan. 606, 29 Pac. 1145 ; Stirk v. Hamilton, $83 \mathrm{Me}$. 524, 22 Atl. 391 ; Ames Iron Works $v$. Warren, 76 Ind. 512, 40 Am. Rep. 258.

2 See post, $\S 132$; Kanaga $v$. Taylor, 7 Ohio St. 134, 70 Am. Dec. 62 ; Handley $v$. Harris, 48 Kan. 606, 29 Pac. 1145 ; Hornthall v. Burwell, 109 N. C. 10, 13 S. E. 721, 722 ; Thuret $v$. Jackson, 7 Mart. (La.) 318 ; Craig $v$. Williams, 90 Va. 500, 505; Crapo $v$. Kelly, 16 Wall. 610, 622 ; Bank v. Lee, 13 Pet. 107 ; Langworthy $v$. Little, 12 Cush. (Mass.) 109 ; Edgerly $v$. Bush, 81 N. Y. 199 ; Martin v. Hill, 12 Barb. (N. Y.) 631 ; Barker v. Stacy, 25 Miss. 477 ; Cagill $v$. Wooldridge, 8 Baxt. (Tenn.) 580, 35 Am. Rep. 716. But see Corbett v. Littlefield, 84 Mich. $30,47 \mathrm{~N}$. W. 581. It is otherwise if the transaction be not completed before the removal of the goods. Cronan $v$. Fox, 50 N. J. L 417, 14 Atl. 119.

37 Ohio St. 134, 70 Am. Dec. 62. 
as against the world. $G$ afterwards carried the piano to Ohio and pledged it to M to secure a loan. The New York mortgage was not recorded in Ohio, and $M$ (a resident of Ohio) had no notice of the incumbrance. M sold the piano to the defendant, who was also a citizen of Ohio, and who knew nothing of the New York lien. Though the law of Ohio requiring the recordation of chattel mortgages was not complied with, the court held the plaintiff's claim to be paramount.

The same principle has been applied in regard to the title of receivers and assignees for the benefit of creditors. If such title has once been fully perfected under the proper law as against the world, a subsequent removal of the chattels to a State by whose law the title of the receiver or assignee would not be good against creditors, will not divest the title once vested.4

In Pond $v$. Cooke, ${ }^{5}$ a manufacturing corporation in New Jersey had contracted to build a bridge in Connecticut. The corporation became insolvent and a receiver was appointed by a New Jersey court, who purchased iron with the funds in his hands and sent it on from New Jersey to Connecticut to com. plete the bridge. Connecticut creditors of the corporation attached the iron after it reached that State. But the Con. necticut court dismissed the attachment on the ground that the receiver's title to the iron was complete as against all persons in New Jersey, where he was appointed and first held possession of the iron, and that the title once thus fully vested in him should not be divested by merely sending the goods to another State.

But it must be remembered that this principle is applicable only in those cases where the transaction is perfected and com.

4 Pond v. Cooke, 45 Conn. 126, 29 Am. Rep. 668 ; Chicago, etc. R. R. Co. v. Packet Co., 108 Ill. 317, 48 Am. Rep. 557 ; Cagill $v$. Wooldridge, 8 Baxt. (Tenn.) 580, 35 Am. Rep. 716 ; Crapo v. Kelly, 16 Wall. 610, 622; Cook $v$. Van Horn, 87 Wis. 291, 50 N. W. 893 ; May v. Wannemacher, 111 Mass. 202, 209; Bank $v$. Hill, 99 Tenn. 42, 41 S. W. 349. But see Walworth $v$. Harris, 129 U. S. 355 ; Donald $v$. Hewitt, 33 Ala. 534, 73 Am. Dec. 431 . In both these cases the lien was imposed by law, not by agreement.

545 Conn. 126, 29 Am. Rep. 668. 
pleted before the property becomes subject to the new jurisdiction. This will not be the case if the property, at the time of the transfer, is situated in the latter jurisdiction. Here third persons, resident in the State where the chattels are situated (and in some cases though not residing there), may justly claim that as to them the title has not completely passed out of the original owner until the law of the actual situs of the chattels has also been complied with. ${ }^{6}$

Another prominent example of this principle may be seen in the rules for the determination of the law governing a person's status. Once permanently fixed by the proper law, ${ }^{7}$ it is not in general altered by any subsequent change of situs on the part of the individual. Thus, if one be born a bastard, and is subsequently legitimated under the proper law by the intermarriage of his parents, his status as a legitimated child becomes permanent, and will not be altered by the assumption of a new situs, though by the law of the latter a subsequent intermarriage of the parents does not legitimate. ${ }^{8}$

So also, if a marriage is valid by the proper law, it will not in general be rendered invalid by a subsequent removai to a State by whose laws such marriages are invalid. Thus in State v. Ross, ${ }^{9}$ a white woman, domiciled in North Carolina, went into South Carolina to marry a negro resident there. They were married there and lived there for several years, when they removed to North Carolina. Upon a prosecution in North Carolina for lewdness, under a statute of that State absolutely prohibiting the marriage of a white person and a negro, it was

- These are the exceptional cases already alluded to, in which the lex fori will prevail over the proper law. The cases illustrating this principle are very numerous, and are collected hereafter. See post, $\$ \S 129,134,135$. Reference is here made to a few only. Green $v$. Van Buskirk, 5 Wall. 307; Guillander v. Howell, 35 N. Y. 657 ; Faulkner v. Hyman, 142 Mass. 53; Catlin v. Plate Co., 123 Ind. 477, 8 L. R. A. 62 ; Sheldon v. Wheeler, 32 Yed. 773 ; Sturtevant $v$. Armsby Co., 66 N. H. 557, 23 Atl. 368.

7 What is the proper law to govern the status will be seen, post, $\S 68$ et seq.

8 Post, $\$ \S 99$ et seq. ; Miller v. Miller, 91 N. Y. 315 ; Ross v. Ross, 128 Mass. 243, 247, 256, 37 Am. Rep. 321.

- 76 N. C. 242, 22 Am. Rep. 678. 
held that since both the parties were domiciled, at the time of the marriage, in South Carolina, where such marriages were not illegal, the subsequent removal of the parties to North Carolina, the former home of one of them, should not affect it. The prosecution therefore failed.

So it is also with divorced persons. If validly divorced in the State of their domicil, their status as single persons will thereafter be recognized, whithersoever they may remove. ${ }^{10}$

This principle explains in some measure the reluctance shown by the courts to substitute the lex fori for the proper law in cases where they are called upon to enforce executory contracts made abroad. The violation of the policy of the forum entailed by an enforcement of the proper law must be very pronounced to induce them to decline its enforcement. Thus executory contracts relating to lotteries, ${ }^{11}$ for the purchase price of slaves, ${ }^{12}$ for the sale of intoxicating liquor, ${ }^{18}$ contracts forbidden by the usury laws of the forum, ${ }^{14}$ and many other contracts of a similar kind, have been enforced in States whose policies strictly prohibit such dealings, because valid by the proper law. Though not expressly stated by the authorities, it is believed that this reluctance to substitute the lex fori for the proper law in these cases is due to the principle that the rights of the parties, once perfected and definitely fixed by the proper law controlling their voluntary agreement, will not be set aside without the gravest consideration and weighty reasons, even though the

10 See post, $\$ \S 89$ et seq. Other examples of the same principle, as applicable to status, may be seen by reference ito the following cases: Taylor $v$. Sharp, 108 N. C. 377,13 S. E. 138 ; Cummington v. Belchertown, 149 Mass. 223, 227, 21 N. E. 435 ; Schluter v. Bank, 117 N. Y. 125, 130, 22 N. E. 572. This principle does not fully apply to status more or less of an unpermanent character, such as the status of guardians, administrators, etc. See post, $\$ \$ 102$ et seq., 114 et seq.

11 Kentucky v. Bassford, 6 Hill (N. Y.), 526; McIntyre v. Parks, 3 Met. (Mass.) 207 ; post, § 178.

12 Greenwood $v$. Curtis, 6 Mass. 358, 4 Am. Dec. 145 ; Roundtree $v$. Baker, 52 Ill. 24I, 4 Am. Rep. 597 ; Osborn $v$. Nicholson, 13 Wall. 654.

13 Tegler v.Snipman, 33 Ia. 194, 11 Am. Rep. 118 ; Hill v. Spear, 50 N. H. 253, 9 Am. Rep. 205 ; post, §§ 177, 178.

14 Post, § 179 
general policy of the forum be violated by its enforcement. Even in the case of executory contracts, however, there are some instances in which the lex fori may be substituted.15

$\S 16$. Value of Precedents in Private International Law. The exceptions and the related principles discussed in the preceding sections exert a very marked influence upon the weight ordinarily to be attached to precedents and decided cases. This effect should be constantly borne in mind in the investigation of the authorities upon a point involving the conflict of laws. If unnoticed, it may result that decisions will be cited to sustain propositions which in reality they do not sustain.

In the exceptional cases, the court, as has been observed, generally substitutes the law of its own State (lex fori) for the proper law. If the court says as much in plain terms, naming the exception to which it belongs, and giving its reasous for believing it to be one of the exceptional cases, no confusion of the lex fori with the proper law is apt to arise. But frequently the courts fail to make the distinction, merely holding that the case is governed by the law of their own State, without even specifically designating it the lex fori; sometimes treating it as the enforcement of the proper law, instead of a law substituted for the proper law; sometimes confusing terms, as in cases of foreign transactions relating to personalty situated in the forum, where they designate the substituted law as the lex situs rather than the lex fori, in which aspect it should be considered, as we have seen. ${ }^{1}$ The consequence of all this confusion is of course that false impressions are created as to the law really looked to by the court as ruling the particular case, and still more with respect to the proper law which should rule similar instances where the circumstances creating the exceptional cases are not present. This has been a most fruitful source of confusion and error. Some hints therefore, drawn from experience, touching the points to be looked to in attaching the proper weight to authorities in these investigations will not be amiss.

1. In distinguishing the various conflicting cases, care must

15 Ante, § 9. See Oscanyon v. Arms Co., 103 U. S. 261. See also post, $\$ 152$.

1 Ante, §14. 
be taken in the first place to observe in what State the suit is brought, for the determination of the governing law in a given case will often depend upon which State is the forum. ${ }^{2}$

2. This point must be observed as well with respect to federal courts sitting in a State to enforce its laws, as with regard to the State courts. ${ }^{8}$

3. After ascertaining and carefully noting which State is the forum, observation should next be directed to the facts of the case. If such as to constitute one of the exceptions, the decision will in general be of little direct authority with respect to the "proper law" governing such transactions. It is only a direct authority for the application of the lex fori in the case of the particular exception disclosed by the facts of that particular case. The rest is dictum, more or less valuable.

4. If the facts in the case under investigation do not disclose an instance of the operation of any of these exceptions, the decision is a direct authority, more or less valuable, touching the "proper law."

5. If there be disclosed ground for the operation of one of the exceptions, but the court enforces a foreign law (not the lex fori), the decision is direct authority of a very strong kind to show that the foreign law thus enforced is the "proper law."

6. The weight to be attached to a particular decision will depend, as in other cases, upon the character of the court, the care bestowed upon the opinion, whether it is decision or merely dictum, its date, the particular facts or statutes in the case, etc.

7. In examining the facts of the case, care must always be taken to note the nature of the transaction in detail, to observe what are the various foreign elements that enter into the case, which of these are given weight in the decision and which are

2 See Armstrong $v$. Best, 112 N. C. 59,17 S. E. 14 ; Robinson $v$. Queen, 87 Tenn. 445, 3 L. R. A. 214. This principle should also be borne in mind in deciding in what State a suit of this nature should be instituted.

3 Hence federal decisions are as much authorities on questions of the con. flict of laws as are the State courts. For example, see Swann $v$. Swann, 21 Fed. 299 ; $\Delta$ therton Co. $v$. Ives, 20 Fed. 894 ; Barnett $v$. Kinney, 147 U. S. 476; Cole $v$. Cunningham, 133 U. S. 107, 129 ; Bowles $v$. Field, 78 Fed. 742, 743 ; Smith $v$. Union Bank, 5 Pet. 518; Green v. Van Buskirk, 5 Wall. 307. 312. 
discarded. Many different combinations of these elements may arise, and each combination may cause a change in the result. It is of the utmost importance therefore to note what combination of foreign elements exists in a particular case, and whether the court had before it the whole combination, in making its decision, or only one or more of the foreign elements. The value of the decision will in large measure depend upon this. Abundant illustrations of these principles will be seen hereafter. 


\section{PART II.}

SITUS OF THE PERSON.

\section{CHAPTER III.}

\section{ACTUAL SITUS OF THE PERSON.}

\section{17. Importance of Situs in Private International Law. -} The foundation principle of the Conflict of Laws is SrTus. Every element in every transaction known to the law has a situs somewhere, and the law of that situs will regulate and control the legal effect of that element. Not only is this true of active steps taken towards the completion of a given transaction, but it is equally true of those elements, not consisting of acts of parties, but merely acts of the law, or of passive characteristics, legal qualities, or disqualifications inherent in the parties, independently of their own will or in spite of it. For example, in the case of an executory contract, not only may each active step in the transaction - the making of the contract, the act to be done in consideration thereof, and the performance of it - have a separate situs of its own, but the capacity or disqualification of the parties to enter into the agreement - a mere passive quality - must also have its situs, which may perhaps be separate from all the rest. These passive qualities of legal capacity or incapacity inhere, not in the transaction (in general), but in the person of the party, and in the main have the same situs as the person whose capacity is in question. ${ }^{1}$

Thus, it is not difficult to conceive of a contract made by $A$, of New York, with B, of Massachusetts, entered into in New Jersey, to be performed in Maryland, in consideration of an act to be performed by $B$ in Pennsylvania. We may even go fur.

1 Post, $\$ \S 69$ et seq. 
ther and suppose the consideration for A's promise to be an executory contract made by $B$ to be performed in Virginia.

In this hypothetical case it will be observed that many different States, possessing various systems of law, are represented, and each may be the situs of some material step (active or passive) connected with the transaction. A's capacity to contract has its situs; B's capacity to contract has its situs; there is a situs for the entry into the contract; another for the consideration of the contract; another for the performance of the contract. And if the consideration be itself executory (as where $B$ makes a promise), there may be a separate situs for the formation and for the performance of that contract.

Each one of these elements may have a separate situs and be governed by a different law. Each such element must be upheld by its proper law, the law of its situs, in order that the transaction as a whole may be upheld. ${ }^{2}$ It is not proposed to consider at this point what is the situs of each of these elements. A complete answer to that question in such a case as the above, and in other cases of which this is but a sample, would constitute a treatise on the Conflict of Laws, and is the purpose of this work. It is intended here merely to point out that the situs of each step in a given transaction is to be carefully noted, and its effect is in general to be tested by the law of that situs. The complete transaction being made up of all these various elements, its ultimate validity will in general depend upon the validity of each of its constituent parts (tested by its proper law). If, when so tested, each element is valid, then the transaction as a whole will be valid; but if one or more of the essential steps be invalid, when measured by its proper law, neither can the transaction as a whole be in general sustained.

Hence, in order to arrive at a correct solution of the law which is to govern a particular transaction, that transaction must be resolved into all its essential parts, and to each of these parts the law of its own situs must be applied.

These elements of a given transaction may be active, dependent upon the will of the party himself. In such cases he may

2 Subject always to the exceptions given in Chapter II. 
perform the particular act or not as he pleases, and if he chooses to do the act, he may and does select the place where it is done. But having once done the particular act at the place selected, the effect of that act must in general be determined by the law of the place where it is done. This is expressed by the maxim "locus regit actum." The party should not be permitted to select one place for the doing of the act in question and then select the law of a different place to govern that act, for that would be to subordinate the sovereignty of the first State to the will of the individual. He cannot thus give the act, by the mere exercise of his will, a constructive situs which it does not actually possess.

Other elements in a transaction may be passive, arising by act of the law. The capacity of a party to do an act or receive a benefit, taxation of property, the succession to a decedent's property, adjudications of insolvency or bankruptcy, marital rights, etc., are instances where elements of this kind occur. Such elements also must possess a situs somewhere. But when the law acts, it must either act upon the person or upon property. If upon the person, the act of the law will generally have the same situs as the person; for if the person be not actually or constructively within its jurisdiction, the act of the law is nugatory. When acting upon the person, the law creates a status. Hose law will govern it, is the situs of the person.

If the law acts upon property, the situs of the act of the law follaws thesitus property, in ather words, the property mate it in cantemplation of law, within the jurisdiction purporting to act upon it. But there may be a legal, as well as an actual, situs of property, at least in case of personal property, the actual situs not being in general considered save in the exceptional cases mentioned in the previous chapter. ${ }^{8}$ It is the legal situs that is usually looked to, and that follows the situs of the owner, upon the maxim "mobilia personam sequuntur." "

These are the basic principles upon which private international law, as a science, is founded. But in their application

8 Ante, $\S 6,7,14$. 
many difficulties and much confusion among the authorities will be encountered, not only in determining what are the essential elements of a given transaction, but in deciding what is their proper situs when ascertained.

Since the situs of status and of personal property generally follows the situs of the party to whom they pertain, in order to determine the law which governs questions relating to these matters we must consider what is the situs of the person.

In regard to contracts, we must look to the same law with respect to questions of capacity (capacity being a status ${ }^{6}$ ), but with regard to those elements which consist of active steps taken by the parties and dependent upon their own will, such as the entering into the contract, the performance of it, or the performance of the act which constitutes the consideration therefor, we must determine what is the situs of each particular act forming a constituent part of the transaction.

So likewise, in regard to torts and crimes, we must determine the situs of the tort or of the crime, in order to ascertain the law properly applicable. ${ }^{6}$ And so it is also with respect to remedies. ${ }^{7}$

\$18. Actual Situs of the Person. - It seems a paradox to say that a person may occupy two places in space at the same time. Yet under the rules of private international law such is the case. But it is not the paradox it seems, for the law only admits one to occupy two places at the same time for different purposes, - never for the same purpose. The latter principle prevents the confusion of applicatory laws that would otherwise result from the former.

The lawassigns to every man immediately upon his birth and throughout his life a situs in the State where he has his domicil, whose laws are those to which primarily he owes allegiance.

4 Ante, $\$ 14$; post, $\S \S 120$ et seq. We will see in the following sections that the situs of the owner may itself be either actual or legal. In regard to immovable property, the actual and legal situs will usually correspond. See ante, $\$ 11$.

6 Post, $\$ 72$.

- Post, $\S 195$ et seq., 204. But in the case of crimes, the exception relating to penal laws applies in full force. Post, $\$ 203$.

I Post, $\S 205$ et seq. 
In order that he should possess this domicil, it is nat nesessary that he should actually be present there at all times. He-may actually be at a given moment in one State, while his domicil is in another. The domicil, then, is the legal situs of the individual, and may or may not be coincident with his actual situs at a given moment. The actual situs of the person at a given moment is the State where, at that moment, he is actually physically present. The legal situs of the person is the State of his domicil, the State of his permanent residence, whether he is actually present there or not.

We have seen that there are certain cases (transactions touching status and personal property) wherein the law of the situs of the person will control. Under some circumstances, it will be the law of the actual situs of the person. Under others, it will be the law of his legal situs or domicil. These two may coincide in a given case, or they may be distinct. In the latter case, the law of one or the other situs may govern a particular element or matter, but never the law of both. In ascertaining which situs should furnish the law to govern a particular matter properly determinable by the law of the situs of the person, the same distinction must be made as was noted in the preceding section between active or voluntary elements, and passive or invotuntary elements, or such as are created by the law itself, without the exercise of the party's will. It will be remembered, as we saw in the last section, that a person's status is the creation of the law, and not dependent upon his will. On the other hand, the disposition or transfer of his personal property may result merely from the exercise of the owner's will, as in case of a conveyance, or it may result merely from the act of the law, as in the case of the succession to an intestate's personal estate.

If a person domiciled in one State enters actively into a particular transaction in another State, he has deliberately chosen for the purposes of that transaction to submit himself and it to the operation of the latter law. In selecting a place for the performance of the act in question, he selects its law as the governing law; to hold otherwise would be to deny to that State sovereignty and control over acts taking place there. Justice to the partw himself, to the other parties to the transaction, and to 
the State where it is entered into, requires the enforcement of its law with respect thereto, rather than the law of the legal situs or domicil, which has no force ex proprio vigore outside its own limits, and which the party limself has temporarily renounced, so far as that transaction is concerned.

This is the natural and proper view for the courts of the State where the transaction occurs or of a third State to take; but it does not necessarily follow that the same view will be taken by the courts of the party's domicil, if in entering into such foreign transaction the party has violated its law or policy. ${ }^{1}$

But if the matter in question (determinable by the lex situs of the person) arises, without the active intervention of the party, merely as a creation of the law, while he is thus temporarily in a State other than the State of his domicil, the same reasoning is not applicable. The laws of each State are enacted primarily for the benefit of its own citizens; and to impose those laws, except where the welfare of the State demands it, as in case of police and criminal laws, upon the citizens of other States temporarily there, in regard to matters in which they have not voluntarily submitted themselves to those laws, would be unjust to them and to the State where they reside, whose sovereignty over its own inhabitants would thus be denied.

If, for example, we take the case of 2 transfer of personal property, which is in general gerned by the law of the situs of the owner, and suppose that the trausfer occurs while the owner is in a State other than his domicil, the transfer will be governed by the law of the actual situs of the owner (the lex loci contractus) or by the law of his legal situs (lex domicilii), according as the transfer is by voluntary agreement on the part of the owner, or arises by operation of law, as in the case of the succession of a distributee to the personal estate of the deceased intestate owner. ${ }^{2}$

Matters of status are always the creatures of the law, being fixed by law, independently of the will of the individual. Hence we should expect to find such matters always regulated by the law of the person's legal situs or domicil, save in the exceptional

1 Post, $\S 72,73$.

2 Post, $\$ \S 128$ et seq., 136 et seq., 139 et seq. 
cases of the preceding chapter. And such is the general rule. But even in respect to status (the status of capacity) the same principle has been applied, and a distinction is made between the law governing a person's capacity to do a voluntary act, such as to enter into a contract, and his capacity in respect to involuntary acts or matters arising by operation of law, such as capacity to hold property under a conveyance or will."

In conclusion, it may be said that there is usually no difficulty in ascertaining the actual situs of a person at a particular time. It is a mere question of fact. But often the ascertainment of the domicil or legal situs of the person is not so easy. It is a mixed question of law and fact. The legal rules by which the domicil is determined will be dealt with at length in the succeeding chapter.

8 Post, $\$ \$ 68$ et seq.

1 Post, $\S$ 70, 144 ; Ross v. Ross, 129 Mass. 243, 246, 37 Am. Rep. 321. 


\section{CHAPTER IV.}

\section{LEGAL SITUS OF THE PERSON, OR THE DOMICIL.}

§19. Domicil, National, Quasi-National, or Municipal. Mr. Jacobs, in his work on the Law of Domicil,' has appropriately divided Domicil into three classes - (1) The national domicil, representing the absolutely sovereign State in which one may be domiciled; (2) the quasi-national domicil, representing residence in a State which is not wholly, but only partially sovereign, such as one of these United States; and (3) the municipal domicil, representing only the intra-State political division, such as a county or city within a State, which is not sovereign at all.

The last class has no place in private international law, but is entirely the subject of the municipal law of the State where the particular county or city is located. And the distinctions to be drawn between the first two are comparatively slight and unimportant. Whether the particular States in question are wholly or only partially sovereign, if they are supreme with respect to the point at issue, that is all that private international law requires. If the law of the domicil of a party is to control, it is usually of small importance whether this be a national or a quasi-national domicil. Occasionally however distinctions must be taken between them.

It follows from what has been said that cases deciding ques. tions relating to municipal domicil should be accepted with caution as authority in regard to matters of national or quasi. national domicil. The former is the subject of municipal law only, the latter of private international law. To argue from the principles of municipal law to those of private interna

1 Jac. Dom. § 77. 
tional law is always apt to be misleading. The failure to remember this fact has sometimes led to serious error. ${ }^{2}$

§ 20. Domicil distinguished from Mere Residence.-Domicil, as we have seen, in the last chapter, is to be distinguished from the actual situs of a person, a mere temporary locality of existence in a particular State at a particular time.

It must now be observed that domicil is also to be distinguished from a mere residence, of a temporary character, not intended to be permanent. Residence in a State is usually said to be necessary to domicil, but it must be a residence of a permanent, not of a temporary or limited, character. When the term "resident" or "residence" is used in connection with private international law, it is generally used in the sense of domicil, though not always. ${ }^{1}$

The Virginia case of Long $v$. Ryan ${ }^{2}$ is a good illustration of the distinction between mere residence and domicil. In that case, a person domiciled in Washington came to Virginia intend. ing to remain there about nine months, until he should complete a contract into which he had entered, proposing afterwards to leave Virginia. His property was attached in Virginia under a statute permitting attachments against "non-residents," but the court, notwithstanding his domicil in Washington, held him to be a resident of Virginia, and dismissed the attachment.

So also a foreign minister actually resides or is personally present at the court to which he is accredited, but his legal residence and domicil are in his own country. Indeed, by the fiction of exterritoriality, the place of his residence is a part of his own country. It is atherwise with consuls.

2 For example, with respect to the right of a guardian to alter the ward's domicil. See post, § 41 .

I In re Wrigley, 8 Wend. (N. Y.) 134 ; Frost $v$. Brisbin, 19 Wend. 11, 32 Am. Dec. 423 ; Langdon v. Doud, 6 Allen (Mass.), 423, 83 Am. Dec. 641 ; Allgood v. Williams, 92 Ala. 551, 8 So. 722 ; Chitty v. Chitty, 118 N. C. 647, 32 L. R. A. 394 ; Wood v. Roeder, 45 Neb. 311,63 N. W. 853 ; Ayer $v$. Weeks, 65 N. H. 248, 18 Atl. 1108; Long v. Ryan, 30 Gratt. (Va.) 718; Tipton v. Tipton, 87 Ky. 243, 8 S. W. 440. See Story, Confl. L. § 49 note $(c)$.

30 Gratt. 718.

\$ Whart. Confl. L. $\$ 49$; Crawford v. Wilson. 4 Barb. (N. Y.) 505. 
So it is with students. Though resident at a college or university for the period necessary to complete their course, they are not domiciled there unless they have the intention to remain there permanently. But the question of domicil is distinct from the right of suffrage. The latter is a matter of municipal law, and is subject to the rules prescribed by each State within its own borders. If those laws do not require a domicil as a condition of suffrage, but only a mere residence, a student may be permitted to vote, though he be not domiciled in the State. Such is the general rule in the United States."

\$21. Domicil distinguished from Nationality or Citizenship. - The distinction between domicil and nationality or citizenship is just as marked as that which exists between domicil and residence. A person may be a subject or citizen of one country, while domiciled in another. ${ }^{1}$ Thus, a citizen of France may actually be in New York. If merely passing through the has only his actual situs in New York. If he resides there, with the intention to remain for a limited period, he is a resident of New York, and if, coupled with the residence, there is the intention to remain there permamently or for an unlimited period, he is domiciled in New York, yet he may all the time remain a citizen of France.

But it must be observed that, so far as citizens of the United States are concerned, the rule is otherwise as between the States of this Union. The fourteenth amendment to the federal constitution expressly providos that "all persons born or naturalized in the United States, and subject to the jurisdiction thereof, are citizens of the United States, and of the State wherein they reside" (that is, are domiciled). 'This provision establishes for the States of the Uniou the rule that a citizen of one State,

4 Whart. Confl. L. $\$ 48$; Opinion of the Judges, 5 Met. (Mass.) 587 ; Fry's Case, 71 Penn. St. 302; Hart v. Lindsey, 17 N. H. 235, 43 Am. Dec. 602 ; Kelley v. Garrett, 67 Ala. 304 ; Sanders $v$. Getchell, $76 \mathrm{Me} .158$; Vanderpoel v. O'Hanlon, 53 Ia. 246, 36 Am. Rep. 216 ; Dale v. Irwin, 78 Ill. 170.

1 Harral v. Harral, 39 N. J. Eq. 379, 51 Am. Rep. 17, 21 ; Haymond v. Haymond, 74 Tex. 414, 12 S. W. 90, 92 ; Larquie $v$. Larqnie, 40 La. Ann. 457, 4 So. 335, 336; Roth $\varepsilon$. Roth, 104 Ill. 35, 44 Am. Rep. 81, 82 ; Powers v. Lynch, 3 Mass. 77. 
who abandons that State and goes to another to reside permanently, thereby ipso facto loses citizenship in the former State and acquires it in the latter, regardless of his own intention or wishes. ${ }^{2}$

\$22. The Legal Situs or Domicil of the Person. - In law, persons are either natural persons, individuals; or artificial persons, corporations. Private international law regards for the most part the domicil of natural persons. The very nature of what is usually termed the "domicil" of corporations differs essentially from that of individuals, and is subject to very different rules. It is manifestly impossible for a mere corporation to possess a permanent home or residence in the same sense as an individual, nor is there usually the same occasion to fix a domicil for it. Many of the transactions, which in the case of an individual must be regulated by the law of his domicil, do not arise at all in the case of corporations, such as most questions of status, the making of wills, the intestate succession to estates, marriage, divorce, etc. But there are some transactions to which a corporation may be a party, just as an individual may be, such as taxation, the conveyance of property, or the making of contracts. In these cases, it sometimes becomes necessary to invoke the aid of some foreign law, corresponding to what would be the law of the domicil, if the party were an individual instead of a corporation. For such purposes (comparatively infrequent), a corporation must be assigned a situs, which is sometimes spoken of as a domicil. ${ }^{1}$

2 Dougherty v. Snyder, 15 S. \& R. (Penn.) 84, 16 Am. Dec. 520 ; Firth v. Firth, 50 N. J. Eq. 137, 24 Atl. 916, 917. Owing to this principle, the American courts are more prone than others to use the terms "residence" and "citizenship," as synonymous with domicil. But even in the United States, this only applies to citizens of the United States, not to citizens or subjects of foreign countries. In general, private international law does not concern itself with mere residence or with citizenship. See post, § 66 .

1 A section will hereafter be devoted to the situs of corporations. Post, $\S 67$. With respect to associations of persons, not incorporated, such as partnerships, it may be observed that, since their existence as a legal entity is not recognized by the law, neither will the law assign them a distinct situs of their own. See Faulkner v. Hyman, 142 Mass. 53, 55. Such associations are sometimes spoken of as "domiciled" or " resident" in a particular place, but what is meant is merely that all the partners or members reside there and 
The domicil of natural persons may be divided for the purposes of the subsequent discussion into the following heads (1) Definition of domicil; (2) Certain general principles touching domicil; and (3) The several kinds of domicil, and the principles governing each. These will be taken up in order.

$\S 23$. Definition of Domicil of Natural Persons. - The domicil of a natural person, as used in private international law, may be defined as the State or country where a party actually or constructively has his permanent home.

The conduct of a man's business, the presence of his family, his roting, the payment of his taxes, etc., are not essential elements of a domicil, but are merely evidences, more or less weighty, of an intention to make the place where these things exist or are done his permanent home. Such circumstances therefore should find no place in the definition. ${ }^{2}$

The definition of domicil above given is very broad, as it must be to cover all the points that may arise. Indeed, owing to the number of points to be covered, there are few terms more difficult to define. As was said in Abington $v$. N. Bridgewater, ${ }^{3}$ "The fact of domicil is often one of the highest importance to a person; it determines his civil and political rights; it fixes his allegiance; it determines his belligerent or neutral character in time of war; it regulates his personal and social relations whilst

that there the firm transacts its business. It is the domicil of the members that is looked to, when that is important, not that of the firm. For instances of the loose employment of these terms, as applied to unincorporated associations, see Williams v. Dry Goods Co., 4 Okl. 145, 43 Pac. 1148; Halsted v. Straus, 32 Fed. 279, 280 ; Long $v$. Girdwood, 150 Penn. St. 413, 24 Atl. 711, 23 L. R. A. 33.

1 Dicey, Confl. L. 79 ; Story, Confl. I. § 41 ; Jopp v. Wood, 4 DeG., J. \& S. 616, 622 ; Mitchell $v$. United States, 21 Wall. 350 ; Desmare $v$. United States, 93 U. S. 605 ; Guier v. O'Daniel, 1 Binn. (Penn.) 349, note; Price $v$. Price, 156 Penn. St. 617, 27 Atl. 291; Gilman v. Gilman, 52 Me. 173, 83 Am. Dec. 502 ; Hairston v. Hairston, 27 Miss. 704, 61 Am. Dec. 530, 532 ; White v. Tennant, 31 W. Va. 790,8 S. E. 596 ; Hart $v$. Lindsey, 17 N. H. $235,43 \mathrm{Am}$. Dec. 597, 601 ; Steer's Succession, 47 La. Ann. 1551, 18 So. 503.

2 Pearce $v$. State, 1 Sneed (Tenn.), 63, 60 Am. Dec. 135; Guier v. O'Daniel, 1 Binn. (Penn.) 349, note ; Steer's Succession, 47 La. Ann. 1551, 18 So. 503, 506 ; Shelton $v$. Tiffin, 6 How. 163.

823 Pick. (Mass.) $170,176$. 
he lives, and furnishes the rule for the disposal of his property when he dies. Yet as a question of fact, it is often one of great difficulty, depending sometimes on minute shades of distinction which can hardly be defined."

To every definition proposed some objection may be offerec'. Thus Story defines domicil to be "the place where a person has his true, fixed, and permanent home and principal establishment, and to which, whenever he is absent, he has the intention of returning." A Among the objections to this definition perhaps the most serious one is that it has no application to the constructive domicil of an infant, married woman, or other person incapable in law of exercising a choice with respect to his or her place of abode. The same fault is to be found with most of the definitions that have been proposed.

$\S 24$. Area of Domicil. - Since the domicil, for the purposes of private international law, is the State or country where a party has his permanent home, it is manifest that the term need. not be confined to the particular tract of land, town, county, or district, immediately occupied by him, ${ }^{1}$ but it also extends to the whole country or State in which he resides, that is, the whole territory over which the sovereignty of the State extends, and controlled therefore by the same system of laws. But it is worthy of notice that the term includes the town, county, or district of residence, as well as the State itself, and that one domiciled in such town, county, or district must also be domiciled in the State of which it forms a part, for the greater includes the less.

Eminent authorities have declared it not essential that one domiciled in a particular State or country should also have a fixed residence in any particular spot in that country. ${ }^{2}$ Thus, let us suppose a Frenchman comes to England, intending to remain permanently, spending his life traveling from one point to another in England, but residing permanently at no particular spot. According to these authorities, England becomes

4 Story, Confl. L. $\$ 41$.

1 This corresponds to the municipal domicil, but the national or quasinational domicil is more comprehensive.

2 Dicey, Confl. L. 91-93; Jac. Dom. § 77. 
his permanent home and national domicil, but 'ie is domiciled in no particular town or county in England, he has no municipal domicil there.

Under this view, the Frenchman's municipal dornicil, if he has any at all, remains in France. But having cease 3 altogether to reside in France, and becoming domiciled in England, he cannot be said to resude in any town or county or province of France. We are then driven to the conclusion that he must be held to have su municipal domicil anywhere. This conclusion is in direct contravention of the great weight of authority in the United States and elsewhere, to the effect that a resident of a State must always be held to posseas a municipal domicil somewhere in that State."

In this country the question is still an operi one. In an Illinois case, ${ }^{4}$ a woman domiciled in Missouri abandoined that State, with her husband, intending to remove to Illinois and to reside either at Bloomington or Salem. She went to Illinois with her husband, but before they had decided in which town they should settle she died intestate. The laws of Missouri governing the succession to personalty differed from those of Illinois, and the question thereupon arose-whether she was domiciled at her death in Illinois or Missouri, the lex domicilii determining the order of succession. The court held ber domicil to be Missouri, but based its decision upon the ground that, not. having definitely fixed upon either town as a place of residence, there was no sufficient evidence of the parties intention to reside permanently in fllinois at all. The main point was left. undecided.

§ 25. Domicil, the Actual Permanent Home. - Domicil usually conveys the idea of "home" in case of persons sui juris

3 Abington $v$. N. Bridgewater, 23 Pick. (Mass.) 170 ; Whitney $v$. Sherborn, 12 Allen (Mass.), 111; Otis v. Boston, 12 Cush. (Mass.) 44; Crawford $v$. Wilson, 4 Barb. (N. Y.) 505 ; Ayer $v$. Weeks, 65 N. H. 248, 18 Atl. 1108 ; Shepherd v. Cassiday, 20 Tex. 24, 70 Am. Dec. 372 ; School Directors $v$. James, 2 W. \& S. (Penn.) 568, 570, 87 Am. Dec. 525 ; Mills $v$. Hopkinsville (Ky.), $11 \mathrm{~S} . \mathrm{W} .776$.

4 Cooper $v$. Beers, 143 Ill. 25, 33 N. E. 61. See Lowry v. Bradley, 1 Speer's Eq. (S. C.) 1, 39 Am. Dec. 1.42, 145, where the court seems to lean the other way. 
and capable of possessing an actual home of their own, but a home need not necessarily be a domicil." "Home" means an actual abode, coupled with the intention of remaining there, but it is not needful that there should be a purpose to remain permanently or for an unlimited time. ${ }^{2}$ But when is added to home the notion of permanency and stability, when te becomes a permanent home, there being no present fixed expectation of changing it at any future time, near or remote, the home then becomes a domicil.

- Indeed it is too well settled for dispute that a person sui juris, who actually resides and has his home in a given State, is domiciled there, provided he has legally formed an intention to remain there permanently, or for an unlimited or indefinite period; ${ }^{8}$ or, to put it somewhat differently, provided he has no present fixed intention of removing therefrom in the future."

$\S 26$. Domicil, the Constructive Permanent Home. - There are some cases in which the law will assume that a person has his home in a particular country, though the fact may be far otherwise, and even though the party may never have set foot upon its shores. In these instances a permanent home is implied by construction of law.

These cases arise for the most part (though not always) where the person whose domicil is to be determined is non sui juris, and is therefore deemed legally incapable of forming an intention of permanent residence, or else where from the circumstances of the case the law must presume a purpose to reside in a given country. One may thus be assigned a domicil in a State where he does not actually live.

1 Otis v. Boston, 12 Cush. (Mass.) 44 ; Steer's Succession, 47 La. Ann. 1551, 18 So. 503.

2 Dicey, Confl. L. 80 et seq.

${ }^{3}$ Guier v. O'Daniel, 1 Binn. (Penn.) 349, note ; Dupuy $v$. Wurtz, 53 N. Y. 556 ; Hairston $v$. Hairston, 27 Miss. 704, 61 Am. Dec. 530 ; Gilman v. Gilman, 52 Me. 173, 83 Am. Dec. 502 ; Allgood v. Williams, 92 Ala. 551, 8 So. 722 ; White $v$. Tennant, 31 W. Va. 790, 8 S. E. 596.

4 Putnam v. Johnson, 10 Mass. 488 ; Hallett $v$. Bassett, 100 Mass. 167 ; Price v. Price, 156 Penn. St. 617, 27 Atl. 291 ; Whitney v. Sherborn, 12 Allen (Mass.), 111 ; Gilman v. Gilman, 52 Me. 165, 83 Am. Dec. 502. The first mode of expression is the more accurate. 
In assigning a constructive domicil, the law will weigh the circumstances of the case, the probabilities as to the party's regarding one or another place as his home, should he exercise a choice, and the duty he may be under to abide at a particular spot. From these data the law raises certain presumptions more or less strong. It should be noticed that it is the law that raises these presumptions, not the courts. Hence they are not so liable to change, with the slightly varying circumstances of each particular case, and are susceptible of being reduced to more or less stable rules. The courts have no other power than to decide the questions thus raised in accordance with the rules and presumptions fixed by the law.

Thus, an infant is assigned the domicil of its parent, though it be born elsewhere and has never been within their domicil. ${ }^{1}$ Here the law conclusively presumes that the home of the child will be with its parents, without regard to the facts of a particular case, and hence wherever their permanent home is his will be also.

So, where a woman marries, the law regards her as identified with her husband, and recognizes a duty resting upon her to live with him. Hence the law presumes her proper home to be with him, and his domicil becomes hers upon the marriage. And thereafter throughout their married life her domicil changes with his, as a general rule, regardless of the actual facts in the case. ${ }^{2}$

The instances mentioned have been cases of persons non sui juris, but the principle of constructive domicil is not confined to them. Thus, if a full grown man should abandon his native country, intending never to return, his domicil is not thereby lost or changed. It is a well settled principle of law that a domicil is retained until a new one is acquired, for no person can ever be without a domicil. ${ }^{3}$ A new domicil, in the case of a person suijuris, can only be acquired by actual residence in the new country, coupled with the intention to remain there permanently. 4 Hence, until he actually takes up his abode else-

1 Post, $\$ \$ 32,36$ et seq.

8 Post, $\$ 29$.
2 Post, $\$ \S 46$ et seq.

1 Post, $\$ \$ 56$ et seq. 
where animo manendi, he retains his former domicil. By construction of law he is presumed still to have his home in his original domicil, though he has turned his back upon his country for ever. ${ }^{5}$

§ 27. Certain General Principles touching Domicil. - I. No Person without a Domicil. - There are four general principles relating to domicil which must be borne in mind throughout every discussion of this subject. With their aid, many problems otherwise difficult may be easily solved.

The first of these may be thus stated: No natural person can ever be without a domicil. ${ }^{1}$

For the purpose of determining rights and liabilities, the courts of all civilized nations have formulated the rule that a person must always be held to have a domicil somewhere. $\mathrm{He}$ may be homeless in the ordinary and popular sense of the word, he may be a vagrant, but legally he will always be deemed to have his domicil in some country. ${ }^{2}$

Thus, in Shaw $v$. Shaw, the facts were that Shaw and his wife, domiciled in Massachusetts, determined to remove to Colorado. They left Massachusetts, not expecting to return, and proceeded as far as Philadelphia. There they stopped temporarily, and during their stay there Shaw was so cruel to his wife that, in fear of her life, she left him and returned to Massachusetts, where she applied for a divorce. Shaw never returned thither. Though fully recognizing the principle that a divorce should only be granted upon the application of one domiciled within the State, ${ }^{4}$ the court granted the application.

S See post, $\$ 29$.

1 Abington v. N. Bridgewater, 23 Pick. (Mass.) 170, 177 ; Crawford v. Wilson, 4 Barb. (N. Y.) 505, 518 ; Dupuy v. Wurtz, 53 N. Y. 556 ; Desmare v. United States. 93 U. S. 605 ; Otis v. Boston, 12 Cush. (Mass.) 44 ; Shaw $v$. Shaw, 98 Mass. 158; Allgood $v$. Williams, 92 Ala. 551, 8 So. 722; Gilman v. Gilman, 52 Me. 165, 83 Am. Dec. 502 ; Ayer v. Weeks, 65 N. H. 248, 18 Atl. 1108 ; De La Montanya $v$. De La Montanya, 112 Cal. 101, 32 L. R. A. 82, 53 Am. St. Rep. 165; Tipton v. Tipton, 87 Ky. 243, 8 S. W. 440 ; Whito v. Tennant, 31 W. Va. 790, 8 S. E. 596.

2 See Lowry v. Bradley, 1 Speer's Eq. (S. C.) 1, 39 Am. Dec. 142 ; Borland v. Boston, 132 Mass. 89, 42 Am. Rep. 424; Shaw v. Shaw, 98 Mass. 158.

898 Mass. 158.

4 Post, $\$ 50$. 
Neither the husband nor wife had acquired a domicil elsewhere, and in the language of the court, "Every one must have a domicil somewhere."

Indeed, the authorities go a step further and lay down the proposition that not only must a person always have a domicil somewhere, but he must further be deemed to be domiciled in some civilized State or at least in a State sufficiently civilized to possess a perfected system of law. Such will certainly be the rule in respect to persons who have once been citizens of a civilized country. The reasons for this last qualification are quite evident. Not only is it generally true in cases where a citizen of a civilized community has exiled himself in this manner, that he does not intend to settle permanently in a barbarous country, ${ }^{\circ}$ but even should such an extraordinary intent dominate his mind, public policy and the safety of the individual alike require that he should be presumed not to have intended to surrender the protection and benefits secured by his home laws in exchange for the barbarous customs of the savages among whom he lives.

§28. II. Only one Domicil at a Time. - The second of these principles may be thus stated: No natural person can have more than one domicil at a time. ${ }^{1}$

It is the settled doctriue both in England and America that one cannot have more than one domicil at the same time for the

5 Thus there are numerous English cases in which citizens of England or Scotland have been held to retain their original domicils, though passing their lives in India or China. Dicey, Confl. L. 88, 149 ; Bruce v. Bruce, 2 B. \& P. 229 ; Jopp v. Wood, 4 DeG., J. \& S. 616.

6 Dicey, Confl. L. 733, 734.

1 This is the form in which this proposition is usually stated, but it is subject to a qualification. It is true that no one court or no one jurisdiction will consider a person domiciled in more than one place at a time. But it is quite possible that the court of one State may adjudge a person to be domiciled therein at a given time, while the court of another State, before whom the same question may be pending, may hold him to be domiciled in the second State at that time. Snch a position has been asserted by the Massachusetts court in passing upon the domicil of an insane person under guardianship there, who takes up his abode in another State, where he is adjudged sane and capable of selecting his own domicil. Talbot v. Chamberlain, 149 Mass. 57, 60, 3 L. R. A. 254. 
same purpose. ${ }^{2}$ But it is sometimes said or intimated that a person may have one domicil for one purpose, and, at the same time, other domicils for other purposes. ${ }^{8}$ These dicta (for they are nothing more) Mr. Dicey explains as being the result of confusion of thought with respect to the terms "domicil" and "residence," domicil being used in these cases to designate different kinds of residence. He maintains with great earnestness that no person can have more than one domicil at a time for any and all purposes, and in this he is supported by strong authority." Indeed, it may be accepted as generally true that no natural person can have more than one domicil at one and the same time, even for different purposes, using the word "domicil" in its technical sense as importing not merely residence, but residence for an unlimited period. ${ }^{5}$

But to this general rule there is one exception, or at least an apparent exception, in the case of-a-married woman suing in one jurisdiction for divorce from her husband, domiciled in another State or country. In such case, notwithstanding the rule of law that the wife's domicil follows that of her husband, ${ }^{6}$ and the other rule, no less authoritative, that a suit for divorce must be brought in the domicil of the complainant, ${ }^{7}$ it is now gen. erally admitted that a wife may acquire a domicil apart from

2 Abington v. N. Bridgewater, 23 Pick. (Mass.) 170, 177; Otis v. Boston, 12 Cush. (Mass.) 44 ; Ayer $v$. Weeks, 65 N. H. 248, 18 Atl. 1108 ; Crawford v. Wilson, 4 Barb. (N. Y.) 505 ; Dupuy v. Wurtz, 53 N. Y. 556 ; Allgood v. Williams, 92 Ala. 551, 8 So. 722; Gilman v. Gilman, $52 \mathrm{Me} .165,83 \mathrm{Am}$. Dec. 502 ; In re Olson's Will, 63 Ia. 145, 18 N. W. 854 ; Somerville v. Somerville, 5 Ves. 750.

8 See Dupuy v. Wurtz, 53 N. Y. 556 ; Allgood v. Williams, 92 Ala. 551, 8 So. 722; Gilman v. Gilman, 52 Me. 165, 83 Am. Dec. 502; De La Montanya $v$. De La Montanya, 112 Cal. 101, 32 L. |R. A. 82, 85; White v. Tennant, $31 \mathrm{~W}$. Va. 790, 8 S. E. 596 ; Abington v. N. Bridgewater, 23 Pick. (Mass.) 170, 177 ; Hallett v. Bassett, 100 Mass. 167; Greene v. Greene, 11 Pick. (Mass.) 409, 415.

4 Dicey, Confl. L. 96, 97; Story, Confl. L. $\$ 45$, note (a); Jac. Dom. $\S \S 91,92$.

5 Jac. Dom. $\$ \S 91,92$; Otis v. Boston, 12 Cush. (Mass.) 14 ; Price v. Price, 156 Penn. St. 617, 27 Atl. 291; De La Montanya v. De La Montanya, 112 Cal. 101, 32 L. R. A. 82, 85, 53 Am. St. Rep. 165.

6 Post. $\$ 46$.

7 Post, $\$ 50$. 
her husband for the purpose of instituting a suit for divorce." If she does not desire a divorce, her domicil remains in general the same as her husband's and changes with his. This principle appears to give the wife one domicil for the purpose of divorce, and a different domicil (at the same time) for all other purposes. The incongruity of this result has even led one court to deny the well nigh universally admitted rule that jurisdiction of . divorce is governed by the domicil of the complainant, and not by his or her mere residence. ${ }^{9}$

But upon a close examination it will probably be found that there is little or no real incongruity here. After the wife has instituted the suit, if then a question should arise which would make it needful to fix her domicil for any purpose, she would probably be held to have acquired a domicil apart from her husband for all purposes. Until she sues for divorce she has but one domicil for any purpose, - that of her husband. After she institutes the suit in a foreign jurisdiction, she still has only one domicil for any purpose, - the one she has voluntarily chosen as the locality in which she wishes to obtain her divorce.

- § 29. III. Domicll retained until another is acquired. The third general principle relating to domicil is as follows: $A$ domicil once acquired is retained until a new domicil is gained. ${ }^{1}$

This principle is but the logical and necessary consequence of the two preceding ones. If one can never be without a domicil, and can never have but one domicil at a time, it must fol-

8 Post, §50.

- De La Montanya $v$. De La Montanya, 112 Cal. 101, 32 L. R. A. 82, 85, 53 Am. St. Rep. 165.

1 Abington v. N. Bridgewater, 23 Pick. (Mass.) 170, 177; Dupuy v. Wurtz, 53 N. Y. 556 ; Hallett $v$. Bassett, 100 Mass. 167; Borland $v$. Boston, 132 Mass. 89, 42 Am. Rep. 424 ; Desmare v. United States, 93 U. S. 605; Mitchell $v$. United States, 21 Wall. 350 ; Shaw v. Shaw, 98 Mass. 158; Allgood $v$. Williams, 92 Ala. 551, 8 So. 722 ; Price $v$. Price, 156 Penn. St. 617, 27 Atl. 291; Gilman v. Gilman, 52 Me. 165, 83 Am. Dec. 502 ; Williams v. Saunders, 5 Coldw. (Tenn.) 60 ; Firth $v$. Firth, 50 N. J. Eq. 137, 24 Atl. 916 ; Lowry v. Bradley, 1 Speer's Eq. (S. C.) 1, 39 Am. Dec. 142, 144 ; Shepherd v. Cassiday, 20 Tex. 24, 70 Am. Dec. 372,373 ; Hart v. Lindsey, 17 N. H. 935, 43 Am. Dec. 597, 601, 602; Somerville v. Somerville, 5 Ves. 750. 
low that a domicil once acquired will be retained until another is gained. ${ }^{2}$ It is to be observed therefore that the abandonment of a domicil does not of itself destroy it, even when coupled with an intent to acquire a new one, but it continues until another is in fact gained. ${ }^{3}$

Many examples of the application of these propositions might be adduced, but one or two will suffice to illustrate them.

A person domiciled in Boston, Massachusetts, left that city in 1876, with his family, to reside in Europe for an indefinite period, with the fixed purpose never to return to Boston, and to make some place other than Boston his residence when he should return. While in Europe, prior to May 1, 1877, he fixed upon a place of residence in another State, but remained in Europe until 1879. The question arose whether, as a domiciled citizen of Massachusets, he was liable to taxation there on his personal property, the taxes falling due May 1, 1877. It was held that he was still domiciled in Boston on that day."

In another case, a married woman left New York for Europe, with her husband, for her health, at first intending to return. But after her husband's death her physicians decided that she must not come back. She wrote letters to that effect, but still seemed to regard New York as her home. She lived in hotels and lodgings in Europe, but never set up any establishment there. She finally died, leaving a will of personalty valid under the laws of New York but invalid under the law of France, where the will was executed and where she died. It was decided that the validity of the will must be determined by the law of her domicil, and that she must be deemed to have retained her New York domicil until she acquired another, which she did not do. ${ }^{5}$

2 White $v$. Tennant, 31 W. Va. 790, 8 S. E. 596 ; Ayer v. Weeks, 65 N. H. 248, 18 Atl. 1108.

${ }^{8}$ Shaw $v$. Shaw, 98 Mass. 158 ; First Nat. Bank v. Balcom, 35 Conn. 351; In re Olson's Will, 63 Ia 145, 18 N. W. 854 ; Hood's Estate, 21 Penn. St. 106 ; Cooper v. Beers, 143 Ill. 25, 33 N. E. 61 ; Somerville v. Somervilla 5 Ves. 750.

4 Borland v. Boston, 132 Mass. 89, 42 Am. Rep. 424.

- Dupuy v. Wurtz, 53 N. Y. 556. 
It is a corollary of these propositions that the legal presumption is in favor of the retention of a previous domicil, and the burden of proof lies on him who asserts a change of domicil." It should be noted however that a change of domicil from one country or State to another under the same general sovereignty, as from Scotland to England, or from one of the United States to another, is more easily inferred than a change to a foreign country, whose laws are strange and whose people are alien. ${ }^{7}$

$\S 30$. IV. Persons Sui Juris may change Domicil at Pleasure. - The fourth principle is: Every natural person, free and sui juris, may change his domicil at pleasure. ${ }^{1}$

This is the result of the personal liberty of locomotion, belonging of right, and now generally accorded to every person not under disabilities and capable of controlling his own movements. It implies the exercise of choice or will, and hence the proposition is applicable only to that kind of domicil known as the domicil of choice. ${ }^{2}$

But persons who are not legally sui juris, such as infants, insane persons, or married women, or those who are incapable of exercising a choice as to their locality, such as persons imprisoned, invalids ordered to a particular place by their physicians, or other persons deprived of freedom of locomotion, cannot in general change their domicil at their own pleasure. ${ }^{8}$

- Desmare v. United States, 93 U. S. 605 ; Mitchell v. United States, 21 Wall. 350; Allgood v. Williams, 92 Ala. 551, 8 So. 722 ; Price v. Price, 156 Penn. St. 617, 27 Atl. 291 ; Hood's Estate, 21 Penn. St. 106 ; Dapuy v. Wurtz, 53 N. Y. 556.

7 Moorehouse $v$. Lord, 10 H. L. Cas. 286, 287 ; Whicker v. Hume, 7 H. L. Cas. 124 ; Steer's Succession, 17 La. Ann. 1551, 18 So. 503, 504; Dupuy v. Wurtz, 53 N. Y. 556.

1 See Jac. Dom. $\$ \S 98,100$; Udny v. Udny, L. R. 1 Sc. App. 441 ; Harral v. Harral, 39 N. J. Eq. 279, 51 Am. Rep. 17.

2 Post, $\S 56$ et seq.

8 Particular instances of these incapacities will be considered hereafter. See post, $\S \S 57,58$. As to domicil of fugitive from justice, see Chitty $v$. Chitty, 118 N. C. 647,24 S. E. 517, 32 L. R. A. 394 ; Young v. Pollak, 85 Ala. 439, 5 So. 279. As to domicil of invalids, see Dicey, Confl. L. 143 ; Dupny v. Wartz, 53 N. Y. 556; Hegeman v. Fox, 31 Barb. (N. Y.) 475. As to domicil of exiles, see Ennis $v$. Smith, 14 How. 400. Of person non compos mentis, see Harral v. Harral, 39 N. J. Eq. 279, 51 Am. Rep. 17 ; Talbot v. Chamber. 
§ 31. Sereral Kinds of Domicil. - I. Domicil of Origin. An individual's domicil may originate in three ways. It may be (1) A domicil of origin, or original domicil ; (2) A constructive domicil, or domicil by operation of law ; or (3) A domicil of choice. Each of these various forms of domicil will be examined in detail.

The domicil of origin is the place assigned by the law to every child as its permanent home or legal situs. It is assigned at the moment of birth, for no person can ever be without a domicil, and so one must be at once assigned him. Upon this account it has been sometimes termed the domicil of birth, ${ }^{1}$ but the use of this term is liable to mislead, since it implies that one's domicil of origin is the place where he is born. In Bruce $v$. Bruce, ${ }^{2}$ Lord Thurlow disapproves this idea, saying: "It is an enormous proposition that a person is to be held domiciled where he drew his first breath, without adding something more unequivocal." Indeed, so far is this from being universally true that it is well established that a domicil of origin may be assigned a child in a State or country he has never seen. The place of birth or the place of actual residence of the child is generally immaterial. ${ }^{8}$

It must be observed that the domicil of origin is the first of all domicils in point of time, since it is assigned at the moment of the child's birth. Any domicil acquired after birth, however short or long the interval, cannot be a domicil of origin. It must be either a domicil by operation of law or a domicil of choice. It must also be remembered that no person can have more than one domicil at a time. Hence it is impossible for one to have more than one domicil of origin. No subsequent occurrence, no combination of circumstances, can make that place a lain, 149 Mass. 57, 3 L. R. A. 254 ; Upton v. Northbridge, 15 Mass. 237 ; Mowry v. Latham, 17 R. I. 480, 23 Atl. 13 ; Sharpe v. Crispin, L. R. 1 P. \& D. 611 ; Bempde v. Johnstone, 3 Ves. Jr. 198.

1 See Story, Confl. I $\$ \S 35,46$; Whart. Confl. L. $\S 35$; Steer's Succession, 47 La. Ann. 1551, 18 So. 583.

22 Bos. \& Pal. 229, 230. See Manro v. Munro, 7 Cl. \& F. 842 ; Somerville

v. Somerville, 5 Ves. 750 ; Price v. Price, 156 Penn. St. 617, 27 Atl. 291.

Somerville v. Somerville, 5 Ves. 750 ; Colburn v. Holland, 14 Rich. Eq. (S. C.) 176, 228 ; Guier v. O’Daniel, 1 Binn. (Penn.) 349, note. 
child's domicil of origin which was not so when he was born. The original domicil may be altered by such a combination of circumstances, and the person may acquire a new domicil, but it will be either a coustructive domicil or a domicil of choice.

These conclusions seem irresistible, but authorities are found to hold that the domicil of origin may be affected by certain circumstances occurring after birth, such as the subsequent legitimation of a child born a bastard. ${ }^{4}$

Since every newborn child must have a domicil somewhere, and since he is incapable of selecting one for himself, the law undertakes to ascertain it by well defined rules. To that end it sets apart as his domicil of origin that country which, under all the circumstances of the case, would be most naturally looked upon by him as his home, had he the power to express a preference. ${ }^{6}$ And since a domicil once acquired is retained until another is gained, it frequently happens that one retains his domicil of origin even after he has reached mature years. ${ }^{6}$

The rules whereby to determine the domicil of origin depend upon various circumstances attending the party's birth, as whether he be born legitimate or illegitimate; if the former, whether the father be living or dead at the time of his birth; or whether the child is a foundling, whose parents are unknown.

$\S 32$. Original Domicil of Child born Legitimate. - If the father is alive at the time of the birth of a legitimate child, the infant has his domicil of origin in the country where the father then had his domicil. ${ }^{1}$ It is the father's highest duty to provide a support and a home for his helpless and dependent offspring, ${ }^{2}$ and it is his privilege to have the care and custody of

4 Dicey, Confl. L. 104. See post, $§ \S 33,34$.

5 See Price $v$. Price, 156 Penn. St. 617, 27 Atl. 291.

6 Guier v. O'Daniel, 1 Binn. (Penn.) 349, note; Crawford v. Wilson, 4 Barb. (N. Y.) 505 ; Price $v$. Price, 156 Penu. St. 617, 27 Atl. 291 ; Firth $v$. Firth, 50 N. J. Eq. 137, 24 Atl. 916 ; In re Steer, 3 H. \& N. 594.

1 Gaier v. O'Daniel, 1 Binn. (Penn.) 349, note; School Directors v. James, 2 W. \& S. (Penn.) 568, 37 Am. Dec. 525; Hiestand v. Kuns, 8 Blackf. (Ind.) 345, 46 Am. Dec. 481 ; Somerville v. Somerville, 5 Ves. 750 ; Sharpe v. Cris. pin, L. R. 1 P. \& D. 611 ; Whart. Confl. L. $\$ 35$; Story, Confl. L. $\$ 46$.

See Price $v$. Price, 156 Penn. St. 617, 27 Atl. 291; Van Matre v. Sankey, 148 Ill. 356, 36 N. E. 628 ; Guier v. O'Daniel, 1 Binn. (Penn.) 349, note. 
the child's person and education. To no other person has the child the same right to look for these things; and if the infant itself had the discretion to express a preference, it would most probably choose as its home that of its father. The probabilities are in favor of that being the child's permanent home rather than any other place. Hence the law, basing a general rule upon convenience and the probabilities of the case, has fixed upon this as the infant's domicil of origin.

If the father is dead when the child is born, he receives as his original domicil that of his mother at that time. In the absence of the father, his natural protector, the infant must look to the mother for a home, and for all the guardian care that childhood requires. ${ }^{3}$

§ 33. Original Domicil of a Bastard - Of Legitimated Child. - The law does not in general fix upon any particular man as the father of a bastard, because of the uncertainty in ascertaining him. The bastard is filius nullius. But there is no more difficulty in ascertaining who is the mother of a bastard than of a legitimate child, though the common law thought otherwise. And since, in most cases, the care and support of an illegitimate child devolves upon the mother, the law justly infers that the probabilities in every case are greatly in favor of the bastard's living with his mother rather than with the father, even if the latter is known.

Hence the general rule of law is that a bastard's domicil of origin is the domicil of the mother at the moment of his birth. ${ }^{1}$

Upon principle, it would seem that no circumstance supervening after the bastard's birth should make his domicil of origin other than that of the mother at that time, though such a circumstance might confer upon him a new domicil by operation of law. Thus, the subsequent acknowledgment by the father, or his intermarriage with the mother, which by the law of many countries renders the bastard legitimate, may, as we

${ }^{8}$ See Jac. Dom. § 105; Dicey, Confl. L. 103; Van Matre v. Sankey, 148 Ill. 356,36 N. E. 628 ; Mears $v$. Sinclair, 1 W. Va. 185.

1 Dicey, Confl. L. 103 ; Wright's Trusts, 2 K. \& J. 595, 25 L. J. (Ch.) 621; Udny v. Udny, L. R. 1 Sc. App. 441; Blythe v. Ayres, 96 Cal. 532, 31 Pac. 915, 19 L. R. A. 40. 
shall presently see, cause the infant's domicil thereafter to be governed by that of the father. ${ }^{2}$ But the bastard's domicil in such case would cease to be the domicil of origin, and would become a constructive domicil. His first and ariginal domicil was that of the mother, and hence when he afterwards acquires the domicil of the father by reason of the legitimation, it cannot be referred back to the time of his birth, even though the legitimation itself be referred to that date. The domicil of origin is assigned at the moment of birth; whatever is then the condition of the child will determine the locality of that domicil. If he be then illegitimate, and the mother's domicil is once assigned him legally as his domicil of origin, no other domicil of origin can be assigned him. That would be to give him two domicils at the same time. ${ }^{8}$

It must be admitted however that there are authorities otherwise." For example, so able and accurate a commentator upon the Conflict of Laws as Mr. Dicey states the rule to be that one born a bastard but afterwards legitimated stands (after legitimation) in the position he would have occupied if he had been born legitimate, and that his domicil of origin is therefore the country where his father was domiciled at the time of the bastard's birth (not at the time of his legitimation). But he admits that this opinion is open to doubt. 5 This view seems to be based upon the theory that the act legitimating the bastard (such as an intermarriage of the parents) is to be referred to the time of conception or of birth, thus causing the conception or birth to take place, by relation, in wedlock. Even if this theory is admitted, it does not materially weaken the force of the reasoning above adduced against the proposition, and would be of no application at all in those cases where the legitimation arises from some other source than a subsequent intermarriage of the parents, such as the mere acknowledgment of the father, which suffices in some States. ${ }^{6}$

2 Post, § 43 ; Dicey, Confl. L. 104 ; Whart. Confl. L. § 38.

8 See Jac. Dom. \$ 30.

4 Dicey, Confl. L. 104. See Munro v. Munro, 7 Cl. \& F. 817.

6 Dicey, Confl. L. 104.

6 See Blythe $v$. Ayres, 96 Cal. 352, 31 Pac. 915, 19 L. R. A. 40; Ires 0. McNicoll, 59 Ohio St. 402, 43 L. R. A. 772. 
\$ 34. Orfginal Domicil of a Foundling - Of an Adopted Child. - A foundling's domicil of origin-is-the country where he is found.' The principle applicable here is not different from that applied in other cases of original domicil. But there is here an element of uncertainty not arising under other circumstances, - an uncertainty as to the locality of the parents' domicil. In other cases this quantity in the equation is known. Here the parents themselves are not ascertained, much less their domicil.

The law therefore in such cases must not only raise the presumption, as in the case of other new-born infants, that they will have their permanent home in the domicil of their parents, but it must make a further presumption as to the locality of that domicil. The law will assume that the parents' domicil is in the country where the child is found, in the absence of evidence to the contrary, upon the principle that where no domicil is shown to exist elsewhere, mere presence in a country suffices to establish a prima facie domicil there. ${ }^{2}$

It is to be observed that the two presumptions above referred to differ in this respect. The presumption that the domicil of the parents is in the country where the foundling is discovered is merely a presumption of fact, rebuttable-by evidence to the contrary; while the other presumption - that a child has as his domicil of origin the domicil of his parents at the time of his birth - is a conclusive presumption of law which cannot be rebutted in a particular case.

Hence, if it is afterwards discovered that the parents' domicil at the birth of the foundling was in reality in some other country than that wherein he is found, his domicil of origin is at once transferred thither, and the latter place will thenceforth be considered his domicil of origin. This last conclusion is not in conflict with the principle that no one can have more than one domicil of origin. The law, in this case, merely acknowledges itself mistaken in assuming that the parents were domiciled in

1 Dicey, Confl. L. 103, 132; Whart. Confl. L. §39. Ses Washington u Beaver, 3 W. \& S. (Penn.) 548, 549.

2 Post, §64; Dicey, Confl. L. 132.

See Washington v. Beaver, 3 W. \& S. (Penn.) 548, 549. 
the country where the child is found, and corrects its mistake. This is a very different case from that of the legitimated bastard adverted to in the preceding section.

Where a child has been adopted by persons, not his natural parents, it is evident that the adoption, like the subsequent legitimation of a bastard, being a circumstance supervening after his birth, cannot confer upon him any other original domicil than the one he already has.

§35. II. Constructive Domicil, arising by Operation of Law. - The domicil of origin, it will be remembered, is assigned at the very moment of birth, and is retained until another is acquired. Such new domicil may be acquired in two ways. The individual, having reached maturity and being free from all disabilities, may choose a new home for himself. This is a domicil of choice. But it often becomes necessary for the law to assign a new domicil other than that of origin to infants and other persons incapacitated from selecting their own homes.

Thus, a child's domicil of origin is the domicil of the father at the moment of its birth. But the father may change his domicil to another State or country. The same reasons which induce the law to make the father's former domicil the child's domicil of origin operate to alter the child's domicil with that of the father. And so it is with disabilities other than infancy, such as those of a married woman or an idiot.

Such domicil, being assigned by the law, is said to arise by construction or operation of law. As in the case of the original domicil, the determination of the constructive domicil is based upon legal presumptions, which however are so strong as to be in the main conclusive and incontrovertible. Indeed the domicil of origin itself is only one instance of constructive domicil, though generally treated separately because of its peculiar importance and influence.

There are two main points of difference between a domicil of origin and a constructive domicil.

The first is that the domicil of origin is assigned to infants at the moment of birth, while a constructive domicil is always assigned after birth, and may be given to others under disabilities as well as to infants. 
The second difference is to be found in the weight sometimes attached to the domicil of origin in ascertaining the domicil of choice in doubtful cases. It is expressed by the maxim: The domicil of origin is less easily abandoned and more easily reverts. ${ }^{1}$ This is simply a rule of evidence and means that it will take more convincing proof to show that one has abandoned his original domicil for a new one than to show that he has abandoned one later domicil for another; and on the other hand, it will require less evidence to prove a resumption of the domicil of origin (upon the abandonment of some later domicil) than to prove the acquisition of an entirely new domicil. ${ }^{2}$

There are a number of instances of constructive domicil, the most important of which, those of infants, married women, and insane persons, will now be examined.

\$ 36. Constructive Domicil of Infant - Legitimate Child. Infants, not having arrived at years of discretion, are incapable in law of exercising that voluntary and discreet choice in regard to their permanent abode which is essential to the acquisition of a domicil of choice. ${ }^{1}$

Furthermore, it being ordinarily true in fact that an infant occupies the home of his parents and is under their fostering care and protection, until he is himself able to battle with the world, the law substitutes the general presumption that such is the case in the place of particular evidence in each case as it arises. We have already noted the application of this rule in ascertaining the domicil of origin. The same principles will in general apply to any subsequent change of domicil during

1 Jac. Dom. §§ 110, 115 et seq. ; Ennis v. Smith, 14 How. 400 ; Hallett v. Bassett, 100 Mass. 167 ; Otis $v$. Boston, 12 Cush. (Mass.) 44 ; Harvard College $v$. Gore, 5 Pick. (Mass.) 370 ; Gilman $v$. Gilman, $52 \mathrm{Me}$. 165, $83 \mathrm{Am}$. Dec. 502 ; Somerville $v$. Somerville, 5 Ves. 750 ; Douglas $v$. Douglas, L. R. 12 Eq. 617. See Steer's Succession, 47 La. Ann. 1551, 18 So. 503; post, $\S \S 65,66$.

2 This last proposition is discussed, and in some measure dissented from, post, $\$ \$ 65,66$.

1 Jac. Dom. \$229 ; Van Matre v. Sankey, 148 Ill. 356, 36 N. E. 628 ; Price v. Price, 156 Penn. St. 617, 27 Atl. 291 ; Lamar v. Micou, 112 U. S. 452 ; Allgood v. Williams, 92 Ala. 551, 8 Sa 722 ; Mears v. Sinclair, 1 W. Va. 185 ; Guier v. O'Daniel, 1 Binn. (Penn.) 349, note. 
the child's minority, and in the main similar distinctions are to be taken.

The domicil of a legitimate child may be brought into question under various circumstances. The child's father may be living; or he may be dead, the mother surviving; or both may be dead; or they may be divorced.

§ 37. Domicil of Legitimate Child - Father Alive. - It is a well established rule that the domicil of an infant will usually change with that of the father, so long as he lives. ${ }^{1}$ It will in general make no difference in the application of this principle that the father and mother actually reside apart in different States or countries, or that in fact the child lives with its mother. ${ }^{2}$

The reason for this presumption of law is not only that in the vast majority of cases the child actually has the home of his father, but it may be placed upon the broader ground of the established legal right of the father, as the natural guardian of the child, to the custody of his person against all the world, - even against the mother, - and his corresponding duty to afford it home and shelter. ${ }^{3}$

It is said that possibly the father's abandonment of his family and the emancipation of the child will constitute exceptions to this rule." And if the parents should have been divorced, under

1 Dicey, Confl. L. 120 ; Jac. Dom. $\$ 235$; Story, Confl. L. $\$ 46$; Whart. Confl. L. $\$ 41$; Sharpe v. Crispin, L. R. 1 P. \& D. 611 ; Lamar v. Micoll, 112 U. S. 452 ; School Directors v. James, 2 W. \& S. (Penn.) 568, 37 Am. Dec. 525 ; Van Matre $v$. Sankey, 148 Ill. 356, 36 N. E. 628; Mears v. Sinclair, 1 W. Va. 185 ; Dresser v. Illuminating Co., 49 Fed. 257 ; Hiestand v. Kuns, 8 Blackf. (Ind.) 345, 46 Am. Dec. 481 ; Woodward $v$. Woodward, 87 Tenn. 644, 11 S. W. 892, 896 ; Kline v. Kline, 57 Ia. 386, 10 N. W. $825,826$.

2 See Jac. D•m. $§ 236$; Allgood v. Williams, 92 Ala. 551, 8 So. 722 ; Kelsey v. Green, 69 Conn. 291, 37 Atl. 679.

3 Allgood $v$. Williams, 92 Ala. 551, 8 So. 722. See Lamar $v$. Micou, 114 U.S. 214. "The nurture and education of the offspring make it indispensable that they be brought up in the bosom of their parents' family ; without which the father could not perform the duties he owes them, or receive from them the service that belongs to him." School Directors $v$. James, 2 W. \& S. (Penn.) 568, 37 Am. Dec. 525, 527.

4 Jac. Dom. $\S \S 231-237$; Allgood v. Williams, 92 Ala. 551, 8 So. 722. See Van Matre $v$. Sankey, 148 Ill. 356, 36 N. E. 628. 
such circumstances of misconduct on the part of the husband that the divorcing court has taken the children from his custody and has turned them over to the mother, thenceforward, provided the court has jurisdiction to make the decree, the domicil of the children will usually be held to depend upon that of the mother, since she then has the legal custody of them. The father has ceased to be the natural guardian, and the foundations upon which this rule of domicil is based are shattered.6

Although it is ordinarily competent for the father to change his child's domicil at any time by changing his own, it is not as a general rule within his power to give the child a domicil apart from his own. ${ }^{6}$

Thus, in Allgood $v$. Williams, ${ }^{7}$ it appeared that the father of an infant, a few weeks before his death, requested his brother to take the child and raise her. The uncle lived in a different county from the father but in the same State. The question arose as to which county was the legal residence of the child after the father's death. It was held that the child's municipal domicil remained in the county where the father had lived, and was not transferred to the home of her uncle.

In De Jarnett $v$. Harper, ${ }^{8}$ the parent, residing in Missouri, actually entrusted the custody of the infant child, before death, to a person in another county in the same State. It was held that that fact did not change the minor's domicil for the purpose of determining in which county a guardian should be appointed on the parent's death.

But though a father will not generally be permitted to change his child's domicil save in so far as he changes his own, there

5 The same resnit would seem to follow without a divorce if the husband's conduct has been such as to make it necessary to withdraw from him the custody of his children. Jac. Dom. $\S 237$. See Kelsey v. Green, 69 Conn. 291, 37 Atl. 679.

6 Jac. Dom. $\$ \S 237,241$; Dicey, Confl. L. 143 ; Woodward $v$. Woodward, 87 Tenn. 644,11 S. W. 892 ; Allgood v. Williams, 92 Ala. 551, 8 So. 722 ; De Jarnett $v$. Harper, 45 Mo. App. 415. These two latter cases refer to munici. pal domicil, but a fortiori the same principle would govern national or quasinational domicil. But see White $v$. Howard, 52 Barb. (N. Y.) 294, 318.

792 Ala. 551, 8 So. 722.

845 Mo. App. 415. 
are qualifications of the rule that deserve attention. If the father should fix the child's residence apart from his own, with the intention of permanently renouncing control over its actions, and surrendering to competent persons his legal right to the cus. tody of its person and the care of its education, this might, in some cases, effect a change in the child's domicil. ${ }^{9}$ Thus if the father should bind the child out as apprentice, the latter's domicil, it is believed, will then become that of the master, and will change with his, even into another State or country, if such a change is within the scope of the contract of apprenticeship. Here not only the actual physical custody, but the legal custody also, has been renounced by the parent. ${ }^{10}$

The same is true if the father surrenders the child to a third person for adoption, at least where the relation of child by adoption is legally recognized. ${ }^{11}$

§38. Same - Father Dead, Mother Surviving. - It is a general principle of the law that, after the father's death, the mother succeeds to his position as the natural guardian of the infant children, so long as she remains unmarried and is fit for the trust. There is a strong moral, if not a strictly legal, duty resting upon her to provide them a home, as in fact she usually will. For these reasons the rule seems now well established that the domicil of the fatherless infant will change with that of the mother, at least so long as she remains unmarried. ${ }^{1}$

- Jac. Dom. $\S \S 246,247,248$; Maddox $v$. State, 32 Ind. 14 ; Ross $v$. Ross, 129 Mass. 243, 37 Am. Rep. 321; In re Johnson, 87 Ia. 130, 54 N. W. 69 ; Washburn $v$. White, 140 Mass. 568.

10 See Maddox $v$. State, 32 Ind. 14, which however is a case of municipal domicil, involving the right to vote.

11 Jac. Dom. §§ 247, 248; Ross v. Ross, 129 Mass. 243, 37 Am. Rep. 321; Washburn $v$. White, 140 Mass. 568 ; Woodward $v$. Woodward, 87 Tenn. 644, $11 \mathrm{~S}$. W. 892 ; In re Johnson, 87 Ia. 130, $54 \mathrm{~N}$. W. 69 ; Foley's Estate, 11 Phila. 47. If the adoption is not a legal status, it is doubtful, to say the least, whether the same result would follow. See Allgood $v$. Williams, $92 \mathrm{Ala}$. 551, 8 So. 722 ; De Jarnett $v$. Harper, 45 Mo. App. 415 . But see Lamar $v$. Micou, 114 U. S. 452.

1 Jac. Dom. §§ 238, 241 ; Dicey, Confl. L. 121; Whart. Confl. L. § 41 ; Story, Confl. L. $\$ 46$, note (c); Potinger $v$. Wightman, 3 Meriv. 67; Johnstone v. Beattie, 10 Cl. \& F. 42, 138; Sharpe v. Crispin, L. R. 1 P.\& D. 611 ; Lamar v. Micou, 112 U. S. 452; Van Matre v. Sankey, 148 Ill. 356, 36 N. E. 
Some question has been made whether this principle applies in cases where the child fails to actually accompany the mother to a new home, remaining apart from her in his old place of abode. Some of the authorities hold that, under such circumstances, the child's domicil does not follow the mother's. ${ }^{2}$ But the better view, and the most reasonable, is that the power of the widowed mother with respect to the infant's domicil is the same as that of the father, were he alive.

It is sometimes said that the widowed mother may change the domicil of her child with hers, if she act without fraudulent intent to thereby alter the rule of succession to the child's personalty (which depends upon the law of the domicil). It may well be doubted whether this is a proper qualification of the rule. ${ }^{4}$

628; Woodward v. Woodward, 87 Tenn. 644 ; 11 S. W. 892 ; Mears v. Sinclair, 1 W. Va. 185 ; Allen v. Thomason, 11 Humph. (Tenn.) 536, 54 Am. Dec. 55, 57, note ; Succession of Lewis, 10 La. Ann. 789, 63 Am. Dec. 600, 601, 602 ; School Directors v. James, 2 W. \& S. (Penn.) 568, 37 Am. Dec. 525; Freetown $v$. Taunton, 16 Mass. 52 ; Dedham $v$. Natick, 16 Mass. 135. In De Jarnett $v$. Harper, 45 Mo. App. 415, it was held that the domicil of a widowed mother, even though she had been adjudged a lunatic, fixes the municipal domicil of her child, and determines the jurisdiction of the court to appoint a guardian. The incompetence or unfitness of the mother as a guardian, says the court in that case, can only be tried by the court of the county where she is domiciled.

2 See Jac. Dom. § 241 ; Dicey, Confl. L. 122-123.

3 Sharpe v. Crispin, L. R. 1 P. \& D. 611; Lamar v. Micou, 112 U. S. 452; Van Matre $v$. Sankey, 148 Ill. 356, 36 N. E. 628 ; Woodward $v$. Woodward, 87 Tenn. 644, 11 S. W. 892 ; Allen v. Thomason, 11 Humph. (Tenn.) 536, 54 Am. Dec. 55, 57, note; Mears v. Sinclair, 1 W. Va. 185 ; Succession of Lewis, 10 La. Ann. 789, 63 Am. Dec. 600, 601-602; School Directors v. James, 2 W. \& S. (Penu.) 568, 570, 37 Am. Dec. 525; Dedham v. Natick, 16 Mass. 135.

4 Dicey, Confl. L. 126, 127; Potinger v. Wightman, 3 Meriv. 67 ; School Directors v. James, 2 W. \& S. (Penn.) 568, 569, 37 Am. Dec. 525, 526; Wheeler $v$. Hollis, 19 Tex. 522, 70 Am. Dec. 363, 365. No reason can be urged why this qualification should be attached in the case of the mother, which would not apply with equal force to the father. Yet it is never applied to restrict the father's power to change the child's domicil. Mr. Jacobs argues against it with force. He says: "Suppose that for the purpose of affecting the personal succession, a mother carries with her her infant child into another State or a foreign country, and the child, instead of dying there, should live and grow up to maturity. Can it be doubted that his general legal capacity 
\$ 39. Effect of Remarriage of the Mother. - A woman, upon marriage, generally ceases to have the power to choose her own domicil. The law fixes it, independently of her volition, as that of her husband, whether she actually resides with him or at his domicil or elsewhere. She becomes a part of her husband's family and thereby ceases to be the head of her own. ${ }^{1}$

Since therefore her domicil becomes subordinate to her husband's, and since he owes no legal duty to provide the stepchildren with a home, some of the authorities hold that the domicil of the wife's minor children, from the time of her remarriage, ceases to follow any further change of domicil by the stepfather and his wife, but remains where it was at the time of the mother's second marriage, until she again becomes discovert, or until the children arrive at maturity and select domicils of their own. ${ }^{2}$

Other authorities seem to hold that the question turns upon whether the child actually changes its residence to the domicil of the stepfather. If, after her remarriage, the infant actually lives with the mother in the stepfather's home, then that becomes his domicil. Otherwise, the child retains the former domicil. ${ }^{\text {s }}$

would be determined by the laws of the new place? Can it be doubted that his personal property would be taxable there?... It seems therefore more logical to hold that while courts would interpose to defeat the fraudulent design with which a parent had attempted to change the domicil of his or her infant child, they would not do so upon the ground that the change of domicil had not been accomplished, but rather upon the ground that, in the particular case, the usual legal effect could not be given to the change of domicil, so as to assist in the perpetration of the fraud." Jac. Dom. § 243. But see Mears v. Sinclair, $1 \mathrm{~W}$. Va. 185.

1 Post, § 46; School Directors v. James, 2 W. \& S. (Penu.) 568, 569, 37 Am. Dec. 525, 526 ; Allen $v$. Thomason, 11 Humph. (Tenn.) 536, $54 \mathrm{Am}$. Dec. 55, 57 ; Lamar $v$. Micou, 112 U. S. 452.

2 Jac. Dom. § 244 ; Dicey, Confl. L. 125, 126 ; Lamar v. Micoll, 112 U. S. 452; Woodward $v$. Woodward, 87 Tenn. 644 , 11 S. W. 892, 896 ; Allen v. Thomason, 11 Humph. (Tenn.) 536, 54 Am. Dec. 55, 57; School Directors v. James, 2 W. \& S. (Penn.) 568, 569, 37 Am. Dec. 525, 526 ; Mears v. Sinclair, 1 W. Va. 185; Freetown v. Taunton, 16 Mass. 52 ; Brown v. Liynch, 2 Bradf. (N. Y.) 214.

3 See Blythe v. Ayres, 96 Cal. 532, 31 Pac. 915, 919 ; Succession of Lewis, 
The second view is more consonant with reason. It must be admitted that the first doctrine leaves out of consideration the strong moral duty resting upon the mother to provide her infant children with a home, as well as other necessaries - a duty which rests upon her no less strongly after her remarriage than during her widowhood. It moreover disregards the usual trend of events in such cases, and instead of assuming to be true what is true in most cases, as in other instances of constructive domicil, it assumes to be true what in most cases is known to be false. For though in law the widowed mother ceases probably upon her remarriage to be the natural guardian of her infant children, and to be as such entitled to the care and custody of their persons, in fact it is otherwise in the vast majority of eases. Indeed the last doubt as to the fact must be dismissed when we suppose the children actually to reside with their mother and her husband."

$\S 40$. Constructive Domicil of Orphan. - Upon the principle that a domicil once acquired is retained until another is gained, the settled rule is that a minor, both of whose parents are dead, will retain the last domicil of the last surviving parent, until it is legally changed. This change the infant cannot bimself make until he becomes sui juris. The law fixes his domicil for him during his minority, regardless of the place of his actual abode. ${ }^{-1}$

But although the authorities are agreed that an orphaned infant cannot by his own act change his domicil, they are much divided upon the question as to the power of his guardian in

10 La. Ann. 789, 63 Am. Dec. 600, 601-602; Wheeler v. Hollis, 19 Tex. 522, 70 Am. Dec. 363, 367 ; Brown v. Lynch, 2 Bradf. (N. Y.) 214. In Succession of Lewis, supra, the mother had been appointed the guardian of her child. In Wheeler $v$. Hollis, supra, the stepfather had been appointed the child's guardian.

4 See Story, Confl. L. $\$ 46$, note (c); Wheeler v. Hollis, 19 Tex. 522, 70 Am. Dec. 363, 367 ; Blythe v. Ayres, 96 Cal. 532, 31 Pac. 915, 919, 19 L. R. A. 40 ; Dalhousie v. M'Douall, 7 Cl. \& F. 817.

1 Van Matre v. Sankey, 148 Ill. 356, 36 N. K. 628 ; School Directors $v$. James, 3 W. \& S. (Penn.) 568, 37 Am. Dec. 525, 527. See Lamar v. Micou, 112 U. S. 452 ; Woodward $v$. Woodward, 87 Tenn. 644, 11 S. W. 892,896 Holyoke $v$. Haskins, 5 Pick. (Mass.) 20, 25-26, 16 Am. Dec. 372. 
this respect. ${ }^{8}$ The examination of this point will lead us to review briefly the several kinds of guardians and their rights and duties, and then to consider especially the guardian's power with reference to the ward's domicil.

The law admits two general classes of guardians, those having the custody and care of the ward's person and those having the custody of his estate. The first class was known to the Roman law as tutors, the second as curators. Under the modified system of the common law, as it exists generally in England and the United States, there are three main classes of guardians: the guardian by nature, or natural guardian; the guardian by appointment of court, or the appointed guardian; and the testamentary guardian.

1. The guardian by nature has charge of the ward's person only, and the care of his education. The father is primarily the natural guardian of a legitimate child, or if he be dead, the mother, so long as she remains unmarried and is fit for the trust. If the child is illegitimate, the case is like that of a legitimate child whose father is dead; the mother is the natural guardian. If both parents be dead, then it seems, according to the common law, that any lineal ancestor of the minor to whom he is heir may be the natural guardian. The father has the first claim; the mother the second; and amongst more remote ancestors, such as grandparents, etc., he who first obtains possession of the infant, pursuant to the maxim, in oequali jure, melior est conditio possidentis. ${ }^{8}$

2. The guardianship by appointment embraces both the care of the person and of the property of the ward. But it applies to the ward's person only in the event that there is no natural guardian." It must be observed that the appointed guardian,

2 See Jac. Dom. $\S 249$ et seq.; Whart. Confl. L. $\S \S 41,42$; Dicey, Confl. L. 123.

3 Jac. Dom. $\S 245$; 1 Minor's Insts. (4th ed.) 452; 1 Bl. Com. 461 ; Lamar v. Micou, 114 U. S. 218 ; Darden $v$. Wyatt, 15 Ga. 414 . But see Marheineke $v$. Grothaus, 72 Mo. 204.

4 See 1 Minor's Insts. (4th ed.) 456-457 ; Wood v. Wood, 5 Pai. Ch. (N. Y.) 596, 28 Am. Dec. 451. But see Townsend v. Kendall, 4 Minn. 412, 77 Am. Dec. 534 . 
even where there is no guardian by nature, has not the same ties of affection and influence to draw the ward to him as has the natural guardian, nor has he the same control over him in fact. ${ }^{5}$

3. Testamentary guardians are statutory guardians, depending for their authority upon the statutes of the various states. They are usually given control of the person and property of the ward. But, like an appointed guardian, a testamentary guardian does not supersede the natural guardian in the custody of the child's person, or the care of his education. Nor can he, in the nature of things, possess the same control over the ward that the parents would have.

In conclusion, it is proper to observe that, independently of statute, these guardianships terminate, as to male wards at twenty-one, and as to female wards at twenty-one or marriage. ${ }^{6}$ Even as to male wards, the common law seems to hold that marriage emancipates the person, but still leaves the property of the ward under the control of the guardian.

$\S 41$. Power of Guardian to alter Ward's Domicil. - From the brief summary, just given, of the various guardians, and remembering the principle that the law, in establishing a constructive domicil, looks to the actual probabilities of the case and the presumed choice of the incompetent party, as well as to the legal right to the custody and control of the ward, some deductions may be drawn of importance in the solution of the question, how far a guardian may influence the ward's domicil.

With respect to the natural guardian, united as he is to the infant by ties of parental love and obligation on the one hand, and filial dependence, respect, and duty on the other, it is not difficult to understand that all the presumptions of fact, as well as of law, are in favor of the general rule that the minor's domicil will be with the parent wherever he is, and will change with his. The infant is an integral part of his family. And

5 See Jac. Dom. $\$ \$ 251$ et seq.

6 Charlestown $v$. Boston, 13 Mass. 468, 472.

71 Minor's Insts. (4th ed.) 464. See Com. $v$. Graham, 157 Mass. 73, 75 . Washington $v$. Beaver, 3 W. \& S. (Penn.) 548, 549. 
such is the general rule, not only where the natural guardian is the father or the mother, ${ }^{1}$ but even in case of the grandparent also, at least where the infant actually resides with him. ${ }^{2}$ Hence, in the further consideration of this much vexed question we may eliminate from the discussion the right of the natural guardian to change the minor's domicil and confine our atteution to the powers of the appointed and testamentary guardians in this respect, where there is no natural guardian.

Upon the rights of such guardians to change the ward's domicil during his minority there has been great division of opinion. Some courts have held that these guardians take in law the place of the parents of the infant, and succeed to all the powers of the parents - amongst others, that of changing his domicil. ${ }^{8}$

Others have held with equal positiveness that the guardian's intentions or acts have no effect whatever upon the ward's domicil, which remains fixed where it was at the death of his last surviving parent or natural guardian."

Some of the cases have made a distinction in this respect between testamentary guardians and those appointed by court,

1 Ante, $\$ \S 37,38$.

2 Lamar v. Micou, 114 U. S. 218 ; Darden v. Wyatt, 15 Ga. 414 ; Kirkland v. Whately, 4 Allen (Mass.), 462 ; Dresser v. Illuminating Co., 49 Fed. 257 ; Jac. Dom. § 245. But see Woodward $v$. Woodward, 87 Tenn. 644, $11 \mathrm{~S}$. W. 892.

3 Townsend v. Kendall, 4 Minn. 412, 77 Am. Dec. 534, 536 ; Wheeler $v$. Hollis, 19 Tex. 522, 70 Am. Dec. 363, 365 ; Wood v. Wood, 5 Pai. Ch. (N.Y.) 596, 28 Am. Dec. 451; White v. Howard, 52 Barb. (N. Y.) 294, 318 ; Woodworth $v$. Spring, 4 Allen (Mass.), 321. See Lamar v. Micou, 112 U. S. 452 ; Talbot v. Chamberlain, 149 Mass. 57, 20 N. E. 305, 3 L. R. A. 254 . These cases relate to nationsl or quasi-national domicil. Other decisions hold that the guardian is permitted to change the municipal domicil of the ward. See Mills v. Hopkinsville (Ky.), 11 S. W. 776 ; Kirkland $v$. Whately, 4 Allen (Mass.), 462 ; Holyoke $v$. Haskins, 5 Pick. (Mass.) 20, 25-26, 16 Am. Dec. 372.

4 Woodward $v$. Woodward, 87 Tenn. 644,11 S. W. 892, 896 ; Mears $v$. Sinclair, 1 W. V2. 185; Daniel v. Hill, 52 Ala. 430 ; Hiestand v. Kuns, 8 Blackf. (Ind.) 345, 46 Am. Dec. 481 . See Lamar $v$. Micou, 112 U. S. 452. As to municipal domicil, see School Directors v. James, 2 W. \& S. (Penn.) 568, $37 \Delta \mathrm{m}$. Dec. 525. See Jac. Dom. $\$ 261$ et seq. 
permitting the change of the ward's domicil in the former case, but not in the latter. It is difficult to discover any valid basis for this distinction.

With regard to the ward's national or quasi-national domicil, since the guardian (whether testamentary or appointed) has no legal authority as of right over the person of the ward outside of the jurisdiction where he is appointed and qualifies as such, ${ }^{6}$ and since furthermore the ward is not generally in fact a member of his guardian's family, not expected and not-intending to make his home permanently with him, " it would seem reasonable to suppose that a change of such domicil on the part of the guardian would not ordinarily cause a corresponding change of the ward's.

But if the ward, as a matter of fact, is a member of the guardian's family, living with him as such, and actually removung with him to his new abode, his domicil, it is believed, will change with that of the guardian. ${ }^{8}$

As between a natural and a testamentary or appointed guardian, it will be remembered that the legal custody of the infant's person belongs, by municipal law as well as by the law

5 Jac. Dom. § 260 ; Lamar v. Micou, 112 U. S. 452 (a dictum). The distinction rests upon this dictum of the Supreme Court, for which no reason is given and to sustain which only one case (Wood $v$. Wood, 5 Pai. Ch. (N. Y.) 596, 605, $28 \mathrm{Am}$. Dec. 451) is cited. The language of the latter case is applicable to all guardians. See contra, Mears $v$. Sinclair, 1 W. Va. 185.

6 Post, § 115. See Lamar v. Micou, 112 U. S. 452 ; Donglas v. Douglas, L. R. $12 \mathrm{Eq} .617,625$.

7 See Jac. Dom. $\S 251$; School Directors v. James, 2 W. \& S. (Penn.) 568, 37 Am. Dec. 525, 527.

${ }^{8}$ Such were the facts in Wheeler $v$. Hollis, 19 Tex. 522, $70 \mathrm{Am}$. Dec. 363 ; White $v$. Howard, 52 Barb. (N. Y.) 294, wherein it was held that the ward's domicil followed the guardian's. See also Townsend $v$. Kendall, 4 Minn. 412, 77 Am. Dec. 534, 536. But in Daniel v. Hill, 52 Ala. 430, where the same state of facts arose, the court decided against a change of domicil. So also in Mears $v$. Sinclair, $1 \mathrm{~W}$. Va. 185, which was the case of a testamentary guardian. In Wood v. Wood, 5 Pai. Ch. (N. Y.) 596, 28 Am. Dec. 451, the court refused to allow a testamentary guardian residing in another state to remove the wards from New York, where their mother lived. The language of the decision supports the proposition that a guardian may alter his ward's domicil, but the court clearly had in mind the state of facts referred to in the text. 
of nature, to the former, so long as he remains fit for the trust. Hence we should expect to find that, so long as there is a natural guardian living, the child's domicil will follow his, rather than that of the testamentary or appointed guardian. And this conclusion is borne out by the cases. ${ }^{\circ}$.

It should be observed that the guardian herein alluded to, as competent to alter the ward's domicil with his own under certain circumstances, is the domiciliary guardian, the guardian appointed in the State where the ward is domiciled. If appointed in a State where the ward is resident, but not domiciled, his powers are strictly local. $\mathrm{He}$ may be able to change the ward's municipal domicil, but he cannot affect his national or quasi-national domicil. ${ }^{10}$

With respect to the municipal domicil of the ward, the guardian's power to alter or affect it is a matter of municipal law. It seems however to be generally conceded that the powers of the guardian in this respect, there being no natural guardian, ${ }^{11}$ are much more extensive. There is indeed but little dissent from the proposition that a guardian may change an orphan ward's municipal residence whenever such a course is for the benefit of the ward, not necessarily, it seems, being confined in his choice to the place where he himself lives. ${ }^{12}$

There are several reasons why the guardian's powers should here be extended. In the first place he has the powers of a guardian in every portion of the State of his appointment; wherever he places the ward, he has the authority of guardian. This is not the case when he takes the ward to another State. ${ }^{18}$

- Seiter v. Straub, 1 Demar. (N. Y.) 264 ; School Directors v. James, 2 W. \& S. (Penn.) 568, 37 Am. Dec. 525; Kirkland v. Whately, 4 Allen (Mass.), 462; Wood v. Wood, 5 Pai. Ch. (N. Y.) 596, 28 Am. Dec. 451 ; Lamar $v$. Micou, 114 U. S. 218.

10 Lamar $v$. Micou, 112 U. S. 452.

11 In School Directors v. James, 2 W. \& S. (Penn.) 568, 37 Am. Dec. 525, it was held that a ward's personalty could not be taxed in the borough where the guardian lived, the ward residing with his mother in another borough.

12 Jac. Dom. \$257 ; Lamar v. Micou, 112 U. S. 452 ; Mills $v$. Hopkinsville (Ky.), 11 S. W. 776 ; Kirkland $v$. Whately, 4 Allen (Mass.), 462 ; Holyoke $v$. Haskins, 5 Pick. (Mass.) 20, 25, 16 Am. Dec. 372.

13 Jac. Dom. § 261 ; Lamar v. Micon, 112 U. S. 452 ; Douglas v. Douglaq I. R. 12 Fq. 617 . 
Again, the removal of the ward's residence from one part of the State to another does not expose him to be subjected to any change in the law governing him and his property, as does a change of his national domicil. The courts are very jealous of a change of that character. ${ }^{14}$ Finally, the guardian has the management of the ward's estate, and his pecuniary interests may often require a change of residence, for example, for purposes of less rigorous taxation, ${ }^{15}$ education, ${ }^{16}$ or cheaper living.

$\S 42$. Constructive Domicil of an Illegitimate Child. The father of a bastard being unknown, it devolves upon the mother to provide a home for him, and she, as the natural guardian, has the custody of his person and the care of his education. The same principles will apply here as in the case of a legitimate child whose father is dead, and whose mother survives. $^{1}$

The domicil of the mother is the domicil of the bastard, the place of the infant's birth and the domicil of the father being immaterial elements. ${ }^{2}$ Should the mother marry, her domicil will thereafter be governed by that of her husband. Whether the bastard's domicil will be correspondingly changed would seem to depend upon whether he actually resides with his mother and stepfather, the principle being the same as in the case of a legitimate child, whose widowed mother marries again. But if the mother marries the father of the child, it is believed the rule would be different, even though legitimation does not result. In such case, it would seem that the infant bastard's domicil would shift with the mother's, whether he actually resides with his mother and father or not.

14 See Pedan $v$. Robb, 8 Ohio, 227 ; Wheeler $v$. Hollis, 19 Tex. 522, 70 Am. Dec. 363 .

15 Mills $v$. Hopkinsville (Ky.), $11 \mathrm{~S}$. W.776; Kirkland $v$. Whately, 4 Allen (Mass.), 462.

16 School Directors $v$. James, 2 W. \& S. (Penn.) 568, 57 Am. Dec. 525, 527.

1 Ante, §§ 38, 39.

2 Jac. Dom. § 244, $a$; Dicey, Confl. L. 120, 121 ; Whart. Confl. L. § 37 ; Blythe $v$. Ayres, 96 Cal. 532, 31 Pac. 915, 19 L. R. A. 40.

3 Ante, § 39 . See Blythe v. Ayres, 96 Cal. 532, 19 L. R. A. 40, 31 Pac. 915, 919. 
§ 43. Constructive Domicil of Child subsequently Legitimated. - At common law a child born out of wedlock was a bastard, and no subsequent intermarriage of the parents or acknowledgment of the child by the father, or-any other supervenient act, would legitimate him. But by the Roman or civil law, and by statute in most of these States, the subsequent intermarriage of the parents, either-standing-alone, or coupled with an acknowledgment by the father, will legitimate an illegitimate child. ${ }^{1}$ In some of the States, the mere acknowledgment of the father, without marriage, will have the same effect. ${ }^{2}$

The question in all such cases is, has the child become legitimate under the proper law ? $^{8}$ If so, it is immaterial how that result came about. Thenceforth he is in exactly the same position in all respects as if he were born legitimate, and his domicil will thereafter be governed by the same rules. It will follow the domicil of his father, or if he be dead that of the mother, so long as the child remains under age.

$\S 44$. Constructive Domicil of an Adopted Child. - Under the common law (it was otherwise by the civil law) there was no such-legal relation as that of adopted child. Such child had no legal right to look to the adopting parent for support or home, in the absence of special contract, or to succeed to any portion of his property. But in many, if not in most, of these States statutes have been passed in accordance with the civil law, permitting this relation to be created upon the observance of certain formalities. These statutes generally impose upon the adopting parent, after the adoption, the same duties that the law places upon him in respect to his own children. The natural parents or the guardians surrender their control to the adopting parent, and he, on the other hand, must supply to the adopted child all the necessaries he would be bound to supply to his own children, amongst other things, a home.1

1 See Ross $v$. Ross, 129 Mass. 243, 249, 37 Am. Rep. 321.

2 See Blythe v. Ayres, 96 Cal. 532, 31 Pac. 915, 19 L. R. A. 40.

8 For the proper law to determine this question, see post, $\$ \$ 98-100$.

1 Ross $v$. Ross, 129 Mass. 243, 263, 37 Am. Rep. 321; Washburn $v$. White, 140 Mass. 558 ; Foster $v$. Waterman, 124 Mass. 592 ; Woodward $v$. Woodward, 87 Tenn. 644,11 S. W. $892,896$. 
Under such a state of the law, the adopting parent becomes the natural guardian of the child, and his domicil becomes that of the child also. ${ }^{2}$

Possibly this result may also follow, even in the absence of legal adoption, in cases where the parents are dead, and the children are taken to distant localities, to be reared by relatives or others interested in the orphans. ${ }^{8}$ But if the parents or either of them be alive, it would seem that, no matter how clearly they may intend or agree to surreuder the control of the child, its domicil is not thereby changed."

$\S 45$. Domicil of a Married Infant. - As we have seen in speaking of the functions of guardians, ${ }^{1}$ it is the better opinion that at common law, even as to male wards, all guardianship ceases, so far as the ward's person is concerned, at twenty-one or marriage. In jurisdictions where this is the rule it follows that if a minor is married and has a family and home of his own, he becomes "emancipated," and may acquire a domicil of choice. ${ }^{2}$

If the infant is a female and marries, she merely exchanges one dependence for another. Her domicil ceases to be that of her parents and becomes that of her husband, ${ }^{8}$ even though she continues to reside with her parents, provided the husband be in no default. ${ }^{4}$

An interesting question might be raised as to the domicil of

2 See cases above cited. See also In re Johnson, 87 Ia. 130, 54 N. W. 69 ; Foley's Estate, 11 Phila. 47 ; Jac. Dom. $\$ \$ 247,248$.

8 See Lamar $v$. Micou, 114 U. S. 218 (the child here resided with the grandparent, whom the court beld to be the natural guardian); Dresser $v$. Illuminating Co., 49 Fed. 257 (also case of grandparent) ; Cutts v. Haskins, 9 Mass. 543 (case of brother). But see Woodward $v$. Woodward, 87 Tenn. 644,11 S. W. 892, 896, criticising Lamar v. Micou, supra.

4 De Jarnett $v$. Harper, 45 Mo. App. 415. See Armstrong v. Stone, 9 Gratt. (Va.) 102.

1 Ante, § 40.

2 Whart. Confl. L. $\$ 41$; Allgood v. Williams, 92 Ala. 551, 8 So. 722 ; Van Matre $v$. Sankey, 148 Ill. 356, 36 N. E. 628; Washington $v$. Beaver, 3 W. \& S. (Penn.) 548, 549. See Com. v. Graham, 157 Mass. 73, 75. But see Jac. Dom. §§ 231, 232 ; Dicey, Confl. L. 128, 129.

See the following sections.

Charlestown $v$. Boston, 13 Mass. 468, 472. 
an infant widow or divorcée. Has she been emancipated by the marriage so as to give her power to change her domicil at pleasure upon the termination of the coverture? Is she thereby relegated to the condition of dependence upon her parents from which her marriage took her? Or is she to retain her last domicil (that of her husband) until she becomes twenty-one or remarries? The first view seems the more reasonable, especially if she is left with children to support and is not again received into the bosom of her parents' family. ${ }^{5}$

§ 46. Constructive Domicil of Married Woman. - It is a general principle of the common law, and one that is more or less inherent in all systems of jurisprudence, that a married woman merges her legal identity in her husband's, and solemnly yields her will to his. Hence it results that the husband is bound to support her, has the control of her person, and is entitled to her services.

From this principle follows the general rule of law which fixes her domicil. It is established beyond dispute that a woman, upon marriage, immediately acquires the domicil of her husband, and that her domicil ordinarily changes with every alteration of his, regardless of the actual locality of her residence after the marriage. ${ }^{1}$

This rule is founded not only on the above-mentioned prin-

6 Warrender $v$. Warrender, 2 Cl. \& F. 488, 525. But Mr. Dicey favors the last view. Dicey, Confl. L. 130, note 1 .

1 Jac. Dom. $\S \S 209,213,214$; Barber v. Barber, 21 How. 582 ; Cheely v. Clayton, 110 U.S. 701, 705; Suter v. Suter, 72 Miss. 345, 16 So. 674 ; Burtis v. Burtis, 161 Mass. 508, 510 ; Watkins v. Watkins, 135 Mass. 83, 85 ; Hunt ı. Hunt, 72 N. Y. 217, 28 Am. Rep. 129 ; Hill v. Hill, 166 Ill. 54, 46 N. E. 751,752 ; White $v$. White, 18 R. I. 292, 27 Atl. 506 ; Kline $v$. Kline, 57 Ia. 386,10 N. W. 825,826 ; Arrington $v$. Arrington, 102 N. C. 491, 9 S. E. 200 ; Harding $v$. Alden, 9 Greenl. (Me.) 140, 23 Am. Dec. 549; Williams $v$. Saunders, 5 Coldw. (Tenn.) 60; Smith $v$. Smith, 19 Neb. 706, 28 N. W. 296, 298 ; Champon $v$. Champon, 40 La. Ann. 28, 3 So. 397, 399 ; Shreck $v$. Shreck, 32 Tex. 578, 5 Am. Rep. 251, 252 ; Harrison $v$. Harrison, 20 Ala. 629, 56 Am. Dec. 227; Jenness $v$. Jenness, 24 Ind. 355, 87 Am. Dec. 335 ; Harral $v$. Harral, 39 N. J. Eq. 379, 51 Am. Rep. 17, 23 ; Dougherty v. Snyder, 15 S. \& R. (Penn.) 84, 16 Am. Dec. 520 ; Maguire v. Maguire, 7 Dana (Ky.), 181, 186 ; Warrender $v$. Warrender, 2 Cl. \& F. 488. 
ciple of identity ${ }^{2}$ and upon the duty she owes to submit her will to her husband's, ${ }^{8}$ but also on the broader ground, the operation of which, with respect to constructive domicil, has already been noticed, that the law will presume that to be true which is true in the great majority of cases."

Hence this general rale does not apply when the relations of the husband and wife are of an abnormal character. If they are divorced, or contemplate divorce, or-if the husband deserts the wife, becomes insane or otherwise incompetent to be the head of the family and to furnish her with a support and a home, an abnormal condition-results-which-will-sometimes prevent the operation of the rule, and will authorize the wife to select a domicil apart from that of her husband. Indeed it has been said by an eminent tribunal ${ }^{5}$ that "the rule is that she may acquire a separate domicil whenever it is right and proper that she should do so. The right springs from the necessity for its exercise and endures as long as the necessity continues."

The general rule, however, is in the main strictly adhered to. Save in a few exceptional cases, presently to be adverted to, the wife cannot acquire a domicil separate and apart from her husband, though she actually lives in a different State, or even though they actually reside apart by agreement or under a

9 Harteau v. Harteau, 14 Pick. (Mass.) 181, 25 Am. Dec. 372; Burtis v. Burtis, 161 Mass. 508, 510; Harrison $v$. Harrison, 20 Ala. 629, 56 Am. Dec. 227, 229 ; Smith v. Smith, 19 Neb. 706, 28 N. W. 296, 298 ; Dutcher $v$. Dutcher, 39 Wis. 651; Jenness v. Jenness, 24 Ind. 355, 87 Am. Dec. 335; Hunt $v$. Hunt, 72 N. Y. 217, 243; O'Dea $v$. O'Dea, 101 N. Y. 23, 36.

8 Barber $v$. Barber, 21 How. 582 ; Dedham $v$. Natick, 16 Mass. 135; Harteau $v$. Harteau, 14 Pick. (Mass.) 181, 25 Am. Dec. 372 ; Harding v. Alden, 9 Greenl. (Me.) 140, 23 Am. Dec. 549; Jenness $v$. Jenness, 24 Ind. 355, 87 Am. Dec. 335; Hunt v. Hunt, 72 N. Y. 217, 243; Colburn v. Holland, 14 Rich. Eq. (S. C.) 176, 229.

4 Hartean $v$. Harteau, 14 Pick. (Mass.) 181, 25 Am. Dec. 372 ; Mason $v$. Homer, 105 Mass. 116 ; Hunt v. Hunt, 72 N. Y. 217, 243, 28 Am. Rep. 129 ; Dutcher $v$. Dutcher, 39 Wis. 651 ; Cook v. Cook, 56 Wis. 195, 43 Am. Rep. 706, 14 N. W. 33, 34 ; Smith v. Smith, 19 Neb. 706, 28 N. W. 296 ; Warrender $v$. Warrender, 2 CI. \& F. 488, 523-524 (opinion of Lord Brougham).

5 The Supreme Court of the United States in Cheever $v$. Wilson, 9 Wall. 108, 124. See also Hunt $v$. Hunt, 72 N. Y. 217, 243, 28 Am. Rep. 129 ; Harteau v. Harteau, 14 Pick. (Mass.) 181, 25 Am. Dec. 372. 
deed of separation. ${ }^{6}$ It is otherwise, as we shall presently see, if there be a judicial separation. ${ }^{7}$

Even if the wife is induced to leave the husband because of his ill-treatment and harshness, or for reasons that would give her the right to apply for a separation or a divorce $a$ vinculo, if she do not actually ask for one, and until she does, his domicil will still be hers. ${ }^{8}$ But should she apply for a divorce, and for that purpose change her domicil, it would remain changed for all purposes; otherwise she would have two domicils. ${ }^{9}$

But there may be exceptional circumstauces surrounding the wife that make it necessary that she should in some cases be capable of selecting a domicil apart from her husband. To hold otherwise would in many instances result in grievous injustice to her. ${ }^{10}$ These more or less abnormal conditions will now be considered.

§ 47. Domicil of a Deserted Wife. - If the wife applies for a separation or a divorce $a$ vinculo because of the husband's de-

6 Jac. Dom. $\S \S 215,216$; Barber v. Barber, 21 How. 582 ; Greene $v$. Greene, 11 Pick. (Mass.) 409, 415; Hood v. Hood, 11 Allen (Mass.), 196, 199, 87 Am. Dec. 709 ; Williams v. Saunders, 5 Coldw. (Tenn.) 60, 79; Dougherty $v$. Snyder, 15 S. \& R. (Penn.) 84, 16 Am. Dec. 520; Warrender v. Warrender, 2 Cl. \& F. 488, 524. There are a few cases holding that a permanent depart ure of the wife from the husband's home destroys her domicil there, even thongh it be the result of an amicable arrangement. See Colburn $v$. Holland, 14 Rich. Eq. (S. C.) 176, 229; Florance's Will, 54 Hun (N. Y.), 328, 7 N. Y. Suppl. 578; Cook v. Cook, 56 Wis. 195, 43 Am. Rep. 706, 14 N.W. 33, 34; Smith $v$. Smith, 19 Neb. 706, 28 N. W. 296, 298 ; Chapman v. Chapınan, 129 Ill. $386,21 \mathrm{~N}$. E. 806 . In most of these, there were peculiar circumstances, such as the pendency of divorce or the desertion of the husband, which took the case out of the operation of the general rule.

7 Post, § 52 ; Hunt v. Hunt, 72 N.Y. 217, 243, 28 Am. Rep. 129.

8 Dolphin $v$. Robins, 7 H. L. Cas. 390 ; Harrison v. Harrison, 20 Ala. 629, 56 Am. Dec. 227, 229; Shaw $v$. Shaw, 98 Mass. 158 ; Loker v. Gerald, 157 Mass. 42, 31 N. E. 709, 710 ; Hunt $v$. Hunt, 72 N. Y. 217, 243, 28 Am. Rep. 129 ; Maguire ø. Maguire, 7 Dana (Ky.), 181, 186; Harding v. Alden, 9 Greenl. (Me.) 140, 23 Am. Dec. 549 ; Smith v. Smith, 43 La. Ann. 1140, 10 So. 248. But see Florance's Will, 54 Hun (N. Y.), 328, 7 N. Y. Suppl. 578. See Jao. Dom. § 223.

9 Ante, § $28 . \quad$ See Jac. Dom. § 226 ; Dolphin v. Robins, 7 H. L. Cas. 390.

${ }^{10}$ Cheever $v$. Wilson, 9 Wall. 108, 124 ; Hunt $v$. Hunt, 72 N. Y. 217, 243, 28 Am. Rep. 129 ; Harteau v. Harteau, 14 Pick. (Mass.) 181, 25 Am. Dec. 372. 
sertion, it is now well established that she may renounce the constructive domicil created by the marriage status, and acquire a separate domicil of her own where she may obtain a divorce.

The question becomes more complicated if we suppose the wife unwilling or without intention to obtain a divorce, or if the question should arise before she has begun to put such intention into effect. ${ }^{2}$ It has been said by some eminent authorities that the doctrine of the wife's separate domicil, under such circumstances, does not extend beyond cases of divorce, ${ }^{8}$ or as it is sometimes put, beyond proceedings whose "express object is to show that the relation itself ought to be dissolved or so modified as to establish separate interests, and especially a separate domicil and home; bed and board being put, a part for the whole, as expressive of the idea of home." 4

It is believed that this is the proper solution in those cases (e. g. adultery or cruelty) where the husband's offense does not go to the extent of depriving the wife of his support or of a home provided by him. And the cases do not take a position beyond this. There is good reason for this doctrine. The wife by her silence may be taken to have signified her intention to condone the offense, if indeed any has been committed. And if it be alleged that she has not condoned it, the difficulties in the way of establishing the wrongs alleged in a collateral inquiry would be insurmountable. ${ }^{5}$

1 Barber $v$. Barber, 21 How. 582, 594, 595 ; Harteau $v$. Harteau, 14 Pick. (Mass.) 181, 25 Am. Dec. 372 ; Hood v. Hood, 11 Allen (Mass.), 196, 199, 87 Am. Dec. 709 ; Blackinton $v$. Blackinton, 141 Mass. 432, 435 ; Hunt $v$. Hunt, 72 N. Y. 217, 242-243, 28 Am. Rep. 129 ; Harding v. Alden, 9 Greenl. (Me.) 140, 23 Am. Dec. 549; White $v$. White, 18 R. I. 292, 27 Atl. 506; Kline $v$. Kline, 57 Ia. 386,10 N. W. $825,826$.

2 For example, should the deserted wife die without taking any step towards the prosecution of a divorce suit. The disposition of her personal estate depends upon the law of her domicil at the time of her death. See post, $\S 139-141$.

${ }^{8}$ See Jac. Dom. $\S ~ 226,227$; Dolphin $v$. Robins, 7 H. L. Cas. 390 ; Yelverton $v$. Yelverton, 1 Swab. \& Tr. 574, 29 L. J. (P. \& M.) 34; Burtis $v$. Burtis, 161 Mass. 508, 510-511.

4 Harteau v. Harteau, 14 Pick. (Mass.) 181, 25 Am. Dec. 372.

See Jac. Dom. §§ 226, 227; Dolphin v. Robins, 7 H. L. Cas. 390. 
But where the improper act of the husband is one that amounts to a total renunciation of the marriage relation, as in case of desertion, and as a result the wife is left to make her own way in the world and by her own endeavors to provide a home for herself and her family, it would seem to be a great injustice to deny her the right to make her legal as well as her actual home in any place which will promise her a livelihood, untrammeled by presumptions of law favorable to the husband, which he himself has outrageously cast aside. It is submitted therefore (with deference) that the wife, even without divorce, should be permitted to alter her domicil when deserted by her husband, especially when he has added to his desertion the offense of taking with him a paramour, or otherwise rendering bis new home uninhabitable by his wife. ${ }^{6}$

In Florance's Will, ${ }^{7}$ the wife lived apart from her husband by mutual agreement for a number of years, during which time the children lived with her and were wholly supported by her, the husband living in another State and contributing nothing to the support of his wife or children. She was held to acquire a domicil in the State where she thus lived, so that the husband's rights in her personal estate at her decease were governed by the laws of that State, not by the law of her husband's domicil.

It would seem, upon the same principle, if the husband is under restraint for hopeless lunacy, or is confined for life upon conviction of crime, that the wife should in such cases also be permitted to select a new legal domicil for herself, should she desire to do so. ${ }^{8}$

§ 48. Domicil of wife who Deserts her Husband. - The wife who deserts her husband, eren though for a cause which

6 Champon v. Champon, 40 La. Ann. 28, 3 So. 397, 399 ; Smith v. Smith, 43 La. Ann. 1140, 10 So. 248, 249 ; Barber v. Barber, 21 How. 582, 594, 595 ; Chapman $v$. Chapman, 129 Ill. 386, 21 N. E. 806 ; Cummington $v$. Belchertown, 149 Mass. 223, 226, 21 N. E. 435 ; Blackinton $v$. Blackinton, 141 Mass. 432, 435 ; Harding $v$. Alden, 9 Greenl. (Me.) 140, 23 Am. Dec. 549 ; Dutcher v. Dutcher, 39 Wis. 651,659 ; Doerr $v$. Forsythe, 50 Ohio St. 726, 35 N. E. 1055 .

754 Hun (N. Y.), 328, 7 N. Y. Suppl. 578.

S See post, § 49 ; Whart. Confl. L. \$44; McPherson v. Housel, 2 Beasley (N. J.), 35, 13 N. J. Eq. 35. 
would be ground for a divorce, ar which rould constitute a good defence to a suit by the husband for a restitution of conjugal rights, will still, according to the great weight of modern-authority, be held to retain the domicil of her husband, unless she sues for divorce. ${ }^{1}$ But if she does institute divorce proceedings she may acquire a new domicil for the purpose. It is not essential that she should have left her husband with that intent. ${ }^{2}$

It is also worthy of observation in this connection that the law requires the wife to cling to her husband and to follow him into whatever country the necessities of health or of business require him to make his home. Her refusal to accompany him without legal excuse, and his departure alone, constitute a desertion on her part, not on his. In such cases, her domicil follows that of her husband. ${ }^{8}$

But if the husband refuses, without good cause, or refuses except upon unreasonable conditions, to permit the wife to live with him, and departing to another State sues her there for di-

1 See Whart. Confl. L. § 43; Jac. Dom. \$§ 226, 227 ; Dolphin v. Robins, 7 H. L. Cas. 390 ; Yelverton v. Yelverton, 1 Swab. \& Tr. 574, 29 L. J. (P. \& M.) 34 ; Smith $v$. Smith, 43 La. Ann. 1140, 10 So. 248, 249 ; Barber v. Barber, 21 How. 582; Cheever $v$. Wilson, 9 Wall. 108, 124 ; Shaw $v$. Shaw, 98 Mass. 158; Burlen $v$. Shannon, 115 Mass. 438, 447; Cheely v. Clayton, 110 U. S. 701, 705; Chapman v. Chapman, 129 Ill. 386, 21 N. E. 806; Flower v. Flower, 42 N. J. Eq. 152, 7 Atl. 669; Arrington v. Arrington, 102 N. C. 491, 9 S. E. 200 ; Shreck v. Shreck, 32 Tex. 578, 5 Am. Rep. 251. See Watkins v. Watkins, 135 Mass. 83, 85-86; Florance's Will, 54 Hun (N. Y.), 328, 7 N. Y. Suppl. 578.

2 Flower $v$. Flower, 42 N. J. Eq. 152, 7 Atl. 669 ; Chapman $v$. Chapman, 129 IIl. 386, 21 N. E. 806 ; White v. White, 18 R. I. 292, 27 Atl. 506. But see Lyon $v$. Lyon, 2 Gray (Mass.), 367, 368.

3 Loker $v$. Gerald, 157 Mass. 42, 43, 31 N. E. 709, 710 ; Burlen $v$. Shannon, 115 Mass. 438, 447 ; Hood v. Hood, 11 Allen (Mass.), 196, 199, 87 Am. Dec. 709 ; Watkins $v$. Watkins, 135 Mass. 83, 85-86 ; Cheely $v$. Clayton, 110 U. S. 701, 705 ; Hunt $v$. Hunt, 72 N. Y. 217, 28 Am. Rep. 129 ; Larquie v. Larquie, 40 La. Ann. 457, 4 So. 335, 337; Suter v. Suter, 72 Miss. 345, 16 So. 674 . See Chapman v. Chapman, 129 Ill. 386, 21 N. E. 806 . But see Heath $v$. Heath, 42 La. Ann. 437, 7 So. 540, which, however, turns upon a doctrine of divorce peculiar to Louisiana, namely, that suit for divorce must be brought in the jurisdiction where the married pair have lived together. See slso O'Dea v. O'Dea, $101 \mathrm{~N}$. Y. 23, 38 (dissenting opinion of Danforth, J.). 
vorce because of her desertion, her domicil will not be beld to follow his." So, if the wife living in another State from her husband herself sues for divorce in the State of her actual residence, she cannot allege that her domicil is with her husband, in order to defeat a cross-bill for divorce filed by him in answer to her complaint. ${ }^{5}$

$\$ 49$. Domicil of Wife whose Husband is Insane or otherwise incapacitated. - If the law itself has established the incompetence or incapacity of the husband to be the head of the family and to provide them with a home, as by reason of an adjudication of permanent insanity, the presumption of law that the wife is dependent upon the husband for a home no longer applies, and she is at liberty to select her own domicil as well as that of the minor children. It is similar to, and even stronger than, the case of the husband's desertion. ${ }^{I}$ If there has been no legal adjudication of insanity, it would seem that the wife's domicil must be held to follow that of her husband, notwithstanding mental or physical ailments.

It has been said that if the husband is incapacitated to support the wife by reason of conviction of felony (an incapacity established by the law) his domicil will cease to control that of the wife. ${ }^{2}$ But unless the confinement is permanent, for life, it is difficult to see how it could leave the wife free to select a domicil of her own. ${ }^{8}$

Mere physical weakness or incapacity on the part of the husband will in no event, it is believed, confer upon the wife the privilege of choosing a domicil apart from his. Indeed such a course would generally be a plain violation of the duty she owes her husband, whom she has taken for better or for worse, in sickness as well as in health.

4 Williams $v$. Williams, 130 N. Y. 193, 197, 29 N. E. 98. See Chapman v. Chapman, 129 Ill. 386,21 N. E. 806.

5 Watkins v. Watkins, 135 Mass. 83, 85-86.

1 See Whart. Confl. L. $\$ 44$. This is true however only in case the in. sanity is of a permanent character.

2 Whart. Confl. L. § 44 ; McPherson v. Housel, 2 Beasley (N. J.), 35, 13 N. J. Eq. 35.

${ }^{3}$ See Kelsey $v$. Green, 69 Conn. 291, 37 Atl. 679. 
$\S 50$. Domicil of Wife contemplating Divorce. - The municipal law of almost all States requires that the complainant in a divorce suit should be domiciled in the State where the suit is instituted. Hence it becomes important in such cases to ascertain the domieit of the plaintiff.

It is now settled that an innocent wife may acquire a separate domicil from her husband for purposes of divorce, or probably in any case where her interests are antagonistic to his and are dependent upon the locality of the domicil, provided she actually resides there and actually raises the question in a judicial proceeding. ${ }^{1}$

Mr. Jacobs has expressed the opinion that this rule should not be extended beyond giving to the wife the right to sue for divorce in the State where she and her husband have resided together. ${ }^{2}$ But it is now well settled that the wife may go to an entirely new State, and having become domiciled there may sue for a divorce. ${ }^{\dot{\boldsymbol{s}}}$

This rule is adopted in order to prevent the grave injustice that might be done the wife, if her domicil was held to follow her husband's, otherwise she would be compelled to follow him into any distant State he might select as his domicil, and after expense and trouble sue for her divorce in the forum selected by him, perhaps chosen for the very reason that its laws would deny her the relief she might obtain at home." And if she

1 See Jac. Dom. $\$$ 223-226 ; Cheever v. Wilson, 9 Wall. 108, 123-124; Hunt $v$. Hunt, 72 N. Y. 217, 28 Am. Rep. 129 ; Hill v. Hill, 166 Ill. 54, 46 N. E. 751, 752 ; Chapman v. Chapman, 129 Ill. 386, 21 N. E. 806 ; Dunham $v$. Dunham, 162 Ill. 589, 35 L. R. A. 70, 77 ; Arrington v. Arrington, 102 N. C. 491,9 S. E. 200 ; Smith v. Smith, 43 La. Ann. 1140, 10 So. 248, 249 ; Burtis v. Burtis, 161 Mass. 508, 510; Blackinton v. Blackinton, 141 Mass. 432, 435; Harteau v. Harteau, 14 Pick. (Mass.) 187, 25 Am. Dec. 372 ; White $v$. White, 18 R. I. 292, 27 Atl. 506, 507 ; Van Fossen $v$. State, 37 Ohio St. 317, 41 Am. Rep. 507, 508; Cook v. Cook, 56 Wis. 195, 43 Am. Rep. 706, 14 N. W. 33, 35.

2 Jac. Dom. §§ 224, $224 a$.

8 See cases cited, note 1, supra.

4 Jac. Dom. §224; Whart. Confl. L. §224; Cheever v. Wilson, 9 Wail. 108, 124 ; Harteau v. Harteau, 14 Pick. (Mass.) 181, 25 Am. Dec. 372 ; Burtis v. Burtis, 161 Mass. 508, 510; Hunt v. Hunt, 72 N. Y. 217, 243, 28 Am. Rép. 129 ; Jenness $v$. Jenness, 24 Ind. 355, 87 Am. Dec. 335, 337. 
were relegated to the domicil of her married life, the State where she has lived with her husband, the inconvenience would still be great; she would be compelled to sue for divorce in her former home before she could remove to another State, or else to forego altogether her right to divorce.

This rule is prescribed in order to afford a better protection to the wife. Its adoption ought not to deprive the wife (at least from the standpoint of private international law) of the right she would have had without it of treating her husband's domicil as still her own, if she should prefer that course, and sue there. ${ }^{5}$

But if the allegation of the wife is not that the marriage relation should be dissolved by decree of the court, but that it is absolutely null and void, and she accordingly asks for a decree of nullity, the domicil of the alleged husband will not affect hers, for that would be to suppose the existence of a valid marriage, the very point in dispute. ${ }^{6}$

$\S 51$. Domicil of Wife whose Husband applies for Divorce. - If the husband, in contemplation of divorce, should leave the wife and acquire a new domicil in another State or country, it would in many instances result in great injustice to the wife, should the law require her domicil to follow his. For she would then, merely by construction of law, contrary to the actual fact, be subjected to the laws and jurisdiction of her husband's domicil, chosen by him under circumstances which would lead him to advance his own interests and to antagonize hers. The law will not ordinarily thus disregard the actual state of facts in such cases, nor content itself with idle presumptions

5 See Jac. Dom. §224; Greene v. Greene, 11 Pick. (Mass.) 410. But see Wood $v$. Wood, 54 Ark. 172, 15 S. W. 459 ; Cook v. Cook, 56 Wis. 195, 43 Am. Rep. 706, 14 N. W. 33, 35. In Jenness $v$. Jenness, 24 Ind. 355, 87 Am. Dec. 335,337 , this principle is disapproved on the ground that it gives the wife two domicils. It is manifest that this is not so: it only gives her a choice between two. Her domicil remains that of her husband until she sues for divorce. She may accept the general presumption of law which operates upon her up to the time her suit is instituted, and sue where her husband is domiciled; or she may accept the alternative of separating her domicil from her husband's, suing where she actually resides.

6 See Whart. Confl. L. \& 224. 
which the husband's conduct shows to have no foundation in fact. ${ }^{1}$ Hence it is well settled that the wife, as defendant in a divorce suit brought by her husband in his domicil, is to be considered from the time the suit is instituted as domiciled in the State where she actually resides, under whose jurisdiction and protection-she-actually is. The acquisition of a new domicil by the husband for purposes of divorce does not draw the wife into the same jurisdiction, unless she in fact-removes thither permanently. Their interests are antagonistic. ${ }^{2}$

But a wife cannot thus obtain a separate domicil by her own wrong, so that if she deserts her husband he may sue for divorce in any State where he is domiciled, and she, though actually resident elsewhere, will be deemed in law to be domiciled with him, thus giving the court jurisdiction of both the parties. ${ }^{8}$

\$52. Domicil of Divorced Wife. - We have seen that the law generally assigns the wife the domicil of her husband, because they are one person in law, because it is her duty to live with him, and because in fact she will usually do so. But when the parties are divorced, these reasons cease to operate altogether or in large measure.

Thus in a case of a divorce a mensa, or judicial separation, the law itself, through the courts, has decreed that the parties shall no longer be considered identical, as before, and that they shall thereafter live separate and apart. All the foundations upon which rests the presumption that the husband's domicil is likewise the wife's are thus swept away. Indeed the very opposite presumption at once arises, namely, that the parties have obeyed the decree of the court and have ceased to live together. ${ }^{1}$

1 Watkins $v$. Watkins, 135 Mass. 83, 86.

2 Story, Confl. L. $229 a$, note ; Hunt $v$. Hunt, 72 N. Y. 217, 243, 28 An. Rep. 129 ; Vischer v. Vischer, 12 Barb. (N. Y.) 640, 643 ; Borden v. Fitch, 15 Johns. (N. Y.) 121, 141, 8 Am. Dec. 225 ; Heath v. Heath, 42 La. Ann. 437, 7 So. 540 ; Jenness $v$. Jenness, 24 Ind. 355, 87 Am. Dec. 336-337.

8 Whart. Confl. L. $\S 227$; Loker $v$. Gerald, 157 Mass. 42, 31 N. E. 709 ; Burlen v. Shannon, 115 Mass. 438, 447-448; Harteau v. Harteau, 14 Pick. (Mass.) 181, 25 Am. Dec. 372 ; Hood $v$. Hood, 11 Allen (Mass.), 196, 199, 87 Am. Dec. 709 ; Hunt v. Hunt, 72 N. Y. 217, 243, 28 Am. Rep. 129 ; Heath v. Heath, 42 La. Ann. 437,7 So. 540.

1 So strong is this latter presumption that a child born more than ton 
The fiction that the wife has her home with the husband being thus destroyed by the act of the law itself, there would seem to be no reason why the wife may not actually acquire a separate domicil, even though the dissolution of the marriage ties be not absolute. And such is now the general opinion. ${ }^{2}$

In case of a divorce $a$ vinculo, the parties have in general all the rights and capacities of unmarried persons, amongst other things the right to change their domicils at will. ${ }^{8}$. The fact that the woman is the offending party, and that the court is authorized to decree and does decree that she shall not marry again, would not affect her right in this particular; for such a penal disability cannot follow her into other States, nor does it prevent her status from being in general that of an unmarried woman. ${ }^{4}$

But if the divorce is invalid, as for example if it is granted by a court without jurisdiction, it is of no legal effect in freeing the parties from their marital obligations and disabilities. They are still bound by the rules regulating the relations of married persons, and the wife's domicil is still in law that of her husband's, though she actually resides elsewhere or marries another man. ${ }^{5}$

The divorce, even though valid, does not necessarily ipso facto alter the wife's domicil. She retains the domicil she had immediately before the coverture was determined until she acquires another for herself; and neither her domicil of origin, nor her domicil before marriage, will play any part unless she actually lives there. ${ }^{6}$

months after the decree of separation is prima facie presumed illegitimate. See 1 Minor's Insts. (4th ed.) 297 ; 2 Bright's Husb. \& Wife, 262, Bac. Abr. Marr. \& Div. (F.).

2 Jac. Dom. $\S 217,219,220,221$; Dolphin v. Robins, 7 H. L. Cas. 390 ; Barber $v$. Barber, 21 How. 582 ; Hunt $v$. Hunt, 72 N. Y. 217, 243, 28 Am, Rep. 129 ; Vischer $v$. Vischer, 12 Barb. (N. Y.) 640, 643; Borden v. Fitch, 15 Johns. (N. Y.) 121, 141, 8 Am. Dec. 225.

8 Jac. Dom. § 217; Whart. Confl. L. §46; Dicey, Confl. L. 130 ; Warrender $v$. Warrender, $2 \mathrm{Cl}$. \& F. 488, 525, 527 .

4 Post, § 74.

6 See Dicey, Confl. L. 127-128 ; Dolphin v. Robins, 7 H. L. Cas. 390.

- Jac. Dom. $§ 222$; Dicey, Confl. L. 130 . This principle has already been 
$\S 53$. Domicil of Wife, where the Marriage is $\boldsymbol{V}$ oidable or void. - If the marriage is merely voidable by decree of court, and no decree has been obtained, there would seem to be no doubt that the wife's domicil would continue in general to be governed by that of the husband.'

If the marriage is absolutely void, when tested by the law properly applicable to determine the question, as by reason of the insanity of one of the parties (which in many States renders the marriage absolutely void) or because one of the parties has a consort still living and undivorced, it would seem clear that since there has never been a marriage, the woman's domicil would be identical with her supposed husband's only so far as, by her actual residence there with him animo manendi, she makes it so. The doubt, if there be any, is not whether she may be assigned the domicil of her supposed husband without actual residence there, but whether, even though she does actually reside there with him, she can be said to have acquired a domicil of choice. ${ }^{2}$

$\S 54$. Constructive Domicil of Idiots. - Idiots are those who from birth are so deficient in intellect as to be totally unable to manage their own affairs or to live without the protecting

applied to the case of an infant wife who has been widowed or divorced. Ante, $\S 45$. It should be added that the domicil of a widow is governed by the same rules that govern that of a divorced woman. Story, Confl. L. $\S 46$; Dicey, Confl. L. 130 ; Jac. Dom. $§ 222$; Warrender v. Warrender, 2 Cl. \& F. $488,525,527$.

1 Warrender $v$. Warrender, 2 Cl. \& F. 488, 527, 528. But after a decree avoiding the marriage $a b$ initio for a cause existing at the time of the marriage, it would seem that the wife would be deprived of her right to the husband's domicil from the beginning, save in so far as it is actually her own.

2 Jac. Dom. § 212 ; Concord v. Rumney, 45 N. H. 423. See Middleborough $v$. Rochester, 12 Mass. 363. In both of these cases (which were settlement cases) the marriage was void for insanity. In the first it was the wife who was insane; but the court held that if, in residing with her husband, she had sufficient understanding to choose her place of abode, her municipal domicil must be considered as located at the place where she thus dwelt. In the latter case it was the husband who was insane, and it is not clear that the wife actually resided at his domicil; it appears from the report of the case that she continued to reside where she was living at the time of the marriage. The decision was that her municipal domicil remained unchanged. 
care of some guardian. They are incapable, even after they become adults, of forming such a definite intention and purpose as is necessary to constitute a legal domicil of choice. They must always remain dependent for a home, as infants are, upon those having the legal custody and control of their persons They continue infants perpetually. The rules of law, therefore, which determine an infant's domicil are extended to adults also who have never acquired sufficient intelligence to select and support a home of their own. ${ }^{1}$

§5. Constructive Domicil of Lunatics. - If an infant should become insane during his minority and remain in that state continuously, the incapacity of minority never having been followed by adult capacity to select a home of his own, his domicil must be determined by the same rules that control the domicil of an idiot or infant. ${ }^{1}$ But in those cases where the lunacy has supervened after the party has reached maturity, the domicil must be determined upon different principles.

One point must be observed at the outset, and should be borne in mind. The Supreme Court of New Hampshire ${ }^{2}$ has thus expressed it: "Insanity may exist in various degrees, from the slight attacks which are hardly distinguishable from eccentricity to the most raving and uncontrollable madness. It may be general, seeming to affect all the operations of the mind upon all subjects, or it may exist only in reference to a small number of subjects, or a single subject: the mind in such cases of partial insanity seeming to be in its habitual and natural condition as to all subjects and matters which do not come within the scope of the partial disease. In no case at the present day is it a mere question whether the party is insane. The point to be established is, whether the party is so insane

1 Jac. Dom. \$§ 264-269 ; Whart. Confl. L. \$§ 52, 53 ; Holyoke v. Haskins, 5 Pick. (Mass.) 20, 25-26, 16 Am. Dec. 372 ; Upton v. Northbridge, 15 Mass. 237 ; Overseers of Alexandria $v$. Bethlehem, 1 Harr. (N. J.) 119, 31 Am. Dec. 229.

1 Jac. Dom. $§ 268$; Whart. Confl. L. $\$ 53$; Sharpe v. Crispin, L. R. 1 P. \& D. 611,618 ; Washington $v$. Beaver, 3 W. \& S. (Penn.) $548,549$.

2 Concord $v$. Rumney, 45 N. H. 423. See Culver's Appeal, 48 Conn. 304 ; Holyoke v. Haskins, 5 Pick. (Mass.) 20, 26, 16 Am. Dec. 372 . All these are cases of municipal domicil. 
as to be incapable of doing the particular act with understanding and reason. This would be the essential question now, where marriage is alleged to be void by reason of insanity, and the same test would be applied in determining the question of capacity to change the domicil: Had the party at the time sufficient reason and understanding to choose her place of residence?"

There can be no doubt that a stricter test of insanity should be required to deprive one of the capacity to select his own home than is required to avoid a contract or a will. ${ }^{8}$

The determination of a lunatic's domicil would seem to hinge upon the question whether there has been an adjudication of lunacy, or ratber whether his person has been actually committed to the custody and control of a legal guardian or committee. 4

Indeed, so far as his national or quasi-national domicil is concerned, a question has been made whether even an adjudication and commission of lunacy would be given such force in other States as to affect the lunatic's right, should he go to another State, to acquire a domicil there. ${ }^{6}$ It is submitted that the gist of the inquiry in such cases is not whether the adjudication of lunacy shall be given exterritorial effect ex proprio vigore, bnt whether as a matter of evidence, the action of the court of one State should not be taken as very strong evidence, if not conclusive, of the proposition that, at the time of such decree, the party was really of such unsound mind as to require his person to be controlled. ${ }^{\circ}$

But while this last principle is believed to be sound, it is applicable only to the party's state of mind at the time of the

3 See Harral v. Harral, 39 N. J. Eq. 379, 51 Am. Rep. 17, 21 ; Concord $v$. Rumney, 45 N. H. 423 ; Rodgers $v$. Rodgers, 56 Kan. 483, 43 Pac. 779, 781 ; Talbot $v$. Chamberlain, 149 Mass. 57, 59, 20 N. E. 305, 3 L. R. A. 254 ; Mowry v. Latham, 17 R. I. 480, 23 Atl. 13.

4 See Talbot $v$. Chamberlain, 149 Mass. 57, 58, 20 N. E. 305, 3 L. R. A. 254 ; Mowry $v$. Latham, 17 R. I. 480, 23 Atl. 13.

5 See Talbot $v$. Chamberlain, 149 Mass. $57,59,20$ N. E. 305,3 L. R. A. 254.

See Rodgers $v$. Rodgers, 56 Kan. 483, 43 Pac: 779, 781 ; Mowry v. Lathan, 17 R. I. 480, 23 Atl. 13. 
decree. The continuance of that state of mind may be rebutted. It is not indispensable that there should be an adjudication of restoration to sanity by the same or any other court. ${ }^{7}$

The true principle therefore would seem to be that a lunatic, whose person has been placed under the control of a guardian or committee, is prima facie incompetent to establish a domicil in another State, but, upon satisfactory proof of mental capacity supervening, such domicil may be recognized. In any event, the mere fact that the control of the lunatic's property has been committed to a guardian or committee will not suffice to prevent him from choosing even a municipal domicil, much less a national or quasi-national one. ${ }^{8}$

$A$ fortiori would the party be capable of choosing his own domicil, if there is no adjudication or commission of lunacy at all. Thus, one suffering from habitual intemperance, melancholia, monomania, or very pronounced eccentricities, may ordinarily be fully competent to determine where he should reside. ${ }^{9}$ Nor would an adjudication of lunacy in a collateral proceeding to set aside a contract have the effect of depriving the party of the right to choose his own domicil, for the tests in the two cases are different, and no control is thereby assumed of the lunatic's person.

If the insanity is so marked or so violent as to require the duress of an asylum, there can then of course be no question of any selection of domicil by the lunatic.

The question remains, what is the locality of the lunatic's domicil when he is himself too insane to choose one? Shall the guardian or committee have power to change it, or must it remain unalterably where it was when the disability was first incurred?

The case is closely analogous to that of the guardian's power to change an infant ward's domicil, already discussed. ${ }^{10}$ As to

7 Rodgers $v$. Rodgers, 56 Kan. 483, 43 Pac. 779, 781.

8 JIowry $v$. Latham, 17 R. I. 480, 23 Atl. 13; Talbot v. Chamberlain, 149 Mass. 57,20 N. F. 305,3 L. R. A. 254.

9 Concord $v$. Rumney, 45 N. H. 423. See Harral $v$. Harral, 39 N. J. Eq 379, 51 Am. Rep. 17.

10 Ante, $\$ 41$. 
the lunatic's municipal domicil, it seems that the guardian has the power, but not so with respect to his national or quasinational domicil.11 His latter domicil will remain unchanged, regardless of the place of his actual residence. He will retain the domicil he possessed before he became insane, upon the principle that a domicil once acquired is retained until another is gained. ${ }^{12}$

§56. III. Domicil of Choice - Three Essential Elements. - The domicil of origin assigned to an infant immediately upon his birth, upon principles already considered, is retained by him, even after maturity, until another has been acquired. ${ }^{1}$ Unless one is acquired by operation of law in the meanwhile, an infant will always arrive at the age of majority with his original domicil still clinging to him. ${ }^{2}$ From that time, if free from disabilities, he may choose a new home for himself. But it does not follow that he will do so. On the contrary, he will usually retain his original domicil all his life.

The burden of proof is on him who alleges a change of domicil, or in other words there is a prima facie presumption in favor of the retention of a domicil once acquired. This presumption applies not only to the original domicil but to domicils of every sort. ${ }^{3}$

A domicil of choice, as the name implies, means simply that a party is legally competent to exercise his own choice with respect to his permanent home, and has exercised it.

11 Talbot v. Chamberlain, 149 Mass. 57, 59, 3 L. R. A. 254 ; Culver's Appeal, 48 Conn. 165 ; Mowry $v$. Latham, 17 R. I. 480, 23 Atl. 13; Anderson v. Anderson, 42 Vt. 350, 1 Am. Rep. 334 ; Rodgers $v$. Rodgers, 56 Kan. 483, 43 Pac. 779, 781.

12 Bempde v. Johnstone, 3 Ves. Jr. 198, 201 ; Harral v. Harral, 39 N. J. Eq. 379, 51 Am. Rep. 17, 21 ; Rodgers $v$. Rodgers, 56 Kan. 483, 43 Pac. 779, 781 ; Mowry $v$. Latham, 17 R. I. 480, 23 Atl. 13.

1 White $v$. Tennant, 31 W. Va. 790, 8 S. E. 596, 597; Steer's Succession, 47 La. Ann. 1551, 18 So. 503, 505 ; Firth v. Firth, 50 N. J. Eq. 137, 24 Atl. 916, 917.

2 Price v. Price, 156 Penn. St. 617, 27 Atl. 291; Hiestand v. Kuns, 8 Blackf. (Ind.) 345, 46 Anı. Dec. 481.

3 Desmare $v$. United States, 93 U. S. 605 ; Mitchell $v$. United States, 21 Wall. 350 ; Dupuy $v$. Wurtz, 53 N. Y. 556 ; Allgood v. Williams, 92 Ala 551, 8 So. 722 ; Price v. Price, 156 Penn. St. 617, 27 Atl. 291. 
There are three elements which are essential to the acquisition of a domicil of choice: (1) Freedom of choice, without which it would be idle to speak of a domicil of choice; (2) Actual presence in the locality chosen; (3) Intention to remain permanently, without which there would be no "permanent home," as the definition of domicil demands.

Curiously enough however, although all these attributes are essential to the acquisition of a domicil of choice, the domicil when once acquired may continue though all three or any of them be absent. Thus, in order to acquire a domicil of choice, one must of his own free will select it, he must actually be present there, and such presence must be coupled with the intention to remain there permanently. But such domicil having been once acquired thus, will continue until another is gained, though the party be kept there against his will, as by imprisonment, or though, while remaining in the State, he changes his mind about residing there permanently, or even though he leaves the State altogether (no new domicil being acquired).

\$57. Party must be free to choose Domicil. - The first essential of a domicil of choice is that the party should be legally and actually free to choose his own place of abode. If not, no place of residence can be said to be his domicil of choice. Besides the cases of legal disability when a constructive domicil is assigned by the law, such as infants, married women, lunatics, etc., there sometimes occur cases in which, though the party may be under no legal disability, he is in fact deprived of the freedom of volition necessary to the act of choosing his domicil. He does not choose to be where he is; he resides there permanently because he cannot help himself. If he could, he would live elsewhere. Under circumstances such as these, a question may arise as to the place of his domicil.

Instances in which these circumstances are apt to appear are cases of persons imprisoned, exiles, fugitives, and invalids. In all of these cases there is some degree of coercion. They are under the duress of physical confinement, the duress of political power, or the duress of their own fears.

The real question in these cases is not what motive has led the party to make a choice, but whether he has actually chosen 
to reside permanently at the given place. If he has so chosen, the motive which induced him to do so is immaterial. It may even be immoral or illegal. ${ }^{1}$

In the case of a person imprisoned, it is quite obvious that as a general rule his confinement cannot be considered as giving him a domicil of choice in the place of his confinement, if he had it not before. He must be held to retain the domicil previously possessed by him, ${ }^{2}$ unless in fact he becomes so enamored of his prison-house as to determine to remain permanently in that locality. ${ }^{8}$ The application of this latter principle is apparent in the case of one imprisoned for a term of years only, even though he should die while in confinement. And it is be. lieved the same general rule will apply where he is imprisoned for life. But there should be some positive evidence that he has voluntarily made up his mind to live permanently in the place of his confinement. Mere resignation to the inevitable, without the actual mental operation incident to the formation of intention, is not an exercise of choice, and therefore will not suffice."

With respect to exiles, a distinction is to be made between such as are compelled to permanently abandon their country by the command of a superior political power, and those who, because of persecutions and restraints upon liberty, abandon it without compulsion. In the former case the presumption is against a change of domicil, it being never presumed that the exile has abandoned all hope of return. This must be shown by affirmative evidence. ${ }^{5}$

1 Young v. Pollak, 85 Ala. 439, 5 So. 279, 282 ; Hegeman v. Fox, 31 Barb. (N. Y.) 475, 483 ; Fosdick v. Fosdick, 15 R. I. 130, 23 Atl. 140 ; State v. Ross, 76 N. C. 242, 22 Am. Rep. 678, 679; Colburn v. Colburn, 70 Mich. 647, 38 N. W. 607 . See Reed v. Reed, 52 Mich. 117, 17 N. W. 720, 50 Am. Rep. 247, 251; Ennis v. Smith, 14 How. 400, 401; Guarantee Co. v. Bank, $95 \mathrm{Va}$ 480, 28 S. E. 909, 3 Va. Law Reg. 873 . As was said in Chitty v. Chitty, 118 N. C. 647,32 L. R. A. 394,24 S. E. 517 , "the question is one of law, not of morals, and we could not inquire into the latter."

2 Jac. Dom. § 272.

3 Jac. Dom. §§ 272, 273; Gnarantee Co. v. Bank, 95 Va. 480, 28 S. E. 909, 3 Va. Law Reg. 873.

4 Jac. Dom. § 274 . Bat see Whart. Confl. L. \$54.

5 Jac. Dom. $\$ \$ 277$ et seq.; Ennis v. Smith, 14 How. 400; White v. Brown, 1 Wall. Jr. 217, 265; DeBonneval v. DeBonneval, 1 Curteis, 856. 
In the case of fugitives from justice, as in the case of exiles and refugees, there is no presumption indulged of the abandonment of their former homes. An intention to reside permanently in their haven of refuge must be affirmatively shown. ${ }^{6}$

$\$ 58$. Same - Invalids compelled to reside Abroad. - The determination of the domicil of an invalid, compelled by considerations of health to leave his home and reside elsewhere, is often a matter of great perplexity. The principle here is the same as in other cases; the difficulty lies in applying it, in ascertaining the invalid's intention. If his intent is to live permanently in his new abode, the fact that he is impelled to make the choice by reason of fears for his life is immaterial. The motive for his decision will not be inquired into. But he must intend to live at the place to which he goes in search of health. An intention merely to die there is not enough.

Mr. Dicey, with his usual accuracy of thought, has made this matter so plain that it will only be necessary to borrow from him. After noting various confused and confusing dicta on the subject, he says : ${ }^{1}$

"The apparent inconsistency between these doctrines may be removed or explained, if we dismiss all reference to motive, to external necessity, and so forth, avoid the use of the misleading terms 'voluntary' and 'involuntary', and, recurring to the principle that residence combined with the purpose of permanent or indefinite residence constitutes domicil, apply it to the different cases or circumstances under which a domiciled Englishman may take up a foreign residence for the sake of his health."

He then proceeds to give three cases. His first case is that of an Englishman (D) who goes to France for relief from sickness, with the firm intention of residing there six months and no longer. He proceeds: "This case presents no difficulty whatever. $D$ does not acquire a French domicil any more than he does if he goes to France for six months on business or for pleasure. He has not the animus manendi, but the quite

6 Young $v$. Pollak, 85 Ala. 439, 5 So. 279, 282; Chitty v. Chitty, 118 N. C. 647,24 S. E. 517,32 L. R. A. 394 ; Reed v. Reed, 52 Mich. 117, 50 Am. Rep. $247,248,17$ N. W. 720 .

1 Dicey, Confl. L. 144 et sea. 
different intention of staying for a determinate time or definite purpose."

His next case: "D, finding that his health suffers from the English climate, goes to France and settles there, that is, he intends to reside there permanently or indefinitely. $\mathrm{D}$ in this case acquires a French domicil. Here again there is no deviation from general principle. D acquires a French domicil because he resides in France with the animus manendi." 2

His third case: "D goes to France in a dying state, in order to alleviate his sufferings, without any expectation of returning to England.

"This is the case which has suggested the doctrine that a change of residence for the sake of health does not involve a change of domicil. The doctrine itself, as applied to this case, conforms to common sense. It would be absurd to say that D, who goes to $\mathrm{Pau}$ to spend there in peace the few remaining months of his life, acquires a French domicil. But the doctrine in question, as applied to this case, is in conformity not only with common sense, but with the general theory of the law of domicil. D does not acquire a domicil in France because he does not go to France with the intention of permanent or indefinite residence in the sense in which these words are applied to a person settling in another country, but goes there for the definite and determinate purpose of passing in France the few remaining months of his life. The third case, now under consideration, is in its essential features like the first, and not like the second, of the cases already examined. If $\mathrm{D}$ knew for certain that he would die precisely at the end of six months from the day he left England, it would be apparent that the first and third case were identical. That the definite period for which he intends to reside is limited, not by a fixed day, or by the conclusion of a definite piece of business, but by the expected termination of his life, can make no difference in the character of the residence. In neither the first nor the third case is the residence combined with the proper animus manendi. . . . The

2 Hoskins $v$. Matthews, 8 DeG. M. \& G. 13, 25 L. J. (Ch.) 689, 35 Eng. L. \& Eq. 532; Hegeman v. Fox, 31 Barb. (N. Y.) 475. 
dicta of the authorities who lay down that a residence adopted for the sake of health does not involve a change of domicil are obviously delivered by persons who had before their minds the third, not the second, of our supposed cases. These dicta, again, embody what, in reference to such a case, is a perfectly sound conclusion. Their only defect is that they are expressed in terms which are too wide, and which therefore cover circumstances probably not within the contemplation of the authorities by whom they were delivered; and further, that, while embodying a sound conclusion, they introduce an unnecessary and misguiding reference to the motives which may lead to the adoption of a foreign domicil." 3

\$59. Further Elements of Domicil of Choice - Actual Presence and Animus Manendi. - Supposing that nothing appears in the circumstances of a particular case to show a want of freedom of choice, two elements must concur to establish a domicil of choice, namely, actual presence in the country, and the intention to remain there permanently or for an indefinite time at least (animus manendi). Indeed, the first essential referred to in the preceding sections, freedom of choice, is a necessary implication from the requirement of an intention to reside, for there can usually be no real or active intention where there is no freedom of choice. It has been treated separately however for the sake of clearness. In this aspect it may be truly said that wherever the two elements of presence and inteution combine, a domicil of choice is created, and all former domicils are ipso facto abandoned. ${ }^{1}$

It must be observed that neither presence alone, ${ }^{2}$ nor intention alone, will suffice to create a domicil of choice. Both must

3 See Dicey, Confl. L. 145-146 ; Jac. Dom. \$§ 287-296; Johnstone v. Beattie, 10 Cl. \& F. 42, 138; Moorehouse v. Lord, 10 H. L. Cas. 272, 292 ; Anderson $v$. Laneuville, 9 Moore, P. C. 325 ; Hoskins $v$. Matthews, 8 DeG. M. \& G. 13, 28, 25 L. J. (Ch.) 689, 35 Eng. L. \& Eq. 532 ; Dupuy v. Wurtz, 53 N. Y. 556; Hegeman v. Fox, 31 Barb. (N. Y.) 475; Isham v. Gibbons, 1 Bradf. (N.Y.) 69; Mayo v. Equitable Assurance Society, 71 Miss. 590, 15 So. 791 ; Still $\bullet$. Woodville, 38 Miss. 646. See Udny v. Udny, L. R. 1 Sc. App. 441.

1 Dicey, Confl. L. 104 ; Story, Confl. L. $\$ 46$; Jac. Dom. $\$ 125,126$.

- For a qualification of this statement, see post, $\S 64$. 
concur, and at the very moment they do concur the domicil is created. As it is sometimes expressed, the factum (presence) and the animus (intention) must unite. ${ }^{8}$ And thereafter no change of locality alone (there being no change of intent) or vice versa, no change of intention (there being no change of locality), will effect an alteration of the domicil of choice, which remains where it was, until the factum and the animus again unite. ${ }^{4}$

These two essential elements of domicil must now be examined a little more fully.

$\S 60$. Actual Presence. - It is usually said that the elements necessary to the creation of a domicil of choice are residence and the animus manendi. The term "residence," as here used, means simply the actual bodily presence of the party, if that presence is coupled with the intention to remain permanently. It but tends to confusion to designate this presence as a "residence," though in fact and in law it is a residence if it is coupled with the intention to remain.

The possible confusion incident to the use of the term "residence" in this connection is well illustrated by the state of facts in White $v$. Tennant. ${ }^{1}$ In that case the party abandoned his residence in one State, with no intention of resuming it, and

8 Ringgold v. Barley, 5 Md. 186, 59 Am. Dec. 107, 109; Hairston v. Hairston, 27 Miss. 704, 61 Am. Dec. 530 ; Mitchell v. United State8, 21 Wall. 350 ; Allgood $v$. Williams, 92 Ala. 551, 8 So. 722 ; Price $v$. Price, 156 Penn. St. 617, 27 Atl. 291 ; White $v$. Tennant, 31 W. Va. 790, 8 S. E. 596, 597 ; Dupuy v. Wurtz, 53 N. Y. 556; De Meli v. De Meli, 120 N. Y. 485, 491 ; City of Hartford v. Champion, 58 Conv. 268, 20 Atl. 471, 473-474; Shaw $v$. Shaw, 98 Mass. 158.

4 Dupuy v. Wurtz, 53 N. Y. 556 ; De Meli v. De Meli, 120 N. Y. 485, 491 ; Vischer v. Vischer, 12 Barb. (N. Y.) 640 ; Steer's Succession, 47 La. Ann. 1551, 18 So. 503, 504; Mayo v. Equitable, etc. Society, 71 Miss. 590, 15 So. 791 ; Hart v. Lindsey, 17 N. H. 235, 43 Am. Dec. 597, 601 ; Lowry v. Bradley, 1 Speer's Eq. (S. C.) 1, 39 Am. Dec. 142, 143-144.

131 W. Va. 790,8 S. E. 596, 597. See also Hill v. Hill, 166 Ill. 54, $46 \mathrm{~N}$. E. 751. The difficulty, where the term "residence" is used, is that there is an implication that the stay must be more or less protracted, and that if merely momentary, even though there exists at the time an intention to remain permanently, it will not suffice to create a domicil. The reverse of this is true, however, as shown by the above cases. 
went with his family to a house in another State where he intended to reside thereafter. After he and his family arrived at their new house, only about one half mile from the State line, they deposited their baggage, and returned the same day to spend the night with a relative residing across the line in the State of their former home, intending to return the following morning. But the man was detained there by sickness and subsequently died there, never having returned to his new home, and never having in fact resided there. The court however held him domiciled in the State of his new home, because, though he had never actually lived there, he had been physically present there with the intention forthwith to make it his permanent home. ${ }^{2}$

Since physical presence (coupled with the animus manendi) is all that is required, it is immaterial to inquire whether the party is living in a house of his own, in a rented house, in a hotel, in lodgings, or has no place to lay his head. These may be, and often are, of the greatest importance as evidences whereby to determine whether he has the proper animus; but if that is established otherwise they become unimportant. ${ }^{3}$

But it must not be supposed that the physical presence must continue in order to the formation of the domicil of choice. At the moment when a party, being present in a place, forms the definite intention to remain there permanently, from that moment a domicil of choice is created, which will in general continue until a new domicil is acquired, though the party for a long period absents himself, or though he is actually there for ever so short a time. ${ }^{4}$

2 See also Lowry $v$. Bradley, 1 Speer's Eq. (S. C.) 1, 39 Am. Dec. 142, 144.

${ }^{8}$ Guier $v$. O'Daniel, 1 Binn. (Penn.) 349, note. See ante, $§ 24$.

4 Dicey, Confl. L. 107. Mr. Dicey names "residence" as the first essen. tial of domicil, defining it as "habitual physical presence in a country," and then finds it necessary to define "habitual." It is submitted that the word "habitual" is unnecessary. All such qualifications tend to confound the factum with the animus, and also tend to confuse the creation of the domicil with its continuance, which latter is presumed generally, until physical presence elsewhere coupled with the animus manendi creates a new domicil. See Hart v. Lindsey, 17 N. H. 235, 43 Am. Dec. 601 ; Lowry v. Bradley. 1 Speer's 
Physical presence in a country is a tangible fact, and may be proved, like other facts of that kind, by the testimony of eyewitnesses or by circumstantial evidence. It is susceptible of easier proof than the animus, because it is tangible, visible, and more or less notorious, ${ }^{5}$ while the intention, being rarely expressed, must usually be inferred from the acts of the parties or from surrounding circumstances.

Circumstantial evidence is seldom needed to prove the fact of presence. If such evidence is called for, it will usually be by reason of uncertainty as to the party's identity. In most cases where a question of domicil is raised, the dispute is not with regard to the party's presence, but with respect to the intention. ${ }^{6}$

$\S 61$. The Animus Manendi. - The last essential of a domicil of choice is the intention to remain permanently or for an indefinite time. The intention should not be to remain for a fixed period (however long) and then to move away. There must be a fixed and definite purpose to remain permanently, or at least for an unlimited or indefinite time, without any definite intention of ultimate removal. ${ }^{\mathrm{I}}$

But it is not necessary that there should be a fixed intention to remain during one's whole life. A mere floating intention to return to a former home or to live elsewhere at some future period unfixed and contingent upon circumstances, as upon an indefinite restoration to health or when one's fortune has been made, will not prevent the acquisition of a domicil at the new

Eq. (S. C.) 1, 39 Am. Dec. 142, 143-144; White v. Tennant, 31 W. Va. 790, 8 S. E. 596, 597 ; Hairston $v$. Hairston, 27 Miss. 704, 61 Am. Dec. 530 ; Price v. Price, 156 Penn. St. 617, 27 Atl. 291 ; Hill v. Hill, 166 Ill. 54, 46 N. E. 751 ; State $v$. Palmer, 65 N. H. 9, 17 Atl. 977.

5 Gilman $v$. Gilman, 52 Me. 165, 83 Am. Dec. 502, 508 ; Jac. Dom. $§ 364$.

6 Jac. Dom. $§ 364,365$.

1 Allgood v. Williams, 92 Ala. 551, 8 So. 722 ; Young v. Pollak, 85 Ala. 439, 5 So. 279, 282 ; Hairston v. Hairston, 27 Miss. 704, 61 Am. Dec. 530 ; Price $v$. Price, 156 Penn. St. 617, 27 Atl. 291; Hood's Estate, 21 Penn. St. 106, 116; Firth v. Firth, 50 N. J. Eq. 137, 24 Atl. 916, 917 ; Harral v. Harral, 39 N. J. Eq. 379, 51 Am. Rep. 17, 21 ; Hill v. Hill, 166 Ill. 54, 46 N. E. 751, 752; Dupuy v. Wurtz, 53 N. Y. 556 ; Vischer $v$. Vischer, 12 Barb. (N. Y.) 640, 643 ; Jennison v. Hapgood, 10 Pick. (Mass.) 77, 98, 19 Am. Dec. 258 ; Lowry $v$. Bradley, 1 Speer's Eq. (S. C.) 1, 39 Am. Dec. 142, 144 ; City of Hartford $v$. Champion, 58 Conn. 268, 20 All. 471, 473. 
abode. $^{2}$ The intention however must be settled and fixed. The party must have definitely made up his mind to remain. A mere probability, however great, that he will stay, or an intention conditional upon a contingency, such as his obtaining employment, finding the climate suitable to his health, or liking the people of the community, will not suffice. ${ }^{3}$

The latter case is to be distinguished from that of one who, induced by the probability of finding employment, a suitable climate, etc., definitely determines to live permanently in a particular spot. In the former case the definite animus has not been formed. In the latter, it has been formed, though induced by probabilities only.

$\S 62$. Commencement of the Intention. - The animus manendi alone is not sufficient to constitute a domicil of choice, nor is mere physical presence enough. Both must unite. The moment that both exist at the same time the domicil is created.

Hence no formation of an intention is of avail unless and until it is accompanied by physical presence. Though one breaks up his home in one State, intending to remove to another, but in itinere changes his mind before reaching the latter State, he cannot be held to have been domiciled there. He retains his abandoned domicil until he acquires another facto et animo. ${ }^{1}$

2 Story, Confl. L. $\S 46$; Hoskins v. Matthews, 25 L. J. (Ch.) 689,8 DeG. M. \& G. 13, 35 Eng. L. \& Eq. 532 ; Brunel v. Brunel, L. R. 12 Eq. 298 ; Steer's Succession, 47 La. Ann. 1551, 18 So. 503, 505; Larquie $v$. Larquie, 40 La. Ann. 457, 4 So. 335, 336-337; Hallett v. Bassett, 100 Mass. 167; Holmes $v$. Greene, 7 Gray (Mass.), 299; Whitney $v$. Sherborn, 12 Allen (Mass.), 111, 114 ; Williams $v$. Saunders, 5 Coldw. (Tenn.) 60, 79 ; White $v$. Tennant, 31 W. Va. 790, 8 S. E. 596, 597; Ringgold $v$. Barley, 5 Md. 186, 59 Am. Dec. 107, 109 ; Firth v. Firth, 50 N. J. Eq. 137, 24 Atl. 916, 917 ; Harral $v$. Harral, 39 N. J. Eq. 379, 51 Am. Rep. 17, 21 ; Hart $v$. Lindsey, 17 N. H. 235, 43 Am. Dec. 597, 601.

3 Ross $v$. Ross, 103 Mass. 576, 577; Whitney $v$. Sherborn, 12 Allen (Mass.), 111, 114 ; Mayo $v$. Equitable, etc. Society, 71 Miss. 590, 15 So. 791, 792 ; Smith $v$. People, 44 Ill. 23.

4 See Hegeman $v$. Fox, 31 Barb. (N. Y.) 475, 483-484.

1 Steer's Succession, 47 La. Ann. 1551, 18 So. 503; Borland v. Boston, 132 Mass. 89, 42 Am. Rep. 424 ; Shaw $v$. Shaw, 98 Mass. 158 ; Otis $v$. Boston, 12 Cush. (Mass.) 44 ; Ringgold $v$. Barley, 5 Md. 186, 59 Am. Dec. 107, 109. See White $v$. Tennant, 31 W. Va. 790,8 S. E. $596,597$. 
Some question has been raised whether the same principle will apply where the emigrant, instead of changing his mind, dies in itinere. Some most respectable authority seems to favor a change of domicil in such case. ${ }^{2}$ But it is believed there is no sound principle upon which this exception to the general rule can be predicated, and the weight of authority is against it. ${ }^{8}$

Again, an intention, though definitely fixed, to reside in a given State at a future time, even though it be in the immediate future, and though coupled with actual presence there at the time of the formation of the intent, will not suffice to constitute a domicil of choice. The presence must be coupled with the intent to reside there from that moment. ${ }^{4}$

Thus, one who contemplates moving from one State to another

2 White v. Tennant, 31 W. Va. 790, 8 S. E. 596, 597. See Story, Confl. L. $\$ \$ 47,48$; Munroe v. Douglas, 5 Madd. 405 . Judge Story however here applies this principle only in case the party is returning from a foreign domicil of choice to his original or native domicil, but he does not confine it to the case of death in itinere. He admits the doctrine in any case where a party leaves a foreign domicil of choice on a final return to his original domicil, basing it upon the maxim that the domicil of origin easily reverts. See post, $\S \S 65,66$.

8 Bell v. Kennedy, L. R. 3 H. L. 323 ; Brace v. Bruce, 2 Bos. \& Pul. 229, 230, note; Shaw v. Shaw, 98 Mass. 158 ; Harvard College v. Gore, 5 Pick. (Mass.) 370.

4 See Otis $v$. Boston, 12 Cush. (Mass.) 44. The case of White $v$. Tennant, 31 W. Va. 790,8 S. E. 596, 597, is not opposed to this view, though at first sight it appears to be. In that case, the party broke up his establishment in West Virginia and removed to a house across the State line in Pennsylvania, which he had already rented. Upon leaving his West Virginia honse in the morning, he intended to make the Pennsylvania house forthwith his home, intending to remain there thenceforward. But after arriving there he decided to return for the night to his brother's house in Pennsylvania, where he was taken ill and died, without ever having returned to the Pennsylvania house. It was held he was domiciled in Pennsylvania. This decision was clearly correct. The physical presence in Pennsylvania united with the intention to reside there permanently from that moment. His subsequent decision to return for the night to West Virginia did not affect the question. If when he started ont that day from the West Virginia house he had had the intention not to begin his residence in the Pennsylvania house until the following morning, the decision would probably have been different. 
and goes thither to select a suitable dwelling before moving, will not by that act alone be held to have acquired a domicil there. His intention to reside will be regarded as conjectural merely, and not definite enough to create a domicil; nor has he in such case as yet finally abandoned his former domicil. ${ }^{5}$ But if under like circumstances, before he goes into the new State upon his tour of investigation, he breaks up his establishment in his former domicil entirely, even though he does not bring his family with him but sends them to a third State pending his selection of a dwelling-place, so that he does not anticipate returning to his former domicil at all, it is said that he will acquire a new domicil even before a final settlement, for he has definitely abandoned his former domicil. ${ }^{6}$

On the other hand, it is not essential to the creation of a domicil of choice that the intention should be formed immediately upon one's entry into a State. The mere presence there will not suffice of itself; there must be an intention also, and until both concur no domicil arises. But the intention may spring up later, and if the actual presence continues at that time the new domicil is at that instant acquired. ${ }^{7}$

§63. Duration of the Intention. - A domicil once created is retained until another is acquired, which in the case of a domicil of choice can in general only be facto et animo. If the purpose to remain in a country permanently has once existed, and while in existence was coupled with actual physical pres-

5 Behrensmeyer $v$. Kreitz, 135 Ill. 591, 26 N. E. 704; Cooper v. Beers, 143 IIl. 25,33 N. E. 61 . See Bruce $v$. Bruce, 2 Bos. \& Pul. 229, 230, note; Guier v. O'Daniel, 1 Binn. (Penn.) 349, note.

6 Behrensmeyer $v$. Kreitz, 135 Ill. 591, 26 N. E. 704. See Cooper $v$. Beers, 143 Ill. 25, 33 N. E. 61 . In the latter case, it seems from the opinion that there had been no actual breaking up of the establishment in St. Louis (the parties' former home). The court says : "No act intended as an act of removal or in aid of removal to Illinois is proved." If the proposition mentioned in the text is true, a fortiori would it apply if the party brings his family with him to the State of his intended residence. See White $v$. Tennant, 31 W. Va. 790, 8 S. E. 596. The whole principle howerer must be taken in subordination to what has been said ante, $\$ 24$.

7 Udny v. Udny, L. R. 1 Sc. App. 441, 458. See Colburn v. Holland, 14 Rich. Eq. (S. C.) 176, 233. 
ence there, a domicil of choice arises. And since it can be changed thereafter only by the acquisition of a new domicil in the same way, ${ }^{1}$ it follows that no subsequent change of intention (alone), though the change take place the next day or the next moment, will effect a change of domicil.

We may even go a step further and lay it down as a corollary that though physical absence from the country be united with an intention to make that country no longer the party's home, the domicil will not in general be thereby destroyed. These mere negative propositions will effect no change of domicil. The propositions must be affirmative. The party must not only be absent from his former home, but must be present in the new; he must not only intend not to make the former home his permanent abode hereafter, but must affirmatively intend to make the new home his permanent abiding place. And both these affirmative propositions must coexist. ${ }^{2}$

$\S 64$. Evidence of Animus Manendi. - As in all questions of intention, it is often extremely difficult to arrive at a certain conclusion touching the animus manendi in cases of domicil. Much of the difficulty in ascertaining the domicil arises from this source. The trouble for the most part lies in the fact that the intention is rarely expressed, and must be inferred from all the surrounding circumstances.

The question in such cases is not what the party has said, but what was his real intention. The fact that one openly proclaims a place to be his permanent home does not make it so unless in fact the intention to reside there permanently exists. In general, however, the declarations of the party are admitted in evidence of the intention, as part of the res gestce. ${ }^{1}$

1 A modification of this principle may be noted in the case of a party who abandons a foreign domicil of choice, purposing to return to the country of which he is a citizen. See post, $\S 66$.

2 See City of Hartford v. Champion, 58 Conn. 268, 20 Atl. 471; Dupuy v. Wurtz, 53 N. Y. 556 ; Jennison v. Hapgood, 10 Pick. (Mass.) 77, 98, 19 Am. Dec. 258; Shaw v. Shaw, 98 Mass. 158; Price v. Price, 156 Penn. St. 617, 27 Atl. 291 ; Cooper $v$. Beers, 143 IIl. 25, 33 N. E. 61; Mitchell v. United States, 21 Wall. 350.

1 Jac. Dom. $\S \S 449$ et seq., to which the reader is referred for a full 
Frequently there are no declarations, or they are ambiguous or untrustworthy as evidence. In such cases the courts are compelled to rely upon the acts of the party and the surrounding circumstances. In the decision of this question there are no points in a man's life, however trifling they may appear, which may not be examined. Amongst the acts and circumstances which have been considered by the courts in the determination of domicil are the exercise of the voting franchise; ${ }^{2}$ the payment of taxes on personalty; ${ }^{3}$ the ownership of a place of residence or of business $;{ }^{4}$ continued residence in a country $;{ }^{5}$ attendance upon a church, and active participation in its affairs; ${ }^{6}$ and various other circumstances of themselves trivial but sufficient to turn

discussion. See Guier v. O'Daniel, 1 Binn. (Penn.) 349, note; Wilson $v$. Terry, 11 Allen (Mass.), 206 ; Holmes v. Greene, 7 Gray (Mass.), 299, 300 ; Viles v. Waltham, 157 Mass. 542, 32 N. E. 901 ; Thorndike $v$. Boston, 1 Met. (Mass.) 242 ; Mitchell $v$. United States, 21 Wall. 350 ; Ennis v. Smith, 14 How. 400, 401 ; Hairston v. Hairston, 27 Miss. 704, 61 Am. Dec. 530 ; Steer's Succession, 47 La. Ann. 1551, 18 So. 503, 506; Robert's Will, 8 Pai. Ch. (N. Y.) 519 ; Hegeman v. Fox, 31 Barb. (N. Y.) 475, 478-479; Fulham v. Howe, 62 Vt. 386, 20 Atl. 101. But see Wright $v$. Boston, 126 Mass. 161; Ayer $v$. Weeks, 65 N. H. 248, 18 Atl. 1108.

2 Jac. Dom. $\$ 435$ et seq.; Mitchell v. United States, 21 Wall. 350 ; Steer's Succession, 47 La. Ann. 1551, 18 So. 503, 506. Voting has even been said to be conclusive evidence of the party's intention to remain permanently, since there should be no presumption of fraud on the part of the voter. See Shelton $v$. Tiffin, 6 How. 163 . But the weight of authority is in favor of its being considered only prima facie evidence of the animus manendi, since it may result from fraud or from the voter's bona fide mistake as to his legal rights. East Livermore v. Farmington, $74 \mathrm{Me}$. 154 ; Easterly v. Goodwin, 35 Conn. 279 ; Hayes $v$. Hayes, 74 Ill. 312 ; Folger $v$. Slaughter, 19 La. Ann. 323.

3 Jac. Dom. $\S 442$ et seq.; Mitchell $v$. United States, 21 Wall. 350 ; Harvard College v. Gore, 5 Pick. (Mass.) 370. Such property is liable to taxation generally at the domicil of the owner.

${ }^{4}$ Some authorities are inclined to give these last preponderating weight. See Story, Confl. L. $\S ~ 46,47$. But though raising strong presumptions, they are not conclusive. Jac. Dom. $\$ \S 401,410$ et seq.

5 Dupuy v. Wurtz, 53 N. Y. 556; Elbers v. Ins. Co. 16 Johns. (N. Y.) 128 ; Mowry v. Latham, 17 R. I. 480, 23 Atl. 13 ; Ennis v. Smith, 14 How. 400 , 401 ; Shelton $v$. Tiffin, 6 How. 163. But see Jopp $v$. Wood, 4 DeG. J. \& S. 616,622 .

- Fulham $v$. Howe, 62 Vt. 386, 20 Atl. 101. 
the scale in a close case, many of which will be found enumerated in more copious treatises on the subject of Domicil.?

There is one combination of circumstances which deserves special attention in this connection and has given the courts much trouble. It is the case of double residence.

A person may have two residences between which he divides his time. Since he can have only one domicil, it is often difficult to tell which should be so regarded. If one is his principal establishment, the other being used only for short periods of the year, the first will clearly be the place of his domicil. ${ }^{8}$ Or if one is his residence and the other his place of business, though he actually spends more time at the latter, there can be no doubt that the first is his domicil. ${ }^{\circ}$ But if both are residences, and he passes about an equal portion of the year in each, with his family and establishment, it often becomes extremely difficult to decide which is his domicil. Great weight in these doubtful cases should be attached to the presumption of the retention of a prior domicil, and unless the evidence clearly predominates in favor of the home last acquired, the presumption should be in favor of the first as the party's domicil. ${ }^{10}$

In the absence of any circumstances from which the courts may infer the animus, they are accustomed to fall back on two legal presumptions, without which it would in some cases be impossible to arrive at any conclusion as to a party's domicil.

The first of these is the presumption that the party has retained the last domicil known to have been possessed by him. 'This follows from the principle that a domicil once acquired is retained until another is gained, and from the other principle growing out of it that the burden of proof is on him who alleges a change of domicil."

7 See Jac. Dom. ch. xxii et seq. ; Whart. Confl. L. \$§ 63 et seq. ; Dicey, Confl. L. 134, 135; Story, Conft. L. \$§ 46-49.

8 Thayer $v$. Boston, 124 Mass. 132.

9 Ibid.

10 See Jac. Dom. §§ 422, 423 ; Gilman v. Gilman, 52 Me. 165, 83 Am. Dec. 502, 507. In Chenery $v$. Waltham, 8 Cush. (Mass.) 327, a curious instance of double residence occurred, the dividing line between two towns running through a man's house. See Jac. Dom. $\$ 425$.

11 Dicey, Confl. L. 133 ; ante, $\$ \S 29,56$. 
The second is the presumption of domicil inferred from mere presence in a country, in the absence of evidence to the contrary.

We have already seen that residence in a country may se ground to infer the animus manendi, in the absence of evidence to the contrary. ${ }^{12}$ This second presumption proceeds a step further, and provides for those cases (otherwise not to be solved) in which all that is known of the party is that he is found in a particular State. A newborn child may be laid at some one's door, or a stranger may be found dead, leaving no clue to identify him. In these cases, there being no evidence upon which to base an opinion, since according to the general principle no person can ever be without a domicil, the law must rely upon the weak presumption afforded by mere presence there. There is no ground upon which to fix his domicil elsewhere. ${ }^{18}$

$\S 65$. Effect of Abandonment of Domicil - Conflicting views. - In the case of the domicil of origin, it is very clear that the intention to abandon it permanently, even when coupled with an actual abandonment thereof in pursuance of such intention, will not cause it to be lost, provided the party does not acquire a new domicil, for no person can be without a domicil, and there is none other that can be assigned him. ${ }^{1}$

But if the abandoned domicil be not the domicil of origin, it is possible for his original domicil to be assigned him. Even though no new domicil be acquired, the party will always have

12 Dupuy v. Wurtz, 53 N. Y. 556 ; Elbers v. Ins. Co., 16 Johns. (N. Y.) 128 ; Mowry v. Latham, 17 R. I. 480, 23 Atl. 13 ; Ennis v. Smith, 14 How. $400,401$.

13 Dicey, Confl. L. 132-133; Jac. Dom. $\S \S 375,376$; Bempde v. Johustone, 3 Ves. Jr. 198 ; Bruce _. Bruce, 2 Bos. \& Pul. 229, 230, note ; Taylor $v$. Sharp, 108 N. C. 377, 13 S. E. 138 ; Guier v. O'Daniel, 1 Binn. (Penn.) 349, note. See Flood $v$. Growney, 126 Mo. 262, 28 S. W. 860 . We have seen the application of this principle to determine the original domicil of foundlings, ante, $\S 34$.

1 De Meli v. De Meli, 120 N. Y. 485, 491; Price $v$. Price, 156 Penn. St. 617, 27 Atl. 291; Hallett $v$. Bassett, 100 Mass. 167 ; Shaw $v$. Shaw, 98 Mass. 158 ; Jennison $v$. Hapgood, 10 Pick. (Mass.) 77, 98, 19 Am. Dec. 258; Har. vard College v. Gore, 5 Pick. 370 ; Bell $v$. Kennedy, L. R. 3 H. L. 307 . But see In re Rice, 42 Mich. 528, 4 N. W. 284. 
his domicil of origin in reserve, which he may consider his home. In such case therefore the question arises, Shall the presumption of the retention of the last domicil be respected? Shall the party, having voluntarily abandoned a foreign domicil, be considered as still residing there, contrary to the notorious fact and to his evident desire and intention, merely because he has not yet made a home for himself elsewhere? Or shall he be presumed (for the nonce) to have resumed his original and native domicil ?

The English authorities are in favor of the latter view, holding one who has abandoned a foreign domicil but has not acquired a new one to have resumed ipso facto his domicil of origin, though he has no intention of actually returning thither. ${ }^{2}$

Mr. Jacobs considers the American doctrine to be that the domicil of origin reverts only in the single case where the party, npon an abandonment of his foreign domicil, sets out to return to his original domicil; he then acquires as his domicil, even in itinere, the domicil of origin. ${ }^{8}$ But it cannot be doubted that the great current of American authority lays down the principle without qualification that a domicil oneo-acquired by one sui juris is retained, even after abandenment, until another is acquired facto et animo, and no hint is given of any exception."

The cases cited (by no means an exhaustive collectiou) are believed to establish the American doctrine in favor of the retention of the formex-domicit in all cases until another is acquired animo et facto.

2 Dicey, Confl. L. 117, 118 ; Udny v. Udny, L. R. 1 Sc. App. 441, 454 See also Story, Confl. I. $\S 48$; The Venus, 8 Cr. 253.

3 Jac. Dom. § 201. See also Story, Confl. L. $\$ 47$.

4 Mitchell v. United States, 21 Wall. 350; Desmare $v$. United States, 93 U. S. 605 ; Allgood $v$. Williams, 92 Ala. 551, 8 So. 722 ; Lowry $v$. Bradley, 1 Speer's Eq. (S. C.) 1, 39 Am. Dec. 142 ; Price v. Price, 156 Penn. St. 617, 27 Atl. 291; City of Hartford v. Champion, 58 Conn. 268, 20 Atl. 471; Olson's Will, 63 Ia. 145, 18 N. W. 854 ; Hood's Estate, 21 Penn. St. 106 ; Williams $v$. Saunders, 5 Coldw. (Tenn.) 60, 79, 80 ; Harvard College $v$. Gore, 5 Pick. (Mass.) 370; Shaw v. Shaw, 98 Mass. 158; Vischer v. Vischer, 12 Barb. (N. Y.) 640, 643. Indeed, in Harvard College v. Gore, supra, the court expressly disapproves such an exception. 
§ 66. Same - A Solution suggested. - Mr. Jacobs has pointed out some strong objections to the English view of the reverter of the original domicil, ${ }^{1}$ and the English judges have denounced the American rule as entirely irrational. ${ }^{2}$ Indeed objection, more or less pronounced, may be taken to all the theories mentioned in the preceding section.

There is another theory, not specifically adverted to by the authorities, which is submitted as being logical and at the same time going far to reconcile the conflicting views, lying as it does between the extremes.

A distinction should be taken between those cases where the party's ties to the original domicil may be presumed to be close and those where they are of a slight character: between those cases where the party owes allegiance to, and is a citizen of, the country of his origin, whither his thoughts would naturally turn, and those cases where he has either never owed such alleyiance to that country or else has thrown it off by naturalization elsewhere.

It is manifest that an Englishman, born in England of parents domiciled there, who lives there until he is twenty-one, but who subsequently changes his domicil to Holland, ${ }^{8}$ would regard hinself, if he should abandon his Dutch domicil, still an Englishman, and his home as in England until he selects another (though he does not return thither). ${ }^{4}$ In such case, it is plainly reasonable that the law should not compel him to retain his Dutch domicil and be governed in many respects by its laws, after he has deliberately abandoned it. On the contrary, it would be natural and just to infer that he intends to resume his English domicil of origin in the interim, though he does not actually return to England and does not intend to do so. The question is not whether he intends to live in England, but whether he intends to place himself in the same position he would have occupied if he had acquired no domicil of choice.

1 Jac. Dom. § 199.

2 Udny v. Udny, L. R. 1 Sc. App. 441.

3 This is the case suggested by Lord Westbury in Udny v. Udny, L. R. 1 Sc. App. 441.

4 This case is adduced in Udny $v$. Udny, supra, against the retention theory. 
Now let us suppose the same Englishman to be born of English parents, domiciled at the time of his birth in America, who shortly afterwards return to England to live, and there bring up their son, the other circumstances remaining the same. ${ }^{6} \mathrm{He}$ bas no ties of allegiance or connection with America. There is no logical reason here to suppose that, having abandoned his Dutch domicil as before, he would look upon America, his accidental domicil of origin, as his home, rather than England. ${ }^{6}$

Or if his domicil of origin be English, but he (or his parents for him), having in childhood or after maturity deliberately severed the ties of allegiance that bind him to that country, becomes a naturalized citizen of the United States, and then (as before) acquires and abandons his Dutch domicil, why should the law presume that he regards England as his home, whose allegiance he has cast off, rather than America, whose citizen he is? In such case, England certainly has the least claim of any of the States concerned.

The true theory (if we do not accept citizenship in all such cases as the true basis ${ }^{7}$ ), it is submitted, is that, upon an abandonment of a foreign domicil, none being actually acquired elsewhere, the original domicil is resumed, if it be the State whereof the party is a citizen (whether native or naturalized), for the law may justly presume him when homeless to look upon that country as his home. But if he were never a citizen of the country wherein is his domicil of origin, or if he has since become a naturalized citizen of another, the reason ceases for this exception to the general rules regulating the acquisition of domicil, and the doctrine of the retention of the domicil, until a new one is acquired facto et animo, will apply.

This is in accord with the great mass of American authority, which, as we have seen, pays little heed to the English principle

5 This is in substance the case supposed by Mr. Jacobs to illustrate the irrational character of the English doctrine of reverter of original domicil. See Jac. Dom. § 199.

8 See Douglas $v$. Douglas, L. R. 12 Eq. 617, 643.

7 The most reasonable doctrine is to adopt citizenship in this instance as the criterion of domicil, under ell circumstances, but as yet none of the au. thorities have gone so far. 
of the reverte $y$ of the original domicil. For with us, a citizen of the United States, no matter where his domicil of origin, is a sitizen of the State wherein he resides (or is domiciled). Hence, upon the principle above mentioned, a citizen of the United States, whose original domicil is in one State, who acquires a domicil of choice in another, which he subsequently abandons (acquizing no new domicil elsewhere) should not resume his domicil of origin in the interim, but should retain his last domicil until he actually acquires another facto et animo. For, when he abandons the State of his original domicil and becomes domiciled in another State of the Union, he ipse facto abandons his citizenship of the first State also, and there is no ground upon which to base a presumption of the reverter of the original domicil. The case is thus seen to be similar to that, above adverted to, of the Englishman who abandons his Dutch domicil of choice, after becoming a naturalized American citizen. ${ }^{9}$

In Udny $v$. Udny, ${ }^{10}$ Lord Westbury criticises a doctrine nearly approaching this laid down in First Nat. Bank $v$. Balcom, ${ }^{11}$ declaring that to so hold "is to confound the political and civil states of an individual, and to destroy the difference between patria and domicilium."

8 U. S. Const. Amendment XIV.

9 It is worthy of remark that some of the American courts seem to have taken this view. First Nat. Bank $v$. Balcom, 35 Conn. 351; Steer's Succession, 47 La. Ann. 1551, 18 So. 503, 504; In re Rice, 42 Mich. 528, 4 N. W. 284. But see dictum in Allen $v$. Thomason, 11 Humph. (Tenn.) 536, 54 Am. Dec. 55, 57, quoting Story, Confl. L. $\$ 47$. Story's view, it is believed, is not far removed from that above given. He says $(\$ 48)$ : "A national character acquired in a foreign country by residence changes when the party has left the country animo non revertendi, and is on his return to the country where he had his antecedent domicil. And especially if he be in itinere to his native country with that intent, his native domicil revives while he is yet in transitu, for the native domicil easily reverts. The moment a foreign domicil is abandoned, the native domicil is reacquired."

10 L. R. 1 Sc. App. 441, 460.

1135 Conn. 351. In that case the court uses the following language, which was the subject of Lord Westbury's animadversion: "The principle that a native domicil easily reverts applies only to cases where a native citizen of one country goes to reside in a foreign country, and there acquires a domicil by residence without renouncing his original allegiance. In such cases his 
With all the deference due to such eminent authority, .t is submitted that to advert to citizenship as a means of determining the probable intention and wishes of the party is not to confound citizenship with domicil, but, on the contrary, to recognize them as distinct, and from the natural influence of nationality or citizenship to deduce the probable intention to resume the domicil of origin or not to resume it.

There are other instances in which the probability of an intention or a desire to consider a particular country as one's permanent home supplies a rule whereby to ascertain the constructive domicil, as in the case of infants and married women.

And the effect of a probability of one's desire to resign his domicil of origin on account of citizenship in another country is expressly recognized in several cases as entitled to great weight. ${ }^{12}$

There seems therefore to be no valid reason why the probability of one's desire to resume his domicil of origin, upon the abandonment of a domicil of choice, should not in like manner be inferred from his citizenship in the former country. And on the other hand, in the absence of the probability of such desire: there is no reason to imply it.

§67. Situs (or Domicil) of Corporations. - There is, strictly speaking, no such thing as the "domicil" of a corporation, for it can have no permanent home in the ordinary and usual meaning of the term. But a corporation, like every other thing, act, or circumstance known to the law, may and must have a situs.

The situs of a corporation, like that of a natural person,

native domicil reverts as soon as he begins to execute an intention of returning; that is, from the time be puts himself in motion bona fide to quit the country sine animo revertendi, because the foreign domicil was merely adventitious and de facto, and prevails only while actual and complete. . . . This principle has reference to a national domicil in its enlarged sense, and grows out of native allegiance or citizenship. It has no application when the question is between a native and acquired domicil, where both are under the same national jurisdiction."

12 Sharpe v. Crispin, L. R. 1 P. \& D. 611, 621; Douglas v. Douglas, L. R. 12. Eq. 617, 643; Otis v. Boston, 12 Cush. (Mass.) 44 ; Greene v. Greene, 11 Pick. (Mass.) 409, 415. 
may be either actual or legal. It is the legal situs with which we now have to do, which is generally styled, inaccurately, the domicil of the corporation. It is not such, however, in the full sense of the term, and hence the rules for ascertaining the so-called domicil of a corporation, though in large measure analogous to those by which the natural person's domicil is determined, are by no means identical with them.

The general rule is well settled that a corporation is " domiciled "or has its legal situs in the State where it is incorporated, not where its stockholders reside. ${ }^{1}$ And it does not change its domicil by merely doing business elsewhere. Its actual situs (through its agents) may be in the latter place, but its legal situs is unchanged. ${ }^{2}$

But if a corporation is chartered in several States successively, as sometimes in the case of railroad companies, it becomes a citizen of each of those States, and thus may, unlike an individual, have several domicils at the same time. ${ }^{8}$

1 B. \& O. R. R. Co. v. Glenn, 28 Md. 287, 92 Am. Dec. 688 ; Boehme $v$. Rall, 51 N. J. Eq. 574, 26 Atl. 832; Chafee v. Bank, 71 Me. 514, 36 Am. Rep. 345, 351 ; Chamberlain $v$. Chamberlain, 43 N. Y. 424, 432; Bank of Augusta $v$. Earle, 13 Pet. 520, 586, 587 ; B. \& O. R. R. Co. v. Koontz, 104 U. S. 10, 11 ; Douglas v. Ins. Co., 138 N. Y. 209, 33 N. E. 938 ; Boston Investment Co. v. Boston, 158 Mass. 461 ; Railroad Co. v. Barnhill, 91 Tenn. 395, 19 S. W. 21 ; Memphis, etc. R. Co. v. Alabama, 107 U. S. 581.

2 Faulkner v. Hyman, 142 Mass. 53, 55; Chamberlain v. Chamberlain, 43 N. Y. 424, 432; Chafee $v$. Bank, 71 Me. 514, 36 Am. Rep. 345, 351 ; Bank of Augusta $v$. Earle, 13 Pet. 520, 586.

8 See Whart. Confl. L. $\$ 48 a$; B. \& O. R. R. Co. •. Glenn, 28 IId. 28j, 92 Am. Dec. 688. 


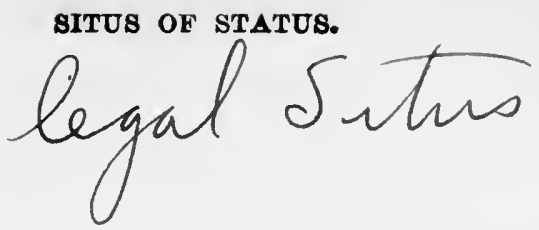

\section{P A R T III.}

\section{SITUS OF STATUS.}

\section{\$68. Preliminary - Situs of Status follows the Situs of the} Person. - The attributes and qualities attached to a person by operation of law,-regardless of his own wishes, constitute his status in law. As well defined in a leading English case: ${ }^{3}$ "The status of an individual, used in a legal sense, is the lega relation in which that individual stands to the rest of the community." 2

These legal relations may be various. One who is under age does not occupy the same relation to the rest of the community as one who is an adult: the relations of a single man differ from those of one who is married; one who is competent to transact business occupies a different relation from one who is not; a legitimate or adopted child from one who is not; a ward from one who is not under guardianship; a fiduciary from one who is acting for himself, etc. All these and others that need not be enumerated are instances of status.

It is natural and proper that these personal attributes or qualities, grouped under the generic term status, should follow the person to whom they are attached, and should in the main be regulated and governed by the same law that governs him. Indeed, for the most part, it is through these qualities and attributes that a particular law can be said to govern a person at all. The law which governs the person is in general the law of his situs. Hence the law governing the status of the person is

1 Niboyet $v$. Niboyet, 4 P. D. 11.

2 See also Ross $v$. Ross, 129 Mass. 243, 246, 37 Am. Rep. 321 ; Van Matre v. Sankey, 148 Ill. 356, 36 N. E. 628 ; Freeman's Appeal, 68 Conn. 533, 37 Atl. 420, 421; De La Montanya $v$. De La Montanya, 112 Cal. 101, 32 I. R. A. $82,87,53$ Am. St. Rep. 165 
the law of his situs. The law of the person's situs then is "the proper law" controlling the status.

But we have seen in a preceding chapter ${ }^{8}$ that when a "proper law" comes to be enforced in another State, there are certain circumstances, such as the consequent violation of the policy of the forum or the perpetration of injustice upon its people, that may lead the courts of the forum to substitute the lex fori in a given case in the place of the proper law. This is exemplified in some whole groups of status, as in the case of fiduciaries, ${ }^{4}$ where the application of the lex fori is the rule rather than the exception; and sometimes in other cases of status where the exceptional circumstances arise.

But when we say that "the proper law" to determine status is the law of the person's situs, we must bear in mind that the person's situs may be twofold. He may have an actual situs or he may have a distinct legal situs or domicil; that is, his actual situs may be recognized for one purpose, and his legal situs for another, and the two need not coincide. ${ }^{5}$

We have also seen that the actual situs of a person is looked to in those matters which are the result of the person's activity and voluntary efforts, for in respect to such matters the recognition of the sovereignty of the State wherein they arise demands that its law should govern them, and to the operation of that law the party has voluntarily and deliberately submitted himself. ${ }^{\circ}$ On the other hand, if the rights or liabilities in dispute have been conferred upon the party, not by his own voluntary act, but as a result of the operation of law, if they are dependent upon the law of the person's situs at all, it will in general be the legal, not the actual, situs of the person, that will furnish the applicatory law. ${ }^{7}$ We shall hereafter have occasion to apply these principles more than once; they are at the foundation of many of the problems that present themselves.

With respect to the particular instance, now under consideration, of the application of the law of the person's situs, namely, the status of the individual, it may be said that it belongs in the

8 Chapter II.

5 See ante, $\S 18$.

7 See ante, $\$ 17,18$
4 Post, Chapter IX.

- See ante, $\S \S 17,18$. 
main to the second class of cases above mentioned, that is, matters arising by operation of law without the active intervention of the party. Hence, the general rule of private international law is that questions of status are to be determined by the law of the legal situs or domicil (lex domicilii) of the party whose status is in dispute. ${ }^{8}$

But this is not universally true, and under some circumstances "the proper law" to determine a status may be the law of the person's actual situs, ${ }^{\circ}$ while in other cases the lex fori may be substituted for the proper law altogether.

The status may be considered under four main groups, to each of which one or more chapters will be devoted. These are: (1) Personal capacity; (2) The marriage status; (3) The status of legitimacy and adoption; and (4) The status of fiduciaries.

8 Lamar v. Micou, 112 U. S. 452 ; Ross $v$. Ross, 129 Mass. 243, 246, 37 Am. Rep. 321 ; Watkins $v$. Watkins, 135 Mass. 83, 84; Adams v. Adams, 154 Mass. 290 ; Kinney v. Com., 30 Gratt. (Va.) 858 ; Miller v. Campbell, 140 N. Y. 457, 460, 35 N. E. 651 ; Miller v. Miller, 91 N. Y. 315 ; Moultrio v. Hunt, 23 N. Y. 394, 403-404 ; Woodward $v$. Woodward, 87 Tenn. 644, 11 S. W. 892,893 ; Armstrong v. Best, 112 N. C. 59,17 S. E. 14 ; State v. Kennedy, 76 N. C. 251, 22 Am. Rep. 683 ; Peoplè v. Dawell, 25 Mich. 247, 12 Am. Rep. 260; Blythe $v$. Ayres, 96 Cal. 532, 19 L. R. A. 40, 31 Pac. 915 ; Gray v. Holmes, 57 Kan. 217, 33 L. R. A. 207, 45 Pac. 596 ; Melvin v. Martin, 18 R. I. 650, 30 Atl. 467; Van Fossen v. State, 37 Ohio St. 317, 41 Am. Rep. 507, 508 ; Jones $v$. Jones, 67 Miss. 195, 6 So. 712 ; Gregory v. Gregory, 78 Me. 187, 57 Am. Rep. 792 ; Prosser v. Warner, 47 Vt. 667, 19 Am. Rep. 132, 134 ; Firth $v$. Firth, 50 N.J. Eq. 137, 24 Atl. 916 ; Birtwhistle $v$. Vardill, 7 Cl. \& F. 895 ; Skottowe v. Young, L. K. 11 Eq. 474 ; Price v. Dewhurst, 9 Sim. 279.

9 Post, $\$$ 73, 73. 


\section{CHAPTER V.}

\section{STATUS OF PERSONAL CAPACITY.}

\section{§69. Capacity in General - Several Sorts of Capacity. -} In general, the capacity or incapacity of a person to take part in a particular transaction is not an active but a passive element of the transaction, one imposed by law, and independent of the will of the parties.

Theoretically therefore, upon principles just examined, the proper law governing the capacity or incapacity of the person is the law of the person's legal situs or domicil (lex domicilii), not the law of his actual situs. And in general, as we shall see, this is the rule. ${ }^{1}$

But when the matter with respect to which the party's capacity is questioned is the result of a voluntary and deliberate act on the part of the person, for example, the making of a contract in a particular State (other than his domicil), a serious question arises whether his capacity to enter into such contract is to be governed by the law of his legal situs (lex domicilii) or by the law of his actual situs (the place where the contract is entered into). The point, being one upon which the courts are much confused, will be discussed hereafter. ${ }^{2}$

As illustrating this distinction, in respect to capacity, between the active participation of a party in a given transaction and such participation as is imposed upon him by the law, it will not be amiss to quote the language of a leading Massachusetts decision: ${ }^{3}$

"The capacity or qualification to inherit or succeed to property, which is an incident of the status or condition, requiring no action to give it effect, is to be distinguished from the

1 Post, $\$ \S 70,71$ et seq.

2 Post, \$§ 72, 73.

- Ross $v$. Ross, 129 Mass. 243, 246, 37 Am. Rep. 321, Gray, J. 
capacity or competency to enter into contracts that confer rights upon others. A capacity to take and to have differs from a capacity to do and contract; in short, a capacity of holding, from a capacity to act."

It will be seen that when the actual situs and the legal situs (or domicil) of the party coincide, that is, when the act or matter in question arises in the domicil, the lex domicilii will, under all circumstances, be the proper law to determine the party's capacity, no matter where the question may arise. It is true that the proper law may be substituted by the lex fori, but only in the exceptional cases heretofore discussed.4

If the act is a voluntary one (e. g. making a contract) performed in a third State, the question arising in a State other than the party's domicil, the courts of such State will usually hold that the law of the place where the contract is entered into, or other act is done, that is, the law of the actual situs of the person at that time, will govern his capacity to do the act. ${ }^{5}$

But if, though the act be voluntary and performed in a third State, the question is raised in the party's domicil with respect to his capacity or incapacity to do the act, there is great difference of opinion, or at least apparent difference of opinion, as to the law which should govern. ${ }^{6}$

The status of personal capacity is to be examined, according to the character of the transaction, in different aspects. The primary distinction is that already noted between cases of involuntary transactions (if the expression may be used) and those which are the result of voluntary action by the party. We will consider two instances of capacity under each of these heads.

The first instance of capacity under the head of involuntary transactions is that of the capacity to make a will and to be a beneficiary thereunder. At first glance, the making of a will would seem to be a voluntary act of the testator, but a moment's reflection will show that though the actual writing of a will is a

4 Chapter II.

5 Post, $\$ \S 72,73$.

- Post, $\$ 72,73$. The discrepancy is due for the most part to the different conceptions of the various courts as to the importance to be attached to the policy of the forum. 
voluntary act on the part of the testator, it is dependent for its effect upon his death, which is involuntary. It is therefore to be classed under this head.?

The second instance of capacity in involuntary transactions may be designated business capacity in general (exclusive of contracts and other voluntary acts). Under this head are grouped all those cases in which the abstract question arises whether the party is a competent agent, but in which he does no voluntary and deliberate act. ${ }^{8}$

Under the head of voluntary transactions, the first instance of capacity will arise in respect to the making of contracts in general, and the second with respect to capacity to enter into the contract of marriage in particular. " The "proper law" to regulate those instances of capacity belonging to the first class is the law of the party's legal situs or domicil; while capacities of the second class are controlled by the law of the party's actual situs at the time of the transaction, subject to modifications which will be discussed hereafter.

$\S 70$. Testamentary Capacity. - In respect to the capacity to make a will, a distinction, already adverted to, must be made between wills of lands and wills of personal property. In respect of wills of lands, the testamentary capacity of the testator is one of the steps in the chain of title, all of which are to be regulated by the law of the place where the land is situated. Hence, it is well settled that the lex situs of the land governs the capacity to devise, as well as the formal and substantial validity of the will. ${ }^{1}$

But in the case of a will of personalty the rule is otherwise, the legal situs of personal or movable property being with the person of the owner. Hence the general rule of private international law is that the law of the owner's situs shall determine his capacity to bequeath it; and since the will takes effect

7 See post, $\S \S 70,142$.

8 Post, $\$ 71$.

- Post, $\S 72,73$.

1 Ante, $\S 11$; Story, Confl. L. $\S 474$; Ross v. Ross, 129 Mass. 243, 246, 37 Am. Rep. 321; Williams v. Saunders, 5 Coldw. (Tenn.) 60, 61, 70; Carpenter $v$. Bell, 96 Tenn. 294, 34 S. W. 209 ; Frazier v. Boggs, 37 Fla. 307, 20 So. 245. 
by the death of the testator (an involuntary act) it is the law of the testator's legal situs (or domicil) at the time of his death that will govern. That the lex domicilii of the testator is the proper law to govern testamentary capacity in case of personalty is settled beyond dispute. ${ }^{2}$

It is not always easy however to determine when a question is really one of testamentary capacity. Because the law of a State prohibits its citizens to make particular testamentary dispositions, it does not follow that the prohibition is against their testamentary capacity. In order to create a true testamentary incapacity, the policy of the prohibiting law must be directed against the right of the testator to dispose of his property, not against some particular form of disposition he may desire to make, nor against the right of his beneficiary to hold the property bequeathed.

Thus, a law prohibiting a person under legal age to make a will creates a testamentary incapacity; or a law prohibiting married women from bequeathing their property, whether applying to all or only part of their possessions. So also, a law providing that no will shall be valid, unless executed a certain time before the testator's death; or a law providing that no will creating a charitable trust shall be valid if executed within a named time before the death of the testator; or a provision that a testator shall not give more than a certain proportion of his estate to charities. The policy of all these provisions is to prevent the testator from making indiscreet dispositions, to the disinheritance of his family. They are aimed to deprive him of a discretion which, if given full sway, might result in injustice to those dependent upon him. They create a true testamentary incapacity. The policy of such laws is applicable to all persons who are subject to them, to all persons domiciled in that State,

2 Roberts' Will, 8 Pai. Ch. (N. Y.) 519; Chamberlain v. Chamberlain, 43 N.Y. 424, 432-433 ; Kerr v. Dongherty, 79 N. Y. 327, 341 ; Cross v. Trust Co., 131 N. Y. 330,340 ; Russell v. Hooker, 67 Conn. 24, 34 Atl. 711, 712 ; Ford $v$. Ford, 70 Wis. 19, 33 N. W. 188, 194 ; Sickles v. New Orleans, 52 U. S. App. 147, 80 Fed. 868,873 ; Montgomery v. Millikin, 5 Sm. \& M. (Miss.) 151, 43 Am. Dec. 507 ; Cameron v. Watson, 40 Miss. 191, 207 ; Wil. liams $v$. Saunders, 5 Coldw. (Tenn.) 60 . 
regardless of their actual situs, or the actual situs of the property bequeathed. Wherever the latter may be, it must for this purpose be regarded as helping to make up the aggregate wealth of the State whose citizen the owner is. The strict lex scripta of the testator's domicil therefore will govern testamentary incapacities of this character. ${ }^{8}$

On the other hand, a law is not a restriction upon testamentary capacity, which avoids a will creating a trust to endure longer than lives in being, or other perpetuity; or which avoids charitable trusts, or other vague and indefinite dispositions. These prohibitions are not for the protection of the testator's estate from his improvident dispositions, but for the general welfare of the State, or because of the incapacity of the courts to enforce the provisions. The State passing such laws is only concerned with their enforcement when the property is designed under the will to be held in perpetuity within its limits, or where its courts are to enforce the vague and indefinite trusts created by the will. This policy is not affected by the residence or the non-residence of the testator, but only by the presence or non-presence of the property disposed of. If the perpetuities or indefinite trusts are to take effect there, the policy of these laws is violated, and the domicil of the testator and its laws are not of material importance. ${ }^{4}$

Another class of these prohibitory laws relate to the capacity of the beneficiary to take the property bequeathed. These laws also are to be distinguished from those which place a restriction upon the capacity of the testator to dispose of his property. The purpose of such laws is not to restrain the testator from improvident dispositions, but to subserve a general policy, which the welfare of the State as a whole requires should be carried out. To this class belong prohibitions upon a corporation to be a legatee, or to hold more than a certain amount of the property bequeathed to it, etc. The purpose is to impose a check upon the aggrandizement of the corporation and for the protection of the State against its undue influence and power.

${ }^{3}$ See Healy $v$. Reed, 153 Mass. 197, 200 ; Montgomery $v$. Millikin, $5 \mathrm{Sm}$. \& M. (Miss.) 151, 43 Am. Dec. 507. See post, $\S 144$.

4 See Healy $v$. Reed, 153 Mass. 197, 200 ; post, $\$ 144$. 
Such is the policy of statutes of mortmain. In such a case, it is evident that the State enacting such law is not interested in enforcing it if the corporation or other beneficiary thus prohibited to take is not within its borders; and on the other hand, if such beneficiary is within its limits, the policy of the law applies, no matter where the testator's domicil may be or what may be its laws. The question here involved is not the testamentary capacity of the testator, but the capacity of the legatee to take, and that capacity should be regulated by the law of the beneficiary's domicil, just as much as the testator's capacity is to be controlled by the law of his domicil. ${ }^{5}$

Thus, in Chamberlain $v$. Chamberlain, ${ }^{6}$ a leading New York case, a testator, domiciled in New York, bequeathed property to a Penusylvania corporation for educational purposes. If the legatee had resided in New York and the property was to have remained there, the disposition would have contravened the New York law placing restrictions upon the capacity of corporations to take as legatees. But inasmuch as the corporation legatee was capable of taking the legacy under the law of Pennsylvania (its situs), the court construed the New York statute not to apply. In the course of its opinion the court says : "It is no part of the policy of New York to interdict per.. petuities or gifts in mortmain in Pennsylvania."

On the other hand, in another New York case, ${ }^{7}$ a testator domiciled in New York bequeathed a legacy to a Pennsylvania corporation for charitable purposes, and died within a month after executing his will. The law of New York provided that no devise or bequest to a corporation by one leaving a wife, child, or parent should be valid in any will not made and executed at least two months before the testator's death. The law of Pennsylvania was the same. It was held that the bequest

5 Chamberlain $v$. Chamberlain, 43 N. Y. 424 ; Kerr v. Dougherty, 79 N. Y. 327; Healy $v$. Reed, 153 Mass. 197, 200 ; Sickles v. New Orleans, 52 U. S. App. 147, 80 Fed. 868; Fellows $v$. Miner, 119 Mass. 541 ; Sohier v. Burr, 127 Mass. 221; Hope v. Brewer, 136 N. Y. 126. See Cameron v. Watson, 40 Miss. 191. See Vansant $v$. Roberts, 3 Md. 119 ; post, \$ 144.

643 N. Y. 424.

7 Kerr v. Dougherty, 79 N. Y. 327, 341. 
was invalid. This decision was clearly correct, but it is submitted that the court erred in following the Pennsylvania law rather than that of New York in reaching its conclusion. The result was the same, for the two laws were similar; but the prohibition of the New York law was directed in this case against the capacity of the testator, not against the capacity of the legatee, and should therefore have furnished the guide, since New York was the testator's domicil. Mr. Wharton's criticism upon this decision is well founded. ${ }^{8}$

Following the same line of reasoning, it would seem that if the question should arise, not in the testator's domicil but in the State where the property is or the legatee resides, the courts of the forum should be governed by the lex domicilii of the testator, it is true, but should construe that law according to the policy indicated thereby. If intended as a restriction upon testamentary capacity, the strict lex scripta of the testator's domicil should be applied. If the lex domicilii is intended to lay down rules governing the mode in which property in tho domicil should be held or enjoyed, as in case of statutes prohibiting gifts in perpetuity; or rules prescribing what persons under its jurisdiction may receive bequests, as in case of statutes of mortmain; or rules governing its courts in the administration of trusts, as in case of provisions that vague and indefinite trusts shall not be enforced, - in all such -cases the policy of the lex domicilii indicated by such laws is confined to the limits of the domicil itself and is not to be construed as applying to property to be enjoyed in other States, to legatees domiciled elsewhere, or to trusts to be administered by the courts of other States. ${ }^{9}$

In those cases in which the law of the testator's domicil is to be applied, it must be observed that it is the domicil possessed by the testator at the time of his death that furnishes the proper

- Whart. Confl. L. § 577. In a similar case in Massachusetts it was held that the lex domicilii of the testator, not of the legatee, should govern. Healy v. Reed, 153 Mass. 197. See Hollis $v$. Seminary, 95 N. Y. 166 ; Curtis v. Hutton, 14 Ves. 537.

- See Chamberlain $v$. Chamberlain, 43 N. Y.424 ; Healy $v$. Reed, 153 Mass. 197 ; Dammert v. Oshorn, 140 N. Y. 30 ; Cross v. Trust Co., 131 N. Y. 330 In the last case the disposition was opposed to the policy of both States. 
law. If he makes his will when domiciled in one State, and then afterwards removes to another where he dies, it is the law of the latter State, not that of the former, which determines his testamentary capacity. ${ }^{10}$

Testamentary capacity under the exercise of a power of appointment depends upon different principles, and will be considered hereafter. ${ }^{11}$

§71. Business Capacity in general. - By "business capacity," as here used, is meant a general capacity for business transactions, exclusive of voluntary acts of the party, such as entering into contracts, which will be discussed in the following sections.

The period of wardship, the age of majority, the effect of settlements between guardian and ward, the ability of a married woman to be a trustee, etc., are matters that do not involve the idea of a voluntary and deliberate entrance into a transaction, but are more or less matters of law, rather than of active consent or contract. All these and others of a like kind may be grouped under the general head of business capacity.

It is the established general rule that this sort of capacity is governed by the law of the iegal situs (or domicil) of the party whose capacity is in question." The lex domicilii is the "proper law," but as in other instances the proper law is liable to be substituted under certain circumstances by the lex fori in the exceptional cases already mentioned in the second chapter.

Thus, in Woodward $v$. Woodward, ${ }^{2}$ a ward domiciled in Louisiana and being of full age there (fixed at eighteen), though

10 Story, Confl. L. $\$ 473$; Jac. Dom. $\$ 43$; Whart. Confl. L. $\$ 570$. See Moultrie v. Hunt, 23 N. Y. 394 ; White $v$. Howard, 46 N. Y. 144. This is eminently reasonable since a will takes effect by the death of the testator, not by its execution.

11 See post, $\$ 150$.

1 Woodward $v$. Woodward, 87 Tenn. 644, 11 S. W. 892 ; Hiestand $v$. Kuns, 8 Blackf. (Ind.) 345, 46 Am. Dec. 481 ; Barrera v. Alpuente, 6 Mart. N. s. (La.) 69, 17 Am. Dec. 179 ; Schluter v. Bank, 117 N. Y. 125, 22 N. E. 572 ; Lamar v. Micon, 112 U. S. 452 ; Kohn's Estate, 1 Pars. Eq. Cas. (Penn.) 399 ; Freeman's Appeal, 68 Conn. 533, 37 Atl. 420; In re Helleman's Wilh L. R. 2 Eq. 363 ; In re Da Cunha, 1 Hagg. Eccl. 237.

87 Tenn. 644,11 S. W. 892. 
under age in Tennessee, sued her guardian in Tennessee, where he was appointed, to compel him to turn over to her her personalty located there. It was held that she was of age and entitled to make this demand, though there was a Tennessee statute providing that a ward might make such demand of the guardian upon attaining the age of "twenty-one," this phrase being construed by the court as equivalent to "full age."

In Hiestand $v$. Kuns, ${ }^{3}$ a guardian removed with his ward (a niece) nine years old from Ohio, where her parents had lived and died, to Indiana. By the law of Ohio she became of age at eighteen; by the law of Indiana at twenty-one. Upon attaining the age of eighteen she gave her guardian a power of attorney to sell her property, and he made a settlement with her which he alleged was a final one. The Indiana court held that her capacity to come to a settlement with her guardian depended upon the law of her domicil; that her Ohio domicil was unchanged by her removal to Indiana with her guardian; but that when she became eighteen, she became under Ohio law competent to select her own domicil; that she did select Indiana; and that the law of her new domicil straightway threw her back into her old status of minority and dependence until she should become twenty-one. The court therefore held her, under the law of Indiana (her newly acquired domicil), incompetent to make a final settlement with her guardian.

In Schluter $v$. Bank, ${ }^{4}$ a married woman domiciled in New York there became a trustee of certain funds deposited there. She afterwards became domiciled in New Jersey, by whose law a married woman was incompetent to act as trustee. Upon the question whether she remained a trustee of the New York funds after her removal to New Jersey, it was held by the New York court that, capacity being conferred upon her at the time of the transaction by the law of her domicil (New York), the transaction was a valid one, and continued to be so notwithstanding her subsequent removal to New Jersey. ${ }^{5}$

38 Blackf. (Ind.) $345,46 \mathrm{Am}$. Dec. 481.

4117 N. Y. 125,22 N. E. 572.

5 Here the married woman's former domicil was also the forum. If the same question had arisen in New Jersey or in a third State, the result might 
With respect to the law governing the age of majority, the time at which an infant becomes an adult for legal purposes, all the authorities agree that the lex domicilii of the party is the proper law to determine the question. ${ }^{6}$ But there is considerable conflict upon the question whether the proper law is the law of the party's domicil of origin or that of his domicil at the time he is alleged to have attained his majority, supposing him no longer to possess his original domicil.

The weight of American authority, and, it may be added, of reason, is in favor of the latter domicil as furnishing the proper law. ${ }^{7}$ But many of the continental jurists incline to the domicil of origin, on the ground that "each State or nation is presumed to be best capable of judging from the physical circumstances of climate or otherwise when the faculties of its citizens are morally or civilly perfect for the purposes of society." 8

have been different, since a capacity conferred by one State upon a citizen does not usually continue after the party becomes domiciled in another State, whose law does not confer it, except in cases of permanent status, such as the marriage status, legitimation, and others of a similar character.

6 Story, Conf. L. $\S 71$; Woodward $v$. Woodward, 87 Tenn. 644, $11 \mathrm{~S}$. W. 892 ; Hiestand $v$. Kuns, 8 Blackf. (Ind.) 345, 46 Am. Dec. 481 ; Barrera $v$. Alpuente, 6 Mart. N. s. (La.) 69, 17 Am. Dec. 179.

7 Woodward $v$. Woodward, 87 Tenn. 644,11 S. W. 892 ; Hiestand $v$. Kuns, 8 Blackf. (Ind.) 345, $46 \mathrm{Am}$. Dec. 481.

8 Story, Confl. L. $\S 72$; Barrera v. Alpuente, 6 Mart. N. 8. (La.) 69, $17 \mathrm{Am}$. Dec. 179. Possibly, when the question arises in the courts of the original domicil, they may be governed by their own law, but, except to preserve their own citizens from injustice, it is difficult to see any adequate reason for such a conrse. See Story, Confl. L. $§ 73$; Whart. Confl. L. $\S 113$. In Barrera $v$. Alpnente, sapra, the plaintiff sued in Louisiana, and was nonsuited, on the ground that she was an infant and incapacitated nnder the laws of Louisiana from suing in her own name. She was twenty-three years old, and had her domicil of origin in Lonisiana. In 1802, when she was born, the age of majority was fixed in that State at twenty-five. In 1808, the Louisiana law was changed so as to make twenty-one the age of majority. The plaintiff had, some years prior to the suit (whether before or after 1808 did not appear), become domiciled in Spain, whose law was similar to the earlier law of Louisiana, and she was domiciled in Spain when the suit was brought. Upon her appeal, the court held that the time at which she attained her majority was to be determined by the law of her domicil of origin (Louisiana), and not by the law of her present domicil (Spain), and refused to give her relief bocause 
But an important distinction is to be made between the law governing the age at which a person reaches maturity and the law regulating the capacity or incapacity of one admittedly an infant. It is one thing to say that a particular law shall govern the question whether one is an infant or not, and a very different thing to say that, admitting him to be an infant, the same law must govern his capacity to transact business. The law of his domicil is the proper law to determine whether or not he is legally an infant, but having determined that he is an infant that law withdraws and leaves the effect of his infancy upon his capacity to transact business to the law proper for determining the effect of his infancy. In the case of business capacity in general - involuntary transactions - the lex domicilii is still the proper law to govern the effect of infancy; but with regard to voluntary transactions, as we shall see in the following sections, the lex domicilii is not the proper law for this purpose.

§72. Voluntary Transactions - Capacity to Contract. We now come to the consideration of the law whereby a party's capacity is to be determined in those cases in which, by voluntarily entering into a transaction abroad, he deliberately puts himself in a position to work an injustice upon others with whom he deals, should he set up an incapacity created by the law of his legal situs or domicil with which those dealing with him at his actual situs in a foreign country cannot be supposed to be familiar. Upon the question as to the proper law governing the party's capacities or incapacities in such cases, there is a great difference of opinion.

It may be regarded as certain that if the party enters into a contract in the State of his domicil, though the contract is to be performed elsewhere, the proper law governing his capacity to enter into the contract is the lex domicilii, no matter where the suit may be brought. ${ }^{1}$

she had not shown whether she left Louisiana before its law had been altered. This decision does not, it is believed, lay down the correct rule.

1 Hill v. Bank, 45 N. H. 300; Bell v. Packard, 69 Me. 105, 31 Am. Rep. 251, 252 ; Polson v. Stewart, 167 Mass. 211, 45 N. E. 737 ; Armstrong v. Best, 112 N. C. 59,17 S. E. 14 ; Wood v. Wheeler, 111 N. C. 231,16 S. E. 
But if the contract is entered into in a State other than the party's domicil, he has not the same right to claim the protection of his domiciliary law. He has voluntarily entered into another State and has there made an agreement with persons who are relying upon the law under which he is acting. To that law he has submitted himself when he makes the contract there, and a just comity will ordinarily demand that the sovereignty of that State over all acts done there should be respected in other States. Every element of a contract may have a separate situs of its own, whose law will govern the effect of that element. The making of the contract may have a situs separate from the performance of it and separate from the consideration. 'The law of the place of the making will determine whether a contract has been validly entered into; the law of the place of performance will determine whether it can be legally performed there; while the law of the situs of the consideration will determine the legality and sufficiency of the consideration. These are elementary principles governing contracts which will be fully discussed hereafter. ${ }^{2}$ If a party has not the legal capacity, he cannot enter into a valid contract; if he has the capacity, he may. This question must be determined at the time he enters into the contract, not when he comes to perform it. It pertains therefore to the making of the contract, and hence the element of capacity must be given the same situs that belongs to the making of the contract.

For these reasons, the general principle of private international law is that the capacity of the party to make a contract, whether executory or executed, is governed by the law of the actual (not the legal) situs of the contracting party at the time he enters into the contract; or, to put it in different form, by the law of the place where the contract is entered into. This is known as the lex loci celebrationis of the contract, in contrar

118; Hanover Nat. Bank v. Howell, 118 N. C. 271, 23 S. E. 1005, 1006 ; Taylor $v$. Sharp, 108 N. C. 377,13 S. E. 138 ; Robinson $v$. Queen, 87 Tenn. 445, 11 S. W. 38,3 L. R. A. 214 ; Kerr v. Urie, 86 Md. 72,37 Atl. 789 ; Union Bank v. Hartwell, 84 Ala. 379, 4 So. 156; Freeman's Appeal, 68 Conn. 533, 37 Atl. 420. See Miller $v$. Campbell, 140 N. Y. 457, 35 N. E. 651.

2 Post, §§ 167-179. 
distinction to the lex loci solutionis, or the law of the place where the contract is to be performed. The proper law then to determine the capacity to contract is the lex celebrationis of the contract. $^{3}$

But this general principle is subject to qualification when the domicil of the party is the forum. Uuder these circumstances, upon the exceptional ground (already discussed) of protection to its citizens as well as of public policy, the lex fori (which will also be the lex domicilii) will be sometimes substituted for the proper law. It is believed however that even the courts of the domicil will follow the lex celebrationis of the contract in determining the capacity of its citizen to enter into the contract, except where the incapacity imposed by the law of the domicil is general or total, such as the common law disabilities of coverture. Only in such pronounced instances of a policy of protection towards its citizens who are non sui juris will the courts of the domicil enforce their own laws.

Hence, if the law of the domicil and forum only declares a few of a married woman's contracts void, and suit is brought there upon a contract made by her in another State and there valid, which is one of those declared to be beyond her capacity by her domiciliary law, the contract will still be enforced against

3 See Milliken $v$. Pratt, 125 Mass. 374, 28 Am. Rep. 241 ; Ross $v$. Ross, 129 Mass. 243, 246, 37 Am. Rep. 321 ; Bell v. Packard, 69 Me. 105, 31 Am. Rep. 251, 253 ; Campbell $v$. Crampton, 2 Fed. 417, 421, 423 ; Matthews $v$. Murchison, 17 Fed. 760 ; Saul v. His Creditors, 5 Mart. N. s. (La.) 569, 16 Am. Dec. 212, 226 ; Wilder's Succession, 22 La. Ann. 219, 2 Am. Rep. 721 ; Pearl v. Hansbrough, 9 Humph. (Tenn.) 426; Robinson $v$. Queen, 87 Tenn. 445, 11 S. W. 38, 3 L. R. A. 214 ; Armstrong v. Best, 112 N. C. 59,17 S. E. 14 ; Wood $v$. Wheeler, 111 N. C. 231,16 S. E. 418, 419 ; Taylor $v$. Sharp, 108 N. C. 377 , 13 S. E. 138, 139; Freeman's Appeal, 68 Conn. 533, 37 Atl. 420 ; Dougherty v. Snyder, 15 S. \& R. (Penn.) 84, 16 Am. Dec. 520; Baum v. Birchall, 150 l'enn. St. 164, $24 \mathrm{Atl}$. 620 . As was said in a well considered case : "Upon principle, no reason can be alleged why a contract, void for want of capacity of the party at the place where it is made, should be held good because it provides that it shall be performed elsewhere, and nothing can be found in any adjudicated case or text-book to support such a conclusion. It is a solecism to speak of that transaction as a contract, which cannot be a contract because of the inability of the parties to make it such." Campbell $v$. Crampton, 2 Fed. $417,423$. 
her even in her domicil. The protective policy of the domicil is partial only, and its enforcement of less importance to the community than the general policy of recognizing the binding effect of contracts and the sovereignty of another State over all matters arising within its jurisdiction. ${ }^{4}$ But if the law of the domicil (and forum) imposes a total incapacity to contract on the part of its married women, the need for this stringent policy of protection cannot be removed by the voluntary act of the woman in making her contract in another jurisdiction. It is against just these voluntary acts that the policy of such laws is directed. In such cases therefore, when it is attempted to enforce the woman's contract in the courts of her domicil, the law of the forum (and domicil) will be generally substituted for the proper law (the lex celebrationis of the contract), upon the ground that this policy of protection to the married women of the State is too important a policy to be overridden by a foreign law, even when that is the "proper law." 5

In Milliken $v$. Pratt, ${ }^{6}$ a leading case, a married woman domiciled in Massachusetts made a contract in Maine as guarantor for her husband. The contract was valid in Maine, but void in Massachusetts, whose law, while permitting a married woman to contract generally, prohibited her from entering into contracts as surety for her husband. Suit being brought against her upon the contract in Massachusetts, it was held that the contract must be enforced, notwithstanding the domiciliary law. In the course of its opinion, the court said: "It is possible also that in a State where the common law prevailed in full force, by which a married woman was deemed incapable of binding herself by any contract whatever, it might be inferred that such

4 Milliken $v$. Pratt, 125 Mass. 374, 28 Am. Rep. 241 ; Bell v. Packard, 69 Me. 105, 31 Am. Rep. 251, 252.

5 Armstrong $v$. Best, 112 N. C. 59, 17 S. C. 14 ; Hanover Nat. Bank $v$. Howell, 118 N. C. 271, 23 S. E. 1005, 1006; Milliken v. Pratt, 125 Mass. 374, 28 Am. Rep. 241 ; Freeman's Appeal, 68 Conn. 533, 37 Atl. 420; Case v. Dodge, 18 R. I. 661, 29 Atl. 785, 786; Baum v. Birchall, 150 Penn. St. 164, 24 Atl. 620; Johnston v. Gawtry, 11 Mo. App. 322 ; Bowles v. Field, 78 Fed. 742, 743 ; Robinson v. Queen, 87 Tenn. 445, 11 S. W. 38, 3 L. R. A. 214.

6125 Mass. 374, 28 Am. Rep. 241. 
an utter incapacity, lasting throughout the joint lives of husband and wife, must be considered as so fixed by the settled policy of the State for the protection of its own citizens that it could not be held by the courts of that State to yield to the law of another State in which she might undertake to contract."

In Armstrong $v$. Best, ${ }^{7}$ a married woman domiciled in North Carolina entered into a contract in Maryland which was valid there. By the law of North Carolina the married woman was under the general common law disabilities, and was totally incompetent to enter into contracts. Suit being brought thereon in North Carolina, the court held that it must enforce the law of North Carolina (the law of the domicil and forum) rather than the law of Maryland (the lex celebrationis and the proper law). The court, in its opinion, thus refers to Milliken $v$. Pratt in speaking of the necessity for sometimes substituting the law of the forum and domicil: "That this qualification is applicable to cases like the present is manifest, not only by reason and necessity, but also by the decisions of other courts. Even in Milliken $v$. Pratt, in which the lex loci contractus is pushed to the extreme limit, it is suggested that where the incapacity of a married woman is the settled policy of the State 'for the protection of its own citizens, it could not be held by the courts of that State to yield to the law of another State, in which she might undertake to contract.'"

$A$ fortiori, if the policy of protection to its citizens adopted by the law of the domicil and forum is not so pronounced as to render the contract void at all, but only voidable, the proper law (lex celebrationis) will be enforced even in the domiciliary courts.

Thus it is the well settled rule that the liability of an infant upon his contracts is to be determined, even in the courts of his domicil, by the lex celebrationis of his contract, not by the law of the domicil and forum. ${ }^{8}$

7112 N. C. 59,17 S. E. 14.

8 Male $v$. Roberts, 3 Esp. 163 ; Thompson $v$. Ketcham, 8 Johns. (N. Y.) 189 ; Saul v. His Creditors, 5 Mart. N. s. (La.) 569, 16 Am. Dec. 212, 226 ; Wilder's Succession, 22 La. Ann. 219, 2 Am. Rep. 721, 724-725 ; Milliken v. Pratt, 125 Mass. 374, 28 Am. Rep. 211. See Campbell v. Crampton, 2 Fed. 
§ 73. Same-Capacity to Marry. - Notwithstanding some strong dicta to the effect that the "proper law" to determine the capacity to marry is the lex domicilii of the parties at the time of the marriage, ${ }^{1}$ the contract of marriage is believed to be governed, in respect to the parties' capacity to enter into the contract, by substantially the same principles as other contracts.

If at the time of the marriage the actual and legal situs of the parties coincide, in other words if the marriage takes place in the parties' domicil, the law of the domicil will govern their capacity, no matter where the question arises. In such case there is no particular foreign element. The domicil of both the parties coincide with the place of celebration of the marriage. The law of that place will therefore control in all respects, even when the marriage is called in question elsewhere as being con-

417,422 . Indeed, it can hardly be said with accuracy that a matter which renders a contract voidable merely is a matter of capacity to make the contract at all. On the contrary, the capacity (of an infant, for example) to enter into the contract is conceded. It is rather in the nature of a privilege accorded to him to disaffirm the contract after he has entered into it. In any event however the privilege attaches, if at all, at the time he enters into the contract, so that the conclusion remains undisturbed that the situs of his privilege is the locus celebrationis of his contract, and its "proper law," the lex celebrationis.

So it is also in other cases where the contract is voidable merely, not void. Thus causes existing at the time of a marriage which render it voidable only, and do not avoid it ipso facto, can hardly be called cases of incapacity to marry, for the marriage is a legal marriage, notwithstanding the existence of these defects, nnless avoided during the lifetime of the parties. Despite the obstacles interposed by the law, the fact remains that the parties are capable of entering into a marriage contract that the law may recognize as legal and valid. Such matters go to the validity of the contract itself, rather than to the capacity of the parties to enter into the contract. See post, $\S 78$.

1 Brook v. Brook, 9 H. L. Cas. 193 ; Shaw v. Gould, L. R. 3 H. L. 83 ; Sottomayor v. De Barros, 3 P. D. 5, 7; Udny v. Udny, 1 H. L. Sc. 441, 457; Kinney v. Com., 30 Gratt. (Va.) 858; Greenhow v. James, 80 Va. 636 ; State v. Ross, 76 N. C. 242,22 Am. Rep. 678 ; State v. Kennedy, 76 N. C. 251 , 22 Am. Rep. 683 ; Campbell v. Crampton, 2 Fed. 417. See Dicey, Confl. L. 642 et seq. In most of these cases the domicil was the forum. But see Sottomayor $v$. De Barros, supra, where it was held that a marriage in England between two first cousins domiciled in Portugal, whose law forbade such marriages, would be held void in England, though the English law did not prohibit first cousins from marrying. 
trary to the law of the forum, unless it be contra bonos mores, as polygamous, or universally incestuous. ${ }^{2}$

Thus, in State $v$. Ross, ${ }^{8}$ a white woman residing in North Carolina left that State and went to South Carolina, with the purpose of there marrying and living with a negro man residing in the latter State. The marriage was valid in South Carolina, but void in North Carolina. Some time after the marriage, the parties determined to remove to North Carolina. Being indicted there for fornication in living and cohabiting together without being lawfully married, they pleaded the South Carolina marriage. The court held it a good defense, since both parties were domiciled in South Carolina when the marriage was contracted.

If the parties are domiciled in one State by whose law they are prohibited to marry, but the marriage occurs in another State where such marriages are permitted, and the validity of the marriage is impugned in the latter or any third State, the general rule is that the lex celebrationis, not the lex domicilii, will govern. ${ }^{4}$

But if, under the circumstances last stated, the validity of the narriage is questioned in the courts of the domicil, much conflict has arisen amongst the authorities as to the law which shall dominate.

Many of the decisions hold that the lex celebrationis must govern the capacity of the parties to enter into the contract, as well as the formal validity of the wedding ceremony, ${ }^{5}$ no matter

2 State $v$. Ross, 76 N. C. 242, 22 Am. Rep. 678; Harral v. Harral, 39 N. J. Eq. 379, 51 Am. Rep. 17, 25 ; West Cambridge $v$. Lexington, 1 Pick. (Mass.) 506, 11 Am. Dec. 231; Sutton v. Warren, 10 Met. (Mass.) 451. Polygamous and incestuous marriages are always roid in Christian countries, though valid where contracted. Post, $\S 75$.

376 N. C. 242, 22 Am. Rep. 678.

4 Story, Confl. L. $\S \S 79,89$; Ross $v$. Ross, 129 Mass. 243, 247-248, 37 Am. Rep. 321; Cummington $v$. Belchertown, 149 Mass. 223, 226, $21 \mathrm{~N}$. E. 435; Camphell v. Cramptoll, 2 Fed. 417, 424; Dickson v. Dickson, 1 Yerg. (Tenn.) 110, 24 Am. Dec. 444; Roth v. Roth, 104 Ill. 35, 44 Am. Rep. 81, 82 ; Succession of Hernandez, 46 La. Ann. 962, 24 L. R. A. 831, 841-842. But see Sottomayor $v$. De Barros, 3 P. D. 5,7 . .

- It is universally conceded that the forms and solemnities of the wedding 
how opposed to the policy of the domicil and forum a marriage between the parties may be (if not immoral), preferring before any special policy of the domicil the general policy which looks to the upholding of marriages valid where contracted. ${ }^{6}$ And these courts hold to this view even though the parties have contracted the marriage abroad in order to evade the domiciliary law. Under this line of decisions, nothing but a statute of the domicil explicitly declaring such a marriage between its citizens void, though entered into abroad, will be permitted to outweigh the general and important policy of upholding marriages.

Thus, in a leading Massachusetts case, ${ }^{7}$ a white person and a negro, resident in Massachusetts, went to Rhode Island and were there married, intending to evade the law of Massachusetts, which invalidated such marriages. They then returned to Massachusetts. The validity of the marriage being called in question before the courts of Massachusetts (the domicil and forum), the court sustained the marriage, inasmuch as it was valid in Rhode Island. In the course of its opinion, the court said: "Motives of policy may likewise be admitted into the consideration of the extent to which this exception is to be allowed to operate. If without any restriction, then it might be that incestuous marriages might be thus contracted. But it is not to be inferred from a toleration of marriages which are prohibited merely on account of political expediency, that others which would tend to outrage principles and feelings of all civilized nations would be countenanced." "

are to be regulated in all cases by the law of the situs of the celebration (lex celebrationis). See post, § 77 .

6 Medway $v$. Needham, 16 Mass. 157, 6 Am. Dec. 131; Putnam v. Putnam, 8 Pick. (Mass.) 433 ; Com. v. Lane, 113 Mass. 458, 18 Am. Rep. 509; Ross $v$. Ross, 129 Mass. 243, 247-248, 37 Am. Rep. 321 ; Cummington v. Belchertown, 149 Mass. 223, 226, 21 N. E. 435 ; Van Voorhis v. Brintnall, 86 N. Y. 18, 25, 40 Am. Rep. 505; Thorp v. Thorp, 90 N. Y. 602 ; Moore v. Hegeman, 92 N. Y. 521, 44 Am. Rep. 408; Stevenson v. Gray, 17 B. Mon. (Ky.) 193.

7 Medway $v$. Needham, 16 Mass. 157, 6 Am. Dec. 131.

8 But matters of political expediency may become of as tremendous importance as matters of moral expediency. It must be remembered that at the date of this decision (1819) there were (and still are) comparatively fow ne. groes in Massachusetts, and the policy which dictated this statute had ceased to be of great importance. 
In a Kentucky case, ${ }^{\circ}$ a man and the widow of his deceased uncle, while domiciled in Kentucky, where they were prohibited from marrying, went into Tennessee, where no such prohibition existed, and were there married, and then returned to Kentucky. The court of the domicil pronounced the marriage good.

In Van Voorhis $v$. Brintnall, ${ }^{10}$ the law of New York provided that, upon a divorce for adultery, the court might decree that the guilty party should not marry again during the lifetime of the consort. A marriage between $\mathbf{E}$ and $\mathbf{B}$ was dissolved there on the ground of B's adultery, the parties being domiciled in New York; and the court ordered that B should not marry during E's lifetime. Thereafter B went to Connecticut, E being still alive, and there married $I$, also a resident of New York. $\mathrm{B}$ and $\mathrm{I}$ went to Connecticut for the purpose of evading the New York law, and returned to New York on the day of the marriage, which was valid under the laws of Connecticut. The New York court held that, although the marriage would have been invalid if celebrated there, it must be considered as valid in New York because valid where it was celebrated, and that the issue of the marriage were therefore legitimate in New York, and entitled to share with the children of the first marriage under a devise "to the issue of B."

On the other hand, many courts, attaching greater weight to the particular domestic policy than to the general policy which seeks to uphold marriages bona fide entered into between the parties, will be found to have arrayed themselves in favor of the enforcement of the law of the domicil and forum, in those cases where the domestic policy is so important and pronounced, or the evils it aims to avert are so imminent, as to justify such a course. ${ }^{11}$ In the view of this line of decisions, the fact that the statutes of the domicil are so framed as explicitly to prohibit

9 Stevenson v. Gray, 17 B. Mon. (Ky.) 193.

1086 N. Y. 18, 40 Am. Rep. 505.

11 Kinney v. Com., 30 Gratt. (Va.) 858 ; State v. Kennedy, 76 N. C. 251, 22 Am. Rep. 683 ; Jackson v. Jackson, 82 Md. 17, 33 Atl. 317, 319 ; Williams v. Oates, 5 Ired. L. (N. C.) 535 ; Pennegar v. State, 87 Tenn. 244, 10 S. W. 305, 2 L. R. A. 703 ; Fx parte Kinney, 3 Hughes (U. S.), 1, 20-21; State v. Tutty, 41 Fed. 753, 759-760 ; True v. Ranney, 21 N. H. 52, 53 Am. Dec. 164; Brook $v$. Brook, 9 H. L. Cas. 193. 
such marriages by its citizens, even when entered into abroad, is only one evidence of the importance attached to its policy by the State of the domicil and forum. But other evidences of the importance of the domestic policy, in the absence of such statute, are not excluded. ${ }^{12}$

No finer illustration of the manner in which this divergence of view comes about can be found than that presented in the comparison of the cases arising upon the validity of marriages between white persons and negroes, valid where contracted, but prohibited by the law of the domicil and forum. In Massachusetts, where negroes are few, it has been held under such a state of facts that the law of the domicil and forum (Massachusetts) could not be invoked to annul a marriage between its citizens, validly contracted elsewhere. On the other hand, under precisely similar circumstances it has been held by the courts of the Southern States, where negroes are numerous and marriages between them and the whites are regarded justly as most contrary to public policy and expediency, as well as utterly repugnant to the sentiment of the people, that marriages of this sort will not be sustained in the domicil and forum, though validly contracted by its citizens in another jurisdiction, even in the absence of a statute embracing such marriages when contracted abroad. 18

The true principle is that it is a question of policy, which each State must determine for itself according to the conditions prevailing there, so far as its own citizens are concerned, and it may determine the question as well through its courts as its legislature. As the North Carolina court expresses it in State $v$. Kennedy: "When it is conceded, as it is, that a State may

12 See State $v$. Tutty, 41 Fed. 753 ; Ex parte Kinney, 3 Hughes (U.S.), 1 ; State $v$. Kennedy, 76 N. C. 251, 22 Am. Rep. 683, 684 ; Pennegar v. State, 87 Tenn. 244, 10 S. W. 305, 2 L. R. A. 703 ; Jackson v. Jackson, 82 Md. 17, 33 Atl. 317, 319.

13 Kinney v. Com., 30 Gratt. (Va.) 858 ; State v. Kennedy, 76 N. C. 251, 22 Am. Rep. 683 ; Ex parte Kinney, 3 Hughes, 1 ; State $v$. Tutty, 41 Fed. 753. See also Jackson $v$. Jackson, 82 Md. 17, 33 Atl. 317, 319 ; Pennegar v. State, 87 Tenn. 244, 10 S. W. 305, 2 L. R. A. 703.

, 1476 N. C. 251,22 Am. Rep. 683,684 . And the same principle, though with the opposite result, was applied in Medway $v$. Needham, 16 Mass. 157, 6 Am. Dec. 131. 
by legislation extend her law prescribing incapacities for contracting marriage over her own citizens who contract marriages in other countries by whose law no such incapacities exist, as Massachusetts did after the decision of Medway $v$. Needham, the main question is conceded, and what remains is of little importance. Nothing remains but the question of legislative intent, to be collected from the statute."

Nor has this divergence always been confined to cases of marriages between white persons and negroes. The same difference of opinion appears with respect to the importance to be attached to the domestic policy prohibiting certain relatives from marrying. ${ }^{15}$ So also a like difference of opinion has been manifested in the effect of a foreign marriage by a guilty party to a divorce suit who has been prohibited to marry again. ${ }^{16}$

It is to be observed that if the parties remove from the State of their domicil, with the bona fide intent to become domiciled in another State, and having settled there then marry according to its laws, the marriage, though prohibited by the law of their first domicil, will be deemed valid everywhere, even in the first domicil, should they afterwards return thither either temporarily or permanently. ${ }^{17}$

If the parties to the marriage are domiciled in different States

15 For example, compare Brook v. Brook, 9 H. L. Cas. 193 (in which a marriage contracted in Holland, between a domiciled Englishman and his deceased wife's sister, who had met there casually, not by design, was held to be void in England, because within degrees of kindred prohibited by English law) with Stevenson $v$. Gray, 17 B. Mon. (Ky.) 193, already quoted, and Com. $v$. Lane, 113 Mass. 458, 18 Am. Rep. 509. The latter case criticises Brook $v$. Brook very severely. And perhaps the enforcement of a domestic policy of that nature at the expense of international comity is going a little further than sound judgment warrants. In England however the lex domicilii is regarded as the "proper law." See Sottomayor $v$. De Barros, 3 P. D. 5, 7.

16 Compare Van Voorhis v. Brintnall, 86 N. Y. 18, 25, 40 Am. Rep. 505 (already quoted), and Com. v. Lane, 113 Mass. 458, 18 Am. Rep. 509, with Pennegar v. State, 87 Tenn. 244, 10 S. W. 305, 2 L. R. A. 703. See post, $\S 74$.

17 State v. Ross, 76 N. C. 242, 22 Am. Rep. 678; West Cambridge v. Lexington, 1 Pick. (Mass.) 506, 11 Am. Dec. 231. See Cummington v. Belchertown, 149 Mass. 223, 227, 21 N. E. 435 ; Sutton v. Warren, 10 Mot. (Mass.) 451. 
at the time of the marriage, perplexing questions may arise. Suppose the law of the intended husband's domicil prohibits the marriage, while that of the intended bride's does not, or vice versa, what law shall govern? The solution of such questions will be found in the principles above stated. The marriage, if valid where contracted, will be valid everywhere, except in the State whose policy towards its own citizens has been violated. In the latter State the marriage will be annulled or sustained according to the view its courts take of the relative importance of the policies involved, or their view of the legislative intent. But it must not be forgotten that after the marriage the parties will generally reside in the husband's domicil, not in the wife's. Hence the importance to be attached to the policy of the wife's prior domicil will not usually be so great as that attached to the policy of the husband's domicil.

$\S 74$. Particular Incapacities to Marry - Guilty Party to Divorce prohibited to Marry again. - In the preceding section the general principles regulating matrimonial incapacity have been considered, and incidentally the disabilities imposed by consanguinity or affinity and by the evils of miscegenation have been discussed pretty fully, and the former will be soon adverted to again. ${ }^{1}$ The disability to marry again imposed under the laws of many States upon the guilty party in a divorce deserves special attention.

In many of the States the legislatures have enacted that a guilty party shall not remarry during the lifetime of the innocent consort, or else they have given to the courts the power to make such decree. What will be the effect if the party does marry again?

If no foreign element is introduced into the case, it is not a question of international, but strictly of municipal law, with which we have no concern. Such will be the case when the divorce takes place in the domicil of both the parties, and the subsequent marriage occurs in the same State, and the question arises there for decision. Here there is no foreign element. But if the question arises elsewhere, or if the subsequent marriage occurs in a State other than the domicil, or if the party

1 Post. $\$ 75$. 
prohibited to remarry is not domiciled in the State where the divorce is granted, a foreign element is introduced which must be reckoned with in the final determination of the law which should govern the validity of the second marriage. There are a number of important distinctions to be noted here, to some of which attention will now be directed.

In all such cases, the first question is: Did the court decreeing the divorce have jurisdiction of the guilty party? The essentials to give a court jurisdiction to make a decree of divorce which will be binding in other States are considered hereafter at large. ${ }^{2}$ A very brief summary is all that will be attempted here.

For the purposes of the divorce itself, if the parties are domiciled in the State of divorce, its courts will have jurisdiction, whether or not the defendant is personally before the court. The suit for divorce is a proceeding in rem to dissolve the marriage status, and according to the better opinion does not require a personal service upon nor appearance by the defendant in order to give to the court jurisdiction of the cause and to its decree an extra-territorial operation. ${ }^{8}$ But when to the decree of divorce is superadded an order that the guilty party shall not marry again, the question arises whether this part of the order is a decree in rem (like the divorce itself) or a decree in personam. If the latter, in order to be exterritorially binding upon the defendant, he or she must voluntarily appear or be personally served with process within the jurisdiction of the court." Whether it shall be deemed a proceeding in rem or in personam depends upon the question whether the prohibition to remarry is looked upon as a denial of relief to the guilty party, leaving him (or her) still married, as has been sometimes averred, ${ }^{5}$ or whether it is regarded as merely inflicting a punishment upon him for his wrong-doing, while still giving full effect to the divorce itself as to both parties. The

2 See post, $\$ \S 88$ et seq.

- Post, $\$ 89$.

See post, $\$ 85,95$.

See Elliott $v$. Elliott, 38 Md. 358, 363 ; Williams v. Oates, 5 Ired. L (N. C.) 535, 538 ; Calloway v. Bryan, 6 Jones L. (N. C.) 570. 
weight of reason and authority is decidedly in favor of the latter view, that it is a mere penalty or punishment. ${ }^{\circ}$

If then it is admitted that such an order merely inflicts a penalty upon the guilty defendant, without impairing his status as a single person, fixed by the decree of divorce, the decree must be regarded as in personam, that is, he must be before the court. (It may perhaps be doubted if even a personal service upon him within the territorial jurisdiction of the court will suffice, if not followed by appearance, for it is in the nature of a sentence pronounced upon him in a crimiual proceeding.) At least if the defendant be a non-resident, served with notice by order of publication only, and not voluntarily appearing, the order of the court that he or she shall not remarry cannot be given any exterritorial effect, for lack of jurisdiction. ${ }^{7}$

But even though we suppose the defendant domiciled in the State where the order is made, and even though he voluntarily appears to defend the suit, so that the court has complete jurisdiction to make the order, it will not in general receive exterritorial recognition for the reason that it is a penalty. Penal disabilities, as we have seen, are never enforced by the courts of other States, nor recognized by them as existing, ${ }^{8}$ even though such States themselves impose similar disabilities upon their own guilty citizens, or though the guilty party seeks to evade the law of his domicil by going elsewhere to be married.'

6 Huntington $v$. Attrill, 146 U. S. 657,663 ; Crawford v. State, 73 Miss. 172, 35 I. R. A. 224, 225 ; State $v$. Weatherby, 43 Me. 248, 69 Am. Dec. 59 ; Van Voorhis $v$. Brintnall, 86 N. Y. 18, 28-29, 40 Am. Rep. 505; Wilson $v$. Holt, 83 Ala. 540, 3 So. 321, 328 ; Succession of Hernandez, 46 La. Ann. 962, 24 L. R. A. 83 ; Dickson v. Dickson, 1 Yerg. (Tenn.) 110, 24 Am. Dec. 444 ; Com. $v$. Lane, 113 Mass. 458, 18 Am. Rep. 509 ; West Cambridge v. Lexington, 1 Pick. (Mass.) 506, 510, 11 Am. Dec. 231; Moore v. Hegeman, 92 N. Y. 521, 524, 44 Am. Rep. 408.

7 See Maguire $v$. Maguire, 7 Dana (Ky.), 181, 187 ; Garner $v$. Garner, 56 Md. 127 ; Van Storch v. Griffin, 71 Penn. St. 240.

8 Ante, $\$ 10$.

9 Wilson v. Holt, 83 Ala. 528, 540, 3 So. 321, 328 ; Dickson v. Dickson, 1 Yerg. (Tenn.) 110, 24 Am. Dec. 444. See Succession of Hernandez, $46 \mathrm{La}$. Ann. 962, 24 L. R. A. 831; West Cambridge v. Lexington, 1 Pick. (Mass.) 506, 510, 11 Am. Dec. 231. 
$A$ fortiori will the domiciliary prohibitions be disregarded, if the party abandons his former domicil, and becoming bona fide domiciled anew in another State, marries there. ${ }^{10}$

It is to be observed likewise that a disability imposed upon the guilty party, not by a decree of the court, but by the statute law itself, operates and is intended to operate only upon citizens, and not upon strangers, whether the divorce is granted there or elsewhere; and the disability, when thus imposed, is penal in its nature, just as where it is imposed by a decree of court. It will not therefore be recognized exterritorially even as against citizens of the penalizing State. Nor will it be applied even in that State to persons other than citizens. ${ }^{11}$

Thus, in a recent Louisiana case, ${ }^{12}$ a citizen of Louisiana had been divorced there for his adultery. The law of Louisiana in such case prohibited the guilty party from marrying his paramour during the life of the innocent consort. He went to New York, and there married another woman, afterwards returning to Louisiana. Had this marriage taken place in Louisiana it would have been valid. The New York law prohibited a person divorced for his own adultery to marry any one during the consort's lifetime. The Louisiana court held that the New York law was not applicable to a citizen of Louisiana, and that the marriage was valid.

But in cases where the disability is imposed by the domicil of the guilty party, and the validity of a subsequent foreign marriage is questioned there, there is much the same division of opinion as in the corresponding case of other incapacities, and upon the same distinctions there taken, namely, a comparison of the respective importance to be attached to the special policy of the domicil and forum (prohibiting a guilty party to remarry), with the general policy of upholding marriages. It

10 West Cambridge v. Lexington, 1 Pick. (Mass.) 506, 510, $11 \mathrm{Am}$. Dec. 231 ; Dickson v. Dickson, 1 Yerg. (Teun.) 110, 24 Am. Dec. 444 ; Fuller v. Fuller, 40 Ala. 301 ; Wilson v. Holt, 83 Ala. 528, 3 So. 321, 328 ; Webb's Estate, 1 Tuck. (N. Y.) 372.

11 See cases before cited. See Crawford $v$. State, 73 Miss. 172, 18 So. 848, 35 L. R. A. 224, 225.

12 Succession of Hernandez, 46 La. Ann. 962, 24 L. R. A. 831. 
is a difficult matter to decide, requiring a wise judicial discretion. Even the decisions of the same State are not always harmonious. ${ }^{18}$

There are other questions also that arise under decrees and statutes creating disabilities of this character. The contention often relates not to the validity of the second marriage contracted elsewhere, but to the criminal aspects of the case, as whether the guilty party, upon his return to his domicil and his cohabitation there with his second consort, is guilty of lewdness, fornication, adultery, or bigamy. It will be observed that the first two offences above named are based upon the invalidity of the second marriage; while the last two are based upon the theory that, so far as the accused is concerned, the first marriage continues in existence. The party accused cannot be guilty of lewdness or fornication with a woman who is legally married to him; he cannot be guilty of adultery or bigamy with a woman if he be not already a married man.

Since it is settled that the prohibition to remarry does not prevent the entire dissolution of the first marriage as to both parties (it being inconceivable that there should be a husband without a wife, or vice versa), but merely operates as a penalty or punishment imposed upon the guilty party, it follows that upon remarriage that party cannot, merely because of such remarriage, be deemed guilty of either adultery or bigamy. ${ }^{14}$ Of course, however, this does not imply that there cannot be a

13 In probably the majority of the States where the question has arisen, it has been held that the special domestic policy in this instance should give way to the more general one of upholding marriages wherever practicable. The following decisions hold such a marriage valid even in the domicil. Com. v. Lane, 113 Mass. 458, 18 Am. Rep. 509 ; Putnam $v$. Putnam, 8 Pick. (Mass.) 433 ; Van Voorhis $v$. Brintnall, $86 \mathrm{~N}$. Y. 18, 40 Am. Rep. 505; Thorp $v$. Thorp, 90 N. Y. 602 ; Moore v. Hegeman, 92 N. Y. 521, 44 Am. Rep. 408. Other decisions give precedence to the domestic policy, and favor the invalidity of the marriage. West Cambridge v. Lexington, 1 Pick. (Mass.) 506, 510, $11 \mathrm{Am}$. Dec. 231; Pennegar v. State, 87 Tenn. 244, 10 S. W. 305, 2 L. R. A. 703 ; Marshall $v$. Marshall, 4 N. Y. Suppl. 449 ; Williams $v$. Oates, 5 Ired. L. (N. C.) 535.

14 Com. v. Putnam, 1 Pick. (Mass.) 136 ; People $v$. Hovey, 5 Barb. (N. Y.) 117; State $v$. Weatherby, 43 Me. 248, 69 Am. Dec. 59 ; Crawford v. State, 73 Miss. 172, 35 L. R. A. 224, 225, 18 So. 848. 
statute providing that a guilty party so remarrying shall be punished as if he were guilty of adultery or bigamy. If there be such a statute, the effect of a foreign marriage by the guilty party must generally depend upon the express or implied intent of the statute, the tendency of judicial construction being opposed to the operation of the statute in such a case, unless it be specifically embraced therein. ${ }^{15}$

On the other hand, if the offence charged be lewdness or fornication, the charge is based, not on the continued existence of the former marriage status, but upon the invalidity of the subsequent union. In these cases therefore the guilt or innocence of the accused will turn upon the view taken of the validity of the second marriage, the principles controlling which question have already been discussed. ${ }^{16}$

In one case, decided in New York, ${ }^{17}$ the question has arisen whether or not such foreign marriage constituted a contempt of the courts of the domicil (New York), and it was held that it did not.

\$ 75. Same-Polygamous and Incestuous Marriages. - If one having a consort living and undivorced marries again, though the subsequent marriage should take place in a barbarous State where dual marriages are valid, it will not be upheld in any civilized country. It is contra bonos mores. ${ }^{1}$ This is merely an instance of the operation of one of the exceptions to the enforcement of a foreign law discussed in the second chapter of this work.

The same principles apply to marriages contracted between relatives so near as to cause the union to be deemed incestuous and illegal in all civilized States. Prohibitions of this sort

15 See Com. v. Lane, 113 Mass. 458, 18 Am. Rep. 509.

16 See Pennegar $v$. State, 87 Tenn. 244, 10 S. W. 305, 2 L. R. A. 703 ; State v. Kennedy, 76 N. C. 251, 22 Am. Rep. 683.

17 Thorp $v$. Thorp, 90 N. Y. 602.

1 Ross v. Ross, 129 Mass. 243, 247, 37 Am. Rep. 321 ; Com. v. Lane, 112 Mass. 458, 463, 18 Am. Rep. 509 ; Van Voorhis v. Brintnall, 86 N. Y. 18, 26, 40 Am.Rep. 505; Collins v. Collins, 80 N. Y. 1; Hutchings v. Kimmell, 31 Mich. 126, 18 Am. Rep. 164, 168; Jackson v. Jackson, 82 Md. 17, 33 Atl. 317,319 ; State v. Ross, 76 N. C. 242, 22 Am. Rep. 678, 680-681 ; Campbell v. Crampton, 2 Fed. 417, 424. See True v. Ranney, 21 N. H. 52, 53 Am. Dec. $164,166$. 
imposed by the policy of the forum alone, or by the policy of a few States merely, will not have the effect necessarily of aroiding a marriage between relations, valid where contracted. ${ }^{2}$ In order that the marriage shall universally be deemed invalid (though valid where contracted) the relationship must be so close as to condemn the union in all civilized countries, and to cause it to be considered in all Christian States as impious and contra bonos mores. It is generally agreed that the only marriages answering this description are those contracted between persons related by blood in the lineal ascending or descending line, and (in case of collateral relatives) between brother and sister. $^{3}$

In case of persons related in more distant degree, the question whether their intermarriage is valid will in general depend upon the lex celebrationis of the marriage. If valid there, it will usually be held valid in every State in which it is called in question." And if it be absolutely void where contracted, it will in general be deemed void everywhere.

But if, where contracted, it is merely voidable by decree of court, and not void per se, the fact that the same marriage would be absolutely void if contracted in another State will not justify the courts of the latter State in pronouncing the parties not to be man and wife, even though they have since lived in the latter State, much less if they are domiciled in the State of the marriage. Such is the rule when the validity of the marriage is questioned in a collateral proceeding.

Thus, in Sutton $v$. Warren, ${ }^{5}$ a marriage was contracted in

2 See ante, $\S 73$. If the question arises in the domicil, the policy of the forum (and domicil) may be held to be paramount to the lex celebrationis of the marriage.

3 Story, Coufl. L. § 114 ; Ross v. Ross, 129 Mass. 243, 247-248, 37 Am. Rep. 321 ; Com. v. Lane, 113 Mass. 458, 463, 18 Am. Rep. 509; Medway v. Needham, 16 Mass. 157, 6 Am. Dec. 131; Wightman v. Wightman, 4 Johns. Ch. (N. Y.) 343, 348-350; Van Voorhis v. Brintnall, 86 N. Y. 18, 26, 40 Am. Rep. 505; Hutchings $v$. Kinmell, 31 Mich. 126, 18 Am. Rep. 164, 168 ; Jackson v. Jackson, 82 Md. 17, 33 Atl. 317, 319 ; State v. Ross, 76 N. C. 242, 22 Am. Rep. 678, 680-681.

4 Except in certain cases where the domicil is the forum. See ante, $\$ 73$.

b' 10 Met. (Mass.) 451. 
England, the domicil of the parties, between a man and his mother's sister. Such marriage was not void by English law prior to the statute of $6 \mathrm{Wm}$. IV. c. 54 , but only voidable in the Ecclesiastical Court. The marriage took place before the statute. The parties removed to Massachusetts, about one year after the marriage, by the law of which State a marriage between such relatives was absolutely void. The wife, Ann Sutton, lent money to Warren on his note, which was not paid, whereupon the husband sued Warren upon the note; and objection being made that he was not the husband of Ann, the court held that the marriage, not being void in England but voidable only and not avoided, could not be attacked collaterally in Massachusetts by reason of the laws of that State. ${ }^{6}$

${ }^{6}$ See Cummington $v$. Belchertown, 149 Mass. 223, 226, 21 N. E. 435 ; post, § 78 . 


\section{CHAPTER VI.}

\section{STATUS OF MARRIAGE.}

§ 76. Dual Nature of Marriage. - There are two senses in which the term marriage is familiarly used, both of which are essential to a true marriage, the one being preliminary to the other. These two essential elements of the legal idea of marriage are: (1) The contract of marriage, the agreement of the parties, the wedding ceremony; and (2) The state of life which is ushered in by that ceremony or agreement, the matrimonial union, or the marriage status. These elements, though both often denominated "marriage," are separate and distinct, and should be so treated. There can be no matrimonial union without a marriage contract; there can be no (valid) marriage contract without a matrimonial union resulting therefrom. Yet they are by no means one and the same. A failure to observe the distinction will cause, as it has already often caused, serious confusion and error. ${ }^{1}$

1 See Cook $v$. Cook, 56 Wis. 195, 43 Am. Rep. 706, 14 N. W. 33, 36. Thus we find the New York courts holding that a divorce is a proceeding in personam, and that it operates to annul the contract of marriage, instead of dissolving the status or union created by that contract, in which latter case the proceeding would be in rem, as is generally held. See post, $\$ 87,89$ et seq. In Jones $v$. Jones, 108 N. Y. 415, 424, - a divorce case, - the New York court says : "The Texas court did not acquire jurisdiction of the defendant by service of citation here. The contract of marriage cannot be annulled by judicial sanction any more than any other contract inter partes, without jurisdiction of the person of the defendant." The distinction between the contract of marriage and the resulting union or status is brought out in many of the cases. See Story, Confl. L. $\S 124 a$, note $(a)$; Brook $v$. Brook, 9 H. L. Cas, 193 ; Kinney $v$. Com., 30 Gratt. (Va.) 858 ; State $v$. Kennedy, 76 N. C. 251, 22 Am. Rep. 683, 684 ; Campbell v. Crampton, 2 Fed. 417, 424 ; State v. Tutty, 41 Fed. 753, 758 ; Adams $v$. Palmer, 51 Me. 481, 483. 
So far as the contract of marriage is concerned, it is an executed agreement between two persons who must be competent to contract, and is governed by the same general rules that control other executed contracts. ${ }^{2}$

But a marriage, in its complete sense, is much more than a contract. It is ushered in by the solemn compact of the parties, with the accompaniment of such formalities and ceremonies as the law may prescribe. The result of this contract is the immediate creation of a union for life between the parties. But the union itself is no more a contract than the ownership of land under a deed of conveyance is a contract. It is a status, a condition, which by their contract has become fastened upon the parties during their lives and in every country whither they may go, whether temporarily or permanently.

The creation, continuation, and dissolution of this relation constitute matters of deepest concern not only to the parties interested but to the State as well. The proper performance of the duties it imposes involves not only the highest happiness and welfare of the individuals immediately concerned, but also that of their offspring and of the countless generations to succeed them. To the State it offers the means of protecting its sitizens from impurity and immorality, secures them the blessings of home and family, and creates a noble nursery for the commonwealth.

Nothing can be of greater importance or interest to the State than this relation, which, with its incident, - the family, - is justly deemed the foundation, corner-stone, and unit of the social order. It is not surprising therefore to find the State regarded almost as a party to the transaction, both in its inception and in its dissolution. ${ }^{8}$

2 The proper law governing the contract of marriage will be considered post, $\$ \S 77,78$.

3 See Hood $v$. State, 56 Ind. 263, 26 Am. Rep. 21, 24 ; People $v$. Dawell, 25 Mich. 247, 12 Am. Rep. 260, 268; Ellis $v$. Ellis, 55 Minn. 401, 56 N. W. 1056, 1059 ; Prosser $v$. Warner, 47 Vt. 667, 19 Am. Rep. 132, 134 ; Gregory v. Gregory, $78 \mathrm{Me.} 187,57 \mathrm{Am}$. Rep. 792; Cook v. Cook, 56 Wis. 195, $43 \mathrm{Am}$. Rep 706, 14 N. W. 33, 36; Dunham v, Dunham, 162 Ill. 589, 44 N. E. 418. 35 L. R. A. 70, 79 ; O'Dea $v$. O'Dea, 101 N. Y. 23, 39 (dissenting opinion). 
Not only will the State prescribe definitely the persons who may enter into the relation and the forms and solemnities with which it shall be ushered in, but it will likewise preside over its dissolution, not permitting a termination of it during the lives of the parties, save with its consent (through its courts) and for causes assigned by itself. Many of the peculiarities incident to the law regulating marriage and divorce are due to the fact that the State is thus a quasi party to the transaction and deeply interested in the proper performance of its obligations. There is perhaps no other private relation in which the State becomes, as it were, a third party. ${ }^{4}$

Keeping the contractual element of marriage distinct from the status, we will examine (1) The "proper law" regulating contracts of marriage; (2) The "proper law" governing the marriage status or the matrimonial union that results from the contract.

\$77. The Contract of Marriage-Formal Validity. - By the contract of marriage, or marriage contract, is meant the solemn agreement of the parties to assume the relation of man and wife, - the wedding ceremony, - which constitutes the vestibule to the matrimonial union.

It is of course to be distinguished from a contract to marry, at least at the present day, when such contracts, even though accompanied by consummation, no longer constitute a marriage. The contract to marry is merely an executory contract, to be performed thereafter by marriage; while the marriage contract itself is an executed contract, performed at the same time and place at which it is entered into. The contract to marry may be performed elsewhere than where it is entered into. The contract to marry may be broken. The contract of marriage cannot be, though the rights and obligations springing from the marital

4 Unless the relation of parent and child be excepted, to which the relation of marriage has been sometimes likened. See Cook $v$. Cook, 56 Wis. 195, 43 Am. Rep. 706, 14 N. W. 33, 36. But the relation of parent and child has its origin in the laws of nature and in municipal law, not in contract. Matrimony is more nearly analogous to the statutory relation of adopted parent and child, which, like marriage, begins with a quasi contract with the State, re. sulting in the creation of a status. See post, $\S 101$. 
relation may be violated. There can be no "breach" of a com. pletely executed contract.

Following the general rule touching the "proper law" to govern executory contracts, ${ }^{1}$ if a contract to marry is made in one-State (locus celebrationis), and it is agreed that the marriage is to take place in another (locus solutionis), or such an intention is to be implied, the law of the place of performance (lex solutionis) is to the performance of the contract, and to determine whether it has been properly performed, or, if it cannot be legally performed there, to determine the validity of the original contract. If the marriage may lawfully be celebrated in the State agreed upon (the locus solutionis of the contract to marry), the contract to marry will be sustained, though made in a State where such marriage (if there celebrated) would be invalid; and if the marriage is contrary to the law of the place where the executory contract is to be performed, that promise will be invalid though it could have been lawfully performed in the State where the promise of marriage is entered into. The lex solutionis of an executory contract governs matters relating to its performance, and this applies as well to promises of marriage as to other executory contracts. ${ }^{2}$

In the discussion of the contract of marriage, which is an executed contract, we must anticipate the principles which determine the "proper law" governing executed contracts gener-

1 See post, $\$ 175$.

2 See Haviland v. Halstead, 34 N. Y. 643 ; Van Voorhis v. Brintnall, 86 N. Y. 18, 26, 40 Am. Rep. 505. But see Campbell v. Crampton, 2 Fed. 417, 421. In the latter case, a man entered into a contract in Alabama, where he resided, with his aunt, to marry her at a future time in New York, where she resided. Such a marriage was invalid in Alabama, but good in New York. The woman sued him in New York for breach of promise. The court held that the contract was invalid, but not on the ground that the contract should be governed by the law of the place where it was made. On the contrary, it was admitted that its validity should be governed by the law of the place of performance (lex solutionis). Bnt it was decided that the place of performance of the promise of marriage was not the place where the marriage was to take place (New York), but was the domicil of the future husband (Alabama), where the parties were to live their married life. This latter ruling can hardly be reconciled with reason. The contract to marry is performed as soon as the marriage occurs. 
ally, from which the contract of marriage does not materially differ.

We have heretofore seen that the marriage is in general to be determined by the law of the place where the contract is to be entered into (oci celebrationis). ${ }^{8}$

Another principle applicable to contracts generally, and equally applicable to the marriage contract, is that the formal validity of the contract (that is, the forms and solemnities with which it is to be entered into) is also to be determined by the law of the place where the contract is entered into (lex loci celebrationis). ${ }^{4}$ With respect to the forms and ceremonies of the marriage, the solemnities with which the parties are required by law to enter into the marriage contract, it is universally conceded by all the authorities, English and American, that the lex celebrationis governs, no matter where the question arises. So far as these matters are concerned, if the marriage is valid in the locus celebrationis, it is valid everywhere; if invalid where contracted, it is in general invalid everywhere. ${ }^{5}$ Thus the lex celebrationis has been held to govern the effect upon the validity of the marriage contract of the omission of banns or license; ${ }^{6}$ of the want of consent of parent or guardian; ${ }^{7}$ of

Ante, \$73.

4 See post, $\$ 172$.

5 Scrimshire $v$. Scrimshire, 2 Hagg. Cons. 395 ; Dalrymple v. Dalrymple, 2 Hagg. Cons. 54 ; Compton v. Bearcroft, 2 Hagg. Cons. 444; Warrender v. Warrender, 2 Cl. \& F. 488, 530 ; Patterson $v$. Gaines, 6 How. 550, 587 ; State $v$. Tutty, 11 Fed. 753, 760; Phillips $v$. Gregg, 10 Watts (Penn.), 158, 36 Am. Dec. 167, 168 ; Dumaresly v. Fishly, 3 A. K. Marsh. (Ky.) 368 ; Hutchings \%. Kimmell, 31 Mich. 126, 18 Am. Rep. 164 ; Com. v. Graham, 157 Mass. 73,75 ; Loring $v$. Thorndike, 5 Allen (Mass.), 257, 265; Vischer $v$. Vischer, 12 Barb. (N. Y.) 640, 645; Kinney v. Com., 30 Gratt. (Va.) 858 ; Clark $v$. Clark, 52 N. J. Eq. 650 , 30 Atl. 81, 83 ; Jackson v. Jackson, 82 Md. 17, 33 Atl. 317, 319 ; Jackson v. Jackson, 80 Md. 176, 30 Atl. 752, 754 ; Pennegar v. State, 87 Teun. 244, 10 S. W. 305, 2 L. R. A. 703, 705; State $v$. Kennedy, 76 N. C. 251,22 Am. Rep. $683,684$.

${ }^{6}$ Compton $v$. Bearcroft, 2 Hagg. Cons. 444 ; Loring $v$. Thorndike, 5 Allen (Mass.), 257, 265. The former was the first case to uphold the validity of "Gretna Green" marriages.

${ }^{7}$ Steele v. Braddell, Milw. (Irish), 1; Simonin v. Mallac, 2 Sw. \& Tr. 67 ; Com. v. Graham, 157 Mass. 73. 
the omission of religions rites, such as a celebrant in holy orders, ${ }^{8}$ etc.

The fact that the parties go abroad to contract the marriage in order to evade the laws of their domicil with respect to license, banns, celebrants, etc. (which are matt form), will not invalidate the marriage if ralid where contracted. Such a marriage will be sustained even in the courts of the domicil upon the parties' return thither' anxiety to evade the law of their domicil, ge inte a barbarous or unsettled country, subject to no particular law, the law of their domici is to be considered as follow and as still governing the contract. And perhaps the same principle applies to marriages contracted on board vessels on the high seas, in evasion of the domiciliary law, no matter what flag the vessel flies. ${ }^{20}$

But the general rule that the lex celebrationis regulates the forms and ceremonies incident to the contract of marriage, and that a marriage invalid in these respects by the law of the place where it is celebrated is invalid everywhere, is subject to

8 Dalrymple $v$. Dalrymple, 2 Hagg. Cons. 54 ; Phillips v. Gregg, 10 Watts (Penn.), 158, 36 Am. Dec. 167, 168 ; Dumaresly v. Fishly, 3 A. K. Marsh. (Ky.) 368; Hutchings v. Kimmell, 31 Mich. 126, 18 Am. Rep. 164; Jackson v. Jackson, 80 Md. 176, 30 Atl. 752, 754 ; Clark v. Clark, 52 N. J. Eq. 650, 30 Atl. 81.

- Where the evasion of the domiciliary law is in respect to, not a matter of form, but a matter of capacity to marry, the courts of the domicil will some. times, as we have seen, substitute the domestic law. See ante, § 73.

${ }^{20}$ Norman v. Norman, 121 Cal. 620, 66 Am. St. Rep. 74. In this case, the parties left California, where they were domiciled, in a small boat, reached the high seas, and there agreed in the presence of the captain of the boat to take each other as man and wife, in evasion of the California law, requiring the consent of the parents. It was held that, the high seas being subject to the laws of no particular State, the law of California followed the parties, and the marriage was invalidated. The decision might, it would seem, have been placed upon a safer foundation. The boat was a California boat, and as such a part of the territory of California while on the high seas, and therefore subject to California law. Should a couple competent to marry elope from their domicil and be married on board a foreign ocean liner, in accordance with the law of the flag, but in evasion of the law of their domicil, it could hardly be maintained that the law of the domicil should control in formal matters. 
an exception in the case of marriages celebrated in barbarous countries, or in a country whose law requires religious rites opposed to the tenets of the faith prevailing in the country to which the parties belong. The exception has its origin in a sort of moral or religious necessity. If the parties, in such case, conform to the requirements of their own domicil, the marriage will generally be valid."

§ 78. Substantial Validity of Marriage Contract. - The contract of marriage is an executed, not an executory contract, and is fully performed as soon as it is entered into. There can be no question of its performance elsewhere. ${ }^{1}$ For the same reason there can be no question of its breach at any other time or place than when and where it is entered into. If a "violation of the marriage contract" is alleged to have taken place after the marriage, as in case of desertion, cruelty, adultery, etc., it is an inaccurate and misleading use of words. In such cases, it is the marriage status or relation whose obligations have been broken, not the marriage contract.

Owing to this misconception, some courts have held that in

11 Story, Confl. I. $\S 118$; Whart. Confl. L. $\$ 175,176$; Ruding v. Smith, 2 Hagg. 390 ; Harford $v$. Morris, 2 Hagg. 430.

1 Many cases, it is true, speak of the performance of the marriage contract in places other than that where the marriage is solemnized, usually the parties' domicil. See Warrender $v$. Warrender, 2 Cl. \& F. 488, 536; Vischer $v$. Vischer, 12 Barb. (N. X.) 640, 646; Campbell v. Crampton, 2 Fed. 417, 425; Shreck $v$. Shreck, 32 Tex. 578, 5 Am. Rep. 251. These cases refer for the most part to the law governing the personal rights and obligations of the married pair, such as the violations of duty which may be grounds to dissolve the marriage. Another group of cases which fall into the same inaccuracy deal with the law governing the marital rights of the parties in property of the consort, subsequently acquired. See Le Breton $v$. Miles, 8 Pai. Ch. (N. Y.) 261, 265 ; Mason $v$. Homer, 105 Mass. 116 ; Harral v. Harral, 39 N. J. Eq. 379, 51 Am. Rep. 17, 23, 24; Kneeland $v$. Ensley, Meigs (Tenn.), .620, 33 Am. Dec. 168, 169.

In all questions of this character, arising after the marriage contract is entered into, the marriage contract itself has no influence. It is the marriage status, resulting from the contract, upon which these rights depend, and the law which controls that status, not that which governs the contract, is the "proper law" to determine such rights. The status may exist or "be performed " elsewhere, but the marriage contract must in its nature be performed where it is entered into. 
divorce cases the law of the place where the marriage was contracted must be looked to in order to determine on what grounds the marriage may be dissolved. ${ }^{2}$ It is now well established however that such matters are not violations of the marriage contract, but of the marriage relation and its obligations, and as such are controlled by the law which governs that status, that is, the law of the parties' domicil at the time of the divorce, regardless of the law of the place where the marriage was celebrated or where the acts complained of occurred. ${ }^{8}$

But if the marriage is alleged to be voidable by decree of court for a cause existing at the time of the marriage contract, though not void per se, quite different considerations present themselves. Here the invalidating matter goes to the very root of the contract itself and renders it voidable. The status in this case may be dissolved, if at all, not for any violation of the marriage relation, for the parties may have been exemplary in their conduct towards each other, but merely because the contract upon which it is dependent may be avoided. This is a very different case from that of supervenient causes for divorce.

The subject is not free from difficulty. If the marriage is valid and free from objection in the State where it is solemnized, there can be no doubt that it will be held free from objection elsewhere, even though the parties should be domiciled in, or should afterwards remove to, another State, by whose laws such a marriage would be voidable $a b$ initio. ${ }^{4}$

2 This was substantially the view taken in England by the earlier decisions. See Dicey, Confl. L. 270, note (1); Lolley's Case, 2 Cl. \& F. 567; McCarthy $v$. De Caix, 2 Cl. \& F. 568 ; Tooey $v$. Lindsay, 1 Dow. 117. See Arrington v. Arrington, 102 N. C. 491,9 S. E. $200,207$.

3 This is now the rule even in England. See Dicey, Confl. L. 270 ; Wilson v. Wilson, L. R. 2 P. \& D. 435, 442 ; Shaw v. Gould, L. R. 3 H. L. 55, 85. And it is so held in America with great unanimity. See Harteau v. Harteau, 14 Pick. (Mass.) 181, 25 Am. Dec. 372 ; Chase v. Chase, 6 Gray (Mass.), 157, 161 ; Watkins $v$. Watkins, 135 Mass. 83 ; Hunt $v$. Hunt, 72 N. Y. 217, 228, 28 Am. Rep. 129 ; Roth $v$. Roth, 104 Ill. 35, 44 Am. Rep. 81, 83; Van Fossen $v$. State, 37 Ohio St. 317, 41 Am. Rep. 507, 508; Felt $v$. Felt, 57 N. J. Eq. 101, 40 Atl. 436. But see Prosser $v$. Warner, 47 Vt. 667, 19 Am. Rep. 132, 134 ; Norris $v$. Norris, 64 N. H. 523, 15 Atl. 19. The last two cases qualify the rule somewhat, - it is believed, erroneously.

4 Such would be the case if the marriage were absolutely void in the latter 
If the marriage is voidable where contracted (but is not there annulled), and the parties remove to another State, the question becomes more complex. If void or voidable by the laws of the latter State also, it would seem reasonable that it should be held to be voidable there. ${ }^{5}$ However this may be, it is certainly not void in the latter State, so as to be susceptible of collateral attack in its courts. ${ }^{6}$

Finally, if the marriage is valid by the law of the latter State, while voidable (though not annulled) in the State where it was contracted, it would seem, upon principle, that it should be voidable in the latter, for the invalidity relates to the marriage contract, and not to the status merely. ${ }^{7}$

In Cummington $v$. Belchertown, ${ }^{8}$ a woman residing in Massachusetts married there, and afterwards became insane. Her husband, leaving her in Massachusetts, went to New York, where he applied to have the marriage annulled on the ground of fraud in its procurement, alleging that his wife had been in. sane before her marriage and that this fact had been concealed from him. The New York court annulled the marriage for the fraud alleged (which was not a ground for annulling the marriage in Massachusetts), and the validity of the New York decree coming in question in Massachusetts, the court held it invalid. One of the grounds of its decision was that the validity of the marriage contract, entered into in Massachusetts, should have been governed by Massachusetts, not by New York, law.

In Sutton $v$. Warren, ${ }^{9}$ an Englishman married in England

State, except, according to some authorities, when it is the actual domicil of the parties at the time of the marriage. See ante, $\S 73$. A fortiori should it be so (probably without even the exception just adverted to) when the marriage is voidable only in the latter State. See Cummington v. Belchertown, 149 Mass. 223, 226, 21 N. E. 435.

5 Cummington $v$. Belchertown, 149 Mass. 223, 226, 21 N. E. 435.

6 Sutton $v$. Warren, 10 Met. (Mass.) 451 ; Com. v. Lane, 113 Mass. 458, 463, 18 Am. Rep. 509.

7 See Cummington $v$. Belchertown, 149 Mass. 223, 226, 21 N. E. 435 . But it is possible that the general favor shown towards marriages would prevent this result.

8149 Mass. 223, 226, 21 N. E. 435.

910 Met. (Mass.) 451, already quoted, ante, $\$ 75$. 
his mother's sister, the English law at that time rendering such a marriage merely voidable. The parties afterwards (the marriage not having been annulled meanwhile) removed to Massachusetts, where such marriage was absolutely void. The husband having brought suit upon a chose in action belonging to the wife, it was objected that the marriage was void under Massachusetts law, but the court held that it could not be subjected to collateral attack.

$\S 79$. The Marriage Status or Matrimonial Union-Its Commencement and Continuance. - As has been already observed, the status of marriage, the legal union between man and wife, is justly deemed one of the most important, if not the most important, of all the relations recognized by the law. ${ }^{1}$

The discussion of the proper law regulating the marriage status may be divided into the following heads: (1) The law governing the commencement of the status; (2) That governing the continuance of the status, with the incidents arising therefrom; and (3) The law governing the dissolution of the status, or divorce, - a separate chapter being devoted to the latter.

The commencement of the marital relation is to be found, as has been already pointed out, in the marriage contract, the proper law governing which, both as to the capacity to enter into it, and as to the formal and substantial validity thereof, has been heretofore sufficiently considered. ${ }^{2}$

The status once acquired under a marriage contract valid by the proper law, the marriage relation is recognized and continues to exist in every State whither the parties may wander, until it is terminated by the death of one, or the divorce of both.

The marriage status is essentially a mode of life, and it is peculiarly appropriate therefore that it should be governed in all particulars by the law of the place where the parties live, that is, by the law of their domicil, and that when their domicil changes the law governing their status should change with it. ${ }^{3}$ But this principle, like most others whose object is

1 Ante, $\$ 76$.

${ }^{2}$ Ante, $\S \S 73,77,78$.

3 Cook v. Cook, 56 Wis. 195, 43 Am. Rep. 706, 14 N. W. 33, 36 ; Clark

v. Clark, 8 Cush. (Mass-d 385. 
the determination of the "proper law," is subject to the operation of the great exceptions mentioned in the second chapter, in which the lex fori will be substituted for a proper foreign law, whenever the policy or interest of the forum or its citizens demands such a course.

Hence, the fact that the law of the legal situs or domicil of the parties gives the husband extraordinary rights over the person of the wife, not authorized by the laws of the State where they happen to be, such as the right of personal chastisement, the right to deprive her of liberty, etc., will not justify the husband in resorting to such measures in the latter State. Its courts and conservators of the peace will interfere in such cases to the same extent as if the parties were residents of the forum. For purposes of police, the law of the actual situs of the person will always govern. ${ }^{4}$

$\S 80$. Incidents of the Marriage Status - Marital Rights in Consort's Property - Lands. - The incidents of the marriage tie arise by operation of law from the marital relation, not from the marriage contract, and are to be determined and controlled in general by the same law that controls that relation, the lex domicilii, unless the particular case is one of the great exceptions. As has been said by a learned judge: ${ }^{1}$ " When the contracting parties have entered into the married state, they have not so much entered into a contract as into a new relation, the rights and duties and obligations of which rest, not upon their agreement, but upon the general law of the State, statutory or common, which defines and prescribes those rights, duties, and obligations. They are of law, not of contract."

Marital rights in the property of the consort are incidents of the matrimonial status implied by $l a w$, and in this aspect may be regarded as partaking of that status. In another aspect, they may be regarded as mutual transfers of interests in prop.

1 Harrison v. Harrison, 20 Ala. 629, 56 Am. Dec. 227, 232 ; Maguire $v$. Maguire, 7 Dana (Ky.), 181, 186 ; Prosser v. Warner, 47 Vt. 667, 19 Am. Rep. 132, 134; Blackinton v. Blackinton, 141 Mass. 432, 435-436. See Whart. Confl. L. $\$ \S 166,167$.

1 Appleton, J., in Adams $v$. Palmer, 51 Me. 481, 483. See State $v$. Tutty, 11 Fed. 753, 758. 
erty by operation of law. In either aspect it will be found that they are in general to be determined and regulated by the same law that regulates the status itself, namely, the law of the parties' legal situs or domicil, at least if the property in question is personalty. ${ }^{2}$ But marital rights may arise not only as incidents of the marriage status, but also from marriage settlements or contracts entered into between the parties. In such cases the rights of the parties are regulated by their contract, not by the law.

In respect to immovable property, it is well settled that in this, as in every other transfer or link in the chain of title, the lex situs of the property in question will control. Hence, as to such property, if there be no nuptial contract the lex situs will govern; if there is a nuptial contract, it will operate only so far as the lex situs permits.

Thus, the dower right of the wife fand the curtesy of thahusband) ands af the consort will be determined and regulated by the law of the place where the land lies, not where the parties live. ${ }^{8}$

In Lamar $v$. Scott, ${ }^{4}$ a man domiciled in Georgia died. He had been seised during the coverture of land in South Carolina, by whose law a seisin at any time during the coverture sufficed to give the wife dower. He had aliened the land without joining his wife in the deed. By the law of Georgia (his domicil) the wife was dowable only in the lands of which the husband died seised. The South Carolina court held that the lex situs should govern, and that the wife must be endowed of the lands there situated.

In Depas $v$. Mayo, ${ }^{5}$ Depas of Louisiana married in Pennsylvania a woman resident in Pennsylvania. They immediately proceeded to Louisiana, where they resided for several years.

2 Post, § 81 .

8 Ante, $\$ 12$; Lamar v. Scott, 3 Strob. L. (S. C.) 562 ; Newcomer v. Orem, 2 Md. 297, 56 Am. Dec. 717, 718; Moore v. Mayor, etc., 8 N. Y. (4 Selden) 110, 59 Am. Dec. 473, 474; Kneeland v. Ensley, Meigs (Tenn.), 620, 33 Am. Dec. 168, 169 ; Depas v. Mayo, 11 Mo. 314, 49 Am. Dec. 88, 90-91.

3 Strob. L. (S. C.) 562 .

- 11 Мo. 314, 49 Am. Dec. 88. 
Both parties at the time of the marriage were destitute of property, but soon by their joint exertions accumulated a consider. able amount. By the laws of Louisiana, one half of all property acquired during the coverture belonged to the wife, and could not be disposed of by the husband. Afterwards Depas and his wife removed to St. Louis, and Depas purchased (with money in part belonging to his wife under Louisiana law) a lot in St. Louis, taking the title in his own name. The parties were afterwards divorced in Louisiana, and the wife claimed one half of the St. Louis lot by way of implied trust. The Missouri court held that the Louisiana law governed as to the personalty acquired while the parties were domiciled there, and that the wife was therefore entitled to one half of such property; but that, as to the land in Missouri, the lex situs must govern. But since, under Missouri law, if one purchased land with the funds of another, the conveyance being made to the former, he was deemed a mere trustee for the latter, the court adjudged that Depas was a trustee for his wife to the extent of one half the St. Louis lot.

So, also, if there be an express ante-nuptial or post-nuptial contract touching the marital rights in land, its effect and validity must be controlled by the lex situs of the laud, not by the law of the place where such contract, or the contract of marriage, was entered into, nor by the lex domicilii of the parties. ${ }^{\circ}$

\$ 81. Marital Rights in Personalty of Consort - In Absence of Express Contract. - We have already had, and will hereafter

6 Richardson $v$. De Giverville, 107 Mo. 422, $17 \mathrm{~S}$. W. 974 ; Heine $v$. Ins. Co., 45 La. Ann. 770, 13 So. 1; Besse v. Pellochoux, 73 Ill. 285, 24 Am. Rep. 242 ; Fuss $v$. Fuss, 24 Wis. 256, 1 Am. Rep. 180, 181; Castro $r$. Illies, 22 Tex. 479, $73 \mathrm{Am}$. Dec. 277, 281. But if the contract is valid and sufficient under the lex situs, and is capable of specific enforcement there, the contract will confer an equitable title to the land, without a deed. See Castro v. Illies, 22 Tex. 479, 73 Am. Dec. 277, 281; Fuss v. Fuss, 24 Wis. 256, 1 Am. Rep. 180, 181. In Polson v. Stewart, 167 Mass. 211, 45 N. E. 737, it was held that the law of the place of contract, not the lex situs, should control in this respect. But this case related to a contract for the relinquishment of marital rights, not for the acquisition of them. This case is discussed post. $\$ 174$. 
still further have, occasion to ohserve an important principle generally applicable to personal property (except in case of conveyances and other voluntary transactions with respect to it), namely, that it has its legal situs at the tegal situs, domicil, of the owner. 'Marital rights in the personalty of the consort, if regarded as mutual transfers of interests in the property, are transfers by operation of law, not by the voluntary act of the parties, and, like other transfers by act of the law, such as the suecession personalty, are to beconted by the law of the legal situs of the not by the of his actual situs, nor by the of the actuat situs of the property.

The law of the domicil will govern the marital rights of the parties in personal property, not only because of the general principle just pointed out, but also because these rights are incidents of the marriage status, and governed therefore by the same law that regulates that status in other respects. And it should be particularly observed that the domicil whose law governs in these matters (supposing the married pair to have changed their domicil several times) is that domicil possessed by them at the time the particular marital right in question became vested. A mere contingency cannot be said to be either a transfer, or an incident of the status.

Hence, as to peither in the personalty of the consort upon his or her death, as distributee or otherwise, the law of their domicil at the time of the death will control, not that of the domicil at the time of the acquisition of the property, nor that of the place place. Such rights do not vest until the death occurs. Indeed this is merely one instance of the rule that the law of the last domicil of a decedent controls the succession to his personal property. ${ }^{3}$

1 See ante, $\S 14$; post, $\S 120$ et seq. This applies to involuntary trans. fers and dealings with personalty. If the owner voluntarily deals with it, as by conveyance, it is the actual, not the legal, situs of the owner that, for the purposes of that transaction, gives the situs to the property. Post, $\S 128$ et seq.

2 That the lex domicilii is the proper law governing succession, see post, $\$ \S 139$ et seq.

8 See White v. Tennant, 31 W. Va. 790, 8 S. E. 596, 599 ; Steer's Succes. 
As to those marital rights in personalty which vest at or during marriage, such as the husband's common law right to the wife's chattels and choses in action, the law of the domicil at the time the right rests will control. If the consort in whose property the right is claimed owned it at the time of the marriage, the marital right vests immediately upon the marriage, and the law of the parties' domicil at that time (that is, the law of the husband's domicil at that time) will determine the character and extent of the rights in question. ${ }^{4}$

It is sometimes said that these marital rights in property owned by the consort at the time of the marriage are to be controlled by the law of the "matrimonial domicil," which is defined to be "the country where the husband is domiciled at the time of the marriage, or in which he intends to settle immediately after the marriage." 5

But it is submitted that to hold the country where the husband intends to settle (the factum not combining with the animus) to be his domicil, whether "matrimonial" or otherwise, is violative of one of the leading principles governing the acquisition of a domicil of choice. This doctrine has recently

sion, 47 La. Ann. 1551, 18 So. 503 ; Succession of Hernandez, 46 La. Ann. 962, 24 L. R. A. 831 ; Hairston v. Hairston, 27 Miss. 704, 61 Am. Dec. 530 ; Hegeman v. Fox, 31 Barb. (N. Y.) 475. See post, $\S 139$ et seq.

4 Mason v. Homer, 105 Mass. 116 ; Graham v. Bank, 84 N. Y. 393, 400, 38 Am. Rep. 528 ; Kneeland v. Ensley, Meigs (Tenn.), 620, 33 Am. Dec. 168, 169 ; Newcomer v. Orem, 2 Md. 297, 56 Am. Dec. 717, 718 ; Fuss v. Fuss, 24 Wis. 256, 1 Am. Rep. 180. See Ford v. Ford, 2 Mart. N. s. (La.) 574, 14 Am. Dec. 201, 203; Townes v. Durbiu, 3 Met. (Ky.) 352, 77 Am. Dec. 176. The lex celebrationis of the marriage, as such, has nothing to do with the question, for the sole effect of the executed contract of marriage, standing alone, is to create the marriage relation or status. See ante, $\$ \S 76$ et seq.

5 Story, Confl. L. $\$ 193$; Fuss v. Fuss, 24 Wis. 256, 1 Am. Rep. 180, 181; Besse $v$. Pellochoux, 73 Ill. 285, 24 Am. Rep. 242, 246, 247-248; Ford v. Ford, 2 Mart. N. s. (La.) 574, 14 Am. Dec. 201, 203 ; Larquie $v$. Larquie, 40 La. Ann. 457, 4 So. 335, 336 ; Champon v. Champon, 40 La. Ann. 28, 3 So. 397, 399 ; Routh v. Routh, 9 Rob. (La.) 224, 41 Am. Dec. 326 ; Allen v. Allen, 6 Rob. (La.) 104, 39 Am. Dec. 553 ; Le Breton $v$. Nouchet, 3 Mart. (La.) 60, 5 Am. Dec. 736 ; Harral v. Harral, 39 N. J. Eq. 379, 51 Am. Rep. 17, 23 ; Castro v. Illies, $22 \mathrm{Tex} .479,73 \mathrm{Am}$. Dec. 277 ; State $v$. Barrow, 14 Tex. 179, 65 Am. Dec. 109. 
been disapproved in England, where it has been adjudged that there is no such thing as a "matrimonial domicil." 6

A somewhat similar question has arisen with respect to property acquired by either consort, while the married pair are actually in transitu from one State to another, having abandoned one domicil and not yet reached the other. It has been held in several cases, in analogy to the theory of the "matrimonial domicil," that the law of the intended domicil should govern. It will not be attempted to reconcile these cases with principle. ${ }^{7}$

In general, with respect to after acquired property, the marital rights will depend upon the la the actual domicil of the parties at the time of such acquisition, for at that time, if at all, the rights vest. ${ }^{8}$

It must be constantly remembered however that these rules for the determination of the "proper law" are subject to the general exceptions discussed in the second chapter, and that the proper law will be substituted by the lex fori (the law of the

6 Le Mesurier v. Le Mesurier, App. Cas. 517, 11 Rep. 527 [1895]. It should be further observed that if the theory is correct that the law of the intended domicil should control the marital rights of the parties, then there must be substituted for the doctrine of the transfer of these interests by operation of law, or as an incident of the marriage status, that of a transfer by tacit or implied contract, for it is only upon that theory that the law of an intended domicil can govern. Yet Judge Story, who is one of the strongest advocates of the " matrimonial domicil," has also placed the seal of his disapproval upon the theory of any implied or tacit contract with reference to marital rights. Story, Confl. L. § 190. See Hairston v. Hairston, 27 Miss. 704, 61 Am. Dec. 530. And even Story admits that if the property is acquired after marriage, the marital rights are governed by the law of the actual domicil at the time of the acquisition. Story, Confl. L. $\$ 187$; State $v$. Barrow, 14 Tex. 179 , 65 Am. Dec. 109 ; Castro $v$. Illies, 22 Tex. 479, 73 Am. Dec. 277 ; Fuss $v$. Fuss, 24 Wis. 256, 1 Am. Rep. 180.

7 See Ford $v$. Ford, 2 Mart. s. s. (La.) 574, 14 Ain. Dec. 201 ; State $v$. Barrow, 14 Tex. 179, 65 Am. Dec. 109.

8 McLean $v$. Hardin, 3 Jones' Eq. (N. C.) 294, 69 Am. Dec. 740 ; State $v$. Barrow, 14 Tex. 179, 65 Am. Dec. 109 ; Ford $v$. Ford, 2 Mart. s. s. (La.) 574, 14 Am. Dec. 201 ; Castro $v$. Illies, 22 Tex. 479, 73 Am. Dec. 277 ; Fuss v. Fuss, 24 Wis. 256, 1 Am. Rep. 180; Murphy $v$. Murphy, 5 Mart. (La.) 83, 12 Am. Dec. 475 ; Hicks v. Pope, 8 La. 554, 28 Am. Dec. 142 ; Succession of Packwood, 9 Rob. (La.) 438, 41 Am. Dec. 341. 
actual situs of the property) whenever the interest or policy of the forum, or the welfare of its own citizens, demand it. ${ }^{9}$

Thus, in Smith $v$. McAtee, ${ }^{10}$ upon a partition of land in Maryland, the land was sold, the proceeds in part belonging to a woman who, with her husband, resided in Illinois. By the law of Illinois the wife's personalty vested in the husband absolutely and was liable for his debts. By the law of Maryland it was the property of the wife, free from the husband's debts. A creditor of the husband attached the fund in Maryland, but it was held that the lex fori should govern, on the ground that to enforce the Illinois law would contravene the established policy of Maryland.11

\$ 82. Same-Express Contract touching Marital Rights. - If there be a contract between husband and wife touching the marital in the property of the other, and such contract embraces only personalty owned at the time of the marriage, the contract, if valid by the law of the place where it is macte, will govern as to the personalty owned at that time, wherever it be actually situated. 'But in as as thereafter acquired, the contract not embracing it, the marital rights will be determined by the same law as if there had been no contract, that is, by the law of the actual domicil at the time of the acquisition. ${ }^{2}$

If the contract embraces personalty then owned or thereafter to be acquired by the parties, and is valid where made, it will fur-

9 Story, Confl. L. § 189 ; Le Breton $v$. Nouchet, 3 Mart. (La.) 60, 5 Am. Dec. 736 ; McLean v. Hardin, 3 Jones' Eq. (N. C.) 294, 69 Am. Dec. 740 ; Smith $v$. McAtee, 27 Md. 420, 92 Am. Dec. 641.

$1027 \mathrm{Md}$. 420, $92 \mathrm{Am}$. Dec. 641.

11 It is the more remarkable that the court should have followed the lex fori instead of the proper law, since the attaching creditor was a citizen of Maryland, while the married woman was not. The decision was based entirely upon the State's policy.

1 Subject to the great exceptions to the proper law. See Story, Confl. L. $\S \S 183$ et seq.; Castro $v$. Illies, 22 Tex. 479, 73 Am. Dec. 277; Fuss $v$. Fuss, 24 Wis. 256, 1 Am. Rep. 180; Wilder's Succession, 22 La. Ann. 219, 2 Am. Rep. 721.

2 Story, Confl. L. $\S \S 183,184$ et seq. ; Fuss $v$. Fuss, 24 Wis. 256, 1 Am. Rep. 180 ; Castro $v$. Illies, 22 Tex. 479, 73 Am. Dec. 277. 
nish the rule by which their marital rights will be determined throughout their wedded life, though they subsequently remove to or acquire property in another State, where such a contract, if made there, would not be upheld. ${ }^{3}$

\$ 83. Rights and Duties of Parents towards Children. - The rights and duties of parents with respect to their children may be regarded as an incident of the marriage relation, or the relation of parent and child may be treated as a distinct status or condition. In either aspect the result is the same.

So far as the rights of personal control, treatment, or chastisement are concerned, these are usually considered questions of local policy or police, the extent of which must be determined and fixed in each State by its own laws, as to all persons within its borders, regardless of their legal situs or domicil. ${ }^{1}$ No State could be justly expected to permit persons within its limits to violate its police or criminal laws, because they are given a right so to act by the law of their legal situs or domicil. Comity is not to be carried so far. It is a case for the substitution of the proper law by that of the forum and actual situs of the party. ${ }^{2}$

But save in such exception the principle is that the law of the legal situs or domitis the "proper law" governing the relation of parent and child, just as in other cases of status.

Thus where a mother domiciled in England had a child born in Scotland, which by the Scotch law she was bound to support (but not by the English law), the Scotch Court of Sessions refused to hold her liable therefor, on the ground that "she has the status of an English woman, and it is the law of the country of her domicil that must determine her obligations now." 3

3 Fuss v. Fuss, 24 Wis. 256, 1 Am. Rep. 180 ; Castro v. Illies, 22 Tex. 479, 73 Am. Dec. 277; Le Breton v. Miles, 8 Pai. Ch. (N. Y.) 261 ; Decouche v. Savetier, 3 Johns. Ch. (N. Y.) 190, 8 Am. Dec. 478 ; Schefferling v. Huffman, 4 Ohio St. 241, 62 Am. Dec. 281; McLeod v. Board, 30 Tex. 238, 94 Am. Dec. 301; Young v. Templeton, 4 La. Ann. 254, 50 Am. Dec. 563.

1 Woodworth $v$. Spring, 11 Allen (Mass.) 321 ; Jac. Dom. $\S 33$. See Blackinton $v$. Blackinton, 141 Mass. 432, 435-436.

2 See Whart. Confl. L. $\S \S 166,167$. See also De Boimont v. Penniman, 10 Blatchf. 436, for other applications of the lex fori.

Macdonald $v$. Macdonald, 8 Bell \& Murray (2d series), 331-334; Whart. Confi. L. $\S 168$. 
The legitimacy of the issue has no necessary connection with the status of marriage, since in some States children may be legitimate without an intermarriage of the parents, nor is it a necessary incident of the relation of parent and child, since that relation may exist without it. The truth is, legitimacy forms a distinct instance of status, and as such will be treated separately in a subsequent chapter. 


\section{CHAPTER VII.}

\section{DISSOLUTION OF THE MARRIAGE STATUS BY DIVORCE.}

§ 84. Causes for Divorce. - The supreme importance of the marriage status to the State as well as to the parties has been adverted to. The interest of the State in this relation leads it not only to demand that it should not be entered into unadvisedly or lightly, and to prescribe with great care who may or may not enter into the contract, as well as the ceremonies accompanying its solemnization, but also to prohibit its dissolution at the mere will or caprice of the parties. The consent of the State thereto must first be obtained through its legislature or its courts, and only for the particular causes assigned by the law-making power.

If the parties abandon their domicil in one State and acquire a residence in another, the interest of the first State in the marriage status ceases; that interest is now transferred to the second State, which will see to the preservation or regulation of the relation with the same zeal that inspired the former State so long as the parties remained domiciled there. The latter State will now permit the status to be dissolved only for causes which seem to it proper, and only with its consent (through its courts). For the marriage relation is essentially a status, a mode of life, and just as the incidents thereof are determined by the law of the place where the parties live (lex domicilii), so also the dissolution thereof is to be regulated by the same law.

Hence it is a well established general principle of private international law that a divorce obtain a state other than the domicil is of no binding effect tn other States, as will presently appear.

The same principle applies to the causes for which a divorce is asked for. If the parties have always resided in the same 
State, and have never lived elsewhere, no difficulty arises. It is manifest that the State where they have always lived (their only domicil) should be the State where the divorce is prosecuted, and upon its municipal law must depend the question whether or not there is sufficient ground to dissolve the marriage relation. ${ }^{1}$

But if the parties since the marriage have lived in several States, a question may arise as to which law shall determine whether there is ground for divorce. So also, if the act on account of which the divorce is asked occurs in another State, by whose law it is no cause of divorce, though constituting a suffcient cause in the State of the divorce forum, or vice versa; especially if the parties at the time of the act were domiciled in the State where it was done, one or both of them removing afterwards to the State of the forum. What law should properly determine such points has been the subject of considerable debate. $^{2}$

Upon principle, it would the question whether or proular act or omission is a ground for divorceshould be determined by the rules of the municipal law of the divorce forum. The fact that the alleged offense occurs in another State, or even that the parties were domiciled in the latter State when the offense occurs there, should not be suffcient, in the absence of explicit legislation of the forum to the

1 Hunt v. Hunt, 72 N. Y. 217, 228, 28 Am. Rep. 129.

2 Various theories will be found advocated in the following cases, some holding that the law of the place where the marriage contract is entered into should regulate the causes for dissolving the status; others holding that the law of the place where the offence is committed should prevail ; others are in favor of the law of the domicil of the parties at the time the offence was committed ; and others in favor of the law of the parties' domicil at the time the divorce is sought. See Lolley's Case, 2 Cl. \& F. 567 ; Arrington $v$. Arrington, 102 N. C. 491,9 S. E. 200,207 ; Norris $v$. Norris, 64 N. H. 523, 15 Atl. 19 ; Prosser $v$. Warner, 47 Vt. 667, 19 Am. Rep. 132, 134 ; Harteau v. Harteau, 14 Pick. (Mass.) 181, 25 Am. Dec. 372; Watkins v. Watkins, 135 Mass. 83 ; Colburn $v$. Colburn, 70 Mich. 647, 38 N. W. 607 ; Lyon $v$. Lyon, 2 Gray (Mass.), 367 ; Cook v. Cook, 56 Wis. 195, 43 Am. Rep. 706, 14 N. W. 33 ; Harding $v$. Alden, 9 Greenl. (Me.) 140, 23 Am. Dec. 549 ; Shreck v. Shreck, 32 Tex. 578, 5 Am. Rep. 251 ; Jones v. Jones, 67 Miss. 195, 6 So. 712, 713. 
contrary, to deprive its courts of the full and complete right to preserve, regulate, or dissolve the marriage status of the citizens of the forum in accordance with its laws. ${ }^{8}$

But if the object of a suit is not to dissolve a marriage status valid in the beginning, but to pronounce the union invalid $a b$ initio for a cause rendering the marriage contract voidable, the principles by which to determine the "proper law" are different. In such cases the lex celebrationis of the marriage contract is the proper law. ${ }^{4}$

In conclusion, it should be observed, that the mere fact that the cause of divorce arises in the State where the divorce is obtained (neither party being domiciled there at the time of the divorce), will not suffice to make the decree of divorce binding in other States, although by the municipal law of the divorce forum jurisdiction is thereby conferred upon its courts independently of the domicil of the parties. Domicil (of one of the parties at least) is an essential prerequisite to give a divorce exterritorial effect. ${ }^{5}$

$\S 85$. Proceedings in Personam and in Rem distinguished. - As preliminary to a discussion of the principles governing the effect of foreign divorce, it is necessary to observe the important distinctions between judicial proceedings in personam and in rem.

The purpose of a proceeding in personam is to impose,

3 Hunt $v$. Hunt, 72 N. Y. 217, 228, 28 Am. Rep. 129 ; Kinnier $v$. Kinnier, 45 N. Y. 535, 539, 6 Am. Rep. 132 ; Pennoyer $v$. Neff, 95 U. S. 714, 734-735 ; People $v$. Dawell, 25 Mich. 247, 12 Am. Rep. 260, 272; Colburn v. Colburn, 70 Mich. 647, 38 N. W. 607, 608 ; Shreck v. Shreck, 32 Tex. 578, 5 Am. Rep. 251 ; Harding $v$. Alden, 9 Greenl. (Me.) 140, 23 Am. Dec. 549; Hood $v$. Hood, 11 Allen (Mass.), 196, 87 Am. Dec. 709 ; Arrington v. Arrington, 102 N. C. 491,9 S. E. 200, 207. But see Norris $v$. Norris, 64 N. H. 523, 15 Atl. 19 ; Prosser $v$. Warner, 47 Vt. 667, 19 Am. Rep. 132, 134 ; Harteau v. Harteau, 14 Pick. (Mass.) 181, 25 Am. Dec. 372. In Massachusetts and Illinois there are statutes more or less affecting this general rule. See Lyon $v$. Lyon, 2 Gray (Mass.), 367 ; Smith $v$. Smith, 13 Gray, 209 ; Watkins $v$. Watkins, 135 Mass. 83 ; Chapman v. Chapman, 129 Ill. 386, 21 N. E. 806.

4 Ante, $\$ 78$.

6 Van Fossen $v$. State, 37 Ohio St. 317, 41 Am. Rep. 507, 508. See post. $\$ \S \& 9$ et seq. 
through the judgment or decree of the court whose aid is in. voked, some responsibility or liability directly upon the person of the defendant. Of this character are criminal prosecutions, suits to compel a defendant to perform some specific act, or actions to fasten a general pecuniary liability upon him. A proceeding in rem, on the other hand, is aimed not at the person of the defendant, but at his property or some other thing within the power and jurisdiction of the court.

Most important consequences flow from the distinction between these modes of procedure. The fourteenth amendment to the federal constitution provides that no State shall deprive any person of life, liberty, or property without due process of law; that is, without notice and a reasonable opportunity to be heard in his own behalf. But the notice required under this constitutional provision is very different in the two modes of procedure.

In proceedings in personam, no judgment or decree against

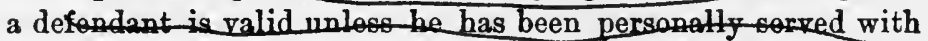
notice of the action or suit within the territorial limits of the court's jurisdiction, or has voluntarily appoered. This much / is always required, and in some instances even more. ${ }^{1}$ But in proceedings in rem, if the res be within the court's jurisdiction, due process of law does not demand that actual notice of the suit should be weren the defendant personally. Even though he be a non-resident of the farmentesthes that he keeps in touch with his property, wherever it may be situated, and that he will be straightway informed if any peril threatens it. Hence in such case the law contents itself with requiring a general proclamation or publication of the fact that a suit has been instituted with respect to the defendant's property, or with a personal notice served upon him outside the limits of the court's territorial jurisdiction.

In either form of procedure, if there has beer no such due process of law as is demanded under the federal constitution, the court is without jurisdiction, and its decree is absolutely void within the limits of its own State as well as elsewhere.

- I As in the trial of felony cases, in which no material step can validly be taken unless the accused is personally present in court. 
The leading case of Pennoyer $v$. Neff ${ }^{2}$ furnishes an excellent illustration of these principles. In that case, an attachment was issued in Oregon upon an order of publication against property there belonging to a non-resident defendant. An Oregon statute permitted the court in such cases to subject the property, and if that proved insufficient to satisfy the debt, to make a personal decree for the balance against the absent debtor. The court pursued this course, and the case was carried on appeal to the United States Supreme Court. That court held that, so far as the attachment of the property was concerned, the proceeding was in rem, and that the presence of the property there gave the court jurisdiction, though the owner was a non-resident, had not appeared, and had been notified of the pendency of the cause no otherwise than by advertisement in a newspaper. But it was also held that the personal decree for the balance of the money due by the non-resident defendant was beyond the court's jurisdiction, and that the statute authorizing such a course contravened the federal constitution.

$\S 86$. Exterritorial Effect of Foreign Judgments and Decrees. - The federal constitution, in its requirement that no State shall deprive any person of life, 'liberty, or property without due process of law, is no stricter than are the principles of private international law, when those principles begin to operate upon judicial proceedings. While the above mentioned clause of the federal constitution is a part of the municipal law of each State of the Union and operates intra-territorially upon domestic proceedings, the rules of private international law come into play only when the inquiry extends to the effect to be given, in one State or country, to the judicial proceedings of another. But the federal constitution and the rules of private international law both unite in declaring that, in order to a valid exercise of jurisdiction by a tribunal, there must be given to the defendant a reasonable notice and opportunity to defend himself; there must be "due process of law." What constitutes such due process in respect to proceedings in personam as well as in rem has already been shown.

295 U. S. 714. See also Alley $v$. Caspari, 80 Me. 234, 6 Am. St. Rop. 185 , note. 
Hence in order that effect may be given abroad to a judgment in rem or in personam, the court rendering the judgment in question must have jurisdiction of the cause, and such jurisdiction of the defendant or of the property threatened as "due process of law" demands. If the judgment or deereen, it is only necessary that the res be within the court's jurisdic-, tion and that a general publication of notice of the suit be given. If in personam, it is essential that the court should have obtained jurisdiction of the defendant's person, either by his voluntary appearance and submission to the court's jurisdic; tion, or by a personal service of process upon him within the territorial limits of the court's authority-

If these conditions are complied with, the foreign judgment will in general be given effect everywhere ; if not complied with, the judgment or decree, even though valid where rendered, will in general be regarded as roid and of no effect outside the jurisdiction where it is rendered.

But, suping the conditions complied with, it does not necessarily follow that the foreign jutgmenth be given efusive effect in other States. In case the judgment or decree be in rem, it is true, the effect given to it is generally conclusive everywhere, if the res is within the court's jurisdiction, for the sovereignty of a State over everything within its limits is supreme, and will usually be respected in other States. ${ }^{1}$

But with respect to judgments and decrees in personam, such as judgments for money, private internationat law goes no further than to declare them a prima facie evidence of indebtedness, permitting the merits of the cause of action to be again inquired into, at least where such is the effect that would be

1 This is universally conceded in the case of decrees in admiralty. See The Rio Grande, 23 Wall. 458; Williams v. Armroyd, 7 Cr. 423 ; Gelston $v$. Hoyt, 3 Wheat. 246; China Mut. Ins. Co. v. Force, 142 N. Y. 90 ; Street v. Ins. Co., 12 Rich. (S. C.) 13 . And generally also in attachment and other proceedings in rem. Freeman $v$. Alderson, 119 U. S. 185 ; Pennoyer $v$. Neff, 95 U. S. 714 ; Green $v$. Van Buskirk, 7 Wall. 139 ; Noble $v$. Oil Co., 79 Penn. St. 354 ; Arndt $v$. Arndt, 15 Ohio, 33. But see Hornthall $v$. Burwell, 109 N. C. 10,13 S. E. 721 ; Singer Mfg. Co. v. Fleming, 39 Neb. $679,42 \mathrm{Am}$ St. Rep. 613. 
given to foreign judgments in the State where the judgment in question was rendered. ${ }^{2}$

As between the States of this Union, the comity enjoined by private international law touching the effect to be given to foreign judgments is reinforced and supplemented by the clause in the federal constitution providing that full faith and credit shall be given in each State to the judicial proceedings of every other State, ${ }^{8}$ and by the act of Congress, made in pursuance thereof, declaring that the judgments of the courts of each State shall have the same faith and credit in other States as they have in the States where they are rendered. ${ }^{4}$

Under these provisions, the judgments and decrees of the courts of one State, if valid and conclusive there, are for the most part valid and conclusive in every other State of the Union. Without them the judgments of each State would be regarded as strictly foreign judgments in every other State. ${ }^{5}$

But it is to be observed that it is not the design of these provisions to confer any new power upon the States, but simply to establish a just rule of comity by which may be regulated the effect of their admitted jurisdiction over the persons and things within their borders. They do not propose to make the judg-

2 Hilton $v$. Guyot, 159 U. S. 113. It is probably otherwise if foreign judgments are given conclusive effect in the State where the particnlar judgment in question is rendered. Ritchie $v$. McMullen, 159 U. S. 235 ; Wunstan v. Higgins, 138 N. Y. 70 ; Rankin $v$. Goddard, 55 Me. 389 . But this rule is subject to qualification where the foreign judgment is based on matters of mere local policy. See Hohner $v$. Gratz, 50 Fed. 369 ; De Brimont $v$. Penniman, 10 Blatchf. 436. Upon the effect of foreign judgments, see a learned and full discussion in Story, Confl. L. $\$ \S 598$ et seq., and notes.

3 U. S. Const. Art. 4, § 1.

4 U. S. Rev. Stats. $\$ 905$.

Slack v. Perrine, 164 U. S. 452 ; McElmoyle v. Cohen, 13 Pet. 312; Carpenter $v$. Strange, 141 U. S. 87 ; Guthrie $v$. Lowry, 84 Penn. St. 533; Elsasser $v$. Haines, 52 N. J. L. 10, 18 Atl. 1095 ; Edwards $v$. Jones, 113 N. C. 453, 18 S. E. 500 ; Dorsey v. Maury, 10 Sm. \& M. (Miss.) 298. These provisions apply not only to judgments of State courts, but also to the judgments of the federal courts, when litigated in the State courts. Pennoyer $v$. Neff, 95 U. S. 714 ; Southern Ins. Co. v. Hardware Co. (Tex.) 19 S. W. 615 ; Barney $v$. Patterson, 6 Har. \& J. (Md.) 182 ; Niblett v. Scott, 4 La. Ann. 246. 
ments of other States domestic judgments to all intents and purposes, but merely give a general validity, faith, and credit to them as evidence. ${ }^{6}$ No execution is to issue upon such foreign judgment without a new suit in the tribunals of the State where it is sought to be enforced. Nor does it enjoy any priority, privilege, or lien which may be accorded it in the State where it is rendered, but only such as the lex fori gives it in its character of a foreign judgment. ${ }^{7}$

Under these provisions, the judgment is to be given the same effect in other States as in the State where it is rendered, and since it is in general conclusive there upon the rights litigated, until reversed, it will also be held to be conclusive in other States, as to the original merits of the controversy.

It is immaterial what the nature of the controversy is. The judgment is equally conclusive, whether it be in rem or in personam; whether it fastens a personal liability upon the defendant, or whether it only affects his property or his status. Thus, the valid judgment of a competent court determining the domicil of a testator and probating his will of chattels is conclusive in every State in the Union. ${ }^{8}$ So also the judgment of the courts of the domicil declaring a child to have been lawfully adopted is in general conclusive. And so it is with almost every kind of judgment; such as judgments for money, or in divorce or attachment proceedings, etc., provided only the court pronouncing the judgment has jurisdiction of the cause, of the person, and of the res. To this general principle there seems to be only one exception. It does not apply with full force to foreign judgments for the enforcement of a penalty. ${ }^{10}$

It follows from what has been already said that when an

6 Story, Confl. L. $\S 609$; McElmoyle v. Cohen, 13 Pet. 312 ; D'Arcy v. Ketchum, 11 How. 165.

7 Wood $v$. Watkinson, 17 Conn. 500 ; McElmoyle v. Cohen, 13 Pet. 312 ; Story, Confl. L. $§ 609$.

8 Thomas v. Morissett, 76 Ga. 384 ; In re Gaines, 45 La. Ann. 1237, 14 So. 233.

9 Van Matre $v$. Sankey, 148 Ill. 356, 36 N. E. 628 . See Foster $v$. Waterman, 124 Mass. 592.

10 Huntington $v$. Attrill, 146 U. S. 657, 672. See ante, $\S 10$. 
action is brought in one of the States of this Union to enforce a judgment rendered in another, only such defenses can be made thereto in generas as wate in the State where it was pronounced, in an action there on such-judgment.

Thus in an action in one State of the Union upon a judgment rendered in another, the defendant may show that the court pronouncing the judgment had not jurisdiction of the cause, of the subject-matter, or of the parties; ${ }^{11}$ or that the judgment is not responsive to the pleadings - at least, if the defendant does not appear at the trial. ${ }^{12}$ So the defendant may show matters ex post facto that go in release or discharge of the judgment, according to the law of the place where the judgment is given. ${ }^{18}$

But an exception to this principle arises where the defendant pleads the statute of limitations to the action upon the judgenent. The scope and effect of this defense is in general determined by the law of the State where the action upon the judgment is brought (lex fori). ${ }^{14}$

\$ 87. Divorce Causes, Procoedings Quasi in Rem. - In divorce causes, the actual subject-matter of the litigation is the marriage status itself. The design is to affect or dissolve the marital relation, not to impose a general personal liability upon either party, or to give personal relief. Hence they partake of the nature of proceedings in rem rather than of proceedings in personam, the res being the status. And this is true whether the suit be for divorce $a$ mens $a^{1}$ or divorce

11 Harris v. Hardeman, 14 How. 334; Cheever v. Wilson, 9 Wall. 108; Thompson $v$. Whitman, 18 Wall. 457; Grover \& B. M. Co. v. Radcliffe, 137 U. S. 287 .

12 Reynolds $v$. Stockton, 140 U. S. 254.

13 MeElmoyle v. Cohen, 13 Pet. 312 ; D'Arcy v. Ketchum, 11 How. 165.

14 Jacquette v. Huguiron, 2 McLean, 129 ; Bauserman v. Charlott, $46 \mathrm{Kan}$. 480, 26 Pac. 1051 ; Packer v. Thompson, 25 Neb. 688, 41 N. W. 650 . See post, $\S 210$. But if the statute of the State where the judgment is rendered declares that the judgment shall not be good after a certain period of years, that law, not the lex fori, must govern. Bowersox v. Gitt, 12 Penn. Co. Ct. 81 .

1 See De Meli v. De Meli, 120 N. Y. 485 ; Butler v. Washington, 45 Ia. Ann. 279,12 So. 356,19 L. R. A. 814 . 
$a$ vinculo. ${ }^{2}$ At the same time theso causes cannot be said to be altogether proceedings in rem. There is a personal element that enters into them, not found in suits instituted merely to subject or affect property. Says one admirably conceived opinion: "Accurately speaking, a proceeding in rem is a proceeding against tangible property, and actual notice is dispensed with on the theory that the owner is bound to know where his property is and whac is being done with it. It is manifest this theory cannot be applied to the relation of husband and wife." s

It results therefore that these causes constitute in some measure a dividing line between proceedings strictly in rem and proceedings strictly in personam, partaking in part of the nature of each, the former however predominating. Hence they are often very properly denominated proceedings quasi in rem. The importance of this line of demarkation will appear hereafter when we come to consider the exterritorial effect of divorce."

But a decree for the costs of a dirorce suit, or a decree for alimony, is a decree strictly in personam, since the object is to fasten upon the defendant a general pecuniary liability, not to affect the status. ${ }^{5}$

\$ 88. The Res in Divorce Causes. - Divorce causes being proceedings quasi in rem, it becomes important and necessary

2 Roth $v$. Roth, 104 Ill. 35, 44 Am. Rep. 81, 84; Anthony v. Rice, 110 Mo. 233, 19 S. W. 423, 424 ; Dunham v. Dunham, 162 Ill. 589, 35 L. R. A. 70,77 ; McGill $v$. Deming, 44 Ohio St. 645, 11 N. E. 118, 122 . The New York courts are peculiar in holding the view that divorce causes are proceedings in personam. See Williams $v$. Williams, 130 N. Y. 193 ; De Meli v. De Meli, 120 N. Y. 485; Jones v. Jones, 108 N. Y. 415; O’Dea v. O'Dea, 101 N. Y. 23 ; People $v$. Baker, 76 N. Y. 78. See also Prosser $v$. Warner, 47 Vt. 667, 19 Am. Rep. 132, 135-136.

3 Doughty v. Doughty, 27 N. J. Eq. 315, 325.

- Post, $\$ \S 89$ et seq.

5 Felt v. Felt, 57 N. J. Eq. 101, 40 Atl. 436 ; De La Montanya v. De La Montanya, 112 Cal. 101, 32 L. R. A. 82, 85; Thurston $v$. Thurston, 58 Minn. 279,59 N. W. 1017, 1018 ; Kline v. Kline, 57 Ia. 386, 10 N. W. 825, 826 ; Prosser $v$. Warner, 47 Vt. 667, 19 Am. Rep. 132, 133, 134. But see Blackinton v. Blackinton, 141 Mass. 432. See post, $\$ 95$. 
to determine what is the res, for the court's jurisdiction in proceedings in rem depends upon its jurisdiction of the res.

It is generally admitted that the res is the marriage status, which includes the status of both consorts, the situs of the status of each being his or her domicil. Strictly speaking, therefore, the jurisdiction of the status of the husband or wife belongs to the courts of his or her domicil, and to no other, because those courts alone have jurisdiction of the res. But in the case of marriage the status is a double or correla. tive status. ${ }^{1}$ There can be no such thing as a husband without a wife, or a wife without a husband. Hence when a court assumes to pronounce a decree destroying the marriage status of one of the consorts, it must necessarily destroy, so far as its decree has any effect at all, the status of the other consort also. If then the consorts are domiciled in different States, it is a matter of grave importance to ascertain how far the power of the courts of either of these domicils extends in dissolving the marital union.

It must be constantly remembered that the present inquiry relates to the extra-territorial, not the intra-territorial, effect of a decree of divorce. It is admitted that, within its own borders, each State has sovereign control over all persons and property there situated either permanently or temporarily, subject only to such restrictions as may be placed upon its courts by its own laws or constitution, or by the constitution and laws of the United States. ${ }^{2}$ Subject to these restrictions, it is in its power to declare, in any form of proceeding it sees fit, that a married man resident there, or there temporarily, or even not there at all, shall be there deemed no longer married, and that whether the wife be within or without the State. This is purely a

1 So it is also with the status of adoption, and hence the principles governing the exterritorial effect of decrees of adoption and the jurisdiction of courts to grant such decrees are very similar to those regulating decrees of divorce. See Van Matre $v$. Sankey, 148 Ill. 356, 36 N. E. 628 ; Foster $v$. Waterman, 124 Mass. 592.

2 The provision of the federal constitution that no State shall deprive any person of life, liberty, or property without due process of law does not apply to the marriage relation. 
matter of municipal law, with which private international law has no concern. And the status being a reciprocal one, since, in that State, the husband must be considered to be without a wife, so in that State the woman must be deemed to be without a husband.

But it does not follow that either will be regarded as unmarried in other States. If in any other State the edict is given sufficient effect to destroy the status of the husband as a married man, it must also be held in that State that the woman is unmarried. If in another State the woman's status is regarded as unaffected by the edict, so must the man's. In other words, a decree of divorce must, in any State, be valid as to both consorts, or void as to both. It cannot be valid as to one and void as to the other, for that would be to affirm that there might be a husband without a wife, or vice versa.

Hence, in considering the exterritorial effect of decrees of divorce the question is whether the court granting the divorce has such complete jurisdiction of the entire res (the status of both parties), as to justify other States in admitting its sover eign right to completely regulate or dissolve the marital union.

Beyond all doubt, a divorce court has absolute and complete jurisdiction of the res if both parties are domiciled within its territory. The situs of the status of each party is then the State where the divorce is obtained, and there is no ground for any other State to complain that its sovereign rights over its own citizens have been violated. Generally full effect will be given to foreign divorces under such circumstances. ${ }^{3}$

On the other hand, if neither husband nor wife is domiciled in the State where the divorce is obtained, its courts are completely without jurisdiction of the res. Other States, especially those wherein the husband and wife are respectively domiciled, might and would justly complain that the State of the divorce had usurped sovereignty that it should not have exercised. Though admitting the validity of the divorce within the bor. ders of the divorcing State, it would be given no exterritorial effect by the courts of other States."

$$
\text { 3 Post, § } 89 .
$$

4 Post, $\$ 90$. 
An intermediate case (and the most difficult) presents itself in those instances where one of the parties is domiciled in the State granting the divorce, while the other is domiciled elsewhere. Here the divorce court has jurisdiction of part of the res (the status of its citizen) but has no jurisdiction of the other part of the res (the status of the non-resident). The whole res is the status of both parties, and owing to the reciprocity of the relation it cannot be severed, so as to give the court complete jurisdiction of the part within its limits.

Except for the personal element involved in the dissolution of the marriage status and the marital rights and obligations, the case is analogous to a proceeding strictly in rem against a ship or other chattel (which we may suppose to be indivisible, like the status of the two parties to the marital union). Let us suppose the ship, at the time of the proceeding in rem, to be partly in one State and partly in another. The court would have jurisdiction (theoretically) of so much of the ship as is within its territory, but would have none over that part within the territory of another State. But practically (the ship being supposed to be inseparable, like the marriage status) the question would have to be decided whether the court, by virtue of its jurisdiction over part of the ship, might draw it all into its power, or whether, since it has no jurisdiction (theoretically) over a part, it should renounce jurisdiction over so much as is within its control. It must do one or the other; it must exercise jurisdiction over the whole or over none.

Such for the most part is the situation in which a divorce court finds itself in cases where only one of the parties is domiciled in the State of the divorce. It is not difficult to imagine that in general the court would resolve the problem in favor of its own jurisdiction, holding that by virtue of its jurisdiction over a part it might draw the whole res into its control. So the court would probably argue in the case of the ship, and accordingly would assume control of it in its entirety. But a more serious question would then arise. What effect would be given to this action of the court in respect to the ship in the other State from which the ship has in part been drawn away? Would that State regard its withdrawal from its own territory 
as a proper and lawful exercise of power, or would it deem the action of the court impertinent, in contravention of its own sovereignty, and therefore void within its limits ? ${ }^{6}$

Precisely these questions have agitated the courts with respect to the effect to be given foreign divorces, where one of the parties (usually the defendant) is a non-resident of the State of divorce. How they have been solved will be seen hereafter. ${ }^{6}$

$\S 89$. Exterritorial Effect of Divorce- Both Parties Domiciled in State of Divorce. - Where both consorts are domiciled in the State where the divorce is obtained, the court has complete jurisdiction of the res, and therefore, as in other cases of judgments in rem, the decree will be binding everywhere, if binding in the State of the domicil and divorce. ${ }^{1}$

From the standpoint of private international law it is immaterial whether or not the parties be actually present within the jurisdiction at the time of the divorce, if only they are there domiciled; ${ }^{2}$ nor is it material how long the residence has continued, even though it be not long enough, under the municipal law of the domicil, to give jurisdiction to its courts.

Generally speaking, it is the laws and courts of the bona fide present domicil of the parties that regulate the divorce, not those of the country of residence (merely), nor of citizen-

5 See Plummer $v$. Hatton, 51 Minn. 181, 53 N. W. 460. But in this case the res was severable, consisting of a wagon in one State, while the tongue was in another. See also Thurston $v$. Thurston, 58 Minn. 279, 59 N. W. 1017.

6 Post, §§ 89-94.

I Clark v. Clark, 8 Cush. (Mass.) 385 ; Barber v. Root, 10 Mass. 260 ; Hood $v$. Hood, 11 Allen (Mass.), 196, 200, 87 Am. Dec. 709 ; Shaw v. Shaw, 98 Mass. 158 ; Burlen v. Shannon, 115 Mass. 438; Loker v. Gerald, 157 Mass. 42, 31 N. E. 709 ; Harrison $v$. Harrison, 20 Ala. 629, 56 Am. Dec. 227 ; Maguire v. Maguire, 7 Dana (Ky.), 181, 185 ; McGill v. Deming, 44 Ohio St. 645,11 N. E. 118, 122 ; Hunt v. Hunt, 72 N. Y. 217, 228, 28 Am. Rep. 129 ; Cheely $v$. Clayton, 110 U. S. 701.

2 Hunt $v$. Hunt, 72 N. Y. 217, 237, 28 Am. Rep. 129 ; Loker v. Gerald, 157 Mass. 42, 31 N. E. 709.

3 Magowan v. Magowan, 57 N. J. Eq. 195, 39 Atl. 364 ; Hill v. Hill, 166 Ill. 54, 46 N. E. 751, 752; Thurston v. Thurston, 58 Minn. 279, 59 N. W. 1017. This is not a jurisdictional defect, but an error of law to be corrected on appeal. 
ship, ${ }^{4}$ nor of the domicil at the time of the marriage or of the offense, nor of the place of marriage, nor of the situs of the offense because of which the divorce is sought. ${ }^{5}$

As between the States of this Union, the "full faith and credit" clause of the federal constitution holds full sway in divorce cases, as in other judgments or decrees. Such decrees, when rendered by a court possessing competent jurisdiction of the subject-matter and of the persons, unless void where rendered, are conclusive in every other State of the matters they decide. It is well settled that this provision does not prevent an inquiry into the competency of the divorce court's jurisdiction by reason of the non-residence of the parties, or by reason of fraud in the procurement of the divorce, ${ }^{6}$ at least where the fraud relates to jurisdictional facts. ${ }^{7}$

There is some difference of opinion among the authorities as to the effect to be given to the recital in the decree of divorce that the parties are domiciled within its territory, when in fact they are not. ${ }^{8}$ Some of the courts have held that such a recital

4 Save as between the States of the Union, where domicil and citizenship are synonymous terms.

5 Dicey, Confl. L. 269 ; Cheever v. Wilson, 9 Wall. 108, 124 ; Cheely v. Clayton, 110 U. S. 701, 705 ; Vischer v. Vischer, 12 Barb. (N. Y.) 640, 647 ; Ellis $v$. Ellis, 55 Minn. 401, 56 N. W. 1056, 1058; Van Fossen v. State, 37 Ohio St. 317, 41 Am. Rep. 507, 508; Cox v. Cox, 19 Ohio St. 502, 2 Am. Rep. 415 ; Jones $v$. Jones, 67 Miss. 195, 6 So. 712 ; Shreck $v$. Shreck, 32 Tex. 578, 5 Am. Rep. 251, 252. But see Norris v. Norris, 64 N. H. 523, 15 Atl. 19.

6 Cheever v. Wilson, 9 Wall. 108, 123 ; Pennoyer v. Neff, 95 U. S. 714, 734 ; Cummington v. Belchertown, 149 Mass. 223, 225 ; Gregory v. Gregory, 78 Me. 187, 57 Am. Rep. 792, 793; Reed v. Reed, 52 Mich. 117, 50 Am. Rep. 247 ; Watkins $v$. Watkins, 125 Ind. 163, 25 N. E. 175; Morgan v. Morgan, 1 Tex. Civ. App. 315, 21 S. W. 154.

7 Hood $v$. Hood, 11 Allen (Mass.), 196, 200, 87 Am. Dec. 709 ; Hunt $v$. Hunt, 72 N. Y. 217, 28 Am. Rep. 129 ; Vischer $v$. Vischer, 12 Barb. (N. Y.) 640, 644; Harding v. Alden, 9 Greenl. (Me.) 140, 23 Am. Dec. 549, 555 ; Magowan v. Magowan, 57 N. J. Eq. 195, 39 Atl. 364 ; People v. Dawell, 25 Mich. 247, $12 \mathrm{Am}$. Rep. 260 ; Thurston $v$. Thurston, $58 \mathrm{Minn} .279,59 \mathrm{~N}$. W. 1017,1018 . In the last case, the plaintiff deceived the divorce court tonching the period of his residence there. It was held that this was not jurisdic. tional and would not avoid the decree exterritorially.

- Cheever $v$. Wilson, 9 Wall. 108, 123 ; Magowan v. Magowan, 57 N. J. Eq 195, 39 Atl. 364. 
in the decree constitutes a finding of fact, and is as binding, until reversed in the same jurisdiction, as any other finding of fact. ${ }^{2}$ But the correct view, both upon reason and authority, is that such a recital is not conclusive, but only prima facie evidence of the truth of the recital, susceptible of rebuttal in other States by parol testimony to the contrary. ${ }^{10}$

$\S 90$. Neither Party Domiciled in State of Divorce. - We have already seen that the matrimonial union is a status of such peculiar importance to the State that it cannot be dissolved merely by the mutual consent of the parties, but the assent of the State interested (the domicil) must generally be obtained in order effectually to dissolve the relation. Though it is within the sovereign capacity of a State to enact laws whereby parties may obtain a divorce even when neither husband nor wife is there domiciled, such a course is condemned by the principles of comity and private international law.

If a divorce is thus given in a State where neither party is domiciled, whether it be that the divorcing court has been deceived as to the domicil of the parties, or whether its own muricipal law permits it to divorce non-residents, it is generally conceded that the decree is of no force in other States or countries, least of all in the State of the parties' domicil, whose sovereignty over the permanent status of its citizens has been

9 Magowan $v$. Magowan, 57 N. J. Eq. 195, 39 Atl. 364 ; Fairchild $v$. Fairchild, $53 \mathrm{~N}$. J. Eq. 678, 34 Atl. 10 ; Waldo v. Waldo, 52 Mich. $94,17 \mathrm{~N}$. W. 710. See Morey v. Morey, 27 Minn. 265, 6 N. W. 783.

${ }^{10}$ Sewall $v$. Sewall, 122 Mass. 156 ; Cummington $v$. Belchertown, 149 Mass. 223, 225 ; Adams $v$. Adams, 154 Mass. 290, 294 ; Hill $v$. Hill, 166 Ill. 54, 46 N. E. 751, 752; Smith v. Smith, 43 La. Ann. 1140, 10 So. 248, 250; People $v$. Dawell, 25 Mich. 247, 12 Am. Rep. 260; Reed $v$. Reed, 52 Mich. 117, 50 Am. Rep. 247, 250; James' Estate, 99 Cal. 374, 33 Pac. 1122, 1123; Magowan $v$. Magowan, 57 N. J. Eq. 195, 39 Atl. 364; Starbuck $v$. Murray, 5 Wend. (N. Y.) 148 ; Hoffman $v$. Hoffman, 46 N. Y. 30, 7 Am. Rep. 299; Ferguson $v$. Crawford, 70 N. Y. 253 ; Cross $v$. Cross, 108 N. Y. 628 ; Gregory v. Gregory, $78 \mathrm{Me} .187,57$ Am. Rep. 792, 793; Thompson $v$. Whitman, 18 Wall. 457; Pennoyer $v$. Neff, 95 U. S. 714, 730. If the divorcing court has tried the question of residence npon conflicting testimony and has decided in favor of the jurisdiction, great cantion should be exercised elserwhere in overthrowing the jurisdiction it has assumed. See Waldo v. Waldo, 52 Mich. 94 17 N. W. 710. 
outraged. ${ }^{1}$ In such cases the direceurt has no jurisdiction of the res, that is, the status of the parties (the situs of which is at their domicil), and hence even though bo bmit their cause to the divorce court, it is without power to affect the res, save within the limits of its own territory. The consent of the parties cannot give juristiction over their foreign status, for that would be to infringe upon the sovereignty of the domicil which is interested in the continuation of the relation. ${ }^{2}$

These general principles of private international law are now so clearly recognized that the municipal laws of the various States almost invariably require that, in order to the granting of a divorce, at least one of the parties (generally the plaintiff) should be bona fide domiciled within the jurisdiction. ${ }^{3}$ A tem-

1 Barber $v$. Root, 10 Mass. 260 ; Hanover $v$. Turner, 14 Mass. 227, 7 Am. Dec. 203 ; Shannon $v$. Shaunon, 4 Allen (Mass.), 134; Sewall v. Sewall, 122 Mass. 156 ; Maguire $v$. Maguire, 7 Dana (Ky.), 181 ; Harrison v. Harrison, 20 Ala. 629, 56 Am. Dec. 227 ; Jackson v. Jackson, 1 Johns. (N. Y.) 424 ; Kerr $v$. Kerr, 41 N. Y. 272 ; Neff $v$. Beauchamp, 74 Ia. 92,36 N. W. 905 ; Hood v. State, 56 Ind. 263, 26 Am. Rep. 21 ; Watkins $v$. Watkins, 125 Ind. 163, 25 N. E. 175 ; Smith $v$. Smith, 19 Neb. 706, 28 N. W. 296 ; Van Fossen $v$. State, 37 Ohio St. 317, 41 Am. Rep. 507 ; People v. Dawell, 25 Mich. 247, 12 Am. Rep. 260, 266 ; Reed $v$. Reed, 52 Mich. 117, 50 Am. Rep. 247 ; Morgan v. Morgan, 1 Tex. Civ. App. 315, 21 S. W. 154 ; Gregory v. Gregory, 78 Me. 187, 57 Am. Rep. 792 ; Gettys $v$. Gettys, 3 Lea (Tenn.), 360, 31 Am. Rep. 637 ; Litowich $v$. Litowich, 19 Kan. 451, 27 Am. Rep. 145.

2 Jackson $v$. Jackson, 1 Johns. (N. Y.) 424; Pawling $v$. Bird, 13 Johns. (N. Y.) 192 ; Maguire $v$. Maguire, 7 Dana (Ky.), 181 ; Harrison $v$. Harrison, 20 Ala. 629, 56 Am. Dec. 227; Smith v. Sinith, 13 Gray (Mass.), 209, 210; People v. Dawell, 25 Mich. 247, 12 Am. Rep. 260, 268, 272-273. See Lond v. Loud, 129 Mass. 14, 18 ; Chase $v$. Chase, 6 Gray (Mass.), 157, 161. Some of the courts however hold the view that, although the court does not acquire jurisdiction over the res, the voluntary submission by the parties to its decision estops them (but not third parties nor the State of their domicil) from afterwards denying the court's jurisdiction elsewhere. See Ellis $v$. Ellis, 55 Minn. 401, 56 N. W. 1056, 1059; Watkins v. Watkins, 135 Mass. 83, 86 ; Loud $v$. Loud, 129 Mass. 14, 19 ; Hood $v$. Hood, 110 Mass. 463 ; Ellis $v$. White, 61 Ia. 644, 17 N. W. 28 ; Chapman $v$. Chapman, 48 Kan. 636, 29 Pac. 1071. And in New York, where the theory prevails that a divorce suit is a proceeding in personam, not in rem, the fact that both parties submit themselves to the jurisdiction of an alien court, is regarded as sufficient to render its decree binding in New York. See Kinnier $v$. Kinnier, 45 N. Y. 535.

3 Williamson v. Parisien, 1 Johns. Ch. (N. Y.) 389 ; Hoffman v. Hoffman, 
porary residence acquired for the mere purpose of instituting the suit, the intent being to remove from the State as soontas the suit is terminated, will not generally suffice under the rules of municipal law, and is never sufficient from the international standpoint." But if the animus really exists to remain there permanently, the fact that the motive of removal is to procure a divorce is immaterial. ${ }^{5}$

For the purposes of municipal law, in the absence of statute, and always for the purposes of private international law, the period during which the party is domiciled is immaterial. $\mathrm{He}$ acquires a domicil at the moment when actual residence is coupled with the animus manendi, and from that moment his status should be determined by the law of that country. ${ }^{\circ}$

It will be remembered that in general the wife's domicil follows that of the husband, but that for purposes of divorce an innocent wife may acquire a domicil apart from her husband, if she desires to do so and conforms to the conditions. ${ }^{7}$ But she is not bound to do so. She is still at liberty to treat her husband's domicil as her own, though she actually resides elsewhere, and may sue for divorce in the State of his domicil, though she has never actually resided there. Thus, where the

46 N. Y. 30 ; St. Sure $v$. Lindsfelt, 82 Wis. 346,19 L. R. A. 515 ; McShane v. McShane, 45 N. J. Eq. 341, 19 Atl. 465; Valk v. Valk, 18 R. I. 639, 29 Atl. 499 ; Neff v. Beauchamp, 74 Ia. 92,36 N. W. 905.

4 Warrender $v$. Warrender, 9 Bligh, 141, 142 ; Dolphin $v$. Robins, 7 H. L. Cas. 390; Dorsey v. Dorsey, 7 Watts (Penn.), 349, 32 Am. Dec. 767; Gettys v. Gettys, 3 Lea (Tenn.), 360, 31 Am. Rep. 637, 638; Neff $v$. Beauchamp, 74 Ia. 92,36 N. W. 905 ; Knowlton $v$. Knowlton, 155 Ill. 158, 39 N. E. 595 ; Dunham v. Dunham, 162 Ill. 589, 35 L. R. A. 70 ; Magowan v. Magowan, 57 N. J. Eq. 195, 39 Atl. 364.

${ }^{5}$ Fosdick $v$. Fosdick, 15 R. I. 130, 23 Atl. 140; Albee $v$. Albee, 141 Ill. 550,31 N. E. 153 ; Colburn $v$. Colburn, 70 Mich. 647, 38 N. W. 607 ; Hegeman $v$. Fox, 31 Barb. (N. Y.) $475,479$.

6 Hill v. Hill, 166 Ill. 54, 46 N. E. 751 ; Magowan v. Magowan, 57 N. J. Eq. 195, 39 Atl. 364; Kern v. Field, 68 Minn. 317, 71 N. W. 393, 394; Thurston $v$. Thurston, 58 Minn. 279, 59 N. W. 1017; Watkins $v$. Watkius, 135 Mass. 83,84 . But the municipal laws of most States require a person to have been domiciled there for a more or less extended period before he or she can institute a suit for divorce.

7 Ante, $\$ \S 50,51$. 
husband deserts the wife and goes to another State to live, whither she follows him, it would seem upon principle that she need not remain there the statutory time in order to acquire such residence as will enable her to sue for divorce. ${ }^{8}$

\$ 91. Only one of the Parties domiciled in State of Divorce. - We have seen in the receding sections that if both the parties are domiciled in the State of the divorce, the decree, if valid there, will be binding everywhere, whatever the character of the proceedings may be, and upon whatev the defendant. On the other hand, if neither party is domiciled in the State of the divorce, the court is without jurisdiction of the res, and in the absence of a res, according to the the court cannot proceed in personam by will be recognized therroly in fact the procedings be ever sojust and fair, and though both the parties are personally before the court. Although the divorce proceeding partakes in some measure of a proceeding in personam, the personatetement it is believed is not sufficient to supersede the necessity for some res upon which the decree may operate. On the other hand, if the complete res is before the court (as where both parties are domiciled in the divorcing State), the personal element sinks out of sight altogether, and the proceeding becomes strictly in rem.

We now come to consider the intermediate case where one of the parties, and only one, is domiciled in the State of the divorce. This case has caused the courts very great difficulty, owing to the fact that the divorcing court has partial, but not complete, jurisdiction of the res. It has control over the status of its own domiciled citizen, but not over the status of the citizen of another State. Yet, owing to the mutuality of the relation between husband and wife, it can make no decree affecting the status of one, without simultaneously and equally affecting the status of the other. Under such circumstances, one of two courses is open to the court. It may either draw to itself (usurp, as it were) jurisdiction over the status of the nonresident, by virtue of its jurisdiction over the status of the

8 Kershaw $v$. Kershaw, 3 Cal. 312; Watkins $v$. Watkins, 135 Mass. 83, 87. But see Valk $v$. Valk, 18 R. I. 639, 29 Atl. 499 ; Wood $v$. Wood, 54 Ark 172, 15 S. W. 459. 
resident, or it may renounce jurisdiction over the status of the resident because it has not jurisdiction of the status of the non-resident.

The municipal law of each State, being primarily interested in and devoted to its own citizens, will usually enjoin upon its courts the first of these courses, as being most conducive to their protection. Accordingly we find provision in the municipal laws of every State directing how divorces may be obtained by citizens against non-resident defendants. In such cases, the laws of many States, ling upon the durefin its aspect of a proceeding in rem, permit their to grant the divorce upon no further notice to the non-resident defendant than is afforded by an order of publication, 1 white others (not losing sight altogether of the personal element in the divorce proceeding) resort to the juster method of requiring actual notice of the pendency of the suit to be mailed or otherwise safely transmitted to the absent defendant. ${ }^{2}$ The nature of this tice is regulated by the municipal law of each State, and if that law is complied with the divorce is valid within the limits of that State. $^{\mathbf{3}}$

But when it is sought to give effect in other States to the divorce so obtained, it becomes a more difficult question to determine the consequence of the merely partial jurisdiction possessed by the divorce court over the res.

It would manifestly be impolitic, as well as unjust, to lay

1 Ditson $v$. Ditson, 4 R. I. 87; Kline $v$. Kline, 57 Ia. 386, 10 N. W. 825 ; Cox v. Cox, 19 Ohio St. 502, 2 Am. Rep. 415 ; Anthony v. Rice, 110 Mo. 233, 19 S. W. 423 ; Butler $v$. Washington, 45 La. Ann. 279, 12 So. 356.

2 Harding $v$. Alden, 9 Greenl. (Me.) 140, 23 Am. Dec. 549 ; Loker $v$. Gerald, 157 Mass. 42 ; Smith $v$. Smith, 43 La. Ann. 1140, 10 So. 248; Cham. pon $v$. Champon, 40 La. Ann. 28, 3 So. 397 . In a proceeding in rem, in which the personal element does not enter, as in a proceeding against property, the two forms of notice above given are regarded as equivalent. See Pennoyer $v$. Neff, 95 U. S. 714, 727. But in a proceeding quasi in rem, where the persoual element enters to a certain extent, it cannot be properly said that an advertisement is equivalent to actual notice. See Doughty $v$. Doughty, 27 N. J. Eq. 315, 325.

3 Harding v. Alden, 9 Greenl. (Me.) 140, 23 Am. Dec. 549; Smith v. Smith, 43 La. Ann. 1140, 10 So. 248. 
down the general principle that a plaintiff shall never obtain a universally valid divorce in his own country, because the defendant happens to be a non-resident. To so hold would force the plaintiff to seek out the defendant and to ask for the divorce in a State chosen by the latter, perhaps for the very reason that its laws are hostile to the plaintiff's cause.

On the other hand, it must be remembered that a suit for a divorce is not a proceeding strictly in rem, but merely quasi in rem; and that while the res in the former proceeding is property whose situation and condition the owner, though non-resident, must be assumed to be familiar with, in proceedings quasi in rem the res is a personal status, an attack upon which in a distant State cannot be justly assumed to be known by the defendant without an actual notification of some sort.

Many theories have from time to time been advanced by the courts, some of which have been incidentally adverted to in prior sections of this work, ${ }^{4}$ and all of which have now been pretty generally discarded, except three leading ones. The first of these is entirely favorable to the resident plaintiff, sacrificing to the sovereignty of his domiciliary law all the rights of the defendant. The second is entirely favorable to the non-resident defendant, sacrificing the rights of the plaintiff to the sovereignty of the defendant's domiciliary law. It forces the plaintiff for the most part to sue for his divorce in the courts of the defendant's domicil, and requires him to subject himself to its laws. This theory is supported by the courts of New York, and may be designated " the New York doctrine." The third strikes a happy mean between the first and second, and while giving to the plaintiff all the rights conferred by his own law, permitting him to sue in the courts of his domicil, yet requires that the defendant should receive a more substantial notification of the existence of the suit than is afforded merely by a published advertisement in a newspaper of the plaintiff's domicil. This may be designated " the New Jersey doctrine," and is believed to be the soundest. The theories thus briefly outlined will now be elaborated more fully.

Ante, $\$ \$ 76$, note 1,78 , notes 2,3 . 


\section{§92. First Theory - Jurisdiction over one Party confers} Jurisdiction over the other also. - According to the first theory, in order that the divorce court may have complete jurisdiction of the res, so that its decree will receive recognition everywhere as dissolving the relation of husband and wife, it is only essential that one of the parties should be domiciled there - it is immaterial which, though it will usually be the plaintiff. 'The courts of that party's domicil, having jurisdiction over his or her status, will draw to themselves, by reason of the mutuality of the marriage relation, jurisdiction of the status of the other party also, thus acquiring jurisdiction of the status of both. The case (under this theory) is practically identical with that where both parties are domiciled within the limits of the State of the divorce, and the proceeding, as in that case, is regarded as one strictly in rem, the personal element of the proceeding being disregarded altogether. Hence (under this theory) only such notice is required to he given the non-resident defendant as is required by the municipal ta the State of divorce in order to give its courts jurisdiction - frequently nothing more than an advertisement publishow in that State. ${ }^{1}$

It will be observed that this doctrine upholds in full measure the sovereignty of the plaintiff's domicil with respect to his status, but in so doing it oftentimes permits grave (and very unnecessary) injustice to be done to the defendant, who fre-

1 Ditson $v$. Ditson, 4 R. I. 87 ; Kline $v$. Kline, 57 Ia. 386,10 N. W. 825 , 826 ; Thurston $v$. Thurston, 58 Minn. 279, 59 N. W. 1017, 1018 ; Morey $v$. Morey, 27 Minn. 265, 6 N. W. 783; Thompson $v$. Thompson, 91 Ala. 591, 8 So. 419; Cox v. Cox, 19 Ohio St. 502, 2 Am. Rep. 415, 416; Doerr $v$. Forsythe, 50 Ohio St. 726, 35 N. E. 1055 ; Anthony v. Rice, 110 Mo. 233, 19 S. W. 423, 424 ; Hawkins $v$. Ragsdale, 80 Ky. 353, 44 Am. Rep. 483 ; Dunham v. Dunham, 162 Ill. 589, 35 L. R. A. 70, 77, 78; Hilbish v. Hattel, 145 Ind. 59, 33 L. R. A. 783 ; Rodgers $v$. Rodgers, 56 Kan. 483, 43 Pac. 779 . In other cases often cited to support this theory, it appears that there was an actual notification of the suit transmitted to the non-resident defendant. Such cases are in reality instances of the third theory, presently to be discussed. See Van Orsdal $v$. Van Orsdal, $6 \tau$ Ia. 35, 24 N. W. 579; Harding $v$. Alden, 9 Greenl. (Me.) 140, 23 Am. Dec. 549; Smith v. Smith, 43 La. Ann. 1140, 10 So. 248 ; Loker $v$. Gerald, 157 Mass. 42, 31 N. E. 709. 
quently finds himself or herself divorced, without any previous knowledge whatever that proceedings for that purpose were pending. The laws and procedure of the plaintiff's domicil are devised to protect the plaintiff's interests, not those of tha alien defendant. This constitutes the weakness of this theery. Its tendency is to violate that general principle of private international law that no man should be condemned unheard. It is a different case from that of a proceeding against property of the defendant. In that case a general publication is deemed sufficient because it is practically certain that the owner will be promptly notified of any blow aimed at his property. But his status is a more intangible thing, and more personal in its nature. ${ }^{2}$

§ 93. Second Theory - Divorce a Proceeding in Personam. - So impressed have the New York courts been by the personal element in the suit for divorce, and the dangers threatening the non-resident defendant under the first theory that they have adopted as extreme (and unjust) a view in the other direction. According to this second theory, the personal element above mentioned preponderates, and causes a proceeding whose purpose is to dissolve a status to be regarded in the light of a proceeding in personam rather than a proceeding in rem; and the same process is required to bring the defendant before the court as is required if the design were to fasten upon him or her a general pecuniary liability. The New York courts hold that no foreign divorce obtained in a State where the plaintiff alone is domiciled will be valid exterritorially, unless the defendant voluntarily appears or is personally served with process within the territorial jurisdiction of the divorce court. ${ }^{1}$

This theory gives undue weight to the personal element in-

2 See Doughty $v$. Doughty, 27 N. J. Eq. 315, 325.

1 Matter of Kimball, 155 N. Y. 62 ; Williams v. Williams, 130 N. Y. 193 ; Cross $v$. Cross, 108 N.Y. 628 ; Jones $v$. Jones, 108 N.Y. 415 ; O'Dea $v$. O'Dea, 101 N. Y. 23 ; Collins $v$. Collins, 80 N. Y. 1 ; People v. Baker, 76 N. Y. 78, 32 Am. Rep. 274 ; Hoffman v. Hoffman, 46 N. Y. 30. The New York view has been adopted by a few other courts. Harris $v$. Harris, $115 \mathrm{~N}$. C. 587, 20 S. E. 187 ; Cook v. Cook, 56 Wis. 195, 43 Am. Rep. 706, 14 N. W. 33, 38. See Elder $v$. Reel, 62 Penn. St. 308, 1 Am. Rep. 414. 
volved. It magnifies the rights of the defendant, and goes far to ensure that no injustice will be done that party ; but it will frequently be at the expense of the plaintiff and the sovereignty of the plaintiff's domicil. It practically, in many cases, forces a plaintiff who desires a divorce, at the very least to seek out the defendant, and sue in the State selected by the latter, for the very reason perhaps that its laws are more hostile to the plaintiff than his or her own; and, since the municipal laws of most States require the plaintiff to be domiciled in the State where he seeks a divorce, this theory would often compel him to abandon his own State altogether, and take up his permanent residence in the domicil of the defendant, or else forego his right to a divorce entirely. It pays no heed to the sovereignty of the plaintiff's domicil and its control over his status, which is just as pronounced as that of the defendant's domicil over the status of the latter. These are serious drawbacks to this theory - so serious indeed that it is not surprising that most courts have rejected it as unsound. ${ }^{2}$

§ 94. Third Theory - Divorce neither in Rem nor in Personam, but Quasi in Rem - Requires Best Notification practicable to Non-Resident Defendant. - The third theory adopted by the courts of New Jersey, is the best in point of reason, principle, and justice to partes, comb it does the advantages of hath the other theories, and minimizing the disadvantages of both. According to this theory, the personal element entering into a divorce suit is neither disregarded to the extent of making the divorce a proceeding in rem, nor so magnified as to make it a proceeding in personam. It is accorded its proper weight, and the divorce is regarded as a proceeding quasi in rem, that is, it is sufficiently a proceeding in rem to permit a court having jurisdiction of even part of the res to adjudicate upon it, without having to bring the person of the defendant within its jurisdiction, either by voluntary appearance or by service of process within the territorial limits of its authority; yet sufficiently in personam to require something more than a mere advertisement of the pendency of the suit, if more than that is practicable.

See Dunham $v$. Dunham, 162 Ill. 589, 35 L. R. A. 70, 77-78. 
Full effect is thus given to the sovereignty of the plaintiff's domicil and to his or her rights. The plaintiff is permitted to get the full benefit of the divorce laws of his own State, and is not required to go to the State of the defendant and subject himself to its laws in order to obtain his divorce. The jurisdiction of the plaintiff's domicil over his status is recognized everywhere. The ouly limitation (and it is surely a most reasonable one) is that the non-resident defendant strould be actually notified of the pendency of the suit, where that is practicable, by mall, message, or actual service of notice (not by advertisement merely).

This affords almost every protection to the defendant which is obtained by the New York rule, and at the same time leaves the plaintiff's rights and the sovereignty of the plaintiff's domicil untrammeled, save by a regulation for the protection of the absent defendant, which, while it can do the plaintiff no injury, affords a protection against the prostitution of justice, which it should be the lofty aim of every system of law to prevent.

This theory does not absolutely demand in all cases, in order to an exterritorial recognition of divorce, actual notice to be given the defendant, but only that the best notice practicable be given him or her. If his address is known, actual notice in some form is necessary; if unknown, only reasonable notice and opportunity to be heard is required. Of course, therefore, the voluntary appearance of the defendant will supersede the necessity for specific notice. ${ }^{1}$

It will be remembered that when the decree directs that the guilty party shall not marry again, the better opinion is that such part of the decree is in personam, not in rem, and hence

1 Doughty $v$. Doughty, 27 N. J. Eq. 315 ; Felt $v$. Felt, 57 N. J. Eq. 101, 40 Atl. 436 ; Magowan v. Magowan, 57 N. J. Eq. 195, 39 Atl. 364 ; Flower v. Flower, 42 N. J. Eq. 152, 7 Atl. 669 . See Whart. Confl. L. $\S \S 236,237$; Harding $v$. Alden, 9 Greenl. (Me.) 140, 23 Am. Dec. 549 ; Smith v. Smith, 43 La. Ann. 1140, 10 So. 248 ; Loker $v$. Gerald, 157 Mass. 42 ; Burlen $v$. Shannon, 115 Mass. 438 ; Van Orsdal v. Van Orsdal, 67 Ia. 35, 24 N. W. 579 .

2 Ante, $\$ 74$. 
the court is without jurisdiction to make such a decree against a non-resident defendant, unless he or she has voluntarily appeared, or (perhaps) has been personally served with process within the territorial jurisdiction of the court. And even then, such part of the decree, being in the nature of a penalty, will be given no exterritorial effect. ${ }^{2}$

§ 95. Exterritorial Effect of Divorce, as respects Costs and Alimony. - We have in the preceding sections considered the principles regulating the exterritorial effect of a divorce upon the status of the parties. We now come to examine its effect, as respects the incidents of the divorce, as in the matter of the costs of the suit, alimony, or the custody of minor children.

With regard to so much of the decree as relates to the costs of the suit and alimony to the wife it is to be observed that, so far as the court undertakes to decree against the defendant for a sum of money, the decree is a proceeding in personam. It seeks to fasten upon the defendant a general pecuniary tiability. Hence, as in the case of other procensenam, no exterritorial for given the court's decree in this respect unless the defendant is within the court's jurisdiction, either by voluntary appearance or by service of process there. ${ }^{1}$

For, under the constitutional provision that no State shall deprive any person of life, liberty, or property, without due process of law, would it be within the bounds even of the municipal law of any State of this Union to give its courts jurisdiction to make such a personal decree against an absent defendant, not served with personal process nor voluntarily appearing. ${ }^{2}$ But if a defendant is a non-resident, it is proper, even upon an

1 Cooper $v$. Reynolds, 10 Wall. 308 ; De La Montanya v. De La Montanya, 112 Cal. 101, 32 L. R. A. 82, 87; Rodgers $v$. Rodgers, 56 Kan. 483, 43 Pac. 779 ; Dow $v$. Blake, 148 Ill. 76, 35 N. E. 761,764 ; Bullock $v$. Bullock, 51 N. J. Eq. 444, 27 Atl. 435 ; Stewart v. Stewart, 27 W. Va. 167 ; Kline $v$. Kline, 57 Ia. 386,10 N. W. 825,826 ; Prosser $v$. Warner, 47 Vt. 667,19 Am. Rep. 132, 134. See Thurston v. Thurston, 58 Minn. 279, 59 N. W. 1017 ; Blackinton v. Blackinton, 141 Mass. 432, 436 ; Barber v. Barber, 21 How. 582.

2 Cooley, Const. Lim. 400 et seq. ; Pennoyer v. Neff, 95 U. S. 714. But see Blackinton v. Blackinton, 141 Mass. 432, 436. 
order of publication, without personal service or appearance, to provide for the seizure and appropriation of the defendant's property within the State, to make good the costs or alimony decreed; for to the extent of the property thus seized the decree would cease to be in personam, and would become a decree in rem. But any part of the personal liability imposed by the decree in excess of the value of such property would still be in personam only, and must conform to the requirements for such proceedings, touching the notice to be given the defendant, or else it will be void both exterritorially and intra-territorially. ${ }^{3}$

§ 96. Exterritorial Effect of Decree for Custody of Minor Children. - This is one of the usual incidents of a divorce. Being nothing less than a determination of the guardianship of the children, it is a question of double status, relating no less to the status of the children than to that of the respective parents. The decree for the children's custody therefore is as much a decree in rem as is the divorce itself, but with a more extended res. The res in this case is not only the status of the parents, but of the children also. But the children being infants, their domicil is necessarily with one or the other of their parents (usually with the father), and the legal situs of their status is at their domicil.

As we shall see however in discussing the status of Guardianship, ${ }^{1}$ the jurisdiction to appoint guardians of infants is not wholly confined to the courts of the ward's domicil. The courts of a State where an infant has his actual situs or has property will also sometimes assume a like jurisdiction, though due weight should always be accorded the domiciliary appointment.

Until the divorce takes place, and it is established that the father is unfit to have the custody of the infant children, their domicil must be presumed to follow his. Hence, primarily and theoretically the courts of the father's domicil alone should have the power to decree the custody of the children to the mother, so as to give the decree any exterritorial effect; for they alone

3 Cooley, Const. Lim. 406 ; Pennoyer v. Neff, 95 U. S. 714 ; Thurston $v$. Thurston, 58 Minn. 279, 59 N. W. 1017 ; Van Orsdal $v$. Van Orsdal, 67 Ia. 35, 24 N. W. 579 ; Wesner v. O'Brien, 56 Kan. 724, 32 L. R. A. 289.

1 Post, §§ 114 et seq. 
have complete jurisdiction of the entire res, - of the status of the father and children by reason of domicil, and of the status of the mother (whether resident or not) by reason of the fact that her status as wife and mother is inseparable from that of her husband and children. Practically, however, the control of the courts of the husband's domicil is complete and perfect only when the actual, as well as the legal, situs of the infant children is within its territory. If the children are actually elsewhere, the court can exercise no real control over their custody, and it may even be doubted whether any exterritorial effect should be accorded such a decree. ${ }^{2}$

But in the nature of things the guardianship of an infant must be of a more or less temporary character. It is not permanent and continuous like the status of marriage. It never endures longer than the minority of the ward. And even within that period circumstances may frequently arise which demand that a new guardian should be appointed. The ward may alter his domicil and thus come under a new law and a new set of tribunals, which may disapprove of the guardian already appointed or of the powers conferred upon him; or the ward may be actually situated in a State other than his domicil under circumstances demanding that his person or his property rights should be safeguarded there also. Thus the status of wardship is one which is liable to shift and change with circumstances. In this respect it differs from the marriage status or the status resulting from the dissolution thereof. Once validly established the latter is permanent until dissolved by death or divorce, and once validly dissolved, the dissolution is as permanent as the original status, no matter into what country the parties may thereafter come. As just shown, this is not true of the status of guardianship. It is a local and temporary, not a universal and permanent, status. Hence a change of domicil on the part of the

2 See Cooley, Const. Lim. 404 ; Kline v. Kline, 57 Ia. 386, 10 N. W. 825, 826 ; De La Montanya v. De La Montanya, 112 Cal. 101, 32 L. R. A. 82, 87 ; Rodgers $v$. Rodgers, 56 Kan. 483, 43 Pac. 779. See Pawling $v$. Bird, 13 Johns. (N. Y.) 192, 209. Indeed these authorities seem to indicate that it is the actual, rather than the legal, situs of the children that confers jurisdic. tion to decree concerning their custody. 
210 FOREIGN DECREE FOR CUSTODY OF INFANTS. \$96 children, or the mere presence of the children in another jurisdiction under different circumstances, may cause the courts of those States to assume jurisdiction to decree their custody to another guardian of their own appointment. This does not necessarily imply a denial of full exterritorial effect to the first decree, for, the status being temporary only, the courts of that very State might subsequently change the guardian. ${ }^{3}$

3 See post, $\S \S 114$ et seq. 


\section{CHAPTER VIII.}

\section{STATUS OF LEGITIMACY AND ADOPTION.}

\section{§ 97. Legitimacy and Adoption Instances of Double Status.} - We have seen that in the case of marriage, the status created is of a double or correlative character. The status of husband cannot exist without the status of wife also. So it is with a parent and an infant child. It so happens however that in these cases the duality of the status is generally immaterial, so long as the relation continues. No conflicts of the "proper law" will usually occur, because the domicil of the wife and of the infant child are in most cases identical with the domicil of the husband and parent, and hence the same law will in general govern the status of both.

No questions of the conflict of laws will be ordinarily likely to arise in regard to the relation of parent and child, both for the reason above given and for the further reason that the laws governing that relation are pretty much the same the world over. Occasionally, however, cases arise in which this simple relation must be subjected to the principles of private international law. ${ }^{1}$

Nor with respect to the marital relation and its incidents will the duality of the status of husband and wife in general play a prominent part, so long as the marriage remains intact, for the reason above given. It is only when the matrimonial union is sought to be dissolved by divorce, when the interests of husband and wife become antagonistic, that they acquire separate domicils, and the situs of their respective status become distinct. Then the duality of the status becomes embarrassing, as has been shown in the last chapter.

1 Instances of this kind have been already discussed. See ante, $\$ \S 83,96$. 
There are still other instances of double status, two of which at least deserve special attention. These are the status of legitimacy and of adoption. Whether one is the legitimate child of a person involves necessarily the status of the parent as well as that of the child. So it is also in the case of a legally adopted child. In these cases, it is not only the status of the child which is to be determined, but incidentally and necessarily that of the parent also. These instances of double status differ from the relation of husband and wife and from that of parent and child, in the important point that it is not necessarily the case, in legitimacy and adoption, that the domicil of the child and parent should be identical. This fact complicates the situation greatly. In such cases therefore, granting the general principle that the law of the legal situs or domicil of the parties governs their status, the question may still arise, the law of whose domicil? Shall it be the law of the domicil of the parents or one of them, or the law of the child's domicil? The status of all is in doubt. In investigating these questions, one or two general principles must be constantly borne in mind.

Both legitimacy and adoption are instances of permanent and universal status (as opposed to that which is merely temporary and local, as in the case of guardianship, etc.) - It would be in the highest degree inconvenient if a status of this sort, once established, were liable to fluctuation and change with time, place, or circumstance. ${ }^{2}$ Hence, when these relations are once established by "the proper law," they remain in general fixed and unchangeable, into whatsoever countries the parties may wander, or wheresoever the question may arise, subject only (in rare cases) to the exceptions enumerated in the second chapter. ${ }^{3}$

It is a corollary of this principle that it is the proper law at the time of the act or circumstance upon which is based the claim of legitimacy or adoption, that is to determine the status. For since the claim is based on the act or circumstance in ques-

2 See Miller v. Miller, 91 N. Y. 315, 319, 43 Am. Rep. 669.

3 Smith $v$. Kelly, 23 Miss. 167, 55 Am. Dec. 87; Miller $v$. Miller, 91 N. Y. 315, 319, 43 Am. Rep. 669 ; Ross $v$. Ross, 129 Mass. 243, 37 Am. Rep. 321 ; Adams v. Adams, 154 Mass. 290, 293, 28 N. E. 260. 
tion, and since, if such act or circumstance does by the proper law create the status, that status will be permanent and unchangeable, it must follow that the law at that time properly applicable must determine finally the effect of the act or circumstance upon the status of the persons concerned.*

The question still remains, what is the "proper law" in these cases? Is it the lex domicilii of the parents, of the child (supposing his domicil to be different from that of his parents or of either of them), or of both? If it is urged that the status of the parent is affected, and that the law of his domicil should govern, it might be replied that the child's status is as much, if not more, affected, and that therefore the law of his domicil should control. Very complicated questions sometimes arise in these cases.

§ 98. Legitimacy - Child Born in Wedlock. - Legitimacy may exist from birth, or it may arise subsequently from a supervenient cause. With respect to the legitimacy of a child born in lawful wedlock, of course no question will arise, since every system of law that recognizes marriage regards such a child as legitimate. Indeed one of the principal designs of the estate of matrimony is to secure certainty of parentage and the legitimacy of children.

The only question apt to occur here is with regard to the validity of the marriage, and the effect of its invalidity upon the legitimacy of the issue. ${ }^{1}$

At common law, if the marriage is void per se or declared void by a competent court, But in many States, statutes have been passed abating the rigor of the cammon law in this respect, and declaring the issue of such marriages legitimate. It is important to as such statutes witl have upon the status of the children of void or voidable marriages, when the question arises in a foreign State.

4 See Smith $v$. Kelly, 23 Miss. 167, 55 Am. Dec. 87.

1 The proper law governing the validity of marriage has been already dealt with, both with respect to the capacity to marry (ante, $\$ \$ 73$ et seq.), and with regard to the formal and substantial validity of the marriage contract. Ante, $\S \S 77,78$. See Greenhow v. James, 80 Va. 636 ; Adams v. Adams, 154 Mass. 290, 292, 28 N. E. 260. 
The general rule being that the law of the domicil regulates the status, if the father, mother, and child are all domiciled at the time of the child's birth in the same State, the law of that State ill fix the status. It is the law of the domicil at the time of the child's birth which controls, for the claim of his legitimacy is based upon the circumstance of his birth in wedlock (though unlawful).

A much more difficult question might arise, if the mother's domicil is different from that of the father at the time of the child's birth, should there be a conflict in the laws of the two domicils upon this point. ${ }^{2}$ The first question would be as to the child's domicil in such case. Will it follow the domicil of the father or that of the mother? ID hod that it takes the father's domicil would be to assume legitimate child, the very point in dispute. It would seem that the child's domicil must be held to follow that of the mother, until it is decided by the proper law to be legitimate.

The next question is, what is the proper law to determine whether the child be legitimate? The child is legally domiciled with its mother, and the State of their domicil will control their status, while the status of the father, as being a legal or only a putative father, must be regulated by the law of his domicil. No law of one State affecting the status of those domiciled there can run into another State and affect the status of the latter's citizens. The embarrassment of the situation is easily recognized. There are no authorities to guide us upon the point, and any conclusions drawn must be largely speculative.

The true solution would seem to depend upon the locality of the forum and the nature of the particular question involved. If the case arises in the father's domicil, the courts of his domicil will probably follow their own law in passing upon the status, especially if it is the relation the child bears to the father which is in controversy. If the mother's domicil is the forum, its courts also will probably follow the domestic law, especially if

2 If a marriage is void per se, or avoided $a b$ initio by a competent court, it might well happen that the woman's domicil at the date of the child's birth is distinct from the man's, if they actually reside in different States. See ante, $\S 53_{s}$ 
the child's relation to the mother is in issue. Should the question come up in the courts of a third State where none of the parties are domiciled, it is probable, upon principles mentioned in the succeeding sections, that the courts, out of tenderness to the child, will recognize his legitimacy, adopting the law of the father's domicil or that of the mother and child, according as one or the other advances this benevolent purpose. ${ }^{3}$

§99. Subsequent Legitimation - Intermarriage of Parents of Infant Bastard. - The laws' of different States vary touching the subsequent legitimation of bastards. At common law no suprenient act could legitimate one not born in wedlock. But the civil tom law of the thates of this Inionation is allowed by statute. Even amongst those States which permit it, however, differences exist with respect to the mode of accomplishing it. By the municipal law of some States a subsequent intermarriage of the parents standing alone will effect this result; in other States, the father's acknowledgment alone suffices; and in others there must be both an intermarriage and an acknowledgment by the father.

In all cases where the intermarriage of the parents precedes or accompanies the alleged legitimation of an infant bastard, there is no difficulty in ascertaining the domicil of the parties. For as soon as the father marries the mother, his domicil becomes hers also, and the domicil of the infant bastard changes with hers and also becomes that of the husband. ${ }^{1}$ Whether the intermarriage alone or the intermarriage followed by acknowledgment is necessary to legitimate the issue, the result is the same; all the domicils coincide and are identical with that of the father. We haper law" to determine legitimation is the law of the domicil of the parties at the time of the act upon which is has legitimacy." In this case this act is the intermarriage of the parents (or the

${ }^{8}$ For the principles applicable to cases of this sort the reader is referred to the discussion, post, $\$ 100$.

1 See ante, $\S 42$. If the bastard is an adult, his domicil is of course unaf. fected by the intermarriage of his parents.

Ante, §97. 
intermarriage followed by the father's acknowledgment), and this intermarriage gives all the parties the same domicil, - that of the father.

It must necessarily follow, therefore, that the lex domicilii of the father at that time is "the proper law" to determine the child's status, as bastard or legitimated, in all cases where an intermarriage of the parents precedes or forms a component part of the steps required for legitimation. If by that law he is thereby rendered legitimate, he will be regarded as legitimated everywhere, even in States whose laws do not recognize subsequent legitimation. If by that law he is not rendered legitimate, neither will he be so regarded anywhere, even where such legitimation is recognized, and though by the law of the infant's (and mother's) domicil before the marriage the acts done would suffice to legitimate him..$^{3}$

The English courts seem to have adopted a principle with regard to this matter, for which it is difficult to assign any sufficient reason. They hold that it is the law of the father's domicil at the time of the birth of the child which should determine the effect of a subsequent marriage of the parents, not the law of the father's domicil at the time of the act upon which is based the claim of legitimation." The English

See Whart. Confl. L. $\S 241$; Sheddon v. Patrick, 5 Paton, 194 ; s. c. 1 Macq. 535, 622 ; Strathmore Peerage, 4 Wils. \& Shaw, Appendix, 89-91, 93, 94 ; s. c. 6 Paton, 645 ; Munro $v$. Saunders, 6 Bligh, N. R. 468 ; Birtwhistlo v. Vardill, 2 Cl. \& F. 571, 587, 592, 595, 600; Munro v. Munro, 7 Cl. \& F. 842, 885; Dalhousie v. M'Douall, 7 Cl. \& F. 817 ; Aikman v. Aikman, 3 Macq. 854; Don's Estate, 4 Drewry, 194 ; In re Grove, $40 \mathrm{Ch}$. Div. 216 ; Shaw $v$. Gould, L. R. 3 H. L. 55, 70 ; Miller $v$. Miller, 91 N. Y. 315, 43 Am. Rep. 669 ; Smith $v$. Kelly, 23 Miss. 167, 55 Am. Dec. 87 ; Ross v. Ross, 129 Mass. 243, 249, 37 Am. Rep. 321 ; Loring $v$. Thorndike, 5 Allen (Mass.), 257 ; Smith $v$. Derr, 34 Penn. St. 126, 75 Am. Dec. 641; Wolf's Appeal (Penn.), 13 Atl. 760 ; Woodward $v$. Woodward, 87 Tenn. $644,11 \mathrm{~S}$. W. 892, 895. See Blythe v. Ayres, 96 Cal. 532, 31 Pac. 915, 19 L. R. A. 40.

4 Dicey, Confl. L. 497 et seq. ; Jac. Dom. $\$ 30$; Udny v. Udny, L. R. 1 Sc. App. 441, 447 ; Wright's Trusts, 2 K. \& J. 595 ; Goodman's Trusts, L. R. 17 Ch. D. 266 ; Goodman \%. Goodman, 3 Giff. 643. See also Miller $v$. Miller, 91 N. Y. 315, 43 Am. Rep. 669. But some of the English decisions faror the law of the father's domicil at the time of the marriage. See Aikman $v$. Aikman, 3 Macq. (H. L.) 854 ; Munro v. Munro, 7 Cl. \& F. 842 ; Dalhousie v. M'Douall, 7 Cl. \& F. 817 ; Whart. Confl. L. $\$ 241$. 
decisions seem to rest upon the theory that the subsequent marriage, in order to legitimate a bastard, must by relation be considered as taking effect at the time of the child's birth, so that he may be held to have been born in wedlock. ${ }^{6}$ This is a very unnecessary fiction, contrary both to truth and reason. Two prominent causes may be assigned for the rule of law prohibiting bastards to assume the status of legitimate children. One is the encouragement which would otherwise be given to illicit amours. The other is the practical difficulty of ascertaining with certainty who is the father of the child. Both of these objections are in large measure removed or remedied by a subsequent intermarriage of the parents, and it is surely needless to go further back than the ipse dixit of the law itself in order to pronounce the issue legitimate. The fiction that the law in such cases "assumes that what is equivalent to marriage took place before the birth or conception of the child" " is not only unnecessary, but, if it came from a less distinguished source, might be characterized as fantastic.

The true rule, if the legitimation is based upon the intermarriage of the parents as the final act necessary to complete it, is that the law of the father's domicil at the time of the marriage (which will also be that of the mother and child) should determine the status of both father and child. But if the marriage of the parents does not of itself complete the legitimation, there being still requisite after the marriage some other act, such as the father's acknowledgment of the child, the law of the father's (and minor's) domicil at the time of the last act essential to complete the legitimation should control. ${ }^{7}$

It should be observed also that since the status of legitimation, once created or denied under the proper law at the time of the act by virtue of which it is alleged to have arisen, is a permanent and universal status, a subsequent removal of the par.

5 See Munro v. Munro, 7 Cl. \& F. 842, 872.

- See Lord Chancellor Cottenham's opinion in Munro v. Munro, $7 \mathrm{Cl}$. \& F. 842,872 .

7 See Ross $v$. Ross, 129 Mass. 243, 256, 37 Am. Rep. 321; Aikman $a$ Aikman, 3 Macq. (H. L.) 854 ; Munro v. Munro, 7 Cl. \& F. (H. L.) 842 ? Dalhousie v. M'Douall, 7 Cl. \& F. 817 ; Whart. Confl. L. $\$ 241$. 
ties' domicil to another State, by whose law the act in question (if performed there) would have caused a different result, will not alter the status. There must be some new act done in the latter State under its law to legitimate a child not legitimated by the former act. And if the child be legitimated under the law of the first State, its status hecomes a beneficial one which no subsequent act of the father under any law should be permitted to destroy. ${ }^{8}$

$\S 100$. Bastard an Adult when Parents Marry - No Intermarriage of Parents. - In the preceding section we have supposed the case of an intermarriage of the parents while the bastard is an infant. If the bastard is an adult at the time of his parents' marriage, or if no marriage occurs, a different state of facts is presented from those appearing in the former case. In the former case, the infant bastard's domicil becomes by virtue of the marriage that of the father, and hence the status of both will be governed by the same law.

But if the bastard is an adult at the time of the marriage, or if there be no marriage between the parents (the act relied upon to establish the legitimation being some act other than the parents' marriage, such as a mere acknowledgment by the father, or an act of the legislature), the circumstances may be different. In such case the domicil of the bastard is not necessarily identical with that of his father at the time of the legitimating act, and their status may thus be subject to different laws. Under such circumstances, shall the law of the father's domicil govern the status of both? If so, the status of the bastard will be permanently fixed by the law of a State of which he is not a citizen, and which has no claim of jurisdiction over him. Shall the law of the bastard's domicil govern? If so, the father's status will equally be fixed by a law which has properly no control over him. It is a more difficult task to ascertain the proper law in a case of this sort than in one like that mentioned in the preceding section.

Two points should be noticed in this connection, which will aid us to determine the proper law in this case. The first is

- Smith v. Kelly, 23 Miss. 167, 55 Am. Dec. 87. 
that the legitimation of a bastard is the creation of a status which is beneficial to him, and it should be presuned in his favor whenever adequate reason exists for such a course. The second is that this beneficial status cannot be accorded the infant at the expense of a change of status on the part of the father not warranted by his domiciliary law. ${ }^{1}$

Applying these two principles, it follows that the law of the father's domicil at the time of the legitimating act will bo the proper law to determine the both parties. If by that law the act in question legitimates the bastard, the beneficial status thus created will in general be recognized everywhere, including the bastard's domicil, though by the law of the latter State the act would not suffice to create a legitimation. ${ }^{2}$ On the other hand, if by the law of the father's domicil legitimation is not the result of the act claimed to have that effect, though under the bastard's domiciliary law legitimation would result therefrom, the status of legitimation should not be conferred upon the bastard, for that would be to subject the status of the father to a law to which it is not properly subject.

These priuciples are as yet but scantily exemplified by decided cases, most of the decisions being instances of legitimation by intermarriage, where the bastard was an infant. Such as have arisen, however, have been decided in accordance with the foregoing views.

In Scott $v . \mathrm{Key},{ }^{3}$ a father and his illegitimate son were both domiciled in Arkansas. The legislature of that State passed an act legitimating the child, and it was held in Louisiana that this legitimation should be recognized there to the same extent as in Arkansas. The legitimated bastard was permitted to in-

1 Except perhaps that the courts of the bastard's domicil, when the ques. tion arises there, might enforce the lex fori and legitimate him, especially should the father do the act (upon which is based the claim of legitimation) in the State of the bastard's domicil, thereby voluntarily submitting himsell to the operation of its law.

2 Under exceptional circumstances, if the question should arise in the bastard's domicil, and the interests of the forum or of its citizens demand it, the lex fori might still be substituted for "the proper law."

311 La. Ann. 232. 
herit the father's land in Louisiana to the exclusion of the father's brothers and sisters.

In Lingen $v$. Lingen, the domicil of the father was not the same as that of the bastard. The case arose in the father's domicil (Alabama). The child's mother was a Frenchwoman, and the child was born in France, where the father acknowledged him to be his son, but did not marry the woman. By the law of France, the mere acknowledgment by the father sufficed to render the child legitimate. It was otherwise in Alabama. Upon the death of the father, the bastard claimed a share of his estate as his legitimate child. But the court held that his legitimation was to be governed by the law of the father's, not the bastard's, domicil.

Just the opposite case arose in the recent case of Blythe $v$. Ayres. ${ }^{6}$ Here too the question arose in the father's domicil (California) upon a claim by his bastard daughter, domiciled in England, to a share of his property in California. Her father had acknowledged her to be his daughter, which under the law of California sufficed to legitimate her. By the law of her own domicil (England), no subsequent act could have legitimated her. It was held that the daughter's status was to be determined by the law of California, her father's domicil, that she was legitimated, and entitled to inherit her father's estate. In this case, the status was purely a beneficial one so far as the daughter was concerned, and even if the case had come before the English courts instead of those of California, it is believed the result would have been the same. But if the question had been, not as to the right of the daughter to inherit from the father, but the right of the father (domiciled in California) to inherit the property of the daughter (domiciled in England), and the case had arisen in England, the English courts might well refuse to enforce the law of the father's domicil, when to do so would no longer benefit the bastard and might deprive her English relatives of the inheritance. This might be a case for the operation of one of the exceptions to the enforcement of the proper law, and for the substitution of the lex fori.

45 Ala. 410.

696 Cal. 532, 31 Pac. 915, 19 L. R. A. 40. 
If, however, the bastard's domicil is in fact the same as the father's at the time of the legitimating act, there is no doubt that the child, though an adult, becomes legitimated. ${ }^{6}$

$\$ 101$. Legal Status of Adoption. - The status of adoption, like that of subsequent a common law, though familiar in the jurisprudence of the Roman law, from which it has been introduced by statute into mairy of the States of the Union. Like subsequent legitimation also, adoption presents the peculiarity of a plural status. Indeed this may be more pronounced in the case of adoption than in that of legitimation, since the relations of more persons are involved therein. This plurality of the status may cause very serious embarrassment in the solution of some of the questions which present themselves under this head.

The result of adoption under the statutes is usually that the adopted child ceases in law to be the child of its natural parents, so far as their rights and obligations are concerned, and becomes the child of the adopting parents to all intents and purposes, with the rights and obligations incident thereto. The statutes usually provide that the adoption shall originate in a judicial proceeding instituted in the court of the child's residence, upon petition filed by the party desiring to adopt it, and that the natural parent or the guardian shall be a party to the proceeding. ${ }^{1}$

Thus it will be seen that adoption involves an alteration, not only in the status of the person adopted and in that of the adopting parent or parents, but in that of the natural parents also. Here are, or may be, three sets of domicils, whose laws may each claim some share in regulating the status of the parties concerned. But practically these will generally be reduced to two, since the person adopted is usually an infant, and hence will have the domicil of its parents.

6 Ives $v$. McNicoll, 59 Ohio St. 402, 43 L. R. A. 772 ; Scott v. Key, 11 La. Ann. 232.

1 For examples of such statutes, see Van Matre $v$. Sankey, 148 Ill. 356, 36 N. E. 628 ; Foster v. Waterman, 124 Mass. 592 ; Furgeson v. Jones, 17 Or. 204, 11 Am. St. Rep. 808.

2 At the same time it is conceivable that he may be an adult, with a domicil of his own apart from his parents. But in such case the domicil of the 
If the adopting parents, the natural parents (if any), and the child are all domiciled in the State where the adoption proceedings take place, and the status is there validly created, no doubt will arise. The status is a permanent and universal one, and once created will continue and will be recognized as existing everywhere, until dissolved according to the law of the parties' domicil, or so long as the recognition of the relation does not work an injustice to the residents of the State where the question arises (forum) or contravene its established policy. ${ }^{3}$

If the dom of the adopting parent is not identical with that of the adopted child, it is believed that the law of the child's domicil will determine the status, if the adoption takes place there (as it usually will), while if the adoption should occur in the domicil of the adopting parent, the law his domidwill govern. The case is analogous to that of divorce. In both, a decree of court is required, and, upon principles already noticed in discussing the exterritorial force of a decree of divorce, a court has no jurisdiction over a matter of status unless one of the parties at least is domiciled in its territory. It can give no decree, which will have exterritorial effect, touching the status of non-residents. But it is not necessary that both parties should be domiciled there. ${ }^{4}$

natural parents will only be of importance when some question of their status, rights, or dnties arises. No cases of the kind have as yet been passed upon. All the decided cases relate entirely to the status as it exists between the child and the adopting parent. See Furgeson v. Jones, 17 Or. 204, 11 Ain. St. Rep. 808.

(3oss v. Ross, 129 Mass. 243, 37 Am. Rep. 321 ; Melvin v. Martin, 18 R. I. 650, 30 Atl. 467; Gray v. Holmes, 57 Kan. 217, 45 Pac. 596, 33 L. R. A. 207; Van Matre v. Sankey, 148 11l. 356, 36 N. E. 628, 23 L. R. A. 665 ; Keegan $v$. Geraghty, 101 Ill. 26. See Woodward $v$. Woodward, 87 Tenn. 644, $11 \mathrm{~S}$. W. 892. In most if not all these cases there were statutes in the State of the forum permitting adoption, differing only in detail from the statutes under which the adoption actually occurred.

4 Ante $\$ \S 88$ et seq. In Van Matre $v$. Sankey, 148 Ill. 356,36 N. E. 628,23 L. R. A. 665, the adopting parent was domiciled in California, the adopted child in Pennsylvania, and the adoption took place under decree of a Pennsylvania court, in accordance with Pennsylvania law. The Illinois court did not even inquire into the law of California (the adopter's domicil) upon the subject of adoption, but looked only to the law of Pennsylvania. 
The proper law to determine whether a particular person is the legitimated or adopted child of another being ascertained in accordance with the principles discussed in this and the preceding sections, it still becomes necessary to consider the effect of the legitimation or adoption in other States. In general the status thus created under the proper law will be recognized everywhere, unless the policy of the forum or the interests of its inhabitants forbid its enforcement and demand the substitution of the lex fori. Instances of this have been already seen. Thus, the domicil of a legitimated or adopted infant at once commences to follow the domicil of the father or adopting parent, as though the child were born to the parent in wedlock. ${ }^{5} \mathrm{We}$ have also seen that in general he will inherit the parent's property, whether personal or real, regardless of the law of its situs touching adoption. ${ }^{6}$

In Foster $v$. Waterman, 124 Mass. 592, the Massachusetts court held that an adopting parent there domiciled could not adopt a child domiciled in New Hampshire under the decree of court aud the statutes of the latter State, so as to be effective in Massachusetts. But this case turns rather upon the construction of the New Hampshire statute, which was held to be applicable only where the adopting parent as well as the adopted child were domiciled in New Hampshire. See Furgeson v. Jones, 17 Or. 204, 11 Am. St. Rep. 808.

5 Ante, $\$ \S 43,44$.

- Ante, § 12. 


\section{CHAPTER IX.}

\section{STATUS OF FIDUCIARIES.}

8102. Dual Nature of Fiduciary Status. - Under the head of "Fiduciary Status" will be grouped the principles regulating the law properly applicable to fiduciaries, not only with respect to their appointment and qualification, but with regard. also to their title to property, their rights, powers, and liabilities, as between them and the beneficiaries on the one hand, and as between them and third persons on the other.

It must be carefully observed that every fiduciary occupies two relations : one towards the beneficial owner of the trust estate, and quite a different one towards third persons interested in the administration of the trust fund,-- for example, creditors.

Thus an executor, administrator, guardian, or trustee is appointed not only for the benefit of his legatee, distributee, ward, or cestui que trust, but also in order to manage and control the property committed to him, to collect and pay debts, to prosecute and defend suits, " sell and invest property, etc. Third persons, as well as the be $e_{\perp}$ ficiaries, may be interested in the trust. And these creditors, debtors, or other third persons may be citizens of other States than that wherein the fiduciary and beneficiaries reside.

It might work a serious injury to the citizens of the forum if a foreign fiduciary were allowed to administer upon property there situated except in accordance with its own laws (lex fori et situs). The fact that the fiduciary is a resident of, and appointed in, another State, and that the beneficiaries also reside abroad, is immaterial. No State can be expected to permit property within its borders to be taken away, sold, or dealt with in any manner by a fiduciary, a mere quasi-legal official appointed in another State and subject to other laws, when to do so might jeopardize the interests of some of her own citizens who might 
justly claim that the property should be administered by theit own law, the law of the forum and situs of the property.

Upon these principles it is now universally admitted that, in the absence of statute, in any case in which third persons are interested, the status of the foreign fiduciary is only local and temporary. He must in general be reappointed and must qualify in every State wherein he desires to administer the property or rights of action committed to his charge. Third persons are entitled to and may demand all the security and protection afforded by the laws of the State where the property is situated. The general rule in thes that the law of the forum and

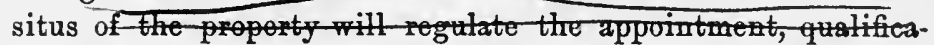
tion, rights, title, and liabilities of fiduciary, so fas-concerns the relations between them and third persons. ${ }^{1}$

But so far as the relations between the fiduciary and the beneficiaries of the trust are concerned (third persons not being interested), even when the question arises in third States, the law of the domicil of the owner or beneficiary (the legal situs of the owner's person and personal property) will control, both in respect to personal rights ${ }^{2}$ and rights relating to the personal property.

Thus it will be seen th thespect to fiduciaries the general rule is to apply the "proper law" as between the fiduciary and the beneficiary, white, as between the fiduciary and third parties, the lex fort is substituted for the proper low.

§ 103. Illustrations - Various Classes of Fiduciaries. The general principles noticed in the preceding section may be better understood with the aid of one or two examples.

1 Burbank $v$. Payne, 17 La. Ann. 15, 87 Am. Dec. 513 ; Speed $v$. May, 17 Penn. St. 91, 94, 55 Am. Dec. 540; Dawes v. Head, 3 Pick. (Mass.) 128, 145 ; Fay $v$. Haven, 3 Met. (Mass.) 109 ; Dial v. Gary, 14 S. C. 573, 37 Am. Rep. 737, 738-739; Townsend $v$. Kendall, 4 Minn. 412, 77 Am. Dec. 534 ; Mayo $v$. Equitable, etc. Society, 71 Miss. 590, 15 So. 791; Smith v. Bank, 5 Pet. 518, 525; Vaughn $v$. Northup, 15 Pet. 1 ; McLean $v$. Meek, 18 How. 16, 18 ; Mackey $v$. Coxe, 18 How. 100, 104; Wilkins $v$. Ellett, 9 Wall. 740, 742.

2 See Townsend $v$. Kendall, 4 Minn. 412, 77 Am. Dec. 534.

3 Mayo v. Equitable, etc. Society, 71 Miss. 590, 15 So. 791 ; Lamar Micou, 112 U. S. 452. 
Let us suppose a man to die, leaving personalty situated in several States. By his will he leaves his property to his children and appoints an executor. The appointment of the executor is not solely for the purpose of preserving the estate for the legatees and distributing it among them, but also to pay and collect debts, etc. A relation is established between the legatees and executor, and also a relation between the executor and the creditors, debtors, and claimants of the estate. These creditors, debtors, or claimants may reside, not only in the State where the owner of the property (the testator) was domiciled, but in other States as well, including those where the personalty of the decedent is situated.

When the executor comes into those latter States to obtain possession of and administer the property there situated, those States will not usually permit him to act merely by virtue of the privileges accorded him by the law of the testator's domicil. The creditors, debtors, and claimants of the estate, if any, who are residents of those States, are entitled to demand that every precaution required by their law to protect their interests shall be taken, regardless of the law of the testator's domicil. ${ }^{1}$ They have the right to demand that the rules of the situs and forum shall be followed, touching the qualification of the executor, the security to be given, the time within which claims may be filed, etc. Hence the executor will be required to show his authority by proving the will again by means of a certified copy of the domiciliary probate: he will be called upon to qualify and to give security in accordance with the law of the situs and forum; and until he has taken all the steps required of home executors, he will not generally be permitted to assume control of the property there situated. The general principle of law that the legal situs of personalty is at the domicil of the owner and is subject to its law has mo application here; for, as has

1 Though the primary object of the substitution of the lex fori in these cases is to protect citizens of the forum, yet it is conceded that a decedent's funds in any State are liable to all creditors who may there apply for settlement, regardless of citizenship or domicil. De Sobry $v$. De Laistre, 2 Har. \& J. (Md.) 191, 3 Am. Dec. 535, 536 ; Goodall v. Marshall, 11 N. H. 88, 35 Am. Dec. 472, 477-479, and note. 
been-shown, the legal situs of personalty yields to the actual situs, wherever any of the great exceptions to the enforcement of the proper law come into play. ${ }^{2}$ Here the substitution of the lex fori and lex situs for the lex domicilit of the testator is justified as a protection to the interests of the people of the forum. ${ }^{8}$

If it turns out that afterall there are no creditors or other third persons who are interested in the administration, the reason for the substitution of the lex fori ceases. The foreign executor will then be allowed to assume full control of the law of the forum and situs ceases to operate upon it, and it becomes subject to the lex domicilii of the testator. If none of the legatees are citizens of the forum, it will usually be sent on to the domicil of the testator, to be there administered and distributed by the executor, under the direction of the domiciliary courts and in accordance with the lex domicilii. ${ }^{4}$ If there are citizens of the situs and forum who are legatees (there being no creditors) the property will still be subject, in its distribution among the legatees, to the lex domicilii of the testator, though it need not necessarily be sent there for distribution. ${ }^{5}$

What has been said above of executors may be repeated in almost the same language with respect to administrators, as will more fully appear hereafter.

Another instance of this double relationship of fiduciaries is to be found in the relation of Guardian and Ward, though not

2 Ante, § 14 ; post, §§ 120, 121 et seq.

8 See Atchison v. Lindsey, 6 B. Mon. (Ky.) 86, 43 Am. Dec. 153 ; Dawes v. Head, 3 Pick. (Mass.) 128 ; Fay v. Haven, 3 Met. (Mass.) 109, 114 ; Dial v. Gary, 14 S. C. 573,37 Am. Rep. 737 ; Vroom v. Van Horne, $10 \mathrm{Pai}$. Ch. (N. Y.) 549, 555; Petersen v. Chemical Bank, 32 N. Y. 21, 43, 88 Am. Dec. 298 ; Welles' Estate, 161 Penn. St. 218, 28 Atl. 1116, 1117 ; Smith v. Bank, 5 Pet. 518 ; Wilkins $v$. Ellett, 9 Wall. 740, 742 ; s. c: 108 U. S. 256, 258. The same principle has in some cases even been extended to resident legatees where the assets are more than sufficient to pay all the creditors of the estate, foreign and domestic. See Graveley $v$. Graveley, 25 S. C. 1, 60 Am. Rep. 478.

4 Post, $\$ 113$.

5. Harvey $v$. Richards, 1 Mason, C. C. 381 ; Graveley v. Graveley, 25 S. C. 1 , 60 Am. Rep. 478. See post, $\$ 113$. 
to so marked an extent. ${ }^{6}$ This double relationship of guardians, and indeed of fiduciaries generally, requires that they too should be governed as to creditors and other third persons by the lex fori et situs.

The several fiduciaries whose status, in respect to the creation, incidents, and termination thereof, we will now consider, are: (1) Executors and Administrators; (2) Guardians; and (3) Receivers.

$\S 104$. Executors and Administrators - Outline of Discussion. - A primary distinction is to be noted between the administration of a decedent's estate and the distribution thereof, the effect of which has already been alluded to in the preceding section. The administration of a decedent's estate involves the dealings and relations of the executor or administrator with third persuos; while the distribution of the estate involves their relations and dealings with the beneficiaries, the legatees or distributees.

It will be remembered thatearresponding distinction as to the law properly applicable. So long as the interests guarded are those only of the objects of the decedent's bounty (his gran as it were), the lex domicilii of the decedent will in general determine all their rights, no matter where the beneficiaries or fiduciaries reside, or the question arises. ${ }^{1}$

But if it is a matter of administration, the rights of third parties intervening, it becos a case for the substitution of the lex fori for the proper lax (the lex domicilii of the decedent). And since administration proceedings are to a certain extent in the nature of proceedings in rem, ${ }^{2}$ the courts will not generally assume to administer upon property not within their jurisdiction. ${ }^{8}$ Hence it comes about that the forum and the situs of

6 See post, $\$ \$ 114$ et seq.

1 See post, $\S 139$ et seq.

2 See Reynolds $v$. Stockton, 140 U. S. 255, 272 ; Rockwell v. Bradshaw, 67 Conn. 9, 34 Atl. 758, 761.

Stacy v. Thrasher, 6 How. 44, 58 ; Hooker v. Olmstead, 6 Pick. (Mass.) 181. Or if it is within the jurisdiction of another court. See Byers $v$. MeAuley, 149 U. S. 608. 
the property administered will always coincide, and the lex fori et situs becomes the law by which the administration of estates is governed.

We shall develop this topic under the following general heads: (1) The law controlling the creation of the status of executor or administrator; (2) The law controlling the incidents of the status; including the powers, rights, duties, and liabilities of executors and administrators in general, the order in which the decedent's debts are to be paid, the order in which the decedent's property is to be subjected to the payment of his debts, and (incidentally) the rights of creditors against the real estate of the decedent, the right of the decedent's heir or devisee to claim exoneration out of the decedent's personal estate, and the right of one heir or devisee paying the decedent's debts to claim contribution from the others; and (3) The law controlling the termination of the fiduciary status; including the settlement of the accounts, the distribution of the residuum after the collection and satisfaction of all claims, and the rules governing ancillary administrations.

$\S 105$. Appointment and Qualification of Administrators and Executors. - An administrator of a decedent's estate is an officer of the law, the order of a competent court, in a proceeding in the nature of a proceeding in rem. ${ }^{1}$ The jurisdiction of the court is local, extending no further than to embrace the property within the limits of its control. For this reason, as well as for the reasons given in the preceding sections, the appointment is in general of no effect outside the jurisdiction where he is appointed; and if the personalty of the decedent is situated in several States, he must be reappointed or a new administrator must be nominated in each State before the property there situated can be administered. ${ }^{2}$

1 See Reynolds v. Stockton, 140 U. S. 255, 272 ; Rockwell v. Bradshaw, 67 Conn. 9, 34 Atl. 758, 761.

2 Dial $v$. Gary, 14 S. C. 573, 37 Am. Rep. 737, 739 ; Graveley v. Graveley, 25 S. C. 1, 60 Am. Rep. 478, 482; Stevens $v$. Gaylord, 11 Mass. 256, 262 ; Merrill $v$. Ins. Co., 103 Mass. 245, 248, 4 Am. Rep. 548; Campbell $v$. Tousey, 7 Cow. (N. Y.) 64 ; Shultz v. Pulver, 3 Pai. Ch. (N. Y.) 182 ; s. c. 11 Wend. 361 ; Vroom v. Van Horne, 10 Pai. Ch. (N. Y.) 549, 556, 42 Am. Dec. 94 ; 
The primaryadminis is the appointed by the courts the decedent's domicil, and to him will ultimately be remitted all the funds of the decedent in other States, after administration there has been accomplished and the creditors there have been satisfied. ${ }^{3}$ In the meantime, however, these ancillary or auxiliary administrators are not to be considered as identical or in privity with the domiciliary administriator, but as independent of him. Hence, a judgment rendered against an administrator, and unsatisfied, will not be evidence of the claim against another administrator of the same decedent appointed in another State. ${ }^{4}$ But if a judgment is rendered in favor of one administrator, it will bar an action for the same claim brought by another administrator of the decedent in another State, at least if the debtor is a citizen of the latter State. ${ }^{5}$

The same general principles apply to administrators de bonis non, administrators with the will annexed, curators, etc., all of whom are appointed not by the decedent, but by the State itself, acting through its courts. ${ }^{6}$

So also the qualification of an administrator must take place in accordance with the law of the State where he is to act, and if the same party has been appointed in several States, he must qualify in each according to its laws. His proper qualification, by taking the prescribed oath and conforming to the regulations touching the giving of bond and security, is a very important safeguard afforded by the law to the creditors of the decedent's estate within the limits of each State. The notoriety afforded by the administrator's appointment and qualification in each

Parsons v. Lyman, 20 N. Y. 103 ; Smith v. Bank, 5 Pet. 518, 525 ; Wilkins v. Ellett, 9 Wall. 740,742 .

3 Post, § 113.

4 Johnson $v$. Powers, 139 U. S. 156, 159, 160 ; McLean v. Meek, 18 How. 16 ; Stacy v. Thrasher, 6 How. 44 ; Merrill v. Ins. Co., 103 Mass. 245, 249 ; Graveley v. Graveley, 25 S. C. 1, $60 \mathrm{Am}$. Rep. 478, 482. As to executors, seo Hill $v$. Tucker, 13 How. 458 ; post, § 107.

5 Stevens $v$. Gaylord, 11 Mass. 256, 265. See Talmage v. Chapel, 16 Mass. 71.

- Harvey $v$. Richards, 1 Mason, C. C. 380 ; Shannon v. White, 109 Mass. 146 ; Selectmen of Boston $v$. Boylston, 2 Mrass. 384. 
State is also a protection to third parties there. Fur these and other reasons of like kind it is now the established rule that an administrator, in order to act within any State, must qualify there, though he has already qualified elsewhere.

With respect to the qualification of foreign executors, the same principles apply. The executor, though he has qualified in the State of the testator's last domicil, must qualify anew in every State where he desires to act, or if action is desired in his absence an administrator with the will annexed must be appointed in his stead. Here also each State will insist that the safeguards of the interests of its own citizens shall be observed. ${ }^{8}$

But so far as relates to the appointment of the executor, it differs from that of an administrator in that the former is the act of the testator himself, and is therefore independent of jurisdiction or the locality of the property, while the latter is the act of the court of probate, and is not generally recognized outside of that court's jurisdiction. ${ }^{9}$ Important consequences may flow from this distinction under certain circumstances. Thus, it has been held in some States that a foreign executor, in the absence of statute, without a new qualification, nay deal with assets of the testator in any State as if he were a domestic executor, save ouly that he must qualify before he can sue or be sued as such, while an administrator appointed in one State can do no act in

7 See Flannery's Will, 24 Penn. St. 502 ; Dawes v. Head, 3 Pick. (Mass.) 128, 144; Ex parte Picquet, 5 Pick. (Mass.) 65 ; Fay $v$. Haven, 3 Met. (Mass.) 109, 116 ; Sheldon v. Rice, 30 Mich. 296, 18 Am. Rep. 136 ; Dial v. Gary, 14 S. C. 573, 37 Am. Rep. 737 ; Morrell v. Dickey, 1 Johns. Ch. (N. Y.) 153 ; Petersen v. Chemical Bank, 32 N. Y. 21, 42-43, 88 Am. Dec. 298 ; Vaughn v. Northup, 15 Pet. 1 ; Johnson v. Powers, 139 U. S. 156.

8 Armstrong $v$. Lear, 12 Wheat. 169 ; Dial $v$. Gary, 14 S. C. 573, $37 \mathrm{Am}$. Rep. 737, 739 ; Campbell $v$. Tousey, 7 Cow. (N. Y.) 64 ; Vroom $v$. Van Horne, 10 Pai. Ch. (N. Y.) 549, 555, 42 Am. Dec. 94 ; Petersen v. Chemical Bank, 32 N. Y. 21, 45, 88 Am. Dec. 298; Fay $v$. Haven, 3 Met. (Mass.) 109; Richards $v$. Dutch, 8 Mass. 506 ; Jennison v. Hapgood, 10 Pick. (Mass.) 77, 19 Am. Dec. 258 ; Welch $v$. Adams, 152 Mass. 74, 25 N. E. 34.

9 Vroom v. Van Horne, 10 Pai. Ch. (N. Y.) 549, 555-556, 42 Am. Dec. 94; Dial v. Gary, 14 S. C. 573, 37 Am. Rep. 737, 739; Hill v. Tucker, 13 How. 458. 
another until he has been reappointed there. ${ }^{10}$ But other courts make no distinction between foreign executors and administrators in this respect, requiring new letters of administration in each State before any act can be done there. The latter would seem to be the sounder view. ${ }^{11}$

\section{$\S 106$. Incidents of Status of Personal Representatives -} Their Rights and Liabilities in general. - As a general rule, the powers and rights of an executor or administrator, as well as his liabilities and duties, are confined to the State where he is appointed and qualifies as such, and do not extend to other States or countries where assets of the decedent are situated, unless he also qualifies there according to the law of the latter place (lex situs et fori). ${ }^{1}$

Thus an administrator, appointed in one State, cannot sell or possess himself by legal process of any assets of his intestate in another State, without appointment there also. Any such action on his part is tortious, and he may be held responsible therefor in the latter State as executor de son tort or otherwise. ${ }^{2}$ Nor can he convey a valid title to chattels situated in a State where

10 See Harper v. Butler, 2 Pet. 239 ; Rand $v$. Hubbard, 4 Met. (Mass.) 252 ; Merrill v. Ins. Co., 103 Mass. 245, 248 ; Vroom v. Van Horne, 10 Pai. Ch. (N. Y.) 549, 555, 42 Am. Dec. 9 ; Campbell v. Tousey, 7 Cow. (N. Y.) 64 ; Vermilya $v$. Beatty, 6 Barb. (N. Y.) 429 ; Petersen $v$. Chemical Bank, 32 N. Y. 21, 43, 88 Am. Dec. 298.

11 See Graveley $v$. Graveley, 25 S. C. 1, 60 Am. Rep. 478, 482 ; Glenn $v$. Smith, 2 Gill \& J. (Md.) 493, 20 Am. Dec. 452, 455; Packwood's Succession, 9 Rob. (La.) 438, 41 Am. Dec. 341, 344. See Dial v. Gary, 14 S. C. 573, 37 Am. Rep. 737, 739 ; post, § 124.

1 Vaughn $v$. Northup, 15 Pet. 1 ; Dial v. Gary, 14 S. C. 573, 37 Am. Rep. 737 ; Graveley $v$. Graveley, 25 S. C. 1, 60 Am. Rep. 478, 482 ; Cutter $v$. Davenport, 1 Pick. (Mass.) 81 ; Sheldon $v$. Rice, 30 Mich. 296, 18 Am. Rep. 136; Flannery's Will, 24 Penn. St. 502 ; Morrell v. Dickey, 1 Johns. Ch. (N. Y.) 153 ; Packwood's Succession, 9 Rob. (La.) 438, 41 Am. Dec. 341, 344. According to the better opinion, the distinction between the modes of appointment of executor and administrator does not create any difference in the law controlling their rights and obligations in the administration of the estate. See ante, $\$ 105$.

2 Glenn v. Smith, 2 Gill \& J. (Md.) 493, 20 Am. Dec. 452, 455; Camp. bell v. Tousey, 7 Cow. (N. Y.) 64. See Andrews $v$. Avory, 14 Gratt. (Va.) 229. 
he has not been appointed administrator; ${ }^{3}$ nor (it is said) can he validly release a foreign debtor of his decedent. ${ }^{4}$

But with respect to the assets situated, or even transiently found, in the State of his appointment, he can convey a title to them, which will be upheld everywhere. ${ }^{5}$

If the goods are situated in the State of appointment and are afterwards removed by the administrator to another State, it is said that he may administer them, and be held liable to creditors and others, in the latter State without a new appointment there. ${ }^{\circ}$ But if he should thus be held responsible, it seems that the nature and extent of his liability would depend upon the laws of the State or country from which he derived his authority to administer the decedent's assets, not upon the law of the State whither he has removed. ${ }^{7}$

If an executor or administrator, without a new appointment, goes into a foreign State, collecting assets there and bringing them back into the State of his appointment, they are to be deemed home assets, and are to be administered and accounted for as such, at least if there are no creditors or claimants resident in the State from which the assets have been withdrawn. ${ }^{8}$

8 Glenn $v$. Smith, 2 Gill \& J. (Md.) 493, 20 Am. Dec. 452, 455; Dial $v$. Gary, 14 S. O. 573, 37 Am. Rep. 737 ; Burbank v. Payne, 17 La. Ann. 15, 87 Am. Dec. 513, 515-516. See Russell v. Hooker, 67 Conn. 24, 34 Atl. 711, 712.

4 Vaughn v. Barret, 5 Vt. 333, 26 Am. Dec. 306. This proposition is open to doubt. The case is closely analogous to that of a voluntary payment by a debtor to a foreign representative, which it is generally conceded is a satisfaction of the debt. Post, § 109. See also note to Vaughn v. Barret, 26 Am. Dec. 306.

5 Petersen v. Chemical Bank, 32 N. Y. 21, 43, 88 Am. Dec. 298; Dial v. Gary, 14 S. C. 573, 37 Am. Rep. 737, 740 ; Merrill v. Ins. Co., 103 Mass. $245,248$.

6 Gulick v. Gulick, 33 Barb. (N. Y.) 92 ; McNamara v. Dwyer, 7 Pai. Ch. (N. Y.) 239, 32 Am. Dec. 627; Johnson v. Jackson, 56 Ga. 326, 21 Am. Rep. 285 ; Embry v. Millar, 1 A. K. Marsh. (Ky.) 300, 10 Am. Dec. 732. But see Fay $v$. Haven, 3 Met. (Mass.) 109, 115-116 ; Jackson $v$. Johnson, 34 Ga. 511, 89 Am. Dec. 263, 268 ; Hedenberg $v$. Hedenberg, 46 Conn. 30, 33 Am. Rep. 10; Tunstall $v$. Pollard, 11 Leigh (Va.), 1.

7 MeNamara v. Dwyer, 7 Pai. Ch. (N. Y.) 239, 32 Am. Dec. 627 ; Evans v. Tatem, 9 Serg. \& R. (Penn.) 252, 11 Am. Dec. 717, 718.

8 Evans $v$. Tatem, 9 Serg. \& R. (Penn.) 252, 259, 11 Am. Dec. 717 ; Andrews $\varepsilon$. Arory, 14 Gratt. (Va.) 229. 
It may be added that it is the duty of an administrator, who has obtained the legal control of notes payable to his intestate, to take the necessary steps to collect them of the debtor under the laws of the debtor's domicil (that is, he should qualify there himself or by agent, and sue the debtor). Otherwise he will be held answerable as for assets received in the State of his appointment. ${ }^{9}$

When the assets consist of choses in action, the question may arise - where is their situs ? - in cases where the creditor and debtor reside in different States. If the choses in action should be held to be located at the domicil of the creditor, upon principles above adverted to the administrator of the creditor there appointed may pass a good title to them which will be recognized everywhere. On the other hand, if the situs of the chose in action is to be deemed the domicil of the debtor, the creditor's administrator appointed in the creditor's domicil will have no power to convey a good title, without having been appointed also in the State where the debt is located. This is one phase of the difficult question of the "situs of debt," and will be considered at large under that head hereafter. ${ }^{10}$

The executor at common law has no control, as such, over the decedent's land at home or abroad. In those cases where he is given the power to sell or control the real estate, he acts as trustee under the will, not as executor. But even as trustee appointed and qualified in one State, he will not be permitted to make title to lands situated in another, without proof of the genuineness and vatidity of his authorization in the latter State. He must probate the will and qualify as executor under the laws of the situs of the land. ${ }^{11}$

Independently of statute, the administrator, being the appointee of the court, not of the decedent, has no authority what.

9 Shultz v. Pulver, 11 Wend. (N. Y.) 361.

10 Petersen $v$. Chemical Bank, 32 N. Y. 21, 43, 88 Am. Dec. 298 ; Dial $v$. Gary, 14 S. C. 573, 37 Am. Rep. 737, 740. See Wilkins $v$. Ellett, 108 U. S. 256,259 . The first of these cases supports the first view, while the second advocates the other view. Probably both are partly right and partly wrong. See post, $\S 121,124$.

11 Williams v. Mans, 6 Watts (Penn.), 278; Bingham's Appeal, 64 Penn. St. 345 ; Whart. Confl. L. $\$ 289$. 
ever to deal with the lands of his intestate. But by statute iu some States such an authority is granted him. In these cases also the rule is strictly applied that the lex situs is to govern the conveyance of the land, and hence, if the lex situs does not permit the administrator to deal with land, a deed by a foreign administrator will not be given effect merely because the law of the State of his appointment gives him control over such property. ${ }^{12}$ On the other hand, if the lex situs permits an administrator to control realty, it meaus an administrator appointed by the courts of the situs. A foreign administrator can convey no title to land. ${ }^{13}$

When a foreign executor or administrator has qualified in another State than that of his original appointment, he may do all acts in connection with the property there situated (and none others) which are permitted to home executors or administrators under the lex situs et fori. Thus, an executor of one dying domiciled abroad, who has duly qualified in England, has been allowed to sell leasehold property in England, though not permitted to do so by the law of the decedent's last domicil. ${ }^{14}$

$\S 107$. Suits by and against Personal Representatives. In accordance with principles already adverted to, it is the general doctrine both in England and America that no suit can be brought by or against an executor or administrator in his official capacity in the courts of any country save that from which he has derived an authority to act by virtue of the letters of probate or of administration there granted him.

Should he desire to institute a suit in a foreign country, he must first obtain new letters and qualify there anew in accordance with the rules there prescribed. ${ }^{1}$ But if the executor or

12 Watkins $v$. Holman, 16 Pet. 26.

13 Cutter v. Davenport, 1 Pick. (Mass.) 81, 11 Am. Dec. 149 ; Sheldon v. Rice, 30 Mich. 296, 18 Am. Rep. 136.

14 Hood v. Barrington, L. R. 6 Eq. 218.

1 See Kerr v. Moon, 9 Wheat. 565; Vaughn v. Northup, 15 Pet. 1 ; Smith $v$. Bank, 5 Pet. 518, 527 ; Johnson $v$. Powers, 139 U. S. 156 ; Cutter $v$. Daven. port, 1 Pick. (Mass.) 81, 85-86, 11 Am. Dec. 149 ; Ex parte Picquet, 5 Pick. (Mass.) 65 ; Goodwin $v$. Jones, 3 Mass. 514, 3 Am. Dec. 173 ; Merrill v. Ins. Co., 103 Mass. 245, 248; Judy $v$. Kelley, 11 Ill. 211, 50 Am. Dec. 455 ; McNamara v. Dwyer, 7 Pai. Ch. (N. Y.) 239, 32 Am. Dec. 627 ; Vroom v. Van 
administrator has already obtained a judgment in the State of his appointment, he may bring an action upon such judgment in another State without a new qualification there, for he is then responsible to the estate as if the debt had been collected, and thus the judgment becomes his own property upon which he may sue in his own right. ${ }^{2}$

If a creditor of a decedent wishes to sue in a foreign State to reach assets situated there, he must have letters of administration taken out there, before the suit can be instituted. He cannot in general sue a domestic administrator in a foreign court or a foreign administrator in a domestic court. ${ }^{8}$

If an administrator, appointed in one State, removes with the assets of the estate into another State, the courts are divided upon the question whether or not the decedent's creditors may sue the administrator in the latter State without a reappointment, the weight of authority seeming to favor the right of the creditors to sue. ${ }^{4}$ But if the administrator should only come into the State transiently or temporarily, the better opinion would seem to be that no action will lie against him there without a new appointment. ${ }^{5}$

It should be observed that if the creditor desires to subject the land of the decedent, instead of suing his personal representa-

Horne, 10 Pai. Ch. 549, 42 Am. Dec. 94; Petersen v. Chemical Bank, 32 N. Y. 21, 40-41, 88 Am. Dec. 298.

2 Talmage v. Chapel, 16 Mass. 71, 73 ; Lewis v. Adams, 70 Cal. 403, 59 Am. Rep. 423. See Moore v. Jordan, $36 \mathrm{Kan} .271,59$ Am. Rep. 550 ; Hall $v$. Harrison, 21 Mo. 227, 64 Am. Dec. 225, 228.

8 Story, Confl. L. $\S 513$; Vaughn $v$. Northup, 15 Pet. 1; Reynolds $v$. Stockton, 140 U. S. 255 ; Vermilya $v$. Beatty, 6 Barb. (N. Y.) 429 ; Richards v. Dutch, 8 Mass. 506 ; Hooker v. Olmstead, 6 Pick. (Mass.) 481.

4 Erans v. Tatem, 9 Serg. \& R. (Penn.) 252, 11 Am. Dec. 717, 718; Atchison v. Lindsey, 6 B. Mon. (Ky.) 86, 43 Am. Dec. 153; Embry v. Millar, 1 A. K. Marsh. (Ky.) 300, 10 Am. Dec. 732; Johnson v. Jackson, 56 Ga. 326, 21 Am. Rep. 285; Gulick v. Gulick, 33 Barb. (N. Y.) 92; McNamara $v$ Dwyer, 7 Pai. Ch. (N. Y.) 239, 32 Am. Dec. 627. But see Fay v. Haven, 3 Met. (Mass.) 109, 115-116 ; Hedenberg $v$. Hedenberg, 46 Conn. 30,33 Am. Rep. 10 ; Jackson v. Johnson, 34 Ga. 511, 89 Am. Dec. 263, 268.

5 Evans v. Tatem, 9 Serg. \& R. (Penn.) 252, 11 Am. Dec. 717, 719. Seo Jackson v. Johnson, 34 Ga. 511, 89 Am. Dec. 263 ; Johnson v. Jackson, 56 Ga. 326, 21 Am. Rep. 285. 
tive, his rights against the real estate are, in accordance with the general rule, to be determined by the lex situs of the land. ${ }^{\circ}$

If there are two or more administrators of a decedent, appointed in different States, there is no privity between them, and hence no action will lie against one of them, upon a judgment obtained against another in the State of his appointment, at least so far as concerns assets received by the former in the course of his own administration and not remitted to him by the admistrator against whom the judgment is obtained.7 Upon the same principle, a judgment against an administrator of the deceased in one State will not be received in another in a suit brought by the same plaintiff against third persons, citizens of the latter State, having assets of the deceased, real or personal, in their possession. ${ }^{8}$

But with respect to executors the rule is different. The interest of an administrator in his intestate's estate is only that which the law of the State of his appointment authorizes, while the interest of an executor in the estate of his testator is that which the testator gives him. Hence where there are several executors, though citizens of, and qualifying in, different States, they are in privity as to the debts of the testator, all bearing towards the creditors the same responsibility as if there were only one executor. It follows therefore, in such case, that a judgment obtained against one executor in one State will be evidence in apother execuior of the same testator in another State.

The same distinctions run through the cases where judgments are obtained by administrators and executors instead of against them. An administrator cannot sue upon a judgment obtained in another State by another administrator of the same

6 See Story, Confl. L. $§ 489$ b.

7 Stacy v. Thrasher, 6 How. 44, 58; McLean v. Meek, 18 How. 16, 18 ; Merrill v. Ins. Co., 103 Mass. 245, 249.

8 Johnson $v$. Powers, 139 U. S. 156, 160. The "full faith and credit" clause of the federal constitution does not affect these principles, as between the several States of the Union. Stacy $v$. Thrasher, 6 How. 44, 59.

- Hill v. Tucker, 13 How. 458, 466, 467. 
intestate. $^{10}$ The doctrine is believed to be otherwise with respect to executors.

In conclusion, notwithstanding the general rule that administrators and executors must qualify in a State before they can sue or be sued there, if the representative misapplies the funds in his hands in a State where he has not qualified, it must be observed that the courts of equity of that State may assume jurisdiction of a suit against him instituted by persons injured by the misapplication. In such cases the administrator or executor is sued in his personal, not his representative, capacity, and the suit may be brought in any court having jurisdiction of his person and of his fraud. ${ }^{11}$ But the nature and extent of his liability is still to be fixed by the law of the country whence he derived his powers and authority. ${ }^{12}$

$\S 108$. Right of Foreign Representative to Sue for Decedent's Death by Wrongful Act. - The reader will recall the common law rule that "personal actions die with the person." This rule has been altered by statute in England and in most of these States, so as to permit suit to be instituted for the tortious killing of a person. But the various statutes differ greatly in detail, and perhaps upon no point more than as to who shall be authorized to sue in such cases. Some of the statutes provide that the suit shall be brought by the personal representative of the deceased for the benefit of his or her consort, children, family, or next of kin (exclusive of creditors), or for the benefit of his general estate; other statutes give the right to sue only to the consort or children; others to the next of kin, etc. If a foreign element enters into the transaction, such as that the death occurs in one State while the action therefor is brought in another, questions of considerable difficulty sometimes arise.

The main discussion of this subject, a fruitful source of conflicts of laws as well as of decisions, will be postponed to a

10 Talmage v. Chapel, 16 Mass. 71, 73. See ante, $\S 105$.

11 Montalvan $v$. Clover, 32 Barb. (N. Y.) 190, 192-193; McNamara $v$. Dwyer, 7 Pai. Ch. (N. Y.) 239, 32 Am. Dec. 627; Leach v. Buckner, 19 W. Va. 36.

12 McNamara v. Dwyer, 7 Pai. Ch. (N. Y.) 239, 32 Am. Dec. 627. 
later period, when the proper law governing torts in general will be examined. ${ }^{1}$ We shall here consider the subject only as it relates to the right of the personal representative to bring such an action. A few general principles however must be premised, for the substantiation of which the reader is referred to the subsequent fuller discussion already alluded to.

The general rule is that the law of the place where the tort resulting in death is committed (lex loci dettcit) wall determine whether an action can be brought therefor, and the parts who is to bring it, as well as the time within which the suit is to be brought, the limit of damages, and the persons for whose benefit the damages are to be given. These rights are the creatures of statute, and the lex loci delicti must be strictly followed. The only qualification is that the lex delicti will not be enforced in other States whose laws or policy would be thereby seriously violated. ${ }^{2}$

In general, therefore, if the lex loci delicti gives the administrator or executor of the decedent the right to sue in such cases, he and he alone will have the right to sue in a foreign State, though the lex fori gives that right to some person other than the representative, for instance, the widow, the heirs, etc. ${ }^{3}$ But the statutes give this right to the representative in his official capacity, not as a personal right. It is only as the duly qualified executor or administrator of the decedent that he can sue for the latter's death. This much is generally conceded, and at this point the difficulties of the subject begin.

As we have seen, in order that the authority of a representative may be recognized in other States, the general principle is that he must qualify in each State where he desires to act or to sue; and on the other hand, if he has qualified in the State where he desires to act or to sue, he need not qualify elsewhere. ${ }^{4}$

But this principle cannot perhaps be accepted so freely in

1 See post, §§ 200-202.

2 Post, §§ 200-202.

3 Usher v. R. R. Co., 126 Penn. St. 207, 17 Atl. 597 ; Wooden v. R. R. Con 126 N. Y. 10. But see Stewart v. R. R. Co., 168 U. S. 445.

4 Ante, $\$ 105$ et seq. 
these cases of death by wrongful act. Since the lex delicti determines who is to sue, and since we have supposed that law to confer the right upon the personal representative of the deceased, must this not be the personal representative appointed by the lex loci delicti itself? Could the legislature of the locus delicti have had in mind representatives appointed or qualifying abroad? If not, since the lex delicti is to be strictly followed, can any person other than the one named by the statute of the locus delicti sue for the tort committed there, even though the action be instituted in another State? Will it be necessary for the representative, having qualified in the locus delicti, to qualify anew in the State of the forum before instituting his action? Or is it needful for a representative, who has qualified in the forum, to have also qualified in the locus delicti in order that he may sue for the death in the forum? If required to qualify in the State of the forum, can he qualify there if there is no property of the deceased located there? Can the representative's right to sue for his decedent's death be regarded as property belonging to the decedent?

These are some of the questions that present themselves in the solution of this problem, and it must be confessed that the answers are rather dimly shadowed in the decisions of the courts. The adjudged cases present many conflicts of opinion and sometimes confusion of thought, so that it is hardly possible to formulate a general rule that can be safely followed in all cases.

In the leading case of Dennick $v . \mathrm{R} . \mathrm{R}$. Co. ${ }^{5}$ the question was squarely presented whether it is the representative of the locus delicti or the representative of the forum who should bring the action. In that case, the death by wrongful act occurred in New Jersey, and the action therefor was instituted in New York, by a New York administrator, the laws of both States conferring upon the personal representative the right to sue. It was contended that the New Jersey statute included only personal representatives there appointed, and that it did not contemplate conferring the right upon foreign representatives. But the Su-

b 103 U. S. 11. The doctrine of this case has since been followed and ex. tended in Stewart v. R. R. Co., 168 U. S. 445. 
preme Court of the United States took the opposite view and sustained the right of the New York administrator to sue in the courts of New York. This case (and those succeeding it) must probably be taken as settling the first questions above mentioned, at least in those cases where both the lex delicti and the lex fori give the representative the right to sue. ${ }^{6}$

It must be admitted that the weight of recent authority, whether or not it can be entirely justified in principle, is in favor of the right of the personal representative of the forum to sue (though he has not been appointed in the locus delicti) wherever the lex delicti confers that right upon "the personal representative" of the deceased, though the dead man has no property in the forum, and the only purpose of the appointment of the administrator is to sue for the damages for his death. ${ }^{7}$

The fact that the lex fori permits the administrator to sue is immaterial, if the lex loci delicti gives the power to another, as the widow, children, heirs, etc. The last named persons are then

6 And the later case of Stewart v. R. R. Co., 168 U. S. 445, carries this doctrine still further, laying down the proposition that an administrator appointed in the State of the forum, whose law confers upon him the right to sue for the death of his decedent, may sue there for such death occurring in another jurisdiction, whose law does not give the right to sue to the personal representative of the deceased, but to the State for the benefit of the dead man's family.

7 See Mo. Pac. R. R. Co. v. Lewris, 24 Neb. 848, 40 N. W. 401 ; Leonard $v$. Nav. Co., 84 N. Y. 48, 38 Am. Rep. 491; Burns v. R. R. Co., 113 Ind. 169, 15 N. E. 230 ; Morris v. R. R. Co., 65 Ia. 727, 23 N. W. 143 ; Nelson v. R. R. Co., 88 Va. 971,14 S. E. 838 . In Limekiller v. R. R. Co., 33 Kan. 83,52 Am. Rep. 523, an administrator appointed in Missouri sued in Kansas for the death of his intestate occurring in Kansas. The Kansas statute authorized "the personal representative" to sue in such cases, but the Missonri statute did not. It was held that the action would not lie. If the Missouri statute had authorized the representative to sue, it would still be exceedingly doubtful whether the representative of the locus delicti would have been permitted to sue in the forum withont a new appointment there. See Perry $v$. R. R. Co., 29 Kan. 420 ; Kansas Pac. R. R. Co. v. Cutter, 16 Kan. 568. Some of the earlier cases have refused on one ground or another to permit the representative of the forum to sue. Vawter v. R. R. Co., 84 Mo. 679, 54 Am. Rep. 105; Ash v. R. R. Co., 72 Md. 144, 19 Atl. 643; Richardson v. R. R. Co., 98 Mass. 85; Taylor $v$. Penn. Co., 78 Ky. 348, 39 Am. Rep. 244. But see Bruce v. R. R. Co., 83 Ky. 174. 
the proper plaintiffs wherever the forum may be. ${ }^{8}$ Thus, in a leading New York case, Wooden v. R. R. Co., ${ }^{9}$ the death occurred in Pennsylvania, whose law authorized the widow to sue, and suit was brought by the widow in New York, whose law required suit to be brought by the executor or administrator. It was held that the widow was entitled to sue in New York, without being appointed administrator there.

The very converse of this case was decided in Usher $v . R$. R. Co. ${ }^{10}$ The New Jersey statute provided that the personal representative should sue for death by wrongful act. The Pennsylvania statute called for suit by the widow. Upon a death occurring in New Jersey, the widow sued in Pennsylvania, without appointment as administrator. It was held that the suit could not be maintained.

\$109. Voluntary Payment of Debts to Foreign Representative. - In England it is held that, since the administrator has no authority to act outside of the jurisdiction from which his powers are derived, the payment of a debt to a foreign administrator will be no bar to a suit by an ancillary administrator in the debtor's domicil, unless the debt be made payable in the country of such foreign administrator. ${ }^{1}$

But in the United States the general rule is that if there is no need of an ancillary administration in the domicil of the debtor, and if the foreign administrator may lawfully receive the payment under the laws of his appointment, a payment to him in another State will operate as a discharge of the debt. ${ }^{2}$ Not only is such a payment, though made to a foreign executor or administrator, a discharge of the debt, so far as the debtor is

8 But if the plaintiff named by the lex delicti is merely a nominal plaintiff, - as the State itself, - the party named by the lex fori, it seems, may bring the suit. Stewart $v$. R. R. Co., 168 U. S. 445.

9126 N. Y. 10.

10126 Penn. St. 207, 17 Atl. 597.

1 Preston $v$. Melville, 8 Cl. \& F. (H. L.) 12 , 14.

2 Doolittle v. Lewis, 7 Johns. Ch. (N. Y.) 45, 11 Am. Dec. 389, 392; Williams $v$. Storrs, 6 Johns. Ch. (N. Y.) 353, 10 Am. Dec. 340, 341-342 ; Dial v. Gary, 14 S. C. 573,37 Am. Rep. 737, 741-742 ; Hall v. Harrison, 21 Mo. 227, 64 Am. Dec. 225, 227; Wilkins v. Ellett, 9 Wall. 740 ; s. c. 108 U. S. 256 ; Mackey v. Coxe, 18 How. 100. 
concerned, but it also operates to charge the fiduciary with the same. He may even be charged as executor de son tort in the State where the payment was made, at the instance of creditors there. ${ }^{2}$ And if no attempt is made there to hold him answerable, he will at least be accountable therefor in the State of his appointment. ${ }^{4}$

$\S 110$. Order of Payment of Decedent's Debts - Marshalling of Assets. - In some countries, all debts are of equal rank in the settlement of a decedent's estate, and are to be paid pari passu. In other countries, certain debts are privileged and take priority over others, and the laws of such countries will differ among themselves as to the debts which shall be privileged.

In general, the lex fori, which, if property is sought to be subjected, will also be the lex situs, will govern the order in which creditors are to be paid. This is essentially a question of administration, to be controlled by the local law. Creditors attempting to subject property in the decedent's domicil will be governed as to their relative priorities by the law of the domicil, for that is the forum and situs of the fund to be distributed. If an ancillary administrator is to pay the debts, then their order will be determined by the law of the State where he is administering the fund (the situs and forum), not by that of the decedent's domicil. ${ }^{1}$

Thus in Smith $v$. Bank, ${ }^{2} \mathrm{R}$ was domiciled in Norfolk, Va.,

3 Campbell v. Tousey, 7 Cow. (N. Y.) 64 ; Glenn v. Smith, 2 Gill \& J. (Md.) 493, 20 Am. Dec. 452, 455 ; Story, Confl. L. § 514.

4 Parsons $v$. Lyman, 20 N. Y. 103 ; Fay $v$. Haven, 3 Met. (Mass.) 109, 115, 116. See Story, Confl. L. $\$ 514 a$.

1 Story, Confl. L. §§ 524, 525; Whart. Confl. L. § 624 ; Harrison v. Sterry, 5 Cr. 289; Smith v. Bank, 5 Pet. 518, 526-527; Dawes v. Head, 3 Pick. (Mass.) 128 ; Miller's Estate, 3 Rawle (Penn.), 312, 24 Am. Dec. 345, 350 ; De Sobry v. De Laistre, 2 Harr. \& J. (Md.) 191, 3 Am. Dec. 535, 542; Holmes $v$. Remsen, 20 Johns. (N. Y.) 229, 11 Am. Dec. 269, 280 ; Derringer $v$. Derringer, 5 Hons. (Del.) 416, $1 \mathrm{Am}$. St. Rep. 150. The same principle is applicable even to judgments rendered in a State other than that of adminis. tration, and that, too, despite the "full faith and credit" clause of the federal constitution. MeElmoyle v. Cohen, 13 Pet. 312.

25 Pet. 518. 
and there contracted a debt on bond to T. He was also indebted to the Union Bank of Georgetown, D. C., or simple contract. He died intestate, leaving personalty in Washington, of which administration was there granted. By the law governing the District of Columbia, all debts were of equal dignity in administration, but by the law of Virginia, where $\mathrm{R}$ was domiciled, debts on bond were preferred. The assets in the hands of the administrator were insufficient to discharge both debts. It was held that the law of the District (the situs and forum) should prevail, and that the two claimants should share pari passu. In the course of its opinion the court said: "Every sovereign has his own code of administration, varying to infinity as to the order of paying debts; and almost without exception asserting the right to be himself first paid out of the assets. And the obligation in the administrator to conform to such laws is very generally enforced, not only by a bond but on oath. On what principle shall we insert into all those laws an amendment in favor of foreign creditors?"

The same principles govern the marshalling of the decedent's assets (that is, the arrangement of them in such a way as to make them go as far as possible towards the payment of all his debts and charges).

The rules regulating this subject, in common with all the other incidents attending the administration of a decedent's estate, are those prescribed by the law of the place where the assets administered are situated (lex fori et situs). ${ }^{2}$ But no attempt should ever be made by a court, in the course of administration, to marshal assets in whole or in part outside of its jurisdiction. The injustice which may result from such a course (leaving out of consideration the court's lack of jurisdiction in the premises) is most forcibly illustrated by the case of Rice $v$. Harbeson. ${ }^{4}$

S Story, Confl. L. $\S 524$. See Harvey $v$. Richards, I Mason, C. C. 380 , 422.

463 N. Y. 493 . In that case, M, an Irishman domiciled in New York, died there possessed of personalty in New York, and also of certain land in South Carolina, upon which he had placed a mortgage. By his will he left all his property, after payment of his debts, to be divided into seven shares, 
Pari ratione, the lex fori et situs will determine the nature of the assets there situated, as whether they are to be deemed real or personal, legal or equitable. Indeed this is in the main but an application of a familiar rule, presently to be discussed, that the lex fori controls matters of procedure, pertaining merely to the remedy. ${ }^{5}$

\section{\$ 111. Right of Creditor to Subject Decedent's Land in} Hands of the Eeir. - Questions of this character, though not

one to go to the children of his deceased sister, $J$, and the other six shares to go to other relatives, all of whom except the children of $J$ were aliens. The will was probated in New York as a will of personalty and realty, but was void in South Carolina as a will of lands, because the South Carolina law required three witnesses to such wills, there being only two in this case. Moreover, the low of South Carolina not permitting aliens to inherit land, all the relatives of $\mathbf{M}$ were cut off from inheriting the South Carolina land as heirs, except the children of J. They therefore brought suit against the executor to recover the land as the sole heirs of M. The South Carolina court gave judgment for J's children, and ordered the executor to pay the mortgage out of M's personal estate (which was in New York). Upon a final accounting by the executor in New York, the mortgagee presented his claim, which was allowed by the surrogate and ordered to be paid out of the personal estate. This was reversed by the General Term, and its decision was confirmed by the Court of Appeals, upon the ground that the testator intended that his whole estate should bear the burden of his debts, not the personalty only, which latter view would deprive the foreign legatees of their portions, since they were cut out of all participation in the South Carolina land. The New York court therefore decreed that the assets should be marshalled, and that the mortgagee, having two funds for his security, must select that one which would least impair the testator's intent. The result was, that, while protecting the foreign legatees, the court deprived the mortgagee by its action of all recourse, notwithstanding the established principle that the marshalling of assets, as well as exoneration, is subsidiary to the payment of debts, which is the first of all the duties of administration.

The mere statement of this conclusion suffices to show that either the South Carolina or the New York court was guilty of error.

It is respectfully submitted that both courts acted in part beyond their jurisdiction. The South Carolina court had no authority to decree exoneration of South Carolina land out of New York personalty, and the New York court had no authority to marshal assets which were in South Carolina and outside its own jurisdiction. It could lawfully enforce the testator's intention only so far as the property in New York was concerned.

5 Post, §§ 205-207. See Dickinson v. Hoomes, 8 Gratt. (Va.) 353, 410; post, $\S 111$. 
strictly a part of the administration of a decedent's estate, are so closely connected with it that they may very appropriately be discussed in this connection.

It is the better opinion that the rights of a creditor against a decedent's land are to be determined by the lex situs of the land sought to be subjected, or in respect to which the right is claimed, not by the law of the place of contract, nor by the lex domicilii of the decedent or creditor.

The very question whether a party claiming the right to subject the decedent's land is a creditor at all, so far as the realty is concerned, is to be determined by the lex situs of the land. Thus, in a Kentucky case, ${ }^{1}$ an Ohio probate court, under the law of that State, gave a widow an allowance of $\$ 4,000$ for her support for one year, declaring it a lien on her deceased husband's lands. Upon her seeking to enforce the lien so created upon some of her husband's land in Kentucky, the court held that, according to Kentucky law (the lex situs), the allowance was not a debt of the estate, and would not be enforced there against the lands in the hands of the heir.

In Dickinson $v$. Hoomes, ${ }^{2}$ land in Virginia had been conveyed with a covenant of general warranty on the part of the grantors and their heirs. Subsequently the heirs set up title to the land under a prior will, and sued to recover part thereof from an assignee of the original grantee. The defendant set up by way of rebutter certain lands in Kentucky descended upon the plaintiffs from their ancestor, the grantor. It was held that the question whether or not the Kentucky lands were assets for the payment of what might be due upon breach of the covenant, was to be determined in accordance with the law of Kentucky (lex situs).

Conflicts too sometimes arise between the lex domicilii of a deceased debtor, or the lex loci contractus of a debt or contract, and the lex situs of the decedent's lands, as to whether certain lands are to be applied to the payment of his debts before others; or where by one law the heirs are liable to the ancestor's debts in proportion to their shares only, while by the other

1 Short v. Galway, $83 \mathrm{Ky} .501$.

28 Gratt. (Va.) 353, 410. 
each heir is liable for the whole debt to the extent of the land descended upon him. In all such cases, it would seem that the lex situs of the particular land in question should govern, since the question is one of charging the land with the debt. All liens, transfers, and charges upon real estate, it is believed, are governed by the lex situs of the land. ${ }^{8}$

$\S 112$. Exoneration of Realty out of Personalty, and vice versa - Contribution between Heirs or Devisees. - Cases sometimes occur in which a decedent dies, possessed of lands in one country and personalty in another, the heirs or devisees succeeding to the land and the personal representative to the personalty. The laws of one of these countries may make the personalty primarily liable for certain debts, while the laws of the other may make the land primarily liable for them.

If under these circumstances the creditors of the decedent subject his lands in one State (in the hands of his devisees or heirs), perplexing questions will arise as to the right of the heirs or devisees to exoneration and reimbursement out of the personalty situated in another State for the loss imposed upon

8 Whart. Confl. L. § 291 ; Story, Confl. L. $\$ \S 489 a, 489 b$; La Selle $v$. Woolery, 14 Wash. 70, 32 I. R. A. 75. But see Story, Confl. L. § 268 ; Brown v. Richardson, 1 Mart. N. s. (La.) 202. These last references relate to a case of a somewhat different character, where the question is not as to the manner in which the land shall be subjected, but whether it can be subjected to the decedent's debt at all. In Brown $v$. Richardson, supra, the decedent, owning lands in Louisiana, contracted a debt in another State by whose law (the common law) heirs were not bound by the simple contracts of their ancestor. By the law of Louisiana, the heirs were bound by such contracts. In a suit by the creditor in Louisiana to subject the lands in the hands of the heir, it was held that this pertained to the obligation of the contract, and was to be determined by the law governing the contract itself (lex loci contractus). This decision receives the approval of Judge Story ; but its soundness is doubtful, since a charge is thereby established upon the land, contrary to the lex situs. It is closely analogous to the case of the charge created by a married woman's contract upon her equitable separate estate in land, which, according to the better opinion, is governed by the lex situs, not by the lex loci contractus. La Selle $v$. Woolery, 14 Wash. 70, 32 L. R. A. 75 ; Wick $v$. Dawson, 42 W. Va. 43, 24 S. E. 587; Johnston v. Gawtry, 11 Mo. App. 322 ; Bank $v$. Williams, 46 Miss. 618, 12 Am. Rep. 319 ; Cochran v. Benton, 126 Ind. 58, 25 N. E. 870. But see Spearman v. Ward, 114 Penn. St. 634, 8 Atl. 430 ; Story, Confl. L. $\$ 267$. 
them ; and on the other hand, if the personalty is first subjected, a similar question will arise touching the rights of the parties succeeding thereto to exoneration out of the realty. ${ }^{1}$

Let us suppose, for instance, that A, domiciled in Virginia, mortgages land owned by him in Scotland, and dies possessed of the Scotch land and Virginia personalty. By the law of Virginia (lex domicilii) the personal estate is primarily bound to pay the mortgage debt, while under the Scotch law (we will suppose) land mortgaged is primarily liable to pay the mortgage. Under these circumstances, the heirs in Scotland pay off the mortgage and release the land. Are they entitled to relief in Virginia out of the decedent's personalty ? ${ }^{2}$

In solving this problem, and others similar to it, it must be observed first of all that the general creditors of the decedent are not interested; the decedent's debts have been paid, and it is purely a contest between the successors to the land and the successors to the personalty of the decedent, as to who shall ultimately bear the burden of the debt. But the very fact that one of the decedent's representatives is claiming exoneration out of the estate in the hands of the other constitutes the first a quasi-creditor of the latter estate, in equity, should his claim be valid.

An heir or devisee claiming exoneration out of the personalty cannot claim to be such a quasi-creditor of the personalty, unless the lex situs of the land makes the real estate only subsidiarily liable. ${ }^{8}$ In the latter event he can in that State doubtless claim exoneration out of the personalty, and should there be any personal estate actually situated there the courts of that country (the situs of the land) will probably administer

1 In such cases (all creditors being paid) the personalty of the decedent, wherever it may be actually situated, must be deemed in law to be situated at the domicil of the owner (the decedent). The law of his last domicil there. fore will furnish the law governing the primary liability of the personalty.

2 This case nearly resembles the case of Drummond $v$. Drummond, 6 Bro. P. C. 601, quoted by Sir William Grant in Brodie v. Barry, 2 Ves. \& B. 127, 132 ; infra, note 11.

3 Drummond $v$. Drummond, 6 Bro. P. C. 601, cited in Brodie $v$. Barry, 2 Ves. \& B. 127, 132 ; Elliott v. Lord Minto, 6 Madd. 16; Earl of Win ehelsea $v$. Garetty, 2 Keen, 293, 308-309. 
it in accordance with its own laws, whether or not the same right be given by the lex domicilii of the decedent. Here the situs of the realty is identical with the actual situs of the personalty, and the lex situs will prevail.

But if there should be no personalty in the situs of the land, or not enough to exonerate the heir or devisee, the two sorts of property may be subject to different laws. Yet if by the lex domicilii of the decedent, as well as by the lex situs of the land, the heir or devisee under such circumstances is entitled to exoneration out of the personal estate, the courts of the decedent's domicil, or of any third State where the personalty may be found, will recognize his statns as a quasi-creditor of the personalty created by the lex situs of the land, and exoneration will be decreed him. 4

If, however, the lex domicilii of the decedent does not recognize, under such circumstances, the heir's or devisee's right to exoneration, the mere fact that the lex situs of the realty gives him that right will not be sufficient. 5

In other words, the true rule would seem to be that both laws must concur in making it a case for exoneration, before exoneration will be decreed the heir or devisee out of the personalty (situated elsewhere than in the situs of the land).

The same result must also be reached in cases where the personalty is first subjected, and the successor to the personalty thereupon claims exoneration out of the realty situated elsowhere. If under the lex domicilii of the decedent and the lex situs of the land also the land is primarily responsible, exoneration will be decreed; but if by either law the personalty is primarily liable, it must bear the loss, and no exoneration will be permitted. ${ }^{6}$

$E$ converso, it was held in New York that if a debt of a decedent domiciled in New York is not permitted to be made out of land in South Carolina, because the personalty in New York is by the law of South Carolina primarily liable therefor, neither

4 Anonymous, 9 Mod. 66 ; Earl of Winchelsea v. Garetty, 2 Keen, 293.

5 Rice $v$. Harbeson, 63 N. Y. 493.

6 Earl of Winchelsea v. Garetty, 2 Keen, 293, 308-310. See Story, Confl. L. \$26fa. But see In re Hewit, 3 Ch. 568. 
can the debt be made out of the personalty in New York, which is there made subsidiarily liable only. The result was that the creditor lost his debt entirely. The mere mention of this consequence is to state that there must have been some error in the conclusion. ${ }^{7}$

Several illustrations may be given of the general principle regulating these cases; namely, that, in order for the doctrine of exoneration to apply, the lex situs of both the realty and the personalty must permit it.

In an English case, ${ }^{8}$ a testator domiciled in Holland owned land there and personalty in England. He devised all his real estate to one person and all his personalty to another, whom he appointed his executor. The testator owed some specialty debts and some simple contract debts to persons in Holland, to satisfy which he had no property in Holland but the land. By the laws of Holland, if decedent had no other assets, his land might be subjected to the payment of his debts, both by specialty and simple contract, and the land in Holland was subjected accordingly. The devisee then sued the executor and legate of the personalty in England for exoneration out of the personalty. The law of both countries made the personalty primarily responsible, and exoneration was accordingly decreed out of the English personalty. ${ }^{9}$

In Earl of Winchelsea $v$. Garetty, ${ }^{10}$ one domiciled in England and possessed of personalty there, owned real estate in

7 Rice $v$. Harbeson, 63 N. Y. 493. The facts of this case have already been given, and what is believed to have been the error of the court pointed out. Ante, $\S 110$, note 4 . It is to be observed that this case was not strictly one of exoneration. The question there did not arise between the successors to the land and the successors to the personalty, but the creditor was a party. It was he who bore the loss.

8 Anonymous, 9 Mod. 66.

9 In this case, it is to be noted that the domicil of the testator was in Holland, where the land was situated. The legal situs of the personalty was therefore in Holland also, except for purposes of administration. It is probable that even if the law of England had not made the personalty ultimately liable for the debts, the law of Holland would have prevailed, at least unless the legatee of the personalty were domiciled in England.

102 Keen. 293. 308-310. 
Scotland. He contracted certain debts and died. The cred. itors went against the land in Scotland and subjected it, and the heirs sought exoneration out of the English personalty. The Scotch law distinguished between "heritable bonds" and "movable debts," making the former primarily chargeable on the land, and the latter on the personal estate. 'The decedent's debts belonged to the latter class. The English law made the personalty primarily liable for all debts. The English court held that exoneration should be decreed on the ground that the heir was made a quasi-creditor of the personal estate by the law of Scotland (the situs of the land), and the English law coinciding, there was no reason why exoneration should be denied.

On the other hand, in Drummond $v$. Drummond, ${ }^{11}$ a person domiciled in England owned real estate in Scotland, upon which he granted a "heritable bond" to secure a debt contracted in England. He died intestate; and the question was whether this debt was ultimately to be borne by the real or personal estate. By English law the personal estate was the primary fund for the payment of all debts. By the law of Scotland, the real estate was the primary fund for the payment of " heritable bonds." It was said for the heir that the personal estate must be distributed according to the law of England (the decedent's domicil), and must bear all the burdens to which it is by that law subject. But in answer to this it was said that the land must go to the heir in accordance with the law of Scotland, bearing all the burdens to which it is by that law subject. The court refused to decree exoneration. In this case the laws of the situs of the two funds were in conflict.

In Staigg $v$. Atkinson, ${ }^{12}$ a testator, after charging his lands with the payment of his debts, provided for his widow, without expressing an intention to bar her of her dower. He owned lands in Minnesota and certain mortgaged lands in Massachusetts. The executor, under a power in the will, sold the Minnesota land and brought the proceeds to Massachusetts. By

116 Bro. P. C. 601 , cited in Brodie v. Barry, 2 Ves. \& B. 127, 132, and in Story, Confl. L. \$ 487.

12144 Mass. 564, 12 N. E. 354. 
the Minnesota law, the provision for the wife in the will did not bar her dower in the land there in the absence of an ex. pressed intention to that effect in the will. That law also provided that her dower should be subject, in its just proportion with the other real estate, to such debts of the deceased as were not paid out of his personal estate. By Massachusetts law her dower was free from the debts of her husband. By the common law of both States, when mortgaged land and other land of a decedent were both charged together with debts, they were bound to contribute ratably to the payment. The widow sued the executor in Massachusetts for her dower share in the proceeds of the Minnesota lands, claiming that she was entitled thereto free from any duty to contribute to pay off the mortgage on the Massachusetts land. But the Massachusetts court held that she must contribute, since under the lex situs of the Minnesota land she was bound to contribute, in the absence of personalty sufficient to pay the husband's debts, and since by the laws of both States mortgaged land was entitled to exoneration pro rata out of the other lands of the decedent. ${ }^{13}$

The equitable principle of contribution between heirs or devisees in the administration of their deceased ancestor's estate is closely assimilated to that of exoneration, and in the main would seem to be governed by similar rules, when the lands in possession of the several heirs or devisees are in different States, whose laws are conflicting touching the order in which the lands are to be primarily liable for the debts. Indeed, contribution in these cases is but a partial exoneration.

The same general principles are applicable here. If the heir of land in one State, subjected to a debt of his ancestor, claims exoneration or contribution from the heir of the lands in another State, not only must he show himself entitled to such relief by the law of the place where his own land is situated, whereby he is constituted a quasi-creditor of the other heir, but the same relief must also be open to him under the law of the State where the land in the hands of the second heir is situated. ${ }^{14}$

13 See also Maxwell v. Hyslop, L. R. 4 Eq. 407.

14 See Staigg v. Atkinson, 144 Mass. 564, 12 N. E..354. 
§ 113. Termination of Status of Executors or Administrators - Auxiliary or Ancillary Administrations. - It has already been observed that the fiduciary status is peculiar, being recognized by the law, not for the benefit of the fiduciary himself, nor chiefly for the benefit of the legatees or other beneficiaries, but mainly for the purpose of dealing with third persons, creditors, debtors, or claimants of the estate. Such third persons may be residents of the decedent's domicil or of other States, and the decedent's personalty may have its actual situs in his domicil or elsewhere.

The primary or principal administration is that conducted at the domicil of the decedent, for there is the legal situs of his personal property. But the legal situs of the personalty yields to the actual situs wherever, under the general exceptions to the "proper law," the lex fori may be substituted for the lex domicilii. Administration proceedings constitute one of these exceptions, for the protection of residents of the forum.

Hence, as we have seen, the domiciliary or principal administrator will not ordinarily be permitted to administer assets in another State, merely by virtue of his domiciliary appointment and qualification, but there must be a fresh appointment and qualification in every State where there are assets.

These are known as ancillary administrations because they are subordinate and auxiliary to the principal or primary or domiciliary administration, and after their purposes are served by satisfying all creditors and claimants in the State of their creation, they are ultimately responsible to the principal administration for the balance of the assets unadministered, and are generally bound to remit such balance to the domicil for distribution. Such is the general theory of ancillary administrations. ${ }^{1}$

1 Wilkins $v$. Ellett, 9 Wall. 740, 742 ; Harvey $v$. Richards, 1 Mason, C. C. 380,409 ; Parsons $v$. Lyman, 20 N. Y. 103 ; Despard v. Churchill, 53 N. Y. 192, 200 ; Cross $v$. Trust Co., 131 N. Y. 330, 346 ; Graveley v. Graveley, 25 S. C. I, 60 Am. Rep. 478, 482 ; Stevens v. Gaylord, 11 Mass. 256 ; Dawes $v$. Head, 3 Pick. (Mass.) 128, 145, 147 ; Davis $v$. Estey, 8 Pick. 475 ; Jennison $v$. Hapgood, 10 Pick. 77, 19 Am. Dec. 258 ; Fay v. Haven, 3 Met. (Mass.) 109, 114 ; Merrill $v$. Ins. Co., 103 Mass. 245, 248; Welles' Estate, 161 Penn St. 218, 28 Atl. 1116 . 
The rights, duties, and liabilities of the principal and ancillary administrators, while administering the funds in their hands, have already been considered in preceding sections, ${ }^{2}$ and will not be here repeated. It may be observed however in this connection that although it is often assumed that ancillary administrations are created solely for the benefit of such claimants as are residents of the forum, ${ }^{8}$ and although that in truth is the real basis upon which they rest, yet such administrations being once created, both convenience, comity, and justice require that the courts of the forum should be open to all claimants who choose to prove their claims there, provided such liberality would not work an injury to those who are actually citizens of the forum, as by exhausting the assets and forcing the citizens themselves to resort to the domiciliary forum. ${ }^{4}$

But it is especially to the relations between the ancillary and domiciliary administrations that attention will now be directed.

Generally speaking, it is the duty of the ancillary administration to collect and pay all debts and claims by or against the estate, arising in the State of such administration, and then to make a settlement before the courts of that State pursuant to its laws, ${ }^{5}$ finally remitting any balance found to exist to the

2 Ante, $\$ \S 105$ et seq.

B See Despard $v$. Churchill, 53 N. Y. 192, 199-200 ; Graveley v. Graveley, 25 S. C. 1, 60 Am. Rep. 478, 483; Welles' Estate, 161 Penn. St. 218, 28 Atl. 1116, 1117 ; Stevens $v$. Gaylord, 11 Mass. 256, 269.

- De Sobry v. De Laistre, 2 Har. \& J. (Md.) 191, 3 Am. Dec. 535, 536; Goodall $v$. Marshall, 11 N. H. 88, 35 Am. Dec. 472, 477-479 and note; Dawes $v$. Head, 3 Pick. (Mass.) 128, 145 ; Harrey $v$. Richards, 1 Mason, C. C. 380, 407. See Bank v. Lacombe, 84 N. Y. 267 ; Atherton Co. v. Ives, 20 Fed. 894 ; Sturtevant $v$. Armsby Co., 66 N. H. 557, 23 Atl. 368 . In the last case a distinction is taken between citizens of one of the States of the Union and citizens of foreign countries. This question or one closely analogous is discussed hereafter. Post, $\S 138$.

5 Lamar v. Micou, 112 U. S. 452 ; Vanghn v. Northup, 15 Pet. 1 ; McLean v. Meek, 18 How. 16, 18 ; Harvey v. Richards, 1 Mason, C. C. 380,414 ; Stevens $v$. Gaylord, 11 Mass. 256, 269 ; Dawes $v$. Head, 3 Pick. (Mass.) 128, 144 ; Parsons v. Lyman, 20 N. Y. 103 ; Despard v. Chnrchill, 53 N. Y. 192, 199 ; Graveley $v$. Graveley, 25 S. C. 1, 60 Am. Rep. 478, 482 ; Russell $v$. Hooker, 67 Conn. 24, 34 Atl. 711, 712. The cases show that in general the accountability of an ancillary administrator is solely to the courts of his own State. See 
domiciliary administration, there to be alministered and distributed as the lex domicilii of the decedent directs.

But it must not be supposed that the courts of the State of ancillary administration are always bound to remit, that they have no jurisdiction to retain and themselves distribute the balance. It seems to have been supposed at one time that there was no other step save to remit the balance to the courts of the domicil, and that legatees or distributees, though residing in the State of ancillary administration, must apply to the domiciliary courts for the distribution. ${ }^{6}$. But the inodern and more reasonable doctrine is that it is not a matter of jurisdiction, but lies within the sound judicial discretion of the court administering the fund, whether after administration it shall proceed to assign their shares to resident legatees or distributees, or remit the fund to the domicil of the decedent, and thus force these parties to resort thither. l'nough the usual rule is to remit, circumstances may justify the other course. ${ }^{7}$ The discretion will usually be exercised in favor of the local distribution of the balance only in those cases where the legatees or distributees are citizens of the forum, where the funds are not needed by the domiciliary administration for the payment of debts, and where to remit them would cause inconvenience, trouble, and perhaps loss to the legatees or distributees resident in the forum.

Vaughn v. Northup, 15 Pet. 1 ; Fay v. Haven, 3 Met. (Mass.) 109, 116. And until he has satisfied all the creditors in his own jurisdiction, no other administrator, not even the domiciliary administrator, can oust him of his authority or lay claim to any property situated there, or recover there of any debtor of the estate. Merrill $v$. Ins. Co., 103 Mass. 245. But if the ancillary administrator has been guilty of fraud so that he may be sued upon his personal responsibility, as for a breach of trust, he may be held accountable therefor in any forum acquiring jurisdiction over him. In such case the accountability is in the court of chancery for breach of the trust. Leach $v$. Buckner, 19 W. Va. 36 ; McNamara v. Dwyer, 7 Pai. Ch. (N. Y.) 239, 32 Am. Dec. 627 ; Powell v. Stratton, 11 Gratt. (Va.) 792, 797.

6 Richards v. Dutch, 8 Mass. 506 ; Dawes v. Boylston, 9 Mass. 337.

7 Welles' Estate, 161 Penn. St. 218, 28 Atl. 1116, 1117 ; Graveley v. Graveley, 25 S. C. 1, 60 Am. Rep. 478 ; Harvey v. Richards, 1 Mason, C. C. 380, 409; Despard v. Churchill, 53 N. Y. 192, 200 ; Parsons v. Lyman, 20 N. Y. 103. 
In Graveley $v$. Graveley, ${ }^{8}$ a testator domiciled in England bequeathed a legacy to a resident of South Carolina, to be paid when he became twenty-one, with interest. The fund was invested by the English executor in British consols, bearing three per cent interest. The South Carolina rate of interest was seven per cent. The executor qualified also in South Carolina, where there were sufficient assets to pay the legacy. All debts and other legacies had been paid. The legatee sued the executor in the South Carolina courts for his legacy with South Carolina interest. It was held to be a case for the exercise of the court's discretion, and the court decreed in favor of the legatee, giving him seven per cent interest. ${ }^{9}$

If in a case of this kind there should be serious doubt as to what is the lex domicilii, it will generally be the duty of the court of ancillary administration to remit to the domicil for distribution, so that the domiciliary courts may interpret their own law. ${ }^{10}$

Even with respect to creditors of the estate, though residents of the State of ancillary administration, the importance of the domiciliary administration, as affording a broader view of the total assets and liabilities of the decedent, is recognized by some of the decisions to the extent that, if the estate is reported insolvent by the domiciliary administration, the creditors in the States of ancillary administration will only be allowed their debts pro rata with all other creditors. They will not be paid in full at the expense of other creditors who have filed their claims in the domiciliary courts. ${ }^{11}$ This is certainly a liberal

25 S. C. 1,60 Am. Rep. 478.

9 It is submitted that in the matter of interest the court erred. For.it is generally conceded that the distribution, even if it occurs in the State of ancillary administration, should be made in accordance with the law of the domicil. See cases supra. The interest the legacy was to bear was not a question of administration, but of distribution. Or if it be taken as a question of the interpretation of the will, it is well settled that ambiguous phrases in a will (" interest") should be interpreted in accordance with the law of the testator's domicil. Post, § 145.

${ }^{10}$ Rockwell $v$. Bradshaw, 67 Conn. 9, 34 Atl. 758, 761 ; Parsons $v$. Lyman, 20 N. Y. 103.

11 Dawes v. Head, 3 Pick. (Mass.) 128; Davis v. Estey, 8 Pick. 475. 
doctrine, but it would seem rather to overlook the real basis of all ancillary administration, the protection of home creditors. ${ }^{12}$

After the completion of the administration of the decedent's estate, both ancillary and domiciliary, follows the distribution of the residuum. The proper law governing this distribution, whether it is made in the State of ancillary administration or in the domicil, is the lex domicilii of the decedent, as will more fully appear hereafter. ${ }^{18}$

$\$ 114$. Status of Guardians. - These fiduciaries, like administrators, are quasi-officers of the law, even when appointed by the individual, as in the case of testamentary guardians. They are also clothed in some measure with a like dual character, being created partly for the protection of the ward and partly for the protection of third persons in their dealings with the ward. Again, the status of guardianship, like that of administration, is a local and temporary status, not a permanent and universal one, and hence the powers and liabilities of the guardian are for the most part local to the place of his appointment and qualification.

There are however several important distinctions between the two classes of fiduciaries. In the first place, the relation of guardianship applies as well to the custody and control of the person of the ward, as of his property, while the status of administration is applicable only to property. In the second place, while the status of administration is created chiefly for the benefit and protection of creditors of the decedent, and other third persons, the main purpose of the guardian is to protect the infant, and the relation towards third persons, though existent and recognized, is only incidental. In the third place, as respects property rights, there is a distinction between the two classes of fiduciaries with regard to the title to the property held by them. As it has been expressed by the Supreme Court of the United States in a leading case on this subject: ${ }^{1}$ "The case of a guardian differs from that of an executor or trustee

12 The United States Supreme Court has taken the opposite view, giving resident creditors precedence in such cases. Smith $v$. Bank, 5 Pet. 518, 527.

13 Post, $\S 139$ et seq.

1 Lamar v. Micou, 112 U. S. 452. 
under a will. In the one case the title in the property is in the executor or the trustee; in the other the title in the property is in the ward, and the guardian has only the custody and management of it, with power to change its investment. The executor or trustee is appointed at the domicil of the testator, the guardian is most fitly appointed at the domicil of the ward, and may be appointed in any State in which the person or property of the ward is found. The general rule which governs the administration of the property in the one case may be the law of the testator's domicil, in the other case it is the lex domicilii of the ward."

Whether the guardian be viewed as the custodian of the ward's person or of his property, it is unquestionably true that he is "most fitly appointed at the domicil of the ward," for that is the legal situs both of the ward and of his personalty. The guardian there appointed is regarded generally as the principal guardian, to whom other guardians appointed elsewhere are answerable and ultimately accountable with respect to the ward's property. ${ }^{2}$

Since the guardian, in the absence of a parent, is intrusted with the custody of the ward's person and the care of his education, as well as with his property, the proper law governing the relation may best be examined with reference to (1) The care of the ward's person; (2) The care of his estate.

$\S 115$. Status of Guardian with respect to Ward's Person. - The legal situs of the ward being his domicil, the guardian appointed there is regarded as having peculiar powers with respect to the ward's person. Although the status is not a permanent one, and other guardians, upon occasion, may be appointed in other States where the ward may happen to have his actual situs, even when his property is not in question, or though he have no property there, yet the authority of such a guardian is always local only. He has no general authority over the ward's person which will be recognized in other States. ${ }^{1}$

But the authority of the domiciliary guardian over the ward's

2 Lamar $v$. Micou, 112 U. S. 452; Earl v. Dresser, 30 Ind. 11, 95 Am. Dec. 660, 665. See Grimmett $v$. Witherington, 16 Ark. 377, 63 Am. Dec. 66, 71.

1 Johnstone $v$. Beattie, 10 Cl. \& F. (H. L.) 42 ; Woodworth v. Spring, 
person, even when the latter is actually in another State, is to a certain extent recognized everywhere. Though a local guardian has been appointed in the State of the ward's actual situs, it is believed to be the better view that the authority of the domiciliary guardian over the ward's person is paramount, unless the welfare of the child or some other very grave reason intervenes. ${ }^{2}$

The English case of Nugent $v$. Vetzera ${ }^{3}$ strongly illustrates the respect shown to the authority of the domiciliary guardian even when the ward is in a foreign country. An Austrian subject of wealth and position married an Englishwoman, and had ten children. The husband died, and the mother sent some of the children to England to be educated. One of the daughters married an Englishman. The mother died, and a guardian was appointed by an Austrian court, which ordered that the children should be brought back to Austria to be educated. The married daughter caused herself to be appointed the guardian of the children in England, and resisted the attempt to take them back to Austria. Both guardians were fit and suitable persons, and the children desired to remain in England. But the English court held that it would be contrary to comity as well as to policy to refuse the domiliciary guardian leave to remove them, as it would tend to check intercourse between the nations, and would react harshly upon English infants abroad.

4 Allen (Mass.), 321 ; People v. Baker, 76 N. Y. 78, 85, 32 Am. Rep. 274. See Kelsey $v$. Green, 69 Conn. 291, 37 Atl. 679; Rogers $v$. NeLean, 31 Barb. (N. Y.) 304.

2 Kraft v. Wickey, 4 Gill \& J. (Md.) 332, 23 Am. Dec. 569, 5i1; Townsend $v$. Kendall, 4 Minn. 412, 77 Am. Dec. 534, 537 ; Woodworth $v$. Spring, 4 Allen (Mass.), 321 ; Wood v. Wood, 5 Pai. Ch. (N. Y.) 596, 28 Am. Dec. 451 ; Grimmett $v$. Witherington, 16 Ark. 377, 63 Am. Dec. 66, 71 ; In re Rice, 42 Mich. 528, 4 N. W. 284, 285 ; Kelsey $v$. Green, 69 Conı. 291, 37 Atl. 679 ; Nugent $v$. Vetzera, L. R. 2 Eq. 704 ; Dawson v. Jay, 3 DeG. M. \& G. 764. This is denied outright by some of the decisions, which hold that no foreign guardian has any control whatever over the person or property of his ward in another State, and that he must be first reappointed there as guardian. Story, Confl. L. § 499; Johnstone v. Beattie, 10 Cl. \& F. 42; Rogers v. McLean, 31 Barb. (N. Y.) 304. See Hoyt $v$. Sprague, 103 U. S. 613, 631.

E L. R. 2 Eq. 704. 
In Woodworth $v$. Spring, ${ }^{4}$ a child domiciled in Illinois, and there under guardianship, was brought to Massachusetts with the consent of his guardian, by an aunt who there caused herself to be appointed his guardian, without the knowledge or consent of the domiciliary guardian. The latter afterwards sought to recover possession of the child by a habeas corpus proceeding. The court, while denying the petition on the ground that such a course was best for the child, remarked: "But it by no means follows that the foreign guardian's claim to the care of the child and the control of his person and the privilege of removing him from this State is to be absolutely denied. On the contrary, it is the duty of the courts of this State, in the exercise of that comity which recognizes the laws of other States when they are consistent with our own, to consider the status of guardian, which the petitioner holds under the laws of another State, as an important element in determining with whom the child is to continue. It would not do to say that a foreign guardian has no claim to his ward in this State. If such were the rule, a child domiciled out of the State, sent hither for purposes of education, or brought here by force or fraud, or coming by stealth, might be emancipated from the control of his rightful guardian. Nor does the appointment of a guardian in this State operate to bar any decree of the court in favor of the foreign guardian."

Kelsey $v$. Green ${ }^{5}$ was a contest between a New York and a Connecticut guardian over the custody of a child actually located in Connecticut. The child had lived there several years with its mother (now dead). The father and the family had lived in New York, where he was convicted of felony and confined in the penitentiary. Upon his release he caused a man in New York to be appointed there the guardian of the child. This man, claiming that he was the domiciliary guardian, petitioned the Connecticut court for a habeas corpus to recover the possession of the child from the Connecticut guardian. The court denied the petition in the interests of the child.

In conclusion, it may be not amiss to state that, however confined the authority of a domiciliary guardian may be over

44 Allen (Mass.), 321.

569 Conn. 291, 37 Atl. 679. 
the person of his ward in another State, the parents (natural guardians) have no such restricted authority. It is universally conceded that they have in general the same control over their children when abroad that they have at home. ${ }^{6}$

$\S 116$. Status of Guardian with respect to Ward's Property. - So far as concerns the ward's property, the appointment of a guardian, though primarily, is not solely for the protection and benefit of the ward. He may be brought into business relations with third persons, whose rights the law must protect. It follows therefore, as in the case of executors and administrators, nowithstanding the general legal fiction that personalty has its legal situs at the domicil of the owner, that if the ward should own personalty in other States, before any one can deal with the property there as guardian of the ward, he must be appointed guardian with all the formalities and securities required by the law of the actual situs of the property. It is generally admitted that the appointment of a guardian, whether in the ward's domicil or elsewhere, gives him no exterritorial authority over the ward's personal property. ${ }^{1}$

And if such is the rule with respect to personal property, a fortiori is it the rule where the ward's property is immovable. Here it is well settled that the lex situs of the land governs, and that law usually requires a guardian to qualify there before he can act with respect to land. ${ }^{2}$

6 Johnstone $v$. Beattie, 10 Cl. \& F. 42 ; Townsend $v$. Kendall, 4 Minn. 412, 77 Am. Dec. 534. But see ante, § 83.

1 Kraft $v$. Wickey, 4 Gill \& J. (Md.) 332, 23 Am. Dec. 569, 571; Rogers v. McLean, 31 Barb. (N. Y.) 304 ; Morrell v. Dickey, 1 Johns. Ch. (N. Y.) 153, 156 ; Lamar v. Micou, 112 U. S. 452 ; Hoyt v. Sprague, 103 U. S. 613, 631. There is some tendency to give effect to the domiciliary guardianship in cases where citizens of the situs are not interested. See Lamar $v$. Micou, 112 U. S. 452 ; Townsend $v$. Kendall, 4 Minn. 412, 77 Am. Dec. 534 ; Grimmett $v$. Witherington, 16 Ark. 377, 63 Am. Dec. 66 ; Earl v. Dresser, 30 Ind. 11, 95 Am. Dec. 660, 664-665.

2 Whart. Confl. L. § 268 ; Hoyt v. Sprague, 103 U. S. 613,631 ; Grimmett $v$. Witherington, 16 Ark. 377, 63 Am. Dec. 66, 69; Rogers $v$. McLean, 31 Barb. (N. Y.) 304. It is said that a guardian appointed in one State has no right even to receive the profits of the ward's real estate located elsewhere, unless he has been duly appointed guardian in the State where the land lies. Story, Conf. L. \$ 504. See Smith v. Wiley, 22 Ala. 396, 58 Am. Dec. 262. 
But after the claims of all third persons are disposed of, or if none arise, the general principle, as between guardian and ward, is the same that regulates the accountability of the executor or administrator to the legatees or distributees. The law of the legal situs of the personalty controls questions arising solely between guardian and ward; that is, the lex domicilii of the owner (the ward).

Thus, in Lamar $v$. Micou, ${ }^{8}$ the guardian was appointed in New York, while the wards were domiciled in auother State. He invested the wards' money in a manner that was lawful under the New York law, but rendered him responsible for its safety under the law of the wards' domicil. The court held that he was accountable according to the latter law. In the course of the opinion, Mr. Justice Gray says: "The form of accounting, so far as concerns the remedy only, must indeed be according to the law of the court in which relief is sought; but the general rule by which the guardian is to be held responsible for the investment of the ward's property is the lex domicilii of the ward."

If the ward has property in his domicil, it is generally the duty of the domiciliary, rather than of an ancillary, guardian to maintain him, even though he be actually in another State, and a fortiori, if he is in the State of his domicil. ${ }^{4}$ But if he has no property in the State of his domicil, so that the principal guardian is unable to maintain him, an ancillary guardian will then be permitted to give or send him funds for his maintenance, subject to a strict accountability. ${ }^{5}$

The principles regulating the powers, duties, and liabilities of the committees or guardians of idiots, insane persons, convicts, etc., are closely analogous to those controlling the ordinary relation of guardian and ward. In general, however, only the property interests of the ward, not his person, are intrusted to this class of fiduciary. ${ }^{\circ}$

8112 U. S. 452.

4 Kraft v. Wickey, 4 Gill \& J. (Md.) 332, 23 Am. Dec. 569.

6 Stephens $v$. James, 1 Mylne \& Keene, 627.

- See Rogers v. McLean, 31 Barb. (N. Y.) 304 ; Glaser v. Priest, 29 Mo. App. 1 ; Schneller $v$. Vance, 8 La. 506, 28 Am. Dec. 140. 
\$ 117. Status of Receivers - In General. - Receivers are fiduciaries appointed by a competent court to take charge of and control property litigated, pending the litigation. The appointment of such a fiduciary is usually incidental to the winding up of insolvent partnerships and corporations. Through the appointment of a receiver the court obtains possession and control of the litigated property, preserves it from waste and destruction, secures and collects the proceeds and profits, and ultimately distributes it according to the rights and priorities of those entitled.

A receiver is nothing more than an officer or creature of the court that appoints him. His acts are the acts of the court, whose jurisdiction may be aided, but not in general enlarged or extended, by his appointment. His powers are for the most part only coextensive with the authority of the court conferring upon him his official character. ${ }^{1}$

It will be observed that the status of a receiver is to a certain extent assimilated to that of the fiduciaries already discussed. But the dual character of the status is in this instance minimized, if not altogether lost. His appointment is principally, if not exclusively, for the benefit and protection of creditors; only in a very slight degree, if at all, do the original owners of the property profit by his appointment.

It follows therefore that the receiver's status is more strictly local than that of either administrator or guardian. Even here, however, there is the distinction between primary or principal and ancillary receiverships. The first court which assumes jurisdiction and appoints a receiver is the court of "principal" administration, while the courts of other States may appoint "ancillary receivers" of the property there situated." "The position of a receiver may be likened to that of an assignee in involuntary bankruptcy, rather than to that of an administrator or guardian. 8

Receivers, being mere officers of the court appointing them, it will be readily seen that, inherently and as a matter of right,

1 Catlin v. Wilcox Silver Plate Co., 123 Ind. 477, 8 L. R. A. 62

2 Reynolds $v$. Stockton, 140 U. S. 255.

8 See Booth $v$. Clark, 17 How. 322 ; post, $\$ 137,138$. 
they can have no title, power, or authority beyond the limits of that court's jurisdiction. ${ }^{4}$

But upon principles of comity, always recognized and in general acted upon, receivers appointed in one jurisdiction are permitted elsewhere to protect interests and enforce claims of which they are the custodians. ${ }^{5}$ But the title of the foreign receiver to property in a State whose residents are creditors of the insolvent concern will not be recognized there as against them, at least if they are not parties to the foreign litigation out of which the receivership grew. ${ }^{6}$ In order to give him such rights against citizens of the State where the property in question is located, he must be appointed a receiver by its courts.

So, if the recoguition of the foreign receivership would contravene the policy of another State, it will not be recognized there. ${ }^{8}$ Nor will it be recognized, even as against non-resident creditors who have attached or otherwise secured a lien upon the property before it was actually vested in the receiver, ${ }^{\circ}$ unless perhaps where the lien creditor is a citizen of the same State whose court has appointed the receiver. ${ }^{10}$

Property situated in the State of his appointment becomes vested in the receiver by the very fact of his appointment, without possession thereof actually taken by him; but as to property outside of that State, in those cases where the authority of a for-

4 Catlin v. Wilcox Plate Co., 123 Ind. 477, 8 L. R. A. 62 ; Boulware v. Davis, 90 Ala. 207, 9 L. R. A. 602, 6 Am. St. Rep. 189 ; Booth v. Clark, 17 How. 334 .

5 Boulware v. Davis, 90 Ala. 207, 9 L. R. A. 602, 6 Am. St. Rep. 189 ; Gilman $v$. Ketcham, 84 Wis. 60, 54 N. W. 395, 397; Pond $v$. Cooke, 45 Conn. 126, 29 Am. Rep. 668; Willetts $v$. Waite, 25 N. Y. 577; Chicago, etc. R. R. Co. v. Packet Co., 108 Ill. 317, 48 Am. Rep. 557; Cagill v. Wooldridge, 8 Baxt. (Tenn.) 580, 35 Am. Rep. 716.

6 Catlin $v$. Wilcox Plate Co., 123 Ind. 477, 8 L. R. A. 62 ; Humphreys v. Hopkins, 81 Cal. 551, 6 L. R. A. 792 ; Boulware v. Davis, 90 Ala. 207, 9 L. R. A. 602,6 Am. St. Rep. 189 ; Willetts $v$. Waite, 25 N. Y. 577.

7 See Farmers' Loan \& T. Co. v. Tel. Co., 148 N. Y. 315, 31 L. R. A. 403, 42 N. E. 707.

8 Boulware v. Davis, 90 Ala. 207, 9 L. R. A. 602, 6 Am. St. Rep. 189.

9 Catlin v. IVilcox Plate Co., 123 Ind. 477, 8 L. R. A. 62.

in Gilman $v$. Ketcham, 84 Wis. 60, 54 N. W. 395. See post, $\$ 138$. 
eign receiver will be recognized, he will not be regarded as having acquired title until he has actually gained control over the property. ${ }^{11}$

If, being vested with the title to the property in the State of his appointment, the receiver should afterwards remove it to another State, where it is attached by creditors, whether resident or non-resident, his title having already fully rested is superior. ${ }^{12}$

In the absence of conflicting claims of creditors in other jurisdictions, it is generally conceded that a foreign receiver may deal with the insolvent's property as if it were in the State of his appointment. ${ }^{18}$ As between two courts of concurrent jurisdiction, such as a Federal court and a State court in the same State, both having jurisdiction of the cause, the settled rule now is that the court first obtaining jurisdiction of the res is entitled to retain it until the litigation is terminated, whether or not a receiver actually has possession of the property. ${ }^{14}$ Indeed the same principle applies in other cases also where a conflict of jurisdiction between the two classes of courts is threatened. ${ }^{15}$

While these general powers are usually recognized as conferred upon foreign receivers, it will sometimes be convenient, and even necessary, to appoint ancillary receivers in other jurisdic-

11 As against citizens of the State of his appointment, he stands vested with the title to all the property, even that which is outside the court's jurisdiction. See Gilman $v$. Ketcham, 84 Wis. 60, 54 N. W. 395 ; Osgood $v$. Maguire, 61 N. Y. 524 ; Bagby v. R. R. Co., 86 Penn. St. 291.

12 Pond v. Cooke, 45 Conn. 126, 29 Am. Rep. 668 ; Cagill v. Wooldridge, 8 Baxt. (Tenn.) 580, 35 Am. Rep. 716 ; Chicago, etc. R. R. Co. v. Packet Co., 108 Ill. 317, 48 Am. Rep. 557. See Humphreys v. Hopkins, 81 Cal. 551, 6 L. R. A. 792 ; Alley v. Caspari, 80 Me. 234, 6 Am. St. Rep. 185, note.

13 Willetts $v$. Waite, $25 \mathrm{~N}$ Y. 577, 584.

14 Shields $v$. Coleman, 157 U. S. 168 ; Hamilton $v$. Chouteau, 6 Fed. 339. But where the State receivership ceases before the new cause of action arises, the federal courts may then assume jurisdiction. Andrews $v$. Smith, 5 Fed. 833. And where a receiver of a State court acts unlawfully he may be sued in tort in a federal court. Curran $v$. Craig, 22 Fed. 101.

15 Thus, in Byers v. McAuley, 149 U. S. 608, it was held that property in the hands of an administrator appointed by a State court could not be disturbed by process issued from a federal court. 
tions where there is property of the insolvent. ${ }^{16}$ In such case, as in the corresponding case of administrators, the two receivers are not in privity, and a judgment obtained against one in the State of his appointment will not be binding upon the other. ${ }^{17}$ The ancillary receiver, after settling with the creditors within his jurisdiction, is accountable to the principal receiver for the balance, as in other cases of administration.

§ 118. Suits by and against Receivers. - A receiver, strictly speaking, has no more right to sue in a foreign State than to do any other act. But if a suit instituted by a foreign receiver will not work a detriment or an injustice to the citizens of the forum, he will generally, upon principles of comity, be permitted to appeal to its courts. ${ }^{1}$

And upon going into a foreign jurisdiction, or sending the trust property thither, he will be protected by the courts of that State in his right to the property which, in the performance of his duty, he has carried or sent thither. In such cases the courts, while protecting their own citizens from wrong, will not permit them to infringe the comity of nations and themselves perpetrate a wrong upon the receiver and the court that has appointed him. ${ }^{2}$

In respect to suits instituted against receivers, it is a general rule that these officials cannot be sued without the leave of the appointing court. A suit instituted without such leave is a contempt of the appointing court, which, if it can reach the plaintiff's person, may restrain him by an injunction or attach

16 Farmers' Loan \& T. Co. v. Tel. Co., 148 N. Y. 315, 325, 31 L. R. A. 403, 42 N. E. 707; Reynolds $v$. Stockton, 140 U. S. 255.

17 Reynolds $v$. Stockton, 140 U. S. 255.

1 Booth v. Clark, 17 How. 322 ; Gilman $v$. Ketcham, 84 Wis. 60, 54 N.W. 395, 397; Boulware v. Davis, 90 Ala. 207, 9 L. R. A. 602, 6 Am. St. Rep. 189; Petersen v. Chemical Bank, 32 N. Y. 21, 43, 88 Am. Dec. 298 ; Toronto, etc. Trust Co. v. R. R. Co., 123 N. Y. 37, 47, 25 N. E. 198 ; Woodward v. Brooks, 128 Ill. 222,20 N. E. 685 ; Humphreys v. Hopkins, 81 Cal. 551, 6 I. R. A. 792 ; Catlin $v$. Wilcox Plate Co., 123 Ind. 477, 8 L. R. A. 62.

2 Pond $v$. Cooke, 45 Conn. 126, 29 Am. Rep. 668 ; Chicago, etc. R. R. Co. v. Packet Co., 108 Ill. 317, 48 Am. Rep. 557; Cagill v. Wooldridge, 8 Baxt. (Telin.) 580, 35 Am. Rep. 716. But see Humphreys v. Hopkins, 81 Cal. 551,

6 L. R. A. 792. 
him for contempt, or both, or may render the proceedings insti. tuted by the plaintiff of no effect within its jurisdiction. ${ }^{3}$ Such is the view taken by the courts of the State where the receiver is appointed.

Whether or not a foreign court will take the same view if a creditor attempts to seize the property of the insolvent in its jurisdiction without leave of the court appointing the receiver, is a matter about which there is some conflict of opinion. It would seem quite clear that such foreign court would not regard the appointment of the receiver in cases where its own citizens attach the property within its jurisdiction. ${ }^{4}$

But opinion is divided upon the question whether citizens of the State where the receiver is appointed shall be permitted to disregard the orders and jurisdiction. of their own home courts, and without their leave sue the receiver in another State. Some of the courts take the view that want of leave to sue the receiver is not a jurisdictional defect; but that such suit may be maintained, the plaintiff taking the risk of the appointing court being able to reach him effectively by injunction or contempt proceedings. ${ }^{5}$ But the more recent and the better opinion is in favor of denying to foreign courts all jurisdiction of suits by home creditors against a home receiver appointed by the home courts, without the latter's leave first obtained. ${ }^{6}$

8 Winswall $v$. Sampson, 14 How. 65; Peale v. Phipps, 14 How. 368 ; Davis $v$. Gray, 16 Wall. 203 ; Barton $v$. Barbour, 104 U.S. 126; Farmers' Loan \& T. Co. v. Tel. Co., 148 N. Y. 315, 31 L. R. A. 403, 42 N. E. 707.

4 Catlin v. Wilcox Plate Co., 123 Ind. 477, 8 L. R. A. 62 ; Boulware v. Davis, 90 Ala. 207, 9 L. R. A. 602, 6 Am. St. Rep. 189 ; Booth v. Clark, 17 How. 322 ; Reynolds $v$. Adden, 136 U. S. 353, 354. It is believed also that the same rule will prevail where the attaching creditors are citizens of States other than that where the receiver is appointed. Cole $v$. Cunningham, 133 U. S. 107, 127. See post, $\S 138$.

5 Kinney v. Crocker, 18 Wis. 74; St. Joseph, etc. R. R. Co. v. Smith, 19 Kan. 225 ; Allen v. Central R. R. Co., 42 Ia. 683.

6 Barton $v$. Barbour, 104 U. S. 126, 128 ; Peale $v$. Phipps, 14 How. 368 ; Kennedy $v$. R. R. Co., 3 Fed. 97; Melendy v. Barbour, 78 Va. 544, 558; Gil man $v$. Ketcham, 84 Wis. 60,54 N. W. 395. See post, $\$ 138$. 


\section{PART IV.}

\section{SITUS OF PERSONAL PROPERTY.}

§ 119. Preliminary - Outline of Discussion. - It has already been observed that the legal and the actual situs of land or immovable property, by reason of the quality of immovability, are one and the same. By no fiction of law nor theory of public policy can land be regarded as constructively located at any other place than its actual situs. It naturally follows that every question affecting the title to land must be governed by the law of the place where the land is situated. ${ }^{1}$

But with that class of property known as personal property it is otherwise. Tangible chattels are movable, and may be carried or sent from one State to another, and therefore may at different times be subjected to different laws at the will or caprice of the owner. By reason of its movability, personal property cannot be said to have any fixed and definite locality like lands. And if this is true of tangible chattels, how much more true is it of those intangible interests known as choses in action, or debts. These cannot be said in strictness to have any situs at all.

Yet it is essential, for the purposes of business, that some situs should be assigned to all these classes of property. They are as susceptible of being dealt with in the ordinary transactions of life as real property; in fact transactions with respect to them are much more frequent. Such transactions must be aneasured by some law, and that law can only be furnished by the situs of the property and of the transactions relating to it.

We shall devote the next chapter to an consideration of the rules by which to determine the situs of tangible chattels and

1 Ante, $\$ 11,12$. 
debts, and in the succeeding chapters we will inquire into "the proper law" governing the various transactions that may arise with regard to personal property, including (1) voluntary trans. fers of personalty inter vivos; (2) involuntary transfers of personalty inter vivos; (3) transfers by succession to an intestate's personal estate; (4) transfers by will. 


\section{CHAPTER $\mathrm{X}$.}

\section{SITUS OF CHATTELS AND OF DEBTS.}

\$ 120. Iegal and Actual Situs of Tangible Chattels. - Bo. cause of their characteristic of movability, it has been a timehonored maxim both of the common and the Roman law, arising from considerations of general convenience, that chattels are to be presumed in legal contemplation to follow the situs of the owner, since it is always in his power to carry or have them sent thither. This maxim is expressed in the phrase, "Mobilia personam sequuntur."

As was said by an eminent English judge, "' It is a clear proposition, not only of the law of England, but of every country in the world where the law has the resemblance of science, that personal property has no locality. The meaning of that is, not that personal property has no visible locality, but that it is subject to that law which governs the person of the owner. With respect to the disposition of it, with respect to the transmission of it, either by succession or act of the party, it follows the law of the person."

The legal situs of chattels then is the situs of the owner. But, as has been shown in a previous section, ${ }^{2}$ the owner may possess, for different purposes, two different localities at the same time. For some purposes, the actual situs of the person at a given time will furnish the applicatory law (though he resides in another State). For other purposes, the legal situs (or domicil) of the party will furnish the proper law.

It will be remembered also that the actual situs of the person is looked to whenever the transaction to which the law of his situs is applied is voluntarily and deliberately entered into by

1 Lord Loughborongh, in Sill $v$. Worswick, 1 H. Bl. 690.

2 Ante, $\S 18$. 
bim, because he thereby deliberately submits himself to the sovereignty of that State, which is complete within its own territory, and which a just and proper comity demands should be respected in other States. But if the matter in question is the result, not of his own voluntary and deliberate act, but of some act of the law, if his participation in the transaction is involuntary, it is his legal situs or domicil that provides the governing law, not his actual situs; for without his deliberate and voluntary submission to the temporary sovereignty of another State, his domiciliary law follows him, whithersoever he may go. ${ }^{8}$

It follows, therefore, since the legal situs of chattels is the situs of the owner, that the legal situs of the chattels will be either the actual situs of the owner or his legal situs (or domicil), according as the particular transaction affecting the chattels is a voluntary or an involuntary transaction, that is, according as his participation therein is active, deliberate and voluntary, or passive and involuntary.

Thus where the owner of chattels, being domiciled in one State, goes into another State and there voluntarily enters into a transaction disposing of them to another, the chattels, for the purposes of that transaction, are to be regarded in general as legally situated in the State where the transaction takes place, whose law accordingly will govern its validity and effect. ${ }^{4}$ But

3 Ante, § 18.

4 Crapo v. Kelly, 16 Wall. 610, 622 ; Barnett $v$. Kinney, 147 U. S. 476 , 481 ; Langworthy $v$. Little, 12 Cush. (Mass.) 109, 111 ; Frank v. Bobbitt, 155 Mass. 112, 29 N. E. 209 ; Williams v. Dry Goods Co., 4 Okl. 145, 43 Pac. 1148, 1150 ; Emery v. Clough, 63 N. H. 552, 4 Atl. 796 ; Hornthall v. Burwell, 109 N. C. 10,13 S. E. 721, 722 ; Long $v$. Girdwood, 150 Penn. St. 413, 24 Atl. 711, 23 L. R. A. 33 ; Fowler's Appeal, 125 Penn. St. 388, 17 Atl. 431; Mackey v. Pettijohn, 6 Kan. App. 57, 49 Pac. 636 ; Guillander v. Howell, 35 N. Y. 657, 663 ; Butler v. Wendell, 57 Mich. 62, 23 N. W. 460, 462 ; Sullivan $v$. Sullivan, 70 Mich. 583, 38 N. W. 472 ; Weinstein $v$. Freyer, 93 Ala. 257, 9 So. 285 ; Marvin Safe Co. v. Norton, 48 N. J. L. 412,57 Am. Rep. 566, 568, 7 Atl. 418 ; Cronan v. Fox, 50 N. J. L. 417, 14 Atl. 119 ; Dial v. Gary, 14 S. C. 573, 37 Am. Rep. 737, 738 ; State v. O'Neil, 58 Vt. 140, 56 Am. Rep. 557 ; Ames Iron Works v. Warren, 76 Ind. 512, 40 Am. Rep. 258. Many of these arc cases where the owner was in his domicil at the time of the 
for the purposes of involuntary transactions touching the chattels, matters arising by operation of law, without the consent or against the will of the owner, as transfers by marriage, by involuntary assignments in bankruptcy, by succession to a decedent, etc., the legal situs of the chattels is the legal situs of the owner (his domicil), regardless of his actual situs, and hence the law of his domicil, not of his actual situs at the time the transfer occurs, is the "proper law" to regulate the validity and effect of such transfer. ${ }^{6}$

But although the legal situs of the chattels will furnish the "proper law" to regulate all kinds of transactions relating thereto, yet there are occasions when the lex fori will be substituted for the proper law, in the cases where the general exceptions to the enforcement of a foreign law apply. In such cases the forum and the actual situs of the chattels will usually be identical, and hence it comes about in these exceptional cases that the transaction may after all be governed by the law of the actual situs of the chattels, which may be entirely distinct both from the legal and from the actual situs of the owner. Indeed, these exceptional cases arise so frequently as almost in some cases to obscure the operation of the law of the legal situs of the chattels altogether, ${ }^{\circ}$ leading a few authorities to aver that the

transaction, so that his legal and actnal situs coincide, while others are cases in which the owner was abroad when he dealt with the chattels.

5 Hairston $v$. Hairston, 27 Miss. 704, 61 Am. Dec. 530 ; Willians v. Saunders, 5 Coldw. (Tenn.) 60, 76-77; Union Bank $v$. Hartwell, 84 Ala. 379, 4 So. 156 ; Paine $v$. Lester, 44 Conn. 196, 26 Am. Rep. 442 ; Russell v. Hooker, 67 Conn. 24, 34 Atl. 711, 712 ; Ames Iron Works $v$. Warren, 76 Ind. 512, 40 Am. Rep. 258, 259; Graham v. Bank, 84 N. Y. 393, 399, 38 Am. Rep. 528 ; Cross $v$. Trust Co., 131 N. Y. 330, 339 ; Guillander $v$. Howell, 35 N. Y. 657, 658; Petersen v. Chemical Bank, 32 N. Y. 21, 46, 88 Am. Dec. 298 ; Speed v. May, 17 Penn. St. 91, 55 Am. Dec. 540 ; Milne $v$. Moreton, 6 Binn. (Penn.) 353, 361, 6 Am. Dec. 466 ; Black v. Zacharie, 3 How. 483, 514 ; Sickles $v$. New Orleans, 52 U. S. App. 147, 80 Fed. 868, 874.

6 Green v. Van Buskirk, 5 Wall. 307, 312 ; Smith v. Bank, 5 Pet. 518, 524 ; Hornthall $v$. Burwell, 109 N. C. 10, 13 S. E. 721, 722 ; Speed $v$. May, 1; Penn. St. 91, 94, 55 Am. Dec. 540; Paine v. Lester, 44 Conn. 1ミ6, 26 Am. Rep. 442, 444 ; Edgerly $v$. Bush, 81 N. Y. 199, 203 ; Barth v. Backus, 140 N. Y. 230, 29 N. E. 209 ; May v. Wannemacher, 111 Mass. 202, 209 ; Ames Iron Works $v$. Warren, 76 Ind. 512, 40 Am. Rep. 258 ; Toof $v$. Miller, 73 
law of the actual situs of chattels is the "proper law" to govern transactions relating to them. ${ }^{7}$

But cases may arise in which it becomes impossible to assign an actual situs to chattels, that is, a situs subject to any particular law. In such cases, the chattel is relegated to its legal situs at the actual or legal situs of the owner. Thus a ship upon the high seas, though actually situated upon the seas, cannot be said to have an actual situs there or elsewhere, in the sense here used, because the high seas are subject to no particular law. ${ }^{8}$

With respect to chattels aboard a ship on the high seas, they are generally deemed to be actually located in the country to which the ship belongs, and whose flag she flies, upon the well known principle of international law, that while upon the high seas even a merchant vessel is a floating part of the territory to which she belongs.

But as to the vessel itself, when upon the high seas, though for purposes of international law it is to be regarded as part of the territory of the State to which it belongs, yet from the standpoint of a mere chattel, property owned by an individual, it is believed that it must be regarded as located at the actual situs or at the legal situs (or domicil) of the owner, according as the transaction respecting it is voluntary or involuntary, even though the owner's situs be a State other than that wherein the vessel is registered. ${ }^{10}$ But after the ship, if it be a mer-

Miss. 756, 19 So. 577; Cronan v. Fox, 50 N. J. L. 417, 14 Atl. 119 ; In re Dalpay, 41 Minn. 532, 43 N. W. 564.

7 Whart. Confl. L. $\S \S 345,346$; Guillander $v$. Howell, 35 N. Y. 657 . See ante, $\S 14$.

8 The same may probably be affirmed of chattels sitnated in a barbarous or unpopulated territory, subject to no civilized law. See Thuret $v$. Jenkins, 7 Mart. (La.) 318, 353, 12 Am. Dec. 508.

9 Whart. Confl. L. $\S 356$; Crapo v. Kelly, 16 Wall. 610, 625. In the United States, whose flag covers many States, the State where the vessel is registered seems to be the one to which she legally belongs. Whart. Confl. L. $\S 357$.

10 Crapo v. Kelly, 16 Wall. 610, 622 ; Thuret v. Jenkins, 7 Mart. (La.' 318, 353, 12 Am. Dec. 508; Moore v. Willett, 35 Barb. (N. Y.) 663, 665. But see Whart. Confl. L. $\$ 357$. 
chant vessel, has arrived in a port, or within marginal waters, it (and probably its cargo also) will be deemed to have its actual situs in the country in whose territory it is."

In conclusion, it must be observed that the actual situs of chattels will always be looked to, where the question is one of jurisdiction of a court over a res. It is the actual, not the legal, situs of property that gives a court jurisdiction to pronounce a judgment or decree concerning it. Thus the court of the owner's domicil or of his actual situs will not assume jurisdiction, in a proceeding in rem, over chattels actually situated in another jurisdiction; nor will a court of a State where a chattel is actually situated refuse jurisdiction of such a proceeding with respect thereto, merely because the actual or legal situs of the owner is elsewhere, and the chattel has its legal situs in another State. ${ }^{12}$

§ 121. Legal and Actual situs of Debts. - As has been shown in the preceding section, there is usually no difficulty in ascertaining the actual situs of tangible chattels, whenever it becomes necessary to discriminate between the actual and legal situs thereof. A tangible chattel occupies space, and may have a definite locality of its own.

But with respect to intangible chattels and choses in action, such as bonds, notes, bills of exchange, accounts, and debts of all sorts, certificates of stock, etc., different principles must be applied. Of course, the material evidence of the right, that is, the paper on which the promise to pay is written, may have an actual locality: it may occupy space. But this is merely the evidence of the right, the value of which lies in the fact that it will suffice to entitle the owner to the valuable property it represents. The value of the property itself lies in the right of the creditcr to enforce the obligation of the debtor to pay the debt. Such intangible rights can of course have no real situs, since they exist only in the mind's eye, but it frequently be-

11 Crapo v. Kelly, 16 Wall. 610, 622 ; Olivier v. Townes, 14 Mart. (La.) 93.

12 This proposition scarcely needs authority for its support. See Rockwell $v$. Bradshaw, 67 Conn. 9, 34 Atl. 758, 761 ; Cronan v. Fox, 50 N. J. 417, 14 Atl. 119 ; Reynolds v. Stockton, 140 U.S. 255, 272 ; Byers v. IcAuley, 149 U.S. 608 ; Stacy v. Thrasher, 6 How. 44, 58. See ante, $\$ 14$. 
comes necessary to assign them a situs somewhere, in order to ascertain the law properly applicable to them.

Before laying down any rules for the determination of the situs of debts, it will repay us to notice briefly the dual meaning of the term "debt." The phrases "chose in action" and "debt" are often used as synonymous. But they are rather correlative than synonymous. They represent the same thing, but viewed from opposite sides. The "chose in action" is the right of the creditor. to be paid, while the "debt" is the obligation of the debtor to pay. This distinction is brought out in the common phrase, "the choses in action and debts of a partnership, upon the death of one of 'the partners, survive." Here both terms are used in the same sentence, but with opposite meanings: the former term signifying the firm's right to be paid certain sums of money, the latter signifying the firm's obligation to pay certain sums of money. Yet the term "debt" is often used indiscriminately to convey both these ideas. ${ }^{1}$ Much confusion has resulted from the failure to observe this distinction, and perbaps still more from the failure to notice carefully the essential characteristics of these several conceptions.

The chose in action, or right of the creditor, is a personal right which adheres to him wherever his situs may be. It may for some purposes be his legal situs (or domicil), for others his actual situs. Just as, in the case of tangible chattels, though the title thereto follows the owner, and its transfer will be regulated by the law of the owner's situs, yet his or his transferee's ability to enforce that title may be in the exceptional cases determinable by a different system of law should the chattels be actually situated elsewhere; so also in the case of debts, though the right to enforce them follows the owner (the creditor), and his transfer is therefore to be governed by the law of his situs, actual or legal, yet his or his transferee's ability to enforce that right may depend upon another jurisdiction and system of law, if he has to resort to another State to sue the debtor. In other words, though the situs of the creditor's right

1 See Dial v. Gary, 14 S. C. 573, 37 Am. Rep. 737, 740. 
follows the creditor, the situs of the debtor's obligation follows the debtor, in the sense that the debtor's legal obligation exists only in the State where it can be enforced against him.

The debtor's obligation may be enforced in a proceeding in rem in any State where he has property, though he be absent or a non-resident; or if in a proceeding in personam, the debtor must have been actually found within the court's jurisdiction and process served upon him there, or else he must have voluntarily appeared. It is not essential that the debtor's obligation should be enforced where he resides, though that will ordinarily be the place of its enforcement.

It will be seen therefore that, while the situs of the creditor's right (chose in action) follows the creditor and corresponds to the legal situs of tangible chattels, the situs of the debtor's obligation follows the actual situs of the debtor, or of his property (in case of a proceeding in rem to enforce it), and corresponds to the actual situs of tangible chattels.

If these principles be kept clearly in mind there will be no difficulty in solving most of the problems that present themselves involving the situs of debt, a subject upon which the decisions of the courts present the utmost confusion. The analogy between the situs of tangible chattels and the situs of debts is complete at every point. The legal situs of a debt, as in case of chattels, is the actual or legal situs of the owner (the creditor) according as the particular transaction in question involves the creditor's voluntary or involuntary participation therein. The actual situs of the debt at a particular moment is the place where payment thereof may at that moment-be enforced, whether by proceeding in rem or by proceeding in per. sonam. If the former procedure is used, the actual situs of the debtwill be the actual situs of the res subjected to its payment; if the latter, it will be the domicil of the debtor or some other State, according as he is sued in his own State or in the courts of another which have acquired jurisdiction over him by due process of law.

And, as in the case of tangible chattels, the legal situs of the debt will furnish the "proper law" governing transactions touching the transfer of the creditor's right, while, in the ex- 
ceptional cases mentioned in the second chapter, the actual situs of the debt (and the forum) will be substituted therefor. The actual situs of the debt will be looked to also, as in the case of chattels, when the debt is the res in a proceeding in rem, the question being whether or not the court has jurisdiction of the res.

These points will all be brought out more fully in the following sections.

It will be observed that the fact that the debt is contracted or is made payable by the debtor in a particular State, other than that of his domicil, though regarded as a circumstance of importance by some of the decisions, ${ }^{2}$ in reality has nothing to do with the question, save only in so far as the law of that place may determine whether or not the debt is valid. It has no bearing upon the situs of a valid debt. That is independent of the place of contract. ${ }^{8}$

Nor does the mere fact that the debt is secured upon land or chattels by mortgage, deed of trust, or otherwise affect its situs, save only where the debt is sought to be recovered by proceeding in rem against the debtor's property, and not by personal proceeding against the debtor; in which case the situs of the debtor's obligation (which is the actual situs of the debt) will be the actual situs of his property. ${ }^{4}$

2 See Dial v. Gary, 14 S. C. 573, 37 Am. Rep. 737, 741; Osgood v. Maguire, 61 N. Y. 524, 529 ; Ill. Cent. R. R. Co. $v$. Smith, 70 Miss. 347, 12 So. 461 ; American Ins. Co. $v$. Hettler, 37 Neb. 849, 56 N. W. 711 ; Smith $v$. Taber, 16 Tex. Civ. App. 154, 40 S. W. 156 ; Reimers v. Seatico Mfg. Co., 70 Fed. 573.

8 Hardware Mfg. Co. v. Lang, 127 Mo. 244 ; Cross v. Brown, 19 R. I. 220 ; 33 Atl. 147; Mashassuck Felt Mill v. Blanding, 17 R. I. 297, 21 Atl. 538; Wyman v. Halstead, 109 U. S. 656; Union Pac. R. R. Co. v. Baker, 5 Kan. App. 253, 47 Pac. 563 ; Neufelder $v$. Ins. Co., 6 Wash. 341, 33 Pac. 870 ; Owen $v$. Miller, 10 Ohio St. 136, 75 Am. Dec. 507 ; East Tenn. R. R. Co. v. Kennedy, 83 Ala. 462 ; Pomeroy $v$. Rand, 157 Ill. 185, 41 N. E. 636 ; Berry v. Davis, 77 Tex. 191, 13 S. W. 978 ; Ins. Co. v. Portsmouth, 3 Met. (Mass.) 420 ; Sturtevant $v$. Robinson, 18 Pick. (Mass.) 175 ; Harwell v. Sharp, 85 Ga. 124 ; Howland $v$. R. R. Co., 134 Mo. 474, $36 \mathrm{~S}$. W. 29 ; Ins. Co. v. Chambers, 53 N. J. Eq. 468, 32 Atl. 663.

4 Vroom v. Van Horne, 10 Pai. Ch. (N. Y.) 549, 555, 42 Am. Dec. 94 ; Doolittle $v$. Lewis, 7 Johns. Ch. 46, 11 Am. Dec. 389 ; Hoyt $v$. Thompson, 19 


\section{§ 122. Situs of Debt for Purposes of Voluntary Transfer.}

- The term "voluntary" trausfer is here used to indicate a transfer by the act and agreement of the creditor himself, by indorsement, assignment, or otherwise, in contradistinction to the "involuntary" transfer which takes place by act of the law, as in the case of the succession to the property of a decedent, transfers of the wife's personalty to the husband upon marriage (as under the common law), and compulsory assignments for the benefit of creditors under bankrupt and insolvent laws.

It is also to be observed that the voluntary transfer or assignment of a debt, which passes title to the claim, is an execrited contract, and must be distinguished carefully from the executory contract which usually accompanies it, whereby the assignor engages to make good the debt to the assignee upon the failure of the original debtor. 'This executory contract is governed by different principles, which will be considered when we come to investigate the proper law controlling executory contracts. At present we shall confine our attention to the law regulating the executed transfer of the creditor's chose in action.

The "voluntary" transfer of choses in action includes not only the transfer of the legal title to negotiable paper by indorsement, but also the assignment thereof without indorsement, the assignment of choses in action not negotiable, with or without indorsement, and the voluntary assignments of choses in action for the benefit of creditors.

In these cases there is no dispute as to the general principle that the law of the legal situs of the chose in action is the "proper law" to govern its transfer. We have seen that the legal situs of the chose in action is the situs of the creditor. But is it the actual or the legal situs (or domicil) of the creditor?

Many of the decisions will be found to state it as a general proposition that the lex domicilii of the creditor (that is the law of his legal situs) controls voluntary transfers or assignments of choses in action. ${ }^{1}$

N. Y. 207, 224 ; Dial v. Gary, 14 S. C. 573, 37 Am. Rep. 737; Van Wyck $v$. Read, 43 Fed. 716.

1 Speed $v$. May, 17 Penn. St. 91, 94, 55 Am. Dec. 540 ; Black v. Zacharie, 3 How. 483 ; Van Wyck $v$. Read, 43 Fed. 716 ; Catlin $v$. Wilcox Plate Co., $12 s$ 
But it must be remembered that the transfer is effected by the voluntary and deliberate act of the owner; and in choosing to enter into the transaction at a particular place, he chooses to submit himself to the sovereignty and laws of that place. $\mathrm{He}$ may, and usually will, make the transfer in his domicil, and in such case the law of his domicil will control, not because it is the law of his domicil however, but because it is the law of the place where the transfer is made (lex loci contractus). ${ }^{2}$ But he may choose to enter into the transaction in a State other than his domicil, under a law different from that of his domicil. There can be little doubt that freedom of locomotion and of action, as well as the demands of trade and commerce, require that the chose should, for purposes of voluntary assignment under the contract of the owner, be generally deemed to be at the actual situs of the creditor at the time of the assignment, and that the transfer should be regulated by the law of the place where he deals, to which the parties must be regarded as submitting themselves for that purpose. The true rule therefore is that the lex loci contractus (which may or may not be identical with the lex domicilii of the creditor) should control voluntary transfers. ${ }^{3}$

Ind. 477, 8 L. R. A. 62 ; Clark v. Peat Co., 35 Conn. 303 ; Paine v. Lester, 44 Conn. 196, 26 Am. Rep. 442; Fowler's Appeal, 125 Penn. St. 388, 17 Atl. 431 ; Long v. Girdwood, 150 Penn. St. 413, 24 Atl. 711, 23 L. R. A. 33 ; Butler $v$. Wendell, 57 Mich. 62, 58 Am. Rep. 329 ; Woodward v. Brooks, 128 Ill. 222,20 N. E. 685 ; Askew v. Bank, 83 Mo. 366, 53 Am. Rep. 590 ; Birdseye $v$. Underhill, 82 Ga. 142, 7 S. E. 863 ; Fuller $v$. Steiglitz, 27 Ohio St. 355, $22 \mathrm{Am}$. Rep. 312. But in all these cases, as well as in others laying down the same rule, the assignment was made by the creditor in the State of his domicil. Hence the legal situs and the actual situs of the assignor are identical, and these cases prove nothing. This is an instance of the looseness of phraseology which has tended so much to add to the intrinsic difficulties of this branch of the law.

2 See cases cited supra, note 1.

3 Dial v. Gary, 14 S. C. 573, 37 Am. Rep. 737, 738; Hoyt v. Thompson, 19 N. Y. 207, 224; Milne v. Moreton, 6 Binn. (Penn.) 353, 369, 6 Am. Dec. 166 ; Tyler $v$. Strang, 21 Barb. (N. Y.) 198 ; Butler $v$. Wendell, 57 Mich. 62, 58 Am. Rep. 329 ; Woodward v. Brooks, 128 Ill. 222, 20 N. E. 685, 686 : First Nat. Bank v. Walker, 61 Conn. 154, 23 Atl. 696; Egbert v. Baker, 58 Conn. 319, 20 Atl. 466; May $v$. Wannemacher, 111 Mass. 202. In the last 
But in ascertaining the "proper law" regulating voluntary transfers and assignments of choses in action, and in fixing it as the lex loci contractus, the reader must not overlook the exceptions to the enforcement of the proper law, already so frequently referred to. ${ }^{4}$ In these cases, it will be remembered, the lex fori will be substituted; and since the question will always arise upon an attempt to enforce the debtor's obligation to pay, the lex fori and the actual situs of the debt will coincide.

The most usual instances of these exceptions are those which arise from danger to the interests of the forum or its citizens, should the proper law be enforced. Hence, if the assignment of the chose in action, though valid where made, would injuriously affect the interests of the State where the debt is sought to be enforced (forum and actual situs of the debt), ${ }^{5}$ or the interests of its citizens, ${ }^{6}$ or would contravene its settled policy or express statutory provisions, ${ }^{7}$ or would be contra bonos mores, ${ }^{8}$ or if such assignment is rendered invalid where made, as a penalty for wrong-doing; ${ }^{\circ}$ in all these cases, the law of the actual situs of the debt, that is, the actual situs of the debtor when sued (in a proceeding in personam), being also the forum, will be substituted for the "proper law." If the debt be sought to be recovered

three of these cases the transfer occurred in a State where the ownew (or some of them) were not domiciled. The situs of the debts assigned was held to be at the place of transfer. In the last two cases the creditors assigning the debts were partners living in different States. Much difficulty might be experienced in such cases if the debt were placed at the creditor's domicil. It will be remembered 2 lso that the cases cited supra, note 1, are not against this position; the domicil and the locus contractus were in those cases identical.

- Ante, Chapter II.

5 Harrison v. Sterry, 5 Cr. 289, 299 ; Holmes v. Remsen, 4 Johns. Ch. (N. Y.) 460, 488, 8 Am. Dec. 581.

6 Blake $v$. Williams, 6 Pick. (Mass.) 286, 17 Am. Dec. 372 ; Milne $v$. Moreton, 6 Binn. (Penn.) 353, 361, 6 Am. Dec. 466; Speed $v$. May, 17 Penn. St. 91, 94, 55 Am. Dec. 540; Dial v. Gary, 14 S. C. 573, 37 Am. Rep. 737, 741.

7 Savings Bank v. Nat. Bank, 38 Fed. 800 ; Black $v$. Zacharie, 3 How. 483, 514 ; Atty. Gen. v. Dimond, 1 C. \& J. 356 ; Atty. Gen. v. Hope, 1 C. M. \& R. 530, 8 Bligh, 44 ; Atty. Gen. $v$. Bouwens, 4 M. \& W. 171. See Story, Conth L. $\$ 383$.

8 See Savings Bank $v$. Nat. Bank, 38 Fed. 800.

$\checkmark$ See Scoville v. Canfield, 14 Johns. (N. Y.) 338. 
by a proceeding in rem, the actual situs of the res (and the forum) will be the actual situs of the debt.

$\S 123$. Situs of Dobt for Purpose of Tazation. - It may perhaps be said to be contrary to the general practice for a State to tax the tangible chattels of a non-resident situated within its limits, such taxation being left to be imposed by the State of the owner's domicil, upon the theory that the property has its legal (though not its actual) situs at the owner's domicil. ${ }^{1}$ But taxation is emphatically an instance where a State has the right to throw aside all fictions and look at things as they are. Accordingly States frequently tax the tangible personalty of non-residents when actually situated within their borders. In such cases, however, the State of the actual situs only imposes the tax burden upon the property within its jurisdiction. It cannot constitutionally impose a personal liability upon the non-resident owner. $^{2}$

But where the property is intangible, such as debts, more difficulty is experienced in ascertaining the situs where it may be taxed. The general practice is to treat debts as located, for purposes of taxation, at the creditor's domicil, and there is no doubt that they may have their situs there for that purpose. ${ }^{8}$ On the other hand, it would seem that, if the creditor were domiciled in one State and the debtor in another, there should be no reason why the latter State (which is the situs of the obligation and

1 Cooley, Taxation (2d ed.) 372 ; People v. Com'rs, 23 N. Y. 224, 240 ; Com. v. R. R. Co., 27 Gratt. (Va.) 344 ; Buck v. Miller, 147 Ind. 586, 45 N. E. 647, 648 ; Thorndike $v$. Boston, 1 Met. (Mass.) 242. See Borland $x$. Boston, 132 Mass. 89, 42 Am. Rep. 424.

2 Mills $v$. Thornton, 26 Ill. 300, 79 Am. Dec. 377; Com. v. Gaines, $80 \mathrm{Ky}$. 489 ; Leonard $v$. New Bedford, 16 Gray (Mass.), 292; Dow v. Sudbury, 5 Met. (Mass.) 73 ; Buck v. Miller, 147 Ind. 586, 45 N. E. 647, 648 ; People $v$. Com'rs, 23 N. Y. 224, 240.

3 Hunt v. Perry, 165 Mass. 287, 43 N. E. 103 ; Dykes v. Lockwood, 2 Kan. App. 217, 43 Pac. 268 ; Bradley v. Bander, 36 Ohio St. 28, 3 Am. St. Rep. 547; Com. v. R. R. Co., 27 Gratt. (Va.) 344 ; Herron v. Keran, 59 Ind. 472 ; Ins. Co. v. Assessors, 47 La. Ann. 1544, 18 So. 519; Wilcox v. Ellis, 14 Kan. 589, 19 Am. Rep. 107; Baltimore v. Hussey, 67 Md. 112 ; Ferris $v$. Kimble, 75 Tex. 476 ; State Bank $v$. Richmond, 79 Va. 113 ; Tax on Foreign Held Bonds, 15 Wall. 300 . 
the actual situs of the debt) cannot lay a tax upon the creditor's property actually situated there, namely, the debtor's obligation to pay, provided in so doing it does not impair the obligation of contracts. And some courts have upheld such taxation." But, strangely enough, the general trend of judicial opinion seems to be in the direction of regarding such taxation as unlawful, upon the ground that the debtor has no property in the debt which can be taxed. ${ }^{5}$ This idea would certainly seem to be founded on a misapprehension. It is conceded that the debtor has no property in the debt belonging to the creditor, but his obligation to pay is itself valuable property belonging to the creditor, at least after the debt becomes due and enforceable, and no reason is perceived why the State could not compel the debtor to pay a tax thereon, erediting him with the amount so paid on his debt. But, at best, this form of taxation is cumbersome, and has been but little used, most States leaving debts of all sorts to be taxed at the domicil of the creditor.

Thus shares of stock in a corporation are usually taxable at the domicil of the owner, not of the corporation; ${ }^{6}$ but the right of the State of the corporation's domicil also to lay a tax upon such stock is admitted. ${ }^{7}$

In States whose policy is to tax choses in action at the domicil of the creditor, a question has sometimes arisen whether this includes negotiable instruments. Some courts, regarding them as actual currency, have sustained taxation upon them where

4 Bridges v. Griffin, 33 Ga. 113 ; Railroad Co. v. Collector, 100 U. S. 595 ; United States v. R. R. Co., 106 U. S. 327 ; Finch v. York County, 19 Neb. 50.

5 Cooley, Taxation ( $2 \mathrm{~d}$ ed.), 22 ; citing State Tax on Foreign Held Bonds, 15 Wall. 300, 319, 320 ; Oliver $v$. Washington, 11 Allen (Mass.), 268 ; Com. v. R. R. Co., 27 Gratt. (Va.) 344 ; and other cases.

6 Bradley $v$. Bander, 36 Ohio St. 28, 38 Am. Rep. 547; Nashville $v$. Thomas, 5 Coldw. (Tenn.) 600 ; Worth $v$. Ashe Co., 90 N. C. 409 . And this, even though a tax has already been paid on the stock in the domicil of the corporation. See McKeen $v$. Northampton Co., 49 Penn. St. 519, 88 Am. Dec. 515 ; Dwight v. Boston, 12 Allen (Mass.), 316 ; Dyer v. Osborne, 11 R. I. 321, 23 Am. Rep. 460 ; Seward $v$. Rising Sun, 79 Ind. 351.

- Tappan v. Bank, 19 Wall. 490 ; Faxton v. McCosh, 12 Ia. 527; American Coal Co. v. Allegheny County, $59 \mathrm{Md}$. 185. But see Union Bank v. State, 9 Yerg. (Tenn.) 490. 
the paper evidences of indebtedness happen to be, regardless of the locality of the creditor's residence. ${ }^{8}$ But this view is inconsistent with the real facts and with general principles, and the better opinion is that they should be taxed at the creditor's domicil. ${ }^{\circ}$

§ 124. Situs of Debt for Purpose of Administration. - In connection with the subject of executors and administrators, we have seen that wherever a decedent's assets are actually situated in a State other than his domicil, it is a general principle that such assets must be first of all administered in conformity to the lex fori and lex situs of the property, in the interest of the citizens of the forum and actual situs of the property, before it is to be regarded as subject to the lex domicilii of the decedent. It will be remembered that the executor or administrator must qualify anew in every jurisdiction where the deceased has left assets, and that until such qualification no act of the domiciliary administrator will be of any effect, as to property situated in another State, at least if there are any citizens of that State who may be injured by such action. ${ }^{1}$

Little difficulty is experienced in applying these principles when the assets are tangible chattels, capable of occupying space, and therefore possessing an actual situs of their own. But the ascertainment of the situs of a debt for these purposes has given the courts some trouble, which has arisen in large measure from the failure to observe the distinction between the legal and the actual situs of debts, already adverted to. ${ }^{2}$

Thus we find the courts divided in opinion upon the question whether an executor or administrator appointed in the State of a deceased creditor's domicil can there assign the debt to a third person so as to enable him to sue the debtor in another State.

8 Redmond $v$. Rutherford, 87 N. C. 133; Wilcox $v$. Ellis, 14 Kan. 588, 19 Am. Rep. 107 ; Poppleton $v$. Yamhill County, 18 Oregon, 377.

9 State Tax on Foreign Held Bonds, 15 Wall. 300 ; Boyd v. Selma, 96 Ala. 144, 11 So. 393 ; State Bank $v$. Richmond, 79 Va. 113; New Orleans $v$. Ins. Co., 30 La. Ann. 876, 31 Am. Rep. 232 ; Lanesborough v. Berkshire County, 131 Mass. 424.

1 Ante, §§ 105 et seq.

2 See Wyman $v$. Halstead, 109 U. S. 656. 
In Dial $v$. Gary, ${ }^{8}$ it was held that the assignee could not sue, since that would be practically to permit a foreign administrator to administer upon the decedent's property in South Carolina, without having qualified therein or administered there, whereby its own citizens might be injured.

On the other hand, in Petersen $v$. Chemical Bank, ${ }^{4}$ the debtor was sued in his domicil (New York) by the assignee of an administrator appointed in Connecticut, the creditor's domicil, and it was held he was entitled to recover. In this case, however, the court states that there were no creditors of the deceased in New York, and that there was no motive for forbidding the withdrawal of the assets. ${ }^{5}$

Upon principles already noted, the law of the actual situs of the debt (and the forum) will govern the administration, so long as the enforcement of that law is necessary to the protection of its citizens. And the actual situs of the debt in the cases given above was the domicil of the debtor, for that was where his obligation to pay was sought to be enforced. No assignment of the debt therefore in its legal situs (the creditor's domicil) could operate to pass title to a debt actually situated in another State (the debtor's domicil) any more than the transfer of a tangible chattel under similar circumstances. To this extent therefore the South Carolina decision was clearly correct. ${ }^{6}$ But if there are no creditors of the decedent in the forum and actual situs, the reason for looking to the actual situs of the debt ceases, and the proper law (lex domicilii) will once more be applicable. ${ }^{7}$ In this aspect of the case, the New York decision was also correct.

It has been said that the first branch of the rule does not apply to negotiable instruments, and that an administrator may

814 S. C. 573, 37 Am. Rep. 737.

42 N. Y. 21, 88 Am. Dec. 298.

532 N.Y. 48. The court seemed to consider that fact of little importance, but it is submitted that it is the point upon which the decision should turn.

- See also Stearns $v$. Burnham, 5 Greenl. (Me.) 261; Vroom v. Van Horne, 10 Pai. Ch. 549, 42 Am. Dec. 94; Hall v. Harrison, 21 Mo. 227, 64 Am. Dec. 225. But see Harper $v$. Butler, 2 Pet. 239.

7 Petersen v. Chemical Bank, 32 N. Y. 21, 48, 88 Am. Dec. 298 ; Harvey v. Richards, 1 Mason, C. C. $380,413$. 
freely dispose of them, though the debtor lives in another State, since to refuse the assignee the right to sue the debtor upon such a note would put a stop to its negotiability. ${ }^{8}$

Another point, upon which the courts are divided, the solution of which is dependent upon the actual situs of a debt, is whether an administrator may sue a debtor of the estate domiciled elsewhere, but whom he finds transiently in the State of his appointment." Since, as we have seen, the actual situs of a debt is any State where the obligation to pay may be enforced by suit, and since in this case the debtor has come within the jurisdiction of the administrator, there is no doubt that, stricto jure, he is entitled to sue him there. The case is analogous to that of a tangible chattel of a decedent, to which one administrator of the deceased is entitled, transiently passing through the State of another administrator of the same decedent. There can be no doubt that the administrator of the latter State may lay hold of such property for the benefit of its own resident creditors. But such action would appear to be closer akin to robbery than to justice, and would hardly comport with the comity that should regulate the relations of States to each other. ${ }^{10}$

If there are no creditors of the deceased, or the administration has been completed, the creditors paid off, and the only thin remaining is to distribute the residuum, the actual situs of the debt ceases to furnish the applicatory law, and its legal situs (in this case the legal situs, or domicil, of the creditor) resumes its sway. 11

$\S 125$. Situs of Debt for Purpose of Attachment and Garnishment. ${ }^{1}$ - Perhaps on no one point has there been a greater

8 Story, Confl. L. $\$ \S 258,259$; Petersen v. Chemical Bank, 32 N. Y. 21, 42, $88 \mathrm{Am}$. Dec. 298. Here there is a conflict of policies, the relative importance of which the courts of the forum must decide.

9 See Merrill v. Ins. Co., 103 Mass. 245 ; Stevens v. Gaylord, 11 Mass. 256 ; Hall $v$. Harrison, 21 Mo. 227, 64 Am. Dec. 225, 227.

10 See Crouch $v$. Dabney, 2 Gratt. (Va.) 415.

11 Mayo v. Equitable Society, 71 Miss. 590, 15 So. 791 ; Petersen v. Chemical Bank, 32 K. Y. 21, 88 Am. Dec. 298; Harvey v. Richards, 1 Mason, C. C. 380,413 . See Dawes $v$. Boylston, 9 Mass. 337.

1 In the preparation of this section, the writer has been much aided by 
variety of judicial opinion than upon the topic now to be exam. ined. Briefly, the question may be thus stated: A of New York owes B of Massachusetts $\$ 1000$. B owes C of New York or Virginia a like sum. B has no property save A's debt. $\mathbf{C}$ desires to sue out an attachment against $B$ in New York, and to summon $\mathrm{A}$ before the Now York courts upon process of garnishment. Have the New York courts jurisdiction of the proceeding, $\mathrm{B}$ being a non-resident and not personally before the court?

The attachment proceeding being in rem, and not in personam, if the res is before the New York courts, it is not necessary that the owner of the property seized should be within their jurisdiction. The fact that he is a non-resident is immaterial. ${ }^{2}$ Hence in these cases the sole question to be determined is this : Is the res within the jurisdiction of the attaching court? The res is the debt due to $\mathrm{B}$ by $\mathrm{A}$, and hence we are confronted with the pregnant question, what is the situs of A's debt to $B$ ? Has it its situs with the creditor (B) at his domicil, or at the domicil of the debtor $(\mathrm{A})$, or at the actual situs of $\mathrm{B}$ or $\mathrm{A}$, respectively? If the debt is to be regarded as with the creditor (B), the fact that $A$ is within the jurisdiction of the court will be of no avail. But if the debt is with the debtor, then the presence of $A$ within the jurisdiction is all important, and the locality of $\mathrm{B}$ is immaterial.

Owing to the great confusion that has existed in respect to this subject, it has frequently happened that a debtor, who in one jurisdiction has been garnished in attachment proceedings and been compelled to pay his debt to his creditor's creditor, has been subsequently compelled in another jurisdiction to pay the same debt over again to another creditor of his creditor, on the ground that the first court had no jurisdiction of the res. Such a state of affairs is a disgrace to the law, calling for a speedy recognition of some principle upon which the question of jurisdiction may be determined once for all.

Many theories have been advanced by the various courts as to

reference to an able thesis on the subject by J. L. Templeman, Esq., formerly a student of the University of Virginia, now a practitioner in Butte, Montana For the assistance thus given, grateful acknowledgment is here made.

2 Ante, $\$ \S 85,86$; Pennoyer $v$. Neff, 95 U. S 714.

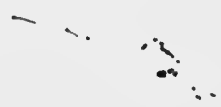


the situs of debts under circumstances like these, some of the more important of which will now be examined briefly. In considering the merits of these various theories, one important principle, already discussed, must be constantly borne in mind: that principle is, that, for purposes of ascertaining the jurisdic. tion of a conrt over a res, the actual situs of the res is regarded, not its legal or constructive situs. ${ }^{8}$

First Theory. - Many of the courts have declared in favor of the extreme view that the situs of a debt is at the domicil of the creditor, and that it cannot be attached in another State for want of jurisdiction over the res. In the example above given, these courts would hold that A's debt to B could only be at. tached by $\mathrm{C}$ in Massachusetts (B's domicil). ${ }^{4}$ This view disregards altogether the dual nature of debt, which, while placing the creditor's right to sue (or chose in action) with the creditor, places the debtor's obligation to pay and the creditor's ability to exact payment with the debtor. In other words, though the question is one of jurisdiction over a res, these courts disregard the actual situs of the property, and look only to its legal or constructive situs. This view would clearly seem to be erroneous.

Second Theory - Legislative Fiat. - Another line of cases, while recognizing the same general principle as those holding the first theory, yet for purposes of garnishment, in order to do effectual justice, find it necessary to resort to phraseology which, if interpreted literally, seems wholly unjustifiable. These cases hold that a debt for most purposes has its situs at the creditor's domicil, but for purposes of garnishment a State may by legislative fiat fix its situs at the debtor's domicil. ${ }^{5}$

8 Ante, §§ 14, 120.

4 Railroad Co. v. Nash, 118 Ala. 477, 23 So. 825 ; Railroad Co. v. Chumley, 92 Ala. 317, 9 So. 286 ; Bucy v. R. R. Co. (Miss.), 22 So. 296; Railroad Co. v. Smith, 70 Miss. 344, 12 So. 461 ; Railrnad Co. v. Sharritt, 48 Kan. 375, 23 Pac. 430; Lovejoy v. Albee, 33 Me. 414, 54 Am. Dec. 630; Smith v. Eaton, 36 Me. 298, 58 Am. Dec. 746; Central Trust Co. v. R. R. Co., 68 Fed. 685 ; Mason v. Beebee, 44 Fed. 556. See also Railroad Co. v. Maggard, 6 Colo. App. 85, 39 Pac. 985 ; Caledonia Ins. Co. v. Wenar (Tex. Civ. App.), 34 S. W. 385.

5 Williams v. Ingersoll, 89 N. Y. 523 ; Douglas v. Ins. Co., 138 N. Y. 209 : 
It can hardly be supposed, however, that the courts mean to say that a legislature, by mere decree, can cause a thing to be situated where in fact it is not. All that is meant probably is that, though ordinarily the law will adopt the fiction that debts are located at the situs of the creditor, this fiction may be disregarded, and the actual situs of the obligation substituted therefor, whenever policy may require it. Under this view, the rules governing the situs of debts are assimilated to those governing the situs of tangible chattels, and the theory becomes identical with the fourth theory hereafter mentioned. ${ }^{6}$

Third Theory - Another theory (which may be denominated the fund theory) distinguishes between the chose in action (following the creditor) and the money owing (in the hands of the debtor), which constitutes a fund held by the debtor but belonging to the creditor, which fund is the res in the attachment proceeding; holding that, since the debtor's funds are to be presumed to be at his domicil, the attachment can only issue there. This theory rests upon the idea that the creditor has the right to recover of the debtor a certain specific sum of money, and that by his attachment the attaching creditor becomes subrogated to this right, and may proceed to recover the debt in the place of the original creditor, and in the same jurisdiction.: It is submitted, however, that this view is fallacious, in that it requires as a basis one of two suppositions (or both): (1) That there is specific property belonging to the original creditor now in the debtor's hands; (2) That the court, which seizes the right of the original creditor to sue and turns it over to the attaching creditor, has jurisdiction of that right, for otherwise it could not attach it. But it is admitted by all the authorities

Swedish-American Bank v. Bleeker, 72 Minn. 383, 75 N. W. 740, 71 Am. St. Rep. 492 ; Bragg v. Gaynor, 85 Wis. 468, 55 N. W. 919 ; Morawetz v. Sun Ins. Office, 96 Wis. 175,71 N. W. 109 ; Renier $v$. Hurlbut, 81 Wis. 24, 50 N. W. 783 ; Reimers $v$. Mfg. Co., 70 Fed. 573.

6 See Mooney $v$. Buford, 72 Fed. 38 ; Railroad Co. v. Nash, 118 Ala. 477, 23 So. 325 ; National Ins. Co. v. Chambers, 53 N. J. Eq. 468, 32 Atl. 663 ; Lancashire Ins. Co. v. Corbett, 165 Ill. 592, 46 N. E. 631.

7 This seems to be in part the theory upon which Mr. Waples bases his interesting treatise on the Situs of Debt. Waples, Debtor and Credicor. Soe Berry v. Davis, 77 Tex. 191, 13 S. W. 978. 
that the right of the original creditor to sue is with the creditor (who is not within the jurisdiction of the courts of the debtor's domicil). And it must be conceded also that there is with the debtor no specific fund or money belonging to the creditor, but only a general liability or obligation to pay.

Fourth Theory. - Another theory, which has been accepted and adopted by many of the courts, is that the legal situs of the creditor's right is to be distinguished from the actual situs of the debtor's obligation; that as the former is located with the creditor at his domicil, so the latter is situated at the debtor's domicil; and that, for purposes of jurisdiction in rem, the court must regard the actual situs of the debt. ${ }^{8}$

The fallacy of this theory is that it treats the obligation of the debtor as local instead of transitory, as fixed at his domicil, instead of following his person whithersoever he may go. In other words, this view regards the actual situs of the debt as at the legal rather than the actual situs of the debtor. This is fallacious. The creditor is not confined to the debtor's domicil for the purpose of enforcing the obligation to pay, but may proceed against him wherever he finds him, unless the municipal law forbids. All that is necessary is that the court should have jurisdiction of the debtor's person, by his voluntary appearance or by process served upon him within the territorial limits of the court's jurisdiction.

Fifth and True Theory. - The fourth theory, as we have just seen, is erroneous simply because of the narrow limits it allows to the actual situs of a debt, confining it to the debtor's domicil. The true theory is that the situs of a debt, for purposes of garnishment, is not only at the domicil of the debtor, but in any state in which the garnishee may be found, provided the municipal law of that State permits the debtor to be garnished, ard provided the court acquires jurisdiction over the

8 Bragg v. Gaynor, 85 Wis. 468, 55 N. W. 924 ; Cross $v$. Brown, 19 R. I. 220, 33 Atl. 147 ; Lawrence $v$. Smith, 45 N. H. 533, 86 Am. Dec. 183 ; Tingley $v$. Bateman, 10 Mass. 343; Lerkin $v$. Wilson, 106 Mass. 120 ; Craig $v$. Gunn, 67 Vt. 92, 30 Atl. 860 ; Newland $v$. Reilly, 85 Mich. 151, 48 N. W. 544. See Chicago, etc. R. R. Co. v. Sturm, 174 U. S. 710 ; King v. Cross, 175 U. S. 396. 
garnishee, through his voluntary appearance or actual service of process upon him within the State. Of course in most cases the question will arise in the garnishee's domicil. ${ }^{\circ}$

Sixth Theory. - A few cases will be found, which regard the place where the debt is payable as important in fixing its situs for the purpose of garnishment. ${ }^{10}$ But these have no basis of principle upon which to rest, and may be disregarded, as founded upon a misapprehension of the question involved. ${ }^{11}$

$\S 126$. Same - Exemptions. - A question incidental to garnishment proceedings sometimes arises as to the law which should govern the legal exemptions to be claimed by the attachment defendant. The question has usually arisen with respect to the wages of laborers, exempt by law from their debts, in cases where the law of the attachment defendant's domicil entitles him to exemption of wages, while the law of the forum (the place of the attachment and garnishment) does not, or not to the same extent; or where there is a difference on this point between the law of the place where the defendant entered into his contract of service and the law of the forum. In such cases,

9 Morgan v. Neville, 74 Penn. St. 52, 57-58; Neufelder $v$. Ins. Co., $6 \mathrm{~W}$ ash. 341, 33 Pac. 870 ; Mooney v. R. R. Co., 60 Ia 346, 14 N. W. 343 ; Harvey v. R. R. Co., 50 Minn. 405, 52 N. W. 905 ; National Ins. Co. v. Chambers, 53 N. J. Eq. 468, 32 Atl. 663 ; Howland v. R. R. Co., 134 Mo. 474, 36 S. W. 29; Manufacturing Co. v. Lang, 127 Mo. 242, 29 S. W. 1010 ; Burlington, etc. R. R. Co. v. Thompson, 31 Kan. 180, 47 Am. Rep. 497 ; Railroad Co. v. Crane, 102 Ill. 249, 40 Am. Rep. 581. See also Chicago, etc. R. R. Co. v. Sturm, 174 U. S. 710 ; Mooney v. Mfg. Co., 72 Fed. 32 . In the last case the court announces the doctrine that a garnishment is a proceeding in personam. This is contrary to the usually accepted idea, but it is believed the court is correct. The attachment is a proceeding in rem, the res being the general liability of the debtor, which general liability upon its seizure by the attaching creditor can be rendered fixed and definite only by a proceeding in personam against the debtor, that is, by garnishment. See Fithian $v$. R. R. Co., 31 Penn. St. 114.

10 See Manufacturing Co. v. Lang, 127 Mo. 242, 29 S. W. 1010 ; Lawrence v. Snith, 45 N. H. 533, 86 Am. Dec. 183 ; Tuller v. Arnold, 93 Cal. 166, 28 Pac. 863 ; American Ins. Co. v. Hettler, 37 Neb. 849, 56 N. W. 711 ; McBee v. Purcell Bank (Ind. Ter.), 37 N. W. 55 ; Mo. Pac. R. R. Co. v. Sharrith, 43 Kan. 375, 387, 23 Pac. 430.

11 Chicago, etc. R. R. Co. v. Sturm, $17 \pm$ U. S. 710, 716-717. 
the decisions of the courts as to what law shall govern the exemption to be accorded have not been uniform.

If the court where the attachment issues has jurisdiction of the res (that is, of the garnishee), following the rule that exemptions usually pertain to the remedy, and that the lex fori therefore ordinarily regulates them, ${ }^{1}$ the general principle is that the law of the forum will usually determine what exemption the attachment-defendant is entitled to. This subject is fully treated hereafter, and its consideration had better be postponed until then. ${ }^{2}$

1 Post, § 209.

2 Post, § 209. 


\section{CHAPTER XI.}

\section{VOLUNTARY TRANSFERS OF PERSONALTY INTER VIVOS.}

$\S 127$. Preliminary - Various Kinds of Transfer. - We have seen that the legal situs of personalty will usually furnish the "proper law" to govern transfers thereof, while the law of the actual situs of the property or the lex fori will be substituted for the proper law whenever the interests of the forum or its citizens demand such a course, and indeed in all cases where the exceptions to the operation of the proper foreign law come into play.

It will also be remembered that the legal situs of personalty follows the actual or the legal situs of the owner, according as the personalty is dealt with in a transaction in which the owner voluntarily participates or in a transaction in which his participation is involuntary or compulsory, a transaction resulting merely by operation of law. In case of voluntary transactions, the actual situs of the owner furnishes the proper law. In case of involuntary transactions, the law of the legal situs of the owner prevails. But both are liable to be substituted by the law of the actual situs of the property under the circumstances mentioned.

Voluntary transfers are always the result of the owner's agreement, made in the exercise of his jus disponendi, such as absolute conveyances, executed sales, chattel mortgages and deeds of trust, conditional sales with reservation of title, deeds of assignment for the benefit of creditors, etc.

Involuntary transfers are those resulting not from the voluntary agreement of the owner, but from the mere operation of law, independently of the parties' will. Some of these transfers are effected by the law solely in the interests of creditors and other third persons, as in the case of involuntary assignments in bankruptcy and insolvency. Others are effected upon 
grounds of public policy, entirely irrespective of the rights of creditors and third persons, as in the case of the husband's common law title to the wife's personalty upon marriage. And still others are based upon both grounds, as in case of the succession to a decedent's estate, in which case the title of the administrator belongs in the main to the first head, while the title of the distributees to the residuum belongs to the second.

If the purpose of the involuntary transfer is the protection of creditors, each State wherein any of the property is located looks first of all to the protection of its own citizens, and a transfer of the owner's property in another State for such purpose, even in the State of the owner's domicil, will be given in general no effect in any other State as to property actually situated there, so long as there are creditors there unsatisfied. The law of the actual situs of the personalty, not of its legal situs (lex domicilii), is applied so regularly in such cases as to obscure and almost wipe out the general principle that in all cases of involuntary transfer the lex domicilii of the owner furnishes the "proper law."

But the latter principle again clearly shines forth when we come to deal with the second class of iuvoluntary transfers, resulting from general motives of policy, not for the protection of creditors. In such cases the substitution of the lex fori et situs for the proper law (lex domicilii) is comparatively rare.

$\S 128$. Absolute Conveyances and Executed Sales of Personalty. - An unbroken line of authority sustains the general proposition that, as between the parties, the law of the actual situs of the owner at the time of the transfer, that is, the law of the place where the transfer is made (lex loci contractus), governs the validity and effect of absolute conveyances of personalty, including assignments of choses in action and executed sales. The conveyance, assignment, or sale, if valid where made, will be upheld, as between the parties, in every jurisdiction in which it may be called in question; if invalid where made, it will not be sustained elsewhere. ${ }^{1}$

1 Black v. Zacharie, 3 How. 483, 514 ; Kerr v. Urie, 86 Md. 72, 37 Atl. 789 ; Fowler's Appeal, 125 Penn. St. 388, 17 Atl. 431; Marvin Safe Co. v. Norton, 45 N. J. L. 412, 57 Am. Rep. 566, 7 Atl. 418; Weinstein $v$. Freyer, 
It must be observed however that while the validity of the substantial provisions and of the formalities of the transfer, as between the parties, is to be tested by the lex loci contractus, its validity, so far as it depends upon the legality of the consideration, may be governed by a different law, in cases where the situs of the consideration is a State other than the locus contractus.

Hence, although in case of articles prohibited to be sold in one State, a sale thereof made in another State and valid there will not be held invalid even in the prohibiting State, and even though the goods were purchased to be resold in the forum and the vendor knew that fact, ${ }^{2}$ yet if the vendor not only knew that the goods were to be resold in the forum, but knew also that such sale was contrary to the law of that State, the vendor will not be allowed, according to the better opinion, to recover the price in the courts of the State whose laws he has deliberately helped to violate. $^{3}$ A fortiori, he would not be entitled to recover there, if he should take any active steps to aid the vendee in disposing of the articles in the prohibiting State, in conscious violation of its law. Nor indeed should he be permitted to sue in any State upon a contract the deliberate purpose of which is to violate the laws of a sister State. ${ }^{5}$

Difficulty is sometimes experienced in ascertaining the locus contractus in case of sales. This topic will be fully developed

93 Ala. 257, 8 So. 285 ; In re Dalpay, 41 Minn. 532, 43 N. W. 564 . So executed sales of personalty, as between the parties, are governed by the lex loci contractus as to their validity and effect. Suit $v$. Woodhall, 113 Mass. 391 ; Tarbox v. Childs, 165 Mass. 408, 43 N. E. 124 ; Erman v. Lehman, 47 La. Ann. 1651, 18 So. 650 ; Claflin v. Meyer, 41 La. Ann. 1048, 7 So. 139 ; Sullivan $v$. Sullivan, 70 Mich. 583, 38 N. W. 472 ; Webber $v$. Howe, 36 Mich. 150, 24 Am. Rep. 590 ; Fred Miller Brewing Co. $v$. De France, 90 Ia. 395, 57 N. W. 959 ; Boothby $v$. Plaisted, 51 N. H. 436, 12 Am. Rep. 140 ; Beverwyck Brew. ing Co. v. Oliver, 69 Vt. 323, 37 Atl. 1110.

2 Merchants' Bank $v$. Spalding, 9 N. Y. 53.

8 Webster $v$. Munger, 8 Gray (Mass.), 584 ; Graves v. Johnson, 156 Mass. 211, 30 N. E. 818,32 Am. St. Rep. 446, 450, note. But see Hill v. Spear, 50 N. H. 253, 9 Am. Rep. 205 ; McIntyre $v$. Parks, 3 Met. (Mass.) 207.

4 Pratt $v$. Adams, 7 Pai. Ch. (N. Y.) 615, 632; Knowlton $v$. Doherty, 87 Me. 518, 47 Am. St. Rep. 349; Hill v. Spear, 50 N. H. 253, 9 Am. Rep. 205.

-Weil v. Golden, 141 Mass. 364. 
hereafter in examining the locus contractus of executory con. tracts. Only a few general principles will here be mentioned."

The locus contractus of a sale is the place where the sale is finally completed. Until that time the contract is in fieri, the title has not passed. It is not until the vendor has done everything in connection with the transfer necessary to pass title that the sale is completed. The place where the final act essential to this result is performed is the locus contractus. The place at which the order is given, or from which the order is sent to the vendor, however important to the determination of the locus contractus of an executory contract, furnishes no safe guide in fixing the place of an executed sale. ${ }^{7} p$

In Dolan $v$. Green, ${ }^{8}$ the plaintiff purchased intoxicating liquors from the defendant, paying him for them, and then sought under the Massachusetts statute to recover the price he had paid, the sale being invalid by the law of Massachusetts. It appeared that the defendant, who resided in Rhode Island, agreed with the plaintiff in Massachusetts to sell the liquors; from time to time he selected them from his stock in Rhode Island and delivered them there on board the cars, the plaintiff paying the freight. It was held that the sale was made in Rhode Island, and being valid there was to be deemed valid in Massachusetts. The plaintiff was not permitted to recover.

On the other hand, in Weil $v$. Golden, ${ }^{9}$ it appeared that an order was taken from Golden in Rhode Island by an agent of a liquor house in Philadelphia. The liquors were delivered at the vendee's place of residence in Rhode Island, the agent paying the freight to the place of delivery. It was held that Rhode Island was the place of the sale, the vendor's last act in com-

6 See post, $\S \S 157,158$.

7 See Sullivan $v$. Sullivan, 70 Mich. 583, 38 N. W. 472; Suit $v$. Woodhall, 113 Mass. 391 ; State $v$. O'Neil, 58 Vt. 140, 56 Am. Rep. 557 ; Beverwyck Brewing Co. v. Oliver, 69 Vt. 323, 37 Atl. 1110 ; Boothby v. Plaisted, 51 N. H 436, 12 Am. Rep. 140; Tegler v. Shipman, 33 Ia. 194, 11 Am. Rep. 118: Abberger $v$. Marrin, 102 Mass. 70 ; Erman $v$. Lehman, 47 La. Ann. 1651, 18 So. 650 ; Newman $v$. Cannon, 43 La. Ann. 712, 9 So. 439 ; Claflin v. Meyes 41 La. Ann. 1048, 7 So. 139.

8110 Mass. 322.

- 141 Mass. 364 . 
pletion of the sale being the carriage of the goods to Rhode Island.

In State $v$. O'Neil, ${ }^{10}$ a resident of Vermont purchased liquor of dealers in New York, upon an order by mail, the goods to be shipped by express, C. O. D. It was held that the sale took place in Vermont, since the shipment C. O. D. indicated an intention to make the payment of charges a condition precedent to the vesting of title in the vendee. ${ }^{11}$

In sales, as in other transactions, the acts of an agent within the scope of his authority are the acts of his principal. If the agent has authority to sell, and does so, the sale takes place at the place where the agent acts, not where the principal lives or does business. But if the agent has no authority to pass the title, but only to forward orders, which are subject to the principal's approval, the contract is not completed until such approval; and the place of the contract must be referred to the place where the approval is given. ${ }^{12}$

It is to be observed furthermore, in connection with conveyances and sales of personalty, that not only does the lex loci contractus govern the substantial validity of the transfer as between the parties, but it also determines the effect of the contract, and in general the interpretation to be placed upon the terms used, when an ambiguity arises touching the legal signification to be attached to them. ${ }^{18}$

1058 Vt. 140, 56 Am. Fep. 557.

11 But see State $v$. Carl, 43 Ark. 353, 51 Am. Rep. 565.

12 Erman v. Lehman, 47 La. Ann. 1651, 18 So. 650; Newman v. Cannon, 43 La. Ann. 712, 9 So. 439 . In these cases the agent had absolute authority to sell. Compare with these Claflin v. Meyer, 41 La. Ann. 1048, 7 So. 139, where the agent had only authority to forward orders. See also Tegler $v$. Shipman, 33 Ia. 194, 11 Am. Rep. 118.

13 Erman v. Lehman, 47 La. Ann. 1651, 18 So. 650; Newman v. Cannon, 43 La. Ann. 712, 9 So. 439 ; Claflin v. Meyer, 41 La. Ann. 1048, 7 So. 139. In all of these cases the question involved was the vendor's right to a lien or "vendor's privilege " under the law of Louisiana. The vendor's right to the privilege was held dependent upon the law of the place of sale. In Codman $v$. Krell, 152 Mass. 214, 218, it was held that the lex loci contractus should determine the legal interpretation of the phrase "heirs at law," used in a deed conveying personalty. See also Meyer $v$. Richards, 163 U. S. 385, where it was 
\$ 129. Same - As to Third Persons. - Notwithstanding the general rule that the lex loci contractus regulates absolute conveyances and sales of personalty, there are some cases in which the "proper law" for this purpose will be substituted by the law of the forum and actual situs of the property. These cases are the exceptional cases mentioned in the second chapter of this work.

But only two of the exceptions there mentioned have much practical bearing in this particular instance. 'It is in general only where the enforcement of the proper law would work an injury, loss, or injustice to the citizens of the forum, or would contravene its policy, that the law of the actual situs of the property will prevail over the lex loci contractus; though it is conceivable that a transfer valid by the latter law might be refused recognition in another State because the consideration therefor is contra bonos mores, ${ }^{1}$ or that a transfer, invalid where made because of a penal disability imposed upon the assignor, might still be enforced in other States. ${ }^{2}$ In the main, however, the operation of the lex fori et situs will be confined to the two cases first mentioned.

Instances of the application of the lex fori et situs (instead of the lex loci contractus), though numerous enough in cases of chattel mortgages and assignments for the benefit of creditors, ${ }^{3}$ are much more infrequent with respect to absolute conveyances and executed sales of personalty, for the reason that there are somparatively few differences of policy between the various States respecting the latter transactions, and therefore conflicts of laws are not so apt to arise. The few cases that have been decided, however, indicate that the lex fori et situs will be applied in these cases in the same way and to the same extent as in the case of chattel mortgages and voluntary assignments

held that the law of the place of transfer should govern the question whether the vendor of certain bonds warranted their validity. For similar questions touching warranties implied in sales of chattels, see McIlvaine v. Legare, 36 La. Ann. 359 ; Maillard v. Nihoul, 21 La. Ann. 412.

1 See Savings Bank v. National Bank, 38 Fed. 800.

2 See Scoville $v$. Caufield, 14 Johns. (N. Y.) 338.

3 Post, §§ 132-134. 
for the benefit of creditors, whenever the circumstances call for the substitution of the lex fori for the proper law.

The mere fact that the property conveyed or sold is in another jurisdiction than the locus contractus, and that citizens of the actual situs may incur loss by reason of the transfer, is not in itself sufficient to call for the overthrow of the transfer, where it is voluntary and contractual." In order that the lex loci contractus and the transfer validly made thereunder should be set aside, the transfer must be positively invalid as to third persons under the law of the actual situs of the property. The courts of the latter State must be able, by substituting their own law, to pronounce the transfer invalid there. There must be an actual substitution of the lex fori for the proper law, as well as a setting aside of the lex loci contractus.

A leading case, in which the lex fori et situs was applied to an absolute conveyance of personal property, arose in Louisiana. ${ }^{5}$ In that case, a transfer of part of a ship was made in Virginia, where the owner resided, the ship at the time of the sale being at the New Orleans port. Before delivery to the vendee she was attached by creditors of the vendor resident in Louisiana. By the common law (prevailing in Virginia), it was argued, a sale of goods is, or may be, complete without delivery, if delivery is impossible at the time and is made within a reasonable time after it becomes possible. On the other hand, by the civil law (prevailing in Louisiana), delivery is absolutely essential to a valid title in the purchaser. The vendor's creditors, attaching the ship before any delivery to the vendee, claimed that the title was still in the vendor (under the Louisiana law), and that they took priority over the vendee. The vendee claimed that he had already, before the attachment, acquired a good title under the law of Virginia (lex loci contractus). There being thus a conflict between the "proper law" on the one side and the lex fori et situs on the other, the court held that since the attaching creditors were citizens of Louisiana and would be injured by the

4 It is otherwise where the transfer is compulsory, as in involuntary assign. ments in bankruptcy. See post, $\$ \S 137,138$.

5 Olivier $v$. Townes, 14 Mart. (La.) 93. See also Union Bank v. Hartwell, 84 Ala. 379,4 So. $156,157$. 
enforcement of the Virginia law, the law of the forum must be substituted, and the attachment was accordingly sustained.

In contrast with this another Louisiana case may be presented. In Thuret $v$. Jenkins, ${ }^{6}$ the circumstances were similar to those above given, except that the ship was at sea at the time of the transfer. It was attached by the vendor's creditors upon reaching port in Louisiana. The court, dismissing the attachment and upholding the "proper law," said: "In transferring the ship, it did not work any injury to the rights of the people of another country; it did not transfer the property of a thing within the jurisdiction of another government. If two persons in any country choose to bargain as to the property which one of them has in a chattel, not within the jurisdiction of the place, they cannot expect that the rights of persons in the country in which the chattel is will be permitted to be affected by their contract. But if the chattel be at sea, or in any other place, if any there be, in which the law of no particular country prevails, the bargain will have its full effect eo instanti, as to the whole world. And the circumstance of the chattel being afterwards brought into a country, according to the laws of which the sale would be invalid, would not affect it."

$A$ fortiori would this be true if the chattel were in the locus contractus at the time of the transfer (which is valid there), and were afterwards brought by the vendee into another State, according to whose law the sale, if made there, would be invalid In such case the lex loci contractus should clearly prevail over the lex fori."

So also cases may be found holding that where the policy of the forum and situs would be contravened by the enforcement of the lex loci contractus, the latter must give way to the former law. ${ }^{8}$

Upon principle, it would seem, in these cases, if the suit should be instituted in the locus contractus and not in the State

67 Mart. (La.) 318, 12 Am. Dec. 508.

7 Davis $v$. Williams, 73 Miss. 708, 19 So. 352; Walker $v$. Marseilles, 70 Miss. 284, 12 So. 211; Bank $v$. Lee, 13 Pet. 107.

8 Matthews $v$. Lloyd, 89 Ky. 625, $13 \mathrm{~S}$. W. 106. See Hoyt $v$. Thompson, 19 N. Y. 207. 
where the chattel is situated (such cases would be rare), that the court should follow the lex loci contractus, the lex situs of the property usually governing only because it is also the forum. Hence when, instead of the forum and the situs at the time of the transfer being identical, it is the locus contractus and the forum that are identical, the exceptional operation of the law of the actual situs of the property at the time of the transfer should cease, and the lex loci contractus should reign supreme. ${ }^{9}$ And so, if the forum is a third State, neither the situs nor the locus contractus.

$\S 130$. Sale of Personalty, with Reservation of Title in Vendor. - At common law a reservation of title in the vendor of a chattel until the purchase price is paid is sustained even as against a purchaser from the vendee for value and without notice of such reservation. But in many States by statute the reservation is void as against third persons unless it is recorded.

If therefore we suppose a chattel sold with such reservation in one State while the chattel is actually situated in another State subject to a different law, or is subsequently removed thither by the vendee, where it is afterwards sold by the vendee to a purchaser for value and without notice of the reservation, which law is to govern the title of the vendee's purchaser?

The policy of the laws which set at nought the contract for the reservation of the title in favor of creditors of and purchasers from the vendee, must be kept in mind in the solution of this question. Some avoid the reservation of title absolutely as

9 See Martin v. Hill, 12 Barb. (N. Y.) 631, 633 ; Edgerly $v$. Bush, 81 N. Y. 199 ; Hornthall $v$. Burwell, 109 N. C. 10,13 S. E. 721 ; Boehme $v$. Rall, 51 N. J. Eq. 574, 26 Atl. 832. This result however is denied in one New York case, in which it was held that even though the suit was brought in the locus contractus, the transfer being valid there, it would not be sus. tained if invalid by the law of the actual situs of the chattels at the time of the transfer. This case would seem to go too far in support of the lex situs. Guillander $v$. Howell, 35 N. Y. 657. Mr. Wharton also goes to great lengths in giving effect to the lex situs, claiming that it is the " proper law." Whart. Confl. I. $\S \S 297$ et seq. The true rule is that the law of the actual situs is effective only when it is also the lex fori, the lex loci contractus, or the lex domicilii. Standing alone, it is of no significance. 
against such creditors and purchasers; ${ }^{1}$ while others avoid it as to such third persons, unless the reservation is in writing and recorded. ${ }^{2}$ The purpose of these laws is to protect persons within the State where they are in force in advancing money to the vendee on the faith of an apparently complete title which is in reality defective, or in their purchasing the chattel from the vendee upon the faith of his title. It is not the purpose of such a law to protect third persons dealing with the property beyond the limits of the State, for with respect to such dealings that State has no authority to legislate. On the other hand it would seem to be the policy of these laws to embrace all dealings by third persons with the property situated within the limits of their authority, regardless of the law of the place where the vendee obtained the property and regardless of the question whether or not by that law the reservation of title in the vendor is valid as against third persons.

Thus it will be seen that the real scope of these laws when they exist in a particular State is to embrace all personalty within that State, whether the vendor's reservation of title was created there or elsewhere; and they do not apply to personalty elsewhere, or to dealings therewith elsewhere by third parties, even though the original sale and reservation of title took place in the former State.

It follows from what has been said and from the policy of these laws invalidating reservations of title in the vendor as against creditors of and purchasers from the vendee, that it is usually the law of the State where the purchaser buys from the vendee or where his creditors seek to subject his interest that will determine the validity of the vendor's reservation of title, the law of the place of the vendor's contract of sale being immaterial. And this is true whether the chattel sold is situated at the time of the transfer in, or is subsequently removed by the vendee into, the State where the subsequent dealings occur. Ordinarily, therefore, in such cases, it is safe to follow the rule

1 See Marvin Safe Co. v. Norton, 48 N. J. L. 412, 57 Am. Rep. 566, 7 Atl. 418.

2 See Public Parks Amusement Co. v. Carriage Co., 64 Ark. 29, 40 S. W. 582. 
that the law of the place where the subsequent dealings occur will govern. ${ }^{8}$

Thus, in Hervey $v$. Locomotive Works, ${ }^{4}$ a Rhode Island company delivered a locomotive in Rhode Island to a contractor on a railroad in Illinois, reserving the title until the payment of the price. By the law of Rhode Island the reservation of title was valid as against subsequent creditors of the rendee. By the law of Illinois it was invalid as against them until recorded. The engine was attached in Illinois by subsequent creditors of the vendee, and sold to Hervey. In a contest between Hervey and the vendor, it was held that the law of Illinois must govern. Here the reservation of title was valid by the lex loci contractus, but invalid by the law of the place where the subsequent dealings therewith were had.

On the other hand, in Weinstein $v$. Freyer, ${ }^{5}$ the circumstances were just reversed, but the same law was held to govern. In that case the vendor sold the vendee a piano in Georgia, reserving title. By the law of Georgia, such a reservation was invalid as to purchasers from the vendee, unless recorded. In this case there was no recordation. Then the vendee removed the chattel to Alabama, and there sold it to a bona fide purchaser. The common law, prevailing in Alabama, held such reservation valid, without recordation. It was held that the rights of the vendee's purchaser were to be determined by the law of Alabama; that the contract reserving the title in the vendor gave the vendee a defective title in Georgia, as between the parties; that when the vendee brought the piano into Alabama, he came with a defective title under the Georgia law; that when he sold the piano in Alabama, that defect had not been cured by the Alabama law, which recognized the vendor's rights; and that the vendee could convey the purchaser no better title than he himself possessed. ${ }^{\circ}$

3 Hervey v. Locomotive Works, 93 U. S. 661; Marvin Safe Co. v. Norton, 48 N. J. L. 412, 57 Am. Rep. 566, 7 Atl. 418 ; Weinstein v. Freyer, 98 Ala. 257, 9 So. 285 ; Public Parks Amusement Co. v. Carriage Co., 64 Ark. 29, 40 s. W. 582 ; The Marina, 19 Fed. 760.

93 U. S. 664 . 593 Ala. 257,9 So. 285.

- See also Marvin Safe Co. o. Norton, 48 N. J. L. 412.57 Am. Rep. 566, 
\$ 131. Donations Mortis Causa. - If property, transferred by donation mortis causa, is situated apart from the dying owner in another State, in determining the "proper law" to govern the validity of the donation, it becomes necessary to consider whether it shall be deemed a transfer inter vivos or a testamentary disposition. In truth, it is neither the one nor the other, though partaking of the nature of both. The title of the donee is not, strictly speaking, contractual, since the transfer is conditional and revocable, nor is it, in strictness, testamentary.

But in ascertaining the "proper law" to govern such a trans. fer it is not so necessary to observe whether the transfer is contractual or not, as to observe whether it is the result of the voluntary act of the owner. If it is, the "proper law" will be the law of the actual situs of the owner at the time of the transfer. On the other hand if the transfer result without the active participation of the owner, it is involuntary, and the "proper law" is the law of the legal situs (or domicil) of the owner. Thus a title arising under the will of a testator, though at first glance it appears to be the result of the testator's voluntary act, in reality takes effect only by his death (an involuntary act), and is therefore classed with involuntary transfers, to be regulated by the lex domicilii of the testator. ${ }^{1}$

Whether a donation mortis causa is to be considered a voluntary transaction, like a conveyance, to be regulated by the law of the actual situs of the owner (lex loci contractus), or whether it is to be deemed an involuntary transfer, like a will, because not taking effect until the donor's death, and therefore to be regulated by the lex domicilii, is still a doubtful matter. Only one case has been found which deals with the question, in which the view was taken that the rendee's title vests immediately upon the donation," but that the title is defeasible by reclamation, deliverance from the peril, etc.

In that case, the decedent was domiciled in New Hampshire. While temporarily in Vermont, he was taken ill, and before his death delivered certain personalty to the defendant mortis causa.

7 Atl. 418; Public Parks Amusement Co. v. Carriage Co., 64 Ark. 29, 40 S. W. 522; The Marina, 19 Fed. 760.

1 Post, § 142. 
'I'he donation was valid by the law of Vermont where it was made, but the law of New Hampshire, the donor's domicil, required that such donations should be proved by the testimony of two indifferent witnesses, upon petition by the donee to the probate court to establish the gift, filed within sixty days after the owner's decease. These conditions were not complied with, and the question arose in New Hampshire as to the validity of the gift, and the "proper law" governing it. The court held that the donation was a voluntary and contractual, rather than a testamentary, disposition, and that the lex loci contractus, not the lex domicilii, was the proper law. ${ }^{2}$

$\S 132$. Chattel Mortgages - Liens upon Personalty. - Chattel mortgages are voluntary, though qualified, transfers, and being the result of contract are governed as between the parties thereto, like other contractual transfers, by the lex loci contractus, not by the lex domicilii of the owner, nor the lex situs of the chattels unless that happens to be identical with the forum, as will usually be the case. ${ }^{1}$

But with respect to creditors of and purchasers from the mortgagor, if the chattels are situated in a State other than the locus contractus at the time of the mortgage, and by the law of the actual situs and forum the chattel is void as to creditors and purchasers, the lex fori et situs will usually be substituted for the proper law, upon the ground that the enforcement of the

2 Emery v. Clough, 63 N. H. 552, 4 Atl. 796.

1 In many of the cases, the language of the opinions would seem to indicate that the lex domicilii is to govern as between the parties, but it will be found in these cases that the transfer was made in the domicil of the owner, and hence the lex loci contractus and lex domicilii are identical. See Green $v$. Van Buskirk, 5 Wall. 307, 311, 312 ; Kanaga $v$. Taylor, 7 Ohio St. 134, 70 Am. Dec. 62 ; Nichols $v$. Mase, 94 N. Y. 160; Martin v. Hill, 12 Barb. (N. Y.) 631, 633 ; Langworthy $v$. Little, 12 Cush. (Mass.) 109 ; Edgerly $v$. Bush, $81 \mathrm{~N}$. Y. 199 ; Hornthall $v$. Burwell, 109 N. C. 10, 13 S. E. 721, 722; Boehme v. Rall, 51 N. J. Eq. 574, 26 Atl. 832 ; Cronan v. Fox, 50 N. J. L. 417, 14 Atl. 119; Barker $v$. Stacy, 25 Miss. 477; Ames Iron Works $v$. Warren, 76 Ind. 512, 40 Am. Rep. 258, 259 ; Fowler v. Bell, 90 Tex. 150, 35 S. W. 822 ; Richardson v. Shelby, 3 Okl. 68 , 41 Pac. 378; Bank v. Hill, 99 Tenn. 42, 41 S. W. 349 ; Mackey v. Pettijohn, 6 Kan. App. 57, 49 Pac. 636 ; Handley $v$. Harris, 48 Kan. 606, 29 Pac. 1145 ; Miles v. Oden, 8 Mart. N. s. (La.) 214, 19 Am. Dec. 177. See Stirk $v$. Hamilton, 83 Me. 524, 22 Atl. 391. 
proper law would contravene the policy of the forum or would work a detriment to its citizens. ${ }^{2}$

In Green $v$. Van Buskirk, ${ }^{8}$ a leading case, Bates, the owner of certain iron safes, situated in Chicago, executed and delivered in New York to Van Buskirk a chattel mortgage upon them. Afterwards and before recordation of the mortgage as the law of Illinois required, Green attached the safes in Illinois as the property of Bates. The mortgage was valid by the law of $\mathrm{New}$ York as to Green, who was a citizen of that State, but by the law of Illinois it was invalid as to him until recorded. The Illinois courts sustained the attachment and ordered the safes to be sold and the proceeds paid to Green, which was done. Van Buskirk afterwards sued Green in the courts of New York for the value of the safes upon the ground that the property belonged to him and not to Bates, under the law of New York. The court held that by the law of New York the property was Van Buskirk's and permitted him to recover against Green." From this decision an appeal was taken to the Supreme Court of the United States upon the constitutional ground that full faith and credit had not been shown by the New York courts to the Illinois judgment, and upon this ground the decision was reversed. The Supreme Court held that Van Buskirk possessed a title under the law of New York equal but not superior to that of Green under the law of Illinois; and that, although Van Buskirk was not a party to the attachment in Illinois, that fact did not permit him to set up anywhere a title which was not superior to that of the attaching creditor. In this case, it will be observed, Green was a citizen of New York, not of Illinois. The court of Illinois proceeded upon the supposition that the intent and policy of the

2 See Green v. Van Buskirk, 5 Wall. 307; Smith $v$. Smith, 19 Gratt. (Va.) 545 ; Chillingworth $v$. Eastern Tinware Co., 66 Conn. 306, 33 Atl. 1009 ; Miles v. Oden, 8 Mart. N. s. (La.) 214,19 Am. Dec. 177. If the ground of the exception is the upholding of a general policy of the forum, the citizenship of the third parties is immaterial. The operation of the lex situs is just as extensive as the legislature intended it should be, no more and no less. See Green $v$. Van Buskirk, 5 Wall. 307; Miles v. Oden, 8 Mart. N. S. (La.) 214, 19 Am. Dec. 177.

5 Wall. 307 ; s. c. 7 Wall. 139.

4 Van Buskirk v. Warren, 2 Keyes (N. Y.), 119. 
Illinois statutes of registry was not merely to protect its own citizens against secret liens, but to prohibit such liens altogether in that State. And the Supreme Court affirmed the sovereign right of the State of Illinois to deal with property within its limits in whatever manner it should see fit, though the owner lived and contracted elsewhere with reference to the property, at the same time admitting the equally sovereign right of the State of New York to make such regulations as it should deem proper touching the persons, transactions, or property within its limits. But the right of New York was only equal to that of Illinois, not superior to it.

On the other hand, where a transfer of chattels in one State is alleged as the result of a contract made in another, the fact that the transfer is valid under the law of the actual situs of the chattels cannot make it a valid agreement, if invalid by the lex loci contractus. In other words, the lex situs cannot make that a valid executed contract which is no contract at the time and place it is entered into.

Thus, in Wattson $v$. Campbell, ${ }^{5}$ a chattel mortgage was executed in Pennsylvania upon a ship situated in New York. By the law of Pennsylvania such a mortgage was invalid as to creditors if unaccompanied by actual change of possession. Before the mortgagee obtained possession the vessel was attached in New York by a Pennsylvania creditor. The court held that the lex loci contractus, not the lex situs, should govern.

Most of the cases however present the question as to the law to be applied in cases where the property mortgaged was at the time of the mortgage in the locus contractus, but was subsequently removed to another State without the consent of the mortgagee, the mortgage being valid as to the whole world by the lex loci contractus, but invalid"as to third persons by the law of the State to which the chattels have been removed, which will also in most instances be the forum. It will be observed

$538 \mathrm{~N}$. Y. 153. But if the invalidity is created by a statute of the locus contractus, which has no exterritorial force, such as an insolvent or a penal law, it has been held that the invalidity will not be regarded in other States. Hoyt v. Thompson, 19 N. Y. 207 ; Scoville ฯ. Caufield, 14 Johns. (N. Y.) 338. 
that we now have on the side of the validity of the mortgage as against third persons the lex loci contractus and the lex situs of the chattels at the time of the transfer, while on the side of its invalidity as to third persons we have the law of the actual situs at the time the mortgagor's creditors subject the property or the property is purchased from him and (usually) the lex fori.

The decided weight of authority is in favor of the view that since the actual situs of the chattels at the time of the transfer coincides with the lex loci contractus, and since by those united laws the mortgagee takes a title valid as against the whole world, no subsequent removal of the chattel without the mortgagee's consent into the dominion of a different law will divest, in whole or in part, the mortgagee's title once vested thus as against the world under the law of the only State which at the time of the transfer could possibly have exercised any sovereignty over the trausaction. Under such circumstances, the lex loci contractus should prevail over every other law. ${ }^{\circ}$

Especially has this view been taken where the question arises in the locus contractus, so that the locus contractus, the former situs of the property, and the forum all coincide. ${ }^{7}$

Thus, in Edgerly $v$. Bush, ${ }^{8}$ a mortgage of horses situated in

6 Barker v. Stacy, 25 Miss. 476, 477; Ames Iron Works v. Warren, 76 Ind. 512, $40 \mathrm{Am}$. Rep. 258, 259 ; Nichols v. Mase, 94 N. Y. 160 ; Langworthy v. Little, 12 Cush. (Mass.) 109 ; Bank v. Hill, 99 Tenn. 42, 41 S. W. 349 ; Richardson $v$. Shelby, 3 Okl. 68, 41 Pac. 378; Handley $v$. Harris, 48 Kan. 606, 29 Pac. 1145 ; Kanaga $v$. Taylor, 7 Ohio St. 134, 70 Am. Dec. 62 ; Mum. ford $v$. Canty, 50 Ill. 370, 99 Am. Dec. 525, 529; Craig v. Williams, 90 Va. 500,505 ; Bank $v$. Lee, 13 Pet. 107. But there are a few cases which regard a chattel mortgage as a mere lien, not as a transfer of title. These cases hold that the lien given by the lex loci contractus, though valid, as between the parties, in other States whither the chattels are removed, will not be given priority over the claims of third parties recognized by the law of the last situs of the chattels and of the forum. See Corbett $v$. Littlefield, 84 Mich. 30, 4i N. W. 581, 22 Am. St. Rep. 681 ; Cronan v. Fox, 50 N. J. L. 417, 14 Atl 119. See Hervey $v$. Locomotive Works, 93 U. S. 664 ; Walworth $v$. Harris 129 U. S. 355.

7 Edgerly v. Bush, 81 N. Y. 199 ; Martin v. Hill, 12 Barb. (N. Y.) 631 i Hornthall $v$. Burwell, 109 N. C. 10, 13 S. E. 721.

881 N. Y. 199. 
New York was there executed, which was valid under the laws of New York against the world. The mortgagor subsequently carried the horses to Canada and had them sold there in market overt by a horse trader. They were sold to a party in Canada, who there sold them to the defendant, a resident of New York. The mortgagee sued the defendant in New York for the conversion of the horses. By the law of Canada a sale in market overt passed an unimpeachable title. The court held that the New York law should govern, and that the action might be maintained.

The case of Hornthall $v$. Burwell, ${ }^{9}$ though somewhat similar to Edgerly $v$. Bush, presents one important variation from it. In the North Carolina case, a mortgage was executed and duly recorded in North Carolina upon certain horses there situated. The mortgagor subsequently took the horses into Virginia, where they were seized and sold under an attachment sued out by creditors of the mortgagor. The mortgagee thereupon sued the attaching creditors in North Carolina to recover the debt secured by the mortgage, and the court held that he was entitled to recover. This case is more complicated than Edgerly $v$. Bush, in that the element of a judicial proceeding in another State is here presented, which, under the "full faith and credit" clause of the federal constitution, must be given the same effect in other States as in the State in which it is rendered. The court, in Hornthall $v$. Burwell, notices these principles, but holds that they did not apply, because the judgment in the attachment proceeding would have been deemed void even in Virginia, since the mortgagee was not a party, and his title had been perfected in North Carolina as against the world, and could not be divested by the act of a third person. ${ }^{10}$ This case differs from Green $v$. Van Buskirk, above cited, in that here the North Carolina title was not only equal,

9109 N. C. 10,13 S. E. 721. The case of Martin v. Hill, 12 Barb. (N. Y.) 631 , exhibits a similar state of facts, except that in the latter case the officer levying the attachment was the defendant, instead of the attaching creditor. The same result was reached in both cases.

${ }^{10}$ See Mumford $v$. Canty, 50 Ill. 370, 99 Am. Dec. 525 ; Craig $v$. Williams, $90 \mathrm{Va}, 500$. 
but superior, to the claim of the attaching creditor under the Virginia law.

A distinction is to be observed between a transfer of title and a mere lien. With respect to liens on personalty, whether acquired by the contract of the parties, ${ }^{11}$ or by implication of law, ${ }^{12}$ it may be laid down as a general proposition that while the lex loci contractus will regulate them as between the parties, regardless of the lex situs of the chattels, as part of the effect or obligation of the transfer, ${ }^{13}$ yet when the question is whether the lien shall take priority over the claims of other persons, the lex loci contractus must yield to the law of the situs and the forum. ${ }^{14}$

\section{$\S 133$. Voluntary Assignments for Benefit of Creditors -} General Principles. - Assignments for the benefit of creditors may be divided into two classes, - those which result from the voluntary transfer by contract of the insolvent debtor, and those which result from an involuntary or compulsory transfer by the act and operation of law to persons named by the law, as in the

11 Corbett $v$. Littlefield, 84 Mich. 30, 47 N. W. 581, 22 Am. St. Rep. 681.

12 Erman v. Lehman, 47 La. Ann. 1651, 18 So. 650.

13 Erman v. Lehman, 47 La. Ann. 1651, 18 So. 650 ; Newman v. Cannon, 43 La. Ann. 712, 9 So. 439 (cases of "vendor's privilege").

14 See Harrison $v$. Sterry, 5 Cr. 289, 298 ; Hervey $v$. Locomotive Works, 93 U. S. 664 ; Corbett v. Littlefield, 84 Mich. 30, 47 N. W. 581, 22 Am. St. Rep. 681. But see Walworth $v$. Harris, 129 U. S. 355 . In the last case, the lien did not arise by contract but by a statute of Arkansas. It was a lien upon crops for rent. The crops were in Arkansas when the lien for rent attached, and Arkansas was the forum. The lessee consigned the crop to a creditor of his in Louisiana, to whom he had given a deed of trust upon his crops to secure advances, the creditor having no notice of the lien for rent. The lessor sought in Arkansas to enjoin the trustee in the deed of trust from selling the crops, but the Supreme Court held that the title obtained by the Louisiana consignees was superior to the lien for rent conferred by the Arkansas statutes. If Louisiana had been the forum, the rationale of this decision would be easily discernible. But with the suit brought in an Arkansas conrt (a federal court, it is true, bat none the less sitting to enforce the municipal law of Arkansas), and the chattels situated there at the time the lien attached, it is difficult to discern the principle upon which the decision was reached. The fact that the lien was statutory and not contractual might be a good reason for not giving it an exterritorial effect; but why should it not have been recognized if Arkansas ? 
case of statutory assignments to assignees in bankruptey and insolvency. It is our purpose here to examine the law regulating the former class only. The latter subject will be discussed hereafter. $^{1}$ Suffice it to say that the distinction between the two is clearly recognized by most of the decisions. ${ }^{2}$

For the very reason that these assignments are voluntary and contractual, they are subject to principles analogous to those controlling absolute conveyances and transfers of personalty, save only that, since they are primarily made for the benefit of creditors, questions as to the rights of the grantor's creditors are much more likely to arise than in cases of absolute transfer. But here, as there, the general leading principle is that the lex loci contractus is the "proper law" to regulate the transfer, though the property conveyed thereby is situated elsewhere, except when the enforcement of the lex loci contractus would contravene the established policy of the actual situs and forum, or would result in injury or injustice to its citizens. ${ }^{3}$ It is also. true here, as there, that many of the decisions use language indicating that it is the lex domicilii, not the lex loci contractus, that is the "proper law." But it is believed that in

1 See post, $\S \S 137,138$.

2 Crapo v. Kelly, 16 Wall. 610, 622 ; Barnett v. Kinney, 147 U. S. 476, 481 ; Williams v. Dry Goods Co., 4 Okl. 145, 43 Pac. 1148, 1150, 1151 ;. Frank v. Bobbitt, 155 Mass. 112, 115 ; May v. Wannemacher, 111 Mass. 202, 208 ; May v. Bank, 122 Ill. 551, 13 N. E. 806, 807 ; Barth v. Backus, 140 N. Y. 230, 235 ; Moore $v$. Willett, 35 Barb. (N. Y.) 663 ; Long $v$. Girdwood, 150 Penn. St. 413, 24 Atl. 711, 23 L. R. A. 33, note; Speed v. May, 17 Penn. St. 91, 94, 55 Am. Dec. 540 ; Milne v. Moreton, 6 Binn. (Penn.) 353,. 361, 369, 6 Am. Dec. 466; Butler v. Wendell, 57 Mich. 62, 23 N.W. 460, 462, 58 Am. Rep. 329 ; Egbert v. Baker, 58 Conn. 319, 20 Atl. 466, 467; Hervey $v$. Edens, 66 Tex. 420, 6 S. W. 306, 309 ; Walters $v$. Whitlock, 9 Fla. 86, 76 Am. Dec. 607, 608.

${ }^{8}$ Barnett $v$. Kinney, 147 U. S. 476 ; Frank $v$. Bobbitt, 155 Mass. 112, 115 ; May v. Wannemacher, 111 Mass. 202, 208 ; Williams v. Dry Goods Co., 4 Okl. 145, 43 Pac. 1148, 1150 ; Butler v. Wendell, 57 Mich. 62, 58 An. Rep. 329, 23 N. W. 460, 462; Egbert $v$. Baker, 58 Conn. 319, 20 Atl. 466; In re Dalpay, 41 Minn. 532, 43 N. W. 564; Law $v$. Mills, 18 Penn. St. 185; Speed $v$. May, 17 Penn. St. 91, 94, 55 Am. Dec. 540; Fuller v. Steiglitz, 27 Ohio St. 355, 22 Am. Rep. 312 ; Walters $v$. Whitlock, 9 Fla. 86, 76 Am. Dec 607; Schuler v. Israel, 27 Fed. 851 ; Atherton Co. v. Ives, 20 Fed. 894. 
all these cases the assignment was made at the domicil, or else the statement is a mere dictum. ${ }^{4}$

Furthermore, if land situated abroad is the subject of the assignment, notwithstanding the general principle that the lex situs governs the validity and effect of all transfers of real estate, the better opinion is that, so far as the mere effect of the assignment as such is concerned, it is to be governed also by the lex loci contractus. The lex situs of the land, it is true, will govern so far as to determine the effect of the assignment in operating to pass the title to the assignee: it must be such a conveyance, in respect to the parties, the form, and the substance, as would operate to transfer the title to land under the lex situs. But these points being settled, it does not necessarily follow, because the deed would fail as an assignment for the benefit of creditors, if executed in the situs of the land, that it will there be considered invalid if valid by the lex loci contractus. In other words, its validity as a conveyance to pass title must be determined by the lex situs, but its effect as an assignment is to be determined by the lex loci contractus, unless the enforcement of the lex loci contractus would contravene the policy of the situs (and forum), or would injure its citizens. ${ }^{5}$

4 See Cole v. Cunningham, 133 U. S. 107, 128; Speed v. May, 17 Penn. St. 91, 55 Am. Dec. 540 ; Barth $v$. Backus, 140 N. Y. 230, 234, 235 ; Ockerman $v$. Cross, 54 N. Y. 29, 32 ; Guillander $v$. Howell, 35 N. Y. 657, 658; Moore v. Land Co., 82 Md. 288, 33 Atl. 641, 642; Fuller v. Steiglitz, 27 Ohio St. 355, 22 Am. Rep. 312.

5 Ante, $\$ 11$; Bentley $v$. Whittemore, 19 N. J. Eq. 462, 97 Am. Dec. 671, 675 ; Williams v. Dry Goods Co., 4 Okl. 145, 43 Pac. 1148, 1151; May v. Bank, 122 Ill. 551, 13 N. E. 806 ; Juilliard v. May, 130 Ill. 87, 22 N. E. 477; Hervey $v$. Edens, 66 Tex. 420, 6 S. W. 306 ; Thurston $v$. Rosenfield, 42 Mo. 474, 97 Am. Dec. 351; Chafee v. Bank, 71 Me. 514, 36 Am. Rep. 345. But some of the decisions are uncompromising in holding that the lex situs of the realty is to control under all circumstances. See Loving $v$. Pairo, 10 Ia. 282, 77 Am. Dec. 108; Moore v. Chnrch, 70 Ia. 208, 59 Am. Rep. 439 ; Bank v. Stelling, 31 S. C. 360,9 S. E. 1028 . So far as principle is concerned, the difference between these two lines of decision is more apparent than real. It is in reality a question of the construction of the statutes of the situs, and of the importance to be attached to their policy. Both lines of decision agree that the lex situs is the final arbiter, but they diverge upon the question as to what are the requirements of the lex situs in respect to foreign assign. 
The same general rule is also applicable where the subject of the assignment is a chose in action. Subject to the exceptions already mentioned, the lex loci contractus is the "proper law," and will control. ${ }^{6}$

If at the time of the transfer the property passing under the assignment is situated in the locus contractus, the assignment being good there, the subsequent removal of the property into another State, by whose law the assignment is invalid, will not affect the operation of the lex loci contractus; and it seems that this is true, whether or not the assignee has actually acquired possession of the property prior to the removal. The union of the lex loci contractus and the lex situs at the time of the assignment bestows upon the assignee a title unimpeachable even in the courts of the State whither the property is removed. ${ }^{7}$

In the following sections we will consider the cases in which the "proper law" will be substituted by the lex fori et situs.

$\$ 134$. What Creditors may Attack a Voluntary Assignment. - The mere fact that an assignment, valid where made, would have been invalid if the assignment had been made in the situs, does not of itself necessarily lead the courts of the situs to pronounce it invalid. The lex loci contractus is the proper law, and will prevail, unless one of two states of facts exists. The lex fori et situs may be substituted for the proper law, and may invalidate an assignment valid where made (though it will not validate an assignment invalid where made) in the following cases: (1) Where the creditors attacking the assignment are citizens of the forum, and rely upon

ments. Is the iex situs to be applied literally in the case of assignments made in another State as well as in the case of domestic assignments, or is the lex situs intended to apply only to assignments made in the situs? See Bentley $v$. Whittemore, 19 N. J. Eq. 462, 97 Am. Dec. 671, 675 ; Chafee $v$. Bank, 71 Me. 514, 36 Am. Rep. 345, 351.

6 Black $v$. Zacharie, 3 How. 483, 511 ; Butler $v$. Wendell, 57 Mich. 62, 23 N. W. 460, 58 Am. Rep. 329 ; Ingraham $v$. Geyer, 13 Mass. 146; Speed $v$. May, 17 Penn. St. 91, 55 Am. Dec. 540 ; Woodward $v$. Brooks, 128 Ill. 222, 20 N. E. 685 ; Egbert $v$. Baker, 58 Conn. 319, 20 Atl. 466 ; Askew $v$. Bank, 83 Mo. 366, 53 Am. Rep. 590 ; In re Dalpay, 41 Minn. 532, 43 N. W. 564.

${ }^{7}$ May $v$. Wannemacher, 111 Mass. 202, 209; Moore $v$. Willett, 35 Barb (N.Y.) 663, 665; Varnum v. Camp, 1 Gr. L. (N. J.) 326, 25 Am. Dec. 476. 
the lex fori as applicable to the transfer; (2) Where the enforcement of the lex loci contractus would contravene a pronounced policy of the forum. The first case is but one instance of the second, and they frequently merge into each other; but for the purposes of discussion here, they will be treated separately.

With respect to the first of these cases, it may be said that if the lex fori et situs invalidates an assignment valid where made, the policy of the law of the situs is at the very least to protect creditors who are its own citizens. It may or it may not intend to extend this protection to citizens of other States also, but it always goes to the former extent. Otherwise there would be no object in invalidating the assignment. Hence there will be found but few cases which, as against resident creditors, support a voluntary assignment declared invalid by the lex fori et situs, though valid by the lex loci contractus. ${ }^{1}$ 'The overwhelming current of authority is to the effect that resident creditors may always take advantage of the invalidity (under the lex fori et situs) of an assignment validly executed elsewhere. ${ }^{2}$

I See Speed v. May, 17 Penn. St. 91, 55 Am. Dec. 540 ; Law v. Mills, 18 Penn. St. 185; Train $v$. Kendall, 137 Mass. 366 ; which seem to go to this extreme in favor of the lex loci contractus. In the following cases the lex loci contractus and the lex fori et situs, despite minor differences, were regarded as substantially similar, and hence resident creditors were deniod relief, thongh some of them contain dicta to the effect that resident and nonresident creditors should always be placed upon the same footing. Atherton Co. v. Ives, 20 Fed. 894; Askew v. Bank, 83 Mo. 366, 53 Am. Rep. 590 ; Fuller $v$. Steiglitz, 27 Ohio St. 355, 22 Am. Rep. 312 ; Law v. Mills, 18 Peun. St. 185 ; First Nat. Bank $v$. Walker, 61 Conn. 154, 23 Atl. 696. The last case did not involve conflicting titles nnder different laws, bnt merely superiority or priority of title. The point in that case was whether a creditor domiciled in Connecticut, having notice of an assignment made in New York, could attach goods in Connecticut embraced in the assignment. It was held that he could not.

2 Barnett $v$. Kinney, 147 U. S. 476, 481 ; Frank v. Bobbitt, 155 Mass. 112 ; Faulkner $v$. Hyman, 142 Mass. 53, 54, 55 ; Zipcey $v$. Thompson, 1 Gray (Mass.), 243 ; May $v$. Bank, 122 Ill. 551, 13 N. E. 806 ; Woodward $v$. Brooks, 128 Ill. 222, 20 N. E. 685 ; Juilliard v. May, 130 Ill. 87, 22 N. E. 477 ; Varnum $v$. Camp, 1 Gr. L. (N. J.) 326, 25 Am. Dec. 476; Bentley $v$. Whittemore, 19 N. J. Eq. 462, 97 Am. Dec. 671, 677 ; Green v. Iron Works, 49 N. J. Eq. 48, 23 Atl. 498; Walters $v$. Whitlock, 9 Fla. 86, 76 Am. Dec. 607 ; Egbert $v$. Baker, 58 Conn. 319, 20 Atl. 466, 467; Williams v. Dry Goods Co., 4 Okb 
Whether or not non-resident creditors will be accorded the same privilege is to be determined, in the absence of express legislative provision, by the policy of the statutes of the forum in the particular case. It is impossible to lay down any general rules by which this can be decided. The statute, its language, provisions, purposes, scope, etc., are all elements which must be reckoned with in determining the policy of the forum. More usually, perhaps, the policy of such statutes is held to be confined to the protection of domestic creditors only. But many cases treat the policy indicated by the statutes of the forum with such respect, when markedly opposed to the lex loci contractus, as to substitute the lex fori et situs for the lex loci contractus in all cases, regardless of the citizenship of the attacking creditors. ${ }^{8}$

Some of the courts also distinguish between cases where the attacking creditors are citizens of the locus contractus and where they are citizens of the forum or of third States. These cases, though giving the benefit of the lex fori et situs to creditors generally, whether resident in the forum or not, refuse it to the citizens of the locus contractus, and require that their rights should be determined by their own law. ${ }^{4}$ It is difficult to see any sound basis for this rule save perhaps some general princi-

145, 43 Pac. 1148, 1151 ; Hervey $v$. Edens, 66 Tex. 420, 6 S. W. 306, 309 ; Chafee v. Bank, 71 Me. 514, 36 Am. Rep. 345; Bacon $v$. Horne, 123 Penn. St. 452, 16 Atl. 794; Thurston v. Rosenfield, 42 Mo. 474, 97 Am. Dec. 351; Sheldon $v$. Wheeler, 32 Fed. 773 ; Schuler $v$. Israel, 27 Fed. 85.

3 Instances of this view taken of the supreme importance of the domestic policy may be found in the following cases: Atherton Co. $v$. Ives, 20 Fed. 894 ; Barth $v$. Backus, 140 N. Y. 230 ; Woodward $v$. Brooks, 128 Ill. 222, 20 N. E. 685,686 ; First Nat. Bank $v$. Walker, 61 Conn. 154, 23 Atl. 696 ; Chafee $v$. Bank, 71 Me. 514, 36 Am. Rep. 345 ; Ramsey $v$. Sterenson, 5 Mart. (La.) 23, 12 Am. Dec. 468 ; Ex parte Dickinson, 29 S. C. 453, 7 S. E. 593; Bank $v$. Stelling, 31 S. C. 360,9 S. E. 1028.

4 See Barnett $v$. Kinney, 147 U. S. 476, 481 ; Cole $v$. Cunningham, 133 U. S. 107, 128, 129 ; Halsted $v$. Straus, 32 Fed. 279 ; Williams $v$. Dry Goods Co., 4 Okl. 145, 43 Pac. 1148, 1150 ; Woodward $v$. Brooks, 128 Ill. 222, 20 N. E. 685 ; Richardson v. Leavitt, 1 La. Ann. 430, 45 Am. Dec. 90 ; Faulkner v. Hyman, 142 Mass. 53, 55; May v. Wannemacher, 111 Mass. 202, 209 ; Whipple v. Thayer, 16 Pick. (Mass.) 25, 26 Am. Dec. 626; In re Dalpay, 41 Minn. 532, 43 N. W. 564, 566. 
ple of estoppel. ${ }^{5}$ But such an explanation loses sight of the fact that it is the policy of the forum which is to be enforced by its courts. That policy, it would seem clear, would generally be intended to apply to the protection either of residents of the forum only, or of all creditors, regardless of citizenship. It would be highly improbable that the legislature, in enacting the statute, intended to create a shifting rule, applicable to some non-resident creditors and not to others; and no such presumption should be made, without plain evidence that such is the legislative intent. The better view is that all non-resident creditors should be placed upon the same footing, whether they reside in the locus contractus or in third States, to be either all included in, or all excluded from, the operation of the lex fori et situs, according as the circumstances point to one or the other course as that contemplated by the policy of the forum. ${ }^{6}$

The above principles are applicable to assignments valid where made, but which, if executed in the forum, would be invalid as against creditors. But some of the courts have gone further, holding that, although the assignment is not inconsistent either with the lex fori et situs or the lex loci contractus, the mere fact that it is a foreign assignment will be sufficient to entitle creditors resident in the forum to attach the property thereby transferred, on the ground that resident creditors are entitled to payment out of property in the forum, before it can be taken out of the State to be distributed according to a foreign law. ${ }^{7}$ But the great weight of authority is in favor of the rule that the title, once validly vested by the lex loci contractus in

- See Faulkner $v$. Hyman, 142 Mass. 53, 55.

${ }^{6}$ See Green $v$. Van Buskirk, 5 Wall. 307 ; s. c. 7 Wall. 139 ; Barth $v$. Backus, 140 N. Y. 230, 238; Warner v. Jaffray, 96 N. Y. 248; Moore $v$. Church, 70 Ia. 208, 59 Am. Rep. 439 ; Chafee v. Bank, 71 Me. 514, 36 Am. Rep. 345, 349 ; Varnnm v. Camp, 1 Gr. L. (N. J.) 326, 25 Am. Dec. 476, 487; Ramsey v. Sterenson, 5 Mart. (La.) 23, 12 Am. Dec. 468 ; Atherton Co. v. Ives, 20 Fed. 894. See Hibernia Nat. Bank $v$. Lacombe, 84 N. Y. 367 . It is probably otherwise, if the transfer is by operation of law. See post, $\S 138$; ante, $\S 118$.

7 Fox $v$. Adams, 5 Me. 245; Woodward v. Brooks, 128 Ill. 222, 20 N. E. 685, 686 ; Holmes $v$. Remsen, 20 Johns. (N. Y.) 255, 265, 11 Am. Dec. 269 : Ingraham $v$. Geyer, 13 Mass. 146. 
the assignee by the voluntary and contractual act of the owner (it is otherwise in the case of involuntary assignments in bankruptcy ${ }^{8}$ ), and not invalidated by the lex fori et situs, is not subject to impeachment by creditors resident in the forum or elsewhere, merely because the contract is made abroad. The assignment is here made in the exercise of the owner's jus disponendi, which should receive exterritorial recognition, save when the disposition is prohibited by the lex fori. ${ }^{9}$

$\S 135$. Policy of the Forum. - Although the invalidity of a foreign assignment under the lex fori et situs will suffice in general to defeat the assignment, so far as residents of the forum are concerned, it does not necessarily follow that the lex fori et situs will be substituted in behalf of non-resident creditors also. Whether or not this result will follow will depend upon the construction placed by the courts of the forum upon the policy of its laws. And this in turn will depend in large measure upon the language and scope of the domestic statutes.

Perhaps the most usual objection that has been taken under the lex fori to voluntary assignments valid in the locus contractus is upon the ground of preferences of creditors.

Under these circumstances, the lex fori et situs will generally be substituted for the proper law, as respects resident creditors, and the assignment will be regarded as ineffectual as to them. ${ }^{1}$ But even as to resident creditors, if the lex fori does not render the assignment void because of preferences, but merely provides in such case that the assignment shall be regarded as made for the benefit of all creditors equally or pro rata, it has been

8 See post, $\S 137,138$.

9 Crapo v. Kelly, 16 Wall. 610, 622 ; Walters v. Whitlock, 9 Fla. 86, 76 Am. Dec. 607, 612 ; Askew v. Bank, 83 Mo. 366, 53 Am. Rep. 590 ; Train v. Kendall, 137 Mass. 366 ; Fuller $v$. Steiglitz, 27 Ohio St. 355, 22 Am. Rep. 312 ; Atherton Co. $v$. Ives, 20 Fed. 894 ; Law v. Mills, 18 Penn. St. 185 ; Ockerman v. Cross, 54 N. Y. 29 ; Cook v. Van Horn, 87 Wis. 291,50 N. W. 893 ; First Nat. Bank $v$. Walker, 61 Conn. 154, 23 Atl. 696.

1 Varnum v. Camp, 1 Gr. L. (N. J.) 326, 25 Am. Dec. 476 ; Bentley v. Whittemore, 19 N. J. Eq. 462, 97 Am. Dec. 671, 674; Green v. Iron Works, 49 N. J. Eq. 48, 23 Atl. 498 ; Williams v. Dry Gonds Co., 4 Okl. 145, 43 Pac. 1148 ; Zipcey $v$. Thompson, 1 Gray (Mass.), 243 ; Bryan $v$. Brisbin, $26 \mathrm{Mo}$ 423, 72 Am. Dec. 219. 
sometimes held that the lex loci contractus should prevail." The reason is that the policy of the forum in such cases is not sufficiently pronounced to justify the courts of the forum in substituting the lex fori for the proper law. But it seems that if the property conveyed is real estate, any material departure from the lex situs in this respect will, as against resident creditors, invalidate the assignment. ${ }^{3}$

With respect to non-resident creditors, much more latitude is shown in enforcing the assignment according to the lex loci contractus. Indeed the lex fori must very clearly include within its protecting scope all creditors and all transactions wherever executed relating to the property situated within its jurisdiction, in order for it to override the lex loci contractus with respect to others than residents. The presumption is that it is intended to apply only to assignments made within its own limits or for the protection of its own citizens. ${ }^{4}$

These principles apply to other regulations of the forum as well as to those relating to preferences of creditors. Thus where

2 Atherton Co. v. Ives, 20 Fed. 894 ; Law v. Mills, 18 Penn. St. 185 ; Ockerman v. Cross, 54 N. Y. 29. See Barnett v. Kinney, 147 U. S. 476 ; Varnum v. Camp, 1 Gr. L. (N. J.) 326, 25 Am. Dec. 476.

3 Williams $v$. Dry Goods Co., 4 Okl. 145, 43 Pac. 1148 ; Bentley $v$. Whittemore, 19 N. J. Eq. 462, 97 Am. Dec. 671; Chafee v. Bank, 71 Me. 514, 36 Am. Rep. 345 ; Hervey $v$. Edens, 66 Tex. 420, 6 S. W. 306. See Moore v. Church, 70 Ia. 208, 59 Am. Rep. 439 ; Loving v. Pairo, 10 Ia. 282, 77 Am. Dec. 108; Bank v. Stelling, 31 S. C. 360 , 9 S. E. 1028.

4 Barnett v. Kinney, 147 U. S. 476 ; Williams v. Dry Goods Co., 4 Okl. 145, 43 Pac. 1148 ; Bentley $v$. Whittemore, 19 N. J. Eq. 462, 97 Am. Dec. 671, 677 ; Frank v. Bobbitt, 155 Mass. 112 ; May v. Bank, 122 Ill. 551, 13 N. E. 806 ; Egbert v. Baker, 58 Conn. 319, 20 Atl. 466 ; Thurston v. Rosenfield, 42 Mo. 474, 97 Am. Dec. 351 ; Law v. Mills, 18 Penn. St. 185 ; Speed v. May, 17 Penn. St. 91, 55 Am. Dec. 540; Chafee v. Bank, 71 Me. 514, 36 Am. Rep. 345. An example of a domestic policy so pronounced as to override the lex loci contractus altogether will be found in Ex parte Dickinson, $29 \mathrm{~S}$. C. 453,7 S. E. 593 , in which a foreign assignment of personalty was aroided as to non-resident creditors under the lex fori which provided that any assignment by an insolvent debtor containing preferences should be absolutely void. See also Douglas $v$. Bank, 97 Tenn. 133, 36 S. W. 874 . Other examples may be found in some of the cases involving real estate. Bank $v$. Stell. ing, 31 S. C. 360,9 S. E. 1028 ; Moore v. Church, 70 Ia. 208, 59 Am. Rep. 439. But see Atherton Co. v. Ives, 20 Fed. 894. 
the lex fori prescribes that assignments must be recorded, unrecorded foreigu assignments, valid and effectual to pass title to the assignee where made, have been sustained or set aside according to the view of the particular court touching the scope of the domestic policy. The tendency is in favor of upholding the assignment, where non-resident creditors are concerned..$^{5}$

So the question whether an assignment is invalid as fraudulent per se, because of reservations and conditions contained in the deed, is to be decided by the same principles. ${ }^{6}$ And so with respect to the effect upon the validity of the assigument of a failure of creditors to consent thereto."

5 Williams $v$. Dry Goods Co., 4 Okl.145, 43 Pac. 1148 ; Warner v. Jaffray, 96 N. Y. 248 ; Speed v. May, 17 Penn. St. 91, 55 Am. Dec. 540 ; Birdseye v. Underhill, 82 Ga. 142, 7 S. E. 863 ; Butler $v$. Wendell, 57 Mich. $62,23 \mathrm{~N}$. W. 460, 58 Am. Rep. 329 ; Cook v. Van Horn, 87 Wis. 291, 50 N. W. 893 . See Douglas $v$. Bank, 97 Tenn. 133, 36 S. W. 874 ; Rice v. Courtis, 32 Vt. 460, 78 Am. Dec. 597.

6 Woodward $v$. Brooks, 128 Ill. 222,20 N. E. 685 ; Livermore $v$. Jenckes, 21 How. 126 ; Rice v. Courtis, 32 Vt. 460, 78 Am. Dec. 597 ; Moore $v$. Wil. lett, 35 Barb. (N. Y.) 663 ; Graves v. Roy, 13 La. 454, 33 Am. Dec. 568 ; Ramsey v. Stevenson, 5 Mart. (La.) 23, 12 Am. Dec. 468 ; Railroad Co. v. Glenn, 28 Md. 287, 92 Am. Dec. 688. See Wattson v. Campbell, 35 N. Y. 153 ; Gardner v. Lewis, 7 Gill (Md.), 378, 393, 398.

7 Frank v. Bobbitt, 155 Mass. 112 ; Faulkner $v$. Hyman, 142 Mass. 53 ; May ข. Wannemacher, 111 Mass. 202. 


\section{CHAPTER XII.}

\section{INVOLUNTARY TRANSFERS OF PERSONALTY INTER VIVOS}

§136. Transfers by Marriage. - We have already observed time and again the distinction between voluntary and involuntary transfers. In the former case, except where the actual situs of the property is the forum and there is ground to substitute the lex fori, the legal situs of the chattels is to be referred to the actual situs of the owner at the time of the transfer, and the lex loci contractus becomes the "proper law." In the case of involuntary transfers by operation of law, on the other hand, the legal situs of the chattels is to be referred to the legal situs (or domicil) of the owner at the time of the transfer, and the lex domicilii becomes the "proper law;" subject to be substituted by the lex fori et situs of the chattels, wherever the policy of the forum requires it.

To this class of involuntary transfers by operation of law belong those transfers, which take place under some laws, of the personal property of one consort to the other upon marriage. Thus the common law conferred upon the husband an absolute title to the chattels of the wife immediately upon the marriage, and a similar title to her choses in action, provided he reduced them into possession during the coverture. By the Roman law the property of the consorts was held in community. Numerous variations of these rules, as well as some entirely distinct, exist in the various States, and it becomes important to observe the law which properly governs the rights of the consorts in the personalty of each other.

These transfers, and the law properly governing them, have already been discussed in preceding sections, where they were regarded in the aspect of incidents of the marriage status, and we there saw that the lex domicilii of the parties at the time the 
property was acquired is (independently of nuptial agreement) the "proper law" to control the rights of the parties." Regarding them now in the aspect of involuntary transfers by operation of law, exactly the same result is reached. The discussion of the principles involved need not be repeated here.

\$137. Involuntary Assignments in Bankruptcy or Insolvency. - In cases of bankruptcy, where bankrupt or insolvent laws prevail, the property of the insolvent is transferred by order of court or by operation of law, for the benefit of all the creditors, to an assignee, who stands to a certain extent in the shoes of the insolvent debtor.

The primary object of such laws is the protection of creditors, and it is only where the assignment takes place at their instance that it can be termed "involuntary." In this respect, such transfers differ from ordinary transfers in invitum, like transfers upon marriage, the primary purpose of which is not the protection of creditors or third persons.

Whether the voluntary feature which appears in some bankrupt laws is to be referred to this head or to that of voluntary transfers of personalty, is not entirely settled, ${ }^{1}$ and in the succeeding discussion it will be left out of consideration.

The question now to be examined is the effect to be given in other States to an involuntary assignment in bankruptcy or insolvency in the State of the insolvent's domicil; whether or not it is to be deemed of universal obligation, so as to transfer to the assignee the insolvent's movable property wherever situated, and thus withdraw it from the reach of creditors in the courts of the actual situs.

1 Ante, $\$ \S 80-82$.

1 See Egbert $v$. Baker, 58 Conn. 319, 20 Atl. 466 ; Barth v. Backus, 140 N. Y. 230 ; May $v$. Wannemacher, 111 Mass. 202, 209; Hervey v. Edens, 66 Tex. 420, 6 S. W. 306, 309 ; Butler $v$. Wendell, 57 Mich. 62, 58 Am. Rep. 329, 23 N. W. 460, 462 ; Paine v. Lester, 44 Conn. 196, 26 An. Rep. 442. It would seem upon principle, siuce the bankruptcy proceeding even when voluntary is in the nature of a judicial adjudication, and, as such, a proceeding in rem, it could only be effectual as to such property as is within the jurisdiction. Nor can such a proceeding be said to be contractual, since it is done without the assent of the creditors whose debts are thereby released. See Barth v. Backus, supra. 
Upon this point the English decisions are directly opposed to the overwhelming weight of American authority. In England, it is the established doctrine that for the purposes of a transfer of this kind the owner's chattels wherever situated must be presumed to have their legal situs at his domicil, and therefore the disposition of them must be governed by the lex domicilii. If by that law the title of the assignee is valid, it must be so held everywhere, even as against creditors resident in the actual situs and forum. ${ }^{2}$

It is impossible to defend the position of the English courts upon any principle of private international law. They admit that upon the transfer of personalty by operation of law to the administrator of a decedent, so far as creditors are concerned, the lex situs et fori is to govern the administration of the assets, and not the lex domicilii. Yet the assignment in bankruptcy is perhaps even a stronger case, for in the former case there may be no creditors at all, whereas, in the latter, the very purpose and the only purpose of the assignment is the protection of creditors. The principle therefore which induces the rule, for the protection of creditors, that the transfer of personalty to an administrator by the lex domicilii has no exterritorial effect, so long as creditors in the situs and forum remain unsatisfied, would seem to apply with even greater force to involuntary assignments in bankruptcy.

Such at least has been the reasoning of the American courts. Although the great weight of Chancellor Kent's opinion was given, in a masterly decision, in support of the English doc-

2 Story, Confl. L. § 409 ; Booth v. Clark, 17 How. 322, 336 ; Holmes $v$. Remsen, 4 Johns. Ch. (N. Y.) 460, 8 Am. Dec. 581 ; Paine v. Lester, 44 Conn. 196, 26 Am. Rep. 442, 443. With respect to land however, even in England, it seems to be admitted that an assignment in bankruptcy will have no effect. See Oakley $v$. Bennett, 11 How. 33 ; Williams v. Dry Goods Co., 4 Okl. 145, 43 Pac. 1148, 1151 ; Hervey v. Edens, 66 Tex. 420, 6 S. W. 30ó; Chipman v. Peabody, 159 Mass. 420, 34 N. E. 563 . In support of the English view it is claimed that the assignment in bankruptcy is after all a volur. tary assignment, since every citizen is supposed to consent to the laws of his country. See Holmes $v$. Remsen, 4 Johns. Ch. 460, 8 Am. Dec. 581 ; Milne $v$. Moreton, 6 Binn. (Penn.) 353, 361, 6 Am. Dec. 466. Pari ratione, an assault or other tort is a breach of contract ! 
trine, ${ }^{3}$ his view bas been overruled in this country. It is now thoroughly established in the United States, that assignments in bankruptcy or insolvency of personal property are to be given no exterritorial force ex proprio vigore." The same general principles are to be applied here as in the case of receivers, ${ }^{5}$ and administrators. ${ }^{6}$

But it does not follow, because ex proprio vigore the assignment has no exterritorial effect, that no such effect is under any circumstances to be accorded it. On the contrary, except with respect to land, the general rule of comity is to recognize the title conferred by the lex domicilii upon the assignee in every State where the insolvent's property may be located, save only where the interests of the forum or of creditors require that it shall be disregarded. Hence, if the case does not affect creditors in the forum, but merely relates to the title of the assignee and his right to collect and sue for debts due the insolvent, the transfer to the assignee under the lex domicilii is sustained. ${ }^{7}$

In Holmes $v$. Remsen, ${ }^{8}$ the question was whether a voluntary

8 Holmes $v$. Remsen, 4 Johns. Ch. 460, 8 Am. Dec. 581. See Blake $v$. Williams, 6 Pick. (Mass.) 286, 309, 17 Am. Dec. 372 ; Paine $v$. Lester, 44 Conn. 196, 26 Am. Rep. 442, 443.

4 Milne $v$. Moreton, 6 Binn. (Penn.) 353, 6 Am. Dec. 466 ; Blake $v$. Williams, 6 Pick. (Mass.) 286, 308, 17 Am. Dec. 372 ; Crapo v. Kelly, 16 Wall. 610 ; Booth $v$. Clark, 17 How. 322 ; Harrison $v$. Sterry, 5 Cr. 289 ; Paine $v$. Lester, 44 Conn. 196, 26 Am. Rep. 442 ; Willetts v. Waite, 25 N. Y. 577, 584, 586; Barth v. Backus, 140 N. Y. 230, 235 ; McClure $v$. Campbell, 71 Wis. 350,37 N. W. 343 ; Hibernia Nat. Bank v. Lacombe, 84 N. Y. 367 ; Hervey $v$. Edens, 66 Tex. 420, 6 S. W. 306 ; Sturtevant v. Armsby Co., 66 N. H. 557, 23 Atl. 368 .

s Ante, $\S \S 117,118$. See Booth $v$. Clark, 17 How. 322.

6 Ante, $\$ 106,107$.

7 Milne v. Moreton, 6 Binn. (Penn.) 353, 363, 365, 6 Am. Dec. 466 ; Paine v. Lester, 44 Conn. 196, 26 Am. Rep. 442, 444 ; Willetts $v$. Waite, 25 N. Y. 577, 583, 584 ; Kirkland v. Lowe, 33 Miss. 423, 69 Am. Dec. 355, 356. But if the property assigned is a non-negotiable chose in action, the assignee takes only an equitable title, and cannot sue thereon in lis own name unless the lex fori permits it. Kirkland v. Lowe, 33 Miss. 423, $69 \mathrm{Am}$. Dec. 355, 356 ; Milne $v$. Moreton, 6 Binn. (Penn.) 353, 6 Am. Dec. 466. This is in conformity to the general principle that the lex fori controls the remedy. See post, $\S 206$.

8 Johns. Ch. (N. Y.) 460, 8 Am. Dec. 581. 
payment in England by a New York debtor to the English assignee of an English bankrupt was a good defence to a New York attachment and garnishment by an American creditor of the bankrupt. Chanceller Kent decided that it was. Reasoning from analogy to the case of the payment of debts to a foreign administrator, ${ }^{9}$ it would seem that this decision was correct, even supposing (as proved to be the case here) that there were creditors to claim the debt in the New York courts. The payment was made in England, the situs of the assignee's authority. This decision has been frequently disapproved in the later American cases, in respect to its general views as to involuntary assignments.

It will be observed that the great practical difference between voluntary assignments for the benefit of creditors and involuntary assignments in bankruptcy, so far as their exterritorial effect is concerned, is that the former, being contractual and an exercise of the owner's jus disponendi, takes effect in other States ex proprio vigore, according to the terms of the disposition, unless it is invalid and prohibited by the lex situs et fori; while the latter, being the result merely of an act of the law for the protection of creditors, has no more inherent exterritorial effect than has the law creating it. Any such effect accorded to it is due merely to comity and policy, and neither of these call for its recognition in other States whose interests or policy dictate a contrary course, as will be the case wherever there are creditors there. And this is true, though there be nothing in the lex situs et fori to invalidate such a transfer, or even though the latter law be identical in terms with the lex domicilii. The mere fact that there are creditors in the forum is sufficient to induce the courts of the forum to disregard the foreign assignment, until the creditors are satisfied. ${ }^{10}$

But as in the case of receivers, ${ }^{11}$ if the property is in the State of the assignment and the assignee in bankruptcy takes posses-

9 Ante, § 109.

$10 \mathrm{So}$, if there are in the forum purchasers of the insolvent's property, without notice of the assignment. See Willetts $v$. Waite, 25 N. Y. 577, 584 ; Johnson $v$. Hunt, 23 Wend. (N. Y.) 88.

11 Ante, $\$ \S 117,118$. 
sion, the fact that it is subsequently found in another State will not deprive the assignee of his title conferred by the lex domicilii and the lex situs also. ${ }^{12}$

Difficulty is sometimes experienced in determining whether a particular assignment under the insolvent laws of a State is to be deemed voluntary or involuntary. It has been said in some cases that if the assignment is "statutory," it comes within the principles above laid down. ${ }^{18}$ But this term is likely to mislead, since it is not true that every assignment regulated by statute is involuntary. In Barth $v$. Backus, ${ }^{14}$ it is said that the test to determine whether an assignment shall be given exterritorial effect is found in the query whether or not the insolvent is thereby discharged of all further liability for his debts. And this is believed to be the true test; for even though the assignment in such a case is a voluntary act on his part it is not voluntary on the part of the creditors, who are thereby compelled to release their debts. The assignment is not contractual, for ouly one party enters into it willingly. And of course if the act is not that of the owner, but through the intervention of a court or officer appointed by law, it is an involuntary assignment. ${ }^{15}$

$\S 138$. Creditors for whose Benefit Assignment disregarded. - Nothing in connection with this subject is better settled than that transfers in bankruptcy or insolvency have no exterritorial force, so far as concerns debts due the State of the situs and forum in the shape of taxes, etc., ${ }^{1}$ or due to residents of that

12 Crapo $v$. Kelly, 16 Wall. $610,622,627$; Cole $v$. Cunningham, 133 U. S. 107, 128; May $v$. Wannemacher, 111 Mass. 202, 209 ; Willetts v. Waite, 25 N. Y. 577, 584 ; Plestoro v. Abraham, 1 Pai. Ch. (N. Y.) 236 ; Smith v. Katon, 36 Me. 298, 58 Am. Dec. 746, 749.

13 Hervey v. Edens, 66 Tex. 420, 6 S. W. 306, 309 ; Frank v. Bobbitt, 155 Mass. 112; Paine v. Lester, 44 Conn. 196, 26 Am. Rep. 442, 445 ; Butler v. Wendell, 57 Mich. 62, 58 Am. Rep. 329, 23 N. W. 460, 462.

14 140 N. Y. $230,237$.

15 See May v. Bank, 122 Ill. 551, 13 N. E. 806, 807 ; Kirkland v. Lowe, 33 Miss. 423, 69 Am. Dec. 355 ; Butler $v$. Wendell, 57 Mich. 62, 58 Am. Rep. 329 ; Willetts $v$. Waite, 25 N. Y. 577, 587; Egbert $v$. Baker, 58 Conn. 319, 20 Atl. 466 ; May v. Wannemacher, 111 Mass. 202, 208, 209.

1 Harrison $v$. Sterry, 5 Cr. 289 ; Willetts v. Waite, 25 N. Y. 577, 586. 
State. ${ }^{2}$ Nor do the American courts stop there. The current of authority is in favor of extending the same privileges to creditors who are residents of third States and who desire to take advantage of the remedies afforded by the situs. ${ }^{3}$

Indeed, some of the courts have gone so far as to say that to hold a foreign assignment invalid as to the residents of the forum, but valid as to residents of other States of this Union, would be in contravention of the federal constitution." Although this position cannot be sustained, it tends to show how fixed with us in such cases is the policy of the open door to creditors generally. No good reason can be assigned for not extending this liberal policy to creditors resident in foreign countries as well as in other States of this Union than the forum; but though some of the decisions contain statements sufficiently general to cover alien creditors, there seem to be no direct decisions to that effect. On the contrary, there are several cases taking the opposite view. ${ }^{6}$

2 May v. Bank, 122 Ill. 551, 13 N. E. 806, 807; Cole v. Cunningham, 133 U. S. $107,127,128$; Reynolds $v$. Adden, 136 U. S. 348 ; Crapo v. Kelly, 16 Wall. 610, 622 ; Blake v. Williams, 6 Pick. (Mass.) 286, 17 Am. Dec. 372 ; Paine v. Lester, 44 Conn. 196, 26 Am. Rep. 442, 444; Speed v. May, 17 Penn. St. 91, 94, 55 Am. Dec. 540 ; Long v. Girdwood, 150 Penn. St. 413, 24 Atl. 711, 23 L. R. A. 33 ; Willetts $v$. Waite, 25 N. Y. 577, 586, 587; Sturtevant v. Armsby Co., 66 N. H. 557, 23 Atl. 368.

3 Cole v. Cunningham, 133 U. S. 107, 127; Crapo v. Kelly, 16 Wall. 610, 628; Harrison v. Sterry, 5 Cr. 289 ; Hibernia Nat. Bank v. Lacombe, 84 N. Y. 367; Willetts $v$. Waite, 25 N. Y. 577, 586 ; Milne v. Moreton, 6 Binn. (Penn.) 353, 6 Am. Dec. 466; Blake v. Williams, 6 Pick. (Mass.) 286, 308, 17 Am. Dec. 372 ; Paine v. Lester, 44 Conn. 196, 26 Am. Rep. 442, 444, 445; Barth v. Backus, 140 N. Y. 230 ; Sturtevant v. Armsby Co., 66 N. H. 557, 23 Atl. 368.

- Sturtevant $v$. Armsby Co., 66 N. H. 557, 23 Atl. 368 ; Paine v. Lester, 44 Conn. 196, 26 Am. Rep. 442, 445. But see Chafee v. Bank, 71 Me. 514, 36 Am. Rep. 345.

5 Sturtevant v. Armsby Co., 66 N. H. 557, 23 Atl. 368 ; Long v. Gird. wood, 150 Penn. St. 413, 24 Atl. 711, 23 L. R. A. 33. The last case may possibly be explained in some measure by the fact that the assignment occurred in Scotland, and the attaching creditors were citizens of Canada, both narts of the British Empire; or perhaps by the fact that the Pennsylvania eourt considered (as it apparently did) that the foreign assignment could only be invalidated by Pennsylvania creditors - a position logical at least, if not liberal. 
But with respect to the rights of creditors who are residents of the State in which the assignment takes place, the courts are divided. Some of the decisions hold that they should be bound by the laws of their own State, and that they cannot, by going in to another State, set at naught the work of their own law. ${ }^{6}$

Although this would seem to be the juster and the wiser view, ${ }^{7}$ many decisions will be found extending the same privileges to these as to other creditors. ${ }^{8}$ However this may be, it is certain that the courts of the State where the assignment occurs may peremptorily enjoin its own citizens from going abroad to attach the property of the insolvent. ${ }^{9}$

6 Cole $v$. Cunningham, 133 U. S. 107, 128; Livermore $v$. Jenckes, 21 How. $120^{\circ}$; Long $v$. Girdwood, 150 Penn. St. 413, 24 Atl. 711, 23 L. R. A. 33 ; Plestoro v. Abraham, 1 Pai. Ch. (N. Y.) 236 ; May $v$. Wannemacher, 111 Mass. 202, 209 ; Sturtevant $v$. Armsby Co., 66 N. H. 557, 23 Atl. 368, 369.

7 In speaking of a similar question arising with respect to voluntary assignments (ante, $\S 134$, note 6 ), it was said that the better opinion was that the citizens of the place of assignnient should be put on the same footing as the residents of other States outside the forum. There the question was one of the construction of the lex situs et fori. Here the question is not at all a question of statutory construction, but of jurisdiction and submission to a personal law.

${ }^{8}$ Cole $v$. Cunningham, 133 U. S. 107, 128 ; May $v$. Bank, 122 Ill 551, 13 N. E. 806 ; Rhawn $v$. Peters, 110 Ill. 350 ; Hibernia Nat. Bank v. Lacombe, 84 N. Y. 367 ; Willetts $v$. Waite, 25 N. Y. 577, 583 ; Taylor $v$. Badoux, 92 Tenn. 249, 21 S. W. 522 ; Commercial Bank v. Motherwell Co., 95 Tenn. 172, 31 S. W. 1002 . See Sturtevant v. Armsby Co., 66 N. H. 557, 23 Atl. 368, 369.

9 Cole v. Cunningham, 133 U. S. 107 ; Dehon v. Foster, 4 Allen (Hass.), 545. It is otherwise, if the assignment is voluntary. Warner $v$. Jallray, 98 N. Y. 248. 


\section{CHAPTER XIII.}

\section{TRANSFER BY SUCCESSION.}

\section{§ 139. Titles of Administrator and Distributee distinguished.} - It is a general rule, upon the death intestate of an owner of property, that his personalty is to be committed to an administrator, whose first duty is to pay the decedent's debts, and after they are paid to turn over the residuum of the estate to those appointed by law as his successors in the ownership of the property, known as his "distributees" or " next of kin."

The title vested in the administrator, and subsequently in the distributees, results not from any voluntary act on the part of the owner, but from the act of the law. Furthermore, so far as the administrator is concerned, his title is vested in him primarily for the protection of creditors, incidentally only for the distribution of the estate amongst the next of kin. With respect to its primary purpose, therefore, the title of an administrator is in mauy respects analogous to that of an assignee in involuntary bankruptcy. ${ }^{1}$ Like such assignee, the administra. tor is a quasi-officer of the law; his authority and title, originating in an act of the law, is ex proprio vigore of no exterritorial force, and will not, as to creditors, extend to personalty situated elsewhere than in the State of his appointment.

'The principles regulating the administration of a decedent's estate, including the law governing his appointment, title, powers, duties, and liabilities, have been already discussed in detail at another place, to which reference is now made. ${ }^{2}$

But if we suppose that there are no debts, or that they have all been paid, the administration of the estate ceases, and its distribution commences. It is the law governing this distribution into which we are now to inquire.

2 Ante, $\$ 137$ et seq.

2 Ante, $\$ \$ 105$ et soq. 
It is the well established general rule that the law of the last domicil of the deceased owner is the "proper law" to govern the distribution of his personalty, not the lex situs of the property (though that law may perhaps be applied in certain exceptional cases, where the situs and the forum coincide); nor the law of the owner's domicil at the time he acquired the property in question; nor the law of the decedent's actual situs at the time of his death. The transfer is involuntary and by act of the law, and therefore it is the owner's legal situs or domicil that furnishes the proper law; and the transfer being effected at the time of his death, it is his domicil at that time that is to be looked to. Hence the general rule that the law of the last domicil of the decedent is the proper law. ${ }^{3}$

\section{$\S 140$. Persons to Take as Distributees - Capacity of Dis-} tributees to Take. - From what has been said in the preceding section it will be seen that the classes of persons who are to succeed to a decedent's personalty as his distributees or next of kin will be determined by the law of the decedent's domicil at the time of his death. ${ }^{1}$

3 Sharpe $v$. Crispin, L. R. 1 P. \& D. 611 ; Somerville $v$. Somerville, 5 Ves. 750 ; Ennis $v$. Smith, 14 How. 400, 424; Wilkins v. Ellett, 9 Wall. 740, 742 ; Sickles $v$. New Orleans, 52 U. S. App. 147, 80 Fed. 868, 874 ; Guier $v$. O'Daniel, 1 Binn. (Penn.) 349, note ; Welles' Estate, 161 Penn. St. 218, 28 Atl. 1116 ; Shultz $v$. Pulver, 3 Pai. Ch. (N. Y.) 182 ; s. c. 11 Wend. 361 ; Vroom v. Van Horne, 10 Pai. Ch. 549, 42 Am. Dec. 94; Hegeman v. Fox, 31 Barb. (N. Y.) 475 ; Parsons $v$. Lyman, 20 N. Y. 103 ; Petersen $v$. Chemical Bank, 32 N. Y. 21, 44, 88 Am. Dec. 298 ; Despard $v$. Churchill, 53 N. Y. 192, 199; White $v$. Tennant, 31 W. Va. 790, 8 S. E. 596 ; Mayo $v$. Equitable, etc. Society, 71 Miss. 590, 15 So. 791 ; Sneed $v$. Ewing, 5 J. J. Marsh. (Ky.) 460, 22 Am. Dec. 41, 57 ; Atchison v. Lindsey, 6 B. Mon. (Ky.) 86, 43 Am. Dec. 153, 156 ; Shannon $v$. White, 109 Mass. 146 ; Cooper v. Beers, 143 Ill. 25, 33 N. E. 61 . If there are no creditors of the decedent, either local or domieiliary, it is usually considered unnecessary to remit the personalty to the owner's domicil for distribution. The local courts may distribute it, but in accordance with the provisions of the lex domicilii. Welles' Estate, 161 Penn. St. 218, 28 Atl. 1116; Gravillon v. Richards, 13 La. 293, 33 Am. Dec. 563, 565 ; Goodall $v$. Marshall, 11 N. H. 88, 35 Am. Dec. 472. But see Succession of Petit, 49 La. Ann. 625, 21 So. 717. It will also be remembered that the succession to land is always to be governed by the lex situs of the land. Ante, § 12.

1 Story, Confl. L. $\$ 481 a$; Sharpe v. Crispin, L. R. 1 P. \& D. 611 ; Bruce 
Thus, in Mayo v. Equitable, etc. Society, ${ }^{2}$ a young man, born in Virginia, went to Tennessee to seek employment, where he remained for a year; he then went to Mississippi, where he remained about a year; returned to Tennessee, where he stayed a month; and then, on account of constant ill-health, returned to Virginia, where he shortly afterwards died. While in Mississippi he had insured his life in the Equitable Assurance Society, and on his return to Virginia left the policy in Mississippi for safe-keeping. The question arose in Mississippi as to the persons entitled to the proceeds of the policy. By the law of Virginia, where the court held the decedent to have been domiciled at his death, the father (who was heavily indebted) was the sole distributee. By the law of Mississippi other members of his family would have shared in the distribution. Notwithstanding the hardship of the case (which evoked much sympathy from the court) it found itself constrained to hold that the lex domicilii at the time of the death must govern; that the youth's estate belonged to the father under the law of Virginia; and that the impoverished family could receive only what was left after paying the father's creditors.

So where the question is not what classes of the kin shall succeed to the property, but whether or not a particular member of the class named by the law of the decedent's domicil, to whom some personal disability is attached, can succeed to the property along with other members of the same class, the "proper law" to determine his capacity of succession, it is believed, is the law of the decedent's domicil, not the law of the domicil of the particular distributee whose capacity is in question. In Bruce $v$. Bruce ${ }^{3}$ the inquiry was whether the decedent's half-brother was entitled to succeed to his estate along with a whole brother. The case was held to turn entirely upon the domicil of the decedent, no mention being made of the half-brother's domicil. By the English law, the half-brother was entitled to a share;

v. Bruce, 2 Bos. \& Pul. 229 ; Ross v. Ross, 129 Mass. 243, 246, 37 Am. Rep. 321 ; Mayo $v$. Equitable, etc. Society, 71 Miss. 590, 15 So. 791 ; Welles' Es tate, 161 Penn. St. 218, 28 Atl. 1116; Ennis v. Smith, 14 How. 400, 425.

71 Miss. 590, 15 So. 791.

32 Bos. \& Pul. 229. 
by the law of Scotland, he was not. It was held that the decedent's last domicil was England, and that its law must control.

The instance in which this point has most frequently arisen is the case of bastards claiming the right to succeed to a relative's estate. If both the decedent and the bastard are domiciled in the same State at the time of the former's death, no question will arise as to what is the "proper law." The two domicils coincide, and the lex domicilii will govern." But if the natural child is domiciled in a State different from the deceased relative, and by the law of one State the capacity to succeed with the other next of kin is given, while denied by the law of the other State, the solution is not so simple. It would seem to be clear that if the lex domicilii of the decedent should forbid succession by the bastard, he could not inherit, because the decedent's property is legally situated at the domicil of the owner, and the prohibitions of that law should be conclusive. ${ }^{5}$ On the other hand, if the law of the decedent's domicil permits the bastard's succession, while the law of the bastard's domicil does not, a moment's reflection will show that the policy of the latter law cannot be directed towards injuring the bastard, but towards protecting the estates of its citizens who die intestate from such doubtful claims. It cannot be supposed that the law of the bastard's domicil was intended to prevent one of its own citizens (even though he be a bastard) from being enriched by sharing in the estate of a foreigner, since the good fortune of the bastard can in no way impair in any way the policy of his domicil. In other words, it would seem manifest that the incapacity to succeed imposed upon the bastard by the law of his domicil, was only an incapacity to succeed to the property of residents of his domicil. ${ }^{\circ}$

But in these cases of involuntary transfer, as in other cases, there may be occasions, where the law of the actual situs and forum may be substituted for the law of the legal situs of the

4 Doglioni v. Crispin, L. R. 1 H. L. 301.

5 Sharpe v. Crispin, L. R. 1 P. \& D. 611.

6 Quite a different question arises where the bastard has been legitimated, or in case of adopted persons. See ante, $\$ 12$. 
personalty (lex domicilii). At least it has been so held in one late Louisiana case, though the wisdom of the decision is, to say the least, doubtful. In Succession of Petit, ${ }^{7}$ a father and his natural son were both domiciled in France, by whose law the bastard was entitled to succeed to a share of the father's estate. The father, upon his death, left personalty in Louisiana, by whose law the bastard was not entitled to inherit. Some of the next of kin were residents of Louisiana, and in their interests the Louisiana court declined to enforce the law of France.

$\S 141$. Shares of Distributees. - The law of the decedent's last domicil controls also the shares into which the personal estate is to be divided, and the proportion that shall belong to each distributee. So, whether primogeniture gives an exclusive right to the succession, or a larger proportion thereof, or is to be entirely disregarded; whether the distributees are to take per capita or per stirpes; the nature and extent of the application of the principle of representation; the shares of a husband, a widow, collaterals of the half-blood, etc., - are all questions properly to be determined by the law of the decedent's last domicil. ${ }^{1}$

For example, in England and in some of the United States, there is no right of representation beyond that of brother's and sister's children in the distribution of personalty. Hence if one domiciled in England should die, leaving a brother and the grandchildren of a deceased brother, the latter would not take the decedent's personalty in virtue of their representation of the deceased brother, even though the personalty were actually situated in a country by whose law such representation was admissible. ${ }^{2}$

749 Ia. Ann. 625, 21 So. 717.

1 Story, Confl. L. $\S 481 a$; Bruce $v$. Bruce, 2 Bos. \& Pul. 229 ; White $v$. Tennant, 31 W. Va. 790,8 S. E. 596 ; Lawrence $v$. Kitteridge, 21 Conn. 577 , 56 Am. Dec. 385 ; Welles' Estate, 161 Penn. St. 218, 28 Atl. 1116 ; DeCouche v. Savetier, 3 Johns. Ch. (N. Y.) 190, 8 Am. Dec. 478, 480 ; Hegeman $v$. Fox, 31 Barb. (N. Y.) 475; Hairston v. Hairston, 27 Miss. 704, $61 \mathrm{Am}$. Dec. 530 ; Williamson v. Smart, Conference Rep. (N. C.) 146, 2 Am. Dec. 638; Ennis $v$. Smith, 14 How. 400, 425.

2 Story, Confl. L. $\$ 481 a$. 


\section{CHAPTER XIV.}

\section{TRANSFERS OF PERSONALTY BY WILL.}

§ 142. Transfer by Will, Involuntary. - From the stand. point of private international law, a will is to be viewed in the light of an involuntary, rather than a voluntary, transfer of property, and therefore the "proper law" is the law of the legal, not the actual, situs of the testator. Though the act of executing a will is a voluntary act, that act ex proprio vigore has no effect in transferring the title. Effect is given to it only by and upon the subsequent death of the owner, without revocation of the will. The real act which gives the will effect as a transfer is the testator's death, and that is involuntary. The fact that he is in a particular country when death overtakes him is no indication that he has voluntarily submitted himself or his property to its laws. So the fact that he is in a particular State when he executes the will is no necessary indication that he submits himself or his property to the laws of that State, for he knows that the will is not to take effect until his death, at which time he may have severed all connection with that State.

In its influence upon the operation of the will as a transfer of property, the death of the testator preponderates over the making of the will to the extent that it is in general the condition of affairs at the time of the death, not that at the time of the making of the will, which furnishes the law of the case; for wills of personalty speak as at the testator's death. But it is not necessarily the State where the death occurs that furnishes the law. Since the death is involuntary, there is no reason to presume the owner's personalty to be legally situate elsewhere than at the legal situs (domicil) of the owner. The law of his actual situs at the time of death, as such, will not 
control, nor (except for purposes of administration) will the law of the actual situs of the property have any influence.

But it does not necessarily follow that the strict letter of the lex domicilii is always to be enforced in regard to wills. It is indeed, as in other cases, the policy of the domicil rather than its law which is to control. The law may be couched in such general terms as to cover cases it was manifestly not intended to cover, cases not at all within the scope of its policy. In such cases the strict letter of the domiciliary law is not applicable, and it may be supposed that that law intends that its provisions may then be substituted by the law of some other State more interested in the matter.

Instances of this have already been seen in our examination of the proper law governing testamentary capacity, ${ }^{1}$ and other instances will be seen in the course of the following discussion.

But this applies only to wills of personalty. With respect to lands, it is perfectly well settled that the strict letter of the lex situs of the land will control the validity of the devise in all respects. ${ }^{2}$

It is to be observed that, although the will consists of dispositions of both real and personal estate, situated in different States, and even though they are given in the same clause of the will and upon the same trusts, the dispositions will in general be severable, and the validity of one will not usually de pend upon the validity of the other. One may be valid by the lex situs, while the other is invalid by the lex domicilii, and vice versa. ${ }^{3}$

$\S 143$. Formal Validity of Wills of Personalty. - The policy of laws controlling the formal validity of wills is directed

1 Ante, § 70.

2 Carpenter $v$. Bell, 96 Tenn. 294, 34 S. W. 209 ; Williams v. Saunders, 5 Coldw. (Tenn.) 60, 72 ; Frazier v. Boggs, 37 Fla. 307, 20 So. 245 ; Wynne v. Wynne, 23 Miss. 251, 57 Am. Dec. 139 ; Ross v. Ross, 129 Mass. 243, 245, 37 Am. Rep. 321 ; Ford v. Ford, 70 Wis. 19, 33 N. W. 188 ; Penfield $v$ Tower, 1 N. D. 216, 46 N. W. 413 ; Darby $v$. Mayer, 10 Wheat. 465 ; Kery $v$. Moon, 9 Wheat. 565 ; Ware $v$. Wisner, 50 Fed. 310. It is otherwise as to the interpretation of the devise. Post, $\$ 145$.

3 Knox v. Jones, 47 N. Y. 389, 395. See Cross v. Trust Co., 131 N. Y. $330,339$. 
towards all wills which owe their effect to those laws, and einbraces therefore all wills of personalty executed by persons domiciled in that State, without regard to the actual locality of the property disposed of or the place where the will may happen to have been actually executed. For this purpose the strict letter of the lex domicilii of the testator at the time of his death will control, and no foreign law can be incorporated into it for the purpose of any particular case. ${ }^{1}$

The result is the same if the testator makes his will in his domicil according to the forms and ceremonies prescribed $v y$ its laws, and subsequently removes to another State to live, by the law of which the ceremonies accompanying the execution of the will are not sufficient. And so, if we suppose the will invalid in the first State and valid in the second. It is in all cases the law of the testator's domicil at the date of his death, not at the time of the execution of the will, that must determine its formal validity. This is true, not only because the will speaks as at the death of the testator, being revocable and ambulatory up to that time, but also because the matter of testacy or intestacy is a status fixed by his death, and as such is to be determined by the lex domicilii at that time. ${ }^{2}$

Thus, in Moultrie $v$. Hunt, ${ }^{8}$ the testator domiciled in South

1 Desesbats $v$. Berquier, 1 Binn. (Penn.) 349, 2 Am. Dec. 448 ; Flannery's Will, 24 Penn. St. 502; Williams $v$. Saunders, 5 Coldw. (Tenn.) 60, 69; McCune $v$. House, 8 Ohio, 144, 31 Am. Dec. 438; Burlington University $v$. Barrett, 22 Ia. 60, 92 Am. Dec. 376 ; Monltrie $v$. Hunt, 23 N. Y. 394 ; Chamberlain $v$. Chamberlain, 43 N. Y. 424, 432 ; Kerr $v$. Dougherty, 79 N. Y. 327,342 ; Hope $v$. Brewer, 136 N. Y. 126, 138 ; Ford $v$. Ford, 70 Wis. 19, 33 N. W. 188 ; Cameron $v$. Watson, 40 Miss. 191, 207 ; Sickles v. New Oreans, 52 U. S. App. 147, 80 Fed. 868; Yates $v$. Thompson, 3 Cl. \& F. 544, 577. In a few cases, expressions will be found to the effect that a will of personalty, if formally valid accorling to the law of the place where it is executed, will be sustained everywhere. See Roberts' Will, 8 Pai. Ch. (N. Y.) 519 ; Sevier $v$. Douglass, 44 La. Ann. 605, 10 So. 804. But an examination of these cases will show that the court was regarding the will as made at the testator's domicil.

2 Moultrie v. Hunt, 23 N. Y. 394 ; Dupuy $v$. Wurtz, 53 N. Y. 556 ; White v. Howard, 46 N. Y. 144 ; McCune v. House, 8 Ohio, 144, 31 Am. Dec. 438 ; Nat $v$. Coons, 10 Mo. 543.

83 N. Y. 394. 
Carolina there executed his will, declaring before the attesting witnesses that it was his signature and seal. This was sufficient in South Carolina to make it a valid will. The testator subsequently removed to New York, where he died. By the law of New York, it was required that the testator should declare in the presence of two attesting witnesses that it was his last will and testament. It was held that the formal validity of the will was to be determined by the law of the testator's domicil at the time of his death, not at the date of the execution of the will.

$\S 144$. Substantial Validity of the Provisions of the Will. - In determining the substantial validity of a will of personalty, the general principle is unquestionably the same as in the case of its formal validity. The law of the testator's last domicil is the proper law. But elements are present here which are absent where the investigation relates to matters of form only, and which give rise to apparent exceptions to the operation of the lex domicilii. But these exceptions are apparent only, since in reality it is the temporary adoption by the lex domicilii of another law in the particular case, which gives such other law its effect. It has none inherently. The general rule is still that the law of the testator's domicil at the time of his death will regulate the validity of the testamentary provisions. ${ }^{1}$

But difficulty is often experienced in these cases in ascertaining what is the law of the domicil in regard to a particular set of circumstances. In order to determine this, the policy of the particular statute or law of the domicil must be looked to. Such laws may be divided into four distinct classes.

One class of these provisions may be created for purposes of convenience and certainty in the administration of estates, such, for example, as that vague and indefinite trusts contained in a will are void. The main purpose of such provisions is to relieve the courts of the domicil of the difficult task of enforcing

1 Williams $v$. Saunders, 5 Coldw. (Tenn.) 60, 76 ; Chamberlain $v$. Cham. berlain, 43 N. Y. 424 ; Cross v. Trust Co., 131 N. Y. 330 ; Dammert v. Osborn, 140 N. Y. 30 ; Fellows $v$. Miner, 119 Mass. 541; Bible Society v. Pendleton, 7 W. Va. 79 ; Ford $v$. Ford, 70 Wis. 19, 33 N. W. 188 ; Penfield v. Tower, 1 N. D. 216, 46 N. W. 413. 
the testator's wishes when vaguely expressed. It is obvious that if the will provides that these vague dispositions are to be enforced in the courts of some other State than the domicil, and the courts of that State are authorized by its law to enforce such dispositions, the strict letter of the domiciliary law is not applicable.

Another class relates to the management and control of the preperty bequeathed, such, for example, as prohibitions against perpetuities or accumulations, etc. Here also, if the provisions of the will are such that these perpetuities or accumulations relate only to property outside the domicil, the strict letter of the lex domicilii is not applicable. The purpose of such laws is to prevent property actually situated in the State from being tied up and not subject to alienation. If therefore the will thus disposes of property in another State than the domicil, the intention being that it should remain there, the domiciliary provisions against perpetuities, etc., are not intended to embrace such a case. That is a question to be dealt with by the law of the place which is the proposed situs of the property.

A third class embraces those cases wherein the policy of the domicil is directed against the holding by certain classes of persons of property under a will, such as corporations under the statutes of mortmain. Here again, if the legatees live elsewhere the policy of the domicil does not apply.

The last class embraces those cases wherein the domiciliary policy is directed towards the protection of the testator or his family from improvident dispositions, such as limitations upon the testator's capacity to bequeath his property to charitable purposes, except to a limited amount, or unless the will be executed a certain period before his death; restrictions upon the capacity of an infant, or a married woman, to make a will, etc. The policy of this class of laws is to protect the citizens of the State where they are enacted. They are directed towards those testators who are resident there, and constitute restrictions upon testamentary capacity. Their application is entirely independent of the locality of the property transferred. Here the lex domicilii governs in full force, without the aid of any foreign law whatever. 
This fourth class of laws controlling testamentary validity, involving the capacity to make a will of personalty, and the third class, involving the capacity of the legatee to take, have been already discussed in connection with the law governing personal capacities. ${ }^{2}$

With regard to the first two classes, though the older rule was that the letter of the lex domicilii should govern in all cases, even though the property disposed of was, under the will, to be enjoyed in another State, ${ }^{8}$ the modern tendency is distinctly in the direction of enforcing the policy rather than the letter of the lex domicilii, and if the property is to have its final situs in another State, to make the law of that State a part of the lex domicilii for the purpose of regulating that disposition."

In Hope $v$. Brewer, ${ }^{5}$ a testator domiciled in New York bequeathed property to trustees in Scotland, to establish a charity in that country. The bequest under the law of New York was too vague and indefinite, but was valid and capable of enforcement under the laws of Scotland. The New York court decided in favor of the validity of the bequest.

2 Ante, $\$ 70$.

3 Wood v. Wood, 5 Pai. Ch. (N. Y.) 596, 28 Am. Dec. 451; Sorrey v. Bright, 1 Dev. \& B. Eq. (N. C.) 113, 28 Am. Dec. 584 ; Montgomery v. Milliken, 5 Sm. \& M. (Miss.) 151, 43 Am. Dec. 507 ; Lowry v. Bradley, 1 Speer's Eq. (S. C.), 1, 39 Am. Dec. 142.

4 Chamberlain v. Chamberlain, 43 N. Y. 424 ; Hope v. Brewer, 136 N. Y. 126 ; Fellows v. Miner, 119 Mass. 541 ; Healy $v$. Reed, 153 Mass. 197 ; Sohier v. Burr, 127 Mass. 221 ; Ford v. Ford, 80 Mich. 42, 44 N. W. 1057. But see Cross v. Trust Co., 131 N. Y. 330 ; Doty v. Hendrix, 16 N. Y. Supp. 284 ; Dammert $v$. Osborn, 140 N. Y. 30 ; Bible Society $v$. Pendleton, 7 W. Va. 79. In Dammert $v$. Osborn, supra, a testator domiciled in Peru bequeathed personalty to charitable uses in New York, invalid under the laws of New York, prohibiting the suspension of the power of alienation for a longer period than two lives in being at the death of the testator, but valid under the law of Peru (lex domicilii). This bequest was sustained in New York, after a special enactment by the New York legislature validating the charity. In the absence of this special enactment, it would seem that the general laws of New York would have governed; unless perhaps the policy of those laws should be deemed so unimportant as to be superseded by the advantages accruing from a valuable charity donated by foreigners. But the courts could hardly con. sider such matters in reaching a decision.

5136 N. Y. 126, 134, 135. See Bible Society v. Pendleton, 7 W. Va. 79. 
In Chamberlain $v$. Chamberlain, ${ }^{6}$ a New York testator bequeathed a legacy to a Pennsylvania corporation for charitable purposes, which was violative of the New York statutes against perpetuities. It was held by the New York court that the validity of the bequest in that respect should depend upon the law of Pennsylvania, whither the property was to be sent for use. In the course of its opinion the court says: "It is no part of the policy of New York to interdict perpetuities or gifts in mortmain in Pennsylvania. Each State determines those matters according to its own views of policy and right, and no other State has any interest in the question. There is no reason why the New York courts should follow the funds bequeathed to this Pennsylvania corporation to see whether they will be there administered in all respects in strict harmony with our policy and laws."

In Despard $v$. Churchill, ${ }^{7}$ it was held that the New York courts would not themselves directly enforce the provisions of a Californian's will, valid in California, disposing of personalty in New York, the will creating perpetuities invalid under New York law, but that the New York assets, after paying certain legacies which were valid under the law of New York, should be remitted to California to be there distributed. If it had been directed by the will that this property was to go to New York legatees and to remain there, doubtless the court would have declared the disposition invalid, as not being within the purview of the California law, but embraced in the policy of the State of New York. As it was, however, the property was to go out of New York, and therefore it would seem, the New York policy not being applicable to the case, there was no particular reason why the court should have refused to itself enforce the provisions of the will.

$\S 145$. Interpretation of the Will. - In the case of any document, whether it be a contract, a conveyance, or a will, the primary rule for the interpretation of ambiguous language is that the

$643 \mathrm{~N}$. Y. 424. It seems impossible to reconcile with this the case of Cross $v$. Trust Co., 131 N. Y. 330 . But the former would seem to lay down the correct rule.

73 N. Y. 192. 
intention of the person using the language must be ascertained and followed. The question is, what does the party mean by the phrases or words he has used? This will often be ascertained by merely considering the context of the document itself, but sometimes the words are such as may be given a technical or customary meaning in one State different from that attached to the same words by the law or custom of another State. Thus, the technical legal words "heirs" or "next of kin," or the words of the vernacular, such as "dollars," "pounds," etc., are instances of phrases which may have different meanings in different countries. So the mere silence of the testator upon certain points may create different interpretations of his intention in different States, as where the testator makes a provision for his wife, without stating whether it is intended in lieu of her dower, or where he makes no provision in his will for the case of the legatee dying before himself, etc.

In such cases the question will arise, which meaning did the grantor or testator intend should be attached to his words or to his silence? The answer cannot always be given with absolute assurance of truth, and in the absence of direct evidence resort must be had here, as in other cases, to presumptions of law. The general proposition may be laid down that the interpretation of such ambiguous phrases should be determined in accordance with the laws and customs of that State most probably in the mind of the grantor or testator when he used the words, and with which he is to be presumed to be most familiar.

If the country whose phrases he adopts is expressly designated by the testator, or is given by implication from the language of the will, there would then be no doubt as to his intention to give his words the same meaning attached to them in that country. ${ }^{1}$

Thus, if one domiciled in New York directs that his estate

1 Dicey, Confl. L. 696 ; Enohin v. Wylie, 10 H. L. Cas. 1 ; s. c. 1 DeG. F. \& J. 470; Anstruther v. Chalmer, 2 Sim. 1 ; Yates $v$. Thompson, 3 Cl. \& F. 544, 588 ; Harrison v. Nixon, 9 Pet. 483, 504 ; Ford $v$. Ford, 80 Mich. 42, 44 N. W. 1057, 1059, 1060 ; Ford $v$. Ford, 70 Wis. 19, 33 N. W. 188, 195 ; s. c. 72 Wis. 621,40 N. W. 502 ; Lincoln v. Perry, 149 Mass. 368 ; Merrill $v$. Preston, 135 Mass. 451 ; Codman v. Krell, 152 Mass. 214. 
shall be distrfbuted among those persons who would answer the description of his "next of kin" or "heirs at law" under the laws of France, the New York courts or the courts of any other State would find no difficulty in applying the French law to the case, and in selecting the beneficiaries in accordance with that law. Their obvious duty would be to follow the intention expressed by the testator.

Again, though the country whose law or usage the testator has in mind when he uses the ambiguous phrases be not expressly designated in the will, yet where, on the face of the instrument, it is apparent that the testator has a particular country in mind, the law and usage of that country, wherever it be, will control the interpretation of the ambiguous phrase. Thus, a testator domiciled in England executes a will in France, in the French language, expressed in all the technical terms of French law. Such a will would generally be interpreted, in respect to ambiguous phrases, etc., in accordance with French law or custom, rather than English. ${ }^{2}$

But as a general ruile nothing will appear to indicate the country whose laws and usages the testator had in mind. In such event, if the ambiguity occurs with respect to the disposition of personalty by will, the presumption of law, in the absence of contrary evidence, is that the testator had in view the laws and usages of his domicil, as being those with which he is supposed to be most familiar. The actual situs of the property disposed of, or the domicil of the legatees, will generally be immaterial. ${ }^{3}$

3 Dicey, Confl. L. 696 ; Chamberlain v. Napier, 15 Ch. D. 614 ; Enohin $v$. Wylie, 10 H. L. Cas. 1 ; s. c. 1 DeG. F. \& J. 470. But see Anstruther v. Chalmer, 2 Sim. 1 ; Caulfield $v$. Sullivan, 85 N. Y. 153.

8 Maxwell v. Maxwell, 3 DeG. M. \& G. 705; Harrison $v$. Nixon, 9 Pet. 483, 504 ; Sickles $v$. New Orleans, 52 U. S. App. 147, 80 Fed. 868, 873 ; Gilman v. Gilman, $52 \mathrm{Me}$ 165, 83 Am. Dec. 502 ; Parsons $v$. Lyman, 20 N. Y. 103 ; Caulfield v. Sullivan, 85 N. Y. 153 ; Dammert v. Osborn, 140 N. Y. 30, 45 ; Bowditch v. Saltyk, 99 Mass. 136 ; Sewall $v$. Wilmer, 132 Mass. 131, 136 ; Merrill v. Preston, 135 Mass. 451 ; Lincoln v. Perry, 149 Mass. 368 ; Welch $v$. Adams, 152 Mass. 74 ; Codman $v$. Krell, 152 Mass. 214 ; Adams $v$. Adams, 154 Mass. 290 ; Mullen $v$. Reed, 64 Conn. 240, 29 Atl. 478 ; Rockwell v. Bradshaw, 67 Conn. 9, 34 Atl. 758, 759 ; Ford $v$. Ford, 70 Wis. 19, 33 N. W. 188, 195 ; Knights Templars Association v. Greene, 79 Fed. 461, 465. 
If the property disposed of be land situated in a State other than the testator's domicil, some question has been made whother the interpretation of the testator's language should be controlled by the law and usage of the domicil or of the situs of the property. A few cases may be found holding that the interpretation of the devise must depend upon the lex situs." But here too the weight of reason and authority is in favor of the rule that the interpretation of a devise is to be governed by the law or usage with which the testator is supposed to be most familiar, namely, that of his domicil; and hence when he uses words he must be presumed to have intended that they should be used in the sense given them in his domicil, unless the contrary appears. ${ }^{5}$ So, also, if it becomes necessary to fill in some hiatus in the expressed intention of the testator, resulting from his failure to provide for all contingencies, as in the case of a lapse, or the obligation of a devisee to elect whether or not to take under the will. ${ }^{6}$

§ 146. Same - Beneficiaries - Property Disposed of. - If a will gives property, real or personal, to a devisee or legatee, not by name but describing him as one of a class, such as "heirs at law," "next of kin," "children," etc., these or the

4 Yates $v$. Thompson, 3 Cl. \& F. 544, 588 ; Jennings $v$. Jennings, 21 Ohio St. 56; Applegate v. Smith, 31 Mo. 166 ; Richardson v. DeGiverville, 107 Mo. 422, 17 S. W. 974, 977 ; McCartney v. Osborn, 118 Ill. 403, 9 N. E. 210 ; Wynne $v$. Wynne, 23 Miss. 251, $57 \mathrm{Am}$. Dec. 139. It is evident that this rule could not be applied if the testator possessed lands in several States, with different interpretations of the words used, should the testator dispose of them all by the same language; for it could not be supposed that the testator would intend the same clause to have different meanings with respect to different tracts of land. See Crusoe $v$. Butler, 36 Miss. 150 ; Wilson $v$. Cox, 49 Miss. 538, 545. This reductio ad absurdum would seem to suffice to throw discredit upon a rule which might produce such results.

5 Ford $v$. Ford, 80 Mich. 42, 44 N. W. 1057, 1059 ; Ford v. Ford, 70 Wis. 19,33 N. W. 188,195 ; s. c. 72 Wis. 621,40 N. W. 502 ; Proctor v. Clark, 154 Mass. 45, 27 N. E. 673 ; Lincoln $v$. Perry, 149 Mass. 368.

6 Trotter $v$. Trotter, 4 Bligh, N. s. 502 ; s. c. 3 Wils. \& Sh. 407 ; Maxwell v. Maxwell, 2 DeG. M. \& G. 705 ; Maxwell v. Hyslop, L. R. 4 Eq. 407 ; Caulfield $v$. Sullivan, 85 N. Y. 153 ; Staigg $v$. Atkinson, 144 Mass. 564, 12 N. E. 354 ; Washburn v. Van Steenwyk, 32 Minn. 336, 20 N. W. 324; Van Steenwyk v. Washburn, 59 Wis. 483,17 N. W. 289. 
rike terms, in the absence of evidence of a contrary intention, are to be construed according to the meaning given such terms in the testator's domicil, as shown in the preceding section. ${ }^{1}$

So where such terms as "estate," "real estate," "movable property," "dollars," "pounds," etc., are used in a will, they are to be construed in accordance with the same law. Thus, in Enohin $v$. Wylie, ${ }^{2}$ an Englishman, domiciled in Russia, and possessed of large real and personal estate, including a considerable amount in the English funds, made a will in the Russian language and form, disposing of all his "movable and immovable property," but without any other language excluding or including his English property. In England, the phrase " movable property" was usually applied to tangible chattels, while in Russia it was the designation by which all personal property, whether tangible or intangible, was known. The question was whether the will passed the money in the English funds. The court held that the meaning given to the words in Russia, the testator's domicil, should prevail.

So also the law of the testator's domicil will determine the meaning of ambignous words used by him to describe the estate or interest intended to be vested in the legatee or devisee. In Brown $v$. Brown, ${ }^{8}$ an English case, a testator domiciled in Virginia, devised to his sister, Mary Brown, "the remaining onefourth share of the balance of my estate, at her death to be equally divided among her children." The question was whether Mary Brown took a life estate or a fee-simple. It appearing that the Virginia courts had construed the will to give her an absolute estate, the House of Lords followed that construction.

So whether a party takes an estate by implication of law under a will; or whether a precatory trust is raised by expressions of hope or confidence, etc., are questions of construction to be determined by the law of the testator's domicil."

1 Merrill v. Preston, 135 Mass. 451 ; Proctor v. Clark, 154 Mass. 45, 27 N. E. 673 ; Lincoln v. Perry, 149 Mass. 368; Harrison v. Nixon, 9 Pet. 483, 504 ; Story, Confl. L. $\$ \$ 479 e, 479 h$.

210 H. L. Cas. 1 ; s. c. 1 DeG. F. \& J. 470.

84 Wils. \& Sh. 28.

4 Story, Confl. L. $\$ \$ 479 b, 479 c$. 
An important corollary of the rule that the law of the testator's domicil governs the interpretation of his will should be noted. The interpretation imposed by the lex domicilii will carry with it in the forum all the incidents which would have followed if the same construction would have been placed upon the will by the lex fori itself. ${ }^{5}$ Thus, in Trotter $v$. Trotter, ${ }^{6}$ an English case, a Scotchman, domiciled in India (by construction of English law, in England), made his will in India, being possessed of Scotch heritable bonds, ${ }^{7}$ as well as of personal property in Scotland. The Scotch law required an heir claiming also personal property under the will, either to throw his heritage into the common fund and take his legacy, or to elect between the two (in accordance with the presumed intention of the testator). The will in this case was ineffectual to carry the Scotch heritage according to the law of Scotland, and the question thereupon arose whether the Scotch heir, clairning the heritable bonds as heir, was also entitled to share in the personalty as legatee under the English will, without throwing the heritable bonds into hotchpot or being put to his election. It was held that the terms of the will must be construed according to the laws of England (lex domicilii), and that by the law of England the terms used were not such as to import an intention to transfer any real estate of the testator; that the law of England did not require a legatee who was also heir to throw his inherited lands into hotchpot or else to elect; and therefore that the heir was entitled both to the heritable bonds and also to his share of the personalty under the will. In this case the forum was the domicil, but it is apprehended the same result would have been reached had the question arisen before the Scotch courts.

\$ 147. Same - Lapse - Election. - In accordance with the general principles already alluded to, the law of the testator's domicil will determine the effect of a lapse by the death

5 See Slaughter $v$. Garland, 40 Miss. 172, 180.

6 4 Bligh, N. s. 502 ; s. c. 3 Wils. \& Sh. 407.

7 Heritable bonds, under the law of Scotland, are bonds chargeable pri. marily on the real estate of a decedent, and descend to the heir of the creditor, not to his versonal representative. 
of a legatee or devisee; that is, whether his share is to descend to his children, heirs, or distributees, or whether as to it the testator shall be regarded as having died intestate, or whether it shall be added to the residuary devise or bequest, if any. It is a contingency which the testator has not provided for, and his silence should be interpreted in accordance with the law of his domicil. ${ }^{1}$

Another frequent instance of the application of these principles arises in case of provisions made for a widow by way of jointure, in lieu of dower. This subject is largely regulated by statute in most of the States, but the statutes vary considerably with respect to the effect to be given such provisions as a bar to the widow's dower or distributive share. If the husband in his will provides for the wife, but the will is silent as to its being a substitute for her ordinary marital rights, the question whether the testamentary provision shall be so taken is a matter of the interpretation of the will, and as such is to be determined in general by the law of the testator's domicil. So far as her distributive share in his personalty is concerned, the law of the testator's domicil is supreme, wherever the property may be. Hence, whether the widow shall be given both funds, or whether she will be allowed only the testamentary provision, or whether she will be required or entitled to elect between the two, is to be determined by the lex domicilii of the testator. ${ }^{2}$

As between the testamentary provision made for her and her dower in lands situated abroad, though the wife cannot be barred of her dower by such a provision, unless it is permitted by the lex situs of the land (since that would be to affect the title to the land), ${ }^{3}$ yet upon ordinary principles of election, if the lex domicilii of the testator forbids the wife to take both

1 Rockwell $v$. Bradshaw, 67 Conn. 9, 34 Atl. 758 ; Anstruther v. Chalmer, $2 \operatorname{Sim} .1$; Thornton $v$. Curling, 8 Sim. 310. The lex domicilii of the legatee or devisee, or the lex situs of the property, has no part in the solution of this question.

2 Slaughter $v$. Garland, 40 Miss. 172.

8 See Jennings v. Jennings, 21 Ohio St. 56 ; Staigg v. Atkinson, 144 Mass 564, 12 N. E. 354 ; Washburn v. Van Steenwyk, 32 Minn. 336, $20 \mathrm{~N}$. W. 324; Van Steenwyk $v$. Washburn, 59 Wis. 483, 17 N. W. 289. 
her dower and the testamentary provision, the courts of the situs of the land will require the wife to elect, though under the les situs, if the will were to be interpreted by that law, the widow would be allowed both provisions. ${ }^{4}$

Furthermore, it seems to be settled that the proper course to be pursued by the widow in such cases, in the event that the law of the testator's domicil requires her to elect between the testamentary provision and her marital rights, is to make her election in the courts of the testator's domicil. Such an election will definitely establish her status with respect to her husband's property everywhere once for all. If on the other hand she should be permitted to elect in the courts of another State, it might result that she has renounced the will in one jurisdiction and elected to hold under it in another, according as her interest dictates. This would be both inconvenient and in direct contravention of the testamentary intention, as construed by the lex domicilii. The safer rule would seem to be always to require the widow to make her election in the courts of the testator's domicil in the first instance. ${ }^{5}$

And if the widow is under disabilities, such as lunacy, so as to be incapable of making an election for herself, it seems the courts of the domicil have the sole jurisdiction to make the election for her. At least, if the election is made by the domiciliary courts, the decree is in the nature of a decree in rem, which will be conclusive in the courts of all other States. ${ }^{6}$

In Slaughter $v$. Garland, ${ }^{7}$ a testator domiciled in Virginia, possessed of certain personalty in Mississippi, provided for his wife in his will. She renounced the testamentary provision made for her in the Virginia court of probate. By the law of Virginia she was entitled to one third of her husband's personalty as his distributee. The Mississippi law gave the widow

4 Washburn v. Van Steenwyk, 32 Minn. 336, 20 N. W. 324.

5 Slaughter $v$. Garland, 40 Miss. 172 ; Washburn v. Van Steenwyk, 32 Minn. 336,20 N. W. 324.

6 Slaughter $v$. Garland, 40 Miss. 172 ; Washburn v. Van Steenwyk, 32 Minn. 336, 20 N. W. 324 ; Van Steenwyk $v$. Washburn, 59 Wis. 483, 17 N.W. 289.

740 Miss. 172. 
one half the personalty as her intestate husband's distributee, and made this applicable to all property situated in that State, regardless of marital rights which might have accrued in other States. The question was whether the widow's renunciation in the Virginia courts operated to make the husband intestate in Mississippi, and therefore made the law of that State applicable so as to entitle her to one half instead of one third of her husband's personalty. The Mississippi court held that the Virginia court was the proper place for the wife's renunciation to be made; that that renunciation did not render the husband "intestate" in the sense used by the Mississippi statutes applicable to all property of intestates within its limits, regardless of the owner's residence; that the general rule that the lex domicilii of the deceased owner governs the distribution of his personalty would therefore apply; and that the widow's share in the husband's Mississippi personalty should be determined by the Virginia law.

Cases of election may also arise where the testator, possessed of real and personal property, makes a will disposing of it all, the will being valid by the law of his domicil (as respects the personalty) or by the lex situs of some of the realty, but invalid as to the rest of the land by its lex situs, a beneficiary under the will being also an heir to the property as to which the will is invalid. In such cases the beneficiary (and heir) is generally required to elect between the valid benefit conferred upon him and the property to which he succeeds as heir. ${ }^{8}$

In Brodie $v$. Barry, ${ }^{9}$ a testator domiciled in England left all his real and personal property upon trusts for the benefit of his nephews and nieces. The land was in Scotland, and the will was insufficient under the Scotch law to pass the realty. Only one of the beneficiaries could under the law of Scotland succeed as heir to the land there. The others sought to make her elect in the English court of chancery, and Sir William Grant compelled her to do so.

${ }^{8}$ Brodie v. Barry, 2 Ves. \& B. 127 ; Balfour v. Scott, 6 Bro. P. C. 550, cited in Brodie $v$. Barry; Washburn $v$. Van Steenwyk, 32 Minn. 336, 20 N. W. 324. See Rice $v$. Harbeson, 63 N. Y. 493. But see Maxwell $v$. Max. Nell, 3 DeG. M. \& G. 705 ; Maxwell $v$. Hyslop, L. R. 4 Eq. 407.

- 2 Ves. \& B. 127. 
§ 148. Same - Change of Domicil after Execution of Will - We have heretofore supposed that the testator's domicil at the time of the execution of the will has remained unchanged up to the time of his death. In such case, in the absence of contrary evidence, we have seen that he will be presumed to have in mind, when he uses certain ambiguous words or phrases, the meaning attached to such terms by the law or vernacular of his domicil.

But it may be that the testator, though domiciled in one State when he executes the will, has subsequently at some time before his death removed permanently to another State, where he dies, without revoking his will executed in the first domicil, and without executing a new one in his last domicil. And the meaning attached to the terms he has used in the will in the last domicil may differ from that attached to the same terms in his first abode.

Under such circumstances, it becomes a matter of extreme difficulty to determine by which law (or usage) the ambiguous phrases shall be interpreted, whether by the law of the domicil at the time of the execution of the will or at the time of the testator's death. Weighty arguments may be advanced to uphold either position.' The point was raised in Harrison $v$.

1 Thus, in favor of the law of the last domicil, it may be said: (1) That the whole subject of wills of personalty is thus made to depend upon the same law, the law of the testator's last domicil being the law upon which depends the validity of the will so far as concerns either the capacity of the testator, the formal validity of the will, or its substantial validity; and that to allow a different law to govern its interpretation or construction would be incongruous and inharmonious. See Cross $v$. Trust Co., 131 N. Y. 330, 349. But this argument overlooks the fact that the interpretation of a will rests upon a very different foundation from matters of validity. The former is based upon the intention of the testator, while the latter is independent of intention, and rests upon the policy of the law. Logically therefore there is no reason why the same law should govern. (2) A second and more powerful argument in favor of the law of the last domicil is to be found in the rule that wills speak as of the death of the testator, not as of the time of their execution. See Moultrie $v$. Hunt, 23 N. Y. 394 ; Wynne v. Wynne, 23 Miss. 251, 57 Am. Dec. 139 ; Lincoln $v$. Perry, 149 Mass. 368, 374. It may be argued that although the testator may have attached to his words when he wrote them the meaning given them by the law of his then domicil, yet 
Nixon, ${ }^{2}$ but was left undecided. Notwithstanding some dicta to the contrary, ${ }^{8}$ the better view is believed to be that the law of the domicil at the execution of the will is to govern its interpretation and construction. ${ }^{4}$

when he changes his domicil to a State whose law gives a different meaning to the words used, it must be supposed that he is as familiar with the latter law as with the first, and that if he had desired the words to have retained their first meaning, he would have altered the language so as to convey that meaning under the law of his new domicil. See Moultrie $v$. Hunt, 23 N. Y. 394,400 .

On the other hand, it may be urged in favor of the domicil at the time the will is executed, that since the law (and usage) of that State certainly determines primarily the meaning to be given to the words used, the will as the testator wrote it is to be construed in accordance therewith; that such was the meaning intended by the testator, and such was his will; that he can ouly alter that will by revoking it, or by executing a new will or a codicil, without which no subsequent change of intention on his part would be of any effect ; that the will is made up, not only of the words the testator has used, but also of the meaning to be attached to those words; that the words, as first written, with the meaning then attached to them, constitute his will; and that it cannot be revoked and a new will substituted for it, except by the ceremonies required by law for the revocation of a will and the execution of a new one. See Staigg $v$. Atkinson, 144 Mass. 564, 569, 12 N. E. 354 ; Holmes v. Holmes, 1 Russ. \& Myl. 660, 662, 663.

It is true that a will speaks as at the death of the testator, not as at its execution, so far as relates to the property owned by the testator, which may pass under the terms of his will; but this is not so much a question of the intention of the testator - of what property he intends shall pass under the will. It is in larger measure a question of testamentary capacity; that is, even supposing his intention fixed to dispose of all his property now or hereafter owned, it is a question whether he has the capacity to dispose of such as he acquires after the execution of the will. See Wynne $v$. Wynne, 23 Miss. 251, 57 Am. Dec. 139, 142. This question of testamentary capacity, and incidentally the question of the testator's intention with respect to the disposition of after acquired property, is settled by the rule that the will speaks as at the death of the testator. But it leaves untouched the intention of the testator in other respects and the interpretation of language used in other connections.

9 Pet. 483.

3 Ford v. Ford, 70 Wis. 19, 33 N. W. 188, 195. See Merrill v. Preston, 135 Mass. 451 ; Story, Confl. L. $\S 479 \mathrm{~g}$.

4 Staigg $v$. Atkinson, 144 Mass. 564, 569, 12 N. E. 354 ; Holmes $v$. Holmes, 1 Russ. \& Myl. 660, 662, 663. See Merrill $v$. Preston, 135 Mass. 451. 
It may at least be asserted positively that the law cr usage of a domicil possessed prior to the execution of the will is not generally to be regarded, if at the time of its executior the testator was domiciled in another State. ${ }^{5}$

$\$ 149$. Revocation of Wills. - With respect to wills of rea estate, the effect of an act of revocation will in general be determined by the lex situs, whether the revocation be express o* implied. ${ }^{1}$ Thus, in Ware $v$. Wisner, ${ }^{2}$ a foreign testator devisea certain lands situated in Iowa. Afterwards an heir was born ta the testator. It was held that the effect of the subsequent birth of the heir as a revocation of the will should depend upon the lex situs of the land, and the will was declared revoked.

With respect to wills of personalty, on the other hand, tha effect of an act of revocation will depend upon the law of the testator's domicil, whether the revocation be express, as by the execution of a new will, or the destruction of the old, anime revocandi, etc., or whether it arises by implication of law, as by the testator's marriage, the birth of pretermitted children. etc. $^{3}$

It should be specially observed that the revocation of a will, whether express or by implication, is not a continuing act, but once validly accomplished the revocation is complete and final; the will at once and forever loses its efficacy as a will, unless afterwards republished or re-executed. It follows therefore that no subsequent subjection of the testator to the law of a new domicil will alter the effect of a revocation once validly completed and perfected. Hence no subsequent change of domicil by the

5 Anstruther $v$. Chalmer, 2 Sim. 1 ; Lincoln $v$. Perry, 149 Mass. 368, 374.

1 Ware $v$. Wisner, 50 Fed. 310 ; Sneed $v$. Ewing, 5 J. J. Marsh. (Ky.) 460, 22 Am. Dec. 41, 53, 55 ; Wynne $v$. Wynne, 23 Miss. 251, 57 Am. Dec. 139. An exception will probably arise if the revocation is dependent upon the interpretation of ambiguous words in a subsequent will. As shown in the preceding section, the interpretation of such words will depend upon the law of the testator's domicil at the execution of the subsequent will.

250 Fed. 310.

3 Price v. Dewhurst, 8 Sim. 437 ; Sneed v. Ewing, 5 J. J. Marsh. (Ky.) 460, 22 Am. Dec. 41, 55 ; Succession of Packwood, 9 Rob. (La.) 438, 41 Am. Dec. 341, 347 ; Senac's Will, 2 Rob. (La.) 258. See Bloomer v. Bloomer, 2 Bradf. (N. Y.) 339. 
testator to a country by whose law a prior act of revocation, effectual in a former domicil, would cease to have that effect, will of itself suffice to revivify the will, which once legally killed is dead forever, unless resurrected by the act of the testator himself, as by a re-execution of the will. It is always therefore the testator's domicil at the time of the occurrence of the act relied upon as a revocation, which will determine its effect.

Thus if the alleged revocation be by tearing or burning the will, animo revocandi, the law of the testator's domicil at the time of the acts in question will determine whether they operate as a revocation. If the prior will be alleged to be revoked by a subsequent will, the effect of the latter in revoking the former would seem to depend in the first instance upon whether the subsequent will operates immediately to revoke the first will completely and finally, or only so operates after the testator's death, when it has itself ceased to be revocable. If it operates immediately, the law of the testator's domicil at the time of the execution of the subsequent will would govern; if only after the testator's death, the law of his last domicil will control. And whether the revoking will is to operate an immediate revocation of the former, or is to operate only post mortem, must be determined by the law of the testator's domicil at the time of the execution of the last will; for if the first is thereby revoked immediately, no subsequent change of domicil will revive it."

In Price $v$. Dewhurst, ${ }^{5} \mathbf{A}$ and his wife, domiciled in the Danish island of St. Croix, made a joint will (which under the Danish law could only be revoked jointly), by which they bequeathed certain legacies. They afterwards became domiciled in England, and the husband made a new will bequeathing his share of their joint property to his wife. After his death, the wife also made a new will bequeathing her property to other legatees than those named in the joint will. The question was whether the testators could, under the law of a subsequent domicil (England), make separate wills which would operate to re-

4 All these results flow from the one principle that a revocation is not a continuing act, but takes effect once and for all. See Cottrell v. Cottrell, L. R 2 P. \& M. 397.

- 8 Sim. 437. 
roke the joint will executed when they were domiciled in St. Croix, and which, under Danish law, could only be revoked by their joint act. It was held that the law of their domicil at the Hate of the execution of the revoking wills and at the time of their deaths should determine the effect of those wills in revoking the joint will.

The same principle applies to revocations implied from the subsequent marriage of the testator, the subsequent birth of pretermitted children, etc. It is the testator's domicil at the time of the circumstance relied upon to show a revocation that will furnish the "proper law" to determine its effect.

Thus, in the case of an alleged revocation by reason of a subsequent marriage, the law of the testator's domicil at the time of the marriage will determine whether it has revoked the will. The fact that the testator afterwards changed his domicil to a State whose law would have given a different effect to the act of marriage is immaterial, and so is the fact that the law of the place of marriage is different. ${ }^{6}$

So, in the case of a pretermitted child, if it is the birth of the child which by the law of the testator's domicil at that time constitutes a revocation of his will, it stands revoked, and is not revived by removal to a new domicil whose law is different. If, by the law of the testator's domicil at the time of the birth of the pretermitted child, it is not the birth of the child which revokes the will, but the death of the testator, leaving the child unprovided for (or if the child be born after the testator's death), it is the law of the testator's last domicil that is to govern the question. ${ }^{7}$

$\S 150$. Wills in the Exercise of a Power of Appointment. It is a peculiar characteristic of a transfer of property made in the exercise of a power of appointment that the law overlooks the intermediate instrument through which the appointment is made, and regards the appointee as in possession by virtue of a direct transfer from the original owner (by the deed or will he

6 See Goods of Reid, L. R. 1 P. \& D. 74.

7 See Sneed v. Ewing, 5 J. J. Marsh. (Ky.) 460, 22 Am. Dec. 41 ; Succes sion of Packwood, 9 Rob. (La.) 438, 41 Am. Dec. 341, 347. 
has used to create the power), and not under the instrument through which the appointment is made.

The original owner of the property is styled the donor of the power; the person upon whom is bestowed the power to appoint is the donee of the power; and the person appointed by the donee to take the property is the appointee. Thus, if $\mathbf{A}$ (the donor of the power) by will leaves his property to $B$ (the donee of the power) for life, and after B's death, to whomsoever B by last will shall appoint, and $B$ wills it to $C$ (the appointee under the power), $\mathrm{C}$ is considered as holding the property under A's will, and not under B's. B is merely the channel through which A's will operates. The property given to $\mathbf{C}$ belongs to $\mathbf{A}$, not to B. ${ }^{1}$

Since it is the will of the donor of the power which really operates to transfer the estate to the appointee, the law governing the donor's will, not that controlling the donee's, should determine most of the questions that arise.

If the property disposed of be real estate, difficulties are not likely to arise, though the donor of the power and the donee reside in different States; for the lex situs of the land will usually govern under any circumstances. ${ }^{2}$ But if it be personalty, the lex domicilii, not the lex situs, is to be looked to. The diffculty in such case is to determine whether the proper law applicable to the particular question is the lex domicilii of the donor of the power or of the donee, if they reside in different States.

With respect to the capacity of the donee to make a will in the exercise of the power, the better opinion seems to be that this is not really a testamentary capacity at all, as nothing passes under the donee's will, but is rather to be viewed as the execution of an authority conferred upon an agent. Whether such an authority can legally be conferred upon the donee de-

1 See Sewall v. Wilmer, 132 Mass. 131; Bingham's Appeal, 64 Penu. St. 345 ; Cotting $v$. De Sartiges, 17 R. I. 668, 24 Atl. 530.

2 Polson $v$. Stewart, 167 Mass. 211, 218, 45 N. E. 737. See Sewall v. Wilmer, 132 Mass. 131, 138. Except perhaps with regard to the interpretation of the donee's will, which is not dependent upon the lex situs, and is probably governed by the same principles as if the property were personalty. Ante. $\$ 145$. 
pends (it is said) upon the law governing the validity of the donor's will. ${ }^{3}$

So since the real disposition to be looked to is that of the donor of the power, the substantial or essential validity of the provisions of the donee's will in the exercise of the power must be regulated by the law and policy of the donor's domicil, not the donee's."

But with regard to the proper law governing the formal validity of the donee's will in the exercise of the power, it would seem upon principle that the donee's will in that respect should be controlled by the lex domicilii of the donee, - at least if the donor's will only provides for an appointment " by the donee's will," without more. In such event, the instrument of appointment must be the donee's "will." It is difficult to see how this provision is complied with, if the instrument is not a will; and it would seem that the fact that it would have been a will, if executed by one resident in the donor's domicil, does not make it a "will" of the donee resident in another State, where it is no will.

With regard, lastly, to the proper law controlling the interpretation of the language used in the donee's will, the question is simply as to the meaning and intention of the donee - at least in those cases where he has a discretion as to the estate to be disposed of or as to the appointees? Who are intended by the donee to be the appointees? What property or interest does he intend them to take? To what extent has the donee intended to execute the power?

Upon principle it would seem that these questions should be answered as similar ones are answered respecting the meaning

3 Dicey, Confl. L. 701, 702. See Cotting v. De Sartiges, 17 R. I. 668, 24 Atl. 530. It might be otherwise in cases where, in default of appointment, the property is to remain in the family of the donee.

1 See Sewall $v$. Wilmer, 132 Mass. 131, 137.

5 But see Story, Confl. L. $\$ 473 a$; Whart. Confl. L. $\$ 590$. In Sewall v. Wilmer, 132 Mass. 131, 137, it is said that the law of the donor's domicil should control the formal validity of the donee's will. But in that case the power conferred was to transfer the property as the donee "should, by deed in writing, or by last will, or by any writing purporting to be her last will, sppoint:" The court based its decision on the last clause. 
and intention of an ordinary testator, namely, by an appeal to the law and usage of the donee's domicil, with the language of which he is supposed to be more intimately acquainted. ${ }^{6}$ And it is probably true that the law of the donee's domicil will furnish the answers to such questions as the first two above mentioned.

Nor is it easy to see why the same rule should not apply to the third question also. It is admitted that the donee, by choice or by accident, may fail to execute the power. Whether he executes it or not is a matter of choice, or if there is a doubt as to his having done so, is a matter of his intention, not the donor's. Yet the few cases that have passed upon the question have held that in the event of an ambiguity or a doubt as to whether the donee has intended by his will to include the property over which he has the power of appointment, that doubt is to be resolved by an appeal to the law of the donor's domicil, not to that of the donee's.

Thus in Sewall $v$. Wilmer, ${ }^{8}$ the donor of the power resided in Massachusetts, while the donee, his daughter, was domiciled with her husband in Maryland. The donee died, and by her will left all her property to her husband, without expressly mentioning the property over which she had a power of appointment. Under the law of Massachusetts, it passed without express mention; under the law of Maryland, it only passed where the intent to make an appointment was manifest. The court held that the law of Massachusetts (the donor's domicil) should govern, upon the ground that the property was the donor's, not the donee's, and that the lex domicilii of the former should determine whether or not the power had been executed, and the property disposed of. ${ }^{9}$

6 Ante, $\S \S 145$ et seq.

7 Sewall $v$. Wilmer, 132 Mass. 131 ; Cotting v. De Sartiges, 17 R. I. 668, 24 Atl. 530 ; Bingham's Appeal, 64 Penn. St. 345.

132 Mass. 131.

- In this case and the others holding the same way, it is to be noticed that the property was actually situated in the donor's domicil, which was also the forum. 


\section{PART V.}

\section{SITUS OF CONTRACTS.}

\$ 151. Contractual Liabilities Transitory - Proper Law to determine Existence of Contract. - Before entering into a detailed investigation of the "proper law" goveruing the various questions that may arise with respect to foreign contracts, some preliminary observatious must be made.

Contracts are either executed or executory. An executed contract is performed as soon as entered into, and being a voluntary act of the contracting party, the "proper law" is always the law of the actual situs of the party at the time of the transaction. We have touched upon the proper law governing such contracts in our discussion of the contract of marriage, ${ }^{1}$ and have dealt with them much more fully in the discussion of voluntary transfers of property. ${ }^{2}$ The explanations there given will suffice; and in the future discussion we will confine our attention to contracts executory. These differ from contracts executed in that they are to be performed at another time and often at another place than the time and place when and where they are entered-into. This characteristic of executory contracts raises difficulties and doubts with regard to the "proper law" to regulate the various phases of the contract, that do not arise at all in the case of executed contracts.

It has never been doubted that liabilities based upon a valid contract executory are, generally speaking, transitory in their nature, and enforceable in the courts of any country obtaining jurisdiction of the promisor's person. ${ }^{8}$ But often the effect given

1 Ante, $\$ \S 77,78$.

2 As to transfers of real property, ante, $\S \S 11,12$. As to transfers of personalty, ante, $\S \S 122,128$ et seq.

See W. U. Tel. Co. v. Phillips, 2 Tex. Civ. App. 608, 21 S. W. 638. 
to a contract in one State differs very materially from that given to it in another. In such cases it becomes necessary to determine by what law the contract is to be governed in respect to the particular question at issue. This frequently presents serious difficulties. Indeed it may be truly said that there is no subject in the law with regard to which so much doubt, uncertainty, and confusion exists. The mixed array of decisions on the subject has been well described as " a trackless forest of cases." "

To this confusion the decisions of the courts have contributed no little by the vague and general expressions often used in cases where precise and accurate language and a careful analysis of the circumstances are essential to a correct conclusion, or at least would render invaluable aid in dissipating the obscurity enveloping the subject. In no branch of the law have ill-considered and conflicting dicta and decisions played such havoc with principle. It is of the utmost importance to correct conclusions with regard to this subject that absolute precision of thought and language be used.

A question which presents itself at the very outset arises with respect to the proper law by which to determine whether any agreement at all has been entered into between the parties. A foreign contract is alleged by one party to have been made, but it is denied by the other that he ever assented to it. By the law of one State there may be a presumption that he has assented to it, while no such presumption may arise in the other. In such a case, the question is held to be merely a matter of evidence (pertaining to the remedy), and as such is to be governed by the lex situs of the remedy (lex fori). ${ }^{5}$

Thus, in Hoadley $v$. Transportation Co., ${ }^{6}$ an engine had been delivered to the defendant at Chicago for transportation to Lawrence, Mass., but was destroyed at Chicago in the great fire of 1871, without the defendant's fault. The defendant had given a receipt, excepting liability for loss by fire while in

4 Gross v. Jordan, 83 Me. 380, 22 Atl. 250.

5 Hoadley $v$. Transportation Co., 115 Mass. 304 ; The Brantford City, 29 Fed. 373, 393. See Hartmann v. R. R. Co., 39 Mo. App. 88.

- 115 Mass. 304. 
depot or in transit. By the law of Illinois, where the receipt was given, the mere acceptance of a receipt did not import assent to its conditions without additional proof; while by the law of Massachusetts (forum) the acceptance of the receipt without dissent was sufficient proof of the contract and of assent to all its exceptions from losses not arising through negligence. At the trial, the receipt was put in evidence without further proof than its delivery to the shipper. The plaintiff recovered in the lower court, on the ground that the law of Illinois governed. But, on appeal, the lower court was reversed, on the ground that the question concerned only the mode of proof of the contract set up in the receipt, and that as a matter of evidence the case was governed by the lex fori.

So, evidence of an oral contract may be introduced under the lex fori, though the statute of Frauds of the State where the contract is made provides that no action shall be brought upon such a contract unless in writing. It is a mere matter of remedy. ${ }^{7}$

But if a contract is alleged to be implied from the circumstances of the case, as an implied contract to pay for services rendered, etc., this is not a matter of evidence, and is not to be controlled by the lex fori. The law of the place where the services are rendered, and the implied agreement, if any to pay therefor springs up, determines the existence or non-existence of the contract. Thus, in Crumlish $v$. Improvement Co., ${ }^{8}$ an officer of a Pennsylvania corporation rendered it certain services there, and afterwards sued the corporation in West Virginia on a quantum meruit. By the law of Pennsylvania no contract for payment was implied in the case of services rendered by an officer of a corporation. By the law of West Virginia a contract for compensation was implied. The West Virginia court held that the Pennsylvania law should govern.

§ 152. Applications of General Exceptions to Foreign Law somewhat restricted in Case of Executory Contracts. - The second chapter of this work has been devoted to a consideration

7 Post, §§ 173, 174, 210.

838 W.. Va. 390, 18 S. E. 456. See also Carnegio v. Morrison, 2 Met (Mass.) 381, 397 et seq. 
of the exceptions to the application of a proper foreign law. Omitting here any mention of the last of those exceptions (transactions affecting title to land), it will be recalled that four general exceptions were there enumerated: (1) Where the enforcement of the foreign law would contravene the policy of the forum; (2) Where it would work injustice to the people of the forum ; (3) Where it would violate the canons of morality; (4) Where the foreign law is penal.

Theoretically, these exceptions apply as fully in the case of foreign executory contracts as in other cases. But, practically, the effect of some of them is much circumscribed by the fact that questions in connection with executory contracts usually arise as between the parties only, third persons generally having no interest therein; and by the fact that such contracts are voluntarily entered into, and are therefore controlled in large measure by the law of the actual situs of the parties. It would come in general with bad grace from one of the parties to afterwards seek the protection of his own law, merely because the performance of the contract had become burdensome.

There are instances however in which these exceptions will be applied to contracts as well as to other matters. Indeed, the third exception, namely, that the transaction is contra bonos mores, has its main application in the case of executory contracts. $^{1}$ So the fact that the enforcement of a foreign contract is contrary to the interests or policy of the forum will be sufficient ground for substituting the lex fori, and declaring the contract invalid, though valid by its proper law. ${ }^{2}$

The second exception, injustice or detriment to the citizens of the forum, is of less frequent application. Indeed some of the courts deny its existence altogether as applied to executory contracts. Such transactions having been voluntarily entered into abroad, and the parties having deliberately submitted themselves to a foreign law, they will not be permitted to claim (according to this view) in the courts of their own State that the enforcement of their contract will work a hardship or a detriment to them. This exception applies to executory con- 
tracts (and even this is denied by many courts) only in cases of incapacity to contract, where the law of the party's domicil has afforded him protection, because of some legal disability, there deemed sufficient to incapacitate him from contracting. Under such circumstances, the protection afforded by the lex domicilii against the party's domestic contracts will sometimes, when his foreign contract is sought to be enforced in the domicil (forum), be held to protect him against the effect of his foreign contracts also. This matter of capacity is the only one in respect of which the second exception can be said to apply to executory contracts. Capacity is a passive quality, not an active step in the making of a contract. ${ }^{3}$

The fourth exception (where the foreign law is penal) also has an occasional application to contracts, in cases where, by way of punishment, or as the result of punishment, a person is incapacitated to enter into particular contracts. Such is the case of a guilty party to a divorce suit who is prohibited to marry again.4

8 This has been fally discussed in connection with the law governing capacity. See ante, $\S \S 72,73$.

4 This however is a case of an executed contract. An instance of the application of this exception to executory contracts would be difficult to find, since punishments do not usually take the turn of prohibiting the party to contract. Penal disabilities in general have been discussed. See ante, $\$ \S 10,74$. 


\section{CHAPTER XV.}

\section{LOCUS CONTRACTUS.}

\$153. Conflicting Views as to Situs of Contract. - (1) If we suppose a contract made in England, to be performed there, in consideration of an act done there by the promisee, and an action to be brought there for its breach, we have, from the standpoint of the English courts, a purely domestic contract. No foreign element whatever enters into it, and therefore there is no room for the application of the principles of private international law.

(2) The other circumstances remaining the same, if we suppose that suit is brought upon the above contract in New York, the situs of the remedy has been shifted to New York, but the situs of the contract remains unquestionably in England. The most ordinary comity and sense of justice demands in such a case that the mere accident of suit being brought in New York should not constitute any ground for giving the parties a different measure of justice than would be meted out to them in England. The law of England should govern the contract in every respect, as before, while the law of New York would now govern the remedy, and only the remedy.

(3) The other circumstances remaining as in the last case, let us now suppose that the contract by its terms was to have been performed in Massachusetts. Another element is thus removed from the operation of the English law, the element of performance, and has been given a situs in Massachusetts.

(4) If we now go a step further, and suppose the contract to have been entered into in Scotland, yet another element has lost its English situs. The making of the contract now has its situs in Scotland. The only element retaining its English situs is the consideration of the contract. 
Thus, by this process of elimination, we have before us a contract made in Scotland, in consideration of an act done in England by the promisee, the contract to be performed in Massachusetts, and suit brought thereon for its breach in New York. Here the situs of the making of the contract is Scotland; the situs of the consideration is England; the situs of the performance is Massachusetts; and the situs of the remedy is New York. The only one of these which, at this stage of the discussion, we may discard as having no bearing upon the proper law governing the contract, is the law of New York, which is only the situs of the remedy.

In the first case mentioned the English courts would have no difficulty whatever in declaring that the situs of the contract was England, and that it should be governed by English law. Most of the cases that arise in the courts are of this character.

In the second case, the New York courts would have scarcely less difficulty in declaring the situs of the contract to be England, and the situs of the remedy to be New York; and that every question pertaining to the substance of the contract, whether relating to the making of the contract, its performance, or its consideration, should be governed by English law, while everything pertaining to the remedy should be governed by New York law. As long as the three essential elements that go to make up an axen:atory contract, the making, the performance, and the consideration, all have the same situs, there is no diffculty in ascribing that situs to the contract as a whole.

But as soon as we begin to dissociate these elements, we meet with difficulties that are insurmountable if we continue to view the situs of the contract as single and indivisible. For example, if we take the third case above mentioned, and suppose the New York court to attempt to ascertain the situs of the contract, or the locus contractus as the courts are fond of designating it, it is evident that it would meet with grave difficulties. Indeed it would be impossible upon any logical ground to fix it at any one spot. Any attempt to do so would be mere guess-work, a dictum ex cathedra. And still more would this be so in the fourth case stated above. Shall the locus contractus be Scotland, where the parties entered into the contract? Or in Eng. 
land, the situs of the consideration? Or in Massachusetts, the situs of the performance? Clearly, it is not in New York, which is merely the situs of the remedy. In other words, if the locus contractus is single and indivisible, is this to be considered a Scotch contract, an English contract, or a Massachusetts contract?

The courts have piled the Ossa of confusion upon the Pelion of uncertainty in their attempts to answer these questions, in cases where the situs of these three elements of a contract are not identical.

Many of the courts define the lex loci contractus and its effect in the following terms (substantially): "The validity, the nature, the interpretation, and the obligation of contracts are to be governed by the lex loci contractus; that is, by the law of the place where the contract is made," - thus holding the situs of the making of the contract to be the locus contractus, though the contract is to be performed elsewhere. ${ }^{1}$

Other courts, with equal looseness and inaccuracy, define the "lex loci contractus" substantially as "the law of the place where the contract is made, if to be performed there; but if to be performed in another State, then the law of the latter place," - thus making the situs of performance the locus contractus, though the contract is entered into elsewhere."

Still other courts define the "lex loci contractus" as "the

1 Lindsay $v$. Hill, 66 Me. 212, 22 Am. Rep. 564, 566 ; Milliken v. Pratt, 125 Mass. 374, 28 Am. Rep. 241 ; Ivey v. Lolland, 42 Miss. 444, 2 Am. Rep. 606; Commercial Bank v. Davidson, 18 Or. 57, 22 Pac. 517, 521 ; Taylor v. Sharp, 108 N. C. 377, 13 S. E. 138, 139 ; Thomson-Houston Electric Co. v. Palmer, 52 Minn. 174, 53 N. W. 1137, 1138. These are but a few samples of cases using language of this character. Some of them are cases in which the situs of the making and performance are identical, but reference is frequently not made to the fact in the opinion. If this is not intended as a universal definition of the "lex loci contractus," the use of such general terms is objectionable, because of the tendency to confuse and mislead.

2 Examples of decisions thus defining the locus contractus are: Pope $v$. Nickerson, 3 Story, 465, 474; Curtis $v$. R. R. Co., 74 N. Y. 116, 120, 30 Am. Rep. 271; The Brantford City, 29 Fed. 373, 386; Dickinson v. Edwards, 77 N. Y. 573, 578, 33 Am. Rep. 671; Chapman v. Robertson, 6 Pai. Ch. 627, 630, 31 Am. Dec. 264 ; Lewis v. Headley, 36 Ill. 433, 87 Am. Dec. 227. See Scudder $v$. Bank, 91 U. S. 406, 411. 
law with reference to which the parties contracted;" or as "the law which the parties had in mind at the time they contracted;" or as "the law which the parties intended should govern the contract." 8

All these definitions are defective for the reason that they attempt to define the locus contractus or the situs of a contract, as if it were a single and indivisible unit, to be determined in every case by the application of a single general rule.

\$ 154. True View - Locus Contractus not necessarily a Single Place, but may consist of One Place for One Purpose, and Another Place for Another Purpose. - The truth is that a contract in its entirety is made up of many different elements, each of which may be the subject of separate judicial investigar tion. Some of these may be express, others implied; some may depend for their effect solely upon the intention of the parties, while the effect of others is to be determined by law and policy, without regard to the parties' intention.

If the particular element in dispute is one which is dependent entirely upon the parties' intention, the law which the parties have in mind at the time they enter into the contract may well

8 This is a favorite definition of the later English decisions and of the de. cisions of the United States Supreme Court. See Peninsular, etc. Co. v. Shand, 3 Moore, P. C. N. s. 272 ; Lloyd v. Guibert, L. R. 1 Q. B. 122, 123 ; Chartered Bank of India $v$. Nav. Co., 9 Q. B. D. 118 ; s. c. 10 Q. B. D. 521, $529,536,544$; Jacobs v. Crédit Lyonnais, 12 Q. B. D. 589 ; Robinson $v$. Bland, 2 Burr. 1077, 1078 ; Liverpool Steam Co. v. Ins. Co., 129 U. S. 397, 448 ; Coghlan v. R. R. Co., 142 U. S. 101, 109 ; Hall v. Cordell, 142 U. S. 116, 120 ; Bell v. Packard, 69 Me. 105, 31 Am. Rep. 251, 253; New England Mortg. Co. v. McLaughlin, 87 Ga. 1, 13 S. E. 81, 82 ; Dickinson v. Edwards, 77 N. Y. 573, 578, 33 Am. Rep. 671; Chapman v. Robertson, 6 Pai. Ch. (N. Y.) 627, 31 Am. Dec. 264 ; Thornton v. Dean, 19 S. C. 583, 45 Am. Rep. 796, 800. But see contra, American Mortg. Co. v. Sewell, 92 Ala. 163, 9 So. 143,147 . In the last case the court says: "The general rule is that the validity of the contract is determined by the place of the contract; the intention of the parties is only looked to in construing the contract; or as forcibly put in the brief of counsel, "the venue of the agreement determines its validity, and not the venue of the intention." This statement, it is believed, is much nearer the truth than the statement found in the cases above cited. See Brauer v. Compania, 57 Fed. 403, 411 ; The Glenmavis, 69 Fed. 472, 476 ; post, $\S 154$. 
be a potent factor in ascertaining that intention. In such cases the last definition of the "lex loci contractus" mentioned in the preceding section will be applicable.

But in many instances the particular element in dispute will not depend altogether upon the intent of the parties, but in part at least upon rules of law and public policy, which the intent of the parties will not be permitted to overcome. There are many cases to which the maxim "Modus et conventio legem vincunt" is not applicable. Instances of such elements are not difficult to find in purely domestic contracts.

Thus, a Virginia married woman contracting in Virginia, whose law prohibits her to make the particular contract, will not be held liable in Virginia upon such contract merely because she intended to enter into a valid contract. So an oral contract made and to be performed in a State whose law renders the contract void if not in writing will not be enforced there merely because the parties intended the contract to be good. Or if one should agree to do something prohibited by the law of the State, its courts will not enforce the contract because of the good intention of the parties, except where the gist of the invalidity is the intentional disregard of the law. Or if one makes a contract, the consideration of which is condemned by the law as immoral or illegal, the parties' intention to bind themselves is immaterial.

These principles are axiomatic, and apply to all contracts which the law declares to be contrary to public policy and void, whether the invalidity arises, as in the above examples, in respect to the capacity of the parties, the formal validity of the contract, the performance of the contract, or its consideration. The proposition would never for one moment be entertained in any of these cases of a domestic contract, that the intention of the parties may validate a contract declared by the law to be contrary to public policy and void.

It seems manifest that the same principles should govern contracts possessing a foreign element. If the contract is declared void in some particular element (such as the mode of entering into it, the act to be done in performance of it, or the act done as a consideration for the promise) by the law properly govern. 
ing that element, comity and justice unite in demanding that the courts of every State should uphold the law and policy of the State where the particular element in question arises or has its situs. The fact that the parties had in view a different law as governing the element in question should have no more influence in this case than in the case of the purely domestic contracts above considered. ${ }^{1}$

Thus, let us suppose a man to enter into a contract in Virginia to do an act in Virginia prohibited by its laws. Of course the fact that he intended his performance of the contract to be governed by the law of another State would not influence the Virginia courts to permit him to perform the prohibited act in Virginia, nor to validate the contract otherwise void. It is the act to be performed in Virginia which the law of Virginia prohibits, the invalidity of which avoids the contract. If the performance is still to take place in Virginia, can it be supposed that the Virginia courts would less rigorously condemn the performance of the contract on Virginia soil because the agreement was entered into in another State, and the parties had in mind the law of the latter State or of no State at all? So far as the Virginia policy is concerned, the contract is as contrary thereto when entered into in another State as when entered into in Virginia. The policy is directed against the performance, and that is to take place in Virginia in either event. The Virginia law therefore would surely govern the Virginia courts.

This being the reasonable and necessary conclusion of the Virginia courts, does not comity as surely demand, if the above contract should come to be enforced in the courts of another State, that those courts should respect the policy of Virginia and should not enforce a contract the purpose of which is the performance of an act in Virginia prohibited by the laws and policy of Virginia, no matter where the contract is entered into, nor what law the parties "had in mind," if any?

And what is true of the element of performance is true of the making of the contract also, and of the consideration to support it, as will appear hereafter.

1 See The Brantford City, 29 Fed. 373, 395; The Hugo, 57 Fed. 403 ; Bot. any Worsted Mills $v$. Knott, 76 Fed. 582. But see Brown v. Finance Co, 31 Fed. 516, 520. 
From what has been said it will be seen that, so far as the validity of the contract is concerned, the third definition of the "lex loci contractus" given in the preceding section is erroneous and misleading. ${ }^{2}$

If the question is not one of the validity of the contract, but merely relates to the interpretation to be given its terms, as, in ascertaining the nature of the contract, or what the promisor has obligated himself to do (obligation of the contract), since these matters generally depend primarily upon the intention of the parties at the time of the contract (the law being invoked, in such cases, if at all, only where the parties have not manifested their intention fully), if the parties have not fully expressed their meaning, the law the parties actually or presumably had in mind when they contracted is the proper law to look to in order to ascertain that intention, and this is as true of domestic as of foreign contracts. Indeed, it may be laid down as a general proposition that wherever the maxim "modus et conventio legem vincunt" is applicable to the particular element of a contract under investigation, the proper law is "the law in the minds of the parties" at the time of the contract, whether that law is the law of the place where the contract is made, or the law of the place of performance, or the lex fori, or the law of some other State.

In such cases, however, it is manifest that unless there is evidence that the law of some other State is in the minds of the parties, the general presumption will be that the parties contracted with reference either to the law of the place where the contract is made or to that of the place of performance, these being the places where the acts of the parties in connection with the contract have been, or are to be, done.

In point of fact, the parties to a contract will usually have no special law in view, or at least will make no mention of any,

2 It may be observed however, even in respect to the validity of a contract that cases may arise in which the gist of the illegality of a particular act may be the intention with which it is done. An act may sometimes be illegal, if the intent be to violate the law, which will be regarded as legal and valid if the intention is innocent. In such cases, the law which the parties "have in mind " may be of importance. 
and hence no direct evidence will be forthcoming of any particular law intended by the parties to govern the case. The courts therefore must resort to presumptions. Naturally, the law which parties are to be presumed to lave in mind when they do an act is the law of the situs of the act in question.

The final result of the reasoning advanced above is that, in general at least, whether the question concerns an element of the contract dependent upon the parties' intention or one that is independent of their intention, the "proper law" to regulate it is the law of the situs of the particular element, circumstance, or act in dispute.

These conclusions will be amply vindicated and exemplified in the following discussion.

\section{$\S 155$. Three Leading Elements in every Contract-Bach} may have a Separate Situs. - There are three leading elements or acts or circumstances in connection with every executory contract, all other elements or incidents being mere resultants of these combined or of one or the other of them. Indeed, without them, there could no more be a contract than there can be a material substance without beginning and without end.

The essential elements or circumstances, around which all the incidents of contracts revolve, are (1) The Making of the contract; (2) The Consideration supporting the contract; and (3) The Performance of the contract.

Each of these may have a different situs, or two of them may have a situs different from the third, or all three of them may have the same situs. ${ }^{1}$ All the incidents or qualities of the contract (apart from those dependent solely upon its expressed terms) relate to or flow from one or the other of these three elements, and will depend upon the effect to be given by its proper law, the law of its situs, to the leading element upon which it depends.

Hence it comes about that, in every inquiry relating to any incident or quality of a contract, the first step is to ascertain whether the particular incident relates to or is dependent upon or results from the making of the contract, or from its consider

1 Ante, § 153. 
ation, or from its performance. When this is ascertained, the law of the situs of the making or of the consideration or of the performance, as the case may be, will regulate the particular incident.

More generally the rule may be thus stated: Everything relating to the making of the contract is to be governed by the law of the place where it is made; everything relating to the performance of the contract is to be controlled by the law of the place of performance; and wherever the legality or the sufficiency of the consideration is the subject of the inquiry, the law of the situs of the consideration is to govern. ${ }^{2}$

Sufficient has been said to show that each of the definitions of the "lex loci contractus," mentioned in a previous section, is incomplete and imperfect. The fault of each is that it assumes the "locus contractus" or situs of the contract to be always one definite fixed locality for all purposes, regardless of the nature of the particular inquiry. It is true that for some purposes, in investigating certain incidents or qualities of the contract, we must look to the law of the place where the con tract is made; for others, we must look to the law of the place where the contract is to be performed; and for others, we must look to the law "in the minds of the parties." It cannot be said that the law of one of these places more than another is the "lex loci contractus." What is the "proper law" for one purpose connected with the contract may not be the "proper law" for another purpose. This has been recognized in a New York case, "where the court said: "The law of the place of contract is not necessarily one place. It is the law of all the places to

2 See Scudder $v$. Bank, 91 U.S. 406, 412, 413 ; Akers $v$. Demond, 103 Mass. 318,324 . This general rule is subject to the qualification mentioned in the preceding section, that is, if the particular incident is one to which the maxim "modus et conventio legem vincunt" is applicable, and the parties clearly contract with reference to the law of a particnlar State, that law will govern as carrying out the "conventio" of the parties. It will rarely happen however that the parties can be shown by direct evidence to have had any particular law in mind, in which latter event the general rule mentioned above in the text will furnish the law which they presumably had reference to.

${ }^{3}$ Hibernia Nat. Bank $v$. Lacombe, 84 N. Y. 367, 378. See also Seamans v. Knapp, 89 Wis. 171,27 L. R. A. 362,365 . 
which and for the purposes for which it has reference. A bill of exchange therefore is to be construed according to the law of each place at which the contract contemplated that something is to be done by either of the parties."

Considering therefore the double or triple meaning that may be attached to the phrase "lex loci contractus" in connection with executory contracts, and the inextricable confusion into which it is apt to lead us, the wiser and safer course will be to discard the term altogether in the discussion of contracts executory. The locus contractus should be analyzed into its constituent parts, as we have done already, and to each of these parts a distinct name should be given. In the future discussion we will designate the place where the contract is entered into as the "locus celebrationis," and the law of that place as the "lex loci celebrationis" or the "lex celebrationis." The place where the contract is to be performed will be known as the "locus solutionis," and its law as the "lex loci solutionis" or the "lex solutionis." The situs of the consideration may be designated the "locus considerationis," and its law the "lex loci considerationis."

$\S 156$. The Various Incidents or Qualities of Contracts. Upon a careful analysis, it will be found that every inquiry relating to an executory contract must be directed towards one or the other of the following circumstances or qualities: (1) The validity of the contract; (2) Its obligation or effect; (3) Its interpretation; or (4) Its discharge. ${ }^{1}$

Some of these incidents or qualities relate to or spring from the making of the contract, others relate to or spring from its performance, and others are connected with the consideration. Some depend upon the intention of the parties, express or implied; others are fixed by the law and are independent of the intention. The proper law governing each of these incidents will be fully discussed hereafter.

1 To these may be added, (5) The remedies for its breach. But since all questions pertaining to the remedy are governed by the law of the situs of the remedy (lex fori), this incident may be omitted from a discussion of the "lex loci contractus." It will be considered hereafter in connection with the Situs of the Remedy. Post, $\$ 205$ et seq. 
To illustrate the dependence of these incidents upon the making, performance, or consideration of the contract, let us examine a little more closely the first one above mentioned, namely, the validity of the contract.

We will suppose $A$ and $B$ to enter into a contract in Virginia (locus celebrationis), by which $\mathrm{A}$ agrees to do a particular act for B in New York (locus solutionis) in consideration of an act done or to be done by $B$ for $A$ in Massachusetts (locus considerationis). Assuming the capacity of the parties to contract, the validity of this contract might be questioned in four distinct ways : (1) By alleging that the making of the contract was prohibited by law; for example, that it was entered into on Sunday; (2) By alleging that it was not entered into with such formalities as the law peremptorily required; for example, in case of some contracts, that it was not in writing and was therefore void ; (3) By alleging that the act to be done by $A$ in New York in performance of the contract was contrary to law; or (4) $\mathrm{By}$ alleging that the act done or to be done in Massachusetts (the consideration for A's promise) was contrary to law.

It will be seen that the first two objections to the validity of the contract relate to the making of the contract; the third to its performance; and the fourth to the consideration. We must therefore look to Virginia (locus celebrationis) to furnish the law governing the first two points of attack; to New York (locus solutionis) to furnish the law governing the third question; and to Massachusetts (locus considerationis) to furnish the law governing the fourth ground of objection to the validity of the contract.

Before considering more fully the various incidents of contracts set forth at the beginning of this section, and the law properly governing each of them, it is expedient and necessary to examine more particularly the situs of the contract in its various aspects, as represented by the locus celebrationis, the locus solutionis, and the locus considerationis. To this inquiry the next chapter will be devoted.

2 See Wolf $v$. Burke, 18 Colo. 264, 32 Pac. 427 ; Hunt v. Jones, 12 R. I. 265, 34 Am. Rep. 635. 


\section{CHAPTER XVI.}

\section{LOCUS CELEBRATIONIS; LOCUS SOLUTIONIS; AND LOCUS CONSIDERATIONIS.}

\section{\$157. Locus Celebrationis - Place where Contract be-} comes finally Binding. - In most cases, the locus celebrationis of an executory contract is perfectly plain. There is nothing to complicate the situation when the parties meet together in a given State, and then and there enter into a binding agreement. The place where the binding contract is thus entered into will be the locus celebrationis.

But frequently cases arise in which overtures are made or the preliminaries are discussed in one State, while the contract becomes finally binding only after some other act is done elsewhere; or cases may arise where the parties to the contract are widely separated from each other, the contract being entered into by correspondence or telegram, or through an agent. In cases of this sort more difficulty is experienced in ascertaining the locus celebrationis of the contract.

It may be laid down as a general proposition that a contract is not "made" until it becomes complete and binding upon the promisor. As soon as the final act is done, and the minds of the parties meet, the promisor becomes irretrievably bound, and the contract is made. The situs of that final act necessary to bind the promisor is the locus celebrationis of the contract. ${ }^{1}$

1 Milliken $v$. Pratt, 125 Mass. 374, 28 Am. Rep. 241 ; Hill v. Chase, 143 Mass. 129, 9 N. E. 30 ; Shoe \& Leather Bank $v$. Wood, 142 Mass. 563, 567, 8 N. E. 753 ; Bell v. Packard, 69 Me. 105, 31 Am. Rep. 251, 252; Western Transportation Co. $v$. Kilderhouse, 87 N. Y. 430, 438; Wayne Co. Bank $v$. Low, 81 N. Y. 566, 572, 37 Am. Rep. 533; Wood v. Ins. Co., 8 Wash. 427, 36 Pac. 267 ; Barrett $v$. Dodge, 16 R. I. 740, 19 Atl. 530; Keiwert $v$. Meyer, 62 Ind. 587, 30 Am. Rep. 206, 208; Hart v. Wills, 52 Ia. 56, 2 N. W. 619, 621 ; Voorheis $v$. Society, 91 Mich. 469, 51 N. W. 1109 ; State Mut. Ins. Co. v. Brinkley Co., 61 Ark. 1. 29 L. R. A. 712 ; Mut. Ben. Ins. Co. v. Robison, 
In Waldron $v$. Ritchings, ${ }^{2}$ the plaintiff, who was at the time in New York, agreed with the defendant, the manager of an opera in Philadelphia, to go there and make her debut. She was assured, if she did not fail in the estimation of the public and the press, of an engagement upon terms specified in the negotiation between the parties. It was held that the contract was not made in New York, but in Philadelphia, upon the fulfilling the test of success.

Notes, deeds, and other contracts of that character do not become completed and binding contracts merely by the fact of the promisor's signing them. They must also be delivered. Hence, if the signing occurs in one State, while the delivery takes place in another, the latter State, not the former, is the locus celebrationis. $^{8}$ Thus, where a bond for the purchase price of land in Delaware was signed and sealed in Pennsylvania by a married woman, but was delivered to the payee in Delaware, the locus celebrationis of the bond was held to be Delaware, not Pennsylvania. ${ }^{4}$

So, the place where an offer is accepted (until which acceptance it is not binding) is the locus celebrationis of the contract, veing the place where the minds of the parties meet. ${ }^{5}$ Hence, if

54 Fed. 580 ; Knights, etc. Indemnity Co. v. Berry, 1 C. C. A. 561,50 Fed. 511,513 ; Hicks $v$. Ins. Co., 9 C. C. A. 215, 60 Fed. 690, 692 ; Tilden $v$. Blair, 21 Wall. 241, 246. But see Beverwyck Brewing Co. v. Oliver, 69 Vt. 323, 37 Atl. 1110.

9 Abb. Pr. N. s. (N. Y.) 359 ; s. C. 3 Daly, 388.

8 Freeman's Appeal, 68 Conn. 533, 37 Atl. 420 ; Akers $v$. Demond, 103 Mass. 318, 324 ; Hubbell $v$. Land Co., 95 Tenn. 585, 32 S. W. 965 ; Watson v. Lane, 52 N. J. L. 550, 20 Atl. 894, 895 ; Sheldon v. Haxtun, 91 N. Y. 124 ; Cook v. Litchfield, 9 N. Y. 279 ; Buchanan v. Bank, 5 C. C. A. 83, 55 Fed. 223. See Suit $v$. Woodhall, 113 Mass. 391, 394.

4 Baum v. Birchall, 150 Penn. St. 164, 24 Atl. 620. See also Phipps v. Harding, 17 C. C. A. 203, 70 Fed. 468, 471 ; Carnegie Steel Co. v. Construction Co. (Tenn.), 38 S. W. 102 ; Bell v. Packard, 69 Me. 105, 31 Am. Rep. 251, 252 ; Lawrence $v$. Bassett, 5 Allen (Mass.), 140.

5 Armstrong v. Best, 112 N. C. 59,17 S. E. 14 ; Hyde $v$. Goodnow, 3 N. Y. 266, 270 ; Vassar $v$. Camp, 11 N. Y. 441 ; Trevor v. Wood, 36 N. Y. 309 ; Suit $v$. Woodhall, 113 Mass. 391, 394 ; Whiston $v$. Stodder, 8 Mart. (La.) 95, 13 Am. Dec. 281 ; Dord v. Bonaffee, 6 La. Ann. 563, 54 Am. Dec. 573 ; Claflin v. Meyer, 41 La. Ann. 1048, 7 So. 139. 
a person in one State sends to a person in another a letter or telegram, containing an offer or proposal, which the latter there accepts by letter or telegram, the contract is complete when the letter of assent is deposited in the post office, properly addressed, or when the reply message is delivered to the telegraph company for transmission. The locus celebrationis is thus definitely fixed at the place where the letter of acceptance is mailed or the message delivered for transmission, and not the place where it is received or addressed, or where the offer was first made. ${ }^{6}$

By parity of reason, the question whether goods shipped in one State upon an order from another constitutes a sale in the former State depends upon the further question whether the parties have done every act necessary to make a binding sale before the goods leave the former State. Thus if the consignor there delivers the goods to a carrier as the agent of the consignee, the sale is complete there; if the carrier is the agent of the consignor, the sale only becomes complete upon the delivery by the carrier to the consignee or his agent, and the place where that occurs is the locus celebrationis. ${ }^{7}$ So also, if the goods are sent C. O. D., the locus celebrationis of the contract of sale is the place where the assignee accepts them. ${ }^{8}$

Upon the same reasoning, it would seem clear that a contract, intended to create a joint obligation, made by one promisor in one State, and by him sent to another promisor in another State to be signed by him there, should be regarded as made in the latter State, for only upon the signing of the contract by the second promisor does the contract become binding upon either.'

6 Milliken $v$. Pratt, 125 Mass. 374, 28 Am. Rep. 241 ; Vassar v. Camp, 11 N. Y. 441 ; Wayne Co. Bank $v$. Low, 81 N. Y. 566, 572 ; Sheldon $v$. Haxtun, 91 N. Y. 124, 131 ; Bell v. Packard, 69 Me. 105, 31 Am. Rep. 251, 252; Baum v. Birchall, 150 Penn. St. 164, 24 Atl. 620 ; Perry v. Iron Co., 15 R. I. 380, 5 Atl. 632 ; Atlantic Phosphate Co. v. Ely, 82 Ga. 438, 9 S. E. 170 ; Garrettson $v$. Bank, 47 Fed. 867, 869 ; Kellogg $v$. Miller, 13 Fed. 198, 200.

7 Webber $v$. Howe, 36 Mich. 150, 24 Am. Rep. 590 ; Dolan $v$. Green, 116 Mass. 322. See ante, §128.

8 State $v$. O'Neil, 58 Vt. 140, 56 Am. Rep. 557. But see State v. Carl, 43 Ark. 353, 51 Am. Rep. 565.

9 In Bryant $v$. Edson, 8 Vt. 325, $30 \mathrm{Am}$. Dec. 472, it was said, under circumstances of this kind, that the locus celebrationis of the contract is the 
On the other hand, if the contract is not joint, but several, or joint and several, the locus celebrationis of the contract is severable, each party's contract having its locus celebrationis at the place where it is entered into. ${ }^{10}$

$\S 158$. Same - Contracts of Agents. - Questions also frequently arise as to the locus celebrationis of contracts made by agents. It is to be noted, in the first place, that an implied authority of an agent to enter into a contract binding upon his principal depends upon the law of the place where the general authority is given or the agency is created, not that of the place where the alleged contract is entered into. ${ }^{2}$ In Pope $v$. Nickerson, ${ }^{2}$ the question arose as to the authority of the master of a ship to bind the owner by certain bottomry bonds valid by the law of the port, but not by the law of the principal's country. The court held that the law of the latter State must govern the extent of the agent's authority. In the course of his opinion, Judge Story said: "Any other rule would subject the principal to the most alarming responsibility, and be inconsistent with that just comity and public convenience, which lies at the foundation of private international law... The authority confided by the principal is in all such cases measured, as to the interpretation and extent of that authority, by or according to the law of the place where it is given - by the lex lociand not by the laws of a foreign country, of which the principal is or may be wholly ignorant, and by whose regulations he is not bound."

But if a person acts as an agent in one State for a person in another, which act is unauthorized, but is afterwards ratified, or the principal becomes otherwise estopped to deny the agent's

State where the contract is first signed. But in that case the real inquiry was not as to the locus celebrationis, but as to the locus solutionis, which is always a question of the parties' intention. See post, $\S 159$.

10 Glenny Glass Co. v. Taylor, 99 Ky. 24, 34 S. W. 711. See Pugh v. Cameron, 11 W. Va. 523, 532 ; Findley $v$. Hall, 12 Ohio, 610.

1 Pope $v$. Nickerson, 3 Story, 465, 476 ; Freeman's Appeal, 68 Conn. 533, 37 Atl. 420, 421. See Arayo v. Currell, 1 La. 528, 20 Am. Dec. 286, note. And so it is also with an express authority, where the question is as to the principal's capacity to give the authority. Freeman's Appeal, supra.

23 Story, $465,476$. 
authority, it would seem that the scope of the authority in such case should depend upon the law of the State where the agent's act is done. Thus, in McMaster $v$. Ins. Co., ${ }^{8}$ a statute of Iowa provided that "any person who shall hereafter solicit insurance ... shall be held to be the soliciting agent of the insurance company, anything in the application or policy to the contrary notwithstanding." It was held that a foreign insurance company should be bound by the acts in Iowa of the person "soliciting " the insurance, though it was expressly stipulated in the policy that the party who brought the insurer and insured together was the agent of the insured, and that the company should not be held responsible for his acts or declarations.

In Brooke $v$. R. R. Co., ${ }^{4}$ a shipping clerk of a railroad company, in collusion with a consignor, issued in New York a fictitious bill of lading, with the consignor's draft upon the consignee attached, without the actual receipt of the goods therein specified. The consignee lived in Philadelphia. He paid the draft and then sued the railroad company because of the fraudulent act of its agent. It was held by the Pennsylvania court that the liability of the principal for the agent's act was to be determined in accordance with the law of New York, the place where the agent's fraud was committed.

The same priuciples apply also with respect to the liability of a firm for the acts or contracts of a partner. If by the law under which the partnership is created the liability of a member of the firm is limited, this limited liability will not be increased merely because the act or contract of another of the partners or of the firm itself is done or made in another State, under whose laws the members of the firm would be liable to the fullest extent.

Thus, in King $v$. Sarria, ${ }^{5}$ the defendant, Sarria, resided in Cuba, and was a special partner of a firm organized and doing business there. The Spanish law (prevailing in Cuba) touching limited partnerships had been complied with so as to limit

378 Fed. 33, 37. See also Mut., etc. Ins. Co. v. Robison, 54 Fed. 580; N. Y. Life Ins. Co. v. Russell, 23 C. C. A. 43, 77 Fed. 94.

108 Penn. St. 530, 1 Atl. 206, 208.

c 69 N. Y. 24, 25 Am. Rep. 128. See Baldwin v. Gray, 4 Mart. N.s. 192. 
his liability to the amount of capital he had contributed. The firm became indebted to the plaintiffs, citizens of New York, by transactions in New York with which Sarria bad no personal connection. The New York court held that the contract of partnership was to be interpreted and regulated by the laws of Spain; that the authority of the acting partner and Sarria's liability were to be determined by those laws; and that the defendant was entitled to set up his limited liability as a defence. ${ }^{6}$

It is an entirely different matter when the question does not relate to the agent's authority to make the contract, but to the contract itself when made. Here the maxim, "qui facit per alium facit per se," applies with full force. If the agent, fully anthorized, makes a contract in a foreign State, it is the same as if the principal were there in person, and had himself entered into it. As was said in Milliken $v$. Pratt $:{ }^{7}$ "If the contract is completed in another State, it makes no difference in principle whether the citizen of this State goes in person or sends an agent, or writes a letter, across the boundary line between the two States. As was laid down by Lord Lyndhurst in Pattison $v$. Mills, 1 Dow \& C. 342, 363: 'If I, residing in England, send down my agent to Scotland, and he makes contracts for me there, it is the same as if I myself went there and made them."

In determining in such cases the principal's liability upon the contract made by the agent, the locus celebrationis of the contract is the place where the principal, through his agent, enters into the contract. ${ }^{8}$

- It is to be observed in this case that the law of New York (forum) also authorized limited partnerships. It would seem however that this is immaterial. But where the question is not of an intrinsic restriction upon the liability of the partners, but the law of the situs of the partnership merely provides that the limited partnership shall not be liable upon a contract unless certain formalities are complied with, as that the contract shall be signed by at least two managers, etc., it becomes then a question of the formal validity of the contract. See post, $\$ 172$. In such case the validity of the contract will be governed by the law of the place where it is entered into. Park $v$. Kelly Axe Co., 1 C. C. A. 395, 49 Fed. 618, 627.

7125 Mass. 374, 375, 28 Am. Rep. 241.

8 Milliken $v$. Pratt, 125 Mass. 374, 375, 28 Am. Rep. 241; Carnegie a 
In many cases, however, the agent is not fully authorized to enter at once into a complete and binding contract, but must refer the negotiations to his principal for approval, before finally closing the bargain; it is understood that he is authorized to make the contract, subject to the principal's approval or ratification. In such cases the contract does not become binding upon the principal until the approval or ratification has taken place, and hence the locus celebrationis is the place where such approval or ratification occurs. ${ }^{9}$

But if the other party to the contract is ignorant that the agent has not plenary authority and believes that he is entering into a binding contract, though it is still true that the existence of the contract will depend upon the approval or subsequent ratification of the principal, the ratification when given relates back to the time of the execution of the contract, and the place where that execution occurs is the locus celebrationis. ${ }^{10}$

§ 159. Locus Solutionis - Optional with the Parties - No Place of Performance named. - In the case of executed contracts (so called for the very reason that they are performed as soon as made), the place of performance must necessarily coincide with the locus celebrationis. ${ }^{1}$ But in the case of contracts

Morrison, 2 Met. (Mass.) 381 ; Baum v. Birchall, 150 Penn. St. 164, 24 Atl. 620 ; Jackson $v$. Mortg. Co., 88 Ga. 756, 15 S. E. 812, 813 ; Merchants' Bank v. Griswold, 72 N. Y. 472, 481, 28 Am. Rep. 159 ; Newman v. Cannon, 43 La. Ann. 712, 9 So. 439; Arayo v. Currell, 1 La. 528, 20 Am. Dec. 286; Hausman $v$. Nye, 62 Ind. 485, 30 Am. Rep. 199, 200 ; Webber v. Howe, 36 Mich. 150, 24 Am. Rep. 590 ; Hicks v. Ins. Co., 9 C. C. A. 215, 60 Fed. 690. See Suit $v$. Woodhall, 113 Mass. 391.

9 Tegler $v$. Shipman, 33 Ia. 194, 11 Am. Rep. 118; Kling $v$. Fries, 33 Mich. 275; Keiwert $v$. Meyer, 62 Ind. 587, 30 Am. Rep. 206, 209; State, etc. Ins. Co. $v$. Brinkley Co., 61 Ark. 1, 29 L. R. A. 712, 713; Dord $v$. Bonaffee, 6 La. Ann. 563, 54 Am. Dec. 573; Claflin v. Meyer, 41 La. Ann. 1048, 7 So. 139 ; Newman v. Cannon, 43 La. Ann. 712, 9 So. 439 ; Shuenfeldt $v$. Junkermann, $20 \mathrm{Fed} .357$.

${ }^{10}$ Golson $v$. Ebert, 52 Mo. 260. See Findley $v$. Hall, 12 Ohio, 610 ; Pugh v. Cameron, 11 W. Va. 523.

1 Scudder $v$. Bank, 91 U. S. 406, 413 ; Bethell v. Bethell, 54 Ind. 428, 23 Am. Rep. 650, 654. Hence, as we have seen, the "proper law" governing voluntary transfers of personal property is always the law of the place where the transfer is made (lex loci contractus). Ante, $\$ \S 127$ et seq. 
executory, since they are to be performed in futuro, opportunity is given the parties to change their situs before the time of performance, and to perform it elsewhere, if the contract so requires.

The locus solutionis of a contract primarily depends upon the intention of the parties. It is a part of the principle of freedom of contract to choose the place where a contract shall be performed. This choice may be expressed in the contract itself; if not, it may be inferred from the surrounding circumstances.

If no place of performance is named by the parties, a very strong presumption arises that the parties intend that it shall be performed where it is made. ${ }^{2}$ But though this presumption is strong, it is not conclusive, and may be rebutted by evidence, or by clear inference from the surrounding circumstances, that the parties intended that the contract should be performed elsewhere. $^{3}$ Thus, if the parties are only transiently in the place where the contract is entered into, with no intention of stopping there, and the contract is to be performed at a time when, under the circumstances of the case, the parties did not contemplate being within the State, this would be sufficient to rebut the presumption that the contract was intended to be performed where made."

2 Pritchard $v$. Norton, 106 U. S. 124, 137 ; Clark $v$. Searight, 135 Penn. St. 173, 19 Atl. 941; Tenant $v$. Tenant, 110 Penn. St. 478, 1 Atl. 532 ; Barrett $v$. Dodge, 16 R. I. 740, 19 Atl. 530; Bell v. Packard, 69 Me. 105, 31 Am. Rep. 251 ; Lewis $v$. Headley, 36 IIl. 433, 87 Am. Dec. 227 ; Parsons v. Trask, 7 Gray (Mass.), 473, 66 An. Dec. 502; Young $v$. Harris, 14 B. Mon. (Ky.) 556, 61 Am. Dec. 170 ; Bryant $v$. Edson, 8 Vt. 325, 30 Am. Dec. 472; Chapman $v$. Robertson, 6 Pai. Ch. (N. Y.) 627, 31 Am. Dec. 264 ; Malpica v. McKown, 1 La. 248, 20 Am. Dec. 279 ; Thompson v. Ketcham, 8 Johns. (N. Y.) 189,5 Am. Dec. 332.

3 Pritchard $v$. Norton, 106 U. S. 124, 137.

4 Dan. Neg. Insts. $\$ 876$; Briggs $v$. Latham, 36 Kan. 255, 13 Pac. 393, 59 Am. Rep. 546, 548; Curtis v. Leavitt, 15 N. Y. 9, 88. See Story, Confl. L. $\$ 273$. But the inference should be very clear in order to change the general rule. See Curtis $v$. Leavitt, supra. It is to be observed that such circumstances do not affect the locus celebrationis of the contract. The parties have their choice before entering into their contract as to the State where they shall make it, but once entered into, their choice is irrevocably laid upon the State where, as a matter of fact, the contract is made. The parties, when they 
Paradoxical as it may seem, there is often more difficulty in determiniug the locus solutionis of a contract which expressly designates a place of performance, than where none is named. The reason is that the parties sometimes attempt to cover their real intentions touching the place of performance by falsely naming a place which they do not really intend to be the true locus solutionis. This is done in order to evade the law of the real place of performance, when it would condemn the contract. In such cases, where the locus solutionis is of importance, it is the duty of the court to disregard the false witness of the parties' contract, and to ascertain the place of performance really intended. For though the parties have the right to choose bona fide the place where their contract is to be performed, they have not the right, in order to evade the law of the place they have really chosen, to pretend that they have selected a different place. $^{5}$ Thus it has been held by courts which take the view that the validity of usurious contracts is dependent upon the lex solutionis ${ }^{\circ}$ that a debt falsely pretended to be made or payable in a particular State, so that usurious interest may be exacted under its law, will not be enforced.?

But the mere fact that the motive for selecting a particular place as the locus celebrationis or locus solutionis of a contract is to evade the law of another State is immaterial, if the choice is bona fide. The important point is that the parties have the right to select the locus. That being conceded, the reasons have entered into a contract in one State, cannot, merely by intending so to do, make it a contract entered into in another.

5 Akers v. Demond, 103 Mass. 318, 324 ; U. S. Sav. \& L. Ass. v. Scott, 98 Ky. 695, 34 S. W. 235 . The same principle applies to the locus celebrationis of the contract, as mentioned in the preceding note. See Mut. Ben. L. Ins. Co. v. Robison, 54 Fed. 580 ; Wall v. Equitable, etc. Society, 32 Fed. 273, 275 ; Fletcher $v$. Ins. Co., 13 Fed. 526 ; American Mortg. Co. v. Jefferson, 69 Miss. 770, 12 So. 464 . But see Strawbridge $v$. Robinson, 5 Gilm. (Ill.) 470, 50 Am. Dec. 420 ; Morris $v$. Hockaday, 94 N. C. 286,55 Am. Rep. 607 and note.

${ }^{6}$ The law governing usurious contracts will be discussed hereafter. See post, $\S 179$.

7 U. S. Sav. \& L. Ass'n v. Scott, 98 Ky. 695, 34 S. W. 235 ; American Mortg. Co. v. Jefferson, 69 Miss. 770, 12 So. 464. See The Energia, 56 Fod. 124, 127. 
which induce them to make a particular choice are not open to inquiry.

Some of the authorities seem to point to the conclusion that where the contract itself designates no place of performance, and where therefore the locus solutionis may be said to be in doubt, a presumption will arise that the parties intended to enter into a valid agreement, and hence, upon the principle that that construction will be placed upon ambiguous terms which will uphold rather than nullify a contract, the presumption that the locus solutionis is identical with the locus celebrationis (by whose law the contract would be invalid) will yield to the presumption that the parties intended to perform their contract in a State whose law would permit of its performance, provided the circumstances point to any such State as reasonably within the view of the parties at the time. ${ }^{8}$

$\S 160$. Same - Several Places of Performance. - It sometimes happens that a contract may be intended by the parties to be performed, as to different parts thereof, in several places. If the contract relates to several distinct and divisible acts, there is no difficulty in perceiving that as to each of these several acts in performance of the contract the contract may have a separate locus solutionis. In reality, they are several contracts in one. ${ }^{1}$

8 Pritchard $v$. Norton, 106 U. S. 124, 137; Bell v. Packard, 69 Me. 105, 31 Am. Rep. 251, 253 ; Dickinson v. Edwards, 77 N. Y. 573, 578, 33 Am. Rep. 671 ; American Mortg. Co. v. Jefferson, 69 Miss. 770, 12 So. 464, 465; Scott v. Perlee, 39 Ohio St. 63, 48 Am. Rep. 421, 423 ; Kellogg v. Miller, 13 Fed. 198,199 . This presumption can only arise in cases where there is no clear evidence or inference as to the place intended by the parties as the locus solationis. It does not (as many of the above cases strongly imply) furnish evidence of what law the parties intend to govern their contract (for in that respect, where the validity of the contract is in question, the parties' inten. tions are immaterial). It merely furnishes evidence of what place the parties intend as the locus solutionis of the contract. It is of value therefore only in cases where the particular element of the contract urged as being contrary to law relates to the performance of the contract, for the locus solutionis is of no importance, where the invalidity alleged relates to the making of the contract or its consideration.

1 Pope v. Nickerson, 3 Story, 465, 484 ; Curtis $v$. R. R. Co., 74 N. Y. 116, 30 An. Rep. 271; Liverpool Steam Co. v. Ins. Co., 129 U. S. 397, 454. 
But where the act contracted to be done is a continuous act, the performance of which may run through several States, such as a contract of through transportation, the weight of authority seems to be to the effect that this constitutes an entire contract, not divisible, and can only have one fixed place of performance, namely, the terminus of the journey. ${ }^{2}$

Some of the decisions however take the view that, although the final place of performance is the terminus of the journey, yet there is a complete performance of part of the contract long before the journey is ended. As each mile is covered, so much of the contract is performed: the performance is by stages, so to speak; and the locus solutionis of the coutract of carriage shifts from one State to another, as the goods or passengers themselves are transferred from one State to the other. ${ }^{3}$

The latter view would seem, upon principle, to be the better; otherwise the carrier might sometimes be subject to different liabilities, according as he is sued in contract or in tort. The New York case of Dike $v$. R. R. Co. ${ }^{4}$ affords an excellent illustration of the inconvenience that may result from the first view. In that case, the plaintiff had purchased a ticket on the defendant's road from Attica, N. Y., to the city of New York. In order to reach New York, the road ran through a part of Pennsylvania and New Jersey. Thus the contract of carriage was made and was to be finally performed in the State of New York. While passing through Pennsylvania, an accident occurred and the plaintiff was injured. A statute of Pennsylvania provided that in such cases the amount of the recovery should be limited to $\$ 3,000$. There was no such limitation in New York. Action was brought in New York for the breach of the contract to carry

2 Liverpool Steam Co. v. Ins. Co., 129 U. S. 397, 454 et seq.; Dike v. R. R. Co., 45 N. Y. 113, 117; Curtis v. R. R. Có, 74 N. Y.116, 30 Am. Rep. 271 ; Brown v. R. R. Co., 83 Penn. St. 316. See Phinney v. Ins. Co., 67 Fed. 493, 498 ; Hale $v$. Nav. Co., 15 Conn. 539, 39 Am. Dec. 398.

3 Barter $v$. Wheeler, 49 N. H. 9, 29, 6 Am. Rep. 434 ; Pope v. Nickerson, 3 Story, 465, 485; Curtis v. R. R. Co., 74 N. Y. 116, 30 Am. Rep. 271; Talbott v. Transportation Co., 41 Ia. 247, 20 Am. Rep. 589 ; Burnett v. R. R. Co., 176 Penn. St. 45, 34 Atl. 972 ; Baetjer $v$. La Compagnie, 59 Fed. 789.

45 N. Y. 113. See Burnett v. R. R. Co., 176 Penn. St. 45, 34 Atl. 972. 
the plaintiff safely, and the court held that the New York law applied on the ground that New York was the locus solutionis of the contract, and that the amount of damages recoverable was not merely a matter of remedy. If the action had been ex delicto instead of ex contractu, the lex loci delicti (Pennsylvania law) would have controlled, ${ }^{5}$ and a different result would have been reached. This would be unfortunate. The New York court attempts to evade this conclusion, but with doubtful success. Under the second view above given the measure of liability would have been the same whether the action was ex contractu or ex delicto. The locus solutionis of the contract would have shifted with the defendant's cars, and at the time of the breach would have been in Pennsylvania.

Another question may arise as to the locus solutionis, when the contract is to be performed, in the option of the promisor, either in one State or in another. Here an alternative is given the promisor, and it would seem upon principle that the locus solutionis would remain undetermined until he exercises his election. Then the place where he actually performs the contract is the locus solutionis. ${ }^{6}$ But there are difficulties in the way of this theory, especially if the promisor never performs his contract at either place. ${ }^{7}$

$\S 161$. Locus Considerationis. - The consideration of a contract is a matter collateral to, not part of, the promise. It need not appear on the face of the promise, but is in general essential to its validity. A promise without a consideration is a mere nudum pactum, and usually creates no legal obligation. So a promise upon a consideration, which is itself prohibited by law or contrary to public policy, creates no legal obligation.

Certain acts or matters may be deemed in one country to be considerations sufficient to support a promise, though not sufficient in another; and considerations regarded as legal in

5 See post, $\$ 198$.

- See Porter $v$. Price, 49 U. S. App. 295, 80 Fed. 655.

7 See Hale $v$. Nav. Co., 15 Conn. 538, 546, 39 Am. Dec. 398. In this case, the court was forced to fall back on the locus celebrationis as the locus polutionis also. A carrier had agreed in New York to deliver the goods gither at Boston, Massachusetts, or at Providence, R. I. 
one State may be held illegal or contrary to public policy in another.

Thus, in Pritchard $v$. Norton, ${ }^{1}$ Norton executed and delivered to Pritchard in New York a bond of indemnity, conditioned to fully indemnify him against all loss arising from his liability on an appeal bond which the latter had signed in Louisiana as surety on behalf of a certain defendant in a judgment in the Louisiana courts, and which he was compelled to pay. The bond of indemnity was executed in New York, but named no place of performance or payment. By the law of New York, a contract under seal was only prima facie evidence of a consideration, and past services constituted no consideration. In Louisiana the law was otherwise. The question was whether the New York bond of indemnity, the only consideration of which was the past service of Pritchard in going upon the appeal bond in Louisiana (no contemporaneous promise of indemnity having been made), was to be deemed nudum pactum. The United States Supreme Court held that the question was to be decided by the law of Louisiana (lex loci considerationis). ${ }^{2}$

Again, if the question relates to the legality of the consideration, it is the lex loci considerationis, not the lex celebrationis nor lex solutionis, which is to determine the effect and consequences of the act set forth as the consideration. Except in cases of considerations which are mala in se, or universally deemed contra bonos mores, ${ }^{8}$ the policy of a State is not usually concerned with acts done elsewhere, and neither encourages nor discourages them: it leaves their effect to be determined by the law of the State where the act in question is done.

Thus, let us suppose that a note is made in Vermont and payable there, being given in consideration of liquor sold and

1106 U. S. 124.

2 The court's decision, however, was not based upon this ground, but upon the ground that Louisiana was the locus solutionis of the contract, though the bond was executed in New York and named no other place for payment or performance. It is respectfully submitted that the law of Louisiana determined the sufficiency of the consideration, not becanse that State was the locus solutionis of the contract, but because it was the locus considerationis. The question was one of consideration, not of performance.

Ante, $\$ 9$. 
delivered to the maker in New York; that the sale of liquor is prohibited by the law of Vermont, and all notes and securities in payment therefor are declared void; but that by the law of Now York the sale of the liquor is valid. It is obvious that the validity of this note is to be determined, not by the law of Vermont, though that is both the locus celebrationis and the locus solutionis of the note, but by the law of New York, the situs of the consideration; for the law of Vermont was manifestly applicable only to sales of liquor in Vermont. The note would therefore be valid." On the other hand, if the above note had been executed and made payable in New York, the sale of the liquor taking place in Vermont, the law of Vermont (lex considerationis) would govern, not the law of New York (lex celebrationis et solutionis), and the note would be void.

Wagers, gaming, lotteries, etc., are not universally condemned as immoral, and therefore should not be classed as considerations mala in se. ${ }^{6}$ Hence, if a contract is made, the consideration for which is a gaming debt, or the sale of lottery tickets, or the conduct of a lottery, the validity of the contract in this respect will depend upon the law of the situs of the consideration, which may or may not be the place where the contract is made or to be performed. ${ }^{7}$

These examples suffice to show that the lex loci considerationis plays no small part in governing the validity of a contract, so that the rules by which the locus considerationis or situs of the consideration is ascertained deserve attention.

4 Webber \%. Howe, 36 Mich. 150, 24 Am. Rep. 590; Boothby v. Plaisted, 51 N. H. 436, 12 Am. Rep. 140 ; Tegler v. Shipman, 33 Ia. 194, 11 Am. Rep. 118.

5 Keiwert $v$. Meyer, 62 Ind. 587, 30 Am. Rep. 206; Webber $v$. Howe, 36 Mich. 150, 24 Am. Rep. 590 ; Suit v. Woodhall, 113 Mass. 391 ; Weil $v$. Golden, 141 Mass. 364.

- The general rule is to consider these matters as subject to their "proper law," though some of the decisions treat them as inimical to morals and contra bonos mores, no matter what the law of their situs. See Flagg $v$. Baldwin, 38 N. J. Eq. 219, 48 Am. Rep. 308.

7 Thatcher $v$. Morris, 11 N. Y. 437; MeIntyre v. Parks, 3 Met. (Mass.) 207; Peet v. Hatcher, 112 Ala. 514, 21 So. 711. See Sondheim v. Gilbert, 117 Ind. 71, 18 N. E. 687. But see Robinson v. Bland, 2 Burr. 1077. 
For the most part they are simple enough if we recur to first principles. 8

\$ 162. Same-Considerations Executed and Executory. - A consideration to support an executory contract may consist either in an act done by the promisee or in an agreement made by him, and such agreement may itself be either executed or executory; or finally it may consist in some antecedent promise or liability of the promisor.

If the consideration be an act done by the promisee, the maxim, "locus regit actum," applies. The validity and effect of the consideration will depend upon the lex loci considerationis, and the locus considerationis in such case is a mere question of fact. Indeed if the consideration is an act done at the time of making the contract, the locus considerationis and the locus celebrationis of the contract will always coincide.

If the consideration is itself an agreement on the part of the promisee, its situs will be the situs of the promisee's contract, and will be determined in accordance with the principles which govern the situs of contracts generally, - the same principles which are now being discussed in this chapter. If the consideration (the promisee's agreement) is an executed contract, its validity and the corresponding validity of the promisor's contract will depend upon the law of the place where the promisee's agreement is entered into (its lex celebrationis). If the consideration (the promisee's agreement) is executory, its validity and the consequent validity of the promisor's contract will depend upon the lex celebrationis or the lex solutionis of the promisee's agreement, according to the particular element attacked as invalid. ${ }^{1}$

It is to be observed, in the cases above mentioned, that in strictness the act done or the agreement made by the promisee, if they are to form the direct consideration for the promisor's promise, must be done or entered into at the moment when, and therefore at the place where, the promisor's contract is entered into. If the promisee's act or agreement is done or made after

8 Post, $\S 176$ et seq.

1 See post, §§ 168-175, where the law governing the different cases of in. validity is fully considered. 
the promisor's, there is no consideration to support the promisor's contract; if done or made before the promisor's, the consideration is a past consideration, which is generally held to be equivalent to none at all.

When a past act or agreement by the promisee is said to constitute a consideration for a promise, it is an inaccurate mode of expression. The past act or agreement may raise a liability in the promisor, - an implied promise on his part, arising at the moment of the act done or the agreement made, which implied promise may subsequently be changed into an express promise. In such case, the consideration for the express promise is not the act or agreement of the promisee at all, but the liability of the promisor arising contemporaneously with that act or agreement and springing out of it. Whether such liability legally arises from the act or agreement of the promisee depends upon the law of the place where the act is done or the agreement is made. If by that law it does arise, it continues a burden upon the promisor wherever he may be, and constitutes a valid consideration to support his express promise wherever made. If no such liability arises in the first instance under the law of the State where the promisee's act is done, or his agreement is made, there is no liability upon the promisor anywhere. In the latter case therefore an express promise made by the promisor is only for a past consideration (which is no consideration), there being no implied liability legally resting upon him.

Hence when we spoke, in the preceding section, of a note made in Vermont in consideration of a sale of liquor in New York, it will be seen that, strictly speaking, such language is inaccurate. The consideration for the note in such a case is not in reality the sale of the liquor: that would be a past consideration. The real consideration for the note is the promise to pay for the liquor purchased, which promise was implied by the law of New York (or validly agreed upon there expressly by the parties). But the inaccuracy is immaterial, since the law of the place of the promisee's act or agreement controls the validity of the liability, and the validity of the note would depend upon the validity of the promisor's antecedent liability, which is the consideration for the note. 
The result of this reasoning is that, for our purposes, we may disregard those considerations which consist of liabilities merely created by the law ; for they will always arise, if at all, immediately upon some act of the parties, and the validity of the contracts for which they are the consideration will always in the end depend upon the law governing the act out of which they arise. We need look therefore only to the locus of the act itself, whose law will govern the validity of the consideration. And, to simplify matters, we may regard the act itself as the consideration, though the act be done before the promise is entered into.

Thus viewed, there will be no difficulty in ascertaining the locus considerationis if the consideration is a mere act done by the promisee, whether it be done in the State where the promisor's contract is made or elsewhere. The validity of the promisee's act, judged by the lex considerationis, will determine the validity of the promisor's contract. And the same may be said where the consideration consists in an executed agreement of the promisee. But where the consideration is an executory contract of the promisee, it may have a distinct locus celebrationis and locus solutionis of its own, and both of these may be different from the locus celebrationis and the locus solutionis of the promisor's contract. In some respects the validity of the promisee's contract may be controlled by its lex celebrationis, in some respects by its lex solutionis. And neither of these are necessarily coincident with the locus celebrationis or the locus solutionis of the promisor's contract. Illustrations of these principles will be given hereafter. ${ }^{2}$

2 See post, $\$ 176$. It would be rarely the case however that the locus celebrationis of the promisee's contract (consideration) would not be identical with the locus celebrationis of the promisor's contract, as the two promises will generally be made contemporaneously. But, bearing in mind the explanation above given touching the effect of the promisor's antecedent liability as a consideration, and our agreement to disregard it, substituting therefor the act out of which that liability arose, we may easily conceive of a case like the following : A promises B in Maryland to do an act for B in Pennsylvania, in consideration of B's doing an act for A in New York. So far both contracts have the same locus celebrationis, though different loci solutionis. Now suppose $A$, in consideration of his existing promise to $B$, enters into another 


\section{§ 163. Situs of Particular Contracts - Contracts to Pay}

Money. - Having noted the general principles by which the locus celebrationis or the locus solutionis of a contract will be ascertained, we will now turn our attention to some particular instances of contracts, which present more or less difficulty in the solution of these questions. It will repay us to examine more closely into the cases of contracts to pay money and contracts of insurance.

With regard to contracts to pay money generally, there is usually little difficulty in applying the principles heretofore noted in determining the locus celebrationis. This will always be the place where the last act is done necessary to bind the promisor. ${ }^{1}$ If the contract is oral, it will be the place where the words of assent or promise are spoken; if written, the mere signing or sealing will not usually be sufficient to bind the promisor. There must be a delivery and acceptance of the instrument also, which is the final token of the promisor's assent. Hence the place of delivery, not the place of signing, is the place where the minds of the parties meet, and is the locus celebrationis of the contract. ${ }^{2}$ But if the note or bond is drawn up by the payees, and sent by them to the maker in another State for his signature, without instructions as to how it shall be returned, the maker's acceptance of the payee's offer is complete upon his signing the note and depositing it in the post

agreement with $B$ in Ohio, by which $A$ agrees to do the same act, before agreed upon, in Virginia, instead of in Pennsylvania as the terms of the first agreement demanded. Here we would have A's promise made in Ohio to be performed in Virginia. The consideration of A's promise would be B's promise made in Maryland, to be performed in New York. There is no need to da more than merely point ont that such a case may arise. As a general rule the loci celebrationis of the two mutual promises will coincide. It might easily be otherwise, however, with the loci solutionis.

1 Ante, $\$ 157$.

2 Baum v. Birchall, 150 Penn. St. 164, 24 Atl. 620 ; Fant $v$. Miller, 17 (rratt. (Va.) 47, 59 ; Akers $v$. Demond, 103 Mass. 318, 324 ; Lawrence v. Bas. sett, 5 Allen (Mass.), 140 ; Bell v. Packard, 69 Me. 105, 31 Am. Rep. 251, 252; Hart v. Wills, 52 Ia. 56, 2 N. W. 619, 35 Am. Rep. 255; Carnegie Steel Co. v. Construction Co. (Tenn.), 38 S. W. 102 ; Phipps v. Harding, 17 C. C. A. 203,70 Fed. $468,471$. 
office, properly addressed to the payees, and the place of the signature is the locus celebrationis of the contract. ${ }^{8}$

The locus solutionis of a bond or note will be the place where the parties intend it to be paid at maturity. If the place where it is payable is designated on the face of the instrument, that is the locus solutionis, ${ }^{4}$ unless the parties have really a different intention as to the place of performance from that expressed on the face of the note. It is the real intent, not the expressions of the parties, that is looked to..$^{5}$

If no place of payment is named on the face of the instrument, the strong presumption is that it was intended to be payable at the locus celebrationis, ${ }^{6}$ though this may be rebutted by clear evidence or inference that the parties looked to some other place as the locus solutionis, as where the maker executes the note while in transit through the State. ${ }^{7}$ In such case, if the bond or note be payable at a future day, it is reasonable to presume that the parties look to the creditor's or the debtor's domicil - as the place of payment, rather than the State which is by mere accident the locus celebrationis; and since it is the duty of the debtor to resort to the creditor's place of business on the appointed day to pay him, it would seem that the locus solutionis should be the creditor's domicil rather than that of the debtor. ${ }^{8}$

3 Barrett v. Dodge, 16 R. I. 740, 19 Atl. 530; Wayne Co. Bank v. Low, 81 N. Y. 566, 572, 37 Am. Rep. 533. See Sheldon v. Haxtun, 91 N. Y. 124, 131. But see Staples $v$. Nott, 128 N. Y. 403, 28 N. E. 515.

4 Bryant $v$. Edson, 8 Vt. 325, 30 Am. Dec. 472.

5 Ante, \$159. See New England Mortg. Co. v. Vaden, 28 Fed. 265.

6 Barrett v. Dodge, 16 R. I. 740, 19 Atl. 530; Hart v. Wills, 52 Ia. 56, 35 Am. Rep. 255, 2 N. W. 619 ; Lewis v. Headley, 36 Ill. 433, 87 Am. Dec. 227 ; Wilson v. Lazier, 11 Gratt. (Va.) 477.

7 Ante, $\S 159$, note 4. Even here, if the note is payable on demand, since it falls due inmediately, it would seem that the locus celebrationis and the locus solutionis must generally be regarded as identical. Smith $v$. Mead, 3 Conn. 253, 8 Am. Dec. 183.

8 See Pritchard $v$. Norton, 106 U.S. 124, 138; De Wolf $v$. Johnson, 10 Wheat. 367, 383 ; Lanusse $v$. Barker, 3 Wheat. 101 ; Boyle $v$. Zacharie, 6 Pet. 635 ; Hickox $v$. Elliott, 27 Fed. 830, 839 ; Chapman $v$. Robertson, 6 Pai. Ch. (N. Y.) $627,630,31 \mathrm{Am}$. Dec. 264. If the bond or note is given in pursuance of an order of court, no place of payment being designated, it seems that it is to be regarded as payable at the situs of the court. Irvine $v$. Bar. 
So, the fact that the bond or note, though executed in one country, is payable in the currency of another, may be evidence of the intention of the parties to make the latter State the place of payment; or the fact that accruing interest is expressly made payable in another State may afford reasonable ground for the presumption that the principal was intended to be paid there. ${ }^{9}$

Some difficulty is found in ascertaining the locus solutionis of a bond or note, naming no place of payment, made in one State and secured by mortgage on property in another. Here as in other cases the question is one of intent. Do the parties intend that the bond or note shall be payable at the place where the mortgaged property is situated? It is not at all a necessary inference that they do. The mortgage is merely a collateral agreement, the object of which is to secure payment at the time and place agreed upon, which may or may not be the situs of the mortgaged property. Unless other circumstances point to that place as the intended place of payment, the mere existence of the mortgage cannot logically give rise to an inference of such an intention; and the better opinion is believed to be that it does not. ${ }^{10}$

If the promise to pay is not express, but implied from the acceptance of goods sold, work done, services rendered, money loaned, account stated, etc., the indebtedness is created at the place where the goods are sold, the services rendered, etc.; for

rett, 2 Grant's Cas. (Penn.) 73; Pritchard $v$. Norton, 106 U. S. 124, 138. In case of the bond of a public officer, conditioned to perform public duties faithfully, the place of payment is the seat of government. Cox $v$. United States, 6 Pet. 172 ; Duncan $v$. United States, 7 Pet. 435 ; Pritchard $v$. Norton, 106 U. S. $124,139$.

${ }^{9}$ Curtis $v$. Leavitt, 15 N. Y. 9, 86, 87. See Coghlan v. R. R. Co., 142 U. S. 101.

${ }^{10}$ De Wolf $v$. Johnson, 10 Wheat. 367, 383 ; Hickox $v$. Elliott, 27 Fed. 830, 839; Central Trust Co. v. Burton, 74 Wis. 329, 43 N. W. 141, 142; Odom v. Mortg. Co., 91 Ga. 505, 18 S. E. 131 ; New England Mortg. Co. v. McLaugh. lin, 87 Ga. 1, 13 S. E. 81 ; Martin v. Johnson, 84 Ga. 481, 8 L. R. A. 170, 10 S. E. 1092 ; American Mortg. Co. v. Sewell, 92 Ala. 163, 9 So. 143; Fessenden v. Taft, 65 N. H. 39, 17 Atl. 713 ; Chapman v. Robertson, 6 Pai. Ch. (N. Y.) ๑27, 633, 634, 31 Am. Dec. 264. See Kellogg v. Miller, 13 Fed. 198 
the indebtedness, if it arises at all, must arise at the moment the benefit is conferred, or the act done which is alleged to create it. And the locus solutionis of the implied promise will of course be identical with the locus celebrationis. ${ }^{11}$

\section{§164. Negotiable Instruments - Contract of Maker or} Acceptor. - The situs of negotiable paper deserves special notice. So far as the maker of a negotiable note is concerned, the locus celebrationis and the locus solutionis of his contract are to be ascertained in accordance with the principles mentioned in the preceding sections. ${ }^{1}$ There is no difference in this respect between the maker of a negotiable note and the maker of any other contract to pay money.

The locus celebrationis of the contract of an acceptor of a bill of exchange is of course the place where his acceptance becomes complete and finally binding upon him. This will usually be the place where the acceptance is given. But if the acceptance is for the purpose of negotiation in another State, the bill being subsequently sent thither for that purpose, the locus celebrationis of the contract of acceptance is the State where such negotiation takes place, for only upon its delivery to the holder does the acceptance become obligatory. ${ }^{2}$ And if the acceptance be made through an agent, the place where the agent acts (if he has plenary authority) will be the locus celebrationis of the principal's contract.

The locus solutionis of an acceptor's contract depends primarily, as in other cases, upon the intention. If the acceptor names in his acceptance the place where he proposes to pay, or if, in the event of his silence, the bill designates a place of pay. ment, that place will be the locus solutionis of his contract.

11 Crumlish v. Cent. Imp. Co., 38 W. Va. 390, 18 S. E. 456; Grant v. Healy, 3 Sumner (U. S.), 523. See Porter v. Price, 49 U. S. App. 295, 80 Fed. 655 ; Lanusse v. Barker, 3 Wheat. 101 ; Merchants' Bank v. Griswold, 72 N. Y. 472,28 Am. Rep. 159.

1 Ante, $\S \S 157,158,163$.

2 Tilden $v$. Blair, 21 Wall. 241, 247 ; Hall $v$. Cordell, 142 U. S. 116 ; Farmers' Nat. Bank v. Sutton, 3 C. C. A. 1, 52 Fed. 191; Merchants' Bank v. Griswold, 72 N. Y. 472, 481, 28 Am. Rep. 159 ; Lennig $v$. Ralston, 23 Penn. St. 137. This applies also to the contract of the maker of a note.

3 Scudder $v$. Bank, 91 U. S. 406 ; ante, $\$ 158$. 
But in the absence of such controlling circumstances, the general rule is that the locus solutionis of the acceptor's contract will be his place of residence or business, or his address on the face of the bill.4

A contract to accept a bill or draft is usually regarded as an actual acceptance thereof, as against a bona fide holder, unless a specific place for the future acceptance of the bill is designated. ${ }^{6}$ But as between the original parties, it is an ordinary contract, and governed by the same rules. ${ }^{6}$

$\S 165$. Indorser's or Drawer's Contract. - Upon the indorsement of a bill or note, the indorser enters into a new contract, collateral to and distinct from the original contract of the maker or scceptor. Indeed the contract of indorsement (unless it be merely for accommodation) comprises two distinct contracts, one of which is an executed assignment, operating to transfer to the indorsee such title to the chose in action as the indorser possesses, and such rights as he has against prior parties to the note or bill, and the other an executory contract, by which the indorser undertakes that the bill or note shall be paid at maturity.

So far as concerns the executed transfer represented by the indorsement, it is an instance of the voluntary transfer of personal property, the "proper law" to govern which we have seen to be the law of the place where the transfer is made (lex loci contractus). ${ }^{2}$ The nature of the title in the indorsee is deter-

4 Lebel $v$. Tucker, L. R. 3 Q. B. 77 ; Scudder v. Bank, 91 U. S. 406, 413 ; Freese $v$. Brownell, 35 N. J. L. 285, 10 Am. Rep. 239 ; Coffman v. Bank, 41 Miss. 212, 90 Am. Dec. 371; Hunt v. Standart, 15 Ind. 33, 77 Am. Dec. 79, 86 ; Worcester Bank v. Wells, 8 Met. (Mass.) 107.

5 Scudder $v$. Bank, 91 U. S. 406 ; Hubbard v. Exchange Bank, 18 C. C. A. 525, 72 Fed. 234 ; Exchange Bank v. Hubbard, 10 C. C. A. 295, 62 Fed. 112 ; Garrettson v. Bauk, 47 Fed. 867 ; Merchants' Bank v. Griswold, 72 N. Y. 472, 28 Am. Rep. 159 ; Carnegie v. Morrison, 2 Met. (Mass.) 381, 398, 400.

6 Hall $v$. Cordell, 142 U. S. 116.

1 Horne v. Rouquette, 3 Q. B. Div. 514, 28 Eng. Rep. 424; Aymar $v$. Sheldon, 12 Wend. (N. Y.) 439, 443, 27 Am. Dec. 137 ; Everett $v$. Vendryes, 19 N. Y. 436, 437; Freese $v$. Brownell, 35 N. J. L. 285, 10 Am. Rep. 239, 241; Nichols $v$. Bank, 2 W. Va. 13, 94 Am. Dec. 501; Felch v. Bugbee, 48 Me. 9, 77 Am. Dec. 203 ; Stubbs $v$. Colt, 30 Fed. 417, 419.

2 Ante, $\$ 122,128$ et seq. But in favor of creditors, and other third persons, it will be remembered, the lex fori is frequently substituted. 
mined by the law of the place of indorsement, and this applies equally to other choses in action as well as to negotiable instruments.

Hence the right of the indorsee as holder of a note or bill, or of the assignee of any chose in action, to sue the original promisors, and the nature and extent of his claim against them, will depend upon the law governing the indorsement or assignment under which he holds. If the law of the place of the transfer confers upon the assignee the legal title to the chose in action, so that he may there sue the original promisors at law in his own name, the same results will follow everywhere, even in States by whose law, if the transfer had taken place there, only an equitable title would have passed to the assignee. ${ }^{3}$

Thus, in Levy $v$. Levy, ${ }^{4}$ an assignment was made in New York of a chose in action, which by the law of New York vested the legal title in the assignee, with the incidental right to sue upon it in a court of law in his own name. By the law of Pennsylvania (the forum) the assignment, if made there, would have rested only an equitable title in the assignee, who could have sued in a court of law only in the name of his assignor. The Pennsylvania court held that, the law of New York (lex loci contractus) having conferred upon the assignee the legal title, he was entitled to sue the promisor in his own name in Pennsylvania. The court admitted that if the law of New York had merely given the assignee the right to sue at law in his own name, without conferring upon him the legal title, this would not have sufficed to sustain an action in Pennsylvania in his own name, since this, standing alone, would be merely a matter pertaining to the remedy, to be controlled by the lex fori. ${ }^{5}$

So, the indorsee or holder of a bill or note succeeds to the rights of his assignor against the prior indorsers to the extent

3 See Brabston $v$. Gibson, 9 How. 263 ; Trimbey $v$. Vignier, 1 Bing. $\mathbf{~ v . ~ c . ~}$ 151, 27 E. C. L. 336 ; Bradlaugh v. De Rin, L. R. 5 C. P. 473 ; Horne $v$. Rouquette, 3 Q. B. Div. 514, 517, 28 Eng. Rep. 424 ; Brook v. Van Nest, 58 N. J. L. 162, 33 Atl. 382.

48 Penn. St. 507, 21 Am. Rep. 35. See also Jordan v. Thornton, 2 Eng. (Ark.) 224, 44 Am. Dec. 546, 548.

5 Post, $\$ 206$. 
permitted by the law of the place where the transfer to him is made, and no further. But since his assignor can hold each indorser only upon his independent collaterai contract of indorsement, and the liability of each such indorser depends upon the "proper law" governing his particular contract of indorsement, it follows that the rights of the indorsee or holder against such prior indorsers will also depend upon the "proper law" of the executory contract of indorsement made by the particular indorser whom he seeks to hold liable. ${ }^{6}$

This brings us to the consideration of the second contract, the executory contract, - created by the act of indorsement. This contract is in the nature of a contract of guaranty, an undertaking that the bill or note will be paid when properly presented at maturity. Being an executory contract, it may have a locus solutionis distinct from the locus celebrationis.

Little difficulty is usually experienced in ascertaining the locus celebrationis of the contract. The place where the indorser puts his name on the paper will ordinarily be the place where his contract is entered into. ${ }^{7}$ But it is not the mere putting of his name upon the paper that constitutes the indorsement. It does not usually take effect, either as an executed or executory contract, until the note so indorsed is delivered to the indorsee or holder. The place where the note is actually indorsed is immaterial if the delivery or transfer occurs elsewhere. ${ }^{8}$

- Carlisle v. Chambers, 4 Bush (Ky.), 272, 96 Am. Dec. 304 ; Bradlaugh $v$. De Rin, L. R. 5 C. P. 473 . See Horne v. Ronquette, 3 Q. B. Div. 514, 517, 28 Eng. Rep. 424; Trimbey $v$. Vignier, 1 Bing. N. c. 151. See Everett $v$. Vendryes, 19 N. Y. 436 ; Reddick $v$. Jones, 6 Ired. L. (N. C.) 107, 44 Am. Dec. 68; Lebel $v$. Tucker, L. R. 3 Q. B. 77, 83. This matter is discussed more at length hereafter. Post, § 182.

7 Young $v$. Harris, 14 B. Mon. (Ky.) 556, 61 Am. Dec. 170 ; Douglas $v$. Bank, 97 Tenn. 133, 36 S. W. 874, 876 ; Brook v. Van Nest, 58 N. J. L. 162, 33 Atl. 382.

8 Fant v. Miller, 17 Gratt. (Va.) 47; Rose v. Bank, 20 Ind. 94, 83 Am. Dec. 306 ; Gay v. Rainey, 89 Ill. 22I, 31 Am. Rep. 76 ; Young v. Harris, 14 B. Mon. (Ky.) 556, $61 \mathrm{Am}$. Dec. 170, 171 ; Briggs $v$. Latham, $36 \mathrm{Kan}$. 255, 59 Am. Rep. 546, 13 Pac. 393 ; Carnegie Steel Co. v. Construction Co. (Tenu.), 38 S. W. 102, 103 ; Stanford v. Pruet, 27 Ga. 243, 73 Am. Dec. 734 ; Dunscomb v. Bunker, 2 Met. (Mass.) 8; Lee v. Selleck, 33 N. Y. 615, 618; Cook v. Litchfield, 9 N. Y. 279 ; Stubbs v. Colt, 30 Fed. 417. 
So, if the indorsement be for accommodation merely, the note or bill being sent or taken to another State for negotiation, the indorsement does not become binding upon the accommodation indorser until the negotiation occurs. The place at which the note goes into the hands of a holder for value is in such case the locus celebrationis of the indorser's contract. ${ }^{9}$

With respect to the locus solutionis of the executory contract of indorsement, the views of the authorities are conflicting. Of course no difficulty will arise if the indorser names in his indorsement the place where he undertakes to pay should such a course become necessary. But this is rarely done. Usually the indorsement is silent upon this point.

Although the general rule is that, if the contract designates no place of performance, the locus solutionis will coincide with the locus celebrationis, it will be remembered that this is founded merely upon the presumption of the intent and purpose of the parties, and may yield to evidence or inference of some other intent.

The locus solutionis of a contract of indorsement depends upon the exact character of the promise implied from the indorsement. We have seen that it constitutes an undertaking on the part of the indorser that the bill or note will be paid upon proper presentment at maturity. But is the indorsement a conditional promise by the indorser to pay generally, or at the place where he makes the promise, or is it a promise to pay at the place where the money should have been paid at maturity, that is, at the locus solutionis of the bill or note?

Upon the answer to these questions depends the locus solutionis of the contract of indorsement. And it is a very impor. tant point to determine, for the lex solutionis of his contract will generally regulate the rights and duties of the indorser with respect to all matters connected with the performance of his contract.

Many of the authorities follow the general rule and hold that the locus solutionis of the contract of indorsement, no special place of performance being named, is identical with the locus

- See cases cited in note 8, supra. 
celebrationis. These go upon the theory that the contract of the indorser is to pay the bill or note generaliy, if at all, that is, at the place where he indorses. ${ }^{10}$

Others hold that the indorser's contract is to make good the bill or note at the place where it was originally designed to be paid, and that that place therefore is the locus solutionis of the indorsement. ${ }^{11}$

Expediency would seem to pronounce in favor of the latter view, and it is believed to be the better. To give every indorsement its own separate locality would impair most seriously the value of all negotiable instruments, even those which are in fact purely domestic, since the holder could not know where the prior indorsements were made and hence could not tell what the liabilities of the prior indorsers are, nor what steps he must take to secure that liability. The tendency of this rule is to destroy or impair the negotiability of such instruments. On the other hand, to hold the locus solutionis of each indorsement to be identical with the locus solutionis of the original contract creates one single law by which the liabilities of all the indorsers are to be ascertained, and would prevent the inconvenience (to use a mild term) to the holder of having to ascertain and comply with a number of different laws as to protest, notice of dishonor, and other steps to be taken in order to fasten responsibility upon the indorsers. ${ }^{12}$

10 Story, Confl. L. \$ 314 ; Horne $v$. Rouquette, 3 Q. B. Div. 514, 28 Eng. Rep. 424 ; Musson $v$. Lake, 4 How. 262 ; Hunt $v$. Standart, 15 Ind. 33, 77 Am. Dec. 79, 84; Park $v$. Rose Bank, 20 Ind. 94, 83 Am. Dec. 306 ; Aymar $v$. Sheldon, 12 Wend. (N. Y.) 439, 443, 27 Am. Dec. 137 ; Hicks v. Brown, 12 Johns. (N. Y.) 142 ; Kuenzi v. Elvers, 14 La. Ann. 391, 74 Am. Dec. 434 ; Powers $v$. Lynch, 3 Mass. 77 ; Williams $v$. Wade, 1 Met. (Mass.) 82 ; Douglas v. Bank, 97 Tenn. 133, 36 S. W. 874 ; Huse v. Hamblin, 29 Ia. 501, 4 Am. Rep. 244.

11 Hirschfield $v$. Smith, L. R. 1 C. P. 340 ; Rothsehild v. Currie, 1 Q. B. 43, 1 Ad. \& Fi. N. s. 43 ; Hibernia Nat. Bank v. Lacombe, 84 N. Y. 367 ; Everett $v$. Vendryes, 19 N. Y. 436 ; Wooley $v$. Lyon, 117 Ill. 244, 57 Am. Rep. 867 ; Peck v. Mayo, 14 Vt. 33, 39 Am. Dec. 205 ; Carnegie Steel Co. $v$. Construction Co. (Tenn.), 38 S. W. 102 ; Pierce v. Indseth, 106 U. S. 546, 550.

12 Hirschfield $v$ Smith, L. R. 1 C. P. $340,352$. 
The contract of the drawer of a bill is practically the same as that of an indorser. He undertakes that the drawee will accept the bill when presented and that he will pay it at maturity upon due presentment; and that if the drawee does not accept, or does not pay at maturity, he (the drawer) will upon due notice pay the amount named in the bill, with such damages as may result from non-payment.

The locus celebrationis of this contract of the drawer is manifestly in general the place where the bill is drawn, just as in a corresponding case the locus celebrationis of the indorser's contract is usually the place where the bill or note is indorsed. And the same qualifications are to be noted here as in the case of the indorser. $^{18}$

With respect to the locus solutionis of the drawer's contract, the same diversity of opinion exists as in the corresponding case of the indorser's contract. Although there is strong authority to the effect that the undertaking of the drawer is to make good the bill at the place where he draws it, ${ }^{14}$ the better opinion is believed to be that the drawer undertakes to make good the bill at the place where it is payable. ${ }^{15}$ It is to be observed that there is this difference between the contract of the indorser and that of the drawer. The former becomes a party to a transaction in the creation of which he has no part, while the drawer himself

18 Aymar v. Sheldon, 12 Wend. (N. Y.) 439, 443, 27 Am. Dec. 137 ; Everett $v$. Vendryes, 19 N. Y. 436 ; Freese $v$. Brownell, 35 N. J. L. 285, 10 Am. Rep. 239 ; Hunt $v$. Standart, 15 Ind. 33, 77 Am. Dec. 79. But see Strawbridge $v$. Robinson, 5 Gilm. (Ill.) 470, 50 Am. Dec. 420, where the court solemnly decides that a bill which is actually drawn in one State was drawn in another, because the parties intended that it should be so.

14 Freese v. Brownell, 35 N. J. L. 285, 10 Am. Rep. 239; Hunt v. Standart, 15 Ind. 33, 77 Am. Dec. 79 ; Briggs $v$. Latham, 36 Kan. 255, 59 Am. Rep. 546, 547 ; Crawford v. Bank, 6 Ala. 12, 41 Am. Dec. 33 ; Kuenzi v. Elvers, 14 La. Ann. 391, 74 Am. Dec. 434 ; Hicks v. Brown, 12 Johns. (N. Y.) 142.

15 Hibernia Nat. Bank v. Lacombe, 84 N. Y. 367 ; Everett v. Vendryes, 19 N. Y. 436 ; Aymar v. Sheldon, 12 Wend. (N. Y.) 439, 27 Am. Dec. 137 ; Coffman v. Bank, 41 Miss. 212, 90 Am. Dec. 371 ; Abt v. Bank, 159 Ill. 467, 42 N. E. 856 ; National Bank of America v. Indiana Banking Co., 114 Ill. 483, 2 N. E. 401. See Wooley v. Lyon, 117 Ill. 244, 57 Am. Rep. 867 ; Hirschfield v. Smith, L. R. 1 C. P. 340 ; Rouquette v. Overmann, L. R. 10 Q. B. 525 . 
draws the original contract, and may make it payable where he chooses. Hence, much more in the case of the drawer than in that of the indorser ought the locus solutionis of his contract to be the place where the bill is payable or upon which it is drawn. ${ }^{16}$

$\S 166$. Situs of Insurance Contracts. - If a place is designated for the payment of the money due upon a policy of insurance (as at the principal office of the company, etc.), there will be no difficulty in fixing upon that place as the locus solutionis of the insurance contract. Frequently, however, contracts of insurance are general in character, designating no particular place for the payment of the policy. The locus solutionis will then be generally presumed to be identical with the locus celebrationis. $^{1}$

But it is by no means always easy to ascertain the locus celebrationis of an insurance contract. The general principle is still the same, namely, that the place where the last act is done that is necessary to make the contract complete and binding is the locus celebrationis. ${ }^{2}$

Thus if the agreement is that the policy becomes binding upon the insurance company as soon as it is issued, or upon its approval of the application of the insured, the place where such issuance or approval occurs is the locus celebrationis of the contract. ${ }^{3}$

16 See Aymar $v$. Sheldon, 12 Wend. (N. Y.) 439, 27 Am. Dec. 137 ; Everett v. Vendryes, 19 N. Y. 436 ; Powers $v$. Lynch, 3 Mass. 77.

1 Seamans $:$ Knapp Co., 89 Wis. 171, 27 L. R. A. 362. This is the better view, though the authorities are divided. Some have held, in the case of fire insurance upon buildings, that the situs of the land is the locus solutionis of the insurance policy. See Gibson $v$. Ins. Co., 77 Fed. 561, 564. Others have held, in case of fire policies upon personal property, and life policies, that the domicil of the owner or beneficiary is the locus solutionis of the contract. See Knights Templars Ass'n $v$. Greene, 79 Fed. 461 ; Fletcher $v$. Ins. Co., 13 Fed. 526 ; Wood $v$. Ins. Co., 8 Wash. 427, 36 Pac. 267.

2 See Ford $v$. Ins. Co., 6 Bush (Ky.), 133, 99 Am. Dec. 663.

8 Equitable, etc. Soc. v. Trimble, 27 C. C. A. 404, 83 Fed. 85 ; Equitable, etc. Soc. v. Nixon, 26 C. C. A. 620, 81 Fed. 796 ; Voorheis $v$. Society, 91 Mich. 469,51 N. W. 1109 ; Seamans $v$. Knapp Co., 89 Wis. 171, 27 L. R. A. 362 ; State, etc. Ins. Co. v. Brinkley Co., 61 Ark. 1, 29 L. R. A. 712; Hyde v. Goodnow, 3 N. Y. 266, 270. 
If the actual or constructive delivery of the policy to the insured is necessary in order to make the contract binding upon the insurance company, the place where such delivery takes place will be the locus celebrationis of the contract. ${ }^{4} \mathrm{~A}$ distinction may perhaps be taken here between the case where the insurance company sends its policy directly to the applicant by mail, in which case the delivery will occur where the policy is mailed, and the case where the company mails the policy to a third person in the State of the applicant, to be by him delivered to the insured, in which case the delivery takes place and the insurance contract is entered into in the latter State. ${ }^{6}$

Again, the payment of the first premium is often, by the terms of the agreement, made the event upon which the policy is to become binding. In such case, the place where the premium is paid is the locus celebrationis of the insurance contract. ${ }^{6}$ And upon the same principle, if it is provided that the policy is not to be binding until countersigned by an agent, or until some other act is done, the State where such final act is performed is the locus celebrationis of the contract. ${ }^{7}$

The contract by which the beneficiary of an insurance policy assigns his interest to a third person is of course entirely distinct from the contract of insurance itself. The assignment is an executed contract, and the law of the place where the assignment is made and completed (lex loci contractus) is the proper

4 Equitable, etc. Society $v$. Clements, 140 U. S. 226 ; Hicks $v$. Ins. Co., 9 C. C. A. 215,60 Fed. 690 ; Knights Templar Co. v. Berry, 1 C. C. A. 561 , 50 Fed. 511 ; Wood v. Ins. Co., 8 Wash. 427, 36 Pac. 267 ; In re Breitung, 78 Wis. 33, $46^{6}$ N. W. 891 ; Perry $v$. Ins. Co., 67 N. H. 291, 33 Atl. 731.

5 See Equitable, etc. Society $v$. Clements, 140 U. S. 226; State Ins. Co. $v$. Brinkley Co., 61 Ark. 1, 29 L. R. A. 712. If the insured is notified by letter or otherwise that his application has been accepted, the contract is thereby completed, and the place of the delivery of the policy is immaterial. See Perry v. Ins. Co., 67 N. H. 291, 33 Atl. 731.

6 Equitable, etc. Society v. Clements, 140 U. S. 226 ; Hicks $v$. Ins. Co., 9 C. C. A. 215,60 Fed. 690 ; Mut. Ben. L. Ins. Co. v. Robison, 54 Fed. 580, 583 ; Marden v. Ins. Co., 85 Ia. 584, 52 N. W. 509 ; Ford v. Ins. Co., 6 Bush (Ky.), 133, 99 Am. Dec. 663.

7 Heebner $v$. Ins. Co., 10 Gray (Mass.), 131 ; In re Breitung, 78 Wis. 33, 46 N. W. 891 ; Gibson $v$. Ins. Co., 77 Fed. 561, 563. See State Ins. Co. v. Brinkley Co., 61 Ark. 1, 29 L. R. A. 712. 
law to regulate it. Thus, in Miller $v$. Campbell, ${ }^{8}$ it was held that a married woman, who was the beneficiary of a Massachusetts policy of insurance, could not assign her interest therein in New York, though the law of Massachusetts permitted it.

In a Wisconsin case, ${ }^{9}$ the question was whether a person who had procured a policy of insurance on his own life for the benefit of another and had paid the premiums thereon, might dispose of the insurance by will or otherwise to the exclusion of the beneficiary designated in the policy. By the law of Wisconsin he could do so, and that law was held to govern the assignment (which was made there), though the insurer was a Massachusetts corporation, and by Massachusetts law such an assignment could not be made. ${ }^{10}$

8140 N. Y. 457,35 N. E. 65.

9 In re Breitung, 78 Wis. 33,46 N. W. 891.

10 In this case the court held that the contract of insurance also was made in Wisconsin, and seems to have based its decision largely on that fact. The capacity of the insured to make the assignment in question may probably be regarded as a part of the obligation of the contract of insurance, and as such (in this peculiar instance) to be governed by the lex celebrationis of the contract; though in general the lex solutionis of the contract governs the obligation thereof, in the absence of evidence that the parties contracted with reference to any other law. The report does not show where the policy was payable (locus solutionis). The obligation (apart from the ralidity) of a contract depends upon " the law in the minds of the parties." Post, § 181. 


\section{CHAPTER XVII.}

\section{VALIDITY OF CONTRACTS.}

$\$ 167$. Preliminary. - The validity of a contract is very distinct from its obligation, its interpretation, or its discharge. The last three matters are reserved for future discussion. This chapter will be devoted to an examination of the "proper law" governing the validity of a contract.

It will be remembered that although sometimes the "proper law" governing a contract in some of its aspects is "the law in the minds of the parties," irrespective of situs, ${ }^{1}$ a different rule applies to questions of the validity of the contract. The design or purpose of the parties to enter into a valid contract, standing alone, can never suffice to validate a contract prohibited by the law, nor to invalidate (except by mutual rescission) a contract not legally prohibited. It is true that where the intent of the parties is doubtful and susceptible of several interpretations, according to one of which the contract would be legal and according to the other illegal, that interpretation will be given to the terms used which will give rise to a lawful, rather than to an unlawful, contract. But if there is no ambiguity, and it is clear that the parties intend to enter into a contract which the law invalidates, their innocence of design to violate the law is entirely immaterial, except in the few cases where it is the guilty intent alone which invalidates. ${ }^{2}$

The question therefore, where the validity of the contract is under investigation, is not what law do the parties intend shall govern a particular element, but what law shall actually govern it. The answer is that the validity of the contract, in respect

1 That is, when the maxim, "modus et conventio legem vincunt," is appli. cable to the question. Ante, $\$ 154$. See Pope v. Nickerson, 3 Story, 465, 484.

2 Ante, § 154; Pope v. Nickerson, 3 Story, 465, 484. 
to each of its elements, is to be controlled by the law of the situs of that element; by the lex loci celebrationis, if the element in question relates to the making of the contract; by the lex loci solutionis, if it relates to the performance of it; and by the lex loci considerationis, if it is the consideration of the contract whose sufficiency or legality is disputed.

For the purposes of this discussion, an executory contract may be defined as " a mutual agreement, not prohibited by law to be entered into, between two or more legally competent persons, made in due legal form, touching a lawful subject-matter, for a legal consideration."

A careful examination of this definition will show that a contract in its very nature must come into contact with legal restrictions at no less than five points. (1) The contract must not be one the entrance into which the law prohibits; (2) The parties must be legally competent to contract (which is really part of the first proposition); (3) The contract must be in the form, if any, required by law (another branch of the first proposition); (4) The thing agreed to be done under the contract must be one not prohibited by law ; (5) The consideration supporting the contract must not be one which the law regards as insufficient or illegal.

The first three of these heads relate to the entering into the contract, or the making of it; the fourth relates to the performance of the contract; and the fifth, to the consideration. All these elements are included in the definition of a contract, and if any one of them fails to measure up to the standard required by the law, the contract must fall; it is invalid.

At all these points the contract comes into contact with "law," and must conform itself to it. But the question remains, what law? Is it the same law for all these elements, or may each have a separate law to govern its validity? To this inquiry we will now address ourselves.

$\S 168$. Contracts Prohibited to be entered into-In General - Lex Ioci Celebrationis. - If the alleged invalidity of a contract turns upon the question whether the law prohibits the contract to be entered into, it is manifest that the situs of this element of the contract is the situs of the making (locus celebra- 
tionis). The act in this case condemned by the law is the making of the contract. . With this act no State has usually any concern save the State where the act is done, that is, the State where the contract is made. Comity and justice unite in demanding that the lex loci celebrationis shall determine the effect to be given to the act of entering into the contract, and neither the lex solutionis nor the lex fori should be permitted to supplant it.

Excellent illustrations of this principle may be found in the case of Sunday contracts. The laws of some States avoid contracts made on Sunday, while other States permit them. It is well settled that the lex loci celebrationis will determine the validity of the contract in this respect. ${ }^{1}$

Thus in McKee $v$. Jones, ${ }^{2}$ suit was brought in Mississippi upon a contract made in Louisiana upon Sunday. The defence was that contracts made on Sunday were void under the law of Mississippi. But the court sustained the contract, holding that its validity in this respect must be controlled by the law of Louisiana.

So in Brown $v$. Browning, ${ }^{3}$ a Connecticut statute prohibited secular business on Sunday between sunrise and sunset. A similar Rhode Island statute prohibited business in one's ordinary calling during the whole of Sunday. It was held by the Rhode Island court that a contract made in Connecticut after sunset, in the course of the plaintiff's ordinary calling, might be sued upon in Rhode Island, it not being contra bonos mores, nor invalid where made.

These conclusions are eminently reasonable. The laws of Mississippi and of Rhode Island were aimed against acts done in those States, not against acts done elsewhere. The laws of those States therefore were not violated by these contracts entered into in other States. As the court, in Brown $v$. Browning, expressed it: "The contract was valid in Connecticut, where it

1 McKee v. Jones, 67 Miss. 405, 7 So. 348 ; Brown v. Browning, 15 R. I. 422, 7 Atl. 403 ; Swann v. Swann, 21 Fed. 299 ; Murphy v. Collins, 121 Mass. 6 ; Arbuckle $v$. Reanme, 96 Mich. 243, 55 N. W. 808.

267 Miss. 405 , 7 So. 348 .

315 R. I. 422,7 Atl. 403. 
was made, because it was not in violation of the law of that State. The making of the contract did not violate the law of this State, because it was not done in this State." 4

On the other hand, in Arbuckle $v$. Reaume, ${ }^{5}$ suit was brought in Michigan on a note executed and delivered in Michigan on Sunday, but payable in Ohio. The court declared the note void, holding that the law of Michigan (lex celebrationis) should apply, and not the law of Ohio (lex solutionis). In the course of its opinion the court said: "The court below was in error in holding that the note could be enforced here by reason of its being made payable in Ohio. Parties cannot be allowed to defy our laws and recover upon a contract void from its inception under our statute by making the place of payment outside the State." 6

Another application of the same principles may be seen in connection with champertous contracts. Champerty cousists in prosecuting a suit upon shares, and is prohibited in some States, while permitted in others. It is the policy of the State where the champertous suit is to be brought that will usually determine the effect of such contracts. Hence the general rule is that the validity of an agreement entered into in one State to conduct a suit upon shares in another State is to be governed by the lex solutionis of the agreement, that is, by the law of the place where the champertous suit is to be brought." Yet, in Blackwell $v$. Webster, ${ }^{8}$ notwithstanding this general rule, it was properly held that the lex celebrationis, not the lex solutionis,

4 The fact that the lex loci solutionis of the contract would have avoided it, if it had been made there, shonld not affect in the slightest the operation of the lex loci celebrationis. Arbuckle $v$. Reaume, 96 Mich. 243, 55 N. W. 808. But see Murphy $v$. Collins, 121 Mass. 6.

596 Mich. 243,55 N. W. 808.

6 But, as we shall presently see, if the contract is to be performed on Sunday, the gronnd of its alleged invalidity is the performance on Sunday. The invalidity in such case, if any, will relate not to the making of the contract, but to its performance, and will be governed by the law of the situs of the performance (lex loci solutionis). W. U. Tel. Co. v. Way, $83 \mathrm{Ala}$. 542, $4 \mathrm{So}$ 844. See Stebbins $v$. Leowolf, 3 Cush. (Mass.) 137. Post, $\$ 175$.

7 Post, $\S 175$. See Hickox $v$. Elliott, 27 Fed. 830.

829 Fed. 614. 
should govern under the circumstances following: An agree. ment was entered into in Maine to prosecute a suit upon shares in New York. Such an agreement was legal in New York (locus solutionis), but a Maine statute provided that "any person agreeing to prosecute or defend a suit at law or in equity upon shares" should be criminally punished. It was held by a federal court sitting in New York, upon a suit brought to enforce the champertous agreement, that since the law of Maine ex. pressly forbade the making of such a contract, the law of Maine (lex celebrationis) should prevail over the law of New York (lex solutionis). The court said: "The validity of the agreement is to be determined by the law of Maine, and it is void; for the plaintiff, when he entered into the agreement, did an act made criminal by the law of Maine. The statute of Maine forbade the doing in Maine precisely what the plaintiff did. The agreement was void at its inception, because the making of it was made criminal by the Maine statute. . . But the plaintiff contends that this contract was lawful because the place of performance was in New York. But it seems to me plain that since the act of making the agreement could not be lawfully done in Maine, the circumstance that other acts were intended to be done in New York cannot render lawful the act that was done in Maine."

So, though the validity of contracts made in one State to purchase lottery tickets in another would ordinarily be governed by the law of the latter State, since the alleged invalidity relates to the performance of the contract (to be controlled by the lex solutionis), ${ }^{9}$ yet if the lex loci celebrationis expressly forbids contracts to be made there for the purchase of lottery tickets elsewhere, the lex celebrationis will govern. ${ }^{10}$

$\$ 169$. Same - Exemptions in Bills of Lading. - It is now well established that the validity of contracts, often found in bills of lading, exempting carriers from liability for damage resulting from the carrier's negligence or otherwise, is to be governed by the law of the place where the contract of carriage

2 Hatch $v$. Hanson, 46 Mo. App. 323.

10 Goodrich $v$. Houghton, 134 N. Y. 115, 31 N. E. 516. 
is entered into (lex celebrationis). In some States, such stipu. lations are valid, in others they are invalid. If the contract is valid where made, it will in general be sustained even in States where such exemptions are looked upon as contrary to public policy and void." And, on the other hand, if the contract is invalid where entered into, it will be invalid everywhere. ${ }^{2}$

It is immaterial whether this result is due to the fact that the question of the validity of the exemption relates to the making of the contract of carriage, and is for that reason to be controlled by the lex celebrationis of that contract; or whether it is due to the fact that the contract of exemption, though entered into at the same time as the contract of carriage, is itself a distinct collateral contract executed, performed as soon as made, the locus solutionis of which is necessarily identical with the locus celebrationis. It is believed that the latter is the true explanation. The fact remains that the lex celebrationis of the contract of carriage governs.

This rule applies not only to exemptions from liability for the negligence of the carrier, but also to exemptions from his common law liability as insurer also. Thus, the question whether a carrier may exempt himself by public notice from

1 O'Regan $v$. Cunard S. S. Co., 160 Mass. 356, 35 N. E. 1070 ; Fonseca $v$. Cunard S. S. Co., 153 Mass. 553, 27 N. E. 665 ; Forepaugh v. R. R. Co., 128 Penn. St. 217, 18 Atl. 503; Hazel v. R. R. Co., 82 Ia. 477, 48 N. W. 926 ; Talbott $v$. Transportation Co., 41 Ia. 247, 20 Am. Rep. 589; Meuer $v$. R. R. Co., 5 So. Dak. 568,59 N. W. 945 ; Western, etc. R. R. Co. v. Cotton Mills, 81 Ga. 522, 7 S. E. 916 ; Knowlton v. R. R. Co., 19 Ohio St. 260, 2 Am. Rep. 395 ; Boetjer $v$. La Compagnie, 59 Fed. 789. But see The Oranmore, 24 Fed. 922 ; The Guildhall, 58 Fed. 796 ; The Glenmavis, 69 Fed. 472 ; Burnett $v$. R. R. Co., 176 Penn. St. 45, 34 Atl. 972. In Knowlton v. R. R. Co., supra, the passenger injured was travelling upon a free pass issued in New York, containing stipulations exempting the carrier from liability for negligence. The court sustained the exemption as valid, though invalid in Ohio, because valid by the law of New York.

2 Liverpool Steam Co. v. Ins. Co., 129 U. S. 397 ; The Majestic, 9 C. C. A. 161, 60 Fed. 624 ; Botany Worsted Mills $v$. Knott, 76 Fed. 582; The Hugo, 57 Fed. 403 ; The Energia, 56 Fed. 124; Lewisohn $v$. National, etc. Co., 56 Fed. 602 ; The Iowa, 50 Fed. 561 ; The Brantford City, 29 Fed. 373 ; Brock. way v. Express Co., 168 Mass. 257, 47 N. E. 87; Davis v. R. R. Co., 93 Wis 470,67 N. W. 16. 
his liability as insurer is governed by the lex celebrationis of his contract of carriage. ${ }^{3}$ And his right to limit his common law liability by special contract is determined by the same law. 4

So also the lex celebrationis of the contract of a telegraph company governs the validity of exemptions contained therein from liability for mistakes made in the transmission of messages. ${ }^{5}$

The question has also been raised whether the same rule does not apply to the exemptions of an employer from liability to his employee for injuries inflicted by the negligence of fellowservants; it being said in such case that the employer's liability for such wrongs or his exemption therefrom is a part of the original contract of service. ${ }^{\circ}$ But it is believed that such liability should be treated, not as contractual, but tortious, and that the question of the extent of the liability is to be determined in accordance with the lex loci delicti. ${ }^{7}$

$\S 170$. Same - Insurance Contracts. - Instances of the application of the lex celebrationis frequently arise also in regard to the validity of provisions contained in insurance policies. ${ }^{1}$

Thus, it is a general rule that if, by the lex celebrationis, the making of an insurance contract by foreign insurance companies is prohibited in that State, unless they have complied with certain conditions imposed by that law, the policy, being void where made, is to be deemed void everywhere, even though it be made payable elsewhere, or though it be expressly stipulated

8 Hale v. Nav. Co., 15 Conn. 539, 39 Am. Dec. 398; The Majestic, 9 C. C. A. 161,60 Fed. 624.

4 Western, etc. R. R. Co. $v$. Cotton Mills, 81 Ga. 522, 7 S. E. 916 ; Tal. bott $v$. Transportation Co., 41 Ia. 247, 20 Am. Rep. 589.

5 Reed $v$. Tel. Co., 135 Mo. 661, 34 L. R. A. 492.

- Alezander v. Pennsylvania Co., 48 Ohio St. 623, 30 N. E. 69, 71.

7 See Alabama, etc. R. R. Co. v. Carroll, 97 Ala. 126, 11 So. 803, 807. See post, $\S 197$.

1 Indeed the law of the place where the contract of insurance is entered into is usually the law which governs most questions of its validity, since the performance of an insurance contract (that is, the payment of the money due thereon) will never be illegal. The lex solutionis of the contract of insurance may control the obligation and construction of the polic., but not its validity 
that it shall be regarded as a contract of another State. ${ }^{2}$ On the other hand, if the contract of insurance is valid where it is entered into, the fact that it insures persons or property in another State, by whose law the company could not have written the insurance there, is immaterial. The lex celebrationis controls. ${ }^{8}$

So the validity of particular provisions in an insurance policy exempting the insurer from liability in certain contingencies must in general be determined by the lex celebrationis of the contract. Like similar clauses of exemptions in bills of lading, they constitute independent collateral contracts executed, and are to be regarded as having their situs at the locus celebra. tionis of the principal contract, regardless of its locus solutionis. Where the law of a State invalidates such exemptions, its policy is to override the intention, and even the express agreement of the parties. Hence the purpose of the parties, though explicitly expressed, to submit themselves to a different law is of no avail, if in fact the contract is made in the first State. It is not a question of the purpose of the parties; the applicatory law admits that purpose and explicitly overrules it. ${ }^{4}$

Thus, a stipulation that the suicide of the insurer shall discharge the contract, even though the suicide be not contemplated at the time of the insurance, has been held to be void in one State, if invalidated by the law of another where the insurance contract was made. ${ }^{5}$ And so the validity of a stipulation that the non-payment of premiums shall avoid the policy is to be determined likewise by the lex celebrationis of the insurance contract. ${ }^{6}$

2 Reliance Ins. Co. $v$. Sawyer, 160 Mass. 413, 36 N. E. 59 ; Wood v. Ins. Co., 8 Wash. 427, 36 Pac. 267; Ford v. Ins. Co., 6 Bush (Ky.), 133, 99 Am. Dec. 663. For the rules by which to determine the locus celebrationis of an insurance contract, see ante, $\$ 166$.

3 Seamans v. Knapp Co., 89 Wis. 171, 27 L. R. A. 362 ; State Ins. Co. v. Brinkley Co., 61 Ark. 1, 29 L. R. A. 712 ; Hyde v. Goodnow, 3 N. Y. 266 ; Western v. Ins. Co., 12 N. Y. 258; Huntley v. Merrill, 32 Barb. (N. Y.) 626.

1 The law of the situs, not the law "in the minds of the parties," is the "proper law" governing matters of validity. See ante, § 154.

5 Knights Templar Indemnity Co. v. Berry, 1 C. C. A. 561, 50 Fed. 511 ; National Union v. Marlow, 21 C. C. A. 89, 74 Fed. 775.

6 Hicks v. Ins. Co., 9 C. C. A. 215, 60 Fed. 690; Equitable, etc. Soc. 
Another question likely to arise in this connection relates to the proper law governing the effect of unintentional or innocent misrepresentations in the policy touching material matters. If the law does not prohibit the parties from stipulating in their contract as to the effect of such misrepresentations, they may either make express stipulations in the policy as to the effect upon it of such misrepresentations, or they may refer to a law of their own choosing to determine the question. ${ }^{7}$

But if express stipulations would be of no avail against the prohibitions of the law of the situs, neither may the parties select a law, other than the law of the situs, to govern such questions; for this would be to permit the parties to do indirectly what the law refuses to allow them to do directly. If they desire a different law to govern the transaction, they must take refuge in a new jurisdiction and submit themselves to another sovereignty. ${ }^{8}$

Upon the same principles, the question whether the party paying the premiums has an insurable interest in the life of the insured, relating as it does to the party's capacity to make the contract, is an element in the making of the contract, to be governed by the lex celebrationis. ${ }^{9}$

$\S 171$. Capacity to Contract - Lex Loci Celebration1s. The capacity to enter into a contract, and the "proper law" applicable to it, has already been fully discussed in connection with the subject of status. ${ }^{1}$ We there saw that though the general rule is that the lex domicilii governs matters of status,

v. Nixon, 26 C. C. A. 620,81 Fed. 796 ; Equitable, etc. Soc. $v$. Trimble, 27 C. C. A. 404, 83 Fed. 85 ; Wall v. Equitable, etc. Society, 32 Fed. 273 . But see Phinney $v$. Ins. Co., 67 Fed. 493, where the court accepted as the guide "the law the parties had in view."

7 Wherever the maxim "modus et conventio legem vincunt" applies, the parties may select their own law. In such cases, "the law in the minds of the parties" is the proper law. Ante, $\$ 154$.

${ }^{8}$ See Perry v. Ins. Co., 67 N. H. 291, 33 Atl. 731 ; Penn Mut. L. Ins. Co. v. Trust Co., 19 C. C. A. 286, 72 Fed. 413 ; Fletcher v. Ins. Co., 13 Fed. 526.

9 Hurst v. Mut. L. Ass'n., 78 Md. 59, 20 L. R. A. 761, 26 Atl. 956 ; Voorheis $v$. Society, 91 Mich. 469, 51 N. W. 1109 ; Ruse v. Ins. Co., 23 N. Y. 516. This really comes more properly under the head of the capacity to con. tract.

${ }^{1}$ Ante, $\$ \$ 2$ et seq. 
including personal capacities of various kinds, yet this is not true where the capacity in question is the power to enter into a voluntary transaction, as in the case of contracts, except only when the contract is sought to be enforced in the domicil of the promisor, and the policy of that domicil is very pronounced in favor of the protection of the promisor resident therein.

Except in this case, the lex loci contractus governs the capacity of parties to contract, but if the contract is executory the "lex loci contractus" furnishes no guide ; it must be further analyzed, and a conclusion reached whether the "proper law" is the lex celebrationis or the lex solutionis.

It is apparent that this question relates to the making of the contract. The only law that can operate to create a contract is the law of the place where the contract is entered into (lex celebrationis). If the parties enter into an agreement in a par ticular State, the law of that State alone can determine whether a contract has been made. If by the law of that State no contract has been made, there is no contract. Hence, if by the lex celebrationis the parties are incapable of making a binding contract, there is no contract upon which the law of any other State can operate. It is void $a b$ initio.

This has been happily expressed in a decision of a federal court in the following language: "Upon principle no reason can be alleged why a contract, void for want of capacity of the party at the place where it is made, should be held good because it provides that it shall be performed elsewhere, and nothing can be found in any adjudicated case or text-book to support such a conclusion. It is a solecism to speak of that transaction as a contract, which cannot be a contract because of the inability of the parties to make it such." 2

$\S 172$. Formal Validity of Contracts - Lex Celebrationis Marriages - Stamps. - By the formal validity of a contract is meant the necessary compliance with the forms and ceremonies prescribed by law upon entering into certain contracts. It is evident that if the forms and ceremonies thus prescribed by the law of a State are essential to the validity of the contract, if entered into in that State, there can never have been any con-

2 Campbell v. Crampton, 2 Fed. 417, 423. 
tract if those forms are wanting. Such matters relate to the making of the contract, and are therefore to be governed by the law of the situs of the making (the lex celebrationis). On the other hand, if the contract is entered into with all the forms required by the lex celebrationis, it is equally obvious that the omission of some of the forms demanded by the law of the place of performance of the contract is immaterial. The law of the latter place manifestly only applies to contracts made there ; to hold otherwise would be to suppose its legislature intent upon usurping the authority of other States over acts done within their limits. It is therefore well settled that the formal validity of a contract is to be governed by the lex loci celebrationis. ${ }^{1}$ The intention or design of the parties to contract under a different law, or the fact that the parties " had in mind" a different law, is immaterial. As said by Judge Story: "The law of the place of the contract acts upon it, independently of any rolition of the parties, in virtue of the general sovereignty possessed by every nation to regulate all persons and property and transactions within its own territory." 2

Ordinarily, the law does not require that contracts should be entered into with any special solemnities. But there are some contracts which, for one reason or another, are in many States required to be executed with certain formalities, and to these the principle above mentioned is applicable.

Such, for example, is the contract of marriage. It is now firmly settled, as we have already seen, that the forms and

1 Dicey, Confl. L. 549 ; Story, Confl. L. $\$ \S 260,301 a$; Whart. Confl. L. \$ 401, 418 ; Pritchard $v$. Norton, 106 U. S. 124, 130, 134 ; Scudder v. Bank, 91 U. S. 406, 411, 412-413 ; Park v. Mfg. Co., 1 C. C. A. 395, 49 Fed. 618, 627; Bowles v. Field, 78 Fed. 742, 743; Phinney v. Ins. Co., 67 Fed. 493, 495 ; Garrettson $v$. Bank, 47 Fed. 867 ; Matthews v. Murchison, 17 Fed. 760 , 768; Campbell v. Crampton, 2 Fed. 417, 420 ; Pope v. Nickerson, 3 Story, 465, 484; Burnett v. R. R. Co., 176 Penn. St. 45, 34 Atl. 972 ; ThomsonHouston Electric Co. v. Palmer, 52 Minn. 174, 53 N. W. 1137, 1138 ; Kinney ». Com., 30 Gratt. (Va.) 858 ; Taylor v. Sharp, 108 N. C. 377, 13 S. E. 138, 139 ; Satterthwaite v. Doughty, Busbee's L. (N. C.) 314, 59 Am. Dec. 554; Wilder's Succession, 22 La. Ann. 219, 2 Am. Rep. 721, 724 ; Vidal v. Thomp son, 11 Mart. (La.) 23 ; Carnegie v. Morrison, 2 Met. (Mass.) 381, 401.

8 Story, Confl. L. \& 261. 
ceremonies essential to the validity of the marriage ceremony are to be regulated by the lex celebrationis, the law of the place where the marriage is solemnized, not that of the domicil, or intended domicil, of the parties. ${ }^{3}$

Another instance, wherein the validity of a contract may depend upon a matter of form, arises under stamp laws. Sometimes, for the purpase of raising revenue, laws are passed requiring contracts of various kinds to be stamped. Such laws differ in their provisions, some avoiding the contract altogether if written upon unstamped paper; others merely declaring that the writing, under such circumstances, is not to be received in evidence.

If the lex celebrationis renders absolutely void a contract written on unstamped paper, the stamping becomes one of the necessary formalities of the contract, the omission of which will avoid the contract everywhere, even though by the lex solutionis or lex fori the contract is valid. The alleged invalidity relates to the making of the contract. If void for the lack of a stamp by the lex celebrationis, it is roid in its incipiency, and cannot be made good by the subsequent application of the lex solutionis or any other law. And so, if valid where made, the requirement of any other law that there should be a stamp will not affect its validity: the contract is valid everywhere. ${ }^{4}$

But if the lex celebrationis merely prohibits a contract on unstamped paper to be received in evidence, or provides that no action shall be brought thereon, the law does not go to the validity of the contract at all, but only to the remedy, and the law of the situs of the remedy (lex fori) will govern. ${ }^{5}$

3 Ante, $\$ 77$.

4 Story, Confl. L. $\$ \S 260,318$; Fant v. Miller, 17 Gratt. (Va.) 47 ; Carnegie $v$. Morrison, 2 Met. (Mass.) 381, 401; Satterthwaite $v$. Doughty, Busbee's L. (N. C.) 314, 59 Am. Dec. 554 ; Vidal v. Thompson, 11 Mart. (La.) 2325 ; Campbell $v$. Crampton, 2 Fed. 417, 420. But in New York it has been held that unstamped contracts made abroad, though void by the lex celebrationis, will not be deemed void in New York, upon the ground that foreign revenue laws will not be enforced. See Ludlow $v$. Van Rensselaer, 1 Johns. 94 ; Skinner $v$. Tinker, 34 Barb. 333.

Story, Confl. L. § 260 ; Fant v. Miller, 17 Gratt. (Va.) 47. See post, $\S 173$. But if the above mentioned provisions should be found in the lex fori, 
§173. Same - Contracts in Writing - Statute of Frauds. - There are many contracts which, by the statutes of Frauds of the various States, or by similar statutes, are required to be in writing. The terms of these statutes are not the same in all the States, nor do they always apply to the same classes of contracts. In the main, the English statute of Frauds forms the basis of all of them, but there is considerable divergence in details. Certain classes of contracts embraced by the English statute of Frauds are omitted in some of these statutes, while other classes of contracts have been sometimes added. Some of these provisions declare that the contracts mentioned therein shall be void unless reduced to writing, while others affirm that no action shall be brought on such contracts unless they are in writing. Owing to the frequency with which these statutes are applied and the diversity of their provisions, conflicts often arise.

The principles governing these cases are the same as those already considered. If it is alleged that the contract is void, because not in writing, it is a question of the formal validity of the contract, to be determined by the lex loci celebrationis. ${ }^{1}$

Thus, in Hunt $v$. Jones, ${ }^{2}$ an oral contract for the sale of goods was made in Rhode Island, but the contract was to be performed in New York by the delivery of the goods there. The New York statute of Frauds provided that "every contract for the sale of any goods . . for the price of $\$ 50$ or more shall be void, unless a note or memorandum of such contract be in

not in the "proper law," it is probable that the question becomes one of the obligation of the contract to be governed in general by the "proper law" of the contract, instead of a matter of remedy to be controlled by the lex fori. See post, $\S 210$.

1 Story, Confl. L. § 262 ; Wolf v. Burke, 18 Colo. 264, 32 Pac. 427 ; Hunt v. Jones, 12 R. 1. 265, 34 Am. Rep. 635 ; Perry v. Mount Hope Iron Co., 15 R. I. 380, 5 Atl. 632 ; Miller v. Wilson, 146 Ill. 523, 34 N. E. 1111 ; Wilson v. Mills Co., 150 N. Y. 314, 44 N. E. 959 ; Scudder v. Bank, 91 U. S. 406 ; Hubbard $v$. Bank, 18 C. C. A. 525, 72 Fed. 234 ; Phinney v. Ins. Co., 67 Fed. 493, 497 ; Houghtaling $v$. Rall, 19 Mo. 84, 59 Am. Dec. 331 ; Hausman $v$. Nye, 62 Ind. 485, 30 Am. Rep. 199 ; Keiwert $v$. Meyer, 62 Ind. 587, 30 Am Rep. 206, 209 ; Sullivan v. Sullivan, 70 Mich. 583, 38 N. W. 472.

z 12 R. I. 265,34 Am. Rep. 635. 
writing," etc. The oral contract was valid in Rhode Island. Upon suit brought in Rhode Island, the defendant requested the court to charge that as the contract was to be performed in New York, its validity and construction were to be judged by the law of the place of performance, and that, the contract being void in New York, the plaintiff could not recover. But it was held that the law of Rhode Island (lex celebrationis) should determine the validity of the contract.

In Scudder $v$. Bank, ${ }^{3}$ a member of a Missouri firm had verbally accepted in Illinois, on behalf of the firm, a draft drawn upon the firm. A statute of Missouri provided that "no person in this State shall be charged as an acceptor of a bill of exchange, unless his acceptance shall be in writing, signed by himself or his lawful agent." The verbal acceptance made in Illinois, though to be performed in Missouri, was sustained.

On the other hand, if the question is not one of the validity of the contract, but only whether or not, under the statute of Frauds, an action may be brought upon a contract not in writing, the requirement that it should be in writing becomes (it is said) merely a matter pertaining to the remedy, to be in all cases governed by the law of the situs of the remedy (lex fori). ${ }^{4}$

Thus, in Leroux $v$. Brown, ${ }^{5}$ a verbal contract not to be performed within a year was made in France, upon which an action was brought in England. By the law of France the contract was enforceable, but the English statute of Frauds provided that no action should be brought upon a contract not to be performed within one year, unless the contract were in writing, etc. The court was unanimously of the opinion that the statute applied to the remedy, and was intended to prohibit an action to be brought in England upon such a verbal contract, no matter where made. The action was accordingly dismissed.

891 U. S. 406.

4 Leroux $v$. Brown, 14 Eng. L. \& Eq. 247, 74 E. C. L. 800 ; Wolf $v$. Burke, 18 Colo. 264, 32 Pac. 427 ; Downer v. Chesebrough, 36 Conn. 39, 4 Am. Rep. 29 ; Hall v. Cordell, 142 U. S. 116. But see Baxter Bank v. Talbot, 154 Mass. 213,28 N. E. 163 ; post, $\S 210$, where this statement is qualified.

5 14 Eng. L. \& Eq. 247 ; s. C. 74 E. C. L. 800 . See Pritchard v. Norton, 106 U. S. 124, 134. It may well be doubted if this decision is correct npon principle. See post, $\$ 210$. 
In Downer $v$. Chesebrough, ${ }^{6}$ the case of Leroux $v$. Brown was quoted with approval, and the court proceeded to say: "If this decision is law, then the converse of the legal proposition must be true. If the statute of Frauds had existed in France at the time the contract was made, but not in England where the suit was brought, the action would have been sustained, though it could not have been by the law of France."

In Leroux $v$. Brown, supra, the court distinguished the fourth section of the statute of Frauds (under which the case arose) from the seventeenth section relating to the sale of goods. By the terms of the latter section it was provided that "no contract for the sale of goods shall be allowed to be good," unless in writing, etc. The court, in the course of its opinion, said that if the French verbal contract had arisen under the seventeenth section of the statute, the action in England would have been sustained for the reason that it related to the validity of the contract (which in such case would be determined by French, not English, law), but did not prohibit the English courts from entertaining jurisdiction of such contracts if not made in England and governed by English law.

Tracing these principles to their legitimate conclusion, it would follow that if the lex celebrationis of a verbal contract should provide that "no action should be brought" upon the contract unless it were in writing, while the lex fori provides that the same contract shall be "void" unless it be in writing, the contract would be enforceable in the forum notwithstanding both these laws; for the formal validity of the contract would be governed by the lex celebrationis of the contract, under which the oral contract is not invalid, while the remedy would be governed by the lex fori. In the case supposed, the statute of the forum relates to contracts made there, while the statute of the locus celebrationis relates to actions brought there. Neither statute therefore would apply to the above case. ${ }^{7}$

$\S 174$. Same - Contracts for the Sale of Land. - It has been doubted by eminent authorities whether the same principles will apply in the case of contracts for the sale or lease of

- 36 Conn. 39, 4 Am. Rep. 29.

I See Wolf $v$. Burke, 18 Colo. 264, 32 Pac. 427. 
real estate, it being said that the lex situs of the land must control the formal validity of the contract, and not the lex celebrationis. Hence where the lex situs of the land declares such contracts void unless in writing, it is said that the lex situs must govern, though the lex celebrationis or the lex fori does not invalidate an oral contract of this sort; and vice versa. ${ }^{1}$

So far as the title to the land in question is conveyed by the contract, this is doubtless true, for the rule is general that every link in the chain of title to real estate must be in accordance with the lex situs. ${ }^{2}$

But though a verbal contract to convey land be void according to the lex situs of the land, and is therefore incompetent to pass the equitable title to the property, it does not follow that as a mere personal contract it should also be treated as void, if valid by the lex celebrationis. ${ }^{3}$ Hence although, if it be attempted to treat the contract as having passed a title to the land, its formal validity must be determined by the lex situs of the land, yet if a suit for specific performance of the contract be brought in the locus celebrationis or in a third State, or (probably) in the situs of the property, ${ }^{4}$ the court having jurisdiction over the promisor's person, there would seem to be no reason why it could not, in pursuance of the executory contract validly entered into under the lex celebrationis, decree a deed to be executed which should conform to all the requirements of the lex situs. And if the promisee, waiving his rights to the land itself, should treat the contract as purely personal, suing at law for damages for its

1 Story, Confl. L. $§ \S 363,364$. See Dicey, Confl. L. 551; Cochran v. Ward, 5 Ind. App. 89, 29 N. E. 795 ; Polson v. Stewart, 167 Mass. 211, 219, 45 N. E. 737 (dissenting opinion).

2 Ante, $\$ \$ 11,12$.

See Whart. Confl. L. $\$ 276 a$.

4 No reason is perceived why the courts of the situs should not in such case respect the lex celebrationis of the contract. The object of the suit is to obtain a deed, the validity of which must ultimately depend upon the lex situs of the land. The policy of the situs is thus made sure of enforcement. So long as the promisee does not claim title to or exercise ownership over the land by virtue of the executory contract of sale, it is a mere personal contract like any other, to be governed, it would seem, by the same law. See Polson v Stewart, 167 Mass. 211, 45 N. E. 737. 
breach, still less reason can be assigned for causing its formal validity to depend upon the lex situs of the land, rather than the lex celebrationis. In such case, the lex celebrationis should govern, whether the action be instituted in the courts of the situs, of the locus celebrationis, or of a third State. ${ }^{5}$

In Polson $v$. Stewart, ${ }^{6}$ a covenant was made by a husband to his wife, in North Carolina, where they were domiciled, to surrender all his rights in land owned by her in Massachusetts The question in this case was not of the formal validity of the covenant, but of the capacity of the parties to enter into such an agreement. But the capacity to contract is in general governed by the same law that governs the formal validity of the contract (lex celebrationis). The covenant in this case was valid by the law of North Carolina (lex celebrationis), but would have been invalid if entered into in Massachusetts (the situs of the land). A bill was filed in Massachusetts against the husband for the specific enforcement of the covenant, and it was held that it could be enforced. The court said: "But it is said that the lex domicilii (sic) of the parties could not authorize a contract between them as to lands in Massachusetts. Obviously this is not true. It is true that the laws of other States cannot render valid conveyances of property within our borders, which our laws say are void, for the plain reason that we have exclusive power over the res. But the same reason inverted establishes that the lex rei sitæ cannot control personal covenants, not purporting to be conveyances, between persons outside the jurisdiction, although

5 See Story, Confl. L. $\$ 372 d$; Whart. Confl. L. $\$ 276 a$; Carnegie v. Morrison, 2 Met. (Mass.) 381, 397-398; Polson v. Stewart, 167 Mass. 211, 45 N. E. 737 ; Wolf $v$. Barke, 18 Colo. 264, 32 Pac. 427 ; Miller $v$. Wilson, 146 Ill. $523,34 \mathrm{~N}$. E. 1111. In both the last two cases the contract was made in the situs of the land, and hence they are indecisive. But the reasoning, especially in the last case, seems to point to the lex celebrationis rather than the lex situs as controlling the question. It should be noted however that even though the lex celebrationis should declare a contract for the sale or lease of land to be void unless in writing, it may perhaps be doubted whether such a statute was intended to embrace land in other States, over which the legislature had no jurisdiction. See Gibson v. Ins. Co., 77 Fed. 561, 564.

6167 Mass. 211, 4.5 N. E. 737.

7 Ante, $\S \S 171,172$. 
concerning a thing within it. Whatever the covenant, the laws of North Carolina could subject the defendants' property to seizure on execution and his person to imprisonment for failure to perform it. Therefore on principle the law of North Carolina determines the validity of the contract."

The same diversity of opinion seems to exist when the statute relating to the sale of lands provides that "no action shall be brought" on such contracts, unless in writing. Where a statute uses this phrase, common sense would seem to dictate that the legislature could not intend thereby to interdict actions brought in other States, for it has no control whatever over the judicial proceedings of other States. It could only have been intended to apply to actions brought on the contract in the State enacting the statute. It is manifest that the legislature must intend to prescribe a rule of procedure for its own courts only. Upon principle therefore it would seem clear that although there is a statute of this sort in the situs of the land or in the locus celebrationis of the contract, yet if there is no such statute in the forum, an action may be maintained there upon the contract, and this is true even though the lex fori declares such a contract not in writing to be void; for the latter law would be applicable only to contracts made in the forum. ${ }^{8}$

Thus, in Wolf $v$. Burke, ${ }^{\circ}$ suit was brought in Colorado upon a verbal contract made in Idaho for the sale of certain mining lands in the latter State. The Colorado statute of Frauds provided that every contract for the sale of land shall be void, unless the contract or some note or memorandum thereof be in writing, etc. The court, assuming the contract to be valid in Idaho, held that an action might be maintained thereon in Colorado.

$\S 175$. Performance of Contract Prohibited - Lex Loci Solutionis. - A contract may be invalid because the act to be done in performance thereof is prohibited by law. A makes a

8 See Wolf $v$. Burke, 18 Colo. 264, 32 Pac. 427. But see Cochran v. Ward, 5 Ind. App. 89, 29 N. E. 795 ; Miller v. Wilson, 146 Ill. 523, 34 N. E. 1111. Where such a statute exists in the formm but not in the place of con. tract, see post, $\S 210$.

- 18 Colo. 264, 32 Pac. 427. 
contract with B in New York by which $\mathrm{A}$ promises to do an act in Virginia. The act is prohibited by New York law, but not by that of Virginia. A moment's analysis will show that the Virginia law should govern, and that the contract should be sustained. The legislature of New York, in prohibiting the particular act to be done, must of course be presumed to contemplate only the doing of the act in New York: it can have no concern with acts done in Virginia. On the other hand, if we suppose the act agreed to be done is permitted by the law of New York, but is prohibited by the law of Virginia, the same conclusion must be reached. No matter in what State the validity of the contract is questioned, a decent comity will require the courts of every State to refuse to enforce a contract, the purpose and effect of which is the performance of an act in another State which is prohibited by its laws.

Hence, as the situs of the making of a contract (locus celebrationis) furnishes the "proper law" to govern all matters of validity connected with the making of the contract, so the situs of performance (locus solutionis) furnishes the law to determine the validity of the contract in respect to matters connected with its performance. ${ }^{1}$

Thus, just as the validity of a contract made on Sunday is to be determined by the law of the place where it is made (lex celebrationis ${ }^{2}$ ), so the validity of a contract made on a week day, but to be performed on Sunday, is to be governed by the law of the place where the contract is to be performed (lex solutionis). For example, in W. U. Tel. Co. $v$. Way, ${ }^{3}$ a message containing an acceptance of an offer to purchase cotton was delivered to the telegraph company in Alabama on Saturday for

1 Dickinson v. Edwards, 77 N. Y. 573, 581, 582, 33 Am. Rep. 671 ; W. U. Tel. Co. v. Way, 83 Ala. 542, 4 So. 844 ; Chambers v. Church, 14 R. I. 398, 51 Am. Rep. 410 ; Merchants' Bank v. Spalding, 9 N. Y. 53, 62; Greenwood v. Curtis, 6 Mass. 358, 4 Am. Dec. 145, 148 ; Carnegie v. Morrison, 2 Met. (Mass.) 381, 397-398; Nickels v. Association, 93 Va.380, 25 S. E. 8 ; First National Bank v. Hall, 150 Penn. St. 466, 24 Atl. 665, 666 ; Hickox v. Elliott, 27 Fed. 830 ; Lehman v. Feld, 37 Fed. 852 ; Scndder v. Bank, 91 U. S. 406, 411. But see Pope v. Nickerson, 3 Story, 465, 484; Smith v. Parsons, 55 Minn. 520, 57 N. W. 311.

2 Ante, $\$ 168$.

83 Ala. 542, 4 So. 844. 
transmission to Germany, the company agreeing to deliver it to the addressee in Germany on Sunday. By the law of Alabama Sunday contracts were void. The validity of this contract being questioned in Alabama, it was held that the effect of the act of performance (the delivery of the telegram in Germany on Sunday) must be determined by German law.

In Chambers $v$. Church, ${ }^{4}$ a contract was made to catch fish in Virginia waters for the manufacture of manure and oil. This act was prohibited by the Virginia statute. The Rhode Island court refused to enforce the contract on the ground that it was invalid by the lex solutionis.

So, the validity of a contract made in one State to prosecute a suit in another upon shares (a champertous suit) will be governed in general by the law of the place of performance; that is, the law of the place where the suit is to be prosecuted. If by the lex loci solutionis it is not illegal to prosecute a suit upon shares there, the contract will usually be valid, though the lex celebrationis prohibits it; if it be illegal under the lex solutionis, the contract will be invalid everywhere. ${ }^{5}$

Upon the same principle it would seem that the validity of a contract entered into in one State not to engage in trade in another specified State should be governed by the law of the latter State (lex solutionis), for it is to be wholly performed there. If the contract made in one State is not to engage in trade in several specified States, it would seem that the promise, as to its performance, should be regarded as severable, the validity of the contract being determined by the law of each of the latter States, according as an attempt is made in one or the other of those States to enter into trade there, in violation of the contract. ${ }^{\circ}$

14 R. I. 398, 51 Am. Rep. 410.

5 See Hickox $v$. Elliott, 27 Fed. 830 ; Richardson $v$. Rowland, 40 Conn. 566. But if the lex celebrationis prohibits the very making of such a contract, that law will govern. See Blackwell v. Webster, 29 Fed. 614 ; ante, $\$ 168$.

6 But if the contract restraining trade in several specified States (though severable if sued upon) constitutes the consideration for the contract in suit, it becomes insererable, and if void by the law of either of its places of per formance, it is roid in its entirety, and cannot support the contract in suit. 
If the contract in restraint of trade is general with respect to locality, covering a territory embracing many different States, but specifically mentioning none, it is quite certain that this should be regarded as a contract to be performed generally, like a promise to pay money naming no place of payment, and the lex celebrationis should govern. Thus, in South African Breweries $v$. King, ${ }^{7}$ an injunction was sought against the violation in Natal, South Africa, of a contract made in the Transvaal not to engage in the brewing business in any part of South Africa for five years. The injunction was refused on the ground that the stipulation was void by the law of the Transvaal.

$\S 176$. Validity of Consideration - Lex Loci Considerationis - Executory 'Consideration - The invalidity of a contract may spring, not only from its unlawful making, or from the illegality of the act to be performed in pursuance thereof, but from the illegality or insufficiency of the consideration which supports it. The legality or sufficiency of the consideration depends upon the law of the situs of the consideration. ${ }^{1}$ Furthermore the consideration may be either executed or executory. ${ }^{2}$ If executory, it may be a promise to be performed where made, or made in one place and to be performed in another, whose validity will be determined by the lex celebrationis or the lex solutionis of the consideration, in accordance with the principles discussed in the preceding sections of this chapter. The locus celebrationis of the consideration (the promisee's contract) will usually coincide with the locus celebrationis of the promisor's contract, but the locus solutionis of the promisee's contract (the consideration) may be entirely distinct from the locus solutionis of the promisor's contract. In such cases the validity of the executory consideration (the promisee's contract) will depend upon its lex celebrationis or its lex solutionis, according as the invalidity alleged relates to the making of the promisee's contract or to its performance.

In Ford $v$. Ins. Co., ${ }^{8}$ suit was brought in Kentucky upon certain notes given by the defendants as premiums for insurance on certain boats. The notes were made in Indiana in consideration

ร 2 Ch. D. 173.

2 Ante, § 162.
1 Ante, § 161.

86 Bush (Ky.), 1 33, 99 Am. Dec. 663. 
of a contract of insurance there entered into. The policy of in. surance was one prohibited by Indiana law to be there made. It was held that the validity of the notes depended upon the validity of the contract of insurance; and as that contract was entered into in Indiana, where its making was prohibited, it was invalid, and the notes were therefore also invalid.

So, in Blackwell $v$. Webster, ${ }^{4}$ suit was brought in New York upon a contract, the consideration for which was a promise made in Maine to prosecute a suit for a legacy in New York upon shares. The making of a champertous contract was probibited by the Maine law, and though such contracts were not unlawful in New York (the locus solutionis of the consideration) it was held that the contract sued upon was void because of the illegality of the consideration therefor under the Maine law.

On the other hand, the lex solutionis of the executory consideration will determine the validity of the promisor's contract, whenever the performance of the promisee's contract (consideration) is alleged to be illegal, without regard to the lex celebrationis or lex solutionis of the promisor's contract.

Thus in Blackwell $v$. Webster, supra, if the Maine statute had not interdicted the making of champertous contracts, the validity of the champertous consideration would have depended upon the New York law (lex solutionis of the consideration), and the promisor's contract would have been valid or invalid, according as the New York law permitted or condemned the champertous contract of the promisee. ${ }^{5}$

So, in Peet $v$. Hatcher, ${ }^{6}$ a note was made in Georgia, payable in Georgia to certain cotton brokers of New Orleans to cover margins upon speculations in cotton. The note was secured by a mortgage of land in Alabama, and suit was brought there to foreclose the mortgage. It was held that the law of Georgia (lex celebrationis et solutionis) should not prevail, but since the objectionable dealings with the cotton were to take place in Louisiana, the law of Louisiana must govern the validity of the

429 Fed. 614 . See ante, $\$ 168$.

5 Hickox $v$. Elliott, 27 Fed. 830. See Richardson v. Rowland, 40 Conn. 566.

- 112 Ala. 514, 21 So. 711, 712. 
note and mortgage, the consideration for which was the speculative dealings in Louisiana. The court said: "The defense mainly relied on is that the dealings between Hatcher and Peet $\&$ Co. (the brokers) were gambling transactions, such as the courts will not enforce. It is pleaded and insisted that those transactions were governed by the laws of Georgia, where the arrangement under which they were had was entered into . . by force of which laws the contracts made in the purchase of cotton were mere wagers and void. It is settled by the decision of this court in a case precisely like the present, except that the dealings were on the New York, instead of the New Orleans, stock exchange, ${ }^{7}$ that the contract under which the cotton dealings were to be had, as to its validity, was governed by the laws of the State wherein it was to be performed (in that case, New York)." 8

In Commonwealth of Kentucky $v$. Bassford, ${ }^{9}$ a Kentucky statute authorized a lottery for a certain college. The law of New York forbade lotteries. A bond was entered into in New York conditioned for the faithful performance of duties in Kentucky touching the sale of lottery tickets authorized by the above Kentucky statute. It was held that as the bond was valid at the place when the consideration was to be performed, the courts of New York would uphold it. ${ }^{10}$

7 Hawley $v$. Bibb, 69 Ala. 52.

8 The conrse of this decision is very curious. The court held, as above stated, that the law of Louisiana should govern the validity of the note. But the law of Louisiana was not in evidence. Under these circumstances the court assumed that the law of Georgia (where the note was made and payable) slould govern. But neither was the Georgia law in evidence. The jurisprudence of Georgia being based upon the common law (it was otherwise in the case of Louisiana) the court assumed the comnon law to prevail there, by which the particular transaction was sustained. See post, $\S 214$. It is submitted that the court erred in principle in substituting the Georgia law for that of Louisiana, merely because the latter was not in evidence. Georgia was not the situs of the consideration, nor could it be made so merely by a failure to prove the law of Louisiana (lex loci considerationis).

96 Hill (N. Y.), 526.

10 In this case there was some doubt whether the bond was executed in New York or in Kentucky, but the court held it to be immaterial. 
\$177. Executed Considerations - Sufficiency of Consideration. - In the majority of cases perhaps the consideration is not executory, but executed, consisting either of a pre-existing liability, an act done, or an executed contract entered into. In such cases, the situs of the consideration is not difficult to ascertain, and when once ascertained the same rules prevail as before; the law of the situs of the consideration will determine the validity of the promisor's agreement, so far as its validity depends upon the validity of the consideration.

If the consideration is malum in se, or universally deemed contra bonos mores, the lex fori will generally be substituted in the place of the lex loci considerationis. ${ }^{1}$ This principle occasionally creates a doubt as to what law should govern the validity of a contract for the reason that it is sometimes a matter of doubt whether a consideration valid by its proper law, though condemned in the forum, is so generally deemed immoral as to give rise to the operation of the lex fori. Thus gaming, wagers, lotteries, the sale or hire of slaves, contracts relating to the slave-trade, etc., constitute considerations which, though condemned by many States, are not forrbidden by all. We find the cases somewhat divided here upon the law which should govern. The weight of authority is in favor of the lex loci considerationis as the proper law, unless the consideration is one which the policies of all (or almost all) civilized States unite in prohibiting. ${ }^{2}$ Bearing in mind the occasional operation of the lex fori in these cases, we will proceed to examine the "proper law" governing the validity of a contract in respect of the consideration.

In the first place it seems clear that if there is no consideration at all to support the contract, the effect of this upon the validity of the contract must depend upon the law of the place where the promisor's contract is entered into, not upon the lex

I Ante, $\S 9$.

2 Story, Confl. L. $\S \S 114,258$; Commonwealth of Kentucky $v$. Bassford, 6 Hill (N. Y.), 526 ; Thatcher $v$. Morris, 11 N. Y. 437 ; Greenwood v. Cur. tis, 6 Mass. 358, 4 Am. Dec. 145 ; Roundtree v. Baker, 52 Ill. 241, 4 Am. Rep, 597. But see Flagg $v$. Baldwin, 38 N. J. Eq. 219, 48 Am. Rep. 308 ; Gist $v$. Tel. Co., 45 S. C. 344,23 S. E. 143 ; Oscanyon v. Arms Co., 103 U. B. 261. 
solutionis; for if the contract is invalid in the locus celebrationis, it will be void $a b$ initio, just as in the case where a contract is formally invalid by the lex celebrationis ${ }^{\mathbf{8}}$ there will never have been any contract to perform, and therefore nothing for the lex solutionis to operate upon. On the other hand, since the matter of the want of consideration enters into the making of the contract, so to speak, in other words, since its effect operates upon the contract at the time it is made, if the contract is then and there valid the want of consideration should not be open to question thereafter or under any other law. Thus, if a bond is given in one State without any consideration, no consideration being there required to support a contract under seal, and the bond is payable in another State where a contract, even though under seal, must be supported by a consideration, the proper law to determine the validity of the contract is the lex celebrationis of the contract, not the lex solutionis. ${ }^{4}$

If the question is not one of a total want of consideration in the incipiency of the contract, but of a subsequent failure of the consideration, the lex celebrationis having performed its function in determining the original validity of the contract, it would seem that the subsequent failure of consideration must be regarded as affecting not the making of the contract but the obligation to perform it, and the lex solutionis of the contract

3 Ante, $\$ 172$.

4 In Pritchard v. Norton, 106 U. S. 124, 135, 136, a somewhat similar question was decided in accordance with the law of the assumed place of per. formance of the contract. But in that case there had been a benefit conferred upou the promisor. There was a past consideration, and the question was whether it was sufficient. This case will be presently explained.

The example given above in the text is based upon the theory that the effect of a seal in importing a consideration is part of the contract itself, which is the view taken in Pritchard $v$. Norton, supra. Upon the theory that the presence of the seal only affords a conclusive presumption that there is a consideration, it may be that as a mere matter of evidence, relating to the remedy, the lex fori would control. If by that law no such presumption obtains, there must be other proof. See Williams $v$. Haines, 27 Iowa, 251. But even if this view is sound (as it is believed not to be), no progress is here made. The question still remains, if there is no proof of consideration, what law shall govern the effect of a want of consideration. The first theory seems altogethet preferable. 
should determine its effect upon the right to enforce perform. ance. ${ }^{5}$ But the question - what constitutes a subsequent failure of consideration - would seem to depend upon the lex loci considerationis, and not upon the lex solutionis of the contract. ${ }^{6}$

So, the question of the sufficiency of certain acts or pre-existing liabilities to constitute a consideration should be determined, upon like principles, either by the lex celebrationis of the promisor's contract (since the validity of the contract in its very incipiency depends upon it) or by the law of the place where the act is done or the liability is incurred (since that law determines the effect of the consideration). Ordinarily these laws will be identical. ${ }^{7}$

But if an act done in one State constitutes a past consideration for a contract made in another, we are forced to choose between them. The very question arose in Pritchard $v$. Norton, ${ }^{8}$ and it was held that the locus considerationis, not the locus celebrationis, should furnish the "proper law." In that case, Pritchard had signed an appeal bond in Louisiana, no

5 There seems to be no case directly in point, but it is a general principle that the obligation and the discharge of contracts by operation of law are in the main governed by the lex solutionis of the contract. See post, $\S 181$, 190. In Glenn $v$. Thistle, 23 Miss. 42, 49, a note was made and payable in Mississippi for the purchase of land in Louisiana. Suit was brought upon the note, and the defense was set up of a failure of consideration by reason of defects in the title to the land. The court said : "The law of Louisiana will of course control the title; it will decide whether the title has failed: but as the contract for payment was made here and was to be performed here, the law of this State must decide on the effect of a failure of consideration." If the lex celebrationis and the lex solutionis had not been identical in this case, the question would have been squarely presented. As it was, the court did not distinguish between them.

6 See Glenn $v$. Thistle, 23 Miss. 42, 49, quoted supra, note 5.

7 If the contract is made in a State other than that wherein the act is done (locus considerationis), one of two effects must follow. Either the act constitutes a past consideration for the contract, or the immediate consideration for the contract is not the act itself, but some liability incurred by the promisor because of the performance of the act. In the latter case the act still indirectly constitutes the consideration for the contract, whose validity in this respect must ultimately depend upon the law of the place where the act is performed. Ante, $\S 162$.

106 U. S. 124. 
promise being made at the time to save him harmless. Later, Norton and another signed a bond of indemnity in New York, payable to Pritchard, no place of payment being designated. By the law of New York a past consideration was not sufficient to support a contract, and a seal only prima facie imported a valuable consideration. By the law of Louisiana the rule was otherwise. Suit was instituted by Pritchard in the federal court in Louisiana upon the New York bond of indemnity, the defense being that there was no sufficient consideration (under the law of New York) to support the contract. The Supreme Court held that the law of Louisiana (lex loci considerationis) should prevail. ${ }^{\circ}$

§178. Same - Legality of Consideration. - With respect to the legality of the consideration as affecting the validity of the contract, it is quite certain that this is to be determined by the lex loci considerationis. No court, having a just sense of the comity due to a sister State or country, can lend its aid in enforcing a contract, the consideration for which is a violation of the law of such sister State. It will no more encourage the violation of her laws than of its own. On the other hand, if the act or liability which is the consideration for the contract is done or incurred in another State, and is valid there, it is manifestly immaterial whether or not such act or liability, if done or incurred in the State of the contract or of the forum, would contravene its laws. As a matter of fact it has not been done or incurred there, and the laws of the latter cannot be supposed to have been intended to extend beyond its own territory and condemn acts done in another State, unless indeed they are mala in se or contra bonos mores. This reasoning inexorably leads to the conclusion that the lex loci considerationis determines the validity of the contract, so far as the legality of the considera-

9 It is true the court decided in favor of the law of Louisiana upon the ground that it was the lex solutionis of the New York bond (though it was made in New York and specified no place of payment). The reasoning of the court in establishing Louisiana to have been the place of performance of the bond is not altogether satisfactory ; and even supposing that to be so, it is difficult to see why the law of the place of performance should govern a question which relates to the validity of the contract in its very incipiency. 
tion is concerned, and this conclusion is abundantly sustained by the authorities. ${ }^{1}$

Hence the validity of a note made in one State, though pay. able there also, given in consideration of liquor sold and delivered to the maker of the note in another State, will be determined by the law of the latter State, not of the former, so far as the sale of the liquor affects it. The lex celebrationis and the lex solutionis have nothing to do with the matter. The law of the place where the liquor is sold will govern the validity of the sale, and the consequent validity of the contract for the price. If by the lex loci considerationis the sale of the liquor is prohibited, the note is invalid. ${ }^{2}$ If by that law the sale is valid, so will the note be, though the sale would have been invalid if made in the locus celebrationis or locus solutionis of the note. ${ }^{3}$

Thus also the validity of a contract, the consideration for which is a gaming debt or the sale of lottery tickets, or the prosecution of a lottery, etc., will depend not upon the lex celebrationis or lex solutionis of the contract, but upon the lex loci considerationis. ${ }^{4}$

1 Webber $v$. Howe, 36 Mich. 150, 24 Am. Rep. 590 ; Boothby v. Plaisted, 51 N. H. 436, 12 Am. Rep. 140 ; Fessenden v. Taft, 65 N. H. 39, 17 Atl. 713; Keiwert $v$. Meyer, 62 Ind. 587, 30 Am. Rep. 206; Pratt v. Adams, 7 Pai. Ch. (N. Y.) 615, 632 ; Commonwealth of Kentucky v. Bassford, 6 Hill (N. Y.), 526 ; McIntyre v. Parks, 3 Met. (Mass.) 207!; Akers v. Demond, 103 Mass. 318, 323-324; Suit $v$. Woodhall, 113 Mass. 391 ; Touro $v$. Cassin, 1 Nott \& McC. (S. C.) 173, 9 Am. Dec. 680 ; Roundtree $v$. Baker, 52 Ill. 241, 4 Am. Rep. 597 ; Bowles v. Field, 78 Fed. 742 ; The Brantford City, 29 Fed. $373,395$.

2 Keiwert $v$. Meyer, 62 Ind. 587, 30 Am. Rep. 206 ; Dolan $v$. Green, 110 Mass. 322 ; Suit $v$. Woodhall, 113 Mass. 391 ; Weil $v$. Golden, 141 Mass. 364 ; Webber $v$. Howe, 36 Mich. 150, 24 Am. Rep. 590.

3 Webber $v$. Howe, 36 Mich. 150, 24 Am. Rep. 590 ; Hill v. Spear, 50 N. H. 253, 9 Am. Rep. 205 ; Boothby v. Plaisted, 51 N. H. 436, 12 Am. Rep. 140 ; Abberger $v$. Marrin, 102 MIass. 70 ; Tegler $v$. Shipman, 33 Ia. 194, 11 Am. Rep. 118 ; Fred Miller Brewing Co. v. De France, 90 Ia. 395, 57 N. W. 959.

4 Thatcher $v$. Norris, $11 \mathrm{~N}$. Y. 437 ; Commonwealth of Kentucky $v$. Bassford, 6 Hill (N. Y.), 526 ; McIntyre $v$. Parks, 3 Met. (Mass.) 207 ; Sondheim $v$. Gilbert, 117 Ind. 71,18 N. E. 687 . But see Robinson v. Bland, 2 Burr. 1077 ; Flagg $v$. Baldwin, 38 N. J. Eq. 219, 48 Am. Rep. 308 ; Gist v. Tel. Co 45 S. C. 344,23 S. E. 143. 
So the validity of a bond or other contract, the consideration of which is the sale or hire of slaves or a policy of insurance upon a slave ship, will depend upon the law of the place where the sale or hire takes place or the contract of insurance is made. ${ }^{6}$

In Atlantic Phosphate Co. v. Ely, ${ }^{6}$ fertilizers were ordered from South Carolina by a farmer living in Georgia, under such circumstances that the sale was held to take place in South Carolina, the purchaser executing a note in Georgia for the price. The law of Georgia avoided sales of fertilizers which had not been inspected before being offered for sale or distribution. The sale was valid in South Carolina. In a suit in Georgia upon the note it was urged that the fertilizers had not been inspected, but the Georgia court held that the validity of the note depended upon the law of South Carolina, not upon the law of Georgia.

$\S 179$. Usurious Considerations. - There is probably no point within the whole range of the law upon which there exist greater conflicts of views, more irreconcilable opinions, or greater confusion of statement, than upon the proper law to govern the effect of alleged usury in a contract. The natural difficulties which beset the subject have been immeasurably increased by the looseness of phraseology indulged by the courts.

Let us suppose for example a case like the following: A citizen of Texas comes to New York and there borrows money, it being understood that he is to pay eight per cent interest. $\mathrm{He}$ returns to Texas, and there; executes a note payable in New York for the principal sum with eight per cent interest. We will suppose further that the law of New York avoids all contracts carrying more than six per cent, while the law of Texas permits eight per cent.

As has been already shown, the validity of a particular act does not in general depend upon whether or not the parties intend to do a valid act. The intent is of importance in ascertaining what act the parties propose to perform, but that once

5 Roundtree $v$. Baker, 52 Ill. 241, 4 Am. Rep. 597 ; Greenwood v. Curtis, 6 Mass. 358, 4 Am. Dec. 145 ; Touro v. Cassin, 1 Nott \& McC. (S. C.) 173, 9 Am. Dec. 680 .

682 Ga. 438, 9 S. E. 170. 
determined definitely, the validity of the act depends entirely upon the law governing the territory wherein the act is done. But to this general principle there may be exceptions in cases where the gist of the illegality of the particular act lies in the intention with which it is done. Such to a certain extent is the case with usurious contracts. The intention to exact usurious interest, contrary to law, is an essential ingredient of usury. ${ }^{1}$ Nor must it be forgotten that, unless there is real oppression of the debtor and advantage taken of him, usury is a more or less odious defense, which the courts will not go out of their way to enforce. Another point to be noticed in this connection is the fact that the rate of interest prescribed by the laws of a particular State is fixed arbitrarily by the legislature, as being on the whole best suited to its own people. Save for the arbitrary decree of the legislature, there would be nothing illegal or immoral in charging a somewhat higher rate of interest. It is a matter with regard to which the policies of different States vary infinitely.

Considerations like those above mentioned have led many of the courts to lean towards sustaining such contracts, if possible, and to hold that it is sufficient if the contract is valid either by the law of the place where it is entered into or where it is to be performed. ${ }^{2}$

1 Balfour $v$. Davis, 14 Or. 47, 12 Pac. 89. Hence if a contract reserves excessive interest merely because of a mistaken calculation, it is not for that reason usurious. There must be an intention to charge the illegal rate. See Lloyd $v$. Scott, 4 Pet. 205 ; Bevier $v$. Covell, 87 N. Y. 50 ; Smythe v. Allen, o7 Miss. 146, 6 So. 627 ; Bearce $v$. Barstow, 9 Mass. 45 ; Price v. Campbell, 2 Call (Va.), 110 ; McElfatrick v. Hicks, 21 Penn. St. 402 ; Brown v. Bank, 86 Ia. 527,53 N. W. 410; Henry v. Sansom, 2 Tex. Civ. App. 150, 21 S. W. 69.

2 The leading case taking this view is Miller $v$. Tiffany, 1 Wall. 298, 310. In that case the court said: " The general principle in relation to contracts made in one place to be performed in another is well settled. They are to be governed by the law of performance, and if the interest allowed by the law of the place of performance is bigher than that permitted at the place of contract, the parties may stipulate for the higher interest without incurring the penalties for usury.' The converse of this proposition is also well settled. If the rate of interest be higher at the place of contract than at the place of performance, the parties may lawfully contract in that case also for the higher rate." See 
Some of the cases even go further, laying hold of the slightest circumstances in connection with the transaction to show that the parties intended to enter into a contract free from the taint of usury, though the rate of interest charged be usurious both by the lex celebrationis and the lex solutionis of the contract. Thus, the fact that the note is secured by a mortgage on land in a State where the rate of interest charged is legal, ${ }^{8}$ or that the borrowed money is to be used in a State whose law permits the rate charged, ${ }^{4}$ has sometimes been held sufficient to uphold the contract.

But, notwithstanding much confusion in the terms used and in the statement of the controlling principles, the current of decision seems to look rather to the actual situs of the acts in question to furnish the "proper law" than to the intention of the parties.

Passing by the intent then, in order to ascertain the situs that shall furnish the proper law we must first determine to what element in the validity of a contract the matter of usury pertains. Does it relate to the making of the contract itself, to its performance, or to the consideration?

Although there are a few cases holding that the validity of a contract alleged to be usurious is to be governed by the lex

Cromwell $v$. County of Sac, 96 U. S. 51, 62 ; Cockle $v$. Flack, 93 U. S. 344. This may probably be said to be the view of the United States Supreme Court. See also Kilgore $v$. Dempsey, 25 Ohio St. 413, 18 Am. Rep. 306 ; American Mortg. Co. v. Sewell, 92 Ala. 163, 9 So. 143, 145-146; Dugan v. Lewis, 79 Tex. 246, 14 S. W. 1024, 1026 ; Nickels $v$. Association, 93 Va. 380, 387, 25 S. E. 8 ; Scott $v$. Perlee, 39 Ohio St. 63, 48 Am. Rep. 421, 422 ; Morris $v$. Hockaday, 94 N. C. 286, 55 Am. Rep. 607, 608 ; Mott $v$. Rowland, 85 Mich. 561, 48 N. W. 638 ; Smith $v$. Parsons, 55 Minn. 520, 57 N. W. 311, 312 ; Hunt v. Jones, 12 R. I. 265,34 Am. Rep. 635,637 ; B. \& L. Association v. Logan, 14 C. C. A. 133, 66 Fed. 827, 829; New England Mortg. Co. v. Vaden, 28 Fed. 265.

3 Chapman $v$. Robertson, 6 Pai. Ch. (N. Y.) 627, 31 Am. Dec. 264 ; Dugan v. Lewis, 79 Tex. 246, 14 S. W. 1024 ; Jackson $v$. Mortg. Co., 88 Ga. 756, 15 S. E. 812 ; Arnold $v$. Potter, 22 Ia. 195 ; Kellogg $v$. Miller, 13 Fed. 198 . But see Mortg. Co. v. Jefferson, 69 Miss. 770, 12 So. 464; Odom v. Mortg. Co., 91 Ga. 505, 18 S. E. 131 ; De Wolf $v$. Johnson, 10 Wheat. 367, 383.

4 Scott $v$. Perlee, 39 Ohio St. 63, 48 Am. Pep. 421 ; Kellogg v. Miller, 13 Fed. 198, 200. But see Central Trust Co. v. Burton, 74 Wis. $32 \mathcal{G}, 43 \mathrm{~N}$. W. 141. 
eelebrationis of the contract, regardless of the lex solutionis or lex considerationis, ${ }^{6}$ reason, as well as the great mass of authority, indicates that the effect of the exaction of usurious interest upon the contract to repay does not depend upon the law of the place where such contract is made (apart from the locus solutionis or locus considerationis). ${ }^{6}$

We are brought then to the consideration of the question whether the matter of usury affects the performance of the contract to pay, or whether it affects the consideration. In other words, why is a contract to pay excessive interest invalid? Does the usury consist in the borrower's promise to repay the principal with excessive interest? Or does it consist in the loan or forbearance of money upon condition that the borrower will repay the principal with excessive interest? The distinction here is close but important, if we regard the situs of the transaction, not the intent of the parties, as furnishing the proper law.

If the first view is correct, the alleged usuriousness and invalidity of the contract to pay relates to its performance, the payment of the excessive interest, and the validity of the payment of the interest agreed upon should be determined by the law of the place where the act of payment is to be performed, that is, by the lex solutionis of the contract to pay. ${ }^{7}$

If the second view is correct, the usury relates to the con-

5 New England Mortg. Co. v. McLaughlin, 87 Ga. 1, 13 S. E. 81 ; Thornton $v$. Dean, 19 S. C. 583, 45 Am. Rep. 796 ; Kellogg v. Miller, 13 Fed. 198. Even these cases are based upon the intention of the parties or upon some other ground than merely that the lex celebrationis of the contract governs.

6 The anthorities cited below amply sustain this proposition.

7 A number of courts take this view and hold that the lex solutionis of the contract, of itself, without regard to the lex celebrationis or the lex considerationis, will govern the matter of usury. See Hosford $v$. Nichols, 1 Pai. Ch (N. Y.) 220 ; Chapman v. Robertson, 6 Pai. Ch. (N. Y.) 627, 630, $31 \mathrm{Am}$. Dec. 264 ; Odom v. Mortg. Co., 91 Ga. 505, 18 S. E. 131 ; Connor $v$. Donnell, 55 Tex. 174; Dickinson v. Edwards, 77 N. Y. 573, 578, 582, 33 Am. Rep. 671 ; Nickels v. Association, 93 Va. 380, 25 S. E. 8 ; National, etc. Association v. Ashworth, 91 Va. 706, 22 S. E. 521 ; Freese v. Brownell, 35 N. J. L. 285, 10 Am. Rep. 239, 241 ; Pioneer Sav. \& L. Co. v. Cannon, 96 Tenn. 599, 36 S. W. 386 ; Kellogg v. Miller, 13 Fed. 198, 199. See Bigelow v. Burnham. 83 Ia. 120,49 N. W 104. 
sideration (the loan of the money), and the law of the place where the money is delivered to the borrower governs the validity of the contract to pay. Just as the validity of a note made and payable in one State, given in payment for liquor sold, depends not upon the lex celebrationis or lex solutionis of the note, but upon the lex loci considerationis (the law of the situs of the sale) $;^{8}$ so, in this case, the validity of the note or promise to repay the money borrowed, will depend not upon the lex celebrationis or lex solutionis of the note or other promise, but upon the lex loci considerationis (the law of the situs of the loan). This is believed to be the better view. The policy of the usury laws is aimed against the exaction of usurious interest by the lender, not against the promise by the debtor to pay usurious interest. The great majority of the decided cases have held that the law of the place where the money is lent governs the question of usury, though comparatively few have rested their decision expressly upon this ground. ${ }^{\circ}$

- See ante, § 178 .

9 In some of the cases emphasis is laid upon the lex considerationis as governing the question, though the lex celebrationis and the lex solutionis of the note, or one of them, were the other way. See Akers $v$. Demond, 103 Mass. 318, 323-324; Bowman v. Miller, 25 Gratt. (Va.) 331, 18 Am. Rep. 686 ; Sheldon $v$. Haxtun, 91 N. Y. 124, 128-129, 131 ; Pratt $v$. Adams, 7 Pai. Ch. (N. Y.) 615,632 ; Kilcrease $v$. Johnson, 85 Ga. 600, 11 S. E. 870 ; Martin $v$. Johnson, 84 Ga. 481,10 S. E. 1092, 8 L. R. A. 170 ; Matthews v. Paine, 47 Ark. 54, 14 S. W. 463 ; Hiatt $v$. Griswold, 5 Fed. 573, 575 ; DeWolf $v$. John. son, 10 Wheat. 367,383 . In some, the loan was made in the State where the contract was payable, though the contract itself was made elsewhere. The law of the situs of the loan prevailed. See Bennett v. B. \& L. Association, 177 Penn. St. 233, 34 L. R. A. 595, 35 Atl. 684, 685 ; Sands v. Smith, 1 Neb. 108, 93 Am. Dec. 331 ; Roberts v. McNeely, 7 Jones L. (N. C.) 506, 78 Am. Dec. 261 ; Pugh $v$. Cameron, $11 \mathrm{~W}$. Va. 523. In most of the cases that have arisen, the locus celebrationis of the contract and the locus considerationis (the place where the money was advanced) have been identical, and have been different from the locus solutionis of the promise to repay. The lex loci considerationis has again prevailed, though the decision is often, indeed generally, rested upon other grounds. See Andrews $v$. Pond, 13 Pet. 65, 78; Tilden $v$. Blair, 21 Wall. 241 ; Sturdivant $v$. Bank, 9 C. C. A. 256, 60 Fed. 730 ; Buchanan $v$. Bank, 5 C. C. A. 83, 55 Fed. 223, 227 ; Kuhn v. Morrison, 75 Fed. 81 ; Van Vleet $v$. Sledge, 45 Fed. 743 ; Brown $v$. Finance Co., 31 Fed. 516, 519 ; Hiatt v. Úriswold, 5 Fed. 573, 575; Watson v. Lane, 52 N. J. L. 550, 20 Atl. 894 ; 
In no case has this view been brought out more plainly than in Akers $v$. Demond. ${ }^{10}$ In that case, bills of exchange, drawn in New York, and payable in Massachusetts, were accepted in Massachusetts for the accommodation of the drawer, and returned to New York, where they were discounted at a rate of interest usurious in New York. Suit was brought against the acceptor in Massachusetts by the holder (the lender). Here it will be seen that while Massachusetts was the lex solutionis of the acceptor's contract, New York was the place where the money was advanced (locus considerationis) and the locus celebrationis of the acceptor's contract. The court, holding that

Lane v. Watson, 51 N. J. L. 186, 17 Atl. 117; Depau v. Humphreys, 20 Mart. (La.) 1; Holmes $v$. Manning (Mass.), 19 N. E. 25 ; Akers v. Demond, 103 Mass. 318, 323 ; Staples v. Nott, 128 N. Y. 403, 28 N. E. 515; Sheldon $v$. Haxtun, 91 N. Y. 124, 128 ; Wayne County Bank v. Low, 81 N. Y. 566, 37 Am. Rep. 533 ; Merchants' Bank v. Griswold, 72 N. Y. 472, 480, 28 Am. Rep. 159 ; Curtis $v$. Leavitt, 15 N. Y. 9, 86 ; Pratt $v$. Adams, 7 Pai. Ch. (N. Y.) 615, 632 : Balme $v$. Wombough, 38 Barb. 352 ; Kilgore $v$. Dempsey, 25 Ohio St. 413, 18 Am. Rep. 306 ; Findley $v$. Hall, 12 Ohio, 610 ; Bascom v. Zediker, 48 Neb. 380, 67 N. W. 148 ; Joslin v. Miller, 14 Neb. 91, 15 N. W. 214 ; Olnstead v. Mortg. Co., 11 Neb. 493, 9 N. W. 650, 652; Overton v. Bolton, 9 Feisk. (Tenn.) 762, 24 Am. Rep. 367, 374-375; Klinck v. Price, 4 W. Va. 4, 6 Am. Rep. 268 ; U. S. Sav. \& L. Association v. Scott, 98 Ky. 695, 34 S. W. 235 ; Southern B. \& L. Association v. Harris, 98 Ky. 41, 32 S. W. 261 ; Pryse v. Association (Ky.), 41 S. W. 574 ; Underwood v. Mortg. Co., 97 Ga. 238, 24 S. E. 847 ; New England Mortg. Co. v. McLaughlin, 87 Ga. 1, 13 S. E. 81; Kilcrease $v$. Johnson, 85 Ga. 600,11 S. E. 870 ; Martin v. Johnson, 84 Ga. 481, 10 S. E. 1092,8 L. R. A. 170 ; Meroney v. B. \& L. Association (N. C.), 17 S. E. 637 ; Falls v. Sav. \& L. Co., 97 Ala. 417,13 So. 25,27 ; American Mortg. Co. v. Sewell, 92 Ala. 163, 9 So. 143. A fortiori, in the cases where the locus celebrationis, the locus solutionis, and the locus considerationis all coincide, the law of that State, not the lex fori, will govern the question of usury. See Glidden $v$. Chamberlin, 167 Mass. 486, 46 N. E. 103 ; Bowman $v$. Miller, 25 Gratt. (Va.) 331, 18 Am. Rep. 686 ; Backhouse $v$. Selden, 29 Gratt. (Va.) 581 ; Fant v. Miller, 17 Gratt. (Va.) 47 ; Berrien v. Wright, 26 Barb. (N. Y.) 208; Pomeroy v. Ainsworth, 22 Barb. 118 ; Maynard v. Hall, 92 Wis. 565, 66 N. W. 715 ; Central Trust Co. v. Burton, 74 Wis. 329,43 N. W. 141 , 142 ; Kennedy $v$. Knight, 21 Wis. 340, 94 Am. Dec. 543 ; Armistead $v$. Blythe (Miss.), 20 So. 298; Hubbell v. Morristown Land \& Imp. Co., 95 Tenn. 585, 32 S. W. 965 ; Hart $v$. Wills, 52 Ia. 56, 35 Aw. Rep. 255; Lockwood $v$. Mitchell, 7 Ohio St. 387, 70 Am. Lec. 78.

10103 Mass. 313.
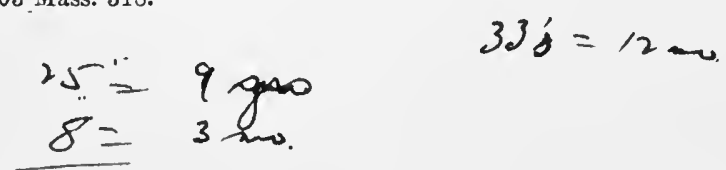
the New York law governed, said: "When a usurious or other illegal consideration is declared by the law of any State to be incapable of sustaining any valid contract, and all contracts arising therefrom are declared void, such contracts are not only void there, but void everywhere. They never acquire a legal existence. Contracts founded on a usurious consideration in New York are of this nature. The fact that the bills were accepted in Boston and were payable there does not exempt them from this operation of the New York law. They were mere 'nude pacts' with no legal validity or force as contracts until a consideration was paid. The only consideration ever paid was the usurious loan made by these plaintiffs in New York. That, then, was the legal inception of the alleged contracts. By the New York law that transaction was incapable of furnishing a legal consideration; and so far as the bills depend upon that, they are absolutely void. The original validity of such a contract must be determined by the law of the State in which it is first negotiated or delivered as a contract.

The fact that usury is a matter of the consideration, not of the performance, of the contract, becomes more evident, if we suppose the excessive interest to be reserved out of the principal sum at the time of the loan, or upon discounting paper. It is manifest in such a case that the subsequent execution of a note as security, whether made in the same State or elsewhere, cannot affect the legality or illegality of the original act. That is over and done with, and its effect must be determined by the law of the State where the reservation is made, that is, where

11 Even in this case, it will be observed, while the court gives full effect to the lex considerationis as determining the matter of usury, the last sentence of the extract above quoted reverts to the fallacy that the law of New York should govern, not because it is the lex considerationis, but because it is the lex celebrationis, of the contract. It is true that the locus celebrationis of the contract will usually be identical with the locns considerationis (as it was in Akers $v$. Demond), and in such case, save for the sake of clearness, it is immaterial whether the proper law is called the lex celebrationis or the lex considerationis. But these two loci are not necessarily identical, as shown by the cases cited in note 9, supra. Confusion must inevitably arise if these vari. ous loci are not kept clear and distinct.
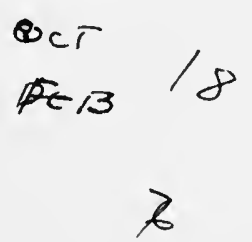
the money is advanced. ${ }^{22}$ Yet the consideration for the contract may be exactly the same without reserving the interest in advance. In either case the consideration for the promise to pay is the loan or forbearance of money at an excessive rate of interest.

The same principles govern a note given in renewal of a previous note or obligation to pay. The validity of the first note is determined by the lex considerationis, the law of the place where the money is advanced; and the validity of the renewal note is governed also by its own lex considerationis. But the consideration for the renewal note is the previous note, and if that is usurious and invalid by its proper law, so should the renewal note be, and vice versa. ${ }^{13}$

Sometimes the parties conduct the negotiations for the loan in one State, while the money is actually advanced in another. In such cases a question arises whether the law of the former or latter State is to govern the rate of interest. The consideration here supposed is not an executed loan, but an executory contract to loan the money at a certain rate of interest. If the loan is to be actually made in the State where the agreement to lend is entered into, there can be no question but that the law of that State should control. ${ }^{14}$

12 Tilden v. Blair, 21 Wall. 241 ; Akers v. Demond, 103 Mass. 318, 323 ; Kilcrease $v$. Johnson, 85 Ga. 600,11 S. E. 870 ; Martin v. Johnson, 84 Ga. 481, 10 S. E. 1092,8 L. R. A. 170 ; Buchanan $v$. Bank, 5 C. C. A. 83,55 Fed. 223, 227 ; Sheldon v. Haxtun, 91 N. Y. 124. But see Dickinson $v$. Edwards, 77 N. Y. 573, 33 Am. Rep. 671; Wayne County Bank v. Low, 81 N. Y. 566, 37 Am. Rep. 533.

13 Wayne County Bank v. Low, 81 N. Y. 566, 37 Am. Rep. 533 ; Bowman v. Miller, 25 Gratt. (Va.) 331, 18 Am. Rep. 686. But some courts, relying on the principle that a renewal note given in exchange for a usurious note, after purging the latter of the excessive interest, is good, hold that the giving of a renewal note in a State by whose law the interest carried by the first usurions note is not excessive, operates in the same way to purge the usury and to make the renewal note good. See Jacks $v$. Nichols, 5 Barb. (N. Y.) 38 ; Sheldon $v$. Haxtun, 91 N. Y. 124, 131 ; De Wolf $v$. Johnson, 10 Wheat. 367 . In the last case however there was an actual reduction of interest npon the renewal.

14 Martin v. Johnson, 84 Ga. 481, 10 S. E. 1092, 1093, 8 L. R. A. 170 ; Staples $v$. Nott, 128 N. Y. 403, 405-406, 28 N. E. 515; Wayne County Bank v. Low, 81 N. Y. 566, 571, 37 Am. Rep. 533 ; Berrien v. Wright, 26 Barb. (N. Y.) 208 . 
But if it is expressly or impliedly agreed that the money is to be actually advanced in another State, that is to say, if the executory consideration is to be performed in another State, the validity of its performance there must be determined by the lex solutionis of the consideration (the law of the place where the loan is to be made). ${ }^{15}$

The case of Hubbell $v$. Morristown Land \& Imp. Co. ${ }^{16}$ presents a good illustration of this principle. In that case the loan was originally agreed upon between Mrs. Hubbell and the borrower, in Connecticut, where Mrs. Hubbell was "summering." The borrower was a Tennessee corporation, and it was agreed that the loan to be thereafter made should bear seven per cent interest and should be secured on the corporation's land in Tennessee. The note evidencing the loan was drawn in North Carolina and was made payable in New Jersey, where Mrs. Hubbell lived. This note was delivered and the money actually advanced in New Jersey, in pursuance of the contract to lend. By the law of Tennessee and of New Jersey the contract was usurious; by the law of Connecticut and of North Carolina it was valid. The trial court decided that the law of New Jersey should govern. The Tennessee Court of Chancery Appeals reversed this decision, and held in favor of the Connecticut law. This in turn was reversed by the Supreme Court of the State, which returned to the law of New Jersey as the place where the loan was finally consummated.

15 Hubbell v. Morristown Land \& Imp. Co., 95 Tenn. 585, 32 S. W. 985 ; Sheldon $v$. Haxtnn, 91 N. Y. 124, 128-129 ; Bascom $v$. Zediker, 48 Neb. 380, 67 N. W. 148 ; Coad v. Home Cattle Co., 32 Neb. 761, 49 N. W. 757. But see Mott $v$. Rowland, 85 Mich. 561, 48 N. W. 638 ; Scott $v$. Perlee, 39 Ohio St. 63, 48 Am. Rep. 421. Both of the last two cases go upon the theory that the law which the parties "had in mind" as governing the contract should control.

1695 Tenn. 585, 32 S. W. 965. 


\section{CHAPTER XVIII.}

\section{OBLIGATION AND INTERPRETATION OF CONTRACTS.}

$\S 180$. Obligation of a Contract. - We have in the preceding chapter considered the "proper law" governing the validity of a contract. We will now suppose it to be established that the contract is valid in every particular, and will proceed to examine the law controlling the rights, duties, and liabilities of the parties under it.

The "obligation" of a contract is defined by Judge Story as " the duty to perform it." 1 In reality, however, the term has a somewhat broader meaning than that ascribed to it by Story. It implies a duty on the part of the promisor to perform the contract in manner and form according to its terms or the true intent of the parties, and a corresponding right on the part of the promisee to expect such a performance.

The "obligation of the contract," as here used (excluding matters of validity, already discussed), has the same meaning as is attached to the same phrase found in that clause of the federal constitution which provides that no State shall pass any law impairing the obligation of contracts. ${ }^{2}$

1 Story, Confl. L. $\$ 266$. He proceeds to describe it further as follows : "It may be a moral obligation, or a legal obligation, or both. But when we speak of obligation generally we mean legal obligation, that is, the right of performance which the law confers on one party and the corresponding duty of performance to which it binds the other. . . . A contract may in its nature be purely voluntary and possess no legal obligation. It may be a mere naked pact (nudum pactum). It may possess a legal obligation; but the laws may limit the extent and force of that obligation in personam or in rem. It may bind the party personally, but not bind his estate ; or it may bind his es. tate and not bind his person. This obligation may be limited in its operation or duration ; or it may be revocable or dissoluble in certain future events or under peculiar circumstances."

2 Hence, if the question in a particular case is whether the point before the 
A practical test therefore by which to determine whether a particular matter relating to a contract constitutes a part of its "obligation" or a part of the remedy merely, is to examine whether the legislature of the State whose law governs the obligation of the contract could, by enactment subsequent to the execution of the contract, make applicable to it a law similar to that sought to be enforced in the forum. If such a retrospective law passed in the proper situs of the contract would not impair its obligation nor violate the provision of the constitution, the matter must be held to relate not to the obligation but to the remedy, and the lex fori will prevail. But if such a retroactive law as the lex fori, passed in the situs of the contract, would be unconstitutional as impairing its obligation, the same law in the forum cannot be held to apply, the question being one of obligation, not of remedy.

This may be illustrated by the case of Ruhe $v$. Buck, ${ }^{8}$ in which the court was divided on the question whether a particular law of Missouri (the forum) related to the remedy or to the obligation of the contract in controversy. In that case, a contract to pay money was made in Dakota, to be performed there, by a married woman who was allowed by the law of Dakota to contract as a feme sole and to sue and be sued as such. She owned land in Missouri which the Dakota creditor sought to attach. By the law of Missouri, a married woman was competent to contract and be sued, but her property could not be attached. The question therefore arose whether the right to use the particular remedy of attachment related to the obligation of the contract or to the remedy. If to the former, the law of Dakota must govern; if to the latter, the law of Missouri. The majority of the court decided in favor of the law of Missouri (lex fori), holding the question to be one of the

court relates to the obligation of the contract or to the remedy, such as questions relating to exemptions, etc., cases of like sort involving this constitutional provision will be authority on the same point as it arises in private international law. See Edwards v. Kearzey, 96 U. S. 595 ; Coffinan v. Bank, 40 Miss. 29, 90 Am. Dec. 311.

, 3124 Mo. 178, 25 L. R. A. 178, note. See also $\S \S 183$, note 3, 209, 210. 
remedy; but there was strong dissent. Applying the criterion above mentioned, it would seem quite clear that the opinion of the majority was correct. If, after the execution of the Dakota contract, the legislature of Dakota had passed a retroactive law, providing that no attachment should thereafter issue against a married woman's property, but leaving untouched other remedies against her, it could scarcely be held that this would have impaired the obligation of the contract.

$\$ 181$. Obligation of Contract dependent upon Intention of Parties. - It is a point to be specially noted that the obligation of a contract depends primarily upon the understanding and intention of the parties. In this respect it differs materially from the element of validity.

In many instances we need look no further than to the terms of the contract itself to ascertain exactly what the promisor has obligated himself to do. But questions often arise which were not foreseen by the parties and for which no provision has been made in the contract; as where a bond or note is given which makes no provision for the payment of interest after maturity. Or the contract itself may be one wholly or in part implied by law, as in case of the implied contract to pay for services rendered, or the contract of an indorser of negotiable paper.

In all such cases the parties having failed for one reason or another to express their meaning fully, the law may presume from the circumstances that they intend to bind themselves to certain duties, and undertakes to fix the scope and extent of those duties accordingly, as to it may seem just, wise, and politic. In such cases the law does not seek to override the intention of the parties, but merely to supply what the parties have left unsaid. On the contrary, the parties may override the law in respect to such matters at any time, and regulate their own duties under the contract by an express agreement to that effect. In other words, the "obligation" of a contract (as here used) is a question of the intention of the parties. If that be expressed, it will prevail over any rule of law; if not expressed, an appeal must be made to the law to ascertain what the presumed intention is. In determining the obligation of a con 
tract, the maxim " modus et conventio legem vincunt" emphati. cally applies. ${ }^{1}$

It follows therefore that it is only necessary to ascertain the law governing the obligation of a contract in those cases where its terms are not sufficiently explicit in themselves to furnish a guide to the intention of the parties. If the parties to a contract desire their obligations to be such as the law of a particular State would prescribe (whether their own or a foreign State), they may effect this result in several ways. They may express in their contract all the stipulations which would be implied by the law to which they have reference, and such express stipulations would prevail over the mere implications of any system of law. Modus et conventio legem vincunt.

Or they may accomplish the same result merely by declaring their intention to obligate themselves in accordance with some particular law. The provisions of that law then become as much the express stipulations of the contract as in the former case.

If we go a step further and suppose that the parties have made no express stipulation at all in their contract as to what law shall control the obligations incurred by them in respect to

1 To this general principle there may be a few exceptions, based on reasons of public policy, or for the protection of third persons; or where the question is one of form rather than obligation; or where the question is one of fact rather than of intention. Thus, it might be weil doubted whether a party may make a contract, answering in every respect to the definition of a negotiable note, yet with the understanding that it should not be so regarded, that is, if third parties become interested. Or whether a party may make a contract under seal, and yet agree that it should be deemed an unsealed instrument. See Warren v. Lynch, 5 Johns. (N. Y.) 239, 244. Or whether one may draw a bill in one State, and yet by agreement or intention make it an inland bill of another State. In Strawbridge $v$. Robinson, 5 Gilm. (11l.) 470, $50 \mathrm{Am}$. Dec. 420 , it was decided that this could be done, but the question there was not whether the bill was an inland bill, but whether it should be followed by the same consequences as if it were an inland bill, which is a matter relating to its obligation, and dependent upon the agreement or intent of the parties. The general rule is certainly that stated in the text.

No reference is here made to provisions in a contract which affect the obligation but which are declared void. Matters of validity have been fully treated in the preceding chapter, and we are now confining our attention to contracto whose validity is unquestioned. 
matters about which the contract itself is silent, but that their contemporaneous declarations and all the surrounding circumstances show that they actually had the law of a particular State in mind when they entered into the contract, it is equally clear that here also the intention of the parties must fix the law which is to determine the obligations incurred by them. ${ }^{2}$

But, as a matter of fact, it rarely happens that the parties have any specific law in view when they enter into a contract. That their contract is ambiguous or has left anything unsaid does not usually occur to them. If it did, they would generally correct it at once, and make explicit provision for the point. In such cases it is the part of private international law by its own implications to fill the gap in the expressed intention of the parties touching the governing law, just as a kindred duty devolves upon the municipal law of a State in case of a domestic contract whose terms are not sufficiently explicit.

Let us suppose then a contract made in one State, to be performed in another, and sought to be enforced in a third. A question arises touching some obligation or liability of the promisor under the contract, which is not covered by its express terms. The lex celebrationis supplies one measure of this implied obligation; the lex solutionis another; and the lex fori a third. Which is to control? To answer merely "the law in the minds of the parties at the time of the contract," as has been said by some of the courts, ${ }^{8}$ does not advance the inquiry materially, since we have supposed the parties to have no law actually in contemplation. We must therefore resort to implications and presumptions founded upon the situs of this element (the obligation).

Turning to the definition of "obligation," 4 it will be noted that it involves in the main the duty to perform the contract. It is obvious therefore that, in the absence of evidence as to the intent of the parties, any doubt as to the duty of the promisor in respect to performance, so far as it depends upon the law, should

2 See Jacobs $v$. Credit Lyonnais, 12 Q. B. Div. 589.

8 See Jacobs $v$. Credit Lyonnais, 12 Q. B. Div. 589, 596 ; Briggs $v$. Latham, 36 Kan. 255, 59 Am. Rep. 546, 13 Pac. 393.

Ante, $\$ 180$. 
be governed by the law of the situs of that performance (lex sol. utionis). The almost unanimous current of authority is to this effect. $^{5}$ If the contract is executed, not executory, or names no

5 Robinson v. Queen, 87 Tenn. 445, 3 L. R. A. 214, 11 S. W. 38 ; Baum v. Birchall, 150 Penn. St. 164, 24 Atl. 620 ; Stevens $v$. Gregg, 89 Ky. 461,12 S. W. 775 ; Hunt $v$. Standart, 15 Ind. 33,77 Am. Dec. 79 ; Rose $v$. Park Bank, 20 Ind. 94, 83 Am. Dec. 306 ; City of Aurora $v$. West, 22 Ind. 88, 85 An. Dec. 413 ; Odell v. Gray, 15 Mo. 337, 55 Am. Dec. 147; Peck v. Mayo, 14 Vt. 33, 39 Am. Dec. 205 ; Mason v. Dousay, 35 Ill. 424, 85 Am. Dec. 368 ; Abt $v$. American Bank, 159 Ill. 467, 42 N. E. 856 ; Shoe \& Leather Bank $v$. Woor, 142 Mass. 563, 8 N. E. 753; Emannel v. White, 34 Miss. 56, 69 Am. Dec. 385 ; Hibernia Nat. Bank $v$. Lacombe, 84 N. Y. 367; Greenwald v. Freese (Cal.), 34 Pac. 73 ; Pierce v. Indseth, 106 U. S. 546 ; Supervisors $v$. Galbraith, 99 U. S. 214 ; Cox v. United States, 6 Pet. 172, 203 ; Brabston v. Gibson, 9 How. 263 ; Sturdivant $v$. Bank, 9 C. C. A. 256,60 Fed. 730 . In only a few instances have the courts adopted the lex celebrationis as against the lex solutionis in determining the obligation of a contract admittedly valid. These have been cases where the intent of the parties has been supposed to point to the former law. One of the most prominent examples is the English case of Jacobs $v$. Credit Lyonnais, 12 Q. B. Div. 589. In that case a contract was made in England between two English firms, by which one agreed to sell to the other twenty thousand tons of "Algerian esparto," to be shipped by a French company at an Algerian port on board vessels furnished by the purchasers at London, and to be paid for by them in Londou upon arrival. It was also agreed that the purchasers should accept and approve the esparto as put on board in Algiers. The outbreak of an insurrection in Algiers prevented the delivery of the entire amount of esparto contracted for. By the French law (prevailing in Algiers) the prevention of the performance of a contract by vis major dis. charged the promisor. It was otherwise by English law. The English court, assuming Algiers to be the locus solutionis of the contract (which is very doubtful), nevertheless held that the English law (lex celebrationis) should control, on the ground that that was the law intended by the parties to govern the contract. See also Gibson $v$. Ins. Co., 77 Fed. 561; Knights Templar Association v. Greene, 79 Fed. 461 ; Penn Mut. Ins. Co. v. Trust Co., 19 C. C. A. 286,72 Fed. 413. Perhaps, however, the lex celebrationis, not the lex solutionis, will be the "proper law" in those cases where the obligation of the contract depends upon some matter of form (not anıunting to a question of validity), as in case of an oral contract enforceable where made, but upon which, under the statute of Frauds of the forum, "no action may be brought," because the contract is not in writing; or the case of contracts, enforceable where made, upon un. stimped paper, to which the lex fori on that account refuses a remedy, or which that law refuses to receive in evidence in a suit thereon. Ante, $\S \S .72,173$; post, $§ 210$. 
place of performance if executory, the locus solutionis and locus celebrationis are identical. In such cases the law of the place where the executory contract is made will govern, not because it is the lex celebrationis, but because it is also the lex solutionis. If the contract is executed, it is performed when and where made. ${ }^{6}$

Thus, the question whether a sale of a machine implies a warranty of fitness for the purpose for which it was sold is a matter relating to the obligation of the contract of sale and is to be determined by the law of the place of sale (lex loci contractus). ${ }^{7}$

In Tenant $v$. Tenant, ${ }^{8}$ the question was whether a surety might discharge himself by notice to the creditor to sue. A note, upon which the defendants were sureties, was delivered to the payee in West Virginia, no place of payment being mentioned. Notice had been orally given the payee by the sureties to proceed at once to sue the maker or they would no longer be responsible. By the law of Pennsylvania, where this suit was brought, and where one of the sureties resided, this notice served to discharge the sureties. By the law of West Virginia, such notice was required to be in writing. It was held that the law of West Virginia should prevail.

In $\operatorname{Cox} v$. United States, ${ }^{9}$ a bond was given by a navy agent at New Orlearns and his sureties to the United States, conditioned for the faithful performance of his duties and a true accounting of all moneys, etc. After the agent's insolvency

6 See Meyer $v$. Richards, 163 U. S. 385 ; Kennebrew $v$. Machine Co., 106 Ala. 377, 17 So. 545; Gross $v$. Jordan, 83 Me. 380, 22 Atl. 250 ; Wilson $v$. Lazier, 11 Gratt. (Va.) 477; Nichols v. Porter, 2 W. Va. 13, 94 Am. Dec. 501; Barrett v. Dodge, 16 R. I. 740, 19 Atl. 530; Griswold v. Golding (Ky.), 3 S. W. 535 ; Heebner v. Ins. Co., 10 Gray (Mass.), 131; Tenant $v$. Tenant, 110 Penn. St. 478, 1 Atl. 532; Lewis $v$. Headley, 36 Ill. 433, 87 Am. Dec. 227; Aymar $v$. Sheldon, 12 Wend. (N. Y.) 439, 27 Am. Dec. 137.

7 Kennebrew v. Machine Co., 106 Ala. 377, 17 So. 545. See Meyer v. Richards, 163 U. S. 385 ; Story, Confl. L. § 264.

8110 Penn. St. 478, 1 Att. 532. This is in reality an instance of the discharge of a contract by operation of law, which is a part of the obligation of the contract. See post, $\S 190$.

96 Pet. 172. 
and decease, the sureties were sued by the government. They claimed that the government was bound (in accordance with the law of Louisiana) to divide its action and to take judgment against each surety for his share of the sum due, since the contract was made in Louisiana. But the court held that the seat of government, Washington, was the true place of performance of the contract, and that the liability of the sureties must be governed by the rules of the common law prevailing in the District of Columbia, and that each was bound to the United States for the whole.

In Abt $v$. American Bank, ${ }^{10}$ a draft was drawn in Illinois on a New York bank and was payable in New York. The question was whether the draft should operate as an assignment pro tanto of the drawer's funds in the bank as against assignees of the drawer under a subsequent deed of assignment. By the law of Illinois a draft or check did not operate as an assignment. By the law of New York it did. It was held that the law of New York (lex solutionis) should control.

In First Nat. Bank $v$. Hall, ${ }^{11}$ the defendants, Hall and others, agreed in Pennsylvania to furnish $\mathrm{C}$ with certain money as he should need it in his business. They were to receive $a$ share of the profits during the time $\mathrm{C}$ retained the money, but he was to be allowed to repay it at the end of five years and relieve his business. The control was left with $\mathrm{C}$, and it was expressly stipulated that the contract should not be construed to create a partnership except as to the profits. The business was conducted in New York, and the contract was to be performed there. It was held that the New York law should determine whether this constituted the defendants partners, so far as creditors were concerned. ${ }^{12}$

10159 Ill. 467, 42 N. E. 856. See also National Bank of America $v$. Indiana Banking Co., 114 Ill. 483,2 N. E. 401.

11150 Penn. St. 466, 24 Atl. 665.

12 It may be well doubted whether this case in reality presents a matter relating to the "obligation" of the contract; but rather a question of the validity of the provision that the parties should not be construed to be partners. The result however would be the same in either case; the law of New York, where the contract was to be performed, would control. If a matter of 
In Baldwin $v$. Gray, ${ }^{18}$ the defendant, Gray, and others owned a boat as partners, the partnership having been entered into in Pennsylvania. Suit was brought in Louisiana to recover for the expenses of the boat while it was in Louisiana. In this suit, it was sought to hold Gray, one of the partners, responsible in solido for the whole indebtedness of the firm on this account. This was the measure of his liability in Pennsylvania, where the contract of partnership was made; but by the law of Louisiana, where the indebtedness occurred, each partner was liable only for his share. It was held that the law of Louisiana (the lex celebrationis et solutionis of the indebtedness) should control. Speaking of the effect of the Pennsylvania law, the court said: "This law governs the obligations of the partners with each other, but not with third persons. It can no more affect the rights of those who contract with them in a different country than particular stipulations between the partners could. The contract entered into in the case before us was made in this State and must be regulated by the lex loci contractus."

These illustrations will suffice to show the application of the general principles by which is determined the "proper law" governing the obligation of a contract. In the succeeding sections we will examine more particularly some of the more important classes of contracts. Though the same general principle runs through them all, namely, that in the absence of evidence of a different intent the lex solutionis of the contract determines its obligation and the auties and liabilities of the promisor, it is not always easy to apply the principle to particular cases. The various contracts to be discussed are (1) Negotiable instruments; (2) Contracts calling for interest; (3) Covenants contained in conveyances of land.

\$182. Negotiable Instruments - Maker's or Acceptor's Contract. - The questions that arise touching the obligations of the maker of a note or the acceptor of a bill are generally of a different order from those presented with respect to the obli-

validity, it is a validity affecting the performance of the contract, namely, the establishment of a partnership in New York.

184 Mart. N. s. (La.) 192, 16 Am. Dec. 169. But see King $v$. Sarria, 69 N. Y. 24, 25 Am. Rep. 122 ; ante, §158. 
gations of the indorser or drawer, and they will be treated sep. arately for this reason, not because there is any great difference in the general principles applicable. In either case the leading rule for the determination of the proper law still holds good. The lex solutionis of the particular contract in general con. trols its obligation. We have already considered at some length the rules by which the locus solutionis of the maker's or indorser's contract is fixed, and the reader is here advised to turn back to that discussion. ${ }^{1}$

The question whether, as to the maker, a note is negotiable, and hence whether or not the maker may plead against a bona fide holder equities existing between himself and the payee arising before notice of the transfer, is to be decided in accordance with the law of the place where the note is payable, though it is indorsed or the suit is brought in another State. ${ }^{2}$

And if the maker or acceptor of a note or bill should urge his right to plead defeuses against the holder on the ground that the holder is not a purchaser for value, the lex solution is of the note or bill, not the law of the place where the holder acquired his title, will govern the question. ${ }^{8}$ Thus, in Woodruff $v$. Hill, ${ }^{4}$ a negotiable note was made and payable in Massachusetts, but was indorsed in another State, the indorsee receiving the note from the payee in satisfaction of a pre-exist. ing debt. By the law of the State where the indorsement was made a note indorsed for a pre-existing debt did not constitute the holder a purchaser for value. By the law of Massachusetts (lex solutionis) it did. In a suit by the indorsee against the maker, it was held that the Massachusetts law must determine

1 Ante, $\$ \S 164,165$.

2 Wilson $v$. Lazier, 11 Gratt. (Va.) 477; Hull v. Blake, 13 Mass. 153; Stevens v. Gregg, 89 Ky. 461, 12 S. W. 775 ; Barrett $v$. Dodge, 16 R. I. 740, 19 Atl. 530; Harrison v. Edwards, 12 Vt. 648, 36 Am. Dec. 364 ; City of Aurora $v$. West, 22 Ind. 88, 85 Am. Dec. 413 ; Rose v. Park Bank, 20 Ind. 94, 83 Am. Dec. 306 ; Odell $v$. Gray, 15 Mo. 337, 55 Am. Dec. 147; Emanue] v. White, 34 Miss. 56, 69 Am. Dec. 385 ; Brabston v. Gibson, 9 How. 263 ; Supervisors $v$. Galbraith, 99 U. S. 214.

8 Woodmff $v$. Hill, 116 Mass. 310 : Woodsen $v$. Owens (Miss.), 12 So. 207; Wehster $v$. Howe Machine Co., 54 Conn. 394, 8 At.. 482

4116 Mass. 310. 
whether the holder was a holder for value; that is, whether the maker was bound under his contract to pay him the money at all events.

In Phipps $v$. Harding, ${ }^{5}$ the plaintiffs in error indorsed a note in Wisconsin for the accommodation of the maker, the note being delivered and payable in Massachusetts. By the general commercial law, as laid down by the United States Supreme Court (and binding upon the federal courts), accommodation indorsers were to be regarded, not as indorsers, but as joint makers of the note, and as such not in general entitled to notice of dishonor. But the law of Massachusetts (lex solutionis) provided that "ali persons becoming parties to notes payable or time, by signature on the oack thereof, shall be entitled to notice of non-payment thereof the same as indorsers." Upon suit brought in the federal court of Wisconsin against the accommodation indorsers, it was held that the Massachusetts law should control, and, though joint makers of the note, they were entitled to notice of dishonor.

The maker's rignt to days of grace, and the nature and ex. tent of that right, will also be governed by the lex solutionis of the maker's contract. ${ }^{6}$

If a note or bill, drawn and payable in one State, is indorsed in another to an indorsee, the indorsement not operating to transfer the title to the indorsee by the law of the place of transfer, but transferring it fully under the lex solutionis of the contract of the defendant (the maker, acceptor, drawer, or prior indorser), it is a mooted question whether the right of the indorsee to sue the defendant is a part of the obligation of the defendant's contract, or is to be governed by the proper law of the indorsement under which the holder claims title, that is, by the law of the place where that indorsement is made. On the

517 C. C. A. 203, 70 Fed. 468 . See Lawrence $v$. Bassett, 5 Allen (Mass.), 140.

6 Pierce $v$. Indseth, 106 U. S. 546, 550 ; Scudder $v$. Bank, 91 U. S. 406, 412; Brown $v$. Jones, 125 Ind. 375, 25 N. E. 452; Stebbins $v$. Leowolf, 3 Cush. (Mass.) 137; Bryant v. Edson, 8 Vt. 325, 30 Am. Dec. 472; Aymar v. Sheldon, 12 Wend. (N. Y.) 439, 444, 27 Am. Dec. 137; Bowen v. Newell, 13 N. Y. 290, 64 Am. Dec. 550. 
one hand, it is urged that the general rule is that the validity and effect of an executed contract of transfer or indorsement is governed by the law of the place where such transfer is made. On the other hand, it is argued that the maker, acceptor, drawer, or prior indorser (the defendant) has undertaken to pay to the payee, or such persons as he may name in accordance with the law with reference to which he, the defendant, contracts (the lex solutionis of the defendant's contract), and that the mere accident that the indorsement to the holder is made abroad under a different law should not affect the defendant's obligation to pay according to his agreement.

In Bradlaugh $v$. De Rin, ${ }^{7}$ a bill was drawn in Brussels on the defendant in London, and there accepted by him. It was afterwards indorsed by $\mathbf{A}$ in Brussels to $\mathrm{C}$, and by $\mathrm{C}$ in Paris to $\mathrm{D}$, and by $\mathrm{D}$ to $\mathrm{E}$, who in Paris indorsed it in blank to the plaintiff, a resident of London. The law of France, where the bill was indorsed to the plaintiff, required that the indorsement of a bill or note should be dated and should express the value received and the name of the indorsee ; and that if the indorsement failed to comply with these requirements, it should not operate as a transfer of the bill, but only as an authority to collect. By the law of England (the lex solutionis of the acceptor's contract) a blank indorsement operated to transfer title to the bill. The court heid that the law of France should govern. ${ }^{8}$

On the other hand, in Lebel $v$. Tucker, ${ }^{9}$ a bill of exchange,

T L. R. 5 C. P. 473 (Exchequer Chamber).

8 The same result was reached in Trimbey $v$. Vignier, 1 Bing. N. c. 151, 27 E. C. L. 336 , the circumstances of which were identical, except that the instrument sued on was a note, the maker of which was the defendant. See also Hibernia Nat. Bank $v$. Iacombe, 84 N. Y. 367, 376.

9 L. R. 3 Q. B. 77 . See also Everett $v$. Vendryes, 19 N. Y. 436, where it was the drawee of the bill who was sued. There the bill was drawn in New Granada and there indorsed in blank, but was payable in New York, where the drawee resided. The drawee refused to accept, and the indorsee sued the drawer in New York. The law of New Granada touching indorsements was similar to the French law mentioned in Bradlaugh $v$. De Rin, supra. It was held that New York was the locus solutionis of the drawee's contract, and that the law of New York should govern the right of the holder to sue the drawee. 
drawn, accepted, and payable in England, was indorsed in France. The circumstances were practically the same as in Bradlaugh $v$. De Rin, supra. But the court, taking the view that it was a matter relating to the obligation of the acceptor's contract, held that it was governed by the English, not the French, law.

Much may be said in favor of either view. It is believed, however, that the sounder doctrine is that enunciated in Bradlaugh $v$. De Rin, supra. ${ }^{10}$

$\S 183$. Same - Obligation of Drawer's or Indorser's Contract. - We have seen in a preceding section, ${ }^{1}$ that much doubt has been expressed whether the locus solutionis of the executory contract of the drawer of a bill or the indorser of a bill or note is the place where the bill or note is payable, or whether it is identical with the locus celebrationis of the drawer's or indorser's contract. It was there stated that the better view was that the locus solutionis of the drawer's or indorser's contract is the place where the bill or note is payable. The important fact to be here noted is that the difference of opinion exists. Hence it is no rebuttal of the general rule that the lex solutionis governs the obligation of his contract to find some of the courts holding that the obligations of the drawer or indorser are governed by the law of the place where the instrument is drawn or indorsed, while others hold them to be governed by the law of the place where the instrument is payable. The principle of both lines of decision is the same: the lex solutionis of the drawer's or acceptor's contract is to govern. The conflict arises in respect to what is the locus solutionis. This question has been already discussed in the section above alluded to. We shall here therefore, for the most part, treat the locus solutionis of the drawer's or indorser's contract indifferently as either identical with the locus celebrationis of that contract or identical with the locus

10 For example, if the facts of Lebel $v$. Tucker had been reversed, and the bill had been accepted in France and payable there, the indorsee claiming under an indorsement made in England, the doctrine of Lebel $v$. Tucker would have necessitated the indorsee's ascertaining the law of France before he took the bill. This would seriously interfere with the negotiability of foreign bills and notes.

1 Ante, $\$ 165$. 
solutionis of the bill or note, according as the particular decisions mentioned take one or the other view. The purpose here is merely to show that the lex solutionis governs.

In Baxter Nat. Bank $v$. Talbot, ${ }^{2}$ suit was brought in Massachusetts against the indorser of a note indorsed in blank in Vermont to the plaintiff. At the time of the indorsement, there had been an oral agreement between the indorser and indorsee (the plaintiff) that the former should not be liable, save to the extent of a certain fund under his control. By the law of Massachusetts (lex fori), evidence could not be introduced of this oral agreement to vary the liability imposed by the indorsement. By the law of Vermont, a contract of indorsement was not an absolute one, but was dependent upon the understanding of the parties, which might be proved. It was urged that the question was one of evidence to be controlled by the lex fori, but the court held it to be part of the obligation of the indorser's contract, to be controlled by the law of Vermont.

With respect to the "proper law" governing presentment, notice of dishonor, protest, and other acts of like kind, ordi-

2154 Mass. 213, 28 N. E. 163.

3 In Downer $v$. Chesebrough, 36 Conn. 39, 4 Am. Rep. 29, a very similar case, the court decided in favor of the lex fori, and yet it is believed both decisions are correct. In Downer $v$. Chesebrough, supra, an action was brought in Connecticut against the indorser of a note, made and indorsed in New York and payable there, it having been orally agreed between the in. dorser and indorsee that the indorsement was only for collection. By the New York law parol evidence of this agreement was not admissible; by the law of Connecticut, it was. The court held that the Connecticut law (lex fori) should control, on the ground that it was a matter of evidence pertaining to the remedy.

If we apply to these two cases the criterion mentioned ante, $\S 180$, as the test by which to ascertain whether a particular matter relates to the obligation of the contract or to the remedy, it will be found that these cases, conflicting as they appear, are both correctly decided. This test is the inquiry whether the lex solutionis might retroactively be altered to the form of the lex fori without impairing the obligation of the contract under the federal constitution. If it could not be so altered constitntionally, the matter relates to the obligation of the contract. Such would seem clearly to be the case, under the circumstances supposed, in Bank $v$. Talbot, supra. If the lex solu. tionis could constitutionally be so altered, the matter relates to the remedy Such would seem to be equally clearly the case in Downer $v$. Chesebrough. 
narily done at the time and place when and where payment is expected to be made, the courts for the most part agree that the law of the place where the bill or note is payable shall govern.

In Rothschild $v$. Currie, ${ }^{4}$ a bill was drawn in England on a French house, and was accepted and made payable there. The payee (the defendant) indorsed the bill in England to the plaintiff. The bill was dishonored at maturity, of which the defendant was notified according to the law of France, but not in accordance with the law of England. The court held the notice sufficient to charge the indorser. ${ }^{5}$

So, in Hirschfield $v$. Smith, ${ }^{6}$ a bill was drawn in England payable to the drawer's order, directed to and accepted by the drawee in France, payable in France and indorsed by the drawer to the defendant in England, who indorsed it to the plaintiff in England. The bill was presented and dishonored, notice of which was given the defendant in accordance with the laws of France, though not within the time required by English law. It was held that the French rule should govern.

In Brown $v$. Jones, ${ }^{7}$ a bill was drawn in Indiana upon a party in Illinois and made payable there. The drawer indorsed the bill to the plaintiff. It was dishonored, and notice thereof was sent to the drawer and indorser within the time permitted by Illinois law, but not by the law of Indiana. It was held that the law of Illinois should control.

In all of these cases a liability was sought to be enforced by the ultimate holder of the bill or note against the drawer or indorser, not by an intermediate indorser against a prior indorser. The same principle, however, should control in the latter case, and the lex solutionis of the bill or note (not of the prior in. dorser's contract) should govern.

Thus, in Horne $v$. Rouquette, ${ }^{8}$ a bill of exchange was drawn

41 Q. B. 43,1 Ad. \& El. N. s. 43.

5 See also Rouquette v. Overmann, L. R. 10 Q. B. 525 ; Wooley v. Lyon, 117 Ill. 244, 57 Am. Rep. 867 ; Gay v. Rainey, 89 Ill. 221, 31 Am. Rep. 76; Briggs $v$. Latham, 36 Kan. 255, 59 Am. Rep. 546, 13 Pac. 393 ; Carnegie Steel Co. $v$. Construction Co. (Tenn.), 38 S. W. 102 ; Stubbs $v$. Colt, 30 Fed. 417.

6 L. R. 1 C. P. 340.

125 Ind. 375,25 N. E. 452 . See also Pierce $v$. Indseth, 106 U. S. 546.

83 Q. B. Div. 514, 28 Eng. Rep. 424. 
in England upon a Spanish house, payable in Spain. It was indorsed in England by the defendant to the plaintiff, who indorsed it in Spain to M, a resident of Spain. Acceptance having been refused in Spain, a delay of twelve days occurred before $\mathbf{M}$ wrote to notify the plaintiff of the dishonor. On the receipt of this notice the plaintiff at once notified the defendant. By the law of Spain, no notice of dishonor by non-acceptance was required. Immediate notice was demanded by the law of England. The defendant pleaded want of due notice, but the court held the plaintiff entitled to recover. ${ }^{9}$

In Musson $v$. Lake, ${ }^{10}$ a bill was drawn in Mississippi upon a firm in Louisiana. It was indorsed by Lake in Mississippi, and was protested by a notary in Louisiana for non-payment. The protest did not show that the bill itself had been exhibited when the demand was made upon the drawee, as the law of Mississippi (but not that of Louisiana) required. The court took the view that Mississippi was the locus solutionis of the indorser's contract, and held that that law should govern the effect of the presentment. It is believed that the better view would be that the law of Louisiana, as the lex solutionis of the bill, should control such questions as this; for with reference to matters connected with the payment of the bill or note at

- In this case, however, the court did not rest its decision clearly upon the ground that the lex solutionis of the bill should govern the obligation of the defendant indorser's contract, though it is believed the ruling amounts to this. It was placed upon the ground that the liability of the plaintiff upon his Spanish indorsement to $\mathbf{M}$, was to be measured by the law of Spain ; that he was responsible to $M$ notwithstanding the delay in the notice of non-acceptance; and that since the plaintiff had paid value to the defendant for the bill, and had himself been legally made liable upon it, he was entitled to look to the defendant for indemnity. If $M$, instead of looking to the plaintiff, had proceeded at once against the defendant in this case, the decision leaves it entirely unsettled what law would have been applicable. It would seem the better and safer rule that the lex solutionis of the bill or note should control in all such cases, thus making the same law the measure of the liability of all the indorsers, no matter where they indorsed.

104 How. 262. See also Slocum v. Pomery, 6 Cr. 221; Powers v. Lynch, 3 Mass. 77; Aymar v. Sheldon, 12 Wend. (N. Y.) 439, 27 Am. Dec. 137; Hunt $v$. Standart, 15 Ind. 33, 77 Am. Dec. 79 ; Douglas $v$. Bank, 97 Tenn 133,36 S. W. 874 . 
maturity, protest, dishonor, etc., all the parties should be presumed to have in mind the law of the place of payment, regardless of the situs of their individual collateral contracts. ${ }^{11}$

Nor is there any reason to presume that the parties have in mind any other law as determining questions of their general liability, at least if we suppose that the place of performance of the indorser's contract is the place where the bill or note is payable. In inquiries relating to such questions, as whether or not the indorser is liable primarily and immediately, or only after due diligence has been used to induce the maker or acceptor to pay, the subject of the inquiry is the obligation of the indorser's contract, which is to be controlled by the lex solutionis thereof. ${ }^{12}$

§184. Obligation to Pay Interest. - If a contract to pay money makes no mention of interest, or though calling for "interest" names no rate at which it shall be paid, it is well settled that the obligation to pay interest on the amount is governed by the lex solutionis of the contract, unless the

11 Scudder $v$. Bank, 91 U. S. 406, 412.

12 Whether the locus solutionis of the indorser's contract is the place where the bill or note is payable, or the place where the indorsement is made, is a mooted question, though the former view is preferable. See ante, $\S 165$. It so happens that the cases which have so far dealt with the particular inquiry mentioned in the text have taken the latter view, and have therefore held that the law of the place of indorsement controls the steps to be taken against the maker or acceptor before forcing the indorser to pay. Hunt $v$. Standart, 15 Ind. 33, 77 Am. Dec. 79; Rose v. Park Bank, 20 Ind. 94, 83 Am. Dec. 306 ; Nichols $v$. Porter, 2 W. Va. 13, 94 Am. Dec. 501 ; Williams v. Wade, 1 Met. (Mass.) 82. See Young v. Harris, 14 B. Mon. (Ky.) 556, 61 Am. Dec. 170 ; Carlisle v. Chambers, 4 Bush (Ky.), 272, $96 \mathrm{Am}$. Dec. 304 . In Rose $v$. Park Bank, supra, a note made in Indiana was payable in New York, and was indorsed in both States. By the law of Indiana, an indorser could not be sued until after suit was brought agaiust the maker. The Indiana court, adopting the theory that the loci solutionis of the indorsers' contracts were the places where they were made, held that as to the New York indorsers the law of New York should govern, while as to the Indiana ipdorsers the law of that State should prevail. This view, it will be observed, throws upon the holder the burden not only of ascertaining the law of each particular place of indorsement, but of ascertaining also the place of such in. dorsement at his peril. This doctrine certainly tends to hamper the negotiability of paper. 
parties clearly contracted with reference to the law of another State. ${ }^{1}$

'The same principle applies whether the claim of interest is made against the maker of a note or acceptor of a bill, or whether it be made against the indorser or drawer. But here again must be noted the line of cleavage amongst the au. thorities as to what is the locus solutionis of the indorser's or drawer's contract. Some of the cases hold that interest is to be computed against the drawer or indorser according to the law of the place where the bill is drawn or the indorsement is made; ${ }^{2}$ while others have held that the interest in such cases is to be computed according to the law of the place where the bill or note is payable. The latter is believed to be the better view. ${ }^{2}$.

A somewhat different question arises in cases where a certain rate of interest is lawfully reserved in the contract in accordance with its lex celebrationis, payable until maturity, no provision being made for interest after maturity. If in such case we suppose the lex solutionis of the contract to authorize a different rate of interest from that expressly reserved in the contract, it becomes important to ascertain which law shall govern the interest after maturity. The parties having shown their intention to contract for interest under the law of the place where the contract is made, that law should govern also as to the

1 Coghlan v. R. R. Co., 142 U.S. 101; Scotland County v. Hill, 132 U. S. 107, 117; Ianusse $v$. Barker, 3 Wheat. 101 ; Kavanaugh v. Day, 10 R. I. 393, 14 Am. Rep. 691; Peck v. Mayo, 14 Vt. 33, 39 Am. Dec. 205; Crawford $v$. Bank, 6 Ala. 12, 41 Am. Dec. 33 ; Morris v. Wibaux, I59 Ill. 627, 43 N. E. 837; Stickney v. Jordan, 58 Me. 106, 4 Am. Rep. 251; Sutro Tunnel Co. $v$. Mining Co., 19 Nev. 121, 7 Pac. 271, 278; Stepp v. Association, 37 S. C. 417, 16 S. E. 134 ; Cooper $v$. Sandford, 4 Yerg. (Tenn.) 452, 26 Am. Dec. 239 ; Ayer $v$. Tilden, 15 Gray (Mass.), 178, 77 Am. Dec. 355 ; Consequa $v$. Fanning, 3 Johns. Ch. (N. Y.) 587, 610; Fanning v. Consequa, 17 Johns. (N. Y.) 511, 8 Am. Dec. 442; Scofield v. Day, 20 Johns. 102 ; Gibbs $v$. Fre. mont, 9 Exch. 24 ; Cooper v. Earl of Waldegrave, 2 Beav. 282, 284.

2 Gibbs v. Fremont, 9 Exch. 24; Crawford v. Bank, 6 Ala. 12, 41 Am. Dec. 33.

s Peck v. Mayo, 14 Vt. 33, 39 Am. Dec. 205 ; Mullen v. Morris, 2 Barı (Penn.), 85. See ante, $\$ 165$. 
unmentioned interest after maturity. ${ }^{4}$ But if the rate of interest legally agreed upon before maturity is that of the place of performance, the latter law will govern interest falling due after maturity. ${ }^{5}$

In Scotland County $v$. Hill, ${ }^{6}$ a Missouri county issued bonds payable in New York, with coupon notes attached representing interest, also payable in New York. The contract was silent upon the point whether or not the coupon notes should themselves bear interest. It was held that the New York law (lex solutionis), not that of Missouri, should govern as to the charging of interest upon the coupons after maturity.

If a judgment be obtained in one State upon a contract to pay money in another, it should be observed that while judgment will be given for the principal sum due, with interest computed according to the law of the place where the contract is payable, yet interest upon that judgment, if unpaid, will be computed in accordance with the law of the place where the judgment is rendered, so far as the courts of that State are concerned. ${ }^{7}$ But if an action is brought in another State upon such judgment, it has been held that interest will be allowed thereon according to the law of the latter State (lex fori), whether or not the judgment sued on specifies the rate of interest it is to bear. ${ }^{8}$

In conclusion, it must be noticed that no question of usury or of invalidity can ever arise upon a contract where no specific rate of interest is agreed upon. In such cases interest is allowed according to the lex solutionis, even though the contract might have been declared usurious and void if the same

4 Cromwell $v$. County of Sac, 96 U. S. 51.

5 Coghlan $v$. R. R. Co., 142 U. S. 101.

6132 U. S. 107.

7 Scotland County v. Hill, 132 U. S. 107.

8 Clark $v$. Child, 136 Mass. 344 ; Wells, Fargo, \& Co. v. Davis, 105 N. Y. 670 ; Neil $v$. Bank, 50 Ohio St. 193, 33 N. E. 720 . And this would seem to be correct upon principle, at least in those cases where the interest upon the first judgment by the law of its situs is greater than that authorized by the lex fori; because the charge thus created is imposed upon the defendant in invitum, and hence the foreign law under which it is claimed should not be given exterritorial force. This is not to deny "full faith and credit" to the foreign judgment. 
rate of interest had been expressly agreed upon, provided the arrangement is not merely a cloak for usury.?

$\S 185$. Covenants and Contracts touching Land. - With respect to the proper law governing the obligations incurred upon covenants of title and the like, contained in deeds of conveyance of land and upon contracts relating to or affecting real estate, much diversity of opinion exists. The disturbing ele ment is found in the influence to be given in such cases to the lex situs of the land.

Here also the chief difficulty lies in ascertaining the locus solutionis of the covenant or contract. Thus, a deed containing covenants is made in one State, conveying land situated in another. It does not necessarily follow that the covenant is to be performed where the land lies, even though it affects the title to the land. If such a deed contains a covenant to repair or to pay taxes, or to do any other act which must be done where the land lies, its locus solutionis is clearly the situs of the land. But if we suppose a covenant of title, as that the grantor is seised in fee, or that he has full power to convey the land in fee, it is not easy to say whether such a covenant is to be performed where the land lies or is to be performed generally, that is, where the covenant is made. The question is of importance, since the obligations incurred by the covenantor will depend upon the lex solutionis. The better opinion seems to be that the lex situs of the land should govern, so far as covenants of title running with the land are concerned, since the grantor must be presumed to be acquainted with that law as well as his own, and to hold otherwise would tend to make the title to the land uncertain. ${ }^{1}$

9 Peck v. Mayo, 14 Vt. 33, 39 Am. Dec. 205. For the "proper law" governing the rate of exchange in respect to foreign contracts, the reader is referred to the lucid discussion in Mr. Justice Story's great work. See Story, Confl. L. §§ 308 et seq.; Greenwald v. Freese (Cal.), 34 Pac. 73.

1 Succession of Cassidy, 40 La. Ann. 827, 5 So. 292; Kling v. Sejour, 4 La. Ann. 128 ; Riley $v$. Burroughs, 41 Neb. 296, 59 N. W. 929 ; Fisher $v$. Parry, 68 Ind. 465; Tillotson v. Prichard, 60 Vt. 94, 14 Atl. 302, 308. In Indiana, the doctrine is that the lex celebrationis of the covenant is also the lex solutionis, and must control. See Worley $v$. Hineman, 6 Ind. App. 240, 33 N. E. 260 ; Cochran ข. Ward, 5 Ind. App. 89, 29 N. E. 795, 796; Jackson 
In Riley $v$. Burroughs, ${ }^{2}$ a deed was made in Nebraska to a tract of land in Iowa, containing a covenant against incumbrances. There had been several prior conveyances of the land, each containing the same covenant, and all the time there had been some unpaid taxes outstanding which constituted a lien on the land. The owner of the land sued a remote grantor for the breach of the covenant. By the law of Nebraska such a covenant was personal only, and none but the immediate grantor could be sued for its breach. By the law of Iowa it ran with the land, and a remote grantor might be sued as well as the immediate grantor. It was held that the law of Iowa should prevail.

In Succession of Cassidy, ${ }^{3}$ Henry Cassidy sold in Louisiana certain lands situated in Texas, with covenants of general warranty, to Horace Cassidy, who sold them in Texas with like covenants to the plaintiffs. By the law of Louisiana suit could be brought upon such covenants only against the immediate grantor, bringing in remote vendors as parties. In Texas, the common law prevailed, by which a suit might be brought upon a breach of covenant of title against any grantor in the chain of title. Suit was brought in Louisiana by the plaintiffs against the estate of Henry Cassidy, they having been evicted by title paramount. Upon the first hearing, the court decided that the Louisiana law should govern, since the matter related to the remedy. But upon a rehearing, it was held that the Texas law should prevail, as it was a matter relating to the obligation of the contract.

That the lex situs of the land will also govern the obligation of a contract to convey the same, the contract being made in another State, can hardly admit of doubt, for the situs of the land is necessarily the ultimate locus solutionis of the contract to convey it; and by that law the measure of performance must be regulated. ${ }^{4}$

The right of one who contracts with another to build or fur-

v. Green, 112 Ind. 341,14 N. E. 89 ; Bethell $v$. Bethell, 54 Ind. 428, 23 Am. Rep. 650 .

241 Neb. 296, 59 N. W. $929 . \quad 340$ La. Ann. 827, 5 So. 292.

4 See Garden City Sand Co. v. Miller, 157 Ill. 225, 41 N. E. 753 ; Carnegie $v$. Morrison, 2 Met. (Mass.) 381, 398. This inquiry must not be con. 
nish materials for the latter, to take out a mechanic's lien upon the latter's houses or lands, is not a part of the obligation of the contract, but is an incident annexed by law to the act of building or furnishing materials for another. Hence, if a mechanic's lien is validly created according to the lex situs of the land, it is immaterial that the contract of which it is the outcome is subject to a different law. ${ }^{b}$

$\S 186$. Interpretation of Contracts. - In ascertaining the obligation of a contract (excluding matters of validity), the important point, as we have seen, is to ascertain the intention of the parties. If the contract is silent with respect to certain obligations of the parties, and they have neither expressly nor impliedly indicated any law by which they intend those matters to be regulated, the general rule is that the law of the place where they propose to act under the contract shall determine what they must do in performance thereof.

We now come to an examination of the law that should control in those cases where the parties have foreseen a certain contingency, and have attempted in their contract to provide for it, but in doing so have used language susceptible of different interpretations in different States or countries. It is immaterial whether the ambiguous terms are technical legal phrases or belong to the ordinary language of the people, or whether the differences of meaning are due to the laws or to the customs of the several States. The result is the same; the parties have used terms which have one meaning in one State and a different meaning in another. The question is which meaning shall be attached to the words used.

fused with that touching the proper law regulating the formal validity of such contract or the capacity of the vendor to enter into it. With respect to these matters, it is believed that the proper law will depend upon whether the contract is treated as an equitable conveyance of the land, or merely as an ordinary personal contract, a breach of which is to be compensated in damages. If the former, the lex situs of the land should govern; if the latter, the lex celebrationis of the contract. Ante, $\$ \S 12,174$. See Polson $v$. Stewart, 167 Mass. 211, 45 N. E. 737.

b U. S. Investment Co. v. Windmill Co., 54 Kan. 144, 37 Pac. 982 ; Campbell $v$. Coon, 149 N. Y. 556,44 N. E. 300 . The lex situs will regulate all charges and liens upon real estate. Ante, $\S 12$. 
The same principles control in this case as are applied in sscertaining the implied obligations of the contract, for the design of the inquiry is the same in both cases, namely, to discover what the promisor has contracted to do.

If the parties expressly refer to the law or usage of a particular State as a guide to ascertain the meaning of the terms they have used, whether that State be the locus celebrationis or the locus solutionis of the contract or a third State, such law or usage becomes part of their contract. So it is also if the surrounding circumstances clearly point to the law or usage of some particular State as in the minds of the parties, though they are silent on the subject themselves. ${ }^{1}$

But if the parties have not thus expressly or by implication indicated the law or usage of any other State as the guide to their meaning, the locus solutionis of the contract will be looked to, just as it would be if the implied obligations of the parties were in question, and for the same reason; because, in the absence of evidence of other intent, the parties must be presumed to have in mind for the purpose of performance the law and usage of the place of performance. Slight evidence of a different intent may suffice however to alter this rule, and to cause the lex solutionis to yield to some other law as the guide to the parties' intention; and the evidence may be circumstan. tial as well as direct.

Thus, it is a general rule that the language used in a life insurance policy, designating the beneficiary (subject to statutory or charter restrictions as to who may be designated), is to be regarded as the language of the assured alone and is to be treated as of a testamentary character, receiving as nearly as possible the same construction as if used in a will under the same circumstances. Hence the phrase "heirs" or "heirs at law," etc., in a policy of life insurance is to be construed, in the absence of evidence of a contrary intent, in accordance with the lex domicilii of the assured, though the insurance contract is entered into or payable in another State, by whose law such terms would be given a different meaning. ${ }^{2}$

1 Dicey, Confl. L. 57-59.

2 Knights Templar Association v. Greene, 79 Fed. 461; Northwestern 
In Heebner $v$. Ins. Co., ${ }^{8}$ a policy of insurance upon a ship was written in one State and signed there by the president and secretary of the company, which was established there. It was however stipulated that it was not to be binding until countersigned by the agent in Massachusetts. The insurance was against "total loss only." The ship was captured and condemned as prize, whereupon the owner notified the underwriters that he abandoned the ship and claimed as for a total loss. The court held that the Massachusetts law should determine not only whether a total loss had occurred, but what was the effect thereof; and accordingly decided that the phrase "total loss" covered a constructive loss, that the notice given the underwriters was a sufficient abandonment, and that, according to the Massachusetts rule, one third new for old was to be deducted in estimating the constructive total loss.

In London Assurance $v$. Companhia de Moagens, ${ }^{4}$ a cargo of wheat was shipped on a British steamer at New York for Lisbon, and was insured by an English company, through its agents in Philadelphia, "free of particular average unless the vessel be sunk, burned, stranded, or in collision," all losses to be paid in sterling at the company's offices in London, and "claims to be adjusted according to the usages of Lloyds." The ship was in collision before it left port, and the consequent injury to the vessel and bad weather causing some leakage, the salt water entered and injured a cargo of wheat. The captain

Association v. Jones, 154 Penn. St. 99, 26 Atl. 253; Masonic Association v. Jones, 154 Penn. St. 107, 26 Atl. 255. In Mullen $v$. Reed, 64 Conn. 240, 29 Atl. 478, a life insurance policy was issued in Massachusetts to a resident of that State, being written in favor of the assured's "heirs at law." The assured afterwards changed his domicil to Connecticut and died there. The court held that the law of Massachusetts, not that of Connecticut, should control the meaning to be attached to the phrase. This decision was clearly correct; for whatever the rule may be tonching the law that should govern the interpretation of a revocable will, npon a change of the testator's domicil (ante, § 148), the above rule must be applied to a contract, whose obligation attaches at the time it is made, and cannot afterwards be altered save by the mutnal consent of the parties.

310 Gray (Mass.), 131.

4 167 U.S. $149,160,167$. 
of the ship found it necessary to put in at Boston, and after a survey decided to sell the whole cargo for the benefit of all concerned. The question was made whether the insurance contract covered this loss, and it was held that the law of England (lex solutionis), being the law with reference to which the parties contracted, must govern the interpretation of the terms used in the contract. The insurance company was held to be responsible for the loss, because according to the English doctrint "if a ship be once in collision during the adventure, after the goods are on board, the insurers are by the law of England liable for a loss covered by the general words in the policy, though such loss is not the result of the original collision, and but for the collision would have been within the exception contained in the memorandum, and free from particular average as therein provided."

In First Nat. Bank $v$. Shaw, ${ }^{5}$ the question was as to the meaning of the phrase "B'k \% to T. W. Griffin \& Co.," occurring in a bill of lading, executed in Toledo, Ohio, of merchandise there shipped to New York and delivered in Ohio to secure advances made to the consignee in New York. The court, holding that the phrase was to be interpreted according to the business usage in Toledo, said in the course of its opinion: "The true inquiry is, what was the intent of the parties. It would seem in a case like the present, when the contract was made in Ohio by Toledo parties, the money being advanced there and the security taken there, that they had in view in employing words their own usages, even though the goods were to be sent to another State and ultimately sold there if the advances were not repaid." 6

Other examples might be given. The terms, "dollars," ? "pounds," 8 "usance," 9 "month," 10 etc., are instances of words possessing different meanings in different countries, with regard to which questions of this sort may arise.

561 N. Y. 283, 293-294.

6 See Huse $v$. Hamblin, 29 Ia. 501, 4 Am. Rep. 244.

7 Greenwald $v$. Freese (Cal.), 34 Pac. 73.

8 Story, Confl. L. $§ 271$.

9 Story, Confl. L. \$ 271.

10 Story, Confl. L. \$270. 
A fuller examination of the authorities would be of little service, since the circumstances of each case must be looked to in order to ascertain the intention of the parties. ${ }^{11}$

11 The reader is referred to Whart. Confl. L. $\$ \S 433-439$, where an attempt has been made to deduce some general principles from the decided cases. 


\section{CHAPTER XIX.}

\section{DISCHARGE OF CONTRACTS.}

\$187. Various Sorts of Discharge. - Under the term dis. charge of a contract are comprised all matters which, arising superveniently to the execution of the contract, may be urged as a total or partial defense to an action brought to enforce it. They may consist in the actual performance of the contract, or tender of performance, in exact accord with its terms; of the substitution of a new agreement therefor, a release, or a mutual rescission of the contract; of the discharge of a surety by the discharge of the principal or the extension of time, or a discharge in bankruptcy, etc.

These various matters of discharge may be classified into three main groups, as follows: (1) Those which result from the performance, or tender of the performance, of the contract according to its exact terms; (2) Those resulting from a supervenient agreement or understanding of the parties; and (3) Those resulting from the mere operation of the law itself, without any express agreement of the parties to that effect, and without performance, or offer of performance, by the promisor.

These several sorts of discharge, being entirely distinct in character, are regulated by different principles. It cannot be expected, nor is it true, that the same law will govern them all. The nature of the particular matter of discharge pleaded must first be ascertained before the proper law controlling its effect can be determined.

$\S 188$. Discharge by Actual Performance or Tender. - If it be alleged that the contract has been discharged in whole or in part by the actual performance thereof according to its terms, the truth of the allegation becomes a mere question of fact after it has been once ascertained what duties the contract imposes on 
the promisor. All that is necessary is to apply the principles already considered, by which to determine the proper law governing the obligation and interpretation of the contract, that is to say, the lex solutionis of the contract (in the absence of evidence that the parties had in view a different law). ${ }^{1}$ As has been said by the Supreme Court of the United States in a leading case, ${ }^{2}$ speaking of the proper law governing a contract: "Matters connected with its performance are regulated by the law prevailing at the place of performance."

Thus in an English case ${ }^{3}$ it was held that a contract payable in South Carolina was validly discharged by its payment in South Carolina in depreciated paper money, which was there legal tender.

In Graham $v$. Bank, Graham and his wife resided in Maryland. The wife being the owner of certain shares of stock in a bank in Norfolk, Virginia, dividends accrued upon the shares, and were paid by the bank officers to her husband. By the law of Maryland the wife was entitled to the sole and separate use and control of her property. In Virginia the common law prevailed, and the husband could give a valid acquittance of the wife's debts. The question was whether the bank's payment of the dividends to the husband constituted a valid discharge of its obligation to pay dividends on the wife's stock. The New York court held that since the dividends were payable in Virginia, a payment according to Virginia law was sufficient, though by the lex domicilii the hushand was not entitled to the wife's personalty. Though the husband was bound to account to the wife for the dividends under the law of Maryland, the payment to the husband discharged the bank under the law of Virginia. ${ }^{5}$

1 See Denny $v$. Williams, 5 Allen (Mass.), 1 ; May v. Breed, 7 Cush. (Mass.) 15, 54 Am. Dec. 700.

2 Scudder v. Bank, 91 U. S. 406, 413.

3 Anon., 1 Bro. Ch. Cas. 376.

184 N. Y. 393, 38 Am. Rep. 528.

5 If the bank had pleaded a release by the husband, instead of payment to him, the husband's title would have depended upon the Maryland law (lex domicilii), and so would the validity of the release 
But a performance "in accordance with the terms of the con. tract" supposes a complete compliance with its terms in respect to the time and place of performance, as well as other matters. Hence a performance, though otherwise strictly in accordance with the terms of the contract, if occurring at another time or place than that named, will not operate to discharge the contract, unless accepted by the promisee. In such case, the discharge ceases to belong to the first class and becomes a discharge by substituted agreement, which is or may be governed by altogether different rules, to be discussed in the following section."

The same principles govern the tender of performance of the contract according to its terms. If the tender is made at the time and place agreed upon for performance, the sufficiency of the tender, and its effect as a total discharge of the contract or os to subsequently accruing interest only, is to be determined by the lex solutionis of the contract, unless the parties had in mind a different law when they entered into the contract. ${ }^{7}$

Thus, in Searight $v$. Calbraith, ${ }^{8}$ a bill of exchange was drawn in Pennsylvania, payable in Paris, and accepted there. Upon presentation for payment, the acceptors offered to pay in French assignats (paper money), which was in France a legal tender for debts. The holder insisted on payment in gold or silver. It was held that the question whether this was a proper tender depended upon the law with reference to which the parties contracted. The court further held that it was for the jury to determine what law the parties had in mind, as regulating the mode of payment.

In Warder $v$. Arell, 9 a bond was made in Pennsylvania, des. ignating no place of payment. On the day appointed for payment, the obligor tendered the money in bills of credit issued by the Congress of the United States, which were refused. A Penusylvania statute, in order to sustain the value of these

6 See Vermont Bank v. Porter, 5 Day (Conn.), 316, 5 Am. Dec. 157.

7 Searight $v$. Calbraith, 4 Dall. 325, 327 ; Warder $v$. Arell, 2 Wash. (Va.) 282, 295, 1 Am. Dec. 488. See Pritchard v. Norton, 106 U. S. 124, 132.

84 Dall. 325.

- 2 Wash. (Va.) 282, 1 Am. Dec. 488. 
bills, had enacted that one refusing to accept them in payment of debts should forfeit the debt. The Virginia court held that the Pennsylvania law should govern, and that since the effect of the tender and refusal there was to discharge the contract totally, the same effect must be given to it in Virginia.

On the other hand, a tender made at a place other than that agreed upon as the place of performance of the contract, though in all other respects conforming to its terms, may be rejected by the promisee. Unless accepted by him, it is of no effect. ${ }^{10}$

§ 189. Discharge by Substituted Agreement. - Under this head are to be included all those acts which, while not constituting an exact performance of the contract according to its terms, yet operate as a discharge because intended and accepted as such by the parties.

Thus the payment of a bond or note, made at a time or place other than that expressly agreed upon, a release, a mutual rescission of the contract, the substitution of a new agreement, etc., are instances of this sort of discharge. In all these cases the effect of the discharge is due to the subsequent agreement of the parties.

If the intention of the parties is clear, and that intention is validly executed, the effect is to discharge the old contract and to destroy its obligation absolutely. The effect of such subsequent agreement therefore cannot be regarded as a part of the obligation of the original contract. Effect is given to it, if at all, not because of any intention of the parties, express or implied, contained in the original contract, but by virtue of their subsequent intention as displayed actually or presumably in their new agreement. Hence the law governing the obligation of the original contract has no necessary connection with the effect to be given the new agreement, which, as to its validity,

10 Noyes $v$. Wyckoff, 114 N. Y. 204, 21 N. E. 158 ; Abshire v. Corey, 113 Ind. 484, 15 N. E. 685 ; People's Bank v. Norwalk, 56 Conn. 547, 16 Atl. 257 ; Allshouse $v$. Ramsay, 6 Whart. (Penn.) 331, 37 Am. Dec. 417 . If no special place of performance is agreed upon, the sufficiency and effect of the tender will be governed hy the law of the place where the contract is made. See Warder v. Arell, 2 Wash. (Va.) 282, 1 Am. Dec. 489 ; Vermont Bank v. Porter, 5 Day (Conn.), 316, 5 Am. Dec. 157. 
its obligation and effect, and its interpretation, must be con. trolled by its own law.

If the new agreement is executed, as in the case of actual performance at a time or place other than that agreed upon in the original contract, or in case of a release, the lex loci contractus will control its validity, obligation, and interpretation.

Thus, the obligation of a bond or other sealed contract cannot by the common law be released except by an instrument of equal dignity, under seal. But by the civil law it is otherwise. Hence if a bond made and payable in England should be discharged in France (where the civil law prevails) by a release not under seal, it should be considered a valid discharge everywhere, including Eugland. ${ }^{1}$

But if the substituted agreement is executory, to be performed in some State other than that wherein it is made, it may be a more difficult matter to ascertain the law which should determine its effect. The reasoning above given would seem to establish definitely that the law governing the obligation of the original contract plays no part in the solution of this question. It is the proper law governing the substituted executory contract which must determine its effect.

Its validity must be determined by the same law that governs the validity of other contracts, that is to say, by the lex celebrationis if the invalidity relates to the making of the contract; by the lex solutionis, if it relates to the performance; and by the lex loci considerationis, if it relates to the consideration.

But if there is no question of the validity of the substituted promise, but only of its effect as a discharge or merger of the original contract, this is a matter pertaining to the obligation of the new agreement, and primarily depends upon the parties' intention. If the agreement is silent upon that point, its effect must be determined by the law with reference to which they actually or presumably contracted. In the absence of evidence of a different intent, since the new contract, if it operates as a discharge at all, takes effect as soon as it is entered into, not when it is performed, the parties should generally be pre

1 Story, Confl. L. $\S \S 351 a, 351 b$. 
sumed to have in view the law of the place where it is entered into (lex celebrationis), though it is to be performed elsewhere.

Thus, by the law of some States, in the absence of evidence of a different intention, a note given for an antecedent indebtedness discharges or merges the original indebtedness, so that thenceforth action can be brought only upon the note. In other States this is not the case. Some of the decisions seem to take the view that the effect of thus taking a note for an antecedent indebtedness is a part of the obligation of the original contract, to be determined by the law governing its obligation (Iex solutionis).2 But the better opinion is that the effect of the note, as constituting a discharge or merger of the original indebtedness, is to be governed by the lex celebrationis (not the lex solutionis) of the note, ${ }^{3}$ unless the note be given in pursuance of a previous agreement of the parties made in another State, under a different law.

§ 190. Discharge by Operation of Law - In General. - This sort of discharge comprehends all those supervenient matters which, though not supposing a performance of the contract nor a substituted agreement of the parties, yet operate by mere act of the law in discharge of the contract. The alteration or interlineation of written contracts in material points; the discharge of a surety by reason of a subsequent change in the terms of the principal contract, or his discharge by giving notice to the creditor to sue; or the discharge of an indorser by reason of failure to give him due notice of dishonor, etc., are instances of discharges resulting purely by operation of law.

It is well settled that the effect of acts of this character, alleged to constitute a discharge of the contract, is a part of its obligation, and therefore in the absence of evidence of other intent it is to be regulated by the lex solutionis of the contract, as being the law presumably in the minds of the parties at the time the promise is made. Such matters constitute, so to

2 Tarbox $v$. Childs, 165 Mass. 408, 43 N. E. 124; Vancleef $v$. Therasson, 3 Pick. (Mass.) 12; Bartsch $v$. Atwater, 1 Conn. 409. The objections to this view have just been mentioned.

8 Thomson-Houston Electric Co. v. Palmer, 52 Minn. 174, 53 N. W. 1137; Gilman $v$. Stevens, 63 N. H. 342, 1 Atl. 202. 
speak, implied conditions upon which the contract is entered into, a breach of which will discharge the promisor from his obligation to perform his agreement.

Many illustrations of the application of these principles have already been given in the previous chapter, where the law governing the obligations of contracts has been discussed, and there is no occasion here to do more than merely refer to that discussion.

$\S 191$. Same - Discharge in Bankruptcy. - The discharge of a debtor in bankruptcy belongs in the main to that class of discharges knowu as discharges by operation of law, in that it neither supposes a performance nor a substituted agreement. But there are peculiar features pertaining to it which do not permit it to be governed altogether by the same principles that control other discharges by operation of law.

There has been in the past much conflict of opinion touching the law controlling the effect upon a contract of a discharge in bankruptcy or insolvency. This conflict seems now in the main to be happily settled in this country, at least as between the States of this Union, by the decisions of the United States Supreme Court and the later decisions of the State courts.'

A discharge in bankruptcy, releasing the debtor from further liability upon a judicial ascertainment of the fact that he has surrendered his property to his creditors, differs from other matters of discharge by operation of law, in that its effect depends in part upon a judicial proceeding somewhat in the nature of a forfeiture of the rights of creditors. In order that a tribunal may decree such a discharge, or at least in order that its decree should have any exterritorial effect, justice demands that the bankrupt's creditors should be given an opportunity to protect their rights, or at least should be themselves subject to the law under which the court acts.

1 These earlier views are discussed and commented upon in Story, Conf. L. $\S \S 335-351 d$, and will not be here considered. The fallacy of these cases lay in not observing the dual nature of the discharge in bankruptcy which, while in some measure dependent for its effect upon the obligation of the contract, is also dependent upon the jurisdiction of the insolvency court. The latter element was disregarded in the earlier cases. 
But a discharge in bankruptcy resembles other discharges by operation of law in that its effect is a part of the obligation of the contract alleged to be thereby discharged, and therefore (sub. ject to the qualification above mentioned) its effect must depend upon the intention or understanding of the parties in entering into the contract, or, in the absence of any expression by them, upon the law with reference to which they must be presumed to have contracted (lex solutionis).

Two conditions then must concur in order to give such a discharge any exterritorial effect. The first is that the tribunal whose duty it is to grant the certificate of discharge should have control and jurisdiction over the creditor. The second is that the "proper law" governing the obligation of the contract should recognize such a discharge as a valid release of the debtor from further obligation to perform it.

In regard to the first of these conditions (supposing the second complied with), it has been held repeatedly by the Supreme Court of the United States that a discharge in bankruptcy or insolvency granted in one State will be of no effect in another State of the Union, if the creditor is a citizen of another State than that of the discharge, unless by voluntarily taking part in the insolvency proceedings, or otherwise, he has come personally under the control and jurisdiction of the court." For "when in the exercise of that power [to discharge a debtor] the States pass beyond their own limits and the rights of their own citizens, and act upon the rights of citizens of other States, there arises a conflict of sovereign power and a collision with the judicial powers granted to the United States, which renders the exercise of such a power incompatible with the rights of other States and with the constitution of the United States." 8

It will be observed that this doctrine rests upon the theory that the federal constitution forbids an interference by one

2 Sturges $v$. Crowninshield, 4 Wheat. 122 ; Ogden $v$. Saunders, 12 Wheat. 213 ; Cook v. Moffat, 5 How. 295 ; Baldwin v. Hale, 1 Wall. 223 ; Gilman v. Lockwood, 4 Wall. 409 ; Denny v. Bennett, 128 U. S. 489, 497. See Pul. len $v$. Hillman, 84 Me. 129, 24 Atl. 795; Rosenheim v. Morrow, 37 Fla. 183 . 20 So. 243.

Baldwin v. Hale, 1 Wall. 223, 231. 
State, having no jurisdiction, with the rights of citizens of another State. Under this theory, not only has the insolvency court of the first State no jurisdiction to grant the debtor a discharge which will be effective in other States as against a non-resident creditor not within its control, but it is without jurisdiction for any purpose in such case. The discharge will be as ineffectual in the State of the discharge as in other States. ${ }^{4}$

A question has been made whether the principles thus laid down by the Supreme Court are applicable to the case of a creditor who was a citizen of the State of discharge when the contract was made, but who has subsequently and before the insolvency proceedings commenced removed out of the jurisdiction into another State, and has never returned thither, nor taken part in the insolvency proceedings. But it now seems to be settled that such a creditor is not ipso facto subject to the insolvent laws of his former domicil. The discharge is of no effect against him, unless he in some way comes personally within the jurisdiction of the insolvency court. ${ }^{5}$

In Chase $v$. Henry, ${ }^{6}$ an action was brought in Massachusetts by a firm consisting of three partners, two of whom were residents of Massachusetts and one of New Hampshire. The defendant pleaded a discharge in insolvency under the Massachusetts law, which the plaintiffs contended was of no effect as to any of them because it was a debt due to them jointly, and one of them being a non-resident of Massachusetts the discharge could not be pleaded as against him. And the court (divided four to three) so held.

Although under the decisions of the Supreme Court this result is attributed to the operation of the federal constitution, and hence those decisions cannot, in strictness, be said neces-

4 Denny $v$. Bennett, 128 U. S. 489 ; Pullen v. Hillman, 84 Me. 129, 24 Atl. 795 ; Silverman v. Lessor, 88 Me. 599, 34 Atl. 526 ; Stoddard $v$. Harrington, 100 Mass. $87,88$.

5 Pullen v. Hillman, 84 Me. 129, 24 Atl. 795 ; Roberts $v$. Atherton, 60 Vt. 563, 15 Atl. 159, 160 ; Norris $v$. Atkinson, 64 N. H. 87, 5 Atl. 710 . But see Stoddard $v$. Harrington, 100 Mass. $87,88$.

6166 Mass. 577 . 
sarily to apply to cases where the creditors affected are citizens of foreign countries, ${ }^{7}$ yet when it is remembered that one great purpose of the constitution was to recognize, as between the States, an even more enlightened comity than that prevailing between States wholly foreign to one another, and to enforce in each a more than ordinary respect for the laws and judicial proceedings of the others, it will be seen that, when the Supreme Court holds that a discharge in insolvency granted in one State shall have no effect in another as against residents of other States, a fortiori should the same reasoning prevent foreign States from recognizing such a discharge, or a State of this Union from recognizing such a discharge in a foreign country, as against creditors not resident in the State of discharge and taking no part in the insolvency proceedings.

But so far as concerns the intra-territorial effect of the disaharge in the State where it is granted, there may be a decided difference between cases, all the elements of which have their situs within the United States, and those in which some of the elements are foreign, for example, in case of an English contract or an English creditor. It is believed that it is impossible for any court in this Union constitutionally to grant a discharge in bankruptcy, if either the situs of the contract discharged thereby or the situs of the creditor is in another State of the Union, the creditor taking no part in the proceeding. ${ }^{8}$ But the federal constitution does not extend in like manner to protect foreign contracts and foreign creditors. Their rights are to be regulated in each State by its own law.

We have heretofore presumed that the contract alleged to have been discharged is to be performed in the State of the discharge, so that the parties must be held to have contemplated the contingency of such a discharge as a part of the obligation of the contract; and we have seen that, regardless of the "proper law," at least as between these States, unless the creditor is subject by residence or otherwise to the jurisdiction of the in-

7 Judge Story seems to take this view. See Story, Confl. L. $\$ 341$. But see Story, Confl. L. $\$ \S 349$ et seq.

8 Cook v. Moffat, 5 How. 295, 308, 312; Baldwin v. Hale, 1 Wall. 223, 232. 
solvency court, it has no power to grant the discharge. The fact that the situs of the contract is elsewhere than in the State of discharge, and that the law of that situs does not recognize such discharges, but serves to emphasize its invalidity. In such case the situs of the contract is immaterial.

But if we suppose the insolvency court to have jurisdiction of the creditor, while the contract itself is to be performed in another State whose law does not recognize a discharge in bankruptcy or insolvency, the question is squarely presented whether the effect of the discharge shall be held to depend wholly upon the jurisdiction of the insolvency court, or in part also upon the law governing the obligation of the contract (lex solutionis). It is believed that both must concur. ${ }^{9}$

9 See Baldwin $v$. Hale, 1 Wall. 223, 232 ; Cook v. Moffat, 5 How. 295, 308,312 


\section{PART VI.}

\section{SITUS OF TORTS AND CRIMES.}

\section{CHAPTER XX.}

SITUS OF 'TORTS.

\$192. Local and Transitory Actions. - A tortious liability may be briefly described as any private liability that is not contractual. ${ }^{1}$ It may consist of an injury done to the person or to property, either real or personal.

If an injury be done to the person or to the personalty of another, it is at common law said to be "transitory;" that is, the liability therefor is deemed to be personal to the perpetrator of the wrong, following him whithersoever he may go, so that compensation may be exacted from him in any proper tribunal which may obtain jurisdiction of the defendant's person, the right to sue not being confined to the place where the cause of action arises. ${ }^{2}$

1 Special statutory liabilities, such as those sometimes imposed by law upon the stockholders of a corporation for its debts, are remedial and contractual in their nature, not tortious. They have been discussed elsewhere. See ante, $\S 10$.

2 See Dennick v. R. R. Co., 103 U. S. 11 ; Stewart v. R. R. Co., 168 U. S. 445, 448 ; Evey v. R. R. Co., 52 U. S. App. 118, 81 Fed. 294 ; Helton v. R. R. Co., 97 Ala. 275, 12 So. 276, 282; Herrick v. R. R. Co., 31 Minn. 11, 47 Am. Rep.771; Nelson v. R. R. Co., 88 Va. 971, 14 S. E. 839 ; De Witt $v$. Buchanan, 54 Barb. (N. Y.) 31 ; Machado v. Fontes, 2 L. R. Q. B. D. 231 . With re. spect to torts to personal property, see Southern Pac. Co. v. Graham, 12 Tex. Civ. App. 565, 34 S. W. 135 ; Belknap Sav. Bank $v$. Robinson, 66 Coun. 542, 34 Atl. 495 . It is to be observed however that when the purpose of the suit is not to recover damages, but a specific chattel tortiously taken or detained, and that alone (not the alternative value), the action is in rem, and like all such proceedings is strictly local, since in a proceeding of that character the 
On the other hand, with regard to real property, the common law held not only that actions to try the title to land were local (as is necessarily the case, they being proceedings in rem), but that all actions for trespasses thereon or torts thereto, though in personam, were local also, and even actions ex contractu if the defendant's liability depended upon ownership of the land and privity of estate, as where the defendant, being an assignee of the land, is sued for a breach of a covenant running with the land. ${ }^{8}$

But in most States at present the distinctions of the common law bave either been totally abrogated (save where the suit is upon the title) or have been regulated by statute. Whether a particular action is to be regarded as local or transitory, and hence whether a remedy shall be giren for a foreign tort, depends upon the lex fori, not upon the law of the place where the cause of action arises. The question relates to the remedy, not to the substantive liability. ${ }^{4}$ But the modern tendency is to throw the doors of the courts wide open to the complaints of suitors with respect to injuries perpetrated in other States against their persons or property, provided proper jurisdiction of the defendant can be obtained, the citizenship or domicil of eithər party being generally immaterial. 5 So marked indeed is this tendency towards liberality in these cases, that it has been held in Minnesota, where a tort was committed upon real property in another State, that an action therefor might be brought in any Minnesota court clothed with jurisdiction of the cause and of the parties, though the Minnesota statutes provided

court must have jurisdiction of the res. Belknap Sav. Bank $v$. Robinson, supra.

3 Huntington v. Attrill, 146 U. S. 657, 669, 670; Tillotson $v$. Prichard, 60 Vt. 94, 14 Atl. 302, 307 ; Worley $v$. Hineman, 6 Ind. App. 240, 33 N. E. $260,262$.

4 See Huntington $v$. Attrill, 146 U. S. 657, 669, 670 ; Worley v. Hineman, 6 Ind. App. 240, 33 N. E. 260, 262 ; Pullman Palace Car Co. v. Lawrence (Miss.), 22 So. 53, 55.

5 Pullman Palace Car Co. v. Lawrence (Miss.), 22 So. 53, 55, 56; St. Louis, etc. R. R. Co. v. Brown, 62 Ark. 254, 35 S. W. 225, 226 ; Mitchell v. Harmony, 13 How. 115. See De Witt $v$. Buchanan, 54 Barb. (N. Y.) 31 : Whart. Confl. L. § 478. 
that actions for torts to land (in Minnesota) should be brought only in the courts of the county where the land lay. Thus, although torts to land situated in Minnesota remained local under the laws of that State, torts to land outside the State were held to be transitory.

$\S 193$. Torts, Common Law and Statutory. - In countries whose jurisprudence is founded upon the common law of England, a primary and important division of torts, which should be noted at the very outset of this discussion, is that subsisting between common law and statutory torts.

Common law torts are such as are actionable, or at least condemned, by the common law without the aid of any statute, the demand for compensation being justified both upon principles of inherent justice and of expediency; while statutory torts comprise those acts for which redress is given by statute, but which were not actionable at common law, either because no essential principle of right and justice demanded it or because redress could not be afforded without violating some technical rule of the common law: ${ }^{1}$

1 Most of the cases hereafter cited sustain this division of torts. But in Stewart $v$. R. R. Co., 168 U. S. 445,448 , this classification seems to be disapproved and substituted by another, referring to the head of "common law torts," all those wrongs, whether actionable at common law or not, which an inherent sense of justice demands should be compensated by damages. Hence, in that case, notwithstanding the common law maxim that "personal actious die with the person," and the rule deduced therefrom that a death by wrongful or negligent act was not actionable at common law, the court held that a tort resulting in death was a "common law tort." The division of torts thus adopted by the Supreme Court in Stewart $v$. R. R. Co., if recognized generally, would probably revolutionize the whole basis upon which the principles of private international law tonching torts now rest.

Torts committed in States which are not governed by the common law at 2ll, as those States whose laws are based upon the Roman law, would seem naturally to fall under the head of statutory torts. But if the wrong is one which an inherent sense of justice demands should be compensated in damages, it would seem that the distinction taken in Stewart $v$. R. R. Co., supra, would be applied to it. It would then be regarded as a common law tort, and strict compliance with the letter of the lex loci delicti (generally required in actions upon foreign statutory torts) would not be rigorously demanded. See Evey v. R. R. Co., 52 U. S. App. 118, 81 Fed. 294, 38 L. R. A. 387. See post, § 214, note 4 . 
As will be seen hereafter, ${ }^{2}$ in case of a State whose jurisprudence is based upon the common law and whose law is brought Into question in another State, the presumption, in the absence of evidence to the contrary, is that the common law remains in force unchanged by statute. Hence, a tort committed in one such State, which is actionable at common law, will be presumed in the courts of another State to be actionable in the former ${ }^{3}$ and $e$ converso, if such tort is not actionable at common law, it will not be presumed by the courts of the forum to be actionable in the common law State where committed. ${ }^{4}$ In the latter case it must be shown affirmatively that the statutes of the locus delicti have made the tort actionable, before the courts of the forum will entertain the action. ${ }^{5}$

If the lex loci delicti is not based upon the common law, but upon the Roman law or some other system, and is under investigation in a State based upon the common law system, no presumption will ordinarily arise as to the provisions of the former law; they must be proved as facts. Sometimes however the courts of the forum will presume a foreign law to be the same as the lex fori. ${ }^{6}$

From what has already been said it will be seen that the ex. istence or recognition of a statutory tort in the State where it is committed is not to be presumed by the courts of other States. The statute upon which it rests must be proved as a fact. That the tort complained of has been rendered actionable by the statutes of the forum will not usually furnish any ground for a presumption that a like statute exists in the State where the tort was committed. ${ }^{7}$

2 Post, § 214.

8 Whitford v. Panama R. R. Co., 23 N. Y. 468; Thurston v. Percival, 1 Pick. (Mass.) 415.

4 Louisville \& N. R. R. Co. v. Williams, 113 Ala. 402, 21 So. 938 ; Kahl v. R. R. Co., 95 Ala. 337,10 So. $661,662$.

5 Whitford v. Panama R. R. Co., 23 N. Y. 468 ; Kahl v. R. R. Co., 95 Ala. 337,10 So. 661,662 . But see post, $\S 214$, as to presumption that the foreign law is identical with lex fori.

6 This whole question of presumptions touching foreign laws is discussed fully hereafter. See post, $\S 214$.

7 Huntington $v$. Attrill, 146 U. S. 657 ; Stewart v. R. R. Co., 168 U. S. 
A principal distinction between common law and statutory torts committed abroad lies in the fact that, if the tort is statutory, all the material provisions of the foreign statute must be carried out, if it is enforced at all, whether they relate to the liability of the defendant, the person who is to sue, the time within which the suit is to be brought, or any other conditions imposed by the statute. ${ }^{8}$ But if the wrong is a common law tort, the lex loci delicti is looked to only in order to ascertain the substantial rights of the parties. The mode of procedure, the time within which the suit is to be brought, etc., are regarded as relating to the remedy and are controlled by the lex fori, not by the lex loci delicti.

§ 194. Exceptions to Operation of Lex Loci Delicti. - The law of the situs of a tort is of course the "proper law" to govern the liabilities and rights arising therefrom. If not liable by the lex loci delicti, the general rule is that the defendant will not be liable elsewhere. ${ }^{1}$ If liable by that law, he will usually be held liable wherever the question arises to the same extent as if he were sued in the locus delicti itself.

But, as in other cases, there are occasions upon which the foreign lex loci delicti will not be enforced in the courts of the forum. These are in the main the same exceptional cases which apply to the operation of any proper foreign law. ${ }^{2}$

As applied to torts, they may be said to consist of (1) Those 445, 448 ; Railroad Co. v. Betts, 10 Colo. 431, 15 Pac. 821. In such cases, however, the courts sometimes presume the foreign law to be identical with the lex fori. See post, $\$ 214$.

8 Post, $\$ \S 200-202$.

1 Carter v. Goode, 50 Ark. 155, 6 S. W. 719 ; Le Forest v. Tolman, 117 Mass. 109. Bnt see Machado $v$. Fontes, 2 L. R. Q. B. D. 231, in which it is held that if the tort is not justifiable or excusable under the lex loci delicti, but is only not actionable there, an action may be brought thereon in another State. This would seem to be an instance in which a hard case made bad law. The decision is in direct contradiction of all the principles of private international law relating to torts, and if followed to its logical conclusions would overturn all the rules established for the governance of such cases. The same question may arise in actions brought in one State for death resulting from a wrongful act in another State. No such principle has been held applicable to them. See post, $\S 200$. But see Stewart v. R. R. Co., 168 U. S. 445, 448.

2 See ante, Chapter II. 
cases where the "proper law" is in direct contravention of the law or policy of the forum $;^{8}$ (2) Where the remedy prescribed $f: r$ the tort by the lex loci delicti is penal in character; ${ }^{4}$ and (3) Statutory torts, where the statute, in creating the liability, at the same time creates a mode of redress peculiar to that State, by which alone the wrong is to be remedied. ${ }^{5}$

It should be especially observed, however, that these exceptional cases differ for the most part in their application from those heretofore dealt with in one important respect. In case of exceptions to the "proper law" governing other matters, such as transfers of property or executory contracts, if the "proper law" is not applied the lex fori is substituted therefor; some law is applied to the case. In the case of torts, if the "proper law" is not applied, the case usually falls to the ground; no law is substituted therefor. ${ }^{6}$

3 Fierrick v. R. R. Co., 31 Minn. 11, 47 Am. Rep. 771, 774 ; St. Luouis, etc. R. R. Co. v. McCormick, 71 Tex. 660, 9 S. W. 540 ; Taylor v. Pennsyl" vania Co., 78 Ky. 348, 39 Am. Rep. 244 ; Vawter v. R. R. Co., 84 Mo. 679, 54 Am. Rep. 105; North Pacific Lumber Co. v. Lang, 28 Or. 246, 42 Pac. 799 ; Knight $v$. R. R. Co., 108 Penn. St. 250, 56 Am. Rep. 200, 201 ; Higgins $v$. R. R. Co., 155 Mass. 176,29 N. E. 534, 536 ; Dennick $v$. R. R. Co., 103 U. S. 11 ; Evey $v$. R. R. Co., 52 U. S. App. 118, 81 Fed. 294 ; Law v. R. R. Co., 91 Fed. 817 ; Illinois, etc. R. R. Co. $v$. Ihlenberg, 21 C. C. A. 546, 75 Fed $873,879-880$.

4 Dale v. R. R. Co., 57 Kan. 601, 47 Pac. 521 ; Adams v. R. R. Co., 67 Vt. 76, 30 Atl. 687 ; Higgins v. R. R. Co., 155 Mass. 176, 29 N. E. 536 ; Hamilton v. R. R. Co., 39 Kan. 56, 18 Pac. 57 ; Herrick v. R. R. Co., 31 Minn. 11, 47 Am. Rep. 771, 772; O'Reilly v. R. R. Cc., 16 R. I. 388, 19 Atl. 245 ; Lyman v. R. R. Co., 70 Fed. 409 : Evev v. R. R. Co., 52 U. S. App. 118, 81 Fed. 294. See Huntington $v$. Attrill, 146 L.S. 657 ; ante, \$10.

5 See Stewart v. R. R. Co., 168 U. S. 447, 448 ; North Pacific Lumber Co. v. Lang, 28 Or. 246, 42 Pac. 799 ; Mex. Nat. R. R. Co. v. Jackson, 89 Tex. $107,33 \mathrm{~S}$. W. 857,860 . This is in reality an enforcement of the lex loci delicti rather than an exception to its operation. The design of such statutes is to give a remedy only in the locus delicti. For instances of such special remedies applied to contractual liabilities, see ante, $\$ 10$.

6 This is certainly true as a general proposition. Cases may be conceived where the lex delicti is so imperfect as to afford no remedy for even a most flagrant wrong, in which perhaps the courts of another State might give redress, especially if it is their own citizen who is thus injured. But even this may well be doubted. Carter $v$. Goode, 50 Ark. 155, 6 S. W. 719 ; W. U. 
§ 195. Situs of Tort or Locus Delicti. - It is not always easy to ascertain the situs of a tort, the locus delicti, which is to furnish "the proper law" of the case. If the whole injury is caused by one single act, or by several acts, all of which occur in the same jurisdiction, there is no trouble usually in locating the tort, as having its situs at the place where the injury occurs.

But if the tort is committed upon the high seas, or if the cause of the injury arises partly in one State and partly in an. other, there is more difficulty.

In case of torts committed on board of merchant vessels on the high seas, the tort must be regarded as committed in the territory of the State or country to which the vessel belongs. The "law of the flag" is the lex loci delicti." But if, when the tort is perpetrated, the vessel is in a foreign port or in the territorial waters of a foreign State, it is generally regarded as becoming subject to the foreign law, and no longer as itself a part of the territory of the State whose flag it flies. The law of the foreign port would in such cases be the lex loci delicti. ${ }^{2}$

If the injury complained of, though committed on the high seas, does not occur aboard a vessel (to which the principle of exterritoriality may apply), as where it results from a collision between two ships belonging to different countries, the tort not occurring wholly on either ship, the general maritime law, as administered in the forum, must govern.

Another case in which there may be doubt as to the situs of a tort arises where the injury is the result of a series of acts, some of which occur in one State, while the culmination takes place in another.

Tel. Co. v. Phillips, 2 Tex. Civ. App. 608, 21 S. W. 638. See Machado v. Fontes, 2 L. R. Q. B. D. 231.

1 Dicey, Confl. L. 663 ; Whart. Confl. L. § 473 ; McDonald v. Mallory, 77 N. Y. 546, 33 Am. Rep. 664; Cavanagh v. Nav. Co., 13 N. Y. Supp. 540; Dupont $v$. Quebec S. S. Co. (Canada), 11 S.C. 188. A fortiori would this be true, under the rules of public international law, of torts committed aboard public vessels.

2 Geoghegan v. Atlas S. S. Co., 22 N. Y. Supp. 749 ; Robinson v. Nav. Co, 43 U. S. App. 191, 73 Fed. 883. But see Dupont v. Quebec S. S. Co. (Canada). 11 S. C. 188.

8 The Brantford City, 29 Fed. 373, 383; The Scotland, 105 U. S. 24. 
The rule in such cases is that the place where the liability of the perpetrator first becomes fixed is the locus delicti, or situs of the tort."

Thus, if the cause of a railway accident is an omission or neglect transpiring in one State, as the result of which the accident and consequent injury occur in another, the seat of the tort is the place where the accident and injury occur which fasten the liability (if any there be) upon the defendant, not the place where the negligence or omission transpired, which of itself would fix no liability upon the defendant, save for the subsequent injury resulting therefrom. The negligence or omission is not in itself actionable, unless and until it is followed by resulting injury. ${ }^{5}$

If the accident and accompanying injury take place in one State, while death results from the injury in another, and suit is instituted to recover damages for the death, the situs of the tort will depend upon the question whether the tort complained of is the injury or the resulting death. Where the laws of the two States differ, this may become of importance. Following the general rule already laid down, since an independent liability is fastened upon the defendant by reason of the injury, such guilt as there is attaching to him at that time, the place

4 Alabama, etc. R. R. Co. v. Carroll, 97 Ala. 126, 11 So. 803, 806 ; Rail. road Co. v. Doyle, 60 Miss. 977 ; Louisville \& N. R. R. Co. v. Williams, 113 Ala. 402, 21 So. 938, 939 ; Rudiger v. R. R. Co., 94 Wis. 191, 68 N. W. 661 ; McCarthy v. R. R. Co., 18 Kan. 46, 26 Am. Rep. 742; De Ham v. R. R. Co., 86 Tex. 68, 23 S. W. 381 ; Needham v. R. R. Co., 38 Vt. 294.

5 Alabama, etc. R. R. Co. v. Carroll, 97 Ala. 126, 11 So. 808, 806 ; Railroad Co. v. Doyle, 60 Miss. 977 . But see Cin., H. \& D. R. R. Co. v. McMullen, 117 Ind. 439, 20 N. E. 287 ; Louisville \& N. R. R. Co. v. Williams, 113 Ala. 402, 21 So. 938 . In the last case, the negligence occurred in Tennessee, and death resulted therefrom in Alabama. It was held that the law of Tennessee should determine the defendant's responsibility. But it does not clearly appear from the opinion whether the accident and injury occurred in Tennessee or in Alabama. Upon this point the correctness of the decision de. pends.

For analogous principles with respect to crimes, see post, § 204 ; Alabamea, etc. R. R. Co. v. Carroll, supra; Simpson v. State, 92 Ga. 41, 44 Am. St. Rep. $r 5$, and note. 
of the injury is the true locus delicti. The death may increase the liability, but it does not create it. ${ }^{6}$

An injury resulting from the act of a living agency will be referred to the place where the act is done. This principle applies not only to the tortious acts of an agent, for which it is sought to hold the principal responsible in another State, ${ }^{7}$ but to cases where the defendant is the owner of an animal which strays into another State and there does an injury for which the owner is held responsible. The place of the injury is the locus delicti.

Thus, in Le Forest $v$. Tolman, ${ }^{8}$ a Massachusetts statute provided that "every owner or keeper of a dog shall forfeit to any person injured by it double the amount of the damage sustained by him, to be recovered in an action of tort" (without regard to the scienter). The defendant lived in Massachusetts and the plaintiff in New Hampshire. The defendant's dog strayed over into New Hampshire and bit the plaintiff, who thereupon sued the defendant in Massachusetts. There was no evidence of any New Hampshire statute on the subject, and by the common law presumed to be in force in New Hampshire the scienter was an essential element of the cause of action. No scienter was shown. The court held that the action could not be maintained in Massachusetts, since the New Hampshire law must control.

It is to be observed furthermore with respect to the situs of torts, that every crime against an individual is also a tort. In such cases, if a private action is brought upon the tort, its situs is the situs of the crime, which will be discussed in a subsequent section.?

The situs of torts to real property will of course be the situs of the land against which the tort is committed. Nor can any

6 Rudiger $v$. R. R. Co., 94 Wis. 191, 68 N. W. 661 ; Needham $v$. R. R. Co., 38 Vt. 294 ; McCarthy v. R. R. Co., 18 Kan. 46, 26 Am. Rep. 742 ; De Ham v. R. R. Co., 86 Tex. 68, 23 S. W. 381. Perhaps also Louisville $\&$ N. R. R. Co. $v$. Williams, 113 Ala. 402, 21 So. 938, may be referred to this principle. The facts of that case are not clearly stated.

7 As in case of railway accidents like those above mentioned.

8117 Mass. 109.

9 Post, 204. 
serious doubt arise that the situs of torts to personal property is the actual situs of the property, not its legal situs at the domicil of the owner, unless that is also its actual situs. ${ }^{10}$ But so far as the liability of the defendant for the conversion of goods depends upon matter of title, etc., the "proper law" regulating the title or other ground of defense is to be looked to, which may or may not be the lex loci delicti. ${ }^{11}$

$\S 196$. Law governing Torts in General. - It is a general rule subject to but few exceptions that the lex loci delicti governs the right of an injured party to sue for a tort, the liability of the perpetrator, and the defenses he may plead. The modern tendency, as we have seen, is in favor of regarding actions for torts as of a transitory nature, not confined to the place where the tort occurs. These principles give birth to another well worthy of notice; namely, a tendency to support an action for a foreign tort, if actionable by the law of the State where it is committed, and subject to that law, regardless of the law of the forum; the only proviso being that it is not expressly contrary to the law or to some very pronounced policy of the forum. The courts are inclined to be very liberal in sustaining such actions.

The tendency of the recent decisions is especially observable in respect to the liberality shown in refusing to set aside the operation of a proper foreign law because of mere dissimilarities

10 Carson v. Smith, 133 Mo. 606, 34 S. W. 855 ; Southern Pac. Co. v. Graham, 12 Tex. Civ. App. 565, 34 S. W. 135. In Hoffman v. Carow, 22 Wend. (N. Y.) 285 , an action was bronght in New York by a plaintiff resident there against certain auctioneers, citizens of Maryland. The action was trover for certain goods stolen from the plaintiff, and put in the defendants' hands by the thief for sale, they being ignorant of the felony. It was held that the law of the legal situs of the goods (the owner's domicil) should deternine the liability of the defendants for the conversion of the goods, not the law of Maryland, where the conversion occurred. It is submitted that the court here confused two distinct principles. It is generally true that the situs of chattels, for the purpose of transfers or dealings with them by the owner, is the situs of the owner. But so far as the dealings of third persons therewith are concerned, as where they steal the chattels situated abroad or convert them to their own use, the actual situs of the chattels is the locus delicti, and fur. nishes the "proper law" to govern both the crime and the tort.

u Soe Martin v. Hill, 12 Barb. (N. Y.) 631 ; Edgerly v. Bush. 81 N. Y. 199. 
to the law of the forum. Thus, it was formerly laid down as a rule in these cases that, in order for the courts to enforce a foreign lex delicti, the tort must not only be actionable in both States, but the laws of both States must be substantially similar, if not identical. ${ }^{1}$ The presumption was rather against the right to recover for a foreign tort than in favor of it. At present, however, the reverse of this is true, the courts favoring the right to recover in such cases, unless the right is vetoed by the lex fori. It may even be doubted whether it is necessary that the lex fori should make the tort actionable at all, provided its policy does not emphatically prohibit a recovery. ${ }^{2}$ However this may be, it is quite certain that it is no longer requisite that the laws of the two States should be substantially similar. If the lex delicti is not opposed to the settled policy of the forum, it will be enforced there, provided the court has jurisdiction of the defendant. ${ }^{8}$

Thus in a recent Canadian case, 4 the action was for false imprisonment against a foreign customs officer. He had arrested the plaintiff without a warrant, under a law of his own country authorizing such arrests in case of persons suspected of violating its customs laws. The point was made that this foreign law (lex loci delicti) was contrary to Canadian notions of justice and propriety and contrary to its policy, but the court ruled that it was not so manifestly unjust as to be rejected as a defense to the action.

§ 197. Defenses to Actions for Tort. - Not only does the lex loci delicti control the plaintiff's right to sue and the grounds

1 See Herrick v. R. R. Co., 31 Minn. 11, 47 Am. Rep. 771 ; Leonard v. Nav. Co., 84 N. Y. 48, 38 Am. Rep. 491 ; St. Louis, etc. R. R. Co. v. McCormick, 71 Tex. 660, 9 S. W. 540 ; Hamilton v. R. R. Co., 39 Kan. 687, 18 Pac. 57, 60 ; Cin., H. \& D. R. R. Co. v. McMullen, 117 Ind. 439, 20 N. E. 287; O'Reilly $v$. R. R. Co., 16 R. I. 388, 19 Atl. 245; Morris v. R. R. Co., 65 Ia. $727,23 \mathrm{~N}$. W. 143.

${ }^{2}$ See Herrick $v$. R. R. Co., 31 Minn. 11, 47 Am. Rep. 771 ; Nelson $v$. R. R. Co., 88 Va. 971,14 S. E. 839.

${ }^{8}$ Herrick $v$. R. R. Co., 31 Minn. 11, 47 Am. Rep. 771 ; Evey $v$. R. R. Co., 52 U. S. App. 118, 81 Fed. 294, 38 L. R. A. 387; Huntington v. Attrill, 140 U. S. 670 ; Law v. R. R. Co., 91 Fed. 817.

4 May v. Smith, 32 N. B. 474. 
of his complaint, but the same law usually governs the defenses which may be made by the defendant. It should be noticed that the courts are more chary of applying exceptions to the complete operation of a foreign lex delicti when it is the ground of the defendant's defense than when it is the ground of the plaintiff's complaint. Few cases are found in which the defense of the alleged wrongdoer, based on the lex delicti, has been swept away by the courts in the maintenance of the supposed policy of the forum, though perhaps in extreme cases such a step might be justifiable. ${ }^{1}$

Thus, the effect of the absence of proof of the scienter, as a defense to an action against the owner of a dog, which has strayed into another State and there bitten the plaintiff, is to be determined by the lex delicti. ${ }^{2}$ And so is the effect of an act of amnesty or oblivion upon acts done in time of rebellion. ${ }^{3}$

So also the effect of contributory negligence as a defense to an action ex delicto will be controlled by the same law. Thus, whether the doctrine of "comparative negligence" applies to the case depends upon the lex delicti. ${ }^{4}$ So, if the lex delicti provides that contributory negligence shall go merely in mitigation of damages, that law will govern, though by the lex fori contributory negligence defeats the action altogether. ${ }^{5}$ And if the lex delicti fixes an age or conclusively presumes an age at which an infant's contributory negligence will excuse a wrongdoer, that law gives the rule for decision. ${ }^{6}$

But if the rule prescribed by the lex delicti with respect to the defendant's negligence is a mere rule of evidence, such as rules respecting the burden of proof touching negligence, the lex fori will govern, not the lex delicti, in accordance with the general principle that rules of evidence relate to the remedy, and

I See May v. Smith, 32 N. B. 474; Machado v. Fontes, 2 L. R. Q. B. D. 231.

2 Le Forest $v$. Tolman, 117 Mass. 109.

8 Phillips $v$. Eyre, L. R. 6 Q. B. 29.

4 See Helton $v$. R. R. Co., 97 Ala. 275, 12 So. 276, 285 ; East Tenn., eto

R. R. Co. v. Lewis, 89 Tenn. 235, 14 S. W. 603.

- Louisville \& N. R. R. Co. v. Whitlow (Ky.), 43 S. W. 711.

- Bridger v. R. R. Co., 27 S. C. 462, 3 S. E. 860. 
like all matters of that character are regulated by the law of the situs of the remedy (lex fori). ${ }^{7}$

In like manner, the scope and effect of the doctrine of "assumption of risk," upon entering into a dangerous employment are to be determined in accordance with the lex loci delicti. $^{8}$

The same law governs in ascertaining the liability of an em. ployer to a servant injured by the negligence of a fellow-servant." The question has been made in these latter cases, whether the liability or non-liability is not rather contractual than tortious. This is of importance in those cases where the contract of employment is made in one State, while the injury occurs in another subject to a different rule touching the employer's liability for such injuries. It is believed however that the liability in such cases is tortious, not contractual, and is therefore controlled by the lex delicti. ${ }^{10}$

So also where the nature and extent of the liability for a tort depends upon the nature of the perpetrator's occupation, as whether he is to be subjected to the liabilities of a common carrier, this question will depend upon the lex delicti. Hence in an action brought in Mississippi against the Pullman Car Company of Illinois for an outrageous assault perpetrated in Illinois upon a passenger by a porter in the employ of the company, the question whether the company was a common carrier (and as such bound to protect its passengers against the acts of its servants even when beyond the scope of their employment)

7 Helton v. R. R. Co., 97 Ala. 275, 12 So. 276, 285. See Van Raden v. R. R. Co., 56 Hun (N. Y.), 96, 8 N. Y. Supp. 914.

8 Railroad Co. v. Ihlenberg, 75 Fed. 879-880; Northern Pac. R. R. Co. v. Babcock, 154 U. S. 190.

9 Alabama, etc. R. R. Co. $v$. Carroll, 97 Ala. 126, 11 So. 803, 807 ; Kahl v. R. R. Co., 95 Ala. 337, 10 So. 661, 662; Alexander v. Pennsylvania Co., 48 Ohio St. 623, 30 N. E. 69, 70, 71 ; Belt v. R. R. Co., 4 Tex. Civ. App. 231, 22 So. 1062, 1064 ; Njus $v$. R. R. Co., 47 Minn. 92, 49 N. W. 527 ; Herrick v. R. R. Co., 31 Minn. 11, 47 Am. Rep. 771.

10 Alabama, etc. R. R. Co. v. Carroll, 97 Ala. 126, 11 So. 803, 807; Belt v. R. R. Co., 4 Tex. Civ. App. 231, 22 S. W. 1062, 1064 ; Herrick v. R. R. Co., 31 Minn. 11, 47 Am. Rep. 771. But see Alexander $v$. Pennsylvania Co. 48 Ohio St. 623,30 N. E. $69,70$. 
was determined in the affirmative, in accordance with the law of Illinois (lex delicti). ${ }^{11}$

$\S$ 198. Damages - Compensatory, Punitive, and Penal. With regard to the law governing damages to be given in an action ex delicto, the distinction between common law and statutory torts becomes of importance. The measure of damages in the case of statutory torts, as will presently appear, ${ }^{1}$ will be governed in general by the lex delicti, at least in those cases where the measure of damages is fixed by the very statute which creates the tortious liability.

The law controlling the measure of damages in actions ex delicto may depend in some degree upon whether the damages demanded are merely compensatory, or are punitive or vindictive, or are by way of statutory penalty.

If the damages demanded are compensatory merely, and the laws of both States authorize compensation (and no more), little question will generally arise as to the "proper law" governing the measure of damages. But occasionally some point may arise upon differences between the lex delicti and the lex fori as to the elements to be taken into consideration in estimating the amount of damage. Such matters pertain to the remedy, and are to be controlled by the lex fori, since they do not involve any substantive right. Thus, if the lex loci delicti allows the social position of the plaintiff to be considered in assessing the damage resulting from a tort, while the lex fori does not, the latter law will control. ${ }^{2}$

So, the question whether, in trover for the value of goods, interest on the value thereof from the time of the conversion shall be included in the damages is to be determined by the lex fori. ${ }^{8}$

But if damages are given by the law of either State, which

11 Pullman Car Co. v. Lawrence (Miss.), 22 So. 53, 57.

1 See cases cited infra, note 4 ; post, $\$ \$ 200,202$.

2 Evey v. Mex. Nat. R. R. Co., 56 U. S. App. 118, 81 Fed. 294, 38 I. R. A. 387; Mex. Nat. R. R. Co. v. Jackson, 89 Tex. 107, 33 S. W. 861,31 L. R. A. 276.

3 Carson $v$. Smith, 133 Mo. 606, 34 S. W. 855, 858. But in case of statutory torts, if interest is included in the damages under the statute of the locus delicti, the lex delicti will prevail. Kiefer $v$. R. R. Co., 42 N. Y. Supp. 171. 
are not merely, or not fully, compensatory for the tort complained of, the general rule is that the measure of damages becomes a matter of substantive right, to be controlled by the lex delicti unless the damages are penal. The plaintiff should have the same substantial relief in the forum that he would be entitled to if he had sued in the locus delicti, provided the enforcement of the lex delicti would not contravene the policy of the forum. ${ }^{4}$

With respect to punitive damages also, if the case is one for which such damages may be given in the discretion of the jury under the lex delicti, that law will govern the legal right to demand such damages in another State, unless the lex fori should expressly prohibit punitive damages, or the enforcement of the lex delicti in this respect would contravene an established policy of the forum. This is a substantive right, not a mere matter of remedy. ${ }^{5}$

In some cases the statutes of the locus delicti provide for a named sum to be given by way of damages, regardless of extenuating circumstances in case the cause of action described in the statute arises, and sometimes regardless of the actual damage done. Such statutes are to be distinguished from those which merely impose an outside limit upon the amount of damages recoverable. The latter are remedial statutes, the former more or less penal, since they are to operate without regard to circumstances of extenuation and do not give merely the actual damages sustained. Such statutes have generally been refused enforcement in other States, upon the ground that they are penal. ${ }^{6}$ And so it is, also, where the statutes of the locus

4 Mex. Nat. R. R. Co. v. Jackson, 89 Tex. 107, 33 S. W. 857, 31 L. R. A. 276; Pullman Palace Car Co. v. Lawrence (Miss.), 22 So. 53, 57; Hanna $v$. R. R. Co., 41 Ill. App. 116; Kiefer v. R. R. Co., 42 N. Y. Supp.. 171. See Dyke v. R. R. Co., 45 N. Y. 113, 6 Am. Rep. 43; Wooden v. R. R. Co., 126 N. Y. 10, 26 Atl. 1050.

5 See Pullman Palace Car Co. $v$. Lawrence (Miss.), 22 So. 53, 57. But see Carson $v$. Smith, 133 Mo. 606, 34 S. W. 855, 858, where the plaintiff's right to punitive damages is discussed without reference to the lex delicti.

6 O'Reilly $v$. R. R. Co., 16 R. I. 388, 17 Atl. 906; Dale v. R. R. Co., 57 Kan. 601, 47 Pac. 521; Adams v. R. R. Co., 67 Vt. 76, 30 Atl. 687; Lyman v. R. R. Co., 70 Fed. 409. 
delicti provide that, under particular circumstances of tort, double or treble damages shall be awarded.7

\$ 199. Statutory Torts - Death by Wrongful Act. - Statutory torts are either acts of an injurious tendency, which (although compensation may not be demandable therefor upon the universal principles that inhere in the common law) are made tortious by statute; or are torts which, not being actionable at common law for some technical reason, are made so by statute. ${ }^{1}$

In cases of statutory torts there should be no presumption that the laws of two States are similar. One may have retained the common law, while the other has altered the common law rule within its limits by statute. Hence the fact that acts of this character are made actionable by statute in the State where the action is brought affords no ground to presume that the same act is also actionable in the locus delicti. ${ }^{2}$ Indeed, if the lex delicti is founded upon the common law system of jurisprudence, the very opposite presumption is indulged, in the absence of proof to the contrary, namely, that the common law remains in force in the locus delicti, unchanged by statute. $^{8}$

The principal instance of a statutory tort is that afforded by the enactment in most of the States of acts based upon the Eng-

7 Bettys v. R. R. Co., 37 Wis. 323 ; Herrick v. R. R. Co., 31 Minn. 11, 47 Am. Rep. 774-775; Langdon v. R. R. Co., 58 Hun (N. Y), 122, 11 N. Y. Supp. 514. It is possible however that such statutes, instead of being regarded as pensl and unenforceable exterritorially, should be looked upon as merely creating a statutory case for punitive damages, and should therefore be referred to the preceding paragraph. See Huntington $v$. Attrill, 146 U. S. 657 ; Evey $v$. R. R. Co., 52 U. S. App. 118, 81 Fed. 294, 302; Hamilton $v$. R. R. Co., 39 Kan. 687, 18 Pac. 57. See ante, $\S 10$. But this construction is hardly probable, since in ordinary cases of punitive damages all the law does is to permit the jury to consider whether upon the evidence additional dam. ages should be awarded in the particular case, whereas under statutes of this eharacter no discretion whatever is left in the jury. Confiscations of this sort are contrary to the policy of most States, and would hardly be enforced elsewhere than in the State which enacts the law. But see Huntington $v$. Attrill, supra.

1 Ante, $\$ 193$.

2 Leonard $v$. Nav. Co., 84 N. Y. 48, 38 Am. Rep. 491.

- Debevoise v. R. R. Co., 98 N. Y. 377. See post, $\$ 214$. 
lish statute, known as "Lord Campbell's Act," whereby in. juries resulting in death are made actionable. At common law the maxim, "personal actions die with the person," applied to such cases. These statutes vary greatly in detail, but the general policy of most of them is the same. That policy is not simply to permit the right of action to survive for the benefit of the dead man's estate, but to give the benefit of the damages obtained to his family, free from the claims of creditors; or in other words, to create a new cause of action, rather than merely to allow the old one to survive. Some of these acts name the personal representative of the deceased as the proper party to sue in this behalf, but the proceeds to go to his family or those named by the statute; others provide that the suit shall be brought directly by the beneficiaries named in the statute; others, that the suit shall be in the name of the State. Some of the statutes specify that only a limited amount may be recovered by way of damages; others designate no limit. Some provide that the suit shall be brought within one year, others within two or more years, from the time of death. Some limit the damages to a certain amount, others to another, others not at all. Many of these acts prescribe other conditions and regulations also, but those mentioned suffice to illustrate the variances and discrepancies existing between them, and which have proved a fruitful source of conflicts of laws.

$\S 200$. Death by Wrongful Act - Increasing Liberality of the Courts. - In the cases on this subject two main questions were first presented. If a tortious death is actionable by the lex fori only, will that statute govern? If actionable by the lex delicti, will that statute control ?

The first question was at once decided in the negative, and the correctness of the ruling cannot be questioned. ${ }^{I}$

It is with regard to the second question that the greatest conflict of opinion has occurred. The view first advanced was that although the lex delicti made the tortious death actionable, it would be of no avail upon an action brought in another State,

1 Crowley $v$. R. R. Co., 30 Barb. (N. Y.) 99 ; Beach v. R. R. Co., 30 Barb. 433; Whitford $v$. Panama R. R. Co., 23 N. Y. 468 ; O'Reilly $v$. R. R. Co., 10 R. I. 388,17 Atl. 906 . See Deberoise v. R. R. Co., 98 N. Y. 377. 
even though the death was made actionable by the lex fori also, because such statutes were to be regarded as penal, or at least as having no exterritorial force. ${ }^{2}$

As more liberal ideas advanced, the next step taken by the courts was to recognize these statutes as remedial, not penal, and to permit actions to be brought in one State for a tortious death resulting in another State and actionable there, provided there was a statute substantially similar in the State of the forum. $^{8}$ But if there were any very marked dissimilarities between the statutes of the two States, this was still taken to indicate that the enforcement of the lex delicti was contrary to the policy of the forum, and the right to sue there would be denied. ${ }^{4}$

The present tendency of the more recent decisions is to advance still further towards liberality and to throw open the courts to litigants whose cause of action has arisen in other States and under the laws thereof, even though not actionable at common law or not actionable if it had arisen in the forum, provided the enforcement of the lex delicti would not seriously contravene the established policy of the forum. The presumption is in favor of the right to sue, and the burden rests upon the party objecting to show that the enforcement of the "proper law" would be inconsistent with the domestic policy. ${ }^{5}$

2 Richardson $v$. R. R. Co., 98 Mass. 85 ; McCarthy v. R. R. Co., 18 Kan. 46 ; Woodard v. R. R. Co., 10 Ohio St. 121 ; Anderson v. R. R. Co., 37 Wis. 321 ; Hamilton v. R. R. Co., 39 Kan. 687, 18 Pac. 57. This doctrine is indefensible, and has long since been discarded.

8 Leonard v. Nav. Co., 84 N. Y. 48, 38 Am. Rep. 491 ; Wooden v. R. R. Co., 126 N. Y. 10,15 ; St. Louis, etc. R. R. Co. v. McCormick, 71 Tex. 660, 9 S. W. 540 ; Hamilton v. R. R. Co., 39 Kan. 687, 18 Pac. 57, 60 ; Cin. H. \& D. R. R. Co. $v$ McMullen, 117 Ind. 439, 20 N. E. 287; Burns v. R. R. Co., 113 Ind. 169,15 N. E. 230 ; O'Reilly $v$. R. R. Co., 16 R. I. 388,19 Atl. 245 ; Morris v. R. R. Co., 65 Ia. 727, 23 N. W. 143.

4 St. Louis, etc. R. R. Co. v. McCormick, 71 Tex. 660, 9 S. W. 540 ; Belt v. R. R. Co., 4 Tex. Civ. App. 231, 22 S. W. 1062, 1063; Ash v. R. R. Co., 72 Md. 144, 19 Atl. 643; Hamilton v. R. R. Co., 39 Kan. 687, 18 Pac. 57, 60 ; Vawter $v$. R. R. Co., 84 Mo. 679, 54 Am. Rep. 105; Taylor $v$. Pennsylvania Co., 78 Ky. 348, 39 Am. Rep. 244.

5 Stewart v. R. R. Co., 168 U. S. 445 ; Texas, etc. R. R. Co. v. Cox, 145 T. S. 593; Huntington v. Attrill, 146 U.S. 657, 670 ; Dennick v. R. R. Co, 
But even under this modern doctrine the right of the plaintiff to sue and the liability of the defendant depend in all sub. stantial matters upon the lex loci delicti, not upon general principles of law and justice as administered in the forum." Hence, both with respect to the party who is to sue for the tort, the time within which suit is to be brought, the measure of damages, and all other conditions named in the statute, affecting the substantive rights of the parties, the lex loci delicti is strictly followed, after it is once determined that its enforcement will not contravene the policy of the forum.

\$201. Same-Proper Plaintiff. - The lex loci delicti is the proper law by which to ascertain the person who is to sue for a death caused by wrongful act. The right to sue accrues, if at all, by reason of the statute of the locus delicti, and in general no one can take advantage of the right conferred by that law save the person to whom that law gives it.

Thus where the lex delicti designates the personal representative as the proper complainant, while the lex fori names the widow, the latter, in her individual capacity at least, will not be permitted to sue in the forum, even though by the lex delicti the representative is to sue for her benefit. ${ }^{1}$ On the other hand, if the lex delicti prescribes that the representative is to sue for the benefit of others than the party designated by the lex fori as the complainant, this does not, under the modern view, prevent the suit from being brought as directed by the lex delicti. $^{2}$

If the lex delicti prescribes the widow, heirs, etc., as the proper parties to sue, while the lex fori prescribes the personal representative of the deceased, the same principle controls, and

103 U. S. 11 ; Law v. R. R. Co., 91 Fed. 817, 819 ; Higgins v. R. R. Co., 155 Mass. 176, 29 N. E. 535, 536 ; Nelson v. R. R. Co., 88 Va. 971, 14 S. E. 839 ; Herrick $v$. R. R. Co., 31 Minn. 11, 47 Am. Rep. 771, 773.

6 In Stewart v. R. R. Co., 168 U. S. 445, there seems to be the hint of a tendency to rely upon general principles, rather than upon the strict lex loci delicti. See also Machado v. Fontes, 2 L. R. Q. B. D. 231, where a similar tendency is exhibited.

1 Usher v. R. R. Co., 126 Penn. St. 206, 17 Atl. 598; St. Louis, ete. B. R Co. v. McCormick, 71 Tex. 660, 9 S. W. 540.

2 See Stewart v. R. R. Co., 168 U. S. 445 
the party designated by the lex delicti is the proper plaintiff, without regard to the provisions of the lex fori."

In cases where the "proper law" names the personal representative as the plaintiff, a question arises as to whether this requires the representative to be appointed in the locus delicti, or whether his appointment in the forum will suffice. This question has once before been discussed, and it was shown that the weight of authority favors the doctrine that the latter is sufficient. ${ }^{4}$

But to the general principle that only the party designated by the lex loci delicti may sue, one exception has been made by the Supreme Court of the United States in Stewart $v . R . R$. Co. ${ }^{5}$ In that case the death took place in Maryland, and suit was brought in the District of Columbia by the administrator of the deceased. By the law of Maryland, suit was to be brought in such cases in the name of the State of Maryland, for the benefit of the wife, husband, parent, or child of the deceased. By the law of the District of Columbia, suit was to be instituted by the representative of the deceased for the benefit of the general distributees. The court upheld the action by the administrator on the ground that the plaintiff designated in the Maryland statute (that is, the State of Maryland) was merely a nominal plaintiff. So was the plaintiff named by the law of the District (the personal representative). The result would hardly have been the same if the party named as plaintiff by the law of the District had been himself the recipient of the damages. The beneficiaries, though not exactly the same under both statutes, seem to have been regarded by the court as practically so. ${ }^{6}$

${ }^{3}$ Wooden $v$. R. R. Co., 126 N. Y. 10 ; Limekiller v. R. R. Co., 33 Kan. 83, $52 \mathrm{Am}$. Rep. 523; Lower $v$. Segal, 59 N. J. L. 66, 34 Atl. 945; Davidow $v$. R. R. Co., 85 Fed. $943,944$.

4 Ante, § 108. See Dennick v. R. R. Co., 103 U. S. 11.

5 168 U. S. 445. But see Wilson $v$. Tootle, 55 Fed. 211.

6 But for this decision of a most eminent tribunal construing the Maryland statute, it might have been thought that that act was intended to have no exterritorial force, since it prescribed that the action should be brought in the name of the State of Maryland, which could not well be applicable to actions brought in any other than a Maryland court. 
$\$ 202$. Same - Other Conditions of Suit. - Not only does the lex delicti determine who is the proper plaintiff in actions for death by wrongful act, but the same law controls also all the other substantive conditions attached to the right to sue.

Thus, in Hamilton $v$. R. R. Co., ${ }^{1}$ the death was caused in Missouri, and action therefor was brought by the widow in Kansas. By the law of Missouri, the widow was authorized to sue in such cases; but should she omit to sue for six months, the minor children of the decedent were to sue. 'The plaintiff's petition alleged that the deceased left minor children surviving him, but did not show that the action was instituted within six months after the decedent's death. Upon demurrer, the petition was adjudged insufficient, in that it did not state all the requirements essential to make a cause of action under the law of Missouri (lex loci delicti). The court said: "The provision designating where and by whom the suit may be brought is more than a mere limitation: it is a condition imposed by the legislature, which qualifies the right of recovery, and upon which its exercise depends."

So also, if the statute of the locus delicti which creates the liability prescribes a period within which the action must be brought, this is not a mere statute of limitation (and as such to be controlled by the lex fori ${ }^{2}$ ), but it is "a condition imposed by the legislature, which qualifies the right of recovery, and upon which its exercise depends." 8 But if the statute of the locus delicti designates no special period within which the action shall be brought, leaving the matter to be controlled by the general statutes of limitation, the question is to be decided in accordance with the lex fori. ${ }^{4}$

So also, it is believed, the lex loci delicti should regulate the

139 Kan. 687, 18 Pac. 57, 61.

2 Post, § 210.

3 Hamilton $v$. R. R. Co., 39 Kan. 687, 18 Pac. 57, 61 ; The Harrisburg, 119 U. S. 199, 214; Cavanagh v. Nav. Co., 13 N. Y. Supp. 540. But in actions for common law torts, the lex fori in general controls in respect to the period within which the suit may be brought. See Nonce $v$. R. R. Co., 33 F'ed. 429, 436 ; Johnston $v$. R. R. Co., 50 Fed. 886.

4 Munos v. R. R. Co., 2 C. C. A. 163, 51 Fed. 188. 
amount of damages recoverable, if limited in the statute creating the right to sue, and the persons who are to enjoy the benefit of the damages recovered. Thus the creditors of the decedent (unless perhaps they are citizens of the forum) should not be permitted to seize such damages, even though that course be allowed under the lex fori, if the lex delicti confers them upon sertain members of his family free from his debts. 


\section{CHAPTER XXI.}

\section{SITUS OF CRIMES.}

§ 203. Crimes generally Local, not Transitory. - Although it is true that in some countries, whose laws are based upon the Roman law, the principle has been established that the criminal laws of the State follow its citizens abroad, and that upon their return they are to be punished for their violations of the domiciliary law while abroad, the reverse is the general rule in those States whose laws are founded upon the common law system. ${ }^{1}$

It is admitted that the State has the power to enact criminal laws which may even follow its citizens abroad, and that, upon their return to its jurisdiction, it may punish them for their violations of such laws, even when those violations occur in other States; and in some instances, even in common law States, such laws have been enacted. ${ }^{2}$ But in the United States there is one limitation imposed upon the power of a State to punish exterritorial offenses against its laws. This limitation is that the accused should be a citizen of the State whose law he has violated at the time when the alleged foreign violation occurs. If he resides in another State at the time of the act, though he was previously a resident of the State whose law he is accused of violating, or subsequently becomes such, he is not liable to punishment there. In this country, the criminal laws of a State can only operate upon citizens and persons actually or constructively perpetrating crimes within its jurisdiction.8

1 Manley v. People, 7 N. Y. 295 ; State $v$. Mitchell, 83 N. C. 674 ; State v. Hall, 114 N. C. 909, 41 Am. St. Rep. 822 ; Com. v. Kunzmanr, 41 Penn. St. 429.

2 Ex parte Kinney, 3 Hughes (U. S.), 9.

8 See Ex parte Kinney, 3 Hughes (U. S.) 9, 19, 20; Hanks v. State, 13 Tex. App. 289. 
If the State has the power to enact laws which by their express terms punish acts of its citizens when committed abroad, it would seem to follow that the same effect must be given to necessary implication arising from the terms and circumstances of the law. In other words, should the policy of the law necessarily point to its exterritorial operation, it must be given effect as against the citizens of the State upon their return thither, if they have violated the law abroad. But the implication should be a necessary one. ${ }^{4}$

In ordinary cases certainly, the general principle of the common law is to be followed, that crimes are strictly local in character, and are to be punished only by the State in whose territory they are committed and in accordance with its laws. The lex loci delicti is the "proper law" here, as in the case of torts; but there is an essential difference between the two kinds of wrong, arising from the fact that, while a tort is an injury to an individual who may have his situs anywhere, a crime is an injury to the State where it is committed. This difference is that the responsibility for torts is in general transitory, and an action may be brought therefor in any State where jurisdiction of the defendant's person may be obtained, while the responsibility for crimes is usually local, no courts in general having jurisdiction thereof save the courts of the State where the crime is committed. ${ }^{5}$ This is based upon the idea that the crime is an offense against the sovereignty and good order of the State within whose jurisdiction it occurs, and that each State must attend to the vindication of its own sovereignty. ${ }^{6}$

$\S 204$. Situs of Crimes. - Although, as already mentioned, the general rule is that the locus delicti furnishes not only the

4 Ex parte Kinney, 3 Hughes, 9.

5 Manley v. People, 7 N. Y. 295; Com. v. Kunzmann, 41 Penn. St. 429 ; State $v$. Mitchell, 83 N. C. 674 ; State $v$. Hall, 114 N. C. 909, 41 Am. St. Rep. 822. See Johns $v$. State, 19 Ind. 421, 81 Am. Dec. 408.

6 Upon a somewhat similar principle it has been held, though often regretted, that the courts of one State will not attempt to enforce the revenue laws of another State (even though not criminal in character), - a remarkable departure, it would seem, from the spirit of friendly comity which usually animates the intercourse of States with each other. See Story, Confl. L. $\$ \$ 245$, 246 ; Henry v. Sargeant, 13 N. H. 321 ; ante, $\$$ ?. 
law by which a crime is to be punished, but also the jurisdiction to punish it, it is not always easy to ascertain what is the situs of the crime in a particular case.

If a principal in the first degree in one State employs an in. nocent or irresponsible agent, sentient or inanimate, through whose aid he commits a crime in another State, the law regards the principal as himself present and acting through the agent or instrumentality at the point where the act is done, just as if he were actually and personally there. He may be in fact the citizen of another State, outside of whose limits he may never have set his foot, but he is nevertheless constructively present at the place where the crime takes effect, through the irresponsible agent set in motion by him. ${ }^{1}$

Thus, in Adams $v$. People, ${ }^{2}$ Adams was a citizen of Ohio who forged a paper and sent it to an agent in New York who knew not that it was forged. The agent there uttered the forged instrument. Afterwards A was apprehended in New York, charged with obtaining money there under false pretenses. It was held that the act of the innocent agent in New York was his act, and therefore that the situs of the crime was New York. The accused pleaded his Ohio citizenship, and that he was not at the time of the offense subject to New York law, but without avail.

The same principle is applied in cases where one, being in one State, discharges a gun or otherwise puts in motion an instrumentality, by which the death of a person results in another State. He is guilty of homicide in the State where the fatal blow takes effect, and is deemed to accompany his bullet or other instrumentality to its destination, and therefore to be constructively present there when it takes effect. ${ }^{8}$ And the fact that the mortal blow is given in one State while the death ensues in another does not alter the principle. The place of the mortal blow is the situs of the homicide, the death being a

1 Adams v. People, 1 Comst. (N. Y.) 173 ; People v. Adams, 3 Denio (N. Y.), 190, 45 Am. Dec. 468; Lindsey v. State, 38 Ohio St. 507.

21 Comst. (N. Y.) 173.

8 State $v$. Chapin, 17 Ark. 561, 65 Am. Dec. 452 ; People v. Adams, 3 Denio (N. Y.), 190, 45 Am. Dec. 468. See Com. v. Macloon, 101 Mass 1, 100 Am. Dec. 89. 
more consequence. Although it has sometimes been doubted whether this was the rule at common law, ${ }^{4}$ the overwhelming weight of authority in the United States is in favor of this doctrine. The place of death is held to be immaterial. ${ }^{6}$ A familiar case of this kind is United States $v$. Guiteau. ${ }^{6}$ President Garfield was shot by Guiteau in the city of Washington and died at Long Branch, in New Jersey. The prisoner was tried and convicted of murder in the courts of the District of Columbia.

But if in the State where the death occurs the law provides expressly for the punishment of the criminal there, though the mortal blow is given elsewhere, it is said that the courts of the former State may assume jurisdiction to try the offender for the murder.'

The same principle, it seems, governs in the case of an assault with intent to kill, as where one standing in one State shoots

41 Hawk. P. C. c. 13 , sec. 13 ; 1 Chitty, Crim. Law, 178 ; 1 Hale, P. C. 426. See Com. v. Linton, 2 Va. Cas. 205.

s United States v. Gniteau, 1 Mackey, 498, 47 Am. Rep. 247; Ex parte McNeely, 36 W. Va. 84, 32 Am. St. Rep. 831 ; State v. Gessert, 21 Minn. 369 ; State $v$. Bowen, 16 Kan. 475 ; State v. Foster, 8 La. Ann. 290, 58 Am. Dec. 678 ; Stout $v$. State, 76 Md. 317, 25 Atl. 299 ; State v. Carter, 27 N. J. L. 499 ; State v. Kelly, $76 \mathrm{Me} .331,49$ Am. Rep. 620 ; Simpson v. State, $92 \mathrm{Ga}$. 41, 44 Am. St. Rep. 75, and note ; State v. Hall, 114 N. C. 909, 41 Am. St. Rep. 822.

6 I Mackey, 498, 47 Am. Rep. 247.

7 Com. v. Macloon, 101 Mass. 1, 100 Am. Dec. 89. In this case the mortal blow was given upon the high seas, the death resulting therefrom in Massachusetts. See also Tyler $v$. People, 8 Mich. 320,333 . It may be more doubtful whether the same rule would apply where the place of the mortal stroke is subject to a definite system of law of its own. The perpetrator commits no overt act in the State where the death occurs, and the constitutional power of that State to punish him may perhaps be questioned. The reasoning of the conrt however in Com. $v$. Macloon, supra, leans towards the constitutionality of such legislation. See Simpson v. State, 92 Ga. 41, 44 Am. St. Rep. 75, 82, note. But see State v. Carter, 27 N. J. L. 499 ; State $v$. Kelly, 76 Me. 331 . If the accused has administered poison or delivered the blow in one State, which he believes has resulted in death in that State, and afterwards takes his victim into another State, where for the better concealment of the crime he decapitates him (the decapitation being the real, though unintended cause of death), the situs of the homicide is the latter State, not the former. Jackson v. Com., $100 \mathrm{Ky} .239,38 \mathrm{~S}$. W. 1091 [Pearl Bryan Case]. 
at another in a neighboring State, even though he misses him altogether, provided the bullet or other missile reaches the territory of the latter State. The assailant is presumed to follow up his bullet, and constructively makes the attempt to kill in the State where the bullet strikes. ${ }^{8}$

A criminal conspiracy is complete where the conspiracy is entered into, without regard to the further perpetration of the illegal act which is the subject of the conspiracy. Hence if the conspiracy is entered into in one State to execute a criminal act in another, the situs of the conspiracy is the former State, and that State has jurisdiction of that offense. ${ }^{9}$ And while it is a general rule of municipal law that the performance of the criminal act itself merges the conspiracy, it may well be doubted if this result would follow in cases where the conspiracy occurs in one State while the criminal act itself takes place in another.

So accessaries before or after the fact in one State to a felony committed in another are guilty in the State where they become accessaries. That State is the situs of their crime, and they must be tried there. ${ }^{10}$

The situs of a forgery, it is said, is the place where the forged instrument is uttered and published with intent to defraud, not the place where the writing is falsely made, added to, or altered. ${ }^{11}$

8 Simpson v. State, 92 Ga. 41, 44 Am. St. Rep. 75.

9 Simpson v. State, 92 Ga. 41, 44 Am. St. Rep. 75, 82, note ; Dealy v. United States, 152 U. S. 539 ; United States v. Britton, 108 U. S. 204 ; Ex parte Rogers, 10 Tex. App. 655, 38 Am. Rep. 654. See United States $v$. Howell, 56 Fed. 21. And this is true perhaps even though the act to be done in pursuance of the conspiracy is not an illegal act in the State where it is to be performed. See Lacey $v$. Palmer, 93 Va. 159, 31 L. R. A. 822, 24 S. E. 930.

10 Simpson v. State, 92 Ga. 41, 44 Am. St. Rep. 75, 82, note; State $v$. Chapin, 17 Ark. 561, 65 Am. Dec. 452 ; State $v$. Wyckoff, 31 N. J. L. 65 ; Johns $v$. State, 19 Ind. 421, 81 Am. Dec. 408; State v. Moore, 26 N. H. 448 ; $59 \mathrm{Am}$. Dec. 354 . But see State v. Grady, 34 Conn. 118 ; Com. v. Chiovaro, 129 Mass. 497 ; Com. $v$. Pettes, 114 Mass. 311.

Il Simpson $v$. State, 92 Ga. 41, 44 Am. St. Rep. 75, 83, note; Lindsey v. State, 38 Ohio St. 507 ; Ex parte Rogers, 10 Tex. App. 655, 38 Am. Rep. 654 ; Rogers $v$. State, 11 Tex. App. 608 ; Foute $v$. State, 15 Lea (Tenn.), 712. See Hanks v. State, 13 Tex. App. 289; Ex parte Carr, 28 Kan. 1. This is certainly the place of the utterance. But a forgery may be complete without utterance. The place of the completion of the offense is the locus delicti. 
So, in the case of obtaining money or property under false pretenses, if the false representations are made in one State while the money or property is obtained in another, the crime is completed in the latter State, not in the former, for the false representations standing alone constitute no criminal offense. The latter State is the situs of the crime. ${ }^{12}$

The situs of a criminal libel is the situs of its publication. Hence one who publishes a libel in one State in a newspaper which circulates in another also, is liable to indictment in either State, or in both. ${ }^{18}$

With respect to the situs of the crime of larceny, some difficulty arises where the goods have been stolen in one State and are afterwards brought into another. A difference of opinion exists in such case whether or not the thief may be prosecuted in the latter State. On the one hand it has been said by eminent authorities that each step taken by the thief after he has stolen the goods constitutes a new asportation of them, and hence a new larceny, and that he is therefore guilty of the larceny of the goods in each State to which he comes bringing them with him. ${ }^{14}$

As between two counties of the same State, it is admitted that a thief stealing goods in one county and carrying them into another may be tried in either county; the reason often assigned for the doctrine being the fiction above given. ${ }^{15}$ But here there

12 Com. $v$. Van Tuyl, 1 Met. (Ky.) 1, 71 Am. Dec. 455 ; Stewart v. Jessup, 51 Ind. 413, $19 \mathrm{Am}$. Rep. 739. See United States $v$. Plympton, $4 \mathrm{Cr}$. C. C. 309 ; State $v$. Schaeffer, 89 Mo. 271, 1 S. W. 293.

13 Com. v. Blanding, 3 Pick. (Mass.) 304 ; Com. v. Macloon, 101 Mass. 1, 100 Am. Dec. $89,93$.

14 Simpson v. State, 92 Ga. 41, 44 Am. St. Rep. 75, 82, note; People $v$. Staples, 91 Cal. 23; Kidd v. State, 83 Ala. 58 ; Powell v. State, 52 Wis. 217 ; Mack v. People, 82 N. Y. 235; People v. Burke, 11 Wend. (N. Y.) 129; Dixon v. State, 15 Tex. App. 480 ; McKenzie v. State, 32 Tex. Cr. R. 568, 40 Am. St. Rep. 795 ; State v. Underwood, 49 Me. 181, 77 Am. Dec. 254 ; Hemmaker $v$. State, 12 Mo. 453, 51 Am. Dec. 172 ; Com. v. Andrews, 2 Mass. 14, $3 \mathrm{Am}$. Dec. 17; Com. v. White, 123 Mass. 433 . But see Com. v. Uprichard, 3 Gray (Mass.), 434, 63 Am. Dec. 762; Com. v. Macloon, 101 Mass. 1, 100 Am. Dec. 89, 92.

${ }^{15}$ Com. v. Macloon, 101 Mass. 1, 100 Am. Dec. 89, 92 ; Strouther's Case, 92 Va. $789,791$. 
is another principle of the common law that comes into play, prohibiting the injustice of a double punishment to the thief for the same offense, which would operate to prevent his punishment in both counties. The same system of law that originates the fiction furnishes this check upon it.

But as between two sovereign States this check is wanting. If the fiction is to prevail, there is nothing to prevent (indeed it is the sworn duty of the courts of each State to require) the punishment of the thief in both States, or in as many as he enters with the goods, provided the jurisdiction of his person can be secured. Certainly it would seem that the removal of the check upon injustice which is imposed when all the transactions take place in the same State, should, as between several States, remove also the fiction which is the origin of the possible injustice.

There are a goodly number of authorities which take this view of the question, and deny to the courts of the State whither a thief has taken stolen goods, in the absence of express statutes of the latter State, the right to try or punish him for the offense. And this would seem to be the better rule. ${ }^{16}$

In cases of crimes committed in a State by one construc. tively, though not actually, present there, as in case of a person in one State shooting a person in another, or sending him poisoned candy, eic., through the mails, an interesting question arises as to whether the criminal may be extradited to the State where the crime has been committed, under the provisions of the federal constitution to the effect that "a person charged with treason, felony, or other crime, who shall flee from justice and be found in another State shall, on demand of the executive

16 Stronther's Case, 92 Va. 789, 792 ; State $v$. Brown, 1 Hayw. (N. C.) 100 ; Simmons $v$. Com., 5 Binn. (Penn.) 617; Simpson v. State, 4 Humph. (Tenn). 456 ; Com. $v$. Uprichard, 3 Gray (Mass.), 434, 63 Am. Dec. 762; Com. $v$. Maçloon, 101 Mass. 1, 100 Am. Dec. 89, 92 ; Lee $v$. State, 64 Ga. 203, 37 Am. Rep. 67; Beal $v$. State, 15 Ind. 378; State $v$. Newman, 9 Nev. 48, 16 Am. Rep. 3. If the larceny in the first State is forcible and violent, making it a robbery, and the goods thus taken are brought into another State, it is certain that the party cannot be tried for robbery in the second State. This is true even as between two counties of the same State. Com. $v$. Macloon, 101 Mass. 1, 100 Am. Dec. 89, 92. 
authority of the State from which he fled, be delivered up, to be removed to the State having jurisdiction of the crime." 17 This provision, according to the current of authority, implies that the accused must have been actually within the jurisdiction of the accusing State and must have fled therefrom. If in fact he was never within the jurisdiction of that State, he cannot by a fair construction of words be said to have fled from its justice. ${ }^{18}$

17 U. S. Const. art. iv. § 2, cl. 2.

18 Ex parte Smith, 3 McLean, 133 ; State $v$. Hall, 114 N. C. 909, 41 Am. St. Rep. 822 ; Jones $v$. Leonard, 50 Ia. 106 ; Hartman $v$. Aveline, 63 Ind. 344. In re Mohr, $73 \mathrm{Ala} .503$. It is argued on the other side that if the wrongdoer can be said to be constructively present in the State of the crime for the purpose of giving it jurisdiction over the offense, his subsequent presence elsewhere can only be accounted for by the fact that (constructively) he has fled from that State. Certainly much failure of justice may result from the first doctrine. For instance, in State $v$. Hall, supra, a person standing in North Carolina shot another in Tennessee. The defendant was first indicted in North Carolina for the killing, but it was held that the crime was committed in Tennessee, and that the North Carolina courts had no jurisdiction to pun. ish him. It was subsequently held that he could not be extradited to Tennessee, since he was not a "fugitive" from the justice of Tennessee. Two judges strongly dissented. See $41 \mathrm{Am}$. St. Rep. 822, note, where the dissent. ing opinion is given in full. 


\section{PART VII.}

\section{SITUS OF REMEDIES.}

\section{CHAPTER XXII.}

\section{SITUS OF REMEDIES.}

$\$ 205$. Nature of the Remedy - Form of the Action. - It is an obvious proposition that the situs of the remedy is the forum in which the remedy is prosecuted. Hence the "proper law" controlling all matters pertaining to the remedy is the lex fori, just as the lex situs of every other element in a given case governs the effect of that element. In accordance with these principles, it is well established that all matters touching the remedy and the mode of procedure, whether the injury complained of be a breach of contract, a tort, or a question of title, are to be governed by the lex fori, regardless of the domicil of the parties or the situs of the cause of action. ${ }^{1}$

It is sometimes extremely difficult to discern whether a particular inquiry relates to the remedy, or is a substantive part of the cause of action or of the rights of the parties. The distinction however is one of the utmost importance, for upon it will often depend the "proper law" which should govern a case."

1 Pritchard $v$. Norton, 106 U. S. 124, 129 et seq. ; Bank $v$. Donnally, 8 Pet. 361 ; Ruhe $v$. Buck, 124 Mo. 178, 25 L. R. A. 178 ; Burchard $v$. Dunbar, 82 IIl. 450, 25 Am. Rep. 334 ; Hoadley $v$. Transportation Co., 115 Mass. 304 ; Russell v. R. R. Co., 113 Cal. 258, 45 Pac. 323, 324 ; Thomson-Houston Electric Co. v. Palmer, 52 Minn. 174, 53 N. W. 1137, 1138; Downer v. Chesebrough, 36 Conn. 39, 4 Am. Rep. 29; Wicks v. Dawson, 42 W. Va. 43, 24 S. E. 587.

2 Instances of these difficulties have already been noted, and a criterion has been laid down in the case of contracts by which to ascertain whether a par. 
Difficult questions sometimes arise also, in actions ex contractu, from the fact that the form of the remedy will frequently depend upon the form of the contract which constitutes the cause of action.

For example, an action of assumpsit does not lie at common law upon a sealed instrument. But supposing the instrument to be made in one State and the remedy thereon to be sought in another, it might be that under the law of one of these States the instrument sued upon might be regarded as a sealed instrument, while it might be unsealed by the law of the other State. In such case, if the inquiry is directed solely toward the form of remedy to be applied, the authorities are agreed that the lex fori is to determine whether for that purpose the contract is under seal, and the law of the situs of the contract is immaterial. ${ }^{3}$ But if the nature of the contract sued upon, as sealed or unsealed, is inquired into, not with a view to ascertaining the form of the remedy, but with the purpose of determining the obligation and effect of the contract, the law of the situs of the contract, not the lex fori, will control. ${ }^{4}$

In Le Roy $v$. Beard, ${ }^{5}$ a covenant was executed and to be performed in Wisconsin, which by the law of Wisconsin was under seal (being sealed with a scroll or scrawl), but which the law of New York did not regard as under seal. Assumpsit being brought thereon in New York, it was held that assumpsit, not covenant, was the proper form of action in New York. In the course of the opinion the court said: "It was obliged to be in assumpsit in the State of New York. . . W We hold this, too, without impairing at all the principle that, in deciding on the obligation of the instrument as a contract, and not the remedy

ticular matter is a part of its obligation or relates to the remedy. See ante, $\$ \$ 180,182$. See also Ruhe v. Buck, 124 Mo. 178, 25 L. R. A. 178 ; Downer v. Chesebrough, 36 Conn. 39, 4 Am. Rep. 29 ; Baxter Nat. Bank v. Talbot, 154 Mass. 213, 28 N. E. 163 ; Hoadley $v$. Transportation Co., 115 Mass. 304 ; Burchard v. Dunbar, 82 Ill. 450, 25 Am. Rep. 334 ; post, §§ 209, 210.

3 Pritchard $v$. Norton, 106 U. S. 124, 133 ; Le Roy v. Beard, 8 How. 451 ; Bank $v$. Donnally, 8 Pet. 361, 373 ; Warren $v$. Lynch, 5 Johns. (N. Y.) 239 ; Andrews v. Herriot, 4 Cow. (N. Y.) 508; McClees $v$. Burt, 5 Met. (Mass.) 198.

4 Pritchard $v$. Norton, 106 U. S. 124, 133 ; Le Roy v. Beard, 8 How. 451.

- 8 How. 451. 
on it elsewhere, the law of Wisconsin, as the lex loci contractus, must govern."

In Trasher $v$. Everhart, ${ }^{6}$ a single bill was made in Virginia (where it was not deemed a specialty). Suit being brought thereon in Maryland, it was held that assumpsit was not maintainable as upon a simple contract, but that the action must be debt; because in Maryland, such single bill was deemed a specialty.

So, in Warren $v$. Lynch, ${ }^{7}$ a promissory note executed in Virginia with a scrawl (which there made it a sealed instrument) was held in New York, for the purpose of determining the proper form of action, to be an unsealed instrument, the laws of New York recognizing no instrument as sealed save such as were sealed with wax or wafer.

On the other hand, in Watson $v$. Brewster, ${ }^{8}$ suit was brought in Pennsylvania, by whose law a scroll was a seal, upon a note executed in New York with a scroll attached by way of seal. It was again held that the nature of the instrument, as sealed or unsealed, for the purpose of determining the form of the remedy, should be governed by the lex fori.

So, the questions whether the remedy shall be at law or in equity, in personam or in rem, summary or by regular process of law, etc., are generally to be regarded as matters pertaining to the remedy only, to be controlled by the lex fori.9

In Burchard $v$. Dunbar, ${ }^{10}$ a promissory note was executed in New York by a married woman for a debt of her husband, and was charged upon her separate estate. An action of assumpsit was brought on the note in Illinois, to which she and her husband were made defendants, and judgment was recovered against them in the lower court. By the law of New York the charge

63 Gill \& J. (Md.) 234.

75 Johns. (N. Y.) 239. See also Andrews v. Herriot, 4 Cow. (N. Y.) 508 ; McClees $v$. Burt, 5 Met. (Mass.) 198.

81 Penn. St. 381.

9 Burchard v. Dunbar, 82 Ill. 450, 25 Am. Rep. 334, 338 ; Drake $v$. Rice, 130 Mass. 410 ; New York L. Ins. Co. v. Aitkin, 125 N. Y. 660, 672 ; Ruhe v. Buck, 124 Mo. 178, 25 L. R. A. 178.

1082 Ill. 450, 25 Am. Rep. 334, 338. 
was valid and could be enforced in an action at law against her and her husband. By the Illinois law, it constituted an equitable charge, enforceable only in equity. The court held that while the obligation of the woman's contract was dependent upon the law of New York, the mode of enforcing that obligation was dependent upon the law of Illinois (lex fori), and that she could not therefore be made liable in an action at law.

In Ruhe $v$. Buck, ${ }^{11}$ a married woman contracted in Dakota, by whose law she could contract and sue and be sued like a feme sole. She owned certain real estate in Missouri which was then attached for the debt. By the law of Missouri, a married woman's property conld not be attached. The woman herself not being. within the jurisdiction of Missouri, the question was whether the right to attach the Missouri property for the Dakota debt was a part of the remedy or a substantive part of the contractual obligation. It was held (some of the judges dissenting) that it. was a matter of remedy, to be controlled by the law of Missouri (lex fori)..$^{12}$

11124 Mo. 178, 25 L. R. A. 178.

12 Though a very close case, this decision would seem to be correct upon principle. See ante, $\$ 180$. But it comes perilously near denying a remedy altogether. Upon a married woman's contract executed in a State where it is valid, a distinction must be drawn between the denial in the forum of a particular remedy, such as attachment, and the denial of all remedy. See Richmond v. R. R. Co., 21 Gratt. (Va.) 611. It would be an absurd proposition for the courts of the forum to admit that a contract made elsewhere is to be regarded as valid in the forum, and then refuse to afford any remedy for its enforcement. Hence the general rule is that if a suit is brought against a married woman on a contract validly executed elsewhere, though by the lex fori she is more or less incompetent to contract or be sued, the suit may nevertheless be maintained against her as if she were a feme sole, or as if it were a case in which, under the lex fori, she were competent to contract. See Gibson v. Sublett, 82 Ky. 596; Evans v. Cleary, 125 Penn. St. 204, 17 Atl. 440 ; Spearman v. Ward, 114 Penn. St. 634, 8 Atl. 430 ; Stoneman v. R. R. Co., 52 N. Y. 429. This statement must, however, be somewhat modified when the forum is also the woman's domicil. See ante, $\S 72$. The difficulty in Ruhe $v$. Buck, supra, was that the married woman was not within the jurisdiction of the Missouri courts, and therefore a denial of the right to attach her property was almost equivalent to a denial of all remedy, unless she were accidentally found within the jurisdiction. But this very qualification prevents it from being a denial of all remedy, and merely limits it to a remedy in personarn. 
It will be remembered that where the statute of a foreign State creates a right not penal, prescribing no special remedy, the right is regarded as transitory and susceptible of enforcement anywhere, as in the case of extraordinary liabilities of stockholders or directors of a corporation. But if special remedies are provided by the same or other statutes for the enforcement of the rights thus created, the courts of other States will go no further towards their enforcement than their own machinery justifies them in going, with due regard to justice and convenience. ${ }^{18}$

$\S 206$. Modes of Procedure - Parties to the Sult. - It is but a corollary of what has been already said, that the lex fori governs all matters relating to the procedure in the trial of causes, including the proper parties plaintiff and defendant, the process, pleadings, and rules of practice, the court wherein the cause is to be tried, the admissibility and effect of evidence, the incidents of the trial, and the appellate procedure, - indeed, everything that pertains to the remedy.

We shall consider (1) The proper parties to the suit; (2) The process, pleadings, and rules of practice; (3) Admissibility and effect of evidence; (4) Incidents of the trial.

With respect to the "proper law" governing who may be plaintiffs in a suit, it may be laid down as a general proposition that the lex fori determines the capacity of a party to sue in the forum. In general all foreigners sui juris, and not otherwise disabled by the lex fori, may maintain an action in the forum to rindicate their rights or to redress their wrongs; and this is true whether the foreign plaintiff be a mere private person, a corporation, or a sovereign. ${ }^{1}$

Thus the lex fori determines whether a foreign married woman shall sue in her own name, by her next friend, or with her husband ${ }^{2}$ or whether the assignee of a chose in action, to whom the equitable title thereto has been assigned under the law of the place where the assignment occurs, shall sue in equity

18 This question is fully discussed ante, $\S 10$.

1 Story, Confl. L. $\$ 565$; Hullett $v$. King of Spain, 1 Dow \& C. 169 United States $v$. Wagner, L. R. 2 Ch. 582 ; The Sapphire, 11 Wall. 164.

2 Bobinson v. Queen, 87 Tenn. 445,3 L. R. A. 214, 216, 11 S. W. 38. 
or at law; or if at law, whether in his own name or in the name of the assignor holding the legal title. ${ }^{3}$ But if the law of the place of assignment confers upon the assignee not only the equitable but the legal title to the chose in action, the title so conferred is a matter of substantive right, not of mere remedy, and is to be controlled by the law of the place of the assignment (lex loci contractus). In this connection, the distinction must not be overlooked between the transfer of the legal title (incidentally conferring upon the assignee the right to sue at law in his own name) and the transfer of the equitable title only, but with the special privilege of suing at law in his own name. The latter relates to the remedy, and is governed by the lex fori; the former relates to the obligation of the contract of transfer, and is governed by the lex loci contractus. ${ }^{4}$

So also with regard to the parties defendant. Thus the question whether a foreign sovereign or corporation may be sued, and if so as to the mode of procedure, will depend upon the lex fori. ${ }^{6}$ Whether an infant defendant to a foreign cause of action is to be sued in his own name, or by next friend or by guardian, is to be determined by the lex fori, not by the law of the situs of the cause of action. ${ }^{6}$ Upon the same principle the question whether a married woman defendant may be sued alone, or must be joined with her husband, depends upon the lex fori. ${ }^{7}$

$\S 207$. Process, Pleadings, and Rules of Practice. - The nature, form, effect, and mode of execution of a process to summon a defendant will depend upon the lex fori, provided it is not violative of the fundamental principles of justice embraced

8 Levy $v$. Levy, 78 Penn. St. 507, 21 Am. Rep. 35 ; Leach $v$. Greene, 116 Mass. 534 ; Foss $v$. Nutting, 14 Gray (Mass.), 484 ; Orr $v$. Amory, 11 Mass. 25 ; Pearsall $v$. Dwight, 2 Mass. 84, 3 Am. Dec. 35, 38 ; Barth v. Furnace Co., 63 Ill. App. 323.

4 Levy v. Levy, 78 Penn. St. 507, 21 Am. Rep. 35; Jordan v. Thornton, 2 Eng. (Ark.) 224, $44 \mathrm{Am}$. Dec. 546 ; ante, $\$ 164$.

5 Duke of Brunswick $v$. King of Hanover, 2 H. L. Cas. 1 ; De Haber $v$. Queen of Portugal, 17 Q. B. 171 ; Columbian Government $v$. Rothschild, 1 Sim. 94 ; Bank of Augusta $v$. Earle, 13 Pet. 579, 588-589.

- Ruhe $v$. Buck, 124 Mo. 178, 25 L. R. A. 178, 184.

7 Robinson $v$. Queen, 87 Tenn. 445, 3 L. R. A. 214, 11 S. W. $38 . \quad$ But see Evans v. Cleary, 125 Penn. St. 204, 17 Atl. 440 ; Halley v. Ball, 66 Ill. 250. 
in the term "due process of law." 1 There should always be, and in the United States there must be, such notice given tho defendant as will properly notify him of the pendency of the suit. If there be such notice, the form of it and the mode of executing it, if valid by the lex fori, will be valid and binding everywhere upon the defendant so notified. If the process is not a sufficient notice to the defendant according to the lex fori, and the judgment of the court is for that reason void under that law, it will be of no binding effect elsewhere. ${ }^{2}$

Sometimes however the process is not confined to a mere summons, but may extend to the arrest of the defendant's person. If we suppose, for example, a contract made in a State where arrests in civil cases are not permitted, or not permitted in the particular case, and suit to be brought thereon in a State where the arrest of the defendant is permissible, a question may arise whether this is a matter pertaining to the remedy or to the obligation of the contract.

Applying the criterion already mentioned, namely, the inquiry whether, if the law governing the obligation of the contract were retroactively altered so as to be identical in terms with the lex fori, it would impair the obligation of the contract, it would seem quite clear that this is a matter pertaining to the remedy. ${ }^{8}$ This is certainly true, in the case above supposed, if the liability is general, binding the promisor personally to performance, and following his person wherever he may be. The lex fori is to govern. But if the defendant's obligation is, by the terms of his contract or by the "proper law," entirely in rem, extending to his property merely, not to his person, so as to exclude any personal liability on the part of the defendant, then the exemption from liability to arrest, or to being proceeded against in personam in any manner, perhaps becomes a part of his substantive rights, and hence might no longer be controlled by the lex fori."

1 See ante, $\$ 85$.

2 Story, Confl. L. $\$ 568$; Whart. Confl. L. $\$ \S 747-750$; Dicey, Confl. L. 711.

Ante, $\$ 180$.

1 Story, Confl. L. $\$ \S 568,569,571,572$; Melan v. Fitz James, 1 Bos. \& 
In Garr $v$. Stokes, ${ }^{5}$ the defendant was proceeded against in New Jersey upon a capias. He insisted that by the laws of New York, where the contract was made, he was exempt from arrest. But the court said: "It is not necessary to spend any time to show the futility of such an objection. This is a question of lex fori, and not of lex loci contractus."

In Melan $v$. Fitz James, ${ }^{6}$ a bond was executed in France and sued on in England, which bond by the French law was understood to bind the property only, and not the person, of the obligor. The defendant, being found in England, was arrested according to the law of England, and applied for his discharge on the ground that the law of France gave no such personal remedy, but only a remedy against the property. Eyre, L. C. J., said: "If it appears that this contract creates no personal obligation, and that it could not be sued upon as such by the laws of France, on the principle of preventing arrests so vexatious as to be an abuse of the process of the court, there seems a fair ground on which the court may interpose to prevent a proceeding so oppressive as a personal arrest in a foreign country at the commencement of a suit in a case which, so far as one can judge at present, authorizes no proceeding against the person in the country in which the transaction passed. If there could be none in France, in my opinion there can be none here. I cannot conceive that what is no personal obligation in the country in which it arises can ever be raised into a personal obligation by the laws of another. If it be a personal obligation there it must be enforced here in the mode pointed out by the law of this country. But what the nature of the obligation is must be determined by the law of the country where it was entered into; and then this country will apply its own law to enforce it."

So also the lex fori will control the sufficiency and effect of an appearance by the defendant. Thus, in Jones $v$. Jones, ${ }^{7}$ a

Pul. 138 ; De La Vega v. Vianna, 1 B. \& Ad. 284, 20 E. C. L. 387 ; Wood $v$. Malin, 10 N. J. L. 208 ; Garr v. Stokes, 16 N. J. L. 404, 405.

516 N. J. L. 404, 405. See Bullock $v$. Bullock, 51 N. J. Eq. 444, 27 Atl. 435, 438.

61 Bos. \& Pul. 142.

T 108 N. Y. 415, 426-427. 
defendant to a divorce suit in Texas resided in New York, and was there served with process. He appeared specially in order to deny the jurisdiction of the Texas court, and that court overruling his objection he proceeded to file an answer. The Texas court found against him, and he afterwards attacked the Texas decree in New York on the ground that the Texas court had no jurisdiction of his person. By the law of New York, a special appearance to plead to the court's jurisdiction, even though followed, when overruled, by an answer, did not give the trial court jurisdiction. By the law of Texas it did. It was held that the Texas law should control, and that the Texas court had acquired jurisdiction of the defendant by his answer for all the purposes of the suit.

The lex fori also controls with respect to the pleadings in the suit and the rules of practice, as, for example, whether the pleadings are to be formal or informal, oral or written, by way of declaration or complaint, under the common law or code system, whether to be supported by affidavit or unverified, as to the sufficiency of the allegations, the mode of pleading defenses, etc. $^{8}$ So questions relating to the effect of a material variance, amendments of pleadings, the filing of several defenses at the same time, the forms of the general issues, the evidence which may be given thereunder, etc., are all to be determined by the lex fori.9

$\S 208$. Admissibility of Evidence - Presumptions of Law - Incidents of the Trial. - The admissibility of particular evidence in a suit is to be governed in general by the lex fori, for it partakes merely of the remedy. And this applies both to

8 Don $v$. Lippmann, 5 Cl. \& F. 1, 14, 15 ; Pritchard v. Norton, 106 U. S. 124, 130 et seq. ; Hubbell $v$. Land \& Imp. Co., 95 Tenn. 585, 32 S. W. 965966 ; Lyons v. R. R. Co. (Tex.), 36 S. W. 1007 ; Harrison v. Edwards, 12 Vt. 648, 36 Am. Dec. 364, 366 ; Lynch $v$. Postlethwaite, 7 Mart. (La.) 69, 12 Am. Dec. 495,500 . But if the question is not as to the proper mode of pleading a defense, but as to the effect of the facts pleaded, this is in general to be determined by the law of the place where those facts transpire. See Vermont Bank v. Porter, 5 Day (Conn.), 316, 5 Am. Dec. 157 ; post, § 211.

- See Whart. Confl. L. §§ 788, 789 ; Bank $v$. Donnally, 8 Pet. 361, 369 et seq. ; McAllister $v$. Smith, 17 Ill. 328, 65 Am. Dec. 651 . 
the kind and the amount of evidence necessary to prove a cause of action. ${ }^{1}$

In The City of Carlisle, ${ }^{2}$ it was held that a clause in the British Shipping Act of 1854, making certain official entries in log-books competent evidence in all courts, did not make them so in suits brought in other countries.

In Downer $v$. Chesebrough, ${ }^{8}$ an action was brought in Connecticut against the indorser of a note, made and indorsed in blank in New York, where it was made payable. The indorser attempted to show that he had indorsed it to the holder only for collection, and that there was a contemporaneous parol agreement to that effect. By the law of New York a parol contract could not be introduced in evidence to alter the legal import of a blank indorsement. By the law of Connecticut (lex fori) it could be. The lex fori was held to govern.

In Hoadley $v$. Transportation Co., ${ }^{4}$ a bill of lading for goods was given by a carrier in Illinois, the goods to be shipped to Massachusetts. The goods were destroyed by fire in Chicago, from responsibility for which the bill of lading exempted the carrier. It was urged by the shipper that he had never assented to the terms of the contract. By the law of Massachusetts, the mere receipt of the bill of lading by the consignor without dissent constituted an assent to its terms. By the law of Illinois, an actual assent was required. The Massachusetts court held that this was a mere matter of evidence to be determined by the law of Massachusetts (lex fori).

But presumptions which are conclusive, not merely prima facie, in general are part of the substantive rights of the parties, not matters of evidence or remedy merely, and therefore are regulated by the law properly governing those sub.

1 Pritchard $v$. Norton, 106 U. S. 124, 130 ; Scudder $v$. Bank, 91 U. S. 406 ; Bowles $v$. Field, 78 Fed. 742 ; McAllister $v$. Smith, 17 Ill. 328, 65 Am. Dec. 651 ; The City of Carlisle, 39 Fed. 807. But see, as to contracts required to be in writing under the statute of Frauds of the fornm, post, $\S 210$.

239 Fed. 807.

36 Conn. 39, 4 Am. Rep. 29. See Baxter Nat. Bank v. Talbot, 154 Mass 213, 28 N. E. 163 ; ante, $\$ 183$.

1115 Mass. 304, 15 Am. Rep. 106. See ante, \$151. 
stantive rights, not by the lex fori. Thus, if a contract under seal be executed in one State, by whose law the seal conclusively imports a valuable consideration, while suit is brought thereon in a State where the seal has no such effect, the law of the former State will control. ${ }^{5}$ So it has been held in Minnesota that a law of Wisconsin, making a tax-deed after the expiration of two years conclusive evidence of the validity of the tax-title to lands in Wisconsin, should be given the same effect in Minnesota. ${ }^{6}$

The lex fori also governs other incidents of the trial, such as motions for a continuance or for a new trial, motions in arrest of judgment, and the relative priority of claims. ${ }^{7}$ And the rate of interest for which judgment will be given, not as part of a contract (for that will be governed by the lex solutionis ${ }^{8}$ ), but by way of damages for the breach of a contract, or in recovering the value of converted goods, will be regulated by the lex fori. ${ }^{9}$

And in general questions as to the elements entering into the quantum of damages and the mode in which they shall be paid, as well as the effect of matter arising after the judgment which may be deemed a satisfaction or aggravation of damages, are to be determined by the lex fori, as pertaining to the remedy. ${ }^{10}$

Thus, in Evey $v$. R. R. Co., ${ }^{11}$ the plaintiff was injured in Mexico by the negligence of the defendant railroad company, and brought suit in Texas. By the law of Mexico he was permitted to recover additional damages for injuries developing after the first suit, and also to recover an "extraordinary indemnity" in consideration of his "social position." It was held that these matters related to the remedy, to be controlled, not by the law of Mexico (lex delicti), but by the law of Texas (lex fori).

5 Pritchard $v$. Norton, 106 U. S. 124, 135 ; ante, $\S 177$.

- Bronson $v$. Lumber Co., 44 Minn. 348, 46 N. W. 570.

7 Story, Confl. L. \$§ 323, 637; Harrison v. Sterry, 5 Cr. 289, 298.

8 Ante, § 184.

9 Goddard $v$. Foster, 17 Wall. 123 ; Carson $v$. Smith, 133 Mo. 606, 34 S. W

855, 858 ; ante, § 198. But see Peck v. Mayo, 14 Vt. 33, 39 Am. Dec. 205

10 See ante, $\$ 198$.

152 U. S. App. 118, 81 Fed. 294. 
Even the very foreign law itself that governs or may govern the substantive rights of the parties acquired abroad, must be pleaded and proved in the courts of the forum in accordance with the lex fori. ${ }^{12}$

$\S 209$. Exemptions. - The principles by which to ascertain the "proper law" governing homestead and other exemptions of property from execution or attachment are at present in a state bordering upon chaotic confusion. Most of the statutes creating such exemptions apply only to residents, so that the property of non-residents, if sought to be subjected under execution or attachment, is not within their purview.

The doctrine probably recognized most generally in the United States is that statutes of this character are mere matters of local policy, having no exterritorial force; that they relate simply to the remedy; and therefore that the lex fori is in all cases to determine what exemptions, if any, are to be allowed. ${ }^{1}$ But it is by means apparent on the face of the matter that exemptions of this sort pertain merely to the remedy, rather than to the obligation of the contract against which the exemption is claimed. Nor is such always the case (it is believed).

As has been already repeatedly shown, the criterion by which to determine whether a particular matter relates to the obligation of a contract or to the remedy is to inquire whether, if the contract were deprived of that element by retrospective legislation, the obligation of the contract would be impaired. If so, the matter should be regarded as part of the obligation of the contract, not as part of the remedy merely. ${ }^{2}$

12 Story, Confl. L. $\S 637$, note $(a)$. See post, $\S 212$ et seq.

1 Boykin v. Edwards, 21 Ala. 264; Kyle v. Montgomery, 73 Ga. 337 ; Mineral Point R. R. Co. $v$. Barron, 83 Ill. 365 ; Newell $v$. Haden, 8 Ia. 140 ; Burlington, etc. R. R. Co. v. Thompson, 31 Kan. 180, 47 Am. Rep. 497 ; Morgan $v$. Neville, 74 Penn. St. 52; Stevens v. Brown, 20 W. Va. 450; Commercial Nat. Bank v. R. R. Co., 45 Wis. 172 ; Lyon v. Callopy, 87 Ia. 567, 43 Am. St. Rep. 396 ; Atchison, etc. R. R. Co. v. Maggard, 6 Colo. App. 85, 39 Pac. 985 ; Harwell $v$. Sharp, 85 Ga. 124, 21 Am. St. Rep. 149 ; Wahash R. R. Co. v. Dougan, 142 Ill. 248, 34 Am. St. Rep. 74; Barker v. Browr (Ky.), 33 S. W. 833.

2 See ante, \$\$ 180, 188. 
In Edwards v. Kearzey, ${ }^{8}$ the United States Supreme Court decided that laws materially increasing exemptions, made applicable to pre-existing debts, impaired their obligation in respect to the rights of the creditor, and were void as contrary to the federal constitution.

On the other hand, it is equally well settled that, so far as the debtor is concerned, exemptions are mere privileges granted him and his family, and may be repealed at any time, without impairing any vested rights of his, and $a$ fortiori without impairing the obligation of any contract. ${ }^{4}$

If therefore the criterion above mentioned be applied to exemptions of property from execution or attachment, it will be seen that it is a part of the obligation of the debtor's contract that his exemptions shall not be materially increased, but it is no part of the obligation of the contract that they shall not be diminished or taken away. According to this view, if the law governing the obligation of the contract should permit a certain exemption, while the law of the forum permits a greater amount of property to be exempted, the former law should control. If the lex fori authorizes a lesser exemption to the debtor, or no exemption at all, the question relates to the remedy only, not to the obligation of the contract, and should be governed by the lex fori.

If this conclusion is correct, the question still remains, what law shall govern the obligation of the contract in respect to exemptions in cases where the exemption forms part of its obligation? In a previous section it has been shown that the "proper law" governing the obligation of a contract (exclusive of its validity) is the law in the minds of the parties at the time the contract is entered into; and in the absence of other evidence of the parties' intention, we must look to the law of the situs of that particular element of obligation which is under investigation. ${ }^{5}$ The element of obligation under investigation

296 U. S. 595. See also Gunn v. Barry, 15 Wall. 610; The Homestead Cases, 22 Gratt. (Va.) 266.

4 Massey $v$. Womble, 69 Miss. 347, 11 So. 188 ; Bull ". Conroe, 13 Wis. 288 ; Cooley, Const. Lim. 383. See Grand Lodge v. New Orleans, 166 U. S. 143.

- Ante, § 181. 
in this case is that relating to the mode of enforcing a judicial proceeding against the debtor. The law of the situs of that judicial proceeding therefore is the law "in the minds of the parties" as governing the exemptions to be allowed. There is only one place which might, with any degree of probability, be regarded at the time of the contract as the place where the con. tract is to be enforced in case of non-performance, namely, the deltor's domicil. Hence the parties will generally be presumed to have the law of the debtor's domicil in mind as governing the exemptions of property to be allowed the debtor, and that law should control in those cases where the exemptions are part of the obligation of the debtor's contract.

This reasoning leads then to the conclusion that if the law of the debtor's domicil permits a less exemption than the lex fori, the law of that domicil should control; while the lex fori will govern, if the lex domicilii of the debtor authorizes a greater exemption than the lex fori. ${ }^{6}$

Although this is believed upon principle to be the correct doctrine, no decision has been found to go so far. The tendency of some of the cases has been to recognize the exemptions as dependent, in part at least, upon the obligation of the contract and upon the law of the debtor's domicil rather than the lex fori, but they do not distinguish between the increase of the exemption in the forum and its decrease or total abolition there. ${ }^{7}$

6 This rule seems to operate hardly upon the debtor, but it is a no harder case (though more frequent) than that presented by the rule of constitutional law, upon which this doctrine is based, which declares that the legislature of a State cannot retrospectively increase the debtor's exemption, though it may retrospectively deprive him of the exemption altogether. As a matter of fact almost all the actual cases arise under the second branch of the rule, and the lex fori is the "proper law;" or else the forum is identical with the debtor's domicil ; so that the lex fori will usually control in any event.

7 Singer MIfg. Co. v. Fleming, 39 Neb. 679, 42 Am. St. Rep. 613 ; Drake v. R. R. Co., 69 Mich. 168, 13 Am. St. Rep. 382 ; Ill. Cent. R. R. Co. v. Smith, 70 Miss. 344, 35 An. St. Rep. 651 ; Mo. Pac. R. R. Co. v. Sharitt, 43 Kan. 375, 19 Am. St. Rep. 143 ; Kansas City, etc. R. R. Co. $v$. Cunningham, 7 Kan. App. 47, 51 Pac. 972 ; Mason $v$. Beebee, 46 Fed. 556. See La Selle $v$. Woolery, 14 Wash. 70, 44 Pac. 115, 32 L. R. A. 75. 
On the other hand, with the same indifference as to whether the provisions of the lex fori call for an increase or diminution in the amount of the exemption authorized by the law of the debtor's domicil, perhaps the majority of the decisions hold that it is in all cases a matter of remedy, to be controlled by the lex fori, regardless of the law of the debtor's domicil. ${ }^{8}$

But whatever law is selected by the courts of the forum in a particular case for their guidance in determining what property within their jurisdiction is exempt from attachment or execution (whether the law of the forum or the law of the debtor's domicil or of some third State), there can be no doubt of the power of the forum to make such provisions touching the exemption of any property within its limits as it may see fit. Hence the decision of the courts of the forum, having jurisdiction of the res in the particular case, is conclusive and binding everywhere as between the parties to the litigation, under the "full faith and credit" clause of the federal constitution."

If therefore the courts of the forum (and situs of the property

8 Mooney v. R. R. Co., 60 Ia. 346, 14 N. W. 343 ; Lyon v. Callopy, 87 Ia. 567, 43 Am. St. Rep. 396 ; Burlington, etc. R. R. Co. v. Thompson, 31 Kan. 180, 47 Am. Rep. 497; Morgan v. Neville, 74 Penn. St. 52, 57-58; Stevens v. Brown, 20 W. Va. 450 ; Carson v. R. R. Co., 88 Tenn. 646,17 Am. St. Rep. 921 ; East Tenn. R. R. Co. v. Kennedy, 83 Ala. 462,3 Am. St. Rep. 755 ; Wabash R. R. Co. v. Dougan, 142 Ill. 248, 34 Am. St. Rep. 74.

9 It will be remembered that when the question arises upon a garnishment proceeding the courts are much divided as to whether the debt attached or seized under execution has its situs with the garnishee or with his creditor, the correct view being that for this purpose the actual situs of the debt is with the garnishee wherever he may be sued. Ante, \$125. In Mason $v$. Beebee, 46 Fed. 556, the rather extraordinary and inconsistent ground is taken, that while the debt is actually with the garnishee for the purpose of jurisdiction, so as to permit it to be attached or seized, it must at the same time be regarded as at the domicil of the garuishee's creditor for the purpose of determining the exemptions to be applied. As a matter of fact (it is submitted), the court erred in supposing that the situs of the property sought to be subjected has anything to do with the matter of exemptions, save only in that, as the proceeding to seize the property must be in rem, the situs of the property is also the situs of the remedy. The question must depend, upon principles above mentioned, either upon the situs of the remedy or the situs of the obligation of the contract for the enforcement of which the remedy is applied. 
sought to be subjected) determine that the lex fori governs as to exemptions, whether or not that be the "proper law" under the rules of private international law, the decision is conclusive everywhere; and though it denies to the debtor exemptions to which he would be entitled under the law of his domicil, it is a complete defense, even in his domicil, to a suit brought by him against the garnishee to recover the exempted property or its value. ${ }^{10}$

But it does not necessarily follow that the judgment will be conclusive in the courts of the debtor's domicil upon a suit brought by the debtor against the attaching or execution creditor for the amount of the exemption allowed by the law of the debtor's domicil. Whether or not the judgment will have this effect in a suit of this kind will depend upon whether the courts of the first forum have adopted the "proper law" in determining the exemption rights of the parties. Thus, in Singer Mfg. Co. v. Fleming, ${ }^{11}$ a corporation was garnished in Iowa for a debt due to a debtor residing in Nebraska, where the plaintiff in the garnishment process also resided. By the law of Nebraska the debt due by the garnishee was exempt from garnishment; by the law of Iowa, the owner of the debt being a nonresident, it was not exempt. The Iowa court held that the Iowa law (lex fori) should control. In a subsequent suit in Nebraska by the debtor against the garnishment plaintiff to recover the money thus obtained under the decision of the Iowa court, the Nebraska court, conceiving (erroneously) that the Iowa court had not enforced the "proper law" (which the Nebraska court believed to be the law of Nebraska, the debtor's domicil), held that, while the Iowa judgment would be a complete defense in Nebraska in a suit against the garnishee, it was no defense there in a suit against the garnishment plaintiff. ${ }^{12}$

10 Singer Mfg. Co. v. Fleming, 39 Neb. 679, 42 Am. St. Rep. 613 ; Chicago, etc. R. R. Co. v. Moore, 31 Neb. 629, 28 Am. St. Rep. 534; East Tenn. R. R. Co. v. Kennedy, 83 Ala. 462, 3 Am. St. Rep. 755 ; Carson v. R. R. Co., 88 Tenn. 646, 17 Am. St. Rep. 921 ; Morgan v. Neville, 74 Penn. St. 52, 57-58.

1139 Neb. 679, 42 Am. St. Rep. 613.

12 There is some reason to question whether this decision does not contra. vene the "full faith and credit" clause of the federal constitution, and does 
Nor does it follow that the mere fact that such a garnishment proceeding is pending in another State will deprive the courts of the debtor's domicil of jurisdiction to entertain an action against the garnishee by the garnishment defendant. ${ }^{18}$

It has also been held, with doubtful propriety, that if the creditor is domiciled in the same State with the debtor, he may be enjoined by the courts of the common domicil from suing the latter in another State, with the design of evading the domiciliary law touching exemptions. ${ }^{14}$

$\$ 210$. Certain Defenses, Matters of Remedy - Statute of Limitations - Statute of Frauds. - Most of the defenses which may be made to an action upon a foreign contract or other transaction relate to the substantive rights or liabilities of the parties, and are governed by the law of the situs of the transaction. But there are certain defenses which have their origin in the fact that the law, while admitting the existence of the cause of action, for one reason or another has prohibited an action to be brought thereon. Such are usually held to be the defenses founded upon the statute of limitations and the statute of Frauds, in cases where such statutes provide that "no action shall be brought" upon the transactions embraced by their terms.

This is the form usually adopted in the case of statutes of limitations, and there can be no question but that it is a matter

not conflict with Green $v$. Van Buskirk, 5 Wall. 307. But it is believed that it does not, and that it more closely resembles Hornthall $v$. Burwell, 109 N.C. 10,13 S. E. 721 . Both of these cases have been discussed in a previous section. Ante, $\$ 132$.

13 Ill. Cent. R. R. Co. v. Smith, 70 Miss. 344, 35 Am. St. Rep. 651 ; Mo. Pac. R. R. Co. v. Sharitt, 43 Kan. 375, 19 Am. St. Rep. 143. But comity demsnds that whichever proceeding is first brought to judgment should operate as a complete defense to the other suit. See Chicago, etc. R. R. Co. v. Sturm, 174 U. S. 710.

14 Morton $v$. Hull, 77 Tex. 13 S. W. 849. See Harwell $v$. Sharp, 85 Ga. 124 , 11 S. E. 561 ; Mason $v$. Beebee, 46 Fed. 556 . In a very recent case, the Missouri court held that a Missonri statute prohibiting creditors from sending claims against residents of Missouri to other jurisdictions to be sued upon for the purpose of evading the Missouri exemptions, was unconstitutional. Whether or not this decision is sound, it shows the impropriety of the arbitrary granting of injunctions in such cases by the courts, without special authority. In re Flukes (Mo.), 57 S. W. 545. 
pertaining essentially to the remedy, and not to the obligation, of the defendant; for (applying the criterion already described) a retrospective statute, either adding to or diminishing the period within which a suit may be brought upon a contract, does not impair its obligation, provided a reasonable period is permitted the promisee within which to sue. ${ }^{1}$ Hence in general the rule of private international law is that the lex fori must control the period within which the action is to be brought. ${ }^{2}$

And this applies not only to the terms of the statute, but to the incidents connected therewith. Thus, it has been held that the effect of partial payments as interrupting the running of the statute of limitations upon a contract is to be governed by the lex fori. ${ }^{3}$ And so it is with regard to the effect of a written acknowledgment of the claim."

It may be observed in passing that a judgment for the defendant upon a plea of the statute of limitations will not prevent another suit upon the same transaction elsewhere. ${ }^{5}$

So far we have supposed the statute of limitations to be in the usual form, merely prohibiting an action to be brought after a certain period. The claim or debt is not extinguished by the termination of the period named in the statute; it remains intact. The only effect of such a statute is to prevent an action

1 Bell v. Morrison, 1 Pet. 351 ; Koshkonong v. Burton, 104 U. S. 668 ; Wheeler $v$. Jackson, 137 U. S. 245 ; Hart v. Bostwick, 14 Fla. 162 ; Ludwig v. Steward, 32 Mich. 27. See Munn v. Illinois, 94 U.S. 113, 134. For the criterion, see ante, $\S 180$.

2 Story, Confl. L. $\$ \S 576,577$ et seq.; Bank v. Donnally, 8 Pet. 361 ; Pritchard $v$. Norton, 106 U. S. 124, 130 ; Burgett $v$. Williford, 56 Ark. 187, 19 S. W. 750 ; Johnston $v$. Railway Co., 50 Fed. 886; Great Western Tel. Co. $v$. Purdy, 162 U. S. 329, 339. This rule applies also where the cause of action is a foreign judgment. See Fauton $v$. Middlebrook, 50 Conn. 44; Bauserman v. Charlott, 46 Kan. 480, 26 Pac. 1051 ; Rice $v$. Moore, $48 \mathrm{Kan}$. 590, 30 Pac. 10 ; Ambler v. Whipple, 139 Ill. 311, 28 N. E. 841.

8 Obear $v$. Bank, 97 Ga. 587, 33 L. R. A. 384.

4 See Walsh $v$. Mayer, 111 U. S. 31.

5 Bank $v$. Donnally, 8 Pet. 361 . And by parity of reason the same is true in case of a judgment for defendant upon the plea that the contract sued upon is not in writing under the statute of Frauds of the forum, or any other defense not going to the merits of the claim. 
upon the claim after that period in the State where the statute is enacted. It can have no effect elsewhere. Such is usually the effect of the statute with regard to actions to enforce a chose in action.

But if we suppose that the claim is rendered void after a certain period, not merely that an action therefor is prohibited to be brought, we are confronted with a very different question. In such cases the statute does not affect the remedy merely, but goes to the substantive rights of the parties wherever those rights are within its influence. Substantive rights are to be governed by the law of the situs of the transaction under which they arise, not by the law of the situs of the remedy. The prescription acts found in some of the European States are of this character. ${ }^{6}$

Other examples of the same principle may be found in regard to the effect of adverse possession of specific personal property, for the period prescribed by the statute of limitations. After the lapse of that period, the statute becomes a sword instead of a shield merely. An actual title is conferred upon the adverse holder, and the original owner's claim is extinguished. Hence, in the case of specific property claimed by adverse possession, it is not the lex fori which will determine the period during which it must be adversely held, but the law of the situs of the adverse possession, that is the lex situs of the property itself.

Thus, in Shelby $v$. Guy, the defendant and those under whom he claimed had been in adverse possession of certain slaves, claimed by the plaintiff, for ten years while they both lived in Virginia. Afterwards the defendant removed to Tennessee and was there sued for the slaves. By the law of Virginia, five years' possession of chattels barred an action of detinue. This Virginia statute the defendant set up in the Tennessee courts as a defense to the action. The Supreme Court of the United

6 Story, Confl. L. $\$ 582$; Don v. Lippmann, 5 Cl. \& F. 1, 16 ; Perkin\& v. Guy, 55 Miss. 153, 30 Am. Rep. 510 ; Lyman $v$. Campbell, 34 Mo. App. 213. This would seem to be a matter of discharge of the contract, to be con trolled by the lex solutionis.

711 Wheat. 361. 
States held that it was a good defense, since it attached to the possession of the property before it left Virginia. ${ }^{8}$

Another instance in which a statute of limitation may become a substantive part of the claim arises in case of actions for death by wrongful act or other statutory torts. If the same statute that creates the remedy prescribes the time within which the action thereon must be brought, it is generally construed as imposing that period for the prosecution of the remedy as a condition essential to prosecuting it at all. It becomes a part of the right itself, and is governed by the same law that regulates the right in other respects (lex loci delicti)..$^{9}$ But if the period of limitation is not prescribed by the same statute which confers the right, but is found in a general statute, the general principle applies, and it becomes a law relating to the remedy, which will have no exterritorial force. In such case, the law of the situs of the remedy (lex fori) again becomes the "proper law." 10

If the statute of Frauds is urged as a defense to an action upon a verbal contract, the statute of Frauds of the forum providing that "no action shall be brought" upon the contract in question unless in writing, etc., while the law governing the obligation of the contract authorizes the contract to be verbal, it would seem upon principle (again applying the criterion ${ }^{11}$ ) that this should be regarded as a part of the obligation of the contract, not of the remedy. For a retroactive statute applicable to an existing oral contract, providing that no action should be brought on such contracts unless in writing, would undoubtedly impair the obligation of the contract, since it takes away all remedy. But it has been more generally held that this is a

8 This case leaves it undecided whether in the case of chattels it should be the law of the actual or of the legal situs of the goods that should govern. There can be little question however that the law of the actual situs of the chattels should control.

9 Canadian Pac. R. R. Co. v. Johnson, 9 C. C. A. 587, 61 Fed. 738 ; Theroux $v$. R. R. Co., 12 C. C. A. 52, 64 Fed. 84 ; Sea Grove, etc. Association v. Stockton, 148 Penn. St. 145, 23 Atl. 1063 ; Rathbone $v$. Coe, 6 Dak. 91,50 N. W. 620 ; Cavanaugh $v$. Nav. Co., 13 N. Y. Supp. 540 ; ante, § 202.

10 Munos v. R. R. Co., 2 C. C. A. 163, 51 Fed. 188 ; Johnston v. R. R. Co., 50 Fed. 886 ; 0'Shields v. R. R. Co., 83 Ga. 621, 10 S. E. 268.

11 Ante, § 180 . 
matter of remedy, of domestic policy, to be governed by the lex fori, no matter where the contract is made or to be performed..$^{12}$

But if by the "proper law" of the oral contract it is provided that "no action shall be brought" thereon unless it be in writing, while the lex fori does not require it to be in writing, obviously the lex fori does not raise any question of the im. pairment of the obligation of the contract. On the contrary, it enforces the obligation to a greater extent than would the "proper law" of the contract. In this case, therefore, the matter is one pertaining to the remedy, to be controlled by the lex fori. ${ }^{13}$

$\S 211$. Set-offs and Counter-claims. - There is another defense which may involve some degree of conflict between the lex fori and the law governing the obligation of a contract. This is the plea of set-off. No difficulty however need arise if care is taken to distinguish between the substantive validity and effect of the claim sought to be set off, viewed as a mere claim against the plaintiff, and its effect as a defense to the plaintiff's action. In the first aspect, it is governed by its proper law, the law of its situs, just as if it were an independent claim upon which the defendant proposes to sue the plaintiff. In its second aspect, as a defense to the plaintiff's action, the question whether it may be alleged in defense thereof, the mode of pleading it, and the effect of the plea, usually pertain to the remedy merely, not to the substantive cause of action, and hence are controlled by the lex fori. ${ }^{1}$

12 Leroux $v$. Brown, 14 Eng. L. \& Eq. 247, 74 E. C. L. 800; Wolf v. Burke, 18 Colo. 264, 32 Pac. 427; Downer v. Chesebrough, 36 Conn. 39, 4 Am. Rep. 29 ; Hall v. Cordell, 142 U. S. 116. But see Baxter Bank $v$. Talbot, 154 Mass. 213,28 N. E. 163 ; Miller $v$. Wilson, 146 Ill. 523, 34 N. E. 1111, 1112; Cochran v. Ward, 5 Ind. App. 89, 29 N. E. 795. See ante, $\S \S 173,174$, where the law controlling the effect of the statute of Frauds is discussed.

13 See ante, $\$ 173,174$; Downer $v$. Chesebrongh, 36 Conn. 39, 4 Am. Rep. 29; Wolf $v$. Burke, 18 Colo. 264, 32 Pac. 427. But see Cochran vWard, 5 Ind. App. 89, 29 N. E. 795.

1 Story, Confl. L. $\$ 574$; Whart. Confl. L. $\$ \S 788,789$; Dicey, Confl. L. 711; Davis $v$. Morton, 5 Bush (Ky.), 161, 96 Am. Dec. 345 ; Fuller $v$. Steig. litz, 27 Ohio St. 355, 22 Am. Rep. 312 ; Midland Co. v. Broat, 50 Minn. 562 
But if the principal contract, in its very nature, implies a denial of the right of set-off, as in case of negotiable paper, where the gist of its negotiability lies in the fact that the maker cannot plead set-offs or other equities against a subsequent bona fide holder, the matter becomes part of the obligation of the principal contract, and is to be controlled by the proper law of that contract, not by the lex fori. Hence, to a contract negotiable by its proper law, sued upon in another State, a setoff or other equity cannot be pleaded, though it might be a proper plea under the lex fori, if the contract were governed by the latter law. ${ }^{2}$

On the other hand, if the contract is not negotiable by the "proper law," and a set-off might be pleaded under that law, it has been said that the set-off may be pleaded in the forum, though by the lex fori the contract is negotiable. ${ }^{3}$

But if we apply the criterion already used so often to distinguish the remedy from the obligation of the contract, it will be seen that, while a retrospective law pernitting a defendant in an action by the holder of a negotiable security to plead set-offs and defenses not before authorized would clearly impair the obligation of the defendant's contract, a similar retrospective law, applicable to a non-negotiable instrument (subject to equities) and prohibiting the defendant to plead set-offs and counterclaims, would not (it would seem) impair the obligation of the contract sued upon, but would merely affect the remedy. The latter question should therefore be governed by the lex fori."

$52 \mathrm{~N}$. W. 972 . The lex fori governs the statute of limitations as applied to a set-off. See Ruggles $v$. Kieler, 3 Johns. (N. Y.) 263, 3 Am. Dec. 482.

2 Pritchard $v$. Norton, 106 U. S. 124, 133; Stevens v. Gregg, $89 \mathrm{Ky} .461$, 12 S. W. 775, 776; Harrison v. Edwards, 12 Vt. 648, 36 Am. Dec. 364; Wilson $v$. Lazier, 11 Gratt. (Va.) 477, 482. See ante, $\$ 182$.

3 Vermont Bank v. Porter, 5 Day (Conn.), 316, 5 Am. Dec. 157. Seo Fuller v. Steiglitz, 27 Ohio St. 355, 22 Am. Rep. 312, 317.

4 See Pritchard $v$. Norton, 106 U. S. 124, 133 ; Midland Co. v. Broat, 50 Minn. 562, 52 N.W. 972, 973. See Bank v. Trimble, 6 B. Mon. (Ky.) 599. 
PART VIII.

\section{PLEADING AND PROOF OF FOREIGN LAWS.}

\section{CHAPTER XXIII.}

\section{PLEADING AND PROOF OF FOREIGN LAWS.}

$\S 212$. Foreign Laws must be specially Pleaded. - It is a fundamental principle of the common law that courts will take judicial notice of the public laws of their own State, and that such laws need not be specially pleaded nor proved. But the laws of other States are universally regarded as facts which, independently of statute, must be specially pleaded, wherever the lex fori requires other facts, under like circumstances, to be pleaded. 1

But if the circumstances are such that, if the foreign law in question were any other fact, it need not be pleaded, neither need the foreign law. Thus, if the foreign law is immaterial to the merits, it of course need not be pleaded. So also if the foreign law is a mere matter of evidence, the lex fori (following the general rules of pleading) not requiring matter of evidence to be pleaded, the failure to plead the foreign law is not exror.

Thus, in Thomson-Houston Electric Co. $v$. Palmer, ${ }^{2}$ a note was executed and made payable in Illinois. The consideration for the note was an antecedent indebtedness. The suit was brought in Minnesota upon the original indebtedness, to which

1 Thatcher v. Morris, 11 N. Y. 437; Thomson-Houston Electric Co. •. Palmer, 52 Minn. 174, 53 N. W. 1137, 1138 ; Liverpool Steam Co. v. Ins Co., 129 U. S. $397,445$.

2 52 Minu. 174, 53 N. W. 1137. 
the defendant pleaded payment by note. By the law of Illinois, the giving and receiving of a note for the amount of a preexisting debt operated as a payment thereof, merging the debt. By the law of Minnesota it did not, but suit might still be brought upon the original debt. The plaintiff objected that since the defendant relied upon a foreign law (the law of Illinois), it should have been specially pleaded. But the Minnesota court held that inasmuch as the proof of that law (being the "proper law" s) was merely by way of evidence of the truth of the defendant's plea of payment, it need not be specially pleaded.

In many of the States statutes have been passed dispensing with the necessity for specially pleading foreign laws, but even in such States they are usually required to be proved like other facts. ${ }^{4}$

$\S 213$. Proof of Foreign Laws. - Foreign laws are matters of fact, and like other facts should be proved, unless established by legal presumptions. A court will not take judicial notice of their existence or of their terms. And for this purpose the States of this Union are foreign to one another. ${ }^{1}$

But the federal courts, in enforcing the laws of States within their territorial jurisdiction, take judicial notice of them. In such cases, the laws are to be regarded as domestic, not as foreign, laws. ${ }^{2}$ A curious consequence flows from these principles and from the fact that the Supreme Court of the United States not only hears appeals from the federal courts, but under certain circumstances from the highest State courts also. Although the Supreme Court, sitting as a court of appeal to the federal courts, will take judicial notice of the laws of the several States, yet, if upon appeal from a State court of last resort, it has no more capacity than the State court itself to take judi-

8 Ante, $\S 189$.

4 Post, $\S 213,214$.

1 Liverpool Steam Co. v. Ins. Co., 129 U. S. 397, 445; Chicago \& A. R. R. Co. v. Ferry Co., 119 U. S. 615 ; In re Capper's Will, 85 Ia. 82, 52 N.W. 6, 8; Kelley v. Kelley, 161 Mass. 111; Ufford $v$. Spanlding, 156 Mass. 65.

2 Liverpool Steam Co. v. Ins. Co., 129 U. S. 397, 445; Lamar $v$ Micou, 112 U. S. 452 ; в. c. 114 U. S. 218. 
eial notice of the laws of other States than that from which the appeal comes. ${ }^{8}$

Primarily, the mode of proving a foreign law depends upon its nature, as statutory or common law, written or unwritten. If the law which is to be proved is statutory, the statute itself must usually be produced, or such a copy thereof as may be approved as evidence under the law of the forum. ${ }^{4}$ The judicial decisions of the State whose law is to be proved are not usually to be received in evidence to prove what is its statute law (for they are not the best evidence), but they should be looked to in order to determine the proper construction of such foreign statutes after they have been otherwise established. ${ }^{5}$ And this is true though the same provisions in the statutes of the forum have been construed differently there. ${ }^{6}$

With respect to the common or unwritten law of a foreign State or country, the general rule is that it is to be proved by the best evidence the nature of the case will admit of. This rule was formerly construed to require as a usual thing that such unwritten law must be proved by the testimony of legal practitioners of the foreign State or other persons learned in it laws. It was thought inadmissible to introduce the reports of

8 Liverpool Steam Co. $v$. Ins. Co., 129 U. S. 397, 445 ; Hanley v. Don. oghue, 116 U. S. 1; Renaud v. Abbott, 116 U. S. 277, 285.

4 Whart. Confl. L. $\$ \S 772-778$; Emery v. Berry, 28 N. H. 473, 61 Am. Dec. 622, 626; Clarke v. Bank, 10 Ark. 516, 52 Am. Dec. 248, and note; Tenant $v$. Tenant, 110 Penn. St. 478, 1 Atl. 532; Phillips $v$. Gregg, 10 Watts (Penn.), 158, 36 Am. Dec. 168.

5 Gilchrist $v$. Oil Co., 21 W. Va. 115, 45 Am. Rep. 555; Van Matre $v$. Sankey, 148 IIl. 356, 23 L. R. A. 665,36 N. E. 628 ; Hnnt v. Hnnt, 72 N. Y. 217, 28 Am. Rep. 129; Jessup v. Carnegie, 80 N. Y. 441, 36 Am. Rep. 643; Ufford $v$. Spanlding, 156 Mass. 65,69 . The same rule prevails in the federal courts. Bailey v. Maguire, 22 Wall. 350 ; Bncher $v$. R. R. Co., 125 U. S. 555.

6 Van Matre v. Sankey, 148 Ill. 356, 23 L. R. A. 665, 36 N. E. 628.

7 Loring $v$. Thorndike, 5 Allen (Mass.), 257; Gardner $v$. Lewis, 7 Gill (Md.), 378. See Whart. Confl. L. \$774. Where however the question is not as to the law of a particular country, but as to its business or other customs, or as to the general practice there, any person familiar with such customs or practice is a competent witness, thongh he knows nothing of the legal effect there of such customs or practice. See Ganer v. Lanesborongh, 
cases adjudged in a particular State as evidence of the common law of that State. ${ }^{8}$ But in recent years the opinions of the courts have undergone a change in this respect, and it is now pretty generally conceded that the published official reports of adjudged cases are competent evidence for this purpose. ${ }^{9}$ In such cases it is the province of the jury to determine whether or not such adjudications have been made in the foreign State, but it is the duty of the court to construe them and to deduce the rules of law they establish. ${ }^{10}$ And such decisions must be presented in evidence at the trial. They cannot be used for the first time in an appellate court. ${ }^{11}$

$\S 214$. Presumptions as to Foreign Laws. - Notwithstanding the rules mentioned in the preceding section touching the proof of foreign laws as facts, there are certain presumptions indulged by the courts as to the state of the law in a foreign country or State, which may operate as evidence thereof, in the absence of proof to the contrary. In other words, presumptions may arise with respect to foreign laws, just as in other matters of fact, wherever the probabilities point to a particular conclusion with sufficient force to overcome the legal principle that the burden of proof rests upon the party alleging a fact.

One of these presumptions frequently indulged by the courts, in the absence of contrary evidence, relates to the existence of the common law in a foreign State whose law is in issue, where the laws of the latter State are based upon the common law system of jurisprudence. It is a reasonable presumption, in the absence of proof to the contrary, that a common law principle applicable to the case is retained in such State. ${ }^{1}$ But where the

Peake, 18, explained in 11 Cl. \& F. 124 ; Phillips v. Gregg, 10 Watts (Penn.), 158, 36 Am. Dec. 168 ; Vander Donck $v$. Thelusson, 8 C. B. 812.

8 Gardner $v$. Lewis, 7 Gill (Md.), 378, 393.

9 Latimer $v$. Elgin, 4 Dess. (S. C.) 26, 32; Ufford $v$. Spaulding, 156 Mass. 65, 69 ; Ames $v$. McCamber, 124 Mass. 85; Thomson-Houston Electric Co. v. Palmer, 52 Minn. 174, 53 N. W. 1137.

10 Alexander $v$. Pennsylvania Co., 48 Ohio St. 623, 30 N. E. 69 ; Ufford $v$. Spaulding, 156 Mass. 65,30 N. E. 360 ; Thomson-Houston Co. $v$. Palmer, 52 Minn. 174,53 N. W. 1137.

11 Kelley $v$. Kelley, 161 Mass. 111.

1 Thorn v. Weatherly, 50 Ark. 237, 7 S. W. 33 ; Eureka Springs Co. 0. 
common law of the forum in respect to the particular question differs from the principles applied to the same question by the courts of other common law States, so that it may reasonably be doubted what the unwritten law of the foreign State may be, the general rule is that that view of the common law taken by the courts of the forum will prevail in the absence of evidence of contrary rulings by the courts of the foreign State whose law is in question. ${ }^{2}$

But it is to be observed that this presumption is applicable only to those States whose system is based upon the common law. It cannot be used to ascertain the law of a foreign State not originally settled by English colonists, or whose laws are founded upon some other system than the common law, such as the civil or Roman law, the laws and customs of Indian tribes, etc. ${ }^{\mathbf{3}}$

If the foreign law in issue is the unwritten law of a State not originally subject to the common law, or in any event if it is a statute or written law, the above presumption does not apply, and in strictness it would seem that there were no such probabilities one way or the other in general as would justify any presumption as to the foreign law. Under this view, it is a mere fact, open to inquiry, susceptible of proof, and like any other material fact must be proved in order to sustain the allegations. Without such proof, the case or the defense founded

Timmons, 51 Ark. 459, 11 S. W. 690 ; Mohr $v$. Miesen, 47 Minn. 228, 49 N. W. 862; Wolf $v$. Burke, 18 Colo. 264, 32 Pac. 427; Dunn v. Adams, 1 Ala. 527, 35 Am. Dec. 42 ; Peet $v$. Hatcher, 112 Ala. 514, 21 So. 711, 712; Flagg $v$. Baldwin, 38 N. J. Eq. 219, 48 Am. Rep. 308, 310; Benbow v. Moore (N. C.), 19 S. E. 156 ; Jones $v$. Rice (Ga.), 18 S. E. 348 ; Knapp v. Knapp (Mich.), 55 N. W. 353; Sandidge \%. Hunt, 40 La. Ann. 766, 5 So. 55, 57; Houghtaling $v$. Ball, 19 No. 84, 59 Am. Dec. 331.

2 Com. v. Graham, 157 Mass. 73; Harvey v. Merrill, 150 Mass. 1, 22 N. E. 49 ; Kelley v. Kelley, 161 Mass. 111 ; Buchanan $v$. Hubbard, 119 Ind. 187, 21 N. E. 538, 539 ; Houghtaling v. Ball, 19 Mo. 84, 59 Am. Dec. 331.

3 Buchanan $v$. Hubbard, 119 Ind. 187, 21 N. E. 538, 539 ; Brown $v$. Wright, 58 Ark. 20, $22 \mathrm{~S}$. W. 1022 ; Flagg $v$. Baldwin, 38 N. J. Eq. 219, 48 Am. Pep. 308, 310 ; Garner $v$. Wright, 52 Ark. 385, $12 \mathrm{~S}$. W. 785 ; Peet $v$. Hatcher, 112 Ala. 514, 21 So. 711, 712; Davison v. Gibson, 5 C. C. A. 543, 56 Fed. 443. 
thereon simply falls to the ground. To this strictly logical view some of the courts have subscribed."

But it must be conceded that the decided trend of the American decisions is towards the presumption, in the absence of contrary evidence, that the foreign law under which either party claims is identical with the lex fori. ${ }^{5}$

4 Atchison, etc. R. R. Co. v. Betts, 10 Colo. 431, 15 Pac. 821 ; Whitford $v$ Panama R. R. Co., 23 N. Y. 465, 468; Leonard v. Nav. Co., 84 N. Y. 48, 53 ; Thompson $v$. Ketcham, 8 Johns. (N. Y.) 189 ; Murphy $v$. Collins, 121 Mass. 6 ; Kelley $v$. Kelley, 161 Mass. 111, 114 ; Houghtaling $v$. Ball, 19 Mo. 84, 59 Am. Dec. 331. See Story, Confl. L. $\S 637$, note $(a)$. But even in States whose laws are not based upon the common law, it may be presumed without actual proof that injuries for which an inherent sense of justice de. mands that redress should be given, such as ordinary breaches of contract, deprivations of liberty without authority, physical injuries cansed by mali. cious attacks or negligent omissions, etc., will be actionable, or at least will be recognized as wrongs, in the State where the act is done. See Whitford $v$. Panama R. R. Co., 23 N. Y. 465, 468; W. U. Tel. Co. v. Phillips, 2 Tex. Civ. App. 608, 21 S. W. 638, 641. See Machado $v$. Fontes, 2 L. R. Q. B. D. 231.

5 Davison $v$. Gibson, 5 C. C. A. 543, 56 Fed. 443 ; Sandidge $v$. Hunt, 46 La. Ann. 766, 5 So. 55; Allen v. Allen, 6 Rob. (La.) 104, 39 Am. Dec. 553; Kuenzi v. Elvers, 14 La. Aun. 391, 74 Am. Dec. 434 ; Shattuck $v$. Chandler، 40 Kan. 516, 20 Pac. 225; Mo. Pac. R. R. Co. v. Sharitt, 43 Kan. 375, $1 y$ Am. St. Rep. 143 ; Haggin $v$. Haggin, 35 Neb. 375, 53 N. W. 209 ; Brown $v$. Wright, 58 Ark. 20, 22 S. W. 1022 ; Bath Gas Light Co. v. Claffy, 151 N. Y. 24, 45 N. E. 390 ; American Oak Leather Co. v. Bank, 9 Utah, 318, 33 Pac. 246 ; Gist $v$. Tel. Co., 45 S. C. 344,23 S. E. 143 ; James v. James, 81 Tex. 373, 16 S. W. 1087; Kennebrew v. Machine Co., 106 Ala. 377, 17 So. 545 ; Peet $v$. Hatcher, 112 Ala. 514, 21 So. 711, 712. A few of the cases hold that in such case the proper foreign law is substituted by the lex fori, on the ground that the laws of a country to which a party appeals for redress furnish prima facie the rule of decision. See Monroe $v$. Douglas, 5 N. Y. 447; Carpenter $v$. R.R. Co., 72 Me. 388, 39 Am. Rep. 340, 341 ; Buchanan $v$. Hubbard, 119 Ind. 187,21 N. E. 538, 539. This is only true so long as the transaction is presumed to be a purely domestic one, as it will be until a foreign element is shown to exist. But as soon as a foreign element in the transaction is proved, the "proper law" becomes applicable, and the lex fori ceases to apply. After proof of such foreign element, the lex fori will govern, if at all, not by way of substitution for the "proper law," but becanse the proper law will be presumed to be identical with the lex fori. It is not the "lex fori" (in its technical sense) that is enforced, but the "proper law" presumed to be the same as the lex fori. It is a case of identity or similarity, rather than of substitution. 
The true basis of this presumption, as a rule of law (if it is to be considered as sound), is to be found in the unwillingness of the courts to deny relief to litigants coming before them, merely for want of a law to administer. Certainly the great weight of authority is in favor of the rule. Nor is it in most instances apt to work any material injustice, since a failure of both parties to present to the court any evidence of the proper foreign law may reasonably justify the court in presuming that noither party finds anything there which would place him in a position more advantageous than he occupies under the lex fori, or which would place his adversary in a less advantageous position. It is not unfair to presume therefore, whatever the real differences may be between the "proper law" and the lex fori, that for the purposes of the case in hand neither party can be injured by the presumption that the two laws are similar. 



\section{N D E X.}

[RKFERENCES ARE TO SKCTIONS.]

ABANDONMENT,

of domicil of choice, effect of, 65-66.

of husband by wife, effect of, upon wife's domicil, 48 .

of wife by husband, effect of, upon wife's domicil, 47, 51 .

ACCEPTANCE,

of bill of exchange,

obligations imposed by, 182.

situs of, 164 .

void, if not in writing, 173.

of offer, situs of contract at place of, 157 .

ACCEPTOR OF BILL OF EXCHANGE. (See Acceptancr.)

ACCESSARIES, situs of crime of, 204. (See Crimes.)

ACCOMMODATION INDORSERS. (See INDORsERs.)

regarded as joint makers, 182.

situs of contract of, 165 .

ACCUMULATIONS, laws prohibiting, 70, 144.

ACKNOWLEDGMENT OF CLAIM, effect of, upon statute of limita tion, 210.

ACTIONS, 205-211. (See Remedy.)

for death by wrongful act, 199-202. (See DeAtr.)

local or transitory, 192.

ACTS, law governing, depends upon whether they are voluntary or invol untary, 17.

ADMINISTRATION, 102-113.

a proceeding in rem, 104.

ancillary or auxiliary, 113.

appointment and qualification of representative, 105 .

contribution between heirs or devisees, 112.

distribution of residuum, 139-150. (See Succession; Wrlus.)

exoneration of realty out of personalty, and vice versa, 112.

marshalling of assets, 110.

order of payment of decedent's debts, 110.

powers of representative over assets, 106.

assets abroad, 106.

assets transiently within State of appointment, 106.

assets subsequently removed to foreign State, 106.

assets in foreign State removed to State of appointment, 106. 
ADMINISTRATION, - continued.

powers of representative over assets,

duty of representative to collect foreign claims, 106.

judgment by or against one representative, effect of, as to an other, 107.

situs of debts for purpose of, 106, 124 .

transfer of assets in course of, chattels, 106, 124.

choses in action, 106, 124.

land, 106.

negotiable securities, 124 .

rights of creditor against decedent's land, 111.

suits by and against personal representatives, 107 .

suits by representative for tortious death, 108. (See DEaTH.)

voluntary payment of debt to foreign representative, 109.

ADMINISTRATOR, powers and duties of foreign, 102-113. (See ADMIN ISTRATION.)

ADMISSIBILITY OF EVIDENCE, 208.

of parol evidence to explain indorser's contract, 183, 208.

ADOPTION,

decree of, in rem, 86.

analogous to decree of divorce, 101.

effect of, upon infant's domicil, 34,44 .

entitles infant to inherit, when, 12.

status of, 101.

ADULTERY, capacity to remarry of guilty party to divorce for, 73,7 .

ADVERSE POSSESSION OF CHATTELS, effect of, 210.

AFFINITY, effect of, upon marriage, $9,73,75$.

AGE OF MAJORITY, law determining, 71.

AGENTS. (See Master.)

contracts by, situs of, 158 .

implied authority of, 158 .

partners as, 158, 181.

subsequent ratification of acts of, 128, 158 .

torts of, 195 .

ALIMONY, decree for, in personam, 95 .

ALTERATION OF CONTRACT, effect of, 190.

AMBASSADOR, domicil of, 20.

ANCILLARY administration, 113. (See Administration.) guardianship, 114-116. (See Guardin.) receivership, 117-118.

ANIMALS, torts by, 195.

ANIMUS MANENDI,

an essential element of domicil, 59, 62, 63 .

cliange of mind in itinere, 62.

commencement of, 62 .

death in itinere, 62. 
[References are to Sections.]

ANIMUS MANENDI, - continued.

duration of, 63.

evidence of, 64 .

in futuro not sufficient, 62 .

must unite with presence, to create domicil of choice, $69,62,68$.

presumptions as to, 64 .

arising from mere presence, 64 .

retention of last domicil, 64 .

what, sufficient, 61 .

ANTE NUPTIAL SETTLEMENT,

with respect to land, 80 .

with respect to personalty, 82 .

APPEARANCE OF DEFENDANT, necessary for judgments in personam, 85-86. not necessary for judgments in rem, 85-86. sufficiency of, law determining, 207.

APPOINTMENT, of administrators, 105. (See Administration.) of executors, 105. (See Administration.) of guardians, 114-116. (See Guardian.) of receivers, 117-118. wills under power of, 150.

APPRENTICE, domicil of, 37.

ARREST, for crimes, 203-204. (See Crimes.)

in civil cases, 207.

ASSAULT, 204. (See Crimes.)

ASSENT TO CONTRACT, law governing, 151, 208.

ASSETS,

administration of, 102-113. (See Administration.)

exoneration of, 112.

land, as, 111.

legal or equitable, 110 .

marshalling of, 110.

real or personal, 110.

ASSIGNEE,

of chose in action may sue in his own name, when, 165, 206.

for benefit of creditors, title of, 133-135. (See Assignment.)

in bankruptcy, title of, 137-138. (See Assignment.)

ASSIGNMENT,

of bill or note, right of maker or acceptor to plead invalidity of, 122

182.

of debt, right of assignee to sue in his own name, 165, 206.

situs of debt, for purpose of, 122.

of fund, bill or check operating as, 181.

of insurance policy, 166.

of land, 11-12. (See ImMOVA BLE8.) 
ASSIGNMENT, - continued.

of personalty, 127-150.

absolute conveyances and sales, 128-130.

as between the parties, 128 .

as to creditors, 129.

sales, reserving title in vendor, 130 .

chattel mortgages, 132.

donations mortis caus $\alpha, 131$.

for benefit of creditors, 133-135.

in case of land, 11.

in case of personalty, 138-135.

fraud per se, 135.

preference of creditors, 135.

recordation of, 135.

subsequent removal of property, 133.

what creditors may attack, 134 .

in bankruptcy or insolvency, 137-138.

distinguished from voluntary, how, 187.

given no exterritorial effect, 137

otherwise in England, 137.

what creditors may attack, 138 .

transfers by marriage, 136.

transfers by succession, 139-141. (See Successiov.)

transfers by will, 142-150. (See Wills.)

ASSUMHTION OF RISK, doctrine of, in dangerous employments, 197.

\section{AT'TACHMENT,}

by creditors, of personalty transferred, 129, 134, 138.

exemptions from, 126, 209.

issuance of, to be controlled by lex fori, 180 .

situs of debt for purpose of, 125.

B.

\section{BANKRUPTCY,}

assignment in, 137-138.

distinguished from voluntary assignment, how, 137.

given no exterritorial effect, in United States, 137.

otherwise in England, 137.

what creditors may attack, 138.

discharge in, effect of, upon contracts, 191.

BANNS, omission of, in celebrating marriage, 77.

DASTARD,

domicil of, $33,42$.

constructive, 42.

original, 33.

legitimation of, 97-100. (See Legrtimacy.)

right of, to succeed to personalty, 140 .

subsequently legitimated, domicil of, 43 .

subsequently legitimated, right of. to succeed to property, 12. 
[References are to Sections.]

BIGAMOUS MARRIAGES, 74, 75.

bill OF EXCHANGE. (See Negotiable Instruments.)

BILL OF LADING. (See Contracts.) assent to, 151, 208.

place of performance of, 160 .

validity of exemptions in, 169 .

BOND. (See Contracts.)

effect of, as merging prior indebtedness, 189.

interest upon, 184 .

situs of, 163.

BO'TTOMRY BOND, authority of shipmaster to execute, 158.

BURDEN OF PROOF,

as to change of domicil, 29,64 .

as to foreign laws, 214 .

as to negligence, 197.

BUSINESS CAPACITY, law governing, 71.

C.

CAPACITY,

a passive, not an active, element, 69 .

a status, 69 .

as relating to voluntary or involuntary transactions, 69 .

for business in general, 71 .

married woman, as trustee, 71 .

period of infancy, 71 .

period of wardship, 71.

settlements of guardian witl ward, 71.

to assign insurance policy, 166.

to contract, $72,171$.

in case of infant. 72 .

in case of married woman, 72,166 .

to make a will of lands, $12,150$.

to make a will of personalty generally, 70, 144 .

under power of appointment, 150.

to marry, 73 .

consanguinity or affinity, 73,75 .

guilty party to divorce prohibited to remarry, 73,74 .

miscegenation, 73.

polygamous marriages, 75 .

to succeed to decedent's estate,

as devisee or legatee, 12, 70, 144.

as heir or distributee, $12,140$.

\section{CARRIER,}

contract of, 160,169 . (See Bill of Ladivg ; Contracts.)

evidence of assent to bill of lading, 151, 208.

exemption of, from liability as insurer, 169. 
CARRIER, - continued.

exemption of, from liability for negligence, 169 .

liability of, for malicious acts of servants, 197 .

liability of, for torts, 195-202. (See TorTs.)

sleeping car company, liable as, 197.

CELEBRATION,

of contracts generally, law governing, 167-174. (See Contracts.)

of marriage, law governing, 77, 172.

CEREMONIES,

for contracts generally, law governing, 172-174.

for marriage contract, law governing, 77, 172 .

for wills, law governing, 143.

CHAMPERTOUS CONTRACTS, validity of, 168, 175, 176.

CHARITABLE TRUSTS, validity of, 70, 144.

ChATTELS. (See Movables.)

CHECK, operation of, as assignment of fund, 181.

CHILD,

adoption of, 101. (See Adoption.)

decree for custody of, in rem, 96.

domicil of, 31-45. (See Dom IcrL.)

guardianship of, 40-41, 71, 114-116. (See Guardran.)

legitimacy of, 97-98.

legitimation of, $12,33,43,97-100$. (See LegitimacY.)

relation of parent and, a double status, 97 .

rights and duties of parents towards, 83 .

CHOICE, domicil of, 56-66. (See Domicil.)

Chose IN ACtion. (See Debt.)

CITAtion. (See Process.)

CITIZENS,

of forum, lex fori substituted in favor of,

in case of executory contracts, when, 7-8, 72, 152.

in case of executed transfers of personalty,

absolute conveyances, 129 .

administration, 102-113. (See Administration.)

assignments for benefit of creditors, 134-135.

assignments in bankruptcy, 138.

chattel mortgages, 132.

guardians, 114-116.

marital rights, $80-82$.

receivers, 117-119.

succession, 140.

in case of status,

adoption, 101.

capacity, 70-74.

divorce, 89-94. (See Drvorce.)

legitimacy, 98-100.

marriage, 73-74. 
CITIZENS, - continued.

of other States, lex fori substituted in favor of,

in case of administration, 102-113.

in case of assignments in bankruptcy, 138 .

in case of receivers, 117-119.

CITIZENSHIP,

distinguished from domicil, 21.

how in United States, 21.

domicil inferred from, when, 66 .

COLLISION,

interpretation of insurance policy excepting losses arising from, 186.

of ships upon high seas, law governing, 195.

COMITY, basis of private international law, 4 .

COMMON CARRIER. (See Carrier.)

COMMON LAW OF ANOTHER STATE

presumptions as to, 214.

proof of, 213.

COMMUNITY OF PROPERTY, 80-82.

COMPARATIVE NEGLIGENCE, 197.

COMPENSATORY DAMAGES, 10, 198.

COMPETENCY. (See CapacitT).

of parol evidence to explain indorser's contract, 183, 208.

of witnesses, generally, 208 .

of witness, convicted of crime abroad, 10 .

CONSANGUINITY, effect of, upon marriage, $9,73,75$.

CONSIDERATION,

antecedent indebtedness a, 176, 182.

executed, 177 .

executory, 176.

failure of, effect of, upon contract, 177 .

for conveyance or mortgage of land, 11 .

for promise, situs of, 154-155, 161-162, 176-179.

gaming, 161, 176, 178.

law of place of, governs validity of contract, when, 11, 176-179.

legality of, 178-179.

malum in se, or contra bonos mores, 9, 152, 177.

past services, as, 177 .

sale of liquor, as, $161,176,178$.

sale of prohibited articles, 178.

sale or hire of slaves, as, $177,178$.

sufficiency of, 177.

usurious, 179.

wagering, 161, 176, 178.

want of, 177.

CONSPIRACY, 204. (See Crimes.)

CONSTRUCTION. (See Interpretatrom.)

CONSUL, domicil of, 20. 
CONTRA BONOS MORES,

foreign law, when substituted by lex fori, 8 .

incestuous marriages, 9,75 .

polygamous marriages, 9,75 .

Sunday contracts, not, 9 .

validity of contract, $9,152,177$.

CONTRACTS,

alteration of, 190.

champertous, 168, 175, 176.

contra bonos mores, $9,75,152,177$. (See Contra Bonos Mores.)

gaming, 161, 176, 178.

implied from work done, etc., 151, 163.

in restraint of trade, 175 .

insurance, 166, 170, 176, 186. (See Insurance Contracts.)

insurer's liability of carrier, qualified by, 169.

interlineation of, 190.

interpretation of, $128,186$.

marriage, 73, 77, 77-78. (See Marriage.)

merger of, by substituted agreement, 189 .

negotiable paper, 121-125, 164-165, 182-183, 211.

nuptial, touching consort's land, 80 .

touching consort's personalty, 82 .

of surety, discharged by notice to sue, 181 .

to convey land, $11,72,174$.

to marry, 77.

executed,

absolute conveyances and sales of land, 11-12.

of personalty, 128-130.

as between the parties, 128 .

as to third persons, 129 ,

assignments for benefit of creditors, 11, 133-135.

fraud per se, 135.

personalty subsequently removed, 133 .

preferences of creditors, 135.

recordation of assignments, 135.

what creditors may attack, 134 .

donations mortis causa, 131 .

liens upon land, 12.

upon personalty, 132.

marriage, 73, 77-78. (See Marriage.)

mortgages, of land, 11.

of personalty, 132 .

sales of chattels, with reservation of title, 130.

executory,

discharge of, 187-191. (See Discuarg z.)

evidence of assent to, 151, 208.

interpretation of, 186.

lex fori controls, when, 6-10, 72-75, 152.

liability upon, transitory, 151. 
[References are to Sections.]

CONTRACTS, - continuea.

executory,

obligation of, $180-185$.

criterion to distinguisl remedy from, 180, 205 .

governed by " law in minds of the parties," 181.

governed by lex solutionis, in general, 181.

in case of contract of acceptor or inaker, 182.

in case of contract of drawer or indorser, 183.

in case of contract to pay interest, 184.

in case of contracts and covenants touching land, 185.

situs of, or locus contractus, 153-166.

conflicting views as to, 153-156.

locus contractus analyzed, 154-155.

locus celebrationis, $157-158$.

locus considerationis, 161-162.

locus solutionis, 159-160.

of contract to pay money generally, 163 .

of insurance contract, 166 .

of negotiable instruments, 164-165.

acceptor's contract, 164 .

drawer's contract, 165.

indorser's contract, 165.

maker's contract, 164 .

validity of, 167-179.

void in the making, - lex celebrationis, 167-174.

capacity, $72,171$.

entry into, prohibited, 168.

exemptions in bills of lading, 169 .

exemptions in insurance policies, 170.

formal validity of, 172-174.

marriage, 77, 172. (See Marriage.)

on unstamped paper, 172.

required to be in writing, 173-174.

roid in the performance, - lex solutionis, 175.

roid in the consideration, - lex loci considerationis, 176-179

executed consideration, 177.

executory consideration, 176.

failure of consideration, 177 .

legality of consideration, 178-179.

past consideration, 177 .

sufficiency of consideration, 177

usurious consideration, 179.

want of consideration, 177.

CONTRIBUTION, between heirs or devisees, 112

CONTRIBUTORY NEGLIGENCE, 197.

CONVERSION OF CHATTELS, 195.

CONVEyanCE. (See Assignment; Contractr.)

of land. 11-12. 
[References are to Sections.]

CONVEYANCE, - continued.

of personalty, 128-150.

CORPORATION,

domicil, or situs of, 67.

legatee, right of, to be a, 70,144 .

officer of, right of, to compensation for services, 151 .

stockliolders of, statutory liabilities of, 10 .

CORRESPONDENCE, situs of contract by, 157-158. (See Contracts.)

COSTS, decree for, in personam, 95.

COUNTER-CLAIM, 211.

COVENANT,

action of, upon unsealed instrument, 205.

in conveyance of land, $12,185$.

of title, 185 .

running with the land, 185.

to relinquish marital rights in land, 174.

COVERTURE. (See Married Woman.)

CREDIT, to be given foreign judgments, 86, 89-94.

CREDITORS,

domestic, preferred to foreign, 7-8.

in case of absolute conveyance of chattels, 129 .

administration, 102-113.

assignments for benefit of creditors, 134-135.

assignments in bankruptcy, 138.

chattel mortgages, 132.

guardianship, 114-116.

marital rights, 80-82.

receivership, 117-119.

sales of chattels, reserving title, 130 .

foreign, upon a par with domestic,

in case of administration, 102-113.

in case of assignments for benefit of creditors, 135 .

in case of assignments in bankruptcy, 138.

in case of chattel mortgages, 132 .

garnishments by, 125, 126, 209.

CRIMES,

disabilities resulting from, not recognized abroad, 10 .

extradition for, 204.

local, not transitory, 203.

may be made transitory, when, 203.

situs of, 204.

accessaries, 204.

adultery, 74 .

agency set in motion, taking effect in another State, 204.

agents, 204.

assault, 204.

bigamy, 74. 
[References are to Section\%.]

CRIMES, - continued.

situs of,

conspiracy, 204.

false pretenses, 204.

forgery, 204.

fornication, 74 .

homicide, 204.

larceny, where goods are brought into another State, 204.

lewdness, 74 .

robbery, where goods are brought into another State, 204.

CURTESY, of husband, 12, 80 .

CUSTODY OF CHILDREN,

decree for, in rem, 96.

guardian's right to, 115 .

\section{D.}

DAMAGES,

elements entering into estimate of, 208.

iuterest by way of, 208. (See INTEREst.)

limits placed upon, in general, 160.

limits upon, in actions for tortious death, 202.

several kinds of, 198.

compensatory, 10, 198.

penal, 10, 198.

punitive, 198.

DANGEROUS EMPLOYMENT, assumption of risk in, 197.

DAYS OF GRACE, 182.

DEATH BY WRONGFUL ACT,

action for, by representative, 108 .

action for, where injury occurs in one State, and death in another, 195

action for, in general, 199-202.

lex delicti controls, 200-202.

limit of damages, 202.

modern tendency to liberality, 200.

proper plaintiff, $108,201$.

time within which, to be brought, 202,210 .

DEBTS,

effect of payment of, to foreign representative, 109.

order of payment of, in administration, 110.

situs of, 106, 121-126.

actual, with debtor, 121-125.

constructive, or legal, with creditor, 121-124.

at creditor's actual situs, when, 121-124.

at creditor's legal situs, or domicil, when, 121-124.

for purpose of administration, 124.

for purpose of attachment and garnishment, 125.

for purpose of taxation, 123.

for purpose of voluntary transfer, 106, 122. 
DECEDENT, administration of assets of, 102-113. (See ADMINIsTRation; Succession.)

\section{DECISIONS,}

as evidence of foreign laws, 213.

value of, as authority, 16.

DECLARATIONS, as evidence of domicil, 64 .

DECREES. (See Judguents.)

distinction between, in rem and in personam, 85-86.

ex-territorial effect of, 86-96.

for alimony, 95 .

for costs, 95 .

for custody of infants, 96 .

for divorce, 87-94. (See Divorce.)

interest upon, 184.

priorities of foreign, 86 .

statute of limitations applicable to foreign, 86 .

DEEDS,

assignment, 11, 133-135. (See Assignmexr.)

conveyance of chattels, 128-132.

absolute transfer of, 128-130.

chattel mortgage, 132 .

sale, reserving title, 130 .

conveyance of lands, 11-12.

consideration for, 11.

covenants in, 12.

interpretation of, 12.

validity of, 12 .

DELIVERY, PLACE OF, the locus celebrationis of bosds, notes, atc., 157, $163,164$.

DESCENT,

of land, 12.

adopted child as heir, 12 .

bastard, subsequently legitimated, as heir, 12 .

heirs, who to be, 12 .

shares of parceners, 12.

of personalty, 139-141. (See Succession.)

DESERTION,

lusband's, gives wife right to choose her own domicil, 47.

effect of, upon her domicil, where husband seeks divorce, 51 .

wife's, leaves her domicil with husband's, 48.

DEVISE,

capacity to, $12,13$.

capacity to receive, 12 .

interpretation of, 12, 145.

trusts in, 12, 70, 144.

validity of, 12,13 .

DIRECTORS OF CORPORATIONS,

liabilities of, 10. 
[References are to Sections.]

DIRECTORS OF CORPORATIONS, - continued.

right of, to compensation for services rendered, 151.

DISABILITY. (See Capacity.)

domicil of persons under, 31-55. (See 1)омıсı.)

of guilty party to divorce to re-marry, penal, 10, 74 .

of penal nature, not recognized abroad, 10 .

DISCHARGE OF CONTRACTS, 187-191.

by operation of law, in general, 190 .

alteration or interlineation, 190.

drawer's or indorser's, 183, 190.

sureties, 181, 190.

by performance, 188 .

by substituted agreement, 188.

merger, 189.

release, 189.

by tender, 188 .

in bankruptcy, or insolvency, 191.

DISHONOR, notice of, to bind drawer or indorser, 183. 190.

DISTRIBUTION,

of bankrupt's assets, 137-138.

of decedent's assets, 102-113, 139-150. (See Administration; Suc CESSION ; WILLS.)

DIVORCE,

domicil of wife for purpose of, $28,48,50-52$.

can she have more than one, 28.

deserted wife may choose her own domicil, 47.

deserting wife domiciled with husband for purpose of 48,51 .

domicil of wife seeking, 50 .

domicil of wife, whose husband seeks, 51 .

effect of, upon marital rights, 12.

effect of, upon wife's domicil, 52.

a mensa, 52.

a vinculo, 52.

invalid, 52 :

effect of foreign, 84-96.

alimony, 95 .

costs, 95 .

custody of minor children, 96 .

jurisdiction to decree, dependent on domicil, 89-94.

both parties domiciled in State of, 89 .

duration of residence, immaterial, 90 .

neither party domiciled there, 90 .

only one party domiciled there, 91-94.

recital of, effect of, 89 .

proceedings for, quasi in rem, 87 .

res in proceedings for, 88 .

fraud in procurement of, vitiates decree. 89 
DIVORCE, - continued. grounds for, law governing, 78, 84 .

guilty party to, prohibited to remarry, 10, 73, 74 .

\section{DOMICIL,}

abandonment of, 65-66.

area of, 24.

burden of proof touching change of, 29.

definition of, 23.

distinguished from citizenship or nationality, 21 .

distinction how far recognized in United States, 21.

distinguished from residence, 20.

ambassadors, 20.

consuls, 20.

students, 20.

effect of change of, upon interpretation of will, 148, 186.

general rules touching, 27-30.

no person without a, 27 .

only one, at a time, 28.

persons suijuris may change, at will, 30 .

retained until anotler is gained, 29.

gives jurisdiction for divorce, $84,89-94$.

law of. (See Lex Domicilir.)

matrimonial, no such thing as, 81 .

zational, quasi-national, and municipal, 19.

of apprentice, 37.

of corporations, 67 .

period of, for purpose of divorce, immaterial, 90 .

several sorts of, 31-64.

of origin, 31-34.

of adopted child, 34 .

of bastard, 33 .

of child born legitimate, 32 .

of foundling, 34 .

of legitimated child, 33 .

constructive, 35-55.

of idiots, 54 .

of infants, 35-45.

adopted child, 44.

bastard, 42 .

bastard subsequently legitimated, 43.

emancipated child, 45.

legitimate child, 37-41.

father alive, 37 .

father dead, mother alive, 38 .

inother's remarriage, 39 .

mother and father both dead, 40-41.

of lunatics, 55 .

power of guardian over, 41. 
DOMICIL, - continued.

constructive,

of married woman, 46-53.

generally same as husband's, 46 .

of deserted wife, 47 .

of deserting wife, 48 .

of divorced wife, 52 .

of wife of insane or incapacitated husband, 49.

of wife seeking divorce, 50 .

of wife whose husband seeks divorce, 51 .

of wife whose marriage is void or voidable, $5 \&$

of choice, 56-66.

actual presence, essential to, 59-60.

but not residence, 60 .

animus manendi, essential to, 59, 61-64.

change of mind in itinere, 62.

commencement of animus, 62 .

deatl in itinere, 62 .

duration of the intention, 63 .

evidence of the intention, 64 .

circumstances, 64 .

declärations, 64 .

double residence, 64 .

presumptions, 64 .

mere presence, 64 .

retention of last, 64 .

future intent, not sufficient, 62 .

must accompany presence, 56,62 .

what animus sufficient, $61-63$.

freedom of choice, 57-58.

motives for selection of, immaterial, 57 .

of exiles, 57 .

of fugitives from justice, 57 .

of invalids, 58.

of prisoners, 57 .

of refugees, 57.

DONATION MORTIS CAUSA, 131.

DOWER OF WIFE,

governed by lex situs, 12,80 .

jointure, a bar to, when, 147.

DRAFT. (See Negotiable Instruments.)

operation of, as assignment of fund, 181.

DRAWER OF BILL. (See Negotiable Instruments.)

discharge of, $183,190$.

notice of dishonor, etc., 183.

obligations of, 183.

situs of contract of, 165.

DUE PROCESS OF LAW, in judicial proceedings, 85-86 
E.

\section{ELECTION,}

of widow to take jointure or dower, 147.

to take under a will, 146, 147.

EMANCIPA'TION, effect of, upon infant's domicil, 45 .

EMPI,OYER'S LIABILITY,

for negligence of servants, 195-197.

for torts by fellow-servants, 169, 197.

risk assumed by servant, when, 197.

EQUITABLE CONVERSION, 13.

EVASION OF PROPER LAW, 9, 77, 159.

EVIDENCE,

admissibility of, 208.

burden of proof, to establish change of domicil, 29 .

of animus manendi, to create domicil, 64 .

of assent to contract, 151, 208.

of foreign laws, 213-214.

of lex loci delicti, in case of torts, 193.

of presence, to create domicil, 60 .

parol, to explain indorser's contract, 183, 208.

presumptions, 177, 197, 208.

conclusive, 177, 208.

prima facie, 177, 197, 208.

stamped contracts, $172,210$.

statute of frauds, 173-174, 210.

EXCEPTIONS TO OPERATION OF FOREIGN LAWS, 5-18

foreign law contra bonos mores, 9, 75, 152.

foreign law penal, 10, 74, 152, 194.

immovable property, 11-13.

injustice or detriment to people of forum, 7-8. (See Creditors.)

interests or policy of forum contravened by foreign law, 6, 135, 137-138

operation of, with respect to

administration, 102-113. (See Administration.)

adoption, 101.

assignments for benefit of creditors, 135 .

assignments in bankruptcy, 138.

capacity, 71-75.

chattel mortgages, 132.

conveyances of personalty, 129 .

distribution of decedent's estate, 139-141.

executed sales of chattels, 129.

with reservation of title, 130 .

executory contracts, 6-10, 72-75, 152.

guardianship, 114-116.

legitimation, 97-100.

marital rights, $80-82$. 
[Roferences are to Sections.]

EXCEPTIONS TO OPERATION OF FUREIGN LAWS, - continued. operation of, with respect to marriage, 73 . receivership, 117-119. torts, 194-197.

EXCHANGE, RATE OF, on foreign contracts, 186.

EXECUTOR, powers and duties of foreign, 102-113. (See Administra. TION).

EXEMPTION,

from liability in bills of lading, 169.

from liability in insurance contracts, 170 .

of property from attaciment, etc., 126, 209.

injunction against foreign garnishment, 209.

judgment decreeing, how far recognized elsewhere, 209.

when part of obligation, 209.

when part of remedy, 209.

EXILES, domicil of, 57.

EXONERATION of decedent's land out of personalty, and vice versa, 112 .

EXTRADITION OF CRIMINALS, 204.

constructively present in another State, and there committing crime, 204.

EXTRATERRITORIAL EFFECT, of administration, 102-113. (See Admivistration.)

of adoption, 101. (See Adoption.)

of assignment for benefit of creditors, 133-135. (See Assignmmrt.)

of assignment in bankruptcy, 137-138. (See Assignment.)

of contracts. (See Contracts.)

of conveyances, 11-12, 127-132.

of crimes, 203-204. (See Crimes.)

of divorce, 87-94. (See Divorce.)

of donation mortis causa, 131.

of intestacy, 139-141. (See Successiov.)

of judgments and decrees, 85-86. (See JoDGMENTs.)

of legitimation, 97-100. (See Legitimacy.)

of marriage, 73, 77-78. (See Marriage.)

of mortgages, 11-12, 132.

of penal laws, 10.

of torts, 192-202. (See TorTs.)

of wills, 142-150. (See Wills.)

F.

FALSE IMPRISONMENT, 196.

FALSE PRETENSES, 204. (See Crimes.)

FATHER. (See ChILD.)

by adoption, status of, 101. (See Adoption.)

domicil of child, same as that of, 32,37 . 
FATHER, - continued.

marriage or acknowledgment of, as legitimating bastard, 97-100. relation of child and, a double status, 97 .

rights and duties of, towards child, 83.

FELLOW-SERVANTS, torts by, 169, 197.

FIDUCIARIES, status of, 102-118, 133-135, 137-138.

administrators, 104-113. (See Administration.)

assignees for benefit of creditors, 133-135. (See Assigrmext.)

assignees in bankruptcy, 137-138. (See Assignuent.)

executors, 104-113. (See Administration.)

guardians, 114-116. (See Guardian.)

receivers, 117-118.

FOREIGN ADMINISTRATION. (See ADministration.)

FOREIGN ADOPTION LAWS. (See ADoption.)

FOREIGN ASSIGNMENTS. (See Assignments.)

FOREIGN CONTRACTS. (See Contracts.)

FOREIGN CREDITORS. (See CREDITORS.)

FOREIGN CRIMES. (See Crimes.)

FOREIGN GUARDIANS. (See Guardians.)

FOREIGN INDORSERS. (See INDORSERs.)

FOREIGN JUDGMENTS. (See JUDGMENTs.)

FOREIGN LAWS,

exceptions to operation of. (See ExcEptions.)

exterritorial effect of. (See Extraterritorial Effect.)

pleading and proof of, 212-214.

FOREIGN LEGITIMATION LAWS. (See Legitimacr.)

FOREIGN MARRIAGES. (See Marriage.)

FOREIGN RECEIVERS. (See ReceIvers.)

FOREIGN STATUS. (See Status.)

FOREIGN SUCCESSION. (See Succession.)

FOREIGN TORTS. (See TORTS.)

FOREIGN WILLS. (See WILLS.)

FORGERY, 204. (See CrIMEs.)

FORM,

validity of contracts in point of, 172-174.

validity of marriages in point of, 77, 172.

FORUM, law of. (See Lex Fori.)

FOUNDLING, original domicil of, 34 .

FRAUDS,

effect of, upon marriage, 78.

effect of, in procurement of foreign divorce, 89.

per se, in assignments for benefit of creditors, 135 .

statute of, 173-174, 210. (See Statete of Fra Uds.)

FREEDOM OF WILL, essential to domicil of choice, 57-58. 
[References are to Sections, ]

FUGITIVE FROM JUSTICE, domicil of, 57.

extradition of, 204.

FULL FAITH AND CREDIT, to be given foreign judgments, 86, 89-94 FUTURES, validity of contracts relating to, 176 .

G.

GAMING CONTRACTS, 161, 176, 178.

GARNISHMENT,

exemptions in case of, 129, 209.

foreign, how far recognized, 209.

injunction against, in another State, 209.

situs of debt for purpose of, 125.

GRACE, DAYS OF, 182.

GUARANTOR. (See Stretirs.)

GUARDIAN, capacity of ward to settle with, 71 .

decree appointing, in rem, 96 .

effect of want of consent of, upon ward's marriage, 77.

power of, to change ward's domicil, 40-41.

status of, 114-116.

with respect to ward's person, 115 .

with respect to ward's property, 116.

GUILTY PARTY TO DIVORCE, prohibited to re-marry, 10, 73, 74

a decree in personam, 74 .

a penal disability, 10,74 .

marriage by, 73,74 .

H.

HEIRS,

contribution among, 112.

interpretation of the term in contracts and wills, 145-146, 186

who are, 12.

HERITABLE BONDS, 112, 146.

HIGH SEAS,

assignment of ship upon, 120 .

collisions upon, 195.

conveyance of ship upon, 120, 129.

marriage upon, 77.

situs of cargo of ship upon, 120.

situs of ship upon, 120, 129 .

torts on ships upon, 195.

HOLDER FOR VALUE, of negotiable paper who is, $18 \%$

HOME. (See DOMICIL).

HOMESTEAD. (See Exemptiox.) 
HOMICIDE, 204. (See Crimes.)

HOTCHPOT, 146.

\section{HUSBAND,}

authority of, over wife, 79.

curtesy of, 12.

distributive share of wife in personalty of, 81, 139-141. (See Sua cession.)

dower of wife in lands of, 80.

effect of change of domicil of, upon wife's domicil, 28, 30, 46-53. (Set Doмicil.)

marital rights of wife in property of, 80-82.

payment to, discharges debt to wife, when, 188.

release by, discharges debt to wife, when, 188 .

surety for, wife as, 72.

IDIOT, domicil of, 54 .

ILLEGITIMA'TE CHILD. (See BAstaRd; Legrtimact.)

IMMORAL CONTRACTS, 9, 75, 152, 177.

IMMOVABLES,

assets in hands of heir, 110-112.

assignment of, for benefit of creditors, 11, 133.

assignment of, in bankruptcy, 137 .

charges and liens upon, 12, 111.

contract to convey, 11, 72, 174, 185.

contribution between co-heirs, 112.

conveyance of, 11-12.

covenants, contained in deeds, 12, 174, 185.

creditor's right to subject decedent's, 111.

deeds of, validity and interpretation of, 11-12.

descent of, 12.

adopted children, 12.

legitimated children, 12.

devises of, 12, 13.

interpretation of, $12,145-148$.

validity of, $12,70,80,144$.

equitable conversion, 13.

exoneration of, out of personalty, and vice versa, 112

guardian's powers over ward's, 116.

marital rights in, 12,80 .

effect of divorce upon, 12.

mortgage of, 11 .

personal representative's rights over, 106.

torts to, local or transitory, 192, 195.

what are, 13.

IMPEDIMENTS TO MARRIAGE, 73, 78. 
[References are to Bections.]

IMPLIED CONTRACTS, 151, 163.

IMPRISONMEN'T,

effect of, upon domicil, 57.

when belonging to remedy, 207.

IN ITINERE,

effect upon domicil of change of intent, 62 .

effect upon domicil of death, 62 .

marital rights in personalty acquired, 81 .

situs of contract made, 159.

IN TRANSITU. (See In Itinere.)

INCAPACITY. (See Capacity.)

INCESTUOUS MARRIAGES, 75.

INDEFINITE 'TRUSTS, validity of, 70, 144.

INDORSER. (See Negotiable Instruments.)

executed contract of, $165,182$.

passes title to indorsee, how far, 165, 182.

validity of, 165, 182.

executor or administrator as, 122, 124.

executory contract of, 165 .

discharge of, 183, 190.

how far to be explained by parol evidence, 183,208 .

interest upon, 184.

obligation of, 183.

validity of. (See Consideration.)

for accornmodation,

liability of, as joint maker, 182.

situs of contract of, 165.

prior indebtedness, a consideration for contract of, 182.

situs of contract of, 165.

INFANT,

action against, 206.

adoption of, 12, 44, 86, 101. (See Adoption.)

capacity of,

for business generally, 71 .

to contract, 72 .

to make a will, $12,70,144$.

domicil of, 30-45. (See DомıсіL.)

guardian's powers and duties with respect to, 114-116. (See Guardiax.)

legitimacy of, 97-100. (See LegrtimaCY.)

parents, duty of, towards, 83.

period during which one remains an, 71.

INSANE PERSON,

domicil of, 55 .

domicil of wife of, 49.

INSOLVENCY,

assignment in, 137-138. (See Assignment.)

discharge in, effect of, upon contract, 191. 
INSOLVENCY, - continued.

distribution of decedent's assets in case of, 113.

receivers appointed, in case of, 117-118.

INSURANCE CONTRACTS,

assignment of, 166.

carrier's, how far qualified by contract, 169.

by notice, 169 .

conditions and exemptions in, 170.

failure to pay premiums, 170 .

insurable interest, 170 .

interpretation of, 186.

misrepresentations, 170.

situs of, 166.

suicide of insured, 170 .

validity of, 170 .

validity of premium notes in consideration of, 176 .

INTEREST,

as damages for failure to pay at maturity, 208.

obligation to pay, in general, 184.

acceptor or maker, 184.

drawer or indorser, 184.

no rate of, named, after maturity, 184 .

upon coupon notes, 184.

upon judgments, 184.

upon legacies, 113.

upon value of chattels in trover, 208.

usurious, 179, 184.

INTERLINEATION OF CONTRACT, 190.

INTERPRETATION,

of contracts, 186.

of conveyances of personalty, 128 .

of deeds, 12, 128.

of wills, 145-148, 186.

of wills under power of appointment, 150 .

INTESTATE,

administration of property of, 102-113. (See Administration.) succession to property of, 12, 139-141. (See Successiox.)

INVALIDS, domicil of, 58.

INVOLUNTARY TRANSACTIONS, situs of, 17, 18 .

transfers of personalty by assignment in bankruptcy, 137-138.

by marriage, 81,136 .

by will, 70, 142-150. (See Wills.)

J.

JOINT CONTRACT, situs of, 157, 182.

JOINTURE, a bar to wife's marital rights, 147. 


\section{JUDGMENTS,}

[References are to Sections.]

by or against personal representatives, effect of, elsewhere, 107 .

distinction between, in rem and in personam, 85-86.

exterritorial effect of, 86-96.

alimony, 95.

costs, 95 .

custody of children, 96 .

divorce, 87-94. (See Divorce.)

when penal, $10,8 b^{\circ}$.

form of, pertains to remedy, 208.

interest upon, 184.

priorities of foreign, 86 .

statute of limitations applicable to, 86 .

upon plea of statute of limitations or of frauds, not conclusive, 210 .

JUDICIAL SEPARATION, effect of, upon wife's domicil, 52.

JURISDICTION,

in adoption cases, 86, 101.

in divorce cases, 87-94. (See Drvorce.)

in exoneration, 112.

in marshalling of assets, 110,112 .

in personam, 85-86.

in rem, 85-86.

recital of, in decree of divorce, 89 .

situs of cliattels for purpose of, 14, 120 .

situs of debts for purpose of, 120, 121, 125.

\section{L.}

LAND. (See ImMOVABLES.)

LAPSE, of bequest or devise, 147.

LAPSE OF TIME, effect of, upon right to sue, 210. (See Limitations.)

LARCENY, goods stolen in one State, brought into another, 204.

LEASEHOLDS, immovable property, 13.

LEGACY. (See WiLLs.)

interest upon, 113.

interpretation of, 145-148, 150, 186.

validity of, 70, 143-144.

LEGAL TENDER, what is, 188.

LEGATEE, capacity to be a, 70, 144 .

right of, to be paid by ancillary administrator, 113 .

\section{LEGITIMACY,}

a permanent status, 97 .

beneficial to child, 98,100 .

child born in lawful wedlock, 98 . 
LEGITIMACY, - continued.

child born in unlawful wedlock, 98 .

child born out of wedlock, 99-100.

legitimated by intermarriage of parents, 99, 100 .

legitimated otherwise than by intermarriage, 100 .

subsequent legitimation, entitles child to inherit, when, 12.

effect of, upon child's original domicil, 33.

effect of, upon child's constructive domicil, 43 .

LEGI'TIMATION. (See Legitimacr.)

LETTER, situs of contract by, 157-158.

LEX DOMICILII, when controlling,

capacity in general, 70-73.

for business, 71 .

to contract, $72,171$.

to make a will, $70,144$.

to marry, 73,74 .

exemptions of property from attachment, etc., 209.

interpretation of contracts, 186.

interpretation of wills of land and personalty, 12, 145-146, 150.

involuntary transfers of personalty,

assignments in bankruptcy, 137-138. (See Assignment.)

marital rights, 80-82, 136.

succession, 139-141. (See Succession.)

will, 142-150. (See Wills.)

status generally, adoption, 101. (See Adoption.)

fiduciaries, 102-118. (See Fiduciaries.)

legitimacy, 97-100. (See LegitimaCy.)

marriage, 79-94. (See Marriage; Divorce.)

LEX FORI, when controlling,

administration of decedent's assets, 102-113. (See Administration) adoption, 101. (See Adoprion.)

assignments for benefit of creditors, 133-135. (See Assignxerr.)

assignments in bankruptcy, 137-138. (See Assignment.)

chattel mortgages, 132.

contracts executory, 6-10, 72, 74, 152.

crimes, 203-204.

distribution of decedent's estate, 139-141. (See Succession.)

divorce, grounds of, 84 .

executors, powers and duties of, 102-113. (See Admivistration.)

executed sales of chattels, 129.

reservations of title, 130 .

guardian, relation of, to ward, 114-116. (See GuARDIAN.)

legitimation, 97-100. (See Legrtimacy.)

marriage contract, 73-75.

marital rights, 79-82.

receivers, status of, 117-119.

remedy, 205-211. (See REMEdY.) 
LEX FORI, - continued.

substitution of, for proper law, 5-14.

contra bonos mores, 9 .

immovables, 11-13.

injustice to people of forum, 7-8.

policy of forum, 6 .

torts, 194, 196, 200.

LEX LOCI CELEBRATIONIS, when controlling,

capacity to contract, $72,171$.

capacity to marry, 73-74.

formal validity of contract, 172-174.

formal validity of marriage, 77 .

substantial validity of contract, 168-170.

validity of conveyances of personalty, 128-135. (See Assignment.)

validity of marriage, 78 .

what is the locus celebrationis of contracts, 157-158.

LEX LOCI CONSIDERATIONIS, when controlling, validity of contracts, 11, 128, 176-179.

what is locus considerationis, 161-162.

LEX LOCI CONTRACTUS, when controlling,

executed contracts,

assignments for benefit of creditors, 133-135. (See Assranment.)

chattel mortgages, 132.

conveyances of chattels, 128.

donations mortis causa, 131.

exemptions in bills of lading, 169.

exemptions in insurance policies, 170.

marriage, 73, 77-78.

nuptial settlements, 80-82.

sales of chattels, 128.

with reservation of title, 130 .

executory contracts, 153-191.

locus contractus, 153-166.

conflicting views as to, 153.

true view, must be analyzed, 154 .

locus celebrationis, 157-158.

locus considerationis, 161-162.

locus solutionis, 159-160.

LEX LOCI DELICTI, when controlling.

actions for torts generally, 195-202. (See TorTs.)

actions for death by wrongful act, 108, 195, 199-202. (See Deatr.)

crimes, 203-204. (See Crimas.)

LEX LOCI REI SIT Æ. (See LeX Forı.)

LEX LOCI SOLUTIONIS, when controlling,

discharge of contracts, 187-191.

obligation of contracts, 180-186.

validity of contracts, whose performance is prohibited, 77,175 .

what is locus solutionis, 159-160. 
LEX SITUS. (See LEx Fori.)

LICENSE, effect of omission of, upon marriage, 77.

LIENS,

of foreign judgments, 86 .

upon chattels, 128, 132, 205.

upon lands, 11-12, 111, 205.

LIMITATIONS, STATUTE OF, actions on foreign judgments, 86 .

actions for tortious death, 202, 210.

adverse possession of chattels, 210 .

application of, generally, 210 .

effect of partial payments, 210 .

effect of written acknowledgment, 210.

no action to be brought after lapse of time, 210 .

transaction void by prescription, 210 .

judgment for defendant, upon plea of, not conclusive, 210.

LIQUOR, contracts to pay for, 161, 176, 178.

LOANS OF MONEY. (See UsURY.)

LOTTERY, contracts relating to, 161, 176, 178.

LUNATIC,

domicil of, 55. (See Domrcru.)

domicil of wife of, 49 .

M.

MAINTENANCE,

contracts void for, $168,175,176$. (See Champertous Contracts.)

of children, parent's duty as to, 83 .

of wife, 95 .

MARITAL,

powers of husband, 79 .

rights in land, $12,80$.

effect of covenant to surrender, 174 .

rights in personalty, 81-82.

in absence of nuptial agreement, 81 .

in case of nuptial agreement, 82 .

union or status, 79-94. (See Marriage; Drvorce.)

MARRIAGE,

by divorced person prohibited to remarry, 73,74 .

contract for, 77 .

contract of, 77-78.

effect upon, of evasion of domiciliary law, 9. of consanguinity and affinity, 9, 73, 75 .

effect of, upon infant's domicil, 45 . upon woman's domicil, 46-53.

validity of, 77-78.

in point of form, 77 .

in point of substance, 78 . 
[References are to Sections.]

MARRIAGE, - continued.

incestuous, 9, 75 .

legitimation by, 97-100. (See Legitimacy.)

miscegenation, 73 .

polygamous, 9,75 .

status of, 79-96.

authority of husband over wife, 79.

commencement of, 79 .

dissolution of, 84-96. (See Divorce.)

grounds for, governed by lex fori, 84 .

duality of, 97 .

incidents of, 80-83.

marital rights, 80-82, 136 .

rights and duties of parents to offspring of, 83 .

transfer of personalty by, 80-82, 136 .

will revoked by, 149 .

MARRIED WOMAN,

action against, $205,206$.

authority of husband over, 79.

capacity of, to be a trustee, 71 .

capacity of, to contract, $72,205$.

capacity of, to make a will, 12, 70, 144, 150.

capacity of, to transfer insurance policy, 166.

charge upon separate estate of, 12, 205.

debt of, when discharged by payment to, or release by, husband, 188 .

distributive sliare of, in husband's personalty, 81, 139-141. (See Suc cession.)

divorce of, 84-96. (See Divorce.)

domicil of, 28, 30, 46-53. (See Domrcı.)

dower of, 12.

jointure of, 147.

marital rights of, in husband's personalty, 81-82.

marital rights of husband in personalty of, 81-82.

support of child by, 83 .

MARRY,

capacity to, 73. (See Capacitr.)

contract to, 77 .

MARSHALLING OF ASSETS in administration, 110.

MASTER,

domicil of, is domicil of apprentice, 37 .

liability of,

for malicious acts of servants, 197.

for negligence of servants, 195-197.

for torts by fellow-servants, 169, 197.

risk assumed by servant, when, 197 .

of ship, authority of, 158 .

MATRIMONIAL DOMICIL, no such thing as, 81

MATRIMONY. (See Marriage.) 


\section{[References are to Sections.]}

MERGER, of contract by substituted agreement, 189.

MERTON, STATUTE OF, 12.

MINISTER, domicil of foreign, 20.

MINORITY. (See INFANT.)

MISCEGENATION, 73.

MORTGAGE,

of chattels, 132 .

of lands, 11-12.

MORTMAIN, STATUTES OF, not restrictive of testamentary capacity, $70,144$.

MOTHER. (See ChILd.)

by adoption, status of, 101. (See Adoption.)

domicil of child, when that of, $38,39,42$.

duality of relation of child and, 97 .

duty of, to support child, 83.

MOVABLES,

application of lex delicti to, in case of torts, 192, 195.

application of lex domicilii to,

assignments in bankruptcy, 137-138.

guardian and ward, 114-116. (See Guardian.)

marital rights, $80-81$.

succession, 139-141. (See Succession.)

taxation, 123.

wills, 142-150. (See WiLLs.)

application of lex loci contractus to,

absolute conveyances or sales, 128 .

assignments for benefit of creditors, 133 .

assignments of chose in action, 122, 135.

chattel mortgages, 132.

donations mortis causa, 131.

marriage settlements, 82 .

sales, reserving title, 130 .

vendor's lien or privilege, 128 .

application of lex situs et fori to,

absolute conveyances, 129 .

administration, 102-113. (See Administration.)

assignments for benefit of creditors, 134-135.

assignments in bankruptcy, 137-138.

assignments of chose in action, 122, 134-135, 137-138.

chattel mortgages, 132.

guardian and ward, 114-116. (See GuardinN.)

liens, 128, 132.

marital rights, 80-82.

receivers, 118-119.

sales, reserving title, 130.

succession, 139.

wills, $70,144$. 
MOVABLES, - continued.

situs of, 119-125.

chattels, 120.

debts, 121-125.

for purposes of administration, 124.

for purposes of assignment, 122.

for purposes of attachment and garnishment, 125.

for purposes of taxation, 123.

ships upon high seas, 120, 195.

MUNICIPAL DOMICIL,

distinguished from national, 119.

is existence of, essential to national domicil ? 24 .

MURDER, 204. (See Crimes.)

N.

NATIONAL DOMICIL,

distinguished from municipal, 19.

is existence of municipal domicil essential to ? $\mathbf{2 4}$.

NATURE OF CONTRACT, law governing, 181, 205.

NECESSARIES, duty of parent to supply infant child with, 83 .

NEGLIGENCE,

committed in one State, injury resulting in another, 195.

comparative, 197.

contributory, 197.

death in one State resulting from injury in another, 195.

presumption of, 197.

validity of contracts exempting from liability for, 169 .

NEGOTIABLE INSTRUMENTS. (See INDORSEr; Contracts.)

accommodation indorsers,

liability of, 182.

situs of contract of, 165 .

days of grace, 182.

defenses to, 182-183, 210, 211.

interest upon, 184.

merger of prior indebtedness by receipt of, 189 .

notice of dishonor, 183.

obligations of acceptor, 182 .

of drawer, 183.

of indorser, 183.

of maker, 182.

operation of bill or check, as assignment of fund, 181.

narol explanation of indorser's contract, 183, 208.

pleas in actions upon,

by acceptor or maker, $182,210,211$.

by drawer or indorser, 183, 211 .

presentment, 183.

protest, 183. 
NEGOTIABLE INSTRUMENTS, - continued.

purchaser of, for value, who is, 182.

situs of, 121-125, 164-165.

validity of. (See Consideratron.)

in point of form, 173.

NEGROES, marriages of whites and, 73.

NON-RESIDENT,

creditors. (See Creditors.)

defendants,

in divorce causes, 87-94. (See Drvorce.)

in proceedings in personam, 85-86.

in proceedings in rem, $85-86$.

transfer of personalty of. (See Movables.)

NOTE. (See Negotiable Instruments; Contracts.)

interest upon, 184.

merger of prior indebtedness, by receipt of, 189 .

situs of, 163-165.

NOTICE,

carrier's liability as insurer qualified by, 169.

of assignment of chose in action, 182, 211.

of dishonor of negotiable paper, 183, 190.

NUPTIAL AGREEMENT,

with respect to chattels, 82 .

with respect to land, 80 .

0.

OBLIGATION OF CONTRACT,

criterion to distinguish remedy from, 180, 205.

nature of, 180.

particular contracts, acceptor's contract, 182.

contracts touching land, 185.

contracts to pay interest, 184. (See INTEREst.)

corenants running with land, 185 .

drawer's contract, 183.

indorser's contract, 183.

maker's contract, 182.

OFFENSES, 203-204. (See Crimes.)

OFFER, place of acceptance of, the locus celebrationis of contract, 128, 157

ORDER OF PAYMENT. (See Priority.)

ORDER OF PUBLICATION,

how far sufficient in divorce causes, 89, 91-94.

insufficient for proceedings in personam, 85 .

sufficient for proceedings in rem, 85 .

ORIGIN,

domicil of, 31-34. (See Dом1сrL.)

of private international law, 1. 
P.

PARENT. (See Child.)

PAROL CONTRACTS, validity of, 173-174, 210.

PAROL EVIDENCE,

to explain indorser's contract, 183.

to explain written contract, 208.

PARTIAL PAYMENTS, effect of, upon statute of limitations, 210.

PARTNERS,

authority of, to bind firm, 158 .

liability of, for firm debts, 181.

sharing in profits creates, 181.

some of whom residents, lex fori substituted for, when, 8 .

in case of discharge in bankruptcy, 191.

PASSENGER, liability of carrier to, for agent's assault, 197. (See CArrier )

PAYMENT,

effeet of, in discharging contract, 188.

effect of partial, upon statute of limitations, 210.

place of, the locus solutionis of bond or note, 163, 164.

of drawer's or indorser's contract, 165.

PENAL DAMAGES FOR TORTS, distinguished from punitive, 10, 198.

PENAL LAWS, not enforceable, 10, 74, 194.

PENALTY, effect of foreign judgment for, 10, 86.

PERFORMANCE OF CONTRACT,

as discharge, 188.

effect of tender of, 188.

law of place of, controls contract, when, 154-155, 175, 180-191.

discharge of contract, 187-191.

obligation of contract, 180-186.

validity of contract, 175 .

place of, 159-160, 163-166.

prohibited, 175.

PERPETUITIES, testamentary dispositions creating, 12, 70, 144.

PERSONAL REPRESENTATIVE, 102-113. (See Administration.)

PERSONALTY. (See Movables.)

PERSONS,

capacities of, 70-75. (See CAPACitY.)

situs of, $18-66$.

actual, 18.

legal, or domicil, 19-66. (See DomiciL.)

status of, 68-96. (See Status.)

PLEADING,

governed by lex fori, 207.

of foreign laws, 212.

POLICY OF FORUM, lex fori substituted for proper law, because of, 6

(See LeX Fori.' 
[References are to Sections.]

POLICY OH INSURANCE. (See Insurance Contract8.)

POLYGAMOUS MARRIAGES, 74, 75.

POST-NUPTIAL SETTLEMENTS, 80-82.

POWER OF APPOINTMENT, wills under, 150.

PRECEDENTS, value of, 16.

PREFERENCE OF CREDITORS, in assignments, 135.

PRESCRIPTION, transactions void by, 210. (See Limitations.)

PRESENCE,

essential to domicil of choice, 59-60.

evidence of domicil, when, 64 .

PRESENTMENT, of negotiable paper, 183.

PRESUMPTIONS,

as to domicil, 64 .

as to existence of common law in another State, 214.

as to foreign laws in general, 214.

as to negligence, 197 .

as to place of performance of contract, 159-160, 163-166.

PRETERMITTED CHILD, will revoked by birth of, when, 149.

PRINCIPAL AND AGENT. (See Agent; Master.)

PRINCIPAL AND INTEREST. (See Interest.)

PRINCIPAL AND SURETY. (See Sureties.)

PRIORITY,

of debts, in administration, 110.

of foreign judgments, 86.

PRIVATE INTERNATIONAL LA W, distinguished from public, 2.

PROBATE, decree of, in rem, 86.

PROCESS,

actual service of, required in proceedings in personam, 85-86.

constructive service of, sufficient for proceedings in rem, 85-86.

of arrest in civil cases, 207.

of law in judicial proceedings, 85-86.

to commence an action, 207 .

PROMISF. (See Contracts.)

of marriage, 77.

PROMISSORY NOTE. (See Negotiable Instruments.)

interest upon, 184.

merger of prior debt in, 189.

situs of, 163-165.

PROOF. (See Evidence.)

PROPER LAW,

meaning of term, 5 .

what is the "proper law" governing,

administration, 102-113. (See Administration.)

adoption, 101. (See Adoptron.)

assignment for benefit of creditors, 133. (See Assignment.)

assignments in bankruptcy, 137-138. (See Assıgmext.) 
[References are to Bections.]

PROPER LAW, - continued.

what is the "proper law" governing,

assignments of chose in action, 122.

capacity, 70-75.

for business generally, 71 .

to contract, 72.

to make a will, 70, 144.

to make a will under power of appointment, 150 .

to marry, 73-75.

contracts, executory. (See Contracts.)

discharge of, 187-191. (See Dischamak.)

interpretation of, 128, 186.

obligation of, 180-186. (See Obligatron.)

validity of, 167-179.

void in the consideration, 176-179. (Ste Cossideration.)

void in the making, 168-174.

capacity, 72, 171.

entry into prohibited, 168.

exemptions in bills of lading, 169 .

exemptions in insurance policies, 170.

formal validity, 171-174.

stamped, 172.

statute of frauds, 173-174.

void in the performance, 175 .

champertous contracts, $168,175,176$.

in restraint of trade, 175.

promise of marriage, 77 .

conveyances of land, 11-12.

conveyances of personalty, 128.

crimes, 203-204.

curtesy, 12, 80.

descent, of land, 12.

devise of land, 12, 145-148, 150.

divorce, 87-94. (See Divorce.)

donations mortis causa, 131.

dower, $12,80$.

guardian and ward, 114-116. (See Guardian.)

legacies, 70, 142-150. (See Wrlis.)

legitimacy, 97-100. (See Legrtimacy.)

legitimation, 98-100. (See Legitimacr.)

marital rights, $80-82$.

marriage contract, 73-78. (See Marriage.)

marriage status, 79-96. (See Marriage.)

mortgages, 11-12, 132.

nuptial contracts, $80-82$.

receivers, $117-119$.

remedies, 205-211. (See Rexedy.)

sales of chattels, 128.

reserving title, 130. 


\section{[References are to Sections.]}

PROPER LAW, - continued.

what is the "proper law" governing, status. (See Status.) succession, 139-141. (See Succession.) taxation of personalty, 123. torts, 192-202. (See Tonts.) wills, 12, 142-150. (See WiLls.)

PROTEST, of negotiable paper, 183, 190.

PUBLIC INTERNATIONAL LA W, distinguished from private, 2. PUBLICATION, ORDER OF,

how far sufficient in divorce causes, 89, 91-94.

insufficient for proceedings in personam, 85-86.

sufficient for proceedings in rem, 85-86.

PUNITIVE DAMAGES, distinguished from penal damages, 198.

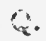

QUANTUM MERUIT, liability upon, 151, 163.

QUASI-CONTRACTS, 10, 151, 163.

QUASI IN REM, divorce a proceeding, 87, 91 .

R.

RATE OF EXCHANGE, 186.

RATE OF INTEREST. (See INTEREST.)

RATIFICATION, of agent's contract, 158.

REAL PROPERTY. (See ImMovabLes.)

RECEIVERS,

status of, $117-118$.

suits by and against, 118 .

title of, to personalty elsewhere, 15, 117.

RECITAL OF JURISDICTION, in foreign decree of divorce, 89.

RECORDATION, of transfers of personalty, 129-135.

RECOUPMENT, 211.

REFUGEES, domicil of, 57 .

RELEASE,

discharge of contract by, 189.

by husband, as discharge of debt to wife, 188 .

of marital rights in land, 174.

RELIGIOUS RITES, effect of omission of, upon marriage, 77.

REMEDY,

action, form of, 205.

against infant, 206.

against married woman, 205, 206.

assumpsit upon sealed contract, 205.

by assignee of chose in action, 206. 
REMEDY, - continued.

action, form ef,

covenant upon unsealed contract, 205.

parties to, 205-206.

criterion to distinguish obligation from, 180, 205.

damages, elements entering in to estimate of, 208.

evidence, 208. (See Evidence.)

exemption laws, 209. (See ExEmption.)

pleadings, 207.

practice, rules of, 207.

presumptions of law, 208.

if conclusive, matter of substance, 208.

if prima facie, matter of evidence, 208.

process, 207. (See l'rocess.)

of arrest, 207.

set-off, 211.

situs of, 205-211.

special statutory, 10, 205.

statute of frauds, 172-174, 210.

statute of limitations, 210. (See Limitations.)

adverse possession of chattels, 210.

claim void by prescription, 210.

no action to be brought, 210 .

REPORTS OF ADJUDGED CASES, as evidence of foreign laws, 213. RESERVA'TION OF TI'TLE, sale of chattels, with, 130.

RESIDENCE,

as evidence of domicil, 64 .

confounded with domicil, $20,21$.

identical with domicil in United States, 21.

distinguished from domicil generally, 20.

double, effect of, upon domicil, 64 .

effect of, upon rights of creditors. (See Credrrors.)

not essential to domicil of choice, 60 .

suits against defendants with, elsewhere, 85-94.

RESTRAINT OF TRADE, contracts in, 175.

REVENUE LAWS, no exterritorial force given to, 9, 172.

REVOCATION OF WILLS, 149.

S.

SALES,

of land, 11-12, 72, 174, 185. (See ImmovabLes.)

of personalty, 128-130.

as between the parties, 128 .

as to third persons, 129 .

executory. (See Contracts.)

warranty implied in, 181.

with reservation of title, 130 . 
INDEX.

[References are to Secticns.]

SCIENTER, proof of, in action for tort, 195, 197.

SCROLL, as a seal, 205.

SEAL,

action upon contract under, 205.

consideration imported by, 161, 177, 207.

release of contract under, 189.

scroll, as a, 205.

what is a, 205.

SEPARATE ESTATE, charge upon wife's, 12, 205.

SEPARATION, effect of judicial, upon wife's domicil, 52.

SERVICES, implied contract to pay for, 151, 163.

SET-OFF,

effect of, as a defense, 211.

validity of counter-claim, 211.

SETTLEMENTS, effect of marriage, $80,82$.

SHAREHOLDERS OF CORPORATIONS, liability of, 10.

SHIP UPON HIGH SEAS,

collision, 195.

conveyance of, 129 .

master, authority of, 158.

situs of, 120.

torts upon, 195.

SICK PERSONS, domicil of, 58.

SITUS. (See Proper Law.)

basis of private international law, 4.

law of, identical with lex fori. (See LEx Forr.)

of contracts. (See Conrracrs.)

of corporations, 67 .

of crimes, 203-204. (See Crimes.)

of debts, 121-125.

for purpose of administration. (See Admisisrration. $j$

for purpose of assignment, 122.

for purpose of attachment and garnishment, 125 .

for purpose of taxation, 123.

of land, 11-13. (See Immovables.)

of marriage contract, 73-78. (See Marriage.)

of negotiable paper, 121-125, 164-165, 182-183.

of personalty, 14-15, 119-126. (See Movances.)

of persons, 17-18, 19-66.

actual, 18.

legal, or domicil, 19-66. (See Domicru.'

of remedy, 205-211. (See REMEDY.)

f status, 68-118.

administrators, 102-113. (See Administration.)

adoption, 101.

assignee for benefit of creditors, 133-135.

sssignee in bankruptcy, 137-138. 
[References are to Sections.]

SITUS, - continued.

of status,

capacity, 69-75. (See Capacity.)

executors, 102-113. (See Administration.)

guardians, 114-116. (See GiJardian.)

legitimacy, 97-100. (See Legitimacy.)

marriage, 76-96. (See Marriage ; Divorce.)

receivers, 117-118.

of succession, 12, 139-141. (See Succession.)

of torts, 192-202. (See Torts.)

of wills, 12, 142-150. (See Wills.)

SLAVERY, contracts relating to, 9, 177, 178.

SLAVES, regarded as immovables, when, 13.

SLEEPING-CAR COMPANY, a carrier, 197.

SOLEMNITIES,

of marriage, $77,172$.

of other contracts, 172-174.

STAMP LAWS, effect of, upon contracts, 172.

STATUS,

change of person's situs does not usually affect his, 15 .

except in cases of local and temporary, 96, 114-118.

definition of, 68 .

law governing, 68-118.

adoption, 101.

capacity, 69-75. (See Capacrtr.)

fiduciaries, 102-118.

administrators, 102-113. (See Administration.)

assignees for benefit of creditors, 133-135.

assignees in bankruptcy, 137-138.

executors, 102-113. (See Administiration.)

guardians, 114-116. (See Guardian.)

receivers, 117-118.

legitimacy, 97-100. (See Leg ITıMacy.)

marriage, 73-96. (See Marriage; Divorce.)

STATUTES,

of frauds, 173-174, 210.

of limitations, 210. (See Limitations.)

presumptions as to foreign, 214.

proof of foreign, 213.

special remedies by foreign, 10.

STOCK, situs of, 121-125. (See DeBrs.)

STOCKHOLDERS OF CORPORATION, liabilities of, 10.

STUDENTS,

domicil of, 20.

right of, to vote, 20.

SUBSTITUTED PROCESS,

how far sufficient in divorce causes, 89, 91-94. 


\section{SUBSTITUTED PROCESS, - continued.}

insufficient for proceedings in personam, 85-86.

sufficient for proceedings in rem, 85-86.

SUCCESSiON. (See Administration.)

to land, 12 .

to personalty, 139-141.

capacity of distributees to take, 140. bastards, 140 .

children by adoption, 12 .

collaterals of half-blood, 140 .

legitimated child, 12.

distributees, who are, 140. shares of, 140.

titles of administrator and distributee contrasted, 139.

SUIT. (See Acrion.)

SUMMONS. (See Process.)

SUNDAY,

contracts, not contra bonos mores, 9.

validity of contracts made on, 168 .

validity of coutracts to be performed on, 175 .

SUPPORT,

of child, duty of parents as to, 83 .

of wife, duty of husband as to, 79,95 .

SURETIES,

discharge of, 181, 190.

married women as, 72 .

obligation of joint, 181, 182.

T.

\section{TAXATION,}

as evidence of domicil, 64 .

situs of chattels for purpose of, 123.

situs of debts for purpose of, 123.

TELEGRAM, situs of contract by, 157 .

TELEGRAPH COMPANY, exemption of, from liability for mistakes, 169 TENDER OF PERFORMANCE, effect of, 188.

TERMS FOR YEARS, immovable property, 13.

TESTAMENTARY DISPOSITIONS. (See WiLLs.)

TESTAMENTARY GUARDIAN, right of, to change ward's domicil, 40-41. (See Guardian.)

TORTS,

actions for, local or transitory, 192.

common law or statutory, 193.

damages for, compensatory, penal or punitive, 198. 
TORTS, - continued.

death by wrongful act, 199-202.

conditions of action for, determined by lex delicti, 202 .

damages, limit of, 202.

injury in one State, death in another, 195.

limitations, period of, 202, 210.

proper plaintiff, 108, 201.

fellow-servants, 197.

lex loci delicti controls, 195-197.

exceptions to operation of lex delicti, 194.

liability of carriers, 195, 199-202.

of carrier of passengers for malicious act of servant, 197.

negligence,

comparative, 197.

contributory, 197.

in one State, injury in another, 195.

presumed, when, 197.

presumptions as to lex delicti, 193.

risk, assumption of, 197.

situs of, 195.

by agents, 195 .

by animals, 195 .

committed on high seas, 195.

to personalty, 195.

to real property, 195.

TRADE, contracts in restraint of, 175.

TRANSFERS OF PROPERTY. (See Assignments.)

TRESPASS. (See Torts.)

TRUSTEE. (See Fiduciaries.)

capacity of married woman to be a, 71 .

in bankruptcy, 138-139.

in deeds of assignment, 133-135.

TRUSTS,

by implication, 80 .

cliaritable, 70, 144.

in wills, 70, 144, 146.

precatory, 146.

U.

USURY, effect of, upon contracts, 179.

V.

VALIDITY,

of assignments of property, 11-12, 122, 127-138. (See AssignMenrs.) of contracts executory, 72, 77, 168-179. (See Contracts.) of foreign divorce, 87-94 (See Divorck.) 
VALIDITY, - continued.

of foreign judgments and decrees, 85-86, 95-96. (See Jodgments.)

of marriage, 73-78. (See Marriage.)

of nuptial agreements, 80-82.

of wills, 12, 142-150. (See WiLls.)

VENDOR,

lien of, upon sale of chattels, 128.

reservation of title in, 130.

warranty of title by, 181.

VESSEL. (See SHIP.)

VIS MAJOR, contract discharged by, 181.

VOLUNTARY ASSIGNMENTS, and transfers of property, 12, 120-135. (See Assignment.)

VOTE,

right to, as evidence of domicil, 64 .

student's right to, 20.

\section{W.}

WAGERING CONTRACTS, validity of, 161, 176, 178.

WAGES, EXEMPTION OF, upon garnishment, 126, 209.

WARD. (See GUaRdiax.)

WARRANTY,

covenants of, in conveyances of land, 185.

implied, in sale of chattels, 181.

WIDOW,

distributive share of, in personalty of husband, 81 .

domicil of, 52 .

dower of, 12,80 .

jointure, as a bar to dower of, 147 .

WIFE. (See Married Womax.)

WILLS,

of land, $12,145,150$.

capacity to make, 12.

capacity to take under, 12 .

interpretation of, $12,145,150$.

trusts in, 12. (See Trusts.)

validity of, 12 .

of land and personalty, 142.

of personalty, 70, 142-150.

accumulations, 70,144 .

capacity of legatee, 70,144 .

capacity to make, 70,144 .

formal validity of, 143 .

interest on legacies, 118. 
WILLS, - continued.

of personalty,

interpretation of, 145-148, 150, 186.

domicil of testator changed after execution of, 148, 186.

election, 146, 147.

hotchpot, 146.

jointure, as a bar to dower, 147.

lapse, 147.

perpetuities, 70,144 .

revocation of, 149 .

birth of pretermitted child, 149.

burning, tearing, etc., 149.

subsequent marriage, 149.

subsequent removal to a State whose law invalidates, 70, 143144.

subsequent will, 149.

statutes of mortmain, 70, 144.

substantial validity of, 70,144 .

under powers of appointment, 150.

capacity to make, 150.

formal validity of, 150 .

interpretation of, 150 .

substantial validity of, 150 .

\section{WITNESSES,}

competency of, determined by lex fori, 208.

convicted of offense abroad, competency of, 10.

WRITING, contracts required to be in, 173-174, 210. 




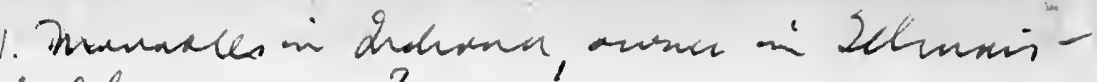
what liv greuns?

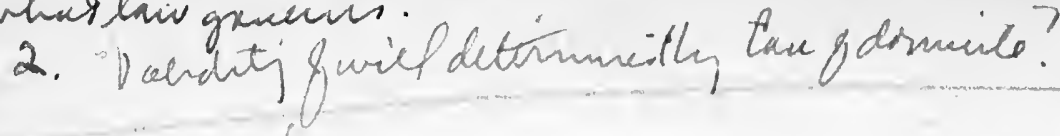

apul $|2|$ to 51

apial $14=$ to 93
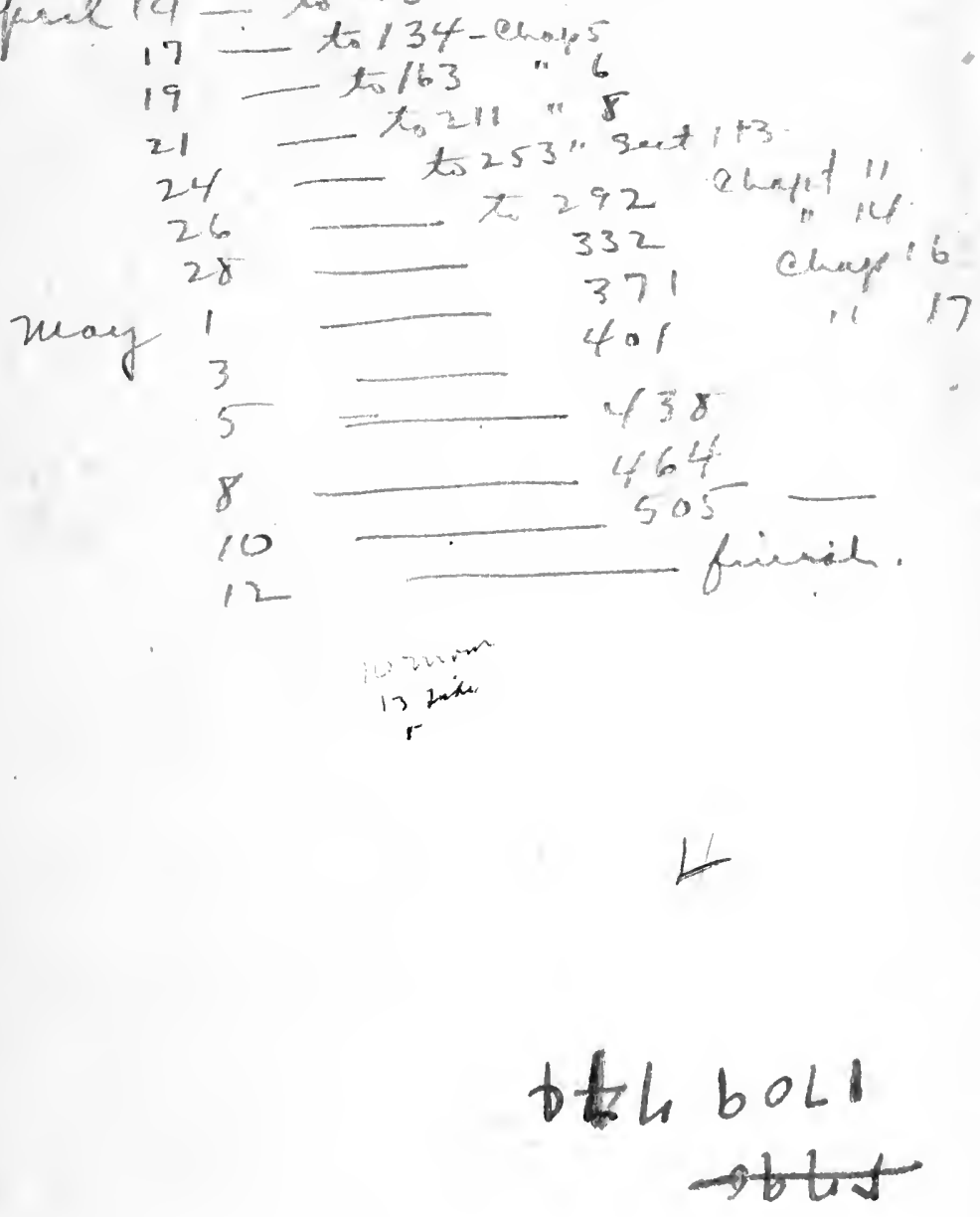

$s(\circ b \varepsilon / 1$

LAW LIBRAKY

UNIVEKSITY OF CALIFORNIA

LOS ANGELES 
$\frac{2 \pi}{270}$

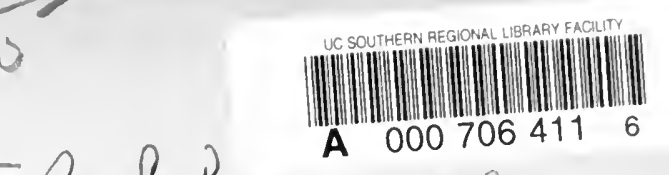

$\frac{\text { Reod PAcp }}{\frac{\text { WiLCS }}{\Delta E E^{2}}}$ cothot.

Squity Blead.

conat. Iun.'

$55, \quad 2-\begin{aligned} & 6 \\ & 3 \\ & 3\end{aligned}$

$1 \because 40 B$ 
